\title{
ESTUDIO DE LOS ESPECTROS DIELÉCTRICOS PARA EL CONTROL DE CAIIDAD DE ALIMENTOS
}

\section{INSTITUTO DE INGENIERÍA DE ALIMENTOS PARA EL DESARROLLO}

UNIVERSIDAD POLITÉCNICA DE VALENCIA

\section{TESIS DOCTORAL}

Presentada por: Marta Castro Giráldez

Dirigida por: $\quad$ Prof. Pedro Fito Maupoey Prof. Fidel Toldrá Vilardell

Dr. Pedro José Fito Suñer 

D. PEDRO FITO MAUPOEY, CATEDRÁTICO DE LA UNIVERSIDAD POLITÉCNICA DE VALENCIA Y PERTENECIENTE AL INSTITUTO DE INGENIERÍA DE ALIMENTOS PARA EL DESARROLLO, D. FIDEL TOLDRÁ VILARDELL, PROFESOR DE INVESTIGACIÓN DEL CONSEJO SUPERIOR DE INVESTIGACIONES CIENTIIFICAS (CSIC) EN EL INSTITUTO DE AGROQUÍMICA Y TECNOLOGÍA DE ALIMENTOS, Y D. PEDRO JOSÉ FITO SUÑER, PROFESOR TITULAR DE LA UNIVERSIDAD POLITÉCNICA DE VALENCIA, PERTENECIENTE AL INSTITUTO UNIVERSITARIO DE INGENIERÍA DE ALIMENTOS PARA EL DESARROLLO.

CONSIDERAN: Que la memoria titulada ESTUDIO DE LOS ESPECTROS DIELÉCTRICOS PARA EL CONTROL DE CALIDAD DE ALIMENTOS que presenta Da MARTA CASTRO GIRÁLDEZ para aspirar al grado de Doctora por la Universidad Politécnica de Valencia, reúne las condiciones adecuadas para constituir su tesis doctoral, por lo que AUTORIZAN a la interesada para su presentación.

Valencia, Junio 2010

Fdo.: Pedro Fito Maupoey

Director de tesis
Fdo.: Fidel Toldrá Vilardell

Director de tesis
Fdo.: P.J. Fito Suñer

Director de tesis 

A mi familia

A Javi 

Evitemos la muerte en suaves cuotas, recordando siempre que estar vivo exige un esfuerzo mucho mayor que el simple hecho de respirar. Solamente la ardiente paciencia hará que conquistemos una espléndida felicidad.

Pablo Neruda 



\section{Agradecimientos}

Pues ya casi he alcanzado el tramo final de este largo camino que me ha costado tantos $y$ tantos duros momentos. Tan sólo quíero aclarar que este documento contiene muchísimo esfuerzo mio y de numerosas personas que me han apoyado y que me quieren, a todos ellos les quíero dar las gracías.

En primer lugar quilero destacar la labor de mis tres directores de tesis; quiero agradecer a pedro su confianza y apoyo durante estos intensos cuatro años, por ayudarme y animarme durante la redacción de esta tesis. A Fidel, por su gran experiencia y por ayudarme siempre que lo he necesítado. Y por último a Pedrojo, por su cariño, por su amistad y por su gran ayuda; por haber estado siempre ahi, en los buenos y en los malos momentos, gracías por todo, de verdad.

A todas las personas que de una u otra forma han contribuido durante estos cuatro años: a creu, por su predisposición y ayuda, gracias por todo lo que hemos vivido juntas. A mis dos amigas y mejores proyectandas, Laura y Patri, porque gracias a vosotras pude superar aquellos momentos tan duros y sacar adelante esta tesis, muchísimas gracias, ya sabéis que os quiero mucho. Al resto de alumnos y también amigos: Raquel, Victor, Juan, Eva y Manel, porque gracias a vosotros aprendi mucho. A Miguel y Dafna, porque siempre estabais ahi para escucharme y darme tantos animos. A Ruth, por haberme ayudado en mis comienzos. A Elisa por atenderme siempre con una sonrisa, a Parreño y a Laura por comprenderme y escucharme. 
Al resto de componentes del instituto que no puedo nombrar personalmente por cuestiones de espacio, por su paciencía y palabras de ánimo. Por último, a todas las personas del IATA que nos ayudaron con el experimental de carne fresca, a Mónica, Aleida, Leti, Elí y Marga. A Mercavalencia, y muy particularmente a carnicas Teva S.L., por su amabilidad. A Marco dalla Rosa, per questa bella permanenza a cesena, per avermi permesso di trascorrere i mesi a cesena e per avermi accolto cosí bene. voglio anche ringraziare tuttí nel suo gruppo di ricerca: ursula, Federica, Patricio, santina, Virginia, Valentina, Pietro, Pinnavaía, Emilíano, Roberto e Laura, e tutti gli altri (Vitto y Ana), per essere stati cosí gentili con me e farmí sentire cosí bene. Grazie mille.

A mis amigas de la especialidad, Mireía, Laura, Amparo y carmen, por su caríno y palabras de animo a lo largo de estos cuatro años. A David Argilés $y$ carlos Ayats por escucharme siempre $y$ comprenderme. A Pablo calvo, de AVG patentes, que ademas de redactar tan bien las dos patentes siempre me ha mostrado su apoyo y me ha hecho sonreir.

A javi, porque siempre estas ahí para apoyarme y escucharme, por tu paciencia y por tu cariño, por quererme tanto y por comprenderme, gracias mi vida, ya sabes que lo eres todo para mi. A mis padres, por darme todo lo que tengo, a vosotros os debo todo lo que soy. A mí hermano, Mabel y Hugo, porque siempre traéis alegría a mi vida, os quiero mucho. A mi familia, porque soy tan afortunada de teneros a todos que ni siquiera tengo palabras suficientes para plasmarlo en este papel. 


\section{Resumen}

Actualmente, la industria agroalimentaria debe hacer frente a numerosas presiones y retos, de entre los que destaca la innovación como la única posibilidad para afrontar la enorme competencia que caracteriza el mercado. La innovación a nivel de proceso está dirigida a la investigación y aplicación de nuevas tecnologías. Mejorar e innovar en los procesos dará lugar a productos más seguros y de mayor calidad, lo cual está relacionado con las exigencias actuales del consumidor. En este contexto, los modernos sensores basados en la aplicación de energía electromagnética suponen un gran avance en el control de calidad en la Industria Alimentaria.

La presente tesis estudia la aplicación de la radiación electromagnética a diferentes productos y procesos de la industria agroalimentaria, con el objeto de solucionar algunos de los grandes problemas del sector cárnico y de la industria postcosecha, así como controlar la operación de deshidratación osmótica en carne y frutas.

En primer lugar se analizó la utilización de energía electromagnética para controlar la calidad de carne fresca; en este sentido se estudió la posibilidad de caracterizar el tipo de carne mediante el análisis de espectros electromagnéticos. Además se trató de analizar la viabilidad de determinar el proceso de maduración de la carne mediante la evolución de los espectros electromagnéticos. Se estudiaron dos rangos de frecuencia: desde $100 \mathrm{~Hz}$ a $0.4 \mathrm{MHz}$; y desde $0.5 \mathrm{GHz}$ a 20GHz. Para ello se emplearon dos equipos, a baja frecuencia los platos paralelos Agilent 16451B conectados a un analizador de impedancias Agilent 4194A; y a frecuencias mayores, la sonda coaxial Agilent 85070E conectada a un analizador de redes Agilent E8362B. Además se realizaron diferentes medidas de parámetros bioquímicos, y físico-químicos de las muestras. Todas estas medidas se realizaron a diferentes horas postmortem que comprendían desde las 2 horas hasta los 7 días tras el sacrificio. 
La principal conclusión de este trabajo de investigación fue que los espectros dieléctricos de muestras de carne mostraron diferencias entre los tres tipos de calidades estudiadas: PSE, DFD y RFN. Estas diferencias fueron significativas a diferentes frecuencias en diferentes tiempos postmortem. Las diferencias se atribuyeron a los diferentes metabolismos de las diferentes clases de carne. Los resultados obtenidos en este estudio permitieron confirmar la viabilidad de desarrollar un equipo industrial capaz de evaluar la calidad de los lomos de cerdo durante las primeras horas postmortem. Por otra parte, se definieron dos Índices (“Ageing Indexes") para determinar el grado de maduración de la carne basados en diferentes frecuencias del espectro y se demostró su eficacia y su relación con los tradicionales indicadores del envejecimiento de la carne como son el valor $\mathrm{K}$, el contenido en aminoácidos libres, así como su relación con algunos parámetros de textura de la carne.

En segundo lugar se realizó un proceso de salado de lomo de cerdo a diferentes tiempos con salmuera saturada. Para cada tiempo de salado y tras un reposo de 16 horas, se midieron las propiedades dieléctricas mediante la sonda coaxial Agilent 85070E conectada a un analizador de redes Agilent E8362B. A las muestras, además, se les determinó la masa, la actividad de agua, la humedad, los cloruros y el volumen.

En este estudio se concluyó que el rigor mortis afecta a las propiedades mecánicas de la carne, y por ello es determinante en el comportamiento de la muestra durante la operación de salado. Además se pudo demostrar la posibilidad de determinar los diferentes mecanismos envueltos en el proceso de salado de carne utilizando un modelo termodinámico de no equilibrio. Se determinaron tres etapas durante el tratamiento de salado de carne con disolución saturada de cloruro sódico: una primera relajación del tejido, comprimido durante el rigor mortis; una contracción del músculo promovida por la rápida relajación de las fibras elásticas; y finalmente, las muestras saladas alcanzaron el equilibrio mecánico. Mediante este trabajo se demostró que las propiedades dieléctricas son una buena herramienta para analizar el reparto de moléculas de cloruro sódico en el músculo durante la operación de salado. 
En tercer lugar se realizó un estudio preliminar de disoluciones patrón que simulaban la fase líquida de la manzana; se concluyó que este sistema permite describir correctamente las relaciones entre los componentes de la manzana y la radiación electromagnética, y permite la identificación de los fenómenos que se atribuyen a las especies químicas claves en el proceso de maduración de la manzana a lo largo del espectro electromagnético. A partir de este estudio preliminar, se realizó un trabajo en tejido de manzana fresco para estudiar su proceso de maduración y analizar la viabilidad de controlar este proceso mediante la aplicación de radiación electromagnética. Se desarrolló un Índice de Madurez basado en las Propiedades Dieléctricas y se obtuvo una buena correlación con el Índice de Thiault en las disoluciones patrón preparadas así como en el tejido estructurado de manzana Granny Smith.

En cuarto lugar, se realizó una operación de deshidratación osmótica de manzana Granny Smith. Las muestras se introdujeron en disolución de sacarosa de $65^{\circ}$ Brix a $30^{\circ} \mathrm{C}$ durante distintos tiempos. Se midieron algunos parámetros fisicoquímicos así como las propiedades dieléctricas en las muestras frescas, tratadas y tras el reposo $\left(24\right.$ horas a $\left.30^{\circ} \mathrm{C}\right)$. La operación de deshidratación fue modelizada mediante una aproximación termodinámica no lineal. Los resultados permitieron diferenciar tres etapas en la operación de deshidratación. Al principio del tratamiento, las células estaban turgentes y el sistema membrana plasmática/pared celular almacena una gran cantidad de energía mecánica. En esta primera etapa se produce un rápido encogimiento de la muestra. En la segunda etapa, la fuerza impulsora del transporte era la difusional. La muestra presentaba importantes perfiles de concentración y es en esta etapa cuando el tejido alcanza el máximo encogimiento, de aproximadamente el 60\%; este encogimiento provoca un gran cambio estructural en el tejido, que hace que desaparezcan los perfiles de concentración, cambiando además la fuerza impulsora del transporte. La última etapa muestra las relajaciones internas del tejido que provocan que el transporte sea gobernado por fenómenos mecánicos. En este estudio se demostró que los espectros dieléctricos permiten controlar el 
proceso de deshidratación utilizando el factor de pérdidas a la frecuencia de relajación.

Por último, se estudió la operación de deshidratación osmótica de kiwi (Actinidia deliciosa cv Hayward). Las muestras se introdujeron en disolución de sacarosa de $65^{\circ}$ Brix a $30^{\circ} \mathrm{C}$ durante distintos tiempos. Se midieron algunos parámetros fisicoquímicos así como las propiedades dieléctricas en las muestras frescas, tratadas y reposadas $\left(24\right.$ horas a $\left.30^{\circ} \mathrm{C}\right)$. La operación de deshidratación fue modelizada mediante una aproximación termodinámica no lineal. Los resultados permitieron describir los términos difusionales y mecánicos del sistema durante el tratamiento; la operación de deshidratación produce fenómenos de contracción/relajación que se traducen en cambios macroscópicos de volumen y estructura, y también se producen cambios composicionales. En este estudio se demostró que los espectros dieléctricos permiten controlar el proceso de deshidratación utilizando el factor de pérdidas a la frecuencia de relajación.

Los resultados de los trabajos de investigación pertenecientes a esta tesis han sido objeto de presentación de dos patentes; la primera patente: "Procedimiento y dispositivo para la discriminación de alimentos", tiene como objeto verificar si los alimentos cumplen criterios de calidad preestablecidos. La segunda patente: "Método de discriminación de piezas de fruta según su grado de madurez y procedimiento de calibración de dicho método", consiste en un método que permite discriminar piezas de fruta según su grado de madurez, por ejemplo para poder llevar a cabo un método de discriminación en procesos continuos de clasificación de frutos recolectados, mediante técnicas de espectroscopia y que no requiere la destrucción del producto. 


\section{Resum}

Actualment, la indústria agroalimentària ha de fer front a nombroses pressions i reptes, entre els quals destaca la innovació com a única possibilitat per a afrontar l'enorme competència que caracteritza el mercat. La innovació a nivell de procés està dirigida a la investigació $\mathrm{i}$ aplicació de noves tecnologies. Millorar $\mathrm{i}$ innovar en els processos donarà lloc a productes més segurs i de major qualitat, la qual cosa està relacionada amb les exigències actuals del consumidor. En aquest context, els moderns sensors basats en l'aplicació d'energia electromagnètica suposen un gran avanç en el control de qualitat en la Indústria Alimentària.

Aquesta tesi estudia l'aplicació de la radiació electromagnètica a diferents productes i processos de la indústria agroalimentària, per tal de solucionar alguns dels grans problemes del sector carni i de la indústria postcollita, així com controlar l'operació de deshidratació osmòtica en carn i fruites.

En primer lloc, es va analitzar la utilització d'energia electromagnètica per controlar la qualitat de carn fresca, en aquest sentit es va estudiar la possibilitat de caracteritzar el tipus de carn mitjançant l'anàlisi d'espectres electromagnètics. A més, es va tractar d'analitzar la viabilitat de determinar el procés de maduració de la carn mitjançant l'evolució dels espectres electromagnètics. Es van estudiar dos rangs de freqüència: des de $100 \mathrm{~Hz}$ a $0.4 \mathrm{MHz}$, i des de $0.5 \mathrm{GHz}$ a $20 \mathrm{GHz}$. Per a això es van emprar dos equips, a baixa freqüència uns plats paral-lels Agilent $16451 B$ connectats a un analitzador d'impedàncies Agilent 4194A, i a freqüències majors, la sonda coaxial Agilent $85070 \mathrm{E}$ connectada a un analitzador de xarxes Agilent E8362B. A més, es van realitzar diferents mesures de paràmetres bioquímics, i fisicoquímics de les mostres. Totes aquestes mesures es van realitzar a diferents hores postmortem que comprenien des de les 2 hores fins als 7 dies després del sacrifici.

La principal conclusió d'aquest treball de recerca va ser que els espectres dielèctrics de mostres de carn van mostrar diferències entre els tres tipus de qualitats estudiades: PSE, DFD i RFN. Aquestes diferències van ser significatives a diferents freqüències en diferents temps postmortem. Les diferències es van 
atribuir als diferents metabolismes de les diferents classes de carn. Els resultats obtinguts en aquest estudi van permetre confirmar la viabilitat de desenvolupar un equip industrial capaç d'avaluar la qualitat dels lloms de porc durant les primeres hores postmortem. D'altra banda, es van definir dos Índexs (“Ageing Indexes") per determinar el grau de maduració de la carn basats en diferents freqüències de l'espectre i es va demostrar la seva eficàcia i la seva relació amb els tradicionals indicadors de l'envelliment en carn com són el valor $\mathrm{K}$, el contingut en aminoàcids lliures, així com la seva relació amb alguns paràmetres de textura de la carn.

En segon lloc, es va realitzar un procés de salat de llom de porc a diferents temps amb salmorra saturada. Per a cada temps de salat i després d'un repòs de 16 hores es van mesurar les propietats dielèctriques mitjançant la sonda coaxial Agilent 85070E connectada a un analitzador de xarxes Agilent E8362B. A les mostres, a més, se'ls va determinar la massa, l'activitat d'aigua, la humitat, els clorurs i el volum.

En aquest estudi es va concloure que el rigor mortis afecta a les propietats mecàniques de la carn i, per això, és determinant en el comportament de la mostra durant l'operació de salat. A més, es va poder demostrar la possibilitat de determinar els diferents mecanismes que afecten al procés de salat de carn utilitzant un model termodinàmic de no equilibri. Es van determinar tres passos durant el tractament de salat de carn amb dissolució saturada de clorur sòdic: una primera relaxació del teixit, comprimit durant el rigor mortis, una contracció del múscul promoguda per la ràpida relaxació de les fibres elàstiques i, finalment, les mostres salades arribaven a l'equilibri mecànic. Mitjançant aquest treball es va demostrar que les propietats dielèctriques són una bona eina per analitzar el repartiment de molècules de clorur sòdic en el múscul durant l'operació de salat.

En tercer lloc, es va realitzar un estudi preliminar de dissolucions patró que simulaven la fase líquida de la poma; es va concloure que aquest sistema permet descriure correctament les relacions entre els components de la poma i la radiació electromagnètica, i permet la identificació dels fenòmens que s'atribueixen a les espècies químiques claus en el procés de maduració de la poma al llarg de 
l'espectre electromagnètic. A partir d'aquest estudi preliminar, es va realitzar un treball amb teixit de poma fresc per estudiar el seu procés de maduració i analitzar la viabilitat de controlar aquest procés mitjançant l'aplicació de radiació electromagnètica. Es va definir un Índex de Maduresa basat en les propietats dielèctriques i es va obtenir una bona correlació amb l'Índex de Thiault en les dissolucions patró preparades així com en el teixit estructurat de poma Granny Smith.

En quart lloc, es va realitzar una operació de deshidratació osmòtica de poma Granny Smith. Les mostres es van introduir en dissolució de sacarosa de $65^{\circ}$ Brix a $30^{\circ} \mathrm{C}$ durant diferents temps. Es van mesurar alguns paràmetres fisicoquímics així com les propietats dielèctriques en les mostres fresques, tractades i després del repòs $\left(24\right.$ hores a $30^{\circ} \mathrm{C}$ ). L'operació de deshidratació va ser modelitzada mitjançant una aproximació termodinàmica no lineal. Els resultats van permetre diferenciar tres etapes en l'operació de deshidratació. Al principi del tractament, les cèl·lules estaven turgents i el sistema membrana plasmàtica/paret cel·lular emmagatzema una gran quantitat d'energia mecànica. En aquesta primera etapa es produeix un ràpid encongiment de la mostra. En la segona etapa, la força impulsora del transport era la difusional. La mostra presentava importants perfils de concentració i és en aquesta etapa quan el teixit arriba al màxim encongiment, d'aproximadament el 60\%; aquest encongiment provoca un gran canvi estructural en el teixit, que fa que desapareguin els perfils de concentració, canviant a més la força impulsora del transport. L'última etapa mostra les relaxacions internes del teixit que fan que el transport sigui governat per fenòmens mecànics. En aquest estudi es va demostrar que els espectres dielèctrics permeten controlar el procés de deshidratació utilitzant el factor de pèrdues a la freqüència de relaxació.

Finalment, es va estudiar l'operació de deshidratació osmòtica de kiwi (Actinidia deliciosa cv Hayward). Les mostres es van introduir en dissolució de sacarosa de $65^{\circ}$ Brix a $30^{\circ} \mathrm{C}$ durant diferents temps. Es van mesurar alguns paràmetres fisicoquímics així com les propietats dielèctriques en les mostres fresques, tractades i després del repòs (24 hores a $30^{\circ} \mathrm{C}$ ). L'operació de deshidratació va ser modelitzada mitjançant una aproximació termodinàmica no lineal. Els 
resultats van permetre descriure els termes difusionals i mecànics del sistema durant el tractament; l'operació de deshidratació produeix fenòmens de contracció/relaxació que es tradueixen en canvis macroscòpics de volum i estructura, i també es produeixen canvis composicionals. En aquest estudi es va demostrar que els espectres dielèctrics permeten controlar el procés de deshidratació utilitzant el factor de pèrdues a la freqüència de relaxació.

Els resultats dels treballs de recerca que pertanyen a aquesta tesi han estat objecte de presentació de dos patents; la primera patent: "Procediment i dispositiu per a la discriminació d'aliments", té com a objecte verificar si els aliments compleixen criteris de qualitat preestablerts. La segona patent: "Mètode de discriminació de peces de fruita segons el seu grau de maduresa i procediment de calibratge d'aquest mètode", consisteix en un mètode que permet discriminar peces de fruita segons el seu grau de maduresa, per exemple per poder dur a terme un mètode de discriminació en processos continus de classificació de fruits recollits, mitjançant tècniques d'espectroscòpia i que no requereix la destrucció del producte. 


\section{Abstract}

Currently, the food industry is facing many pressures and challenges, among which it is important to highlight the innovation as the only way to face the huge competition that characterizes the market.

The innovation in process is oriented to the research and to the application of novel technologies. To improve and to innovate in the processes will lead to safety and better quality products, which are related to current consumer demands. In this context, the modern sensors based on the application of electromagnetic energy are great improvements in the quality control of Food Industry.

This doctoral thesis studies the application of electromagnetic radiation to different products and processes in the food industry, in order to solve some of the major problems in the meat sector and in post-harvest industry, as well as to control the osmotic dehydration operation of meat and fruits.

First, the use of electromagnetic energy to control the quality of fresh meat was analyzed; in this sense, the possibility of characterizing the meat quality class by using electromagnetic spectra was studied. Moreover, the viability of determining the meat ageing process by analyzing the evolution of the electromagnetic spectrum was determined. Two frequency ranges were studied: from $100 \mathrm{~Hz}$ to $0.4 \mathrm{MHz}$, and from $0.5 \mathrm{GHz}$ to $20 \mathrm{GHz}$. For this purpose two equipment were used: the parallel plates Agilent $16451 \mathrm{~B}$ connected to an Impedance Analyser Agilent 4194A for low-frequency measurements, and the coaxial probe Agilent 85070E connected to a vector network analyzer Agilent E8362B for higher frequencies. Different biochemical and physical-chemical parameters were also determined. All these measurements were made at different postmortem times ranged from 2 hours to 7 days after slaughter.

The main conclusion of this research was that the dielectric spectra of meat samples showed differences between the three pork quality classes studied: PSE, DFD and RFN. These differences were significant at different frequencies at different postmortem times. The differences were attributed to the different 
metabolisms of the different kinds of meat. The results obtained in this study confirmed the feasibility of developing an industrial sensor to assess the quality of pork loins during the first hours postmortem. Moreover, two Ageing Indexes were defined based on different frequencies of meat spectrum and its effectiveness was demonstrated. Its relationship with traditional indicators of meat ageing such as the $K$ value, the free amino acids content and some parameters of meat texture was also demonstrated.

Secondly, dielectric spectroscopy studies were performed on raw and salted longissimus dorsi pork samples. Dielectric spectra were measured by an Agilent 85070E open-ended coaxial probe connected to an Agilent E8362B Vector Network Analyzer immediately after salting process and also after 16 hours of repose. Salt content, moisture, water activity and volume were also measured. It was demonstrated that the rigor mortis state affects meat behaviour during the salting operation. Moreover, a thermodynamic model in non-equilibrium has been developed for describing the different behaviors involved in salting process. Three steps were identified during the salting operation with sodium chloride saturated solution: an initial relaxation of tissue, compressed during rigor mortis process; a muscle contraction promoted by the fast relaxation of elastic fibers; and finally, the salted samples reached mechanical equilibrium. The last conclusion of this work was that dielectric properties are a good tool to analyze the share of the added sodium chloride molecules in the muscle tissue during the salting treatment (bounded and solved ions).

Thirdly, a preliminary standard solutions study, simulating the liquid phase of apple fruit, was made; the main conclusion was that this system can correctly describe the relationship between the apple components and electromagnetic radiation, and allows identifying the phenomena attributed to key chemical species in apple maturation process along the electromagnetic spectrum. Subsequently, a study was carried out in fresh apple tissue for analyzing its maturation process and for analyzing the feasibility of controlling this process through the application of electromagnetic radiation. A maturity index based on the dielectric properties was developed and good correlations 
with the Thiault Index were obtained in the standard solutions and in structured tissue of Granny Smith apple.

Fourthly, osmotic dehydration experiments of Granny Smith apple were carried out. Samples were immersed into $65 \%(\mathrm{w} / \mathrm{w})$ sucrose aqueous solution at $30^{\circ} \mathrm{C}$ during different times. Some physical-chemical parameters and also dielectric spectra were measured in fresh, treated and reposed $\left(24 \mathrm{~h}\right.$ at $\left.30^{\circ} \mathrm{C}\right)$ samples. Osmotic dehydration operation was modelled by using a nonlinear thermodynamic approach. The results allow identifying three differentiated steps in the osmotic operation process. At the beginning of the treatment, the cells were turgid and the wall-membrane system stored high level of mechanical energy. In this step, the highest velocity of shrinkage occurred. In the second step, the main driving force was diffusional, with important concentration profiles in the tissue; in this step, the deformation of the tissue reached the maximum shrinkage level of approximately 60\%. It produces an important structural change in the tissue removing the concentration profiles and changing the mechanism driving forces. Last step shows internal relaxation of the tissue, increasing the mechanical transport behaviours. This work demonstrated that dielectric spectra allow controlling the dehydration process by using the loss factor at relaxation frequency.

Finally, the osmotic dehydration of kiwifruit (Actinidia deliciosa cv Hayward) was studied. The samples were introduced in sucrose aqueous solution of $65^{\circ} \mathrm{Brix}$ at $30^{\circ} \mathrm{C}$ for different times. Some physical-chemical parameters and also dielectric spectra were measured in fresh, treated and reposed $\left(24 \mathrm{~h}\right.$ at $\left.30^{\circ} \mathrm{C}\right)$ samples. The dehydration operation was modelled by using a nonlinear thermodynamic approach. The results allowed describing the diffusional and mechanical terms of the system during the treatment; the dehydration operation produces contraction/relaxation phenomena which result in important changes of volume and structure, and also provokes compositional changes. This work demonstrated that dielectric spectra allow controlling the dehydration process by using the loss factor at relaxation frequency. 
The results of this document have led to the presentation of two patents; the first patent: "Method and device for the discrimination of food", which consists in verifying if the foods accomplish predetermined quality criteria. The second patent: "Method of discrimination of fruit pieces according to their degree of maturity and calibration of the method", consists in a method that allows discriminating pieces of fruit according to their degree of maturity, for example to carry out a discrimination method for classifying fruits in postharvest line by using a non-destructive spectroscopic technique. 


\section{Índice de contenidos}

1. Introducción 1

2. Objetivos y plan de trabajo $\quad 61$

3. Materiales y métodos $\quad 67$

4. Resultados

4.1. Estudio de los espectros dieléctricos de lomo de cerdo y su relación con los parámetros de calidad de carne fresca

Development of a dielectric spectroscopy

technique for the determination of key

biochemical markers of meat quality

Use of visible spectroscopy to assess colour

development during ageing of fresh pork from

different quality classes

Microwave dielectric spectroscopy for the

determination of pork meat quality

Low-frequency dielectric spectrum to determine

pork meat quality

Low frequency dielectric measurements for

evaluating the extent of postmortem ageing of

pork meat

4.2. Estudio de la cinética de salado de lomo de cerdo mediante la utilización de los espectros dieléctricos

Non-equilibrium thermodynamic approach to analyze the pork meat (Longissimus dorsi) salting process

Application of microwaves dielectric spectroscopy for controlling pork meat (Longissimus dorsi) salting process

\subsection{Estudio de la influencia de la composición y estructura de la manzana Granny Smith mediante la utilización de espectros dieléctricos}

Development of a Dielectric Spectroscopy

Components of Apple Maturity

Development of a dielectric spectroscopy technique for the determination of apple (Granny Smith) maturity 
4.4. Estudio de la cinética de escarchado de manzana Granny Smith mediante la utilización de espectros dieléctricos

Nonlineal thermodynamic approach to analyze long time osmotic dehydration of parenchymatic apple tissue

Application of microwaves dielectric spectroscopy for controlling long time osmotic dehydration of parenchymatic apple tissue

\subsection{Estudio de la cinética de deshidratación osmótica de kiwi (Actinidia deliciosa cv Hayward) mediante la utilización de espectros dieléctricos}

Nonlinear thermodynamic and structural

approach to analyze osmotic dehydration of kiwifruit (Actinidia deliciosa cv Hayward) at short treatment times

Application of microwaves dielectric spectroscopy for controlling osmotic dehydration of kiwifruit (Actinidia deliciosa cv Hayward)

\subsection{Patentes Internacionales}

PATENTE P200803559: Procedimiento y 
1. Introducción 



\subsection{Importancia de la espectroscopia dieléctrica}

Actualmente las industrias agroalimentarias están sometidas a importantes presiones como son la internacionalización de mercados y la globalización de la economía, lo que provoca una elevada competencia que obliga a las empresas a una innovación constante, a una evolución tecnológica y a responder con eficiencia a los cambios de hábitos de un consumidor cada vez más exigente. Por lo tanto, para poder competir en el mercado, las empresas deberán centrar sus esfuerzos en dos áreas: la innovación en el proceso y la innovación en el producto. La innovación en el proceso, está dirigida a la investigación y aplicación de nuevas tecnologías. Mejorar e innovar en los procesos dará lugar a productos más seguros y de mayor calidad, lo cual está relacionado con las exigencias actuales del consumidor (Muñoz-Pérez, 2008). En este contexto, los modernos sensores juegan un papel importante y suponen un gran avance para el control de determinadas propiedades de los alimentos. Estos sensores están fundamentalmente basados en la radiación electromagnética, ultrasonidos y técnicas de resonancia. Algunas de las aplicaciones industriales de estas técnicas están siendo todavía desarrolladas y se están empleando muchísimos esfuerzos en obtener sensores para control de calidad que puedan ser empleados en línea y que sean no destructivos e incluso no requieran contacto físico con la muestra. Por otra parte, la monitorización durante el procesado es importante a la hora de optimizar los recursos o de evitar la obtención de productos que no cumplan con las especificaciones requeridas.

La espectroscopia dieléctrica ocupa un lugar importante entre los modernos métodos de medida utilizados para el análisis físico y químico de materiales así como de tejidos en numerosos campos de investigación: medicina (Campbell y Land, 1992; Peebles et al, 1992; Joines et al, 1994; Aimoto y Matsumoto, 1996; Fear et al, 2002, 2003; Choi et al, 2004; Lazebnik et al, 2007, Stoneman et al, 2007 ), industria farmacéutica (Smith et al, 1995), tecnología de alimentos (Kent y Jason, 1975; Kent, 1990; 2001; 2003; 2007; Kent et al, 1993; 2000a,b; 2001; 2002; 2004a,b; 2005; 2007; Lepetit y Buffiere, 1995; Kent y Anderson, 1996; Lepetit y Hamel, 1998; Kent y Stroud, 1999; Lepetit et al, 2002; 2006; Clerjon et al, 2003; 
Henry et al, 2003; Li et al, 2003; Trabelsi y Nelson, 2003; Damez et al, 2005; 2006; 2007; 2008a,b; Brunton et al, 2006; Nelson et al, 2006; 2007; Clerjon y Damez, 2007; Grimnes y Martinsen, 2007; Guo et al, 2007a,b, Damez y Clerjon, 2008), ciencia de materiales (Goy et al, 1992; Adous et al, 2006; Martín et al, 2004)... Es una técnica que permite la investigación de los procesos de relajación en un amplio rango de tiempos característicos $\left(10^{4}-10^{-12} \mathrm{~s}\right)$, siendo sensible a la polarización interfacial y a las interacciones intermoleculares (dipolo-dipolo). Aunque este método no posee la selectividad de la Resonancia Magnética Nuclear (NMR) o de la Resonancia Paramagnética de Electrones (ESR), ofrece importante y, en algunos casos, información única sobre los procesos y sobre el estado en el que se encuentran los componentes en los alimentos. De hecho, otras técnicas más selectivas como pueden ser la espectroscopia Raman, la espectroscopia de Infrarrojos, difracción por Rayos-X pueden resultar útiles pero, debido a que producen fenómenos de resonancia, los espectros que proporcionan son muy complejos y difíciles de interpretar (Craig, 1996). Si se compara la espectroscopia dieléctrica, en la zona de microondas y radiofrecuencia, con la espectroscopia de Infrarrojos, la primera posee la ventaja de que permite medir las propiedades dieléctricas en un volumen de material y no sólo en la zona más superficial del mismo; esta característica es fundamental en materiales heterogéneos como pueden ser los alimentos (Kent, 2001). Por otra parte, la utilización de esta técnica, basada en las microondas y radiofrecuencia de señal para la realización de espectros electromagnéticos en un amplio rango de frecuencia, también presenta ciertas desventajas como podría ser la gran inversión en equipos que requiere; debido a ello, para su aplicación en la industria, es necesaria la realización de estudios preliminares para acotar la frecuencia de medida y así conseguir abaratar el coste del sensor. Además, esta técnica es difícil de aplicar en alimentos debido a los cambios que sufren los sistemas biológicos con el tiempo. Por todo lo anteriormente expuesto, es necesario ampliar la investigación en este campo. 


\subsection{Teoría sobre espectros dieléctricos}

\subsubsection{Principios básicos}

La figura 1.1 muestra el espectro electromagnético, el cual se caracteriza por diferentes tipos de radiación en función de la longitud de onda y de la frecuencia.

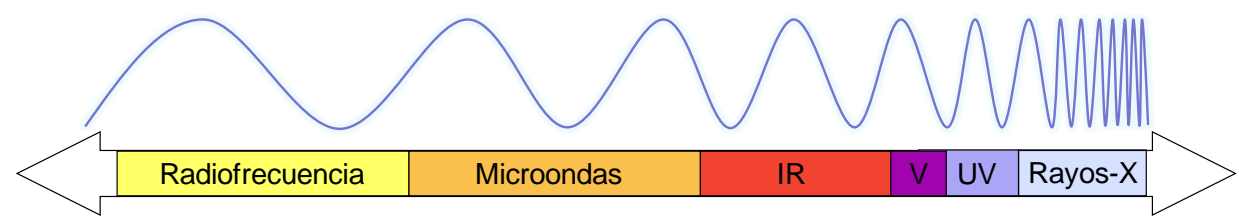

Figura 1.1. El espectro electromagnético (Adaptado de Castro-Giráldez et al, 2010a).

Existen diferentes tipos de sensores basados en la interacción de un material con la radiación electromagnética, en particular: sensores que utilizan la radiación visible, ultravioleta e infrarroja, las microondas, las ondas de radio, los rayos $\mathrm{X}$ y las ondas de alta frecuencia (Resonancia Magnética Nuclear). Algunas de sus aplicaciones se encuentran en el mercado desde hace años, particularmente para su utilización en el laboratorio. Existen numerosos ejemplos de aplicaciones en línea: detección de cuerpos extraños mediante el uso de los rayos $\mathrm{X}$, sensores basados en la luz visible para el análisis de color, infrarrojo cercano para inspecciones de calidad o para la medida de la temperatura (Holm, 2003). Más concretamente, la espectroscopia de microondas se está utilizando actualmente para la determinación de la humedad (Kraszewski, 1996, 2000; Kraszewski y Nelson, 1990, 1992, 1993a,b, 1994; Kraszewski et al, 1998; Nelson y Bartley, 2000), para medir la densidad (Kraszewski y Nelson, 1992; Kress-Rogers y Kent, 1987) y determinación del estado de madurez en fruta (Nelson et al, 1993, 1994, 1995, 2006, 2007).

Esta tesis centra su atención en la utilización de sensores basados en radiación electromagnética en el rango de longitudes de onda que abarca principalmente la radiofrecuencia y las microondas. Las microondas comprenden 
un rango de longitudes de onda desde $3 \mathrm{~m}$ hasta $3 \mathrm{~mm}$. El correspondiente rango de frecuencia va desde $100 \mathrm{MHz}$ a $100 \mathrm{GHz}$ (Kent, 2001). En el espectro electromagnético (Figura 1.1) las microondas se encuentran embebidas entre las ondas de radio a bajas frecuencias, y los infrarrojos y la luz visible a frecuencias más altas. La energía de microondas asociada a esas frecuencias no es suficiente como para romper enlaces químicos o para mover electrones (Shukla y Anantheswaran, 2001). Las microondas forman parte de las radiaciones no ionizantes.

Las ondas electromagnéticas están compuestas por un campo eléctrico y un campo magnético (Figura 1.2). Cuando la energía de microondas incide sobre un alimento, parte de esta energía es absorbida por éste, produciendo un aumento de su temperatura. La cantidad y distribución de la energía de microondas absorbida por el alimento puede ser descrita por las ecuaciones de Maxwell. Estas ecuaciones describen la propagación de las ondas electromagnéticas en los materiales, y pueden ser escritas del siguiente modo:

$$
\begin{gathered}
\nabla x B=j \omega \varepsilon E \\
\nabla x E=-j \omega \mu B \\
\nabla \mu B=0 \\
\nabla \varepsilon E=\rho
\end{gathered}
$$

Donde $\mathrm{B}$ es el vector del campo magnético y E es el vector del campo eléctrico. El parámetro $\varepsilon$ se denomina permitividad del material (medida en Faradios por metro o $\mathrm{F} / \mathrm{m})$; y caracteriza la interacción entre el campo eléctrico de las microondas con el material. En las ecuaciones anteriores la letra $\mu$ se refiere a la permeabilidad del material (medida en Henrios por metro o $\mathrm{H} / \mathrm{m}$ ); $\mathrm{y}$ caracteriza la interacción del material con el campo magnético de las microondas. Ambos parámetros $\varepsilon$ y $\mu$ son variables complejas (Datta et al, 2005). 


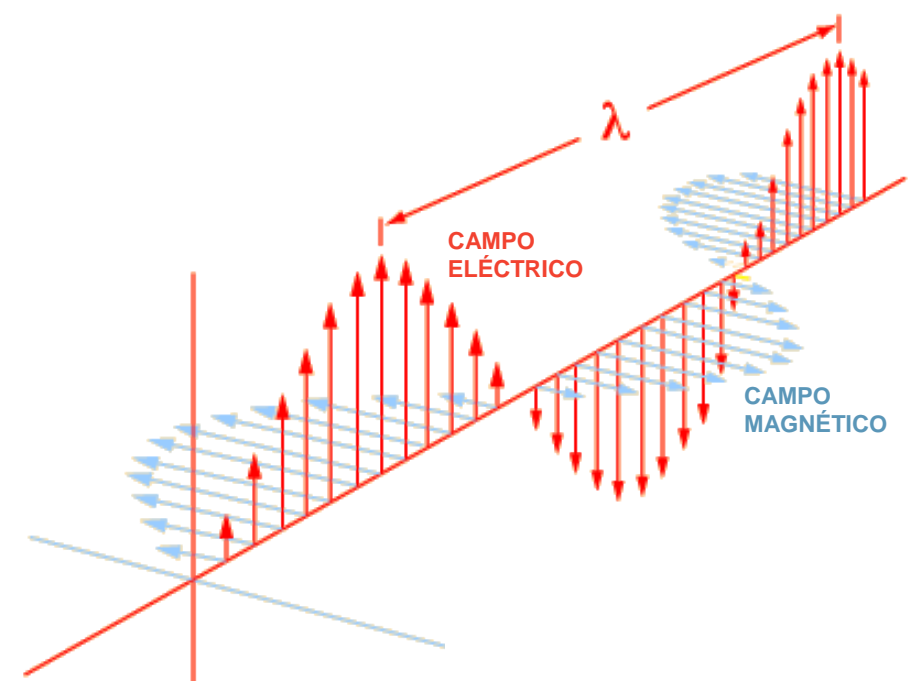

Figura 1.2. La onda electromagnética.

Debido a que en los alimentos predominan los componentes que interaccionan con el campo eléctrico, normalmente se asume que la permeabilidad del alimento es igual a la del vacío $\mu_{0}=\mu=4 \pi 10^{-7} \mathrm{H} / \mathrm{m}$ y es posible despreciar el término magnético en este tipo de estudios (Pethig y Kell, 1987; Grant y Gabriel, 1991; Regier y Schubert, 2005). Por tanto, la permitividad compleja $\left(\varepsilon_{\mathrm{r}}\right)$ es la propiedad dieléctrica que describe el comportamiento de un alimento frente a la influencia de un campo electromagnético (Metaxas y Meredith, 1993; Nelson and Datta, 2001). Esta propiedad viene definida por la siguiente ecuación:

$$
\varepsilon_{r}=\varepsilon^{\prime}-j \cdot \varepsilon^{\prime}
$$

En la ecuación anterior $j=\sqrt{-1}$. La parte real de la permitividad compleja se llama constante dieléctrica $\left(\varepsilon^{\prime}\right)$ y refleja la habilidad del material para almacenar energía cuando el alimento está sometido a un campo eléctrico. A esta capacidad de almacenar energía se le denomina polarización. Este fenómeno se debe fundamentalmente al desplazamiento de cargas positivas y negativas de sus posiciones de equilibrio, bajo el efecto del campo eléctrico aplicado y en contra de la atracción atómica y molecular (Catalá, 1999). Los dieléctricos perfectos 
únicamente tienen parte real, pero si la onda se propaga por dieléctricos no perfectos, la onda pierde parte de su energía y la parte imaginaria de la permitividad adquiere valor. Por tanto, en alimentos, cada fenómeno de polarización lleva asociado un fenómeno de disipación de parte de la energía de la onda en el material, dando lugar a absorciones de energía y al decaimiento de la constante dieléctrica. La parte imaginaria de la permitividad se llama factor de pérdidas $(\varepsilon ”)$ y está relacionada con este fenómeno de absorción y disipación de energía en otras formas de energía como puede ser la térmica.

El subíndice " $r$ " indica que los valores son relativos al vacío, y por ello la variable es adimensional (ecuación 1.6).

$$
\varepsilon_{\mathrm{r}}=\varepsilon^{*} / \varepsilon_{0}
$$

(Ecuación 1.6)

siendo la permitividad del vacío $\varepsilon_{0}=8,8542 \times 10^{-12} \mathrm{~F} / \mathrm{m}$.

Cuando la permitividad compleja se dibuja como un simple vector (Figura 1.3) la parte real e imaginaria están desfasadas $90^{\circ}$. El vector resultante forma un ángulo $\delta$ con el eje real $\left(\varepsilon^{\prime}\right)$. El ratio entre la parte real y la parte imaginaria de la permitividad representa otro parámetro importante, la tangente de pérdidas (Ecuación 1.7), que representa una medida de la habilidad del alimento para disipar energía (Ponne y Bartels, 1995; Içier y Baysal, 2004a).

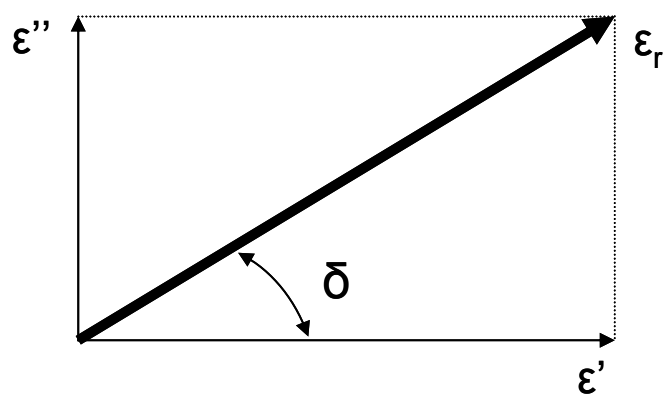

Figura 1.3. Diagrama del vector permitividad compleja 


$$
\tan \delta=\frac{\varepsilon^{\prime \prime}}{\varepsilon^{\prime}}=D=\frac{1}{Q}=\frac{\text { Energía }_{\text {Perdida }} / \text { ciclo }}{\text { Energía }_{\text {Almacenada }} / \text { ciclo }}
$$

D se denomina factor de disipación y Q representa el factor de calidad. A veces se utiliza el término "factor de calidad o Q-factor" que es el inverso a la tangente de pérdidas (von Hippel, 1954b).

\subsubsection{Mecanismos dieléctricos en sistemas celulares}

Existen diferentes mecanismos que afectan al comportamiento dieléctrico de un alimento. Estos mecanismos se dividen en dos clases: fenómenos de resonancia y procesos de relajación.

Los fenómenos de resonancia ocurren cuando el campo eléctrico aplicado tiene una frecuencia que coincide con la frecuencia de oscilación natural del material. Estos fenómenos de resonancia abarcan la polarización electrónica y atómica, y son producidos a las frecuencias más altas de microondas y por encima de ellas. La polarización electrónica se produce debido a la separación de la nube de electrones con respecto al núcleo del átomo al aplicar energía electromagnética, provocando un desplazamiento de la posición de equilibrio (Kao, 2004). El campo eléctrico aplicado causa la deformación de la simétrica distribución de la nube de electrones de átomos. En este caso se induce un momento dipolar en el átomo. Una nueva posición de equilibrio se alcanza cuando el campo eléctrico generado por este dipolo iguala al que está siendo aplicado. Los efectos de esta particular forma de polarización pueden ser observados en la región visible del espectro, donde son responsables de la refracción de la luz (von Hippel, 1954c, Kent, 2003). La polarización atómica (también llamada iónica) aparece cuando átomos enteros son desplazados en una molécula. Este desplazamiento está típicamente asociado con cambios en la longitud de los enlaces o en los ángulos de dichos enlaces, provocando momentos dipolares resultantes. Se produce una distorsión de la vibración natural de la molécula, por lo que a este fenómeno también se le denomina polarización vibracional (Kao, 2004). Su principal efecto se hace patente en la 
región de infrarrojos. Los fenómenos de resonancia no son objeto del estudio de esta tesis, así que no se profundizará en este campo.

Los fenómenos de relajación se producen a frecuencias de microondas y radiofrecuencias y caracterizan, junto con la conductividad, el comportamiento dieléctrico de prácticamente todos los tejidos biológicos a esas frecuencias. En alimentos, estos fenómenos de relajación resultan de la interacción de la radiación electromagnética con los constituyentes del tejido tanto a nivel celular como a nivel molecular; cada relajación está caracterizada por un tiempo determinado de relajación $\tau$. El tiempo de relajación es una medida del tiempo que tardan las moléculas en volver a una distribución al azar cuando cesa la aplicación del campo (Kent, 2001). A pesar de que el agua es uno de los principales constituyentes de los alimentos, estos sistemas complejos no pueden ser reducidos a una única dispersión o relajación ocasionada por las moléculas de agua libre ya que contienen macromoléculas cuyo comportamiento debe ser explicado con detalle.

En un alimento se pueden diferenciar diferentes dispersiones o cambios en las propiedades dieléctricas al variar la frecuencia. Dichas dispersiones se producen por diferentes fenómenos pero, en líneas generales, presentan cualitativamente efectos muy similares, aunque aparecen a frecuencias muy diferentes. A continuación se explicará en primer lugar la dispersión correspondiente a la polarización dipolar ocasionada por las moléculas de agua libre, para la mejor comprensión posterior del resto de fenómenos de relajación que caracterizan a los alimentos con estructura celular.

\subsubsection{Polarización dipolar. Modelo de Debye}

La polarización dipolar fue modelizada por Debye en 1929. Este modelo fue desarrollado para describir el comportamiento de los dipolos permanentes en líquidos y en disoluciones de moléculas polares en solventes no polares. Las ecuaciones de dicho modelo se presentan a continuación: 


$$
\varepsilon_{r}=\varepsilon^{\prime}-j \varepsilon^{\prime \prime}=\varepsilon_{\infty}+\frac{\varepsilon_{s}-\varepsilon_{\infty}}{1+j \omega \tau}
$$

En la ecuación anterior $\varepsilon_{\infty}$ es la permitividad relativa a frecuencia muy elevada, conocida como constante dieléctrica óptica; $\varepsilon_{\mathrm{s}}$ es la constante dieléctrica estática, y $\tau$ es el tiempo de relajación en segundos. Como ya se ha comentado, la orientación de las moléculas en el campo eléctrico no es un proceso instantáneo y se caracteriza por el tiempo de relajación $\tau$. En este caso en concreto, el tiempo de relajación es una medida del tiempo que tardan los dipolos en volver a una distribución al azar cuando cesa la aplicación del campo eléctrico.

A partir de la ecuación anterior se pueden identificar los términos correspondientes a la constante dieléctrica y al factor de pérdidas (Kraszewski y Nelson, 1990):

$$
\begin{aligned}
& \varepsilon^{\prime}=\varepsilon_{\infty}+\frac{\varepsilon_{s}-\varepsilon_{\infty}}{1+\omega^{2} \tau^{2}} \\
& \varepsilon^{\prime \prime}=\frac{\left(\varepsilon_{s}-\varepsilon_{\infty}\right) \omega \tau}{1+\omega^{2} \tau^{2}}
\end{aligned}
$$

El factor de pérdidas alcanza su máximo valor a la frecuencia de relajación $\left(f_{c}\right)$. La frecuencia de relajación se relaciona con el tiempo de relajación $(\tau)$ mediante la ecuación $f_{c}=\frac{1}{2 \pi \tau}$. La frecuencia de relajación es la frecuencia a la cual el factor de pérdidas alcanza su valor máximo en una dispersión concreta (en este caso la polarización dipolar). En general, las moléculas de mayor tamaño tienen una menor movilidad y mayores tiempos de relajación que las moléculas más pequeñas. Por tanto, la frecuencia de relajación disminuye al aumentar el peso molecular (Data et al, 2005).

Para una mejor comprensión de esta dispersión, se ha representado en la figura 1.4 el comportamiento dieléctrico de las moléculas de agua a la temperatura de $20^{\circ} \mathrm{C}$. A bajas frecuencias en la región estática, la constante 
dieléctrica alcanza valores de 80 a la temperatura de $20^{\circ} \mathrm{C}$. La constante dieléctrica estática es dependiente de la temperatura como se verá en la sección 1.2.3.1 y como ya fue demostrado anteriormente por Collie et al (1948). A altas frecuencias en la región óptica, la constante alcanza valores próximos a 6 , y es generalmente independiente de la temperatura (Mudgett, 1985). Entre las regiones ópticas y estáticas existe una dispersión en la cual se aprecia el fenómeno de relajación, es decir, la constante dieléctrica decrece logarítmicamente con la frecuencia desde su valor estático hasta su valor óptico, y el factor de pérdidas se ve incrementado desde un valor insignificante en la región estática, hasta su valor máximo alcanzado a la frecuencia de relajación, para posteriormente disminuir hasta valores insignificantes en la región óptica. La interpretación física de este fenómeno se puede resumir del siguiente modo: a bajas frecuencias los dipolos poseen suficiente tiempo para seguir las variaciones del campo aplicado, y la constante dieléctrica adquiere su máximo valor es. Por otra parte, a las frecuencias mayores de microondas la constante dieléctrica toma el valor de $\varepsilon_{\infty}$, debido a que los dipolos son incapaces de seguir los rápidos cambios del campo eléctrico. El factor de pérdidas en ambos casos, a altas y bajas frecuencias, toma valores de cero. A bajas frecuencias, los dipolos no oscilan con la suficiente velocidad como para generar calor, mientras que a altas frecuencias, los dipolos no reaccionan frente al campo eléctrico aplicado (son incapaces de seguir las rápidas oscilaciones del campo) (Mudgett, 1985). 


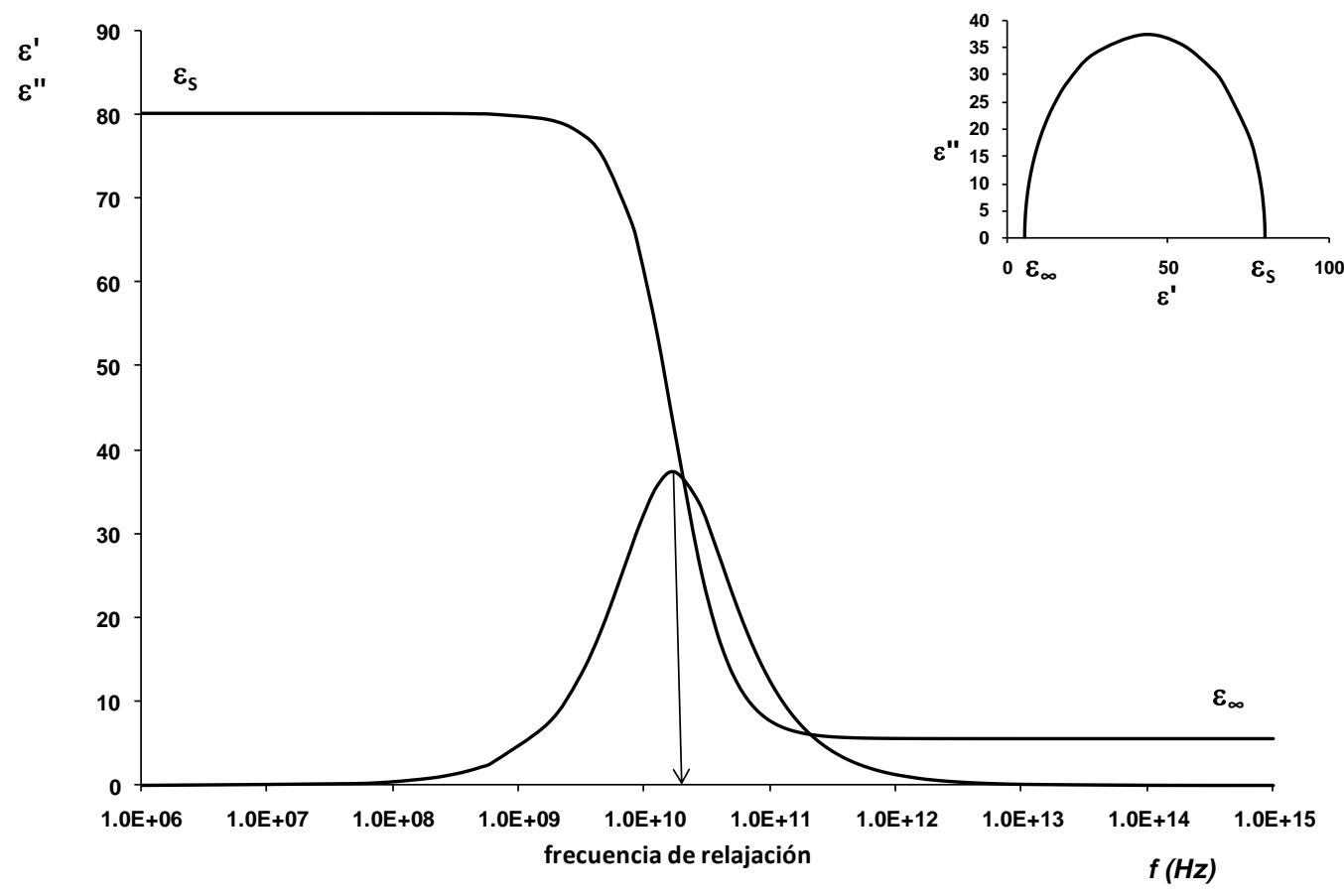

Figura 1.4. Representación de las pérdidas dipolares y la constante dieléctrica del agua a $20^{\circ} \mathrm{C}$ en función del logaritmo de la frecuencia siguiendo el modelo ideal de Debye (adaptado de Debye, 1929). En la parte superior derecha de la figura se ha representado también el modelo de Debye en el plano complejo ( $\varepsilon^{\prime \prime}$ vs $\left.\varepsilon^{\prime}\right)$ como un semicírculo cuyos puntos de corte con el eje de abscisas a baja frecuencia son $\left(\varepsilon^{\prime}=\varepsilon_{s}, \varepsilon^{\prime \prime}=0\right)$, y a alta frecuencia $\left(\varepsilon^{\prime}=\varepsilon_{\infty}, \varepsilon^{\prime \prime}=0\right)$. Esta representación se llama diagrama Cole\&Cole (Cole y Cole, 1941).

\subsubsection{Dispersiones características}

La constante dieléctrica de un tejido celular puede alcanzar valores extremadamente altos a bajas frecuencias, por encima de incluso $10^{6} \mathrm{O} 10^{7}$ por debajo de los $100 \mathrm{~Hz}$ (Gabriel et al, 1996a). La constante dieléctrica va disminuyendo al aumentar la frecuencia en diferentes pasos o dispersiones. La dependencia de las dispersiones con la frecuencia permite identificar e investigar un gran número de fenómenos de relajación, y por ello, el estudio de las 
propiedades dieléctricas en tejidos biológicos ha sido sumamente importante en el campo de la biofísica, así como en otros campos como la medicina, tomando durante los últimos años una marcada importancia en el mundo de la ingeniería de alimentos (Feldman et al, 2003). Un gran número de autores han estudiado estas dispersiones en sistemas biológicos (Grant et al, 1978; Schanne y P-Ceretti, 1978; Pethig, 1979; Schwan y Foster, 1980; Stuchly, 1979; Stuchly y Stuchly, 1980; Schwan, 1981; Foster y Schwan, 1986; Pethig y Kell, 1987; Duck, 1990; Foster y Schwan, 1996; Gabriel y Gabriel, 1996; Gabriel et al, 1996a, b, c; Gabriel, 1996, 2006).

En sistemas biológicos existen principalmente cuatro dispersiones: $\alpha, \beta, \delta$ y $\gamma$ (Figura 1.5) en el rango de frecuencias entre $10 \mathrm{~Hz}$ a $100 \mathrm{GHz}$ (Gabriel et al, 1996b). Cada dispersión corresponde con una determinada polarización producida a una frecuencia de relajación específica. En su forma más simple cada una de estas relajaciones puede ser caracterizada mediante las ecuaciones de Debye (apartado 1.2.2.1). En estas ecuaciones, las constantes ( $\varepsilon_{0}$ y $\left.\varepsilon_{\infty}\right)$ determinan el principio y el final de cada dispersión. El hecho de modelizar las dispersiones puede ser una herramienta de trabajo útil, pero los sistemas biológicos se caracterizan por su elevada complejidad y siempre se debe tener presente esta realidad.

La dispersión $\gamma$, también denominada polarización orientación, se localiza alrededor de $20 \mathrm{GHz}$, y es debida a la polarización de las moléculas de agua libre. Normalmente los alimentos presentan una fase acuosa importante que suele ser la principal responsable del calentamiento de los alimentos mediante energía de microondas. La molécula de agua es, como todo el mundo sabe un dipolo, es decir, la distribución de cargas en dicha molécula es asimétrica, presentando un momento dipolar permanente. Estas moléculas dipolares se orientan al azar en ausencia de un campo eléctrico, de modo que no existe polarización. No obstante y debido a su naturaleza dipolar, al someter a las moléculas de agua a un campo eléctrico a frecuencias de microondas las moléculas se intentan desplazar desde sus posiciones de equilibrio para orientarse siguiendo el campo, almacenando energía que es liberada cuando cesa la aplicación del campo. La contribución de los dipolos a las pérdidas totales tiene lugar cuando aparece un desfase entre la 
alineación del dipolo y el campo; estas pérdidas se conocen como pérdidas dipolares. Cuando este fenómeno ocurre, el material empieza a perder la energía almacenada y la constante dieléctrica decrece. Antes de este momento, el valor de la constante dieléctrica es $\varepsilon_{\mathrm{s}}$ (constante dieléctrica estática). Cuando la frecuencia del campo electromagnético es demasiado alta para la rotación de los dipolos, las pérdidas dipolares cesan y el valor de la constante dieléctrica alcanza de nuevo un valor constante $\left(\varepsilon_{\infty}\right)$. La explicación de este fenómeno es similar a la explicada en el apartado 1.2.2.1, para el caso ideal de los dipolos permanentes en líquidos y en disoluciones de moléculas polares en solventes no polares.

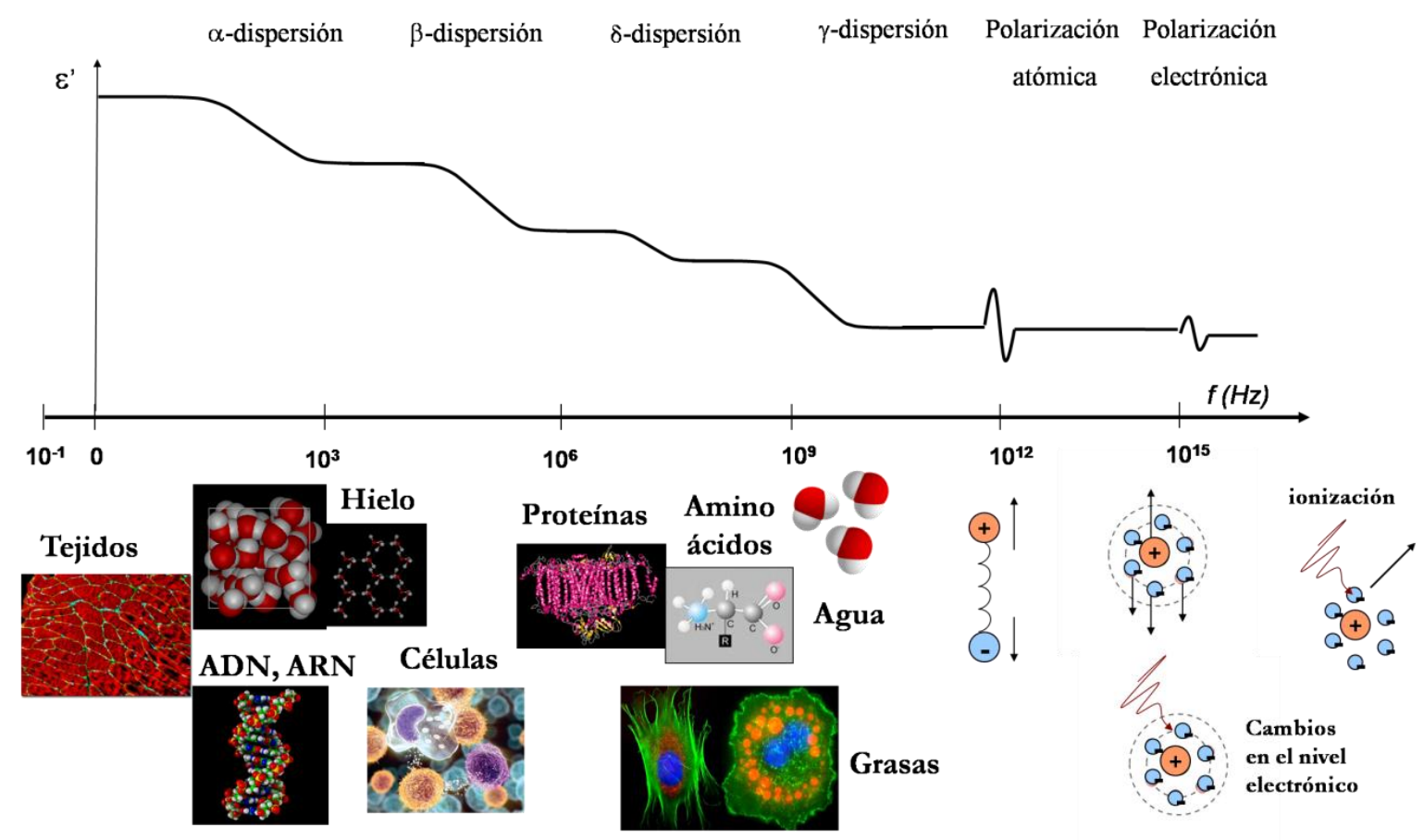

Figura 1.5. Representación esquemática del espectro electromagnético (en escala logarítmica) de los diferentes factores que contribuyen a la constante dieléctrica en sistemas biológicos. Las cuatro relajaciones $(\alpha, \beta, \delta$ y $\gamma)$ que pueden presentarse en estos sistemas han sido también representadas (adaptado de Castro-Giráldez et al, 2008; 2010a). 
La dispersión $\beta$ o polarización interfacial es principalmente debida al efecto Maxwell-Wagner y domina típicamente a frecuencias de radio. Los alimentos son sistemas complejos y eléctricamente heterogéneos, presentando regiones conductoras rodeadas por regiones no conductoras. Este fenómeno es consecuencia de la existencia de las interfases presentes en el material, y son típicas de alimentos coloidales, emulsiones, así como de sistemas biológicos (Foster y Schwan, 1996). Por ejemplo, los alimentos con una estructura celular tienen el citoplasma (región conductora) rodeado por una membrana (región no conductora). En estos casos, los iones se ven atrapados dentro de las interfases (regiones no conductoras) y, debido a que el movimiento de los iones es limitado, las cargas se acumulan incrementando la capacitancia global del alimento (Hewlett-Packard, 1992) y la constante dieléctrica (polarización Maxwell-Wagner o dispersión $\beta$ ). Este fenómeno se produce a bajas frecuencias en las que las cargas tienen suficiente tiempo para acumularse en los bordes de las regiones no conductoras y supone la mayor contribución a la denominada dispersión $\beta$. La contribución al factor de pérdidas relacionada con esta dispersión se conoce como pérdidas Maxwell-Wagner y se debe a que, a frecuencias más altas, las cargas no tienen suficiente tiempo como para acumularse y la polarización de la región conductora no tiene lugar. La curva de las pérdidas Maxwell-Wagner en función de la frecuencia tiene una forma similar a la de la curva de las pérdidas dipolares (Figura 1.8).

Además, otras dispersiones pueden ser producidas por las proteínas u otras macromoléculas a frecuencias comprendidas entre las dispersiones $\beta$ y $\gamma$, dependiendo del tamaño y la carga de las moléculas. La dispersión $\beta$ causada por las proteínas tiene una menor magnitud que la causada por las membranas celulares, y además la frecuencia a la que se produce es ligeramente superior; por ello, la relajación debida a las proteínas aparece como una pequeña cola al final de la gran dispersión $\beta$ causada por la membrana celular (Feldman et al, 2003). Por otra parte, la respuesta dieléctrica de pequeñas biomoléculas como por ejemplo aminoácidos produce también dispersiones a frecuencias características superiores a las descritas para las membranas celulares debido a su menor tamaño. Por ejemplo, la glicina, que es el aminoácido más simple, posee un 
tiempo de relajación parecido al del agua (Figura 1.6). En la figura es posible apreciar en el factor de pérdidas que el pico correspondiente al aminoácido aparece como un pequeño pico en la cola de la relajación correspondiente al agua libre.

El agua ligada a la estructura proteica produce la llamada $\delta$-dispersión que se produce en el rango de frecuencias entre las dispersiones $\beta$ y $\gamma$. Es lógico pensar que las moléculas de agua ligada van a tener una frecuencia de relajación diferente al agua libre ya que su movimiento (polarización) se ve limitado debido a la unión de estas moléculas dipolares al sustrato (Ryynanen, 1995; Craig, 1996). La respuesta dieléctrica del agua depende, por tanto, del entorno en el que estas moléculas dipolares están situadas. Mashimo et al (1987) estudiaron los tiempos de relajación y la estructura del agua ligada en materiales biológicos. Ellos encontraron dos picos debidos a la polarización dipolar del agua a $20^{\circ} \mathrm{C}$ : uno alrededor de $20 \mathrm{GHz}$ (para el agua libre), y el otro alrededor de $100 \mathrm{MHz}$ (posiblemente debido al agua ligada). Además, otros investigadores atribuyeron esa dispersión $\delta$ a la flexibilidad interna de macromoléculas o a la orientación parcial de las cadenas laterales de las mismas (Grant et al, 1978). Por otra parte, la frecuencia de relajación del hielo se encuentra sobre la zona de los kHz (Figura 1.5).

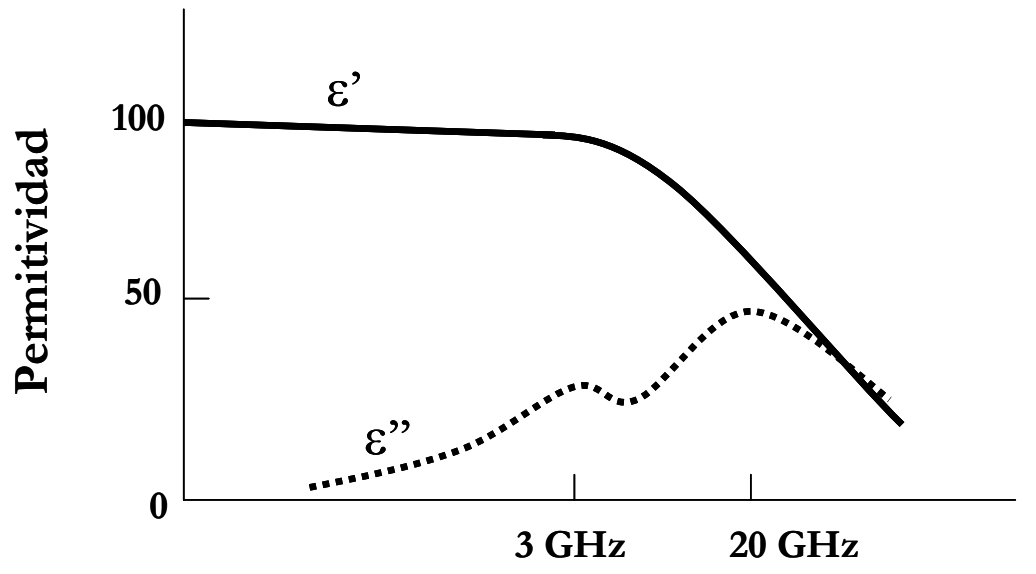

Log frecuencia

Figura 1.6. Espectro dieléctrico de la glicina en agua a $20^{\circ} \mathrm{C}$ (Adaptado de Grant et al, 1978). 
La dispersión $\alpha$ se manifiesta debido a un gran incremento en la permitividad a muy bajas frecuencias; sus causas aún no han sido del todo esclarecidas principalmente debido a los problemas de polarización de electrodos que se presentan al realizar medidas a bajas frecuencias. Esta dispersión puede ser asociada, al menos en parte, a la polarización de la capa de counteriones (doble capa eléctrica) en los tejidos (Gabriel et al, 1996a; Foster y Schwan, 1996). Esta polarización es la principal en sistemas biológicos a frecuencias de Kiloherzios y por debajo de éstas. Muchos investigadores han publicado los efectos correspondientes a la polarización counter en sistemas que contienen superficies cargadas: emulsiones (Hanai, 1968, Dukhin, 1971, Dukhin y Shilov, 1974), suspensiones de esferas de poliestireno cargadas (Schwan et al, 1962), microorganismos (Einolf y Carstensen, 1973), y en cadenas de ADN (Schwarz, 1972). Estudios llevados a cabo por otros autores (Kuang, 1996; Kuang y Nelson, 1997, 1998) asociaron esta dispersión a otro mecanismo: la permeabilidad de la membrana (es decir, los canales iónicos). Estos estudios demostraron la influencia significativa de la estructura de la membrana: su espesor, el tamaño de los poros y el número de éstos, en la dispersión que se produce a bajas frecuencias del espectro.

Por otra parte, este decrecimiento en la permitividad al aumentar la frecuencia va asociado a un incremento de la conductividad eléctrica del tejido. A bajas frecuencias del espectro, la conductividad eléctrica se relaciona directamente con la conductividad del líquido extracelular, ya que se considera que a estas frecuencias la radiación no es capaz de atravesar la membrana celular. La conductividad aumenta ligeramente con el incremento en la frecuencia hasta alcanzar una meseta en el rango de frecuencias $10-100 \mathrm{MHz}$ la cual se asocia a la conductividad de los iones intra y extracelulares. A partir de este punto, la conductividad aumenta drásticamente debido a la relajación de los dipolos de agua (Rigaud et al, 1996) (Figure 1.7). 


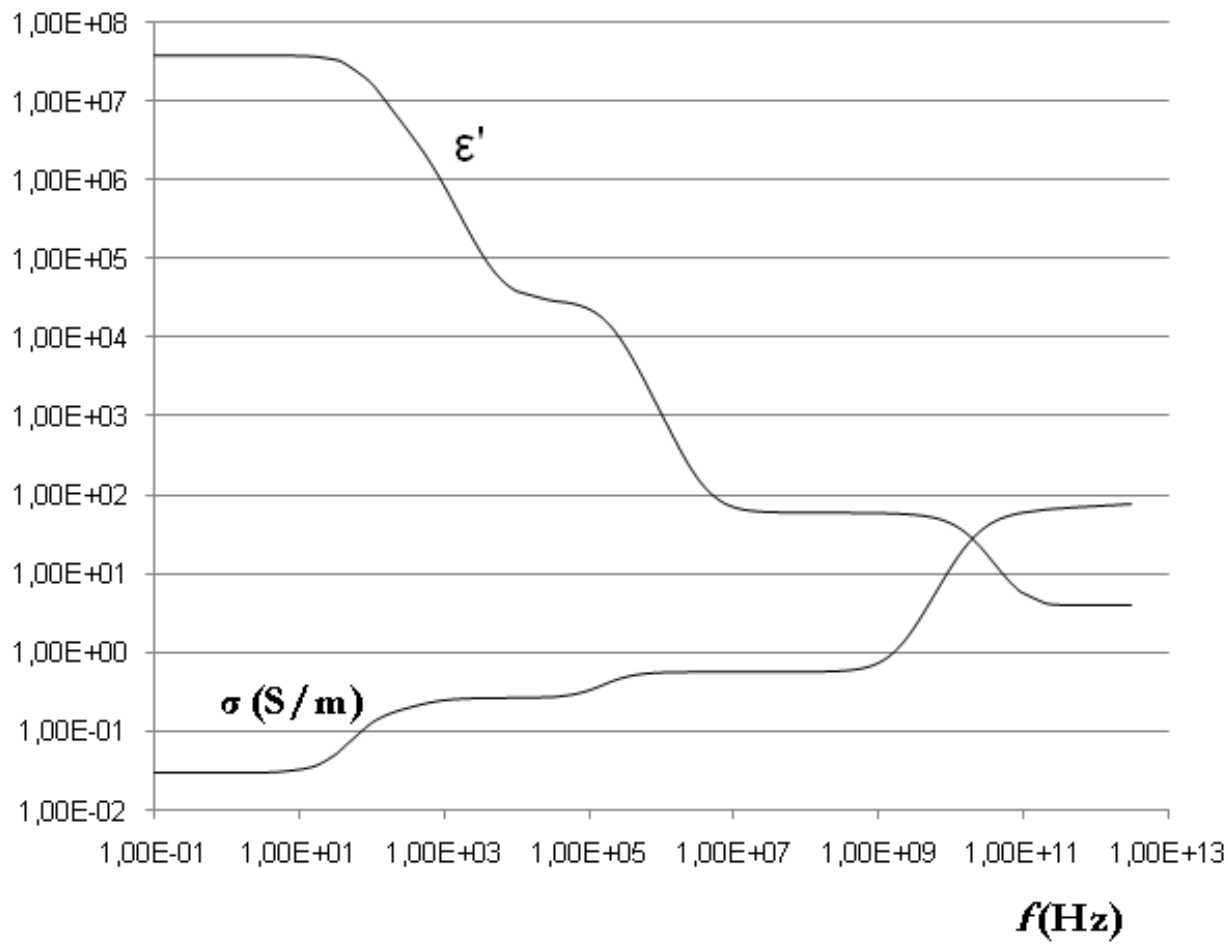

Figura 1.7. Representación ideal de los espectros de la conductividad eléctrica y de la constante dieléctrica (Adaptado de Castro-Giráldez et al, 2010a).

\subsubsection{Contribuciones al factor de pérdidas}

Únicamente un dieléctrico perfecto puede almacenar y liberar la energía electromagnética sin absorberla. Como se ha comentado, el parámetro $\varepsilon$ " está relacionado con la absorción y disipación de energía electromagnética en otros tipos de energía como puede ser por ejemplo la energía térmica (Decareau, 1985). Estas absorciones de energía son causadas por diferentes factores que dependen de la estructura, la composición y la frecuencia.

En la mayoría de técnicas de medida es imposible separar las pérdidas debidas a la conducción de aquellas debidas a polarización. Debido a ello, el factor de pérdidas, $\varepsilon "$, puede ser expresado mediante la siguiente ecuación (Metaxas y Meredith, 1993):

$$
\varepsilon "=\varepsilon_{\mathrm{d}}{ }^{\prime}+\varepsilon_{\mathrm{MWW}} "+\varepsilon_{\mathrm{e}}{ }^{\prime}+\varepsilon_{\mathrm{a}}{ }^{\prime \prime}+\sigma / \varepsilon_{\mathrm{o}} \omega
$$


El último término de la ecuación anterior representa las pérdidas iónicas; $\sigma, \varepsilon_{\mathrm{o}}$ y $\omega$, son la conductividad del material, constante dieléctrica del vacío y frecuencia angular, respectivamente. Los subíndices d, MW, e y a, indican: pérdidas dipolares, efecto Maxwell-Wagner, pérdidas electrónicas y atómicas, respectivamente. Los diferentes mecanismos de contribución al factor de pérdidas en un material con alto contenido en humedad se representan esquemáticamente en la figura 1.8.

Resumiendo, los mecanismos que contribuyen a las pérdidas de energía en sistemas biológicos, en general, incluyen la polarización orientación, polarización electrónica y atómica, conductividad iónica y el efecto Maxwell-Wagner (Metaxas y Meredith, 1993). En los alimentos, las contribuciones más importantes en la banda de microondas y las frecuencias más altas de radio, son debidas principalmente a la rotación de moléculas de agua o de otras moléculas polares como pueden ser los alcoholes, el movimiento de los iones que componen la fase acuosa del alimento, la relajación de las cadenas laterales de las proteínas o del agua ligada a la estructura proteica, o la orientación de los aminoácidos de bajo peso molecular como puede ser la lisina (Grant et al, 1978). 


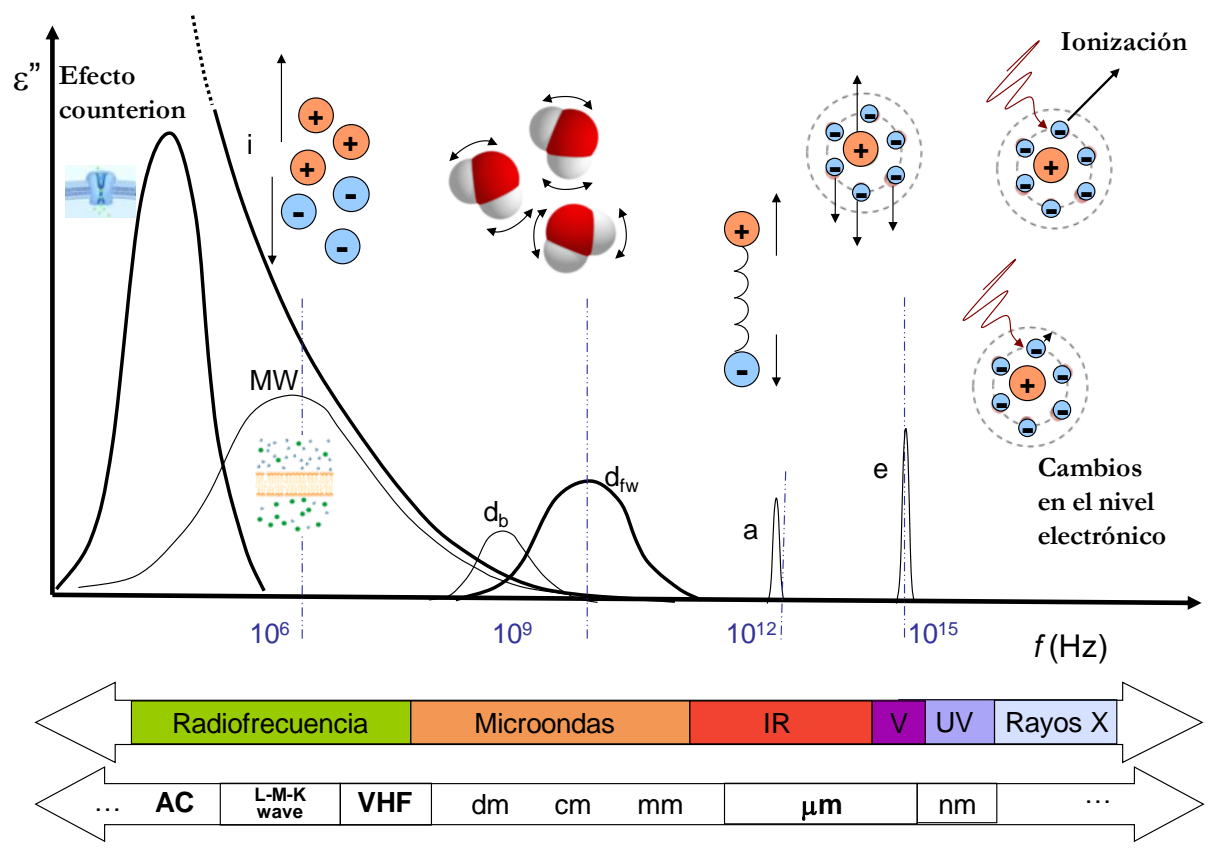

Figura 1.8. Representación esquemática de los diferentes mecanismos que contribuyen al factor de pérdidas a lo largo del espectro electromagnético (Adaptado de Castro-Giráldez et al, 2010a). Donde:

$i:$ pérdidas iónicas, $M W$ : efecto Maxwell-Wagner, $d_{f w}$ : pérdidas dipolares del agua libre, $d_{b}$ : pérdidas dipolares del agua ligada, a: pérdidas atómicas,e: pérdidas electrónicas.

\subsubsection{Principales factores que afectan a las propiedades dieléctricas de alimentos}

Las propiedades dieléctricas de un alimento se ven afectadas por numerosos factores, incluyendo la frecuencia, temperatura, densidad, estructura del alimento, contenido en humedad y otros componentes del alimento como pueden ser el contenido en sales y en grasa (Içier y Baysal, 2004a). A continuación se van a analizar los factores más importantes, tratando de comprender la respuesta del alimento frente a la radiación electromagnética.

\subsubsection{Temperatura}

La temperatura es un factor muy influyente en las propiedades dieléctricas y, como es obvio, debe ser controlado para obtener resultados fiables y 
comparables. A modo de ejemplo, en la figura 1.9 se muestra la influencia de la temperatura sobre el espectro dieléctrico del agua pura. Como se puede apreciar en dicha figura, un incremento en la temperatura provoca un incremento en la frecuencia de relajación. La influencia de la temperatura debe ser estudiada en cada caso ya que el tipo de alimento del que se trate y su composición afectan muy significativamente al efecto que la temperatura tiene sobre las propiedades dieléctricas (Kraszewski y Nelson, 1990). Por ejemplo, las pérdidas dipolares decrecen al aumentar la temperatura para el caso del agua pura como se puede apreciar en la figura 1.8, pero, por el contrario, en disoluciones salinas la contribución de los iones al factor de pérdidas posee un efecto diferente, de tal modo que la conducción iónica provoca un aumento en el factor de pérdidas al aumentar la temperatura debido al decrecimiento en la viscosidad del líquido y al incremento en la movilidad de los iones (Datta et al, 2005). Por otra parte, el factor de pérdidas de disoluciones de glucosa resultó disminuir al incrementar la temperatura debido al incremento en la solubilidad del azúcar (Ver el efecto de los azúcares sobre las propiedades dieléctricas de disoluciones, apartado 1.2.3.3.2) (Liao et al, 2003).

Para la mayoría de alimentos, las propiedades dieléctricas aumentan a medida que el alimento se descongela, después cae gradualmente a medida que se incrementa la temperatura (Bengtsson y Risman, 1971). Las propiedades dieléctricas de la carne congelada son muy bajas y no se ven afectadas a temperaturas por debajo de $-10^{\circ} \mathrm{C}$ (Mudgett et al, 1979). El agua congelada es poco móvil y también afecta a los iones del alimento provocando una reducción en su movilidad. 


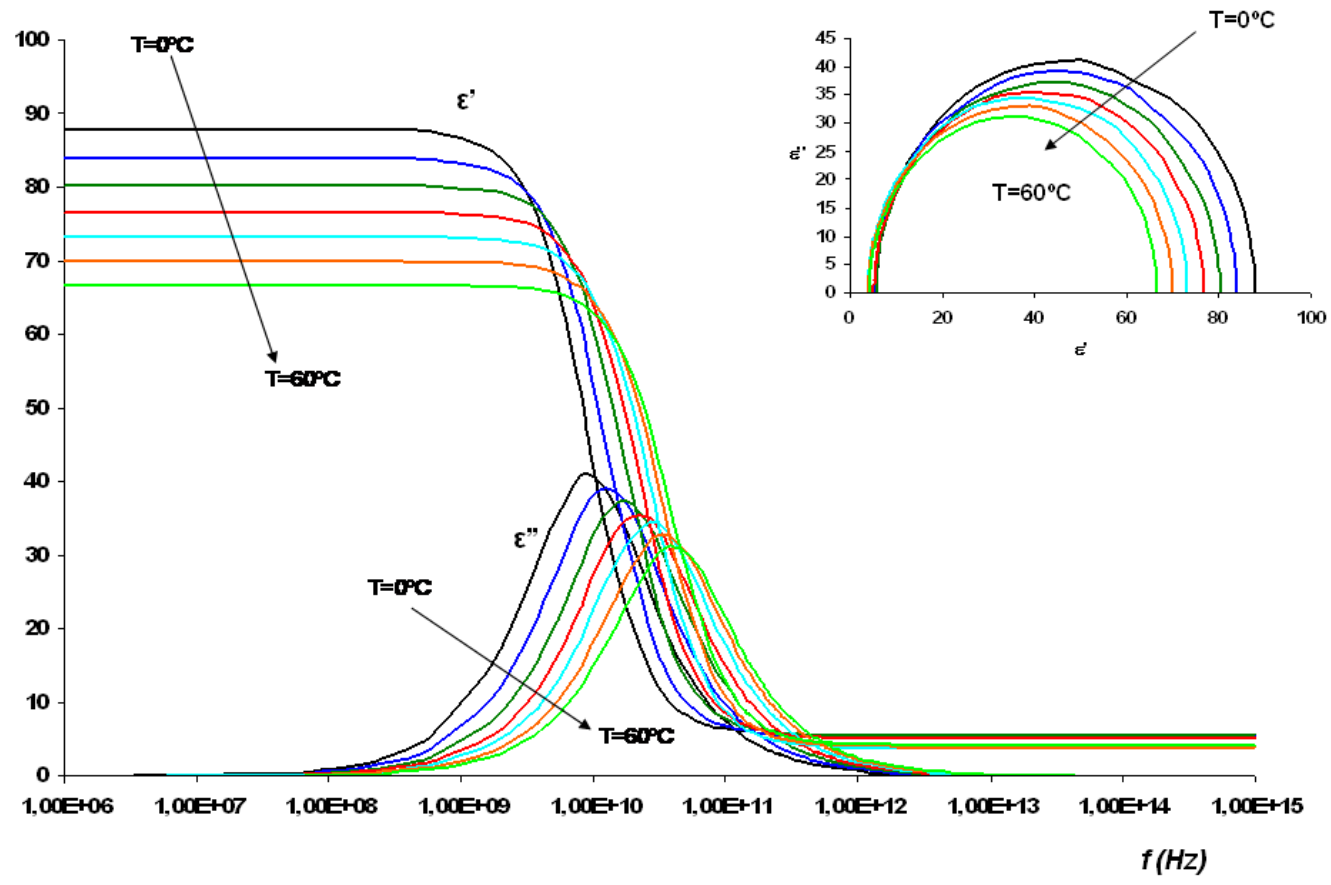

Figura 1.9. Representación de las propiedades dieléctricas para el agua pura a diferentes temperaturas $\left(0,10,20,30,40,50,60^{\circ} \mathrm{C}\right)$. Gráfico de elaboración propia aplicando el modelo de Debye (Debye, 1929) y los parámetros para el agua pura a diferentes temperaturas obtenidos de la fuente: Kaatze (1989).

\subsubsection{Frecuencia}

Las propiedades dieléctricas de los alimentos son fuertemente dependientes de la frecuencia de medida. La figura 1.8 representa la contribución de la conductividad iónica y los mecanismos de polarización sobre el factor de pérdidas. Cada mecanismo contribuye al factor de pérdidas en un rango de frecuencias concreto. Por otra parte, tal y como se observa en la figura 1.5 cada dispersión ocurre en un rango de frecuencias características del espectro.

El modelo de Debye (1929) puede ser utilizado para describir esa dependencia con la frecuencia para el caso de líquidos puros tal y como se explicó en la sección 1.2.2.1. Por otra parte existen extensiones de las ecuaciones de Debye, en las que se tratan de abarcar casos que impliquen la influencia de las partículas vecinas sobre las moléculas dipolares y en las que se considere más de un tiempo de relajación (Cole y Cole, 1941). Algunas de las extensiones al modelo de Debye se presentan en el apartado siguiente. 


\subsubsection{Composición del alimento}

Obviamente las propiedades dieléctricas de los alimentos dependen de su composición. El contenido en humedad, el contenido en sales, hidratos de carbono, proteínas y grasa son algunos de los componentes más influyentes. La constante dieléctrica y el factor de pérdidas están afectados por la presencia de agua libre y agua ligada, las cargas superficiales, electrolitos, no electrolitos, así como por los puentes de hidrógeno presentes en el alimento (Datta et al, 2005). Los cambios físicos sufridos en el alimento durante su procesado, por ejemplo deshidratación, desnaturalización de proteínas, así como los cambios bioquímicos en algunos alimentos con estructura celular, o los cambios sufridos por las frutas durante su senescencia, afectan a las propiedades dieléctricas de manera significativa. Por ello, el estudio del comportamiento de las propiedades dieléctricas cuando existen cambios en la composición del alimento es necesario a la hora de estudiar la viabilidad de estos métodos basados en las microondas y radiofrecuencia de señal para su aplicación como sensores de control en línea no destructivos. Antes de explicar detalladamente la influencia de cada componente sobre las propiedades dieléctricas, en la tabla 1.1 se presenta cualitativamente la contribución al factor de pérdidas de algunos componentes del alimento.

A lo largo de la historia, diversos autores han tratado de modelizar las propiedades dieléctricas en función de la composición del producto. Para el caso de disoluciones salinas, se desarrollaron ecuaciones predictivas utilizando el modelo Hasted-Debye (Mudgett et al, 1974a). Estos modelos podrían aplicarse para estudiar el comportamiento de sólidos solubles y algunos constituyentes proteicos en alimentos reales (Mudgett, 1985). Por otra parte, los constituyentes insolubles, cuyo efecto consiste en deprimir la constante dieléctrica y el factor de pérdidas en mezclas acuosas como pueden ser emulsiones agua-aceite, se pueden predecir por el modelo de Fricke (Mudgett et al, 1974b). Este modelo puede aplicarse en alimentos coloidales para comprender el comportamiento de lípidos, proteínas e hidratos de carbono (Mudgett, 1985). Otros constituyentes como pueden ser alcoholes o azúcares, interaccionan con las moléculas de agua provocando un cambio en la frecuencia de relajación debido a la formación de 
puentes de hidrógeno entre los grupos hidroxilo de estos compuestos y el agua (Buck, 1965, Roebuck et al, 1972). El efecto de estos compuestos se modelizó mediante el modelo de Maxwell-Debye (Mudgett et al, 1974b).

Tabla 1.1. Contribución cualitativa sobre el factor de pérdidas de los constituyentes mayoritarios de los alimentos a frecuencia de microondas (Fuente: Shukla y Anantheswaran, 2001).

\section{Componentes de los alimentos}

Contribución al factor de pérdidas

Agua ligada

Baja

Agua libre

Alta

Proteínas

Baja

Triglicéridos

Baja

Fosfolípidos

Media

Almidón

Baja

Monosacáridos

Alta

Electrolitos ligados

Baja

Iones

Alta

Por tanto, existe una dependencia clara de las propiedades dieléctricas con la composición, que, como se ha visto, ha sido ampliamente modelizada para sistemas simples (disoluciones, mezclas binarias, etc.). Es importante destacar que los alimentos presentan una gran complejidad y que las propiedades dieléctricas reflejan las distintas contribuciones simultáneas de los diferentes componentes presentes en el mismo, y que además estos componentes sufren interacciones entre sí. Los alimentos líquidos y semisólidos pueden ser más fácilmente modelizados en función de su composición, ya que su actividad dieléctrica se asocia fundamentalmente al volumen de fase líquida, en cuyo caso será fundamental la composición de la misma, y cuyo comportamiento puede ser modelizado por los modelos explicados en el párrafo anterior. Por otra parte, la modelización resulta más compleja a medida que aumenta el grado de estructuración (Mudgett, 1985); si además el alimento tiene estructura celular el 
nivel de complejidad es máximo porque se presentan numerosos mecanismos dieléctricos de manera simultánea (véase la sección 1.2.2) que dificultan la comprensión o predicción del valor de las propiedades dieléctricas o de la forma de los espectros completos. Muchos autores han utilizado ecuaciones para predecir el comportamiento dieléctrico de este tipo de alimentos (To et al, 1974, Kent y Jason, 1975, Mudgett et al, 1977, 1980; Swami y Mudgett, 1981; Nelson y Russell, 1986; Ohlsson, 1987). Dichos modelos consideran el alimento constituido por una matriz sólida insoluble y una disolución acuosa dieléctricamente muy activa. Por lo tanto fundamentalmente se considera el volumen de agua libre y la conductividad iónica como los mecanismos dieléctricos más influyentes. Más recientemente se han realizado estudios que han considerado también el mecanismo interfacial (Maxwell-Wagner) y la anisotropía del sistema (Clerjon y Damez, 2007).

\subsection{E1 agua}

El agua es uno de los constituyentes más importantes de los alimentos, por ello es considerado un factor determinante en las propiedades dieléctricas de éstos. En este tipo de sistemas, el agua es el medio en el que se encuentran disueltas sales, proteínas, ácidos nucleicos, y otras moléculas de pequeño tamaño; por ello, es difícil de comprender y predecir el comportamiento dieléctrico de los alimentos basándose únicamente en el comportamiento del agua.

Muchas de sus particulares propiedades físicas se deben a su asimetría molecular, naturaleza polar, y la habilidad que posee de formar puentes de hidrógeno. Sus propiedades dieléctricas han sido ampliamente estudiadas (Cook, 1952; Haggis et al, 1952; Lane y Saxton, 1952; Hasted y El Sabeh, 1953; von Hippel, 1954a; Grant et al, 1957; Hasted, 1961; Grant y Shack, 1967; Bengtsson y Risman, 1971; Roebuck et al, 1972; Grant y Sheppard, 1974; Schwan et al, 1976; Nelson, 1978a,b; Grant et al, 1981; Hasted et al, 1985; Kaatze, 1986, 1988, 1989, 1995, 1996, 1997, 2000, 2005; Buckmaster, 1990; Nelson et al, 1991; Ellison et al, 1996; Barthel et al, 1998; Buchner et al, 1998; Ndife et al, 1998; Kraszewski, 2000). 
El efecto de la humedad sobre la constante dieléctrica del alimento es claro: cuanto mayor es el contenido en humedad del producto mayor es la constante dieléctrica (Nelson, 1978b, 1987; Prakash et al, 1992; Ndife et al, 1998; Funebo y Ohlsson, 1999; Garcia et al, 2001). La adición o sustitución de agua por componentes dieléctricamente menos activos o componentes que liguen agua normalmente decrece la constante dieléctrica del alimento (Ryynanen, 1995). Tanto el agua considerada libre como la ligada contribuyen a la transformación de la energía electromagnética en calor, aunque esta última en mucha menor medida. Por otra parte, el efecto de la humedad sobre el factor de pérdidas no es tan claro y será dependiente de la composición del producto, ya que además de la contribución dipolar al factor de pérdidas también serán importantes las contribuciones iónicas, por lo que la predicción de su variación con respecto al contenido en humedad es compleja. En este sentido se han realizado numerosos estudios en alimentos (Van Dyke et al, 1969; Roebuck et al, 1972; To et al, 1974; Nelson, 1978a,b; Mudgett et al, 1980; Padua, 1993; Tulasidas et al, 1995; Bircan y Barringer, 1998; Funebo y Ohlsson, 1999; Kraszewski, 2000; Sipahioglu, 2002).

Es importante destacar que en los sistemas biológicos, el agua que se encuentra interaccionando con la matriz sólida del alimento (agua ligada) se caracteriza por un tiempo de relajación menor al del agua libre (Feldman et al, 2003). La frecuencia de relajación del agua ligada es $10^{6}-10^{8.5} \mathrm{~Hz}$, mientras que la frecuencia de relajación del agua libre es $10^{9}-10^{11} \mathrm{~Hz}$ (De Loor y Meijeboom, 1966). Algunos estudios dieléctricos de proteínas en sistemas acuosos apoyan esta teoría (Schwan, 1965; Grant, 1965; Grant et al, 1968) debido a que es posible observar un pequeño proceso de relajación llamado dispersión $\delta$ atribuido al agua ligada a las proteínas (Véase sección 1.2.2.2). Esta dispersión se encuentra situada entre dos grandes dispersiones, la $\beta$ y la $\gamma$, debidas a la rotación de las proteínas y al agua libre, respectivamente. Esta dispersión se caracteriza por su gran amplitud. El agua ligada no se encuentra siempre en el mismo estado, unas veces se encuentra fuertemente ligada a las proteínas mediante puentes de hidrógeno, o se encuentra atrapada en el interior de la red proteica, otras veces se encuentra unida mediante fuerzas electrostáticas a grupos hidrofílicos de la superficie de las proteínas, otras veces pueden no encontrarse directamente ligada a las proteínas 
sino que pueden estar fuertemente ligadas a otras moléculas de agua que sí se encuentran ligadas a las proteínas. Por estos motivos, los fenómenos de relajación del agua denominada comúnmente "ligada" no corresponden a un único tiempo de relajación sino a varios en función de en qué estado se encuentren las moléculas de agua, y la dispersión $\delta$ será una superposición de esas dispersiones (Feldman et al, 2003).

\section{$\underline{\text { Actividad del agua }}$}

Las proteínas, los hidratos de carbono, así como las sales interaccionan con el agua produciendo un decrecimiento en la constante dieléctrica. La actividad de agua decrece a medida que aparecen componentes en el alimento que reducen su movilidad, y es una medida termodinámica de la cantidad de agua que se encuentra interaccionando con la matriz sólida del alimento. Por otra parte, la espectroscopia dieléctrica proporciona información sobre las interacciones de las moléculas con su entorno, por ello cabe esperar que las propiedades dieléctricas tengan relación directa con la actividad del agua del alimento, lo cual puede resultar muy interesante debido a la comodidad y facilidad de las medidas dieléctricas. Se han realizado pocos estudios que relacionen la actividad de agua con las propiedades dieléctricas, siendo necesario ampliar las investigaciones en este campo. Un estudio llevado a cabo por Clerjon et al (2003), obtuvo correlaciones entre la actividad del agua y algunas propiedades dieléctricas como la frecuencia de relajación, proporcionando resultados prometedores sobre la influencia del $\mathrm{NaCl}$ en las medidas dieléctricas y la posibilidad de relacionar las propiedades dieléctricas con isotermas de sorción de agua en alimentos.

\subsection{Contribución de los solutos}

\section{Hidratos de carbono}

El efecto de los solutos no polares en disolución acuosa provoca una disminución de la permitividad estática con respecto a la del agua pura a la misma temperatura (Figuras 1.10 y 1.11). Esta disminución es debida a que al existir moléculas del soluto no polar, los dipolos de agua se encuentran diluidos y su 
respuesta dieléctrica es menor. Además, debido a las interacciones de los dipolos de agua con el soluto (puentes de hidrógeno), la dispersión se produce en un intervalo más amplio de frecuencias y se desplaza a frecuencias más bajas (Kaatze, 2005). Estos efectos se acentúan si se aumenta la concentración de solutos (Kaatze, 1995, 1997, Kaatze et al, 2002). Esta dispersión es más ancha que la que se predice con el modelo de Debye y ha sido modelizada mediante otras expresiones: Cole-Cole (1941), Davidson y Cole (1951).

En la figura 1.10 se puede observar el efecto que tiene un azúcar simple, como es la D-Xilosa, en disolución, en comparación con el espectro del agua pura a la misma temperatura. Por otra parte, la figura 1.11 muestra el efecto de un disacárido como es la D-Maltosa, al ser disuelto en agua pura, sobre el espectro dieléctrico.

Por tanto, los azúcares modifican el comportamiento dieléctrico del agua. Los puentes de hidrógeno estabilizan las moléculas de agua y afectan a las propiedades dieléctricas de la disolución. El grado de interacción con las microondas depende de la cantidad de puentes de hidrógeno que puedan ser formados. Los grupos hidroxilo de la glucosa son más accesibles que los del almidón para la formación de puentes de hidrógeno. En el almidón pocos grupos hidroxilo están disponibles para reaccionar con el agua, y por tanto, pocos puentes de hidrógeno pueden ser formados. Por ello, la presencia de almidones en disolución produce una menor reducción en las propiedades dieléctricas que la ocasionada por los azúcares (Roebuck et al, 1972). En la figura 1.12 se muestran los espectros correspondientes a la constante dieléctrica y al factor de pérdidas de disoluciones de sacarosa con distintos ${ }^{\circ}$ Brix, pudiéndose observar la disminución de la constante de pérdidas, así como del aplanamiento del factor de pérdidas y la disminución de la frecuencia de relajación, al aumentar la concentración de sacarosa en la disolución. En la figura 1.13 se muestra la representación Cole\&Cole de las mismas disoluciones de sacarosa. 

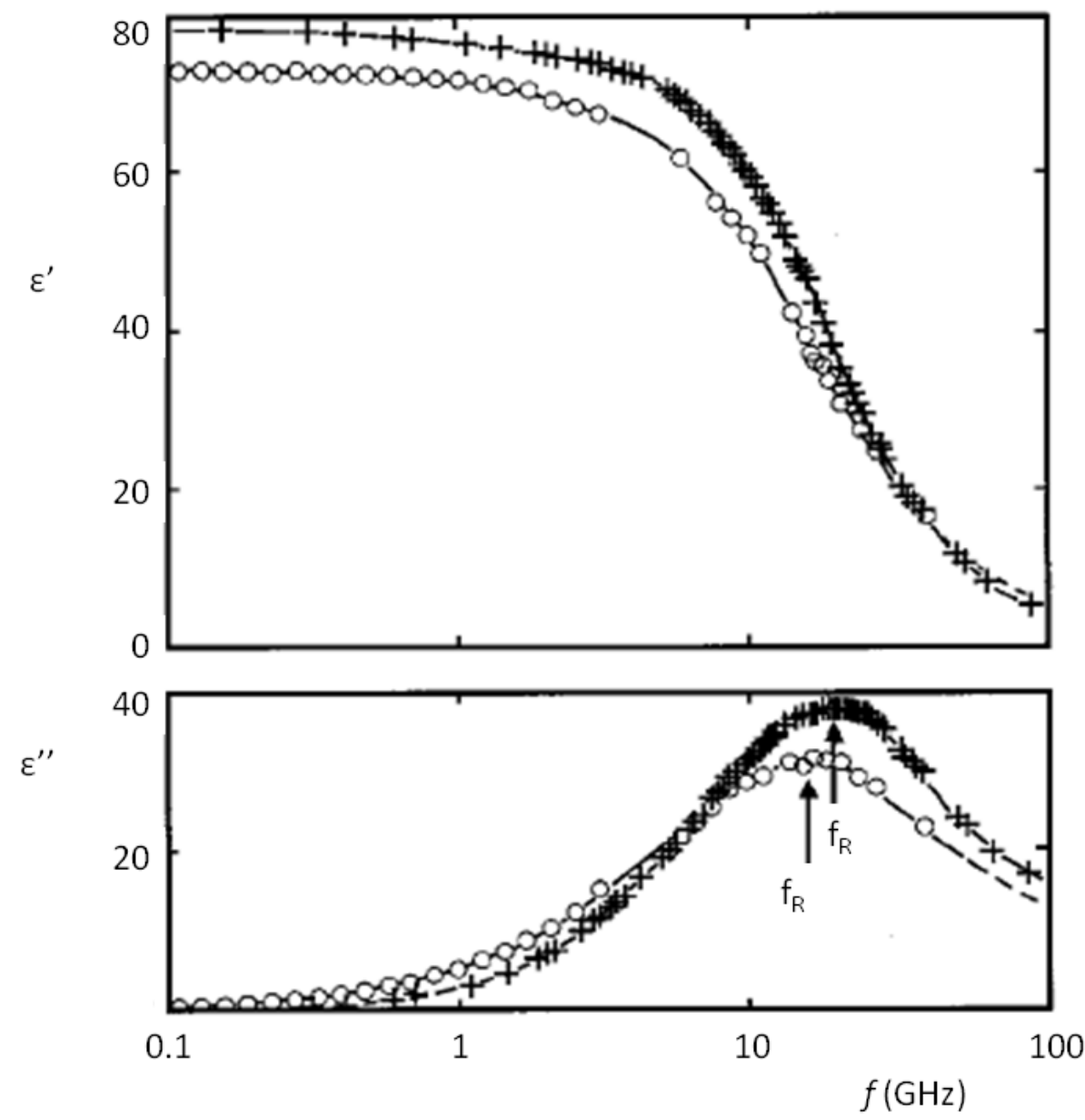

Figura 1.10. Espectros de la constante dieléctrica y del factor de pérdidas para el agua (+) y para una disolución de $1 \mathrm{~mol} / \mathrm{L}$ de $\mathrm{D}$-Xilosa en agua $(\mathrm{O})$ a $25^{\circ} \mathrm{C}$ (Adaptada de Fuchs y Kaatze, 2002).

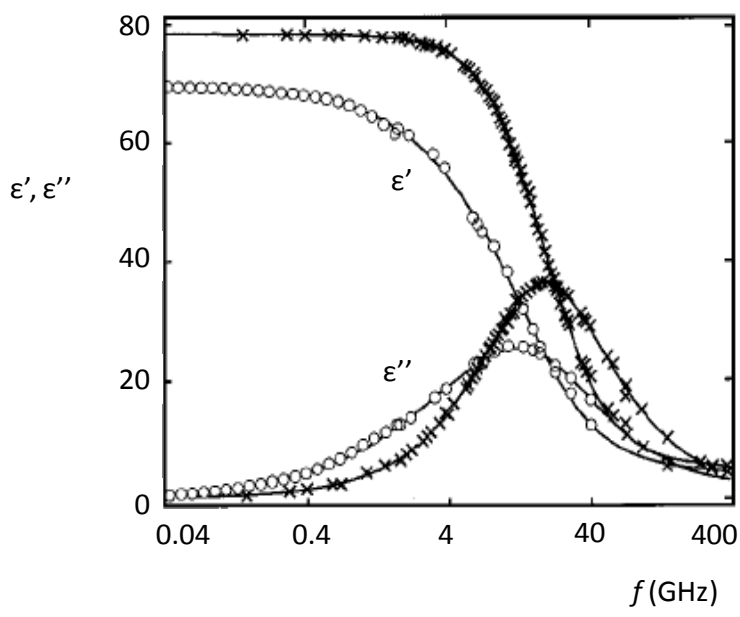

Figura 1.11. Espectros de la constante dieléctrica y del factor de pérdidas para el agua $(\times)$ y para una disolución de $1 \mathrm{~mol} / \mathrm{L}$ de D-Maltosa en agua $(\mathrm{O})$ a $25^{\circ} \mathrm{C}$ (Adaptada de Fuchs y Kaatze, 2002). 


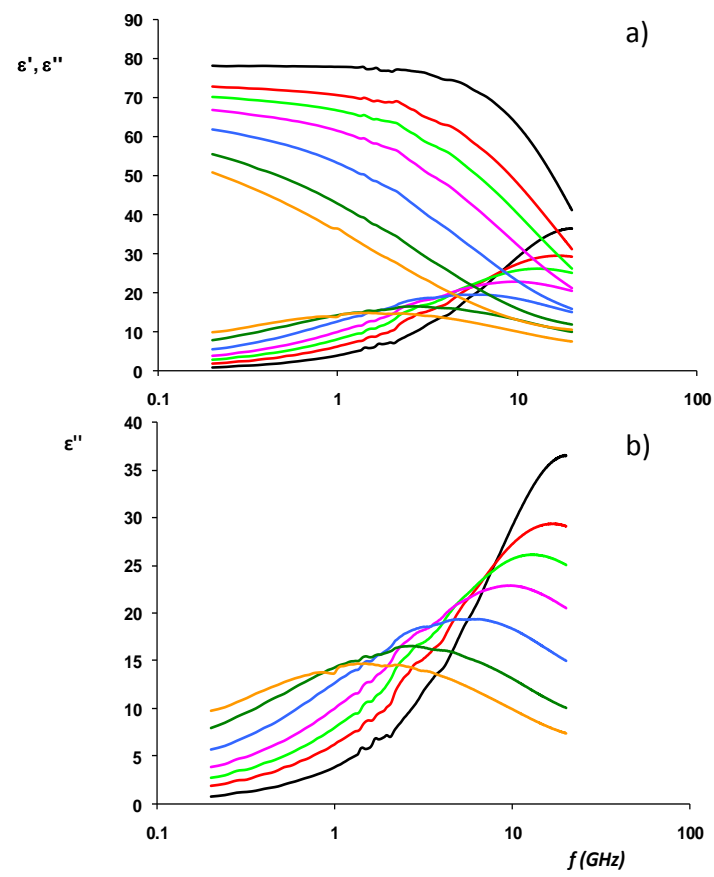

Figura 1.12. a) Espectros dieléctricos de la constante dieléctrica y del factor de pérdidas correspondientes a disoluciones de agua y sacarosa medidos a $30^{\circ} \mathrm{C}$, siendo $(-)$ agua pura, disoluciones (-) $20^{\circ}$ Brix, (-) $30^{\circ}$ Brix, (-) 40 Brix, (-) 50 Brix, (-) $60^{\circ}$ Brix, (-) $65^{\circ}$ Brix. b) Detalle del factor de pérdidas de las mismas disoluciones.

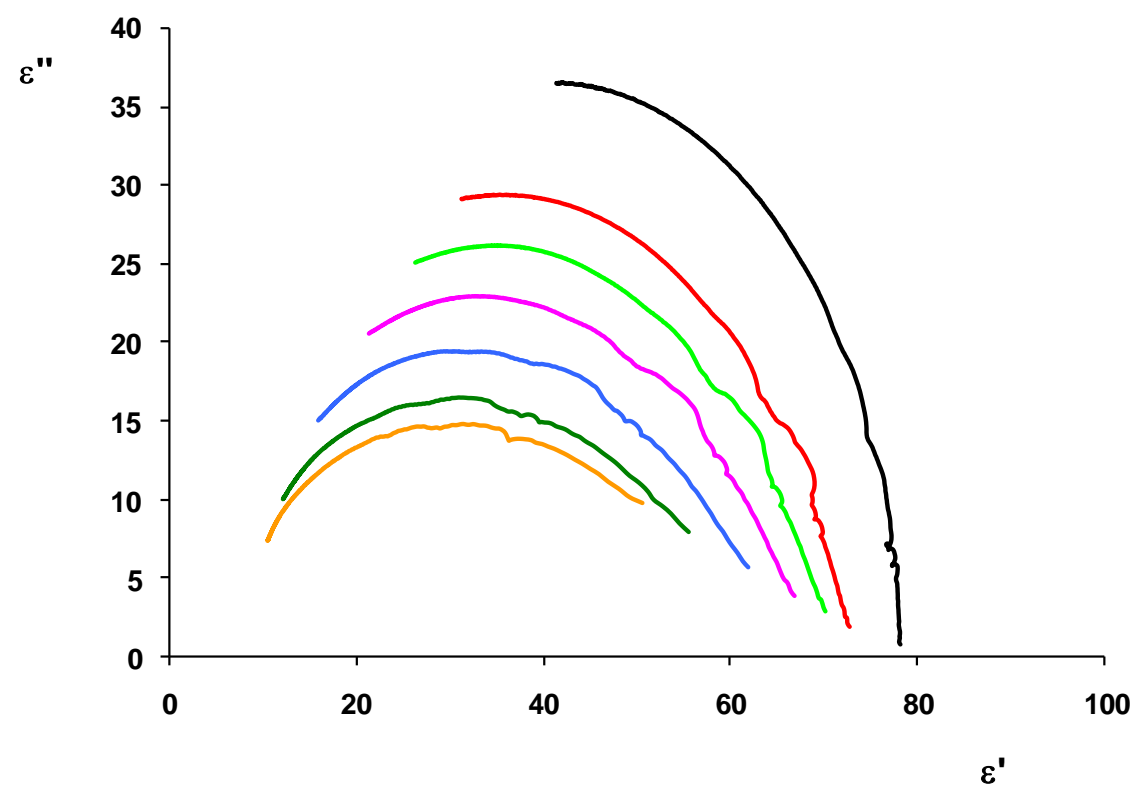

Figura 1.13. Representación Cole\&Cole de disoluciones de agua y sacarosa medidos a

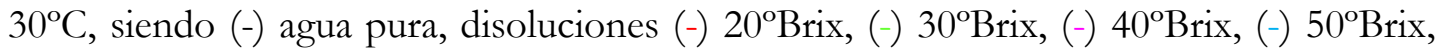
(-) $60^{\circ}$ Brix, (-) $65^{\circ}$ Brix. 


\section{Electrolitos}

El efecto de los electrolitos en las propiedades dieléctricas de alimentos es diferente al de los solutos no polares. En los alimentos, los electrolitos que se encuentran más abundantemente son las sales y ácidos.

Como ejemplo se puede observar en la figura 1.14 el espectro del factor de pérdidas de disoluciones con diferentes contenidos en cloruro sódico a $4^{\circ} \mathrm{C}$. La concentración de sal produce un marcado efecto sobre las propiedades dieléctricas de las disoluciones salinas, como cabía esperar. El incremento en la concentración de sal provoca un aumento en el factor de pérdidas debido a la contribución de la conductividad iónica sobre el factor de pérdidas (Figura 1.14). Dicha contribución aumenta al incrementar el contenido en sal, enmascarándose la contribución de las pérdidas dipolares. Además la presencia de sal produce un marcado decrecimiento en el valor de la permitividad estática que refleja, en parte, la orientación preferencial de los dipolos de agua en el pequeño campo eléctrico provocado por los pequeños iones. Este efecto se denomina saturación dieléctrica (Kaatze, 2005). Por otra parte, en la misma figura se ha representado además el diagrama Cole\&Cole tanto para disoluciones de concentración creciente de $\mathrm{NaCl}$ como para el agua pura, observándose el marcado efecto del $\mathrm{NaCl}$ sobre las propiedades dieléctricas también en este tipo de representación.

De manera similar a lo que se produce en disoluciones salinas, la adición de sal a un alimento provoca una reducción de la constante dieléctrica debido a la habilidad de la sal de ligar moléculas de agua del sistema (Datta et al, 2005). La fuerza que provoca este efecto depende del tamaño y la carga de la molécula añadida. Por otra parte, la adición de sal incrementa el factor de pérdidas por encima de aquel del agua pura debido a la presencia de iones (Shukla y Anantherswaran, 2001). 


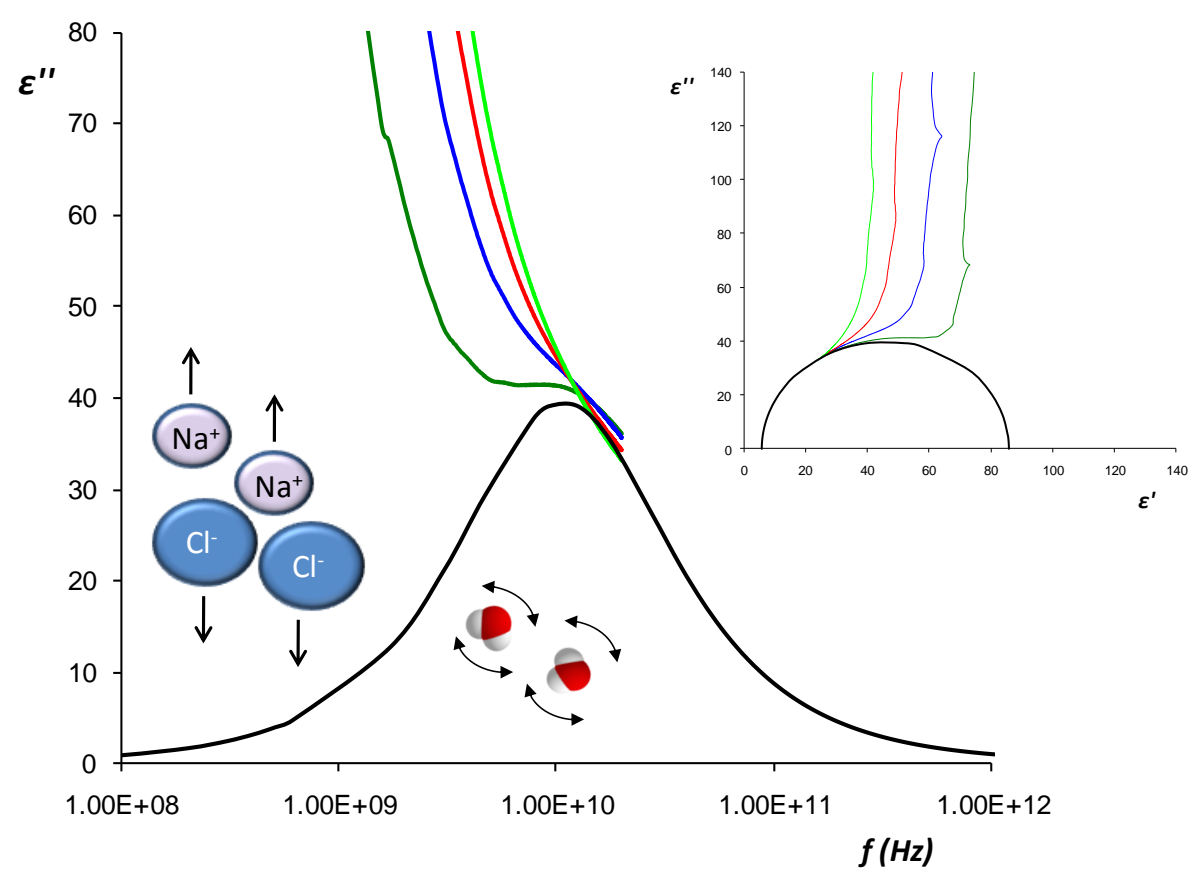

Figura 1.14. Influencia del contenido en $\mathrm{NaCl}$ en la forma del espectro del factor de pérdidas en sistemas con diferentes proporciones de agua (dipolos) y $\mathrm{NaCl}$ (iones) a $4^{\circ} \mathrm{C}$, siendo (-) agua pura, (-) salmuera $5 \%,(-)$ salmuera $10 \%,(-)$ salmuera $15 \%,(-)$ salmuera $20 \%$. En la parte superior derecha de la figura se puede apreciar la representación Cole\&Cole de las mismas disoluciones.

Por otra parte, las propiedades dieléctricas de ácidos no han sido prácticamente estudiadas. En la parte de resultados de esta tesis se presentan medidas dieléctricas de diversos patrones de interés preparados con distintas concentraciones de ácidos en agua.

\section{$\underline{\text { Proteínas }}$}

Los sistemas acuosos pueden contener proteínas u otras biomoléculas que son capaces de mostrar varias dispersiones. Una proteína normalmente posee un peso molecular de varios órdenes de magnitud superiores al agua. Consecuentemente, la dispersión dieléctrica ocasionada por la proteína ocurre a frecuencias menores que la debida a las moléculas de agua pura (Gabriel et al, 1998). En el caso particular de una proteína globular como es la hemoglobina, esta frecuencia de relajación se produce en el rango de $1-10 \mathrm{MHz}$, mientras que para el agua pura la dispersión se produce alrededor de 20GHz. La figura 1.15 
correspondería al espectro de una disolución poco concentrada de proteína en agua; en este caso el volumen de agua apenas se ve afectado por la presencia de proteínas ya que éstas se encuentran a baja concentración (Keefe y Grant, 1974, Grant, 1966, Grant et al, 1971). En dicha figura se aprecian las dispersiones $\beta$ y $\gamma$, correspondientes a la proteína y al agua respectivamente. A mayores concentraciones de proteína, una cantidad significante de agua se ve influenciada por la proteína, comúnmente denominada agua ligada. Este agua produce una dispersión diferente al volumen de agua libre, tal y como se ha explicado en el apartado 1.2.2.2, situándose dicha dispersión entre las dispersiones $\beta$ y $\gamma$.

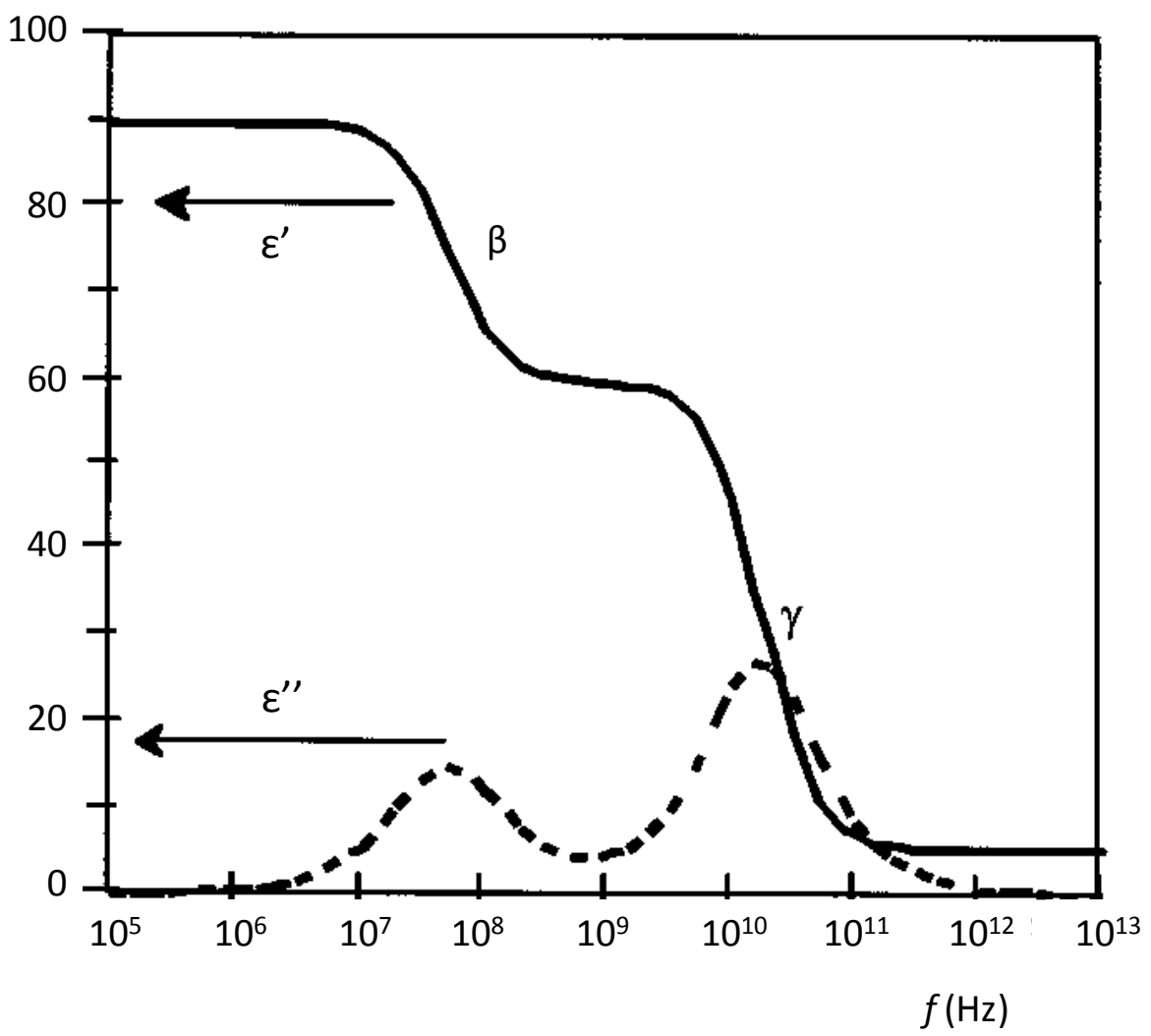

Figura 1.15. Representación esquemática del espectro dieléctrico de disoluciones acuosas de proteínas.

Las proteínas son prácticamente inertes a frecuencias de microondas (Tabla 1.1), pero tienen cargas superficiales que pueden ligar agua o sales, provocando un pequeño efecto a estas frecuencias. Las propiedades dieléctricas de las proteínas dependen de sus cadenas laterales, las cuales pueden ser apolares, 
en orden decreciente: alanina, glicina, leucina, isoleucina, metionina, fenilalanina y valina; o polares, en orden decreciente: tirosina, triptófano, serina, treonina, prolina, lisina, arginina, ácido aspártico, aspargina, ácido glutámico, cisteína e histidina (Shukla y Anantheswaran, 2001). La forma hidratada de las proteínas, proteínas hidrolizadas, polipéptidos y aminoácidos son más reactivos a frecuencias de microondas (Pethig, 1979).

Es importante destacar que la desnaturalización de las proteínas afectará a las propiedades dieléctricas. Este fenómeno se define como el cambio físico sufrido por la molécula debido a diferentes causas: bajada del $\mathrm{pH}$ del medio, calentamiento, adición de $\mathrm{NaCl}$, etc., que resulta en una reducción de la solubilidad proteica, una pérdida de cristalización y un incremento en la viscosidad de la disolución (McWilliams, 1989). Por tanto, debido a la desnaturalización de las proteínas se producen cambios en la estructura de las mismas, así como en el contenido de agua libre del sistema, afectando significativamente a las propiedades dieléctricas (Bircan et al, 2001, Bircan y Barringer, 2002a, b).

\subsubsection{Estructura del alimento}

La estructura tiene una gran influencia en el valor que adquieren las propiedades dieléctricas del alimento. Como ya se ha explicado en el apartado 1.2.2.2, los alimentos con estructura celular son sistemas complejos que poseen el citoplasma (región conductora) rodeado por una membrana (región no conductora); los iones se ven atrapados dentro de las interfases (regiones no conductoras) y, debido a que el movimiento de los iones es limitado, las cargas se acumulan incrementando la capacitancia global del alimento (Hewlett-Packard, 1992) y la constante dieléctrica (polarización Maxwell-Wagner o dispersión $\beta$. A frecuencias de microondas, la principal contibución de la estructura vendrá caracterizada por la limitación del movimiento de dipolos e iones causada por las membranas celulares. A continuación se van a presentar de manera muy resumida las principales características de la estructura del tejido animal así como del vegetal, para comprender mejor el apartado de resultados de la presente tesis. 


\subsection{Estructura del tejido animal}

El músculo esqueletico posee una compleja organización, en parte para transmitir eficientemente la fuerza que se origina en las miofibrillas al músculo entero y, de este modo, generar el movimiento del músculo. Una relativamente fina capa de tejido conectivo, el epimisio, rodea a todo el músculo y lo protege (Figura1.16). En la mayoría de músculos, el epimisio se prolonga hacia el tendón, que ejerce de unión del músculo con los huesos. El músculo se divide en haces o grupos de células musculares. Estos haces, también denominados fascículos, están rodeados por otra capa de tejido conectivo, el perimisio. A su vez, cada fibra está rodeada de una capa de tejido conectivo llamada endomisio (Guil, 2001).

Cada fibra del músculo esquelético es funcionalmente equivalente a una sola célula. Las fibras pueden tener una longitud que oscila de pocos a decenas de centímetros, siendo sin embargo su anchura de tan sólo 60-100 $\mu \mathrm{m}$ de diámetro. Las fibras contienen todos los orgánulos que se pueden encontrar normalmente en una célula viva. Rodeando a la célula está el sarcolema, que es una delicada membrana situada inmediatamente debajo del endomisio (Warris, 2003).

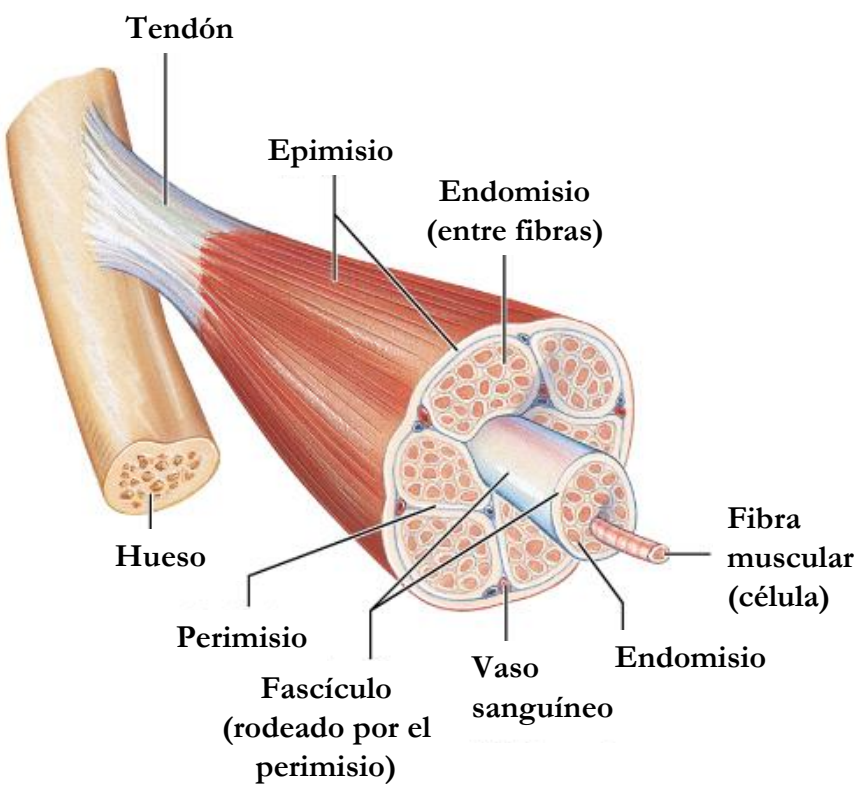

Figura 1.16. Componentes del músculo esquelético (Adaptado de Campbell y Reece, 2005). 
En una sola fibra puede haber entre mil y dos mil miofibrillas de más o menos $1 \mu \mathrm{m}$ de diámetro cada una, dispuestas longitudinalmente. Cada miofibrilla está constituida por elementos de menor tamaño llamados filamentos. Estos pueden ser de dos tipos, filamentos gruesos (sobre $15 \mathrm{~nm}$ de diámetro) compuestos fundamentalmente por la proteína miosina, y filamentos delgados (aproximadamente $7 \mathrm{~nm}$ de diámetro) compuestos fundamentalmente por la proteína actina. Bajo ciertas condiciones la actina y la miosina pueden reaccionar produciendo una contracción del sistema, y por lo tanto del músculo en su totalidad (Warris, 2003).

Una característica peculiar de las fotografías de las secciones longitudinales de músculos esqueléticos cuando son observadas al microscopio es la presencia de bandas o estriaciones transversales regulares. Este hecho ha dado el nombre de estriado como otra posible forma de denominar al músculo esquelético. A menos que se tiña de una manera especial, los músculos no presentan normalmente la apariencia estriada cuando son enfocados correctamente con el microscopio óptico. Sin embargo, las estriaciones pueden observarse usando tanto un microscopio de luz polarizada como uno de contraste de fase. Esto es debido a que las estriaciones son originadas por la alternancia de bandas de proteínas con un índice de refracción mayor o menor, ya que las bandas con un índice de refracción alto son birrefringentes. Las bandas oscuras que se observan en el microscopio de luz polarizada pueden por lo tanto denominarse bandas A y las bandas que las separan (claras) son bandas I. En la actualidad se sabe cómo ese patrón de banda se relaciona con la organización estructural entre los filamentos gruesos y delgados. Así, la banda A está constituida por filamentos gruesos conjuntamente con la parte de los filamentos delgados que se superpone a éstos, mientras que la banda I está formada principalmente por filamentos delgados. Dado que las miofibrillas están alineadas de una manera exacta, el patrón de bandas continúa a lo largo de las fibras musculares. También se han definido otras líneas y zonas, entre las que se encuentran la zona $\mathrm{H}$, y las líneas $\mathrm{M}$ y Z. La línea Z tiene su significado funcional particular; es en realidad un disco a través del que los filamentos delgados pasan. Líneas $Z$ adyacentes delimitan la 
unidad funcional de la miofibrilla, denominada sarcómero (Figura 1.17). Así pues, una miofibrilla está formada por miles de sarcómeros, cuya longitud varía con el estado de contracción (Cassens, 1994, Lawrie, 1998).

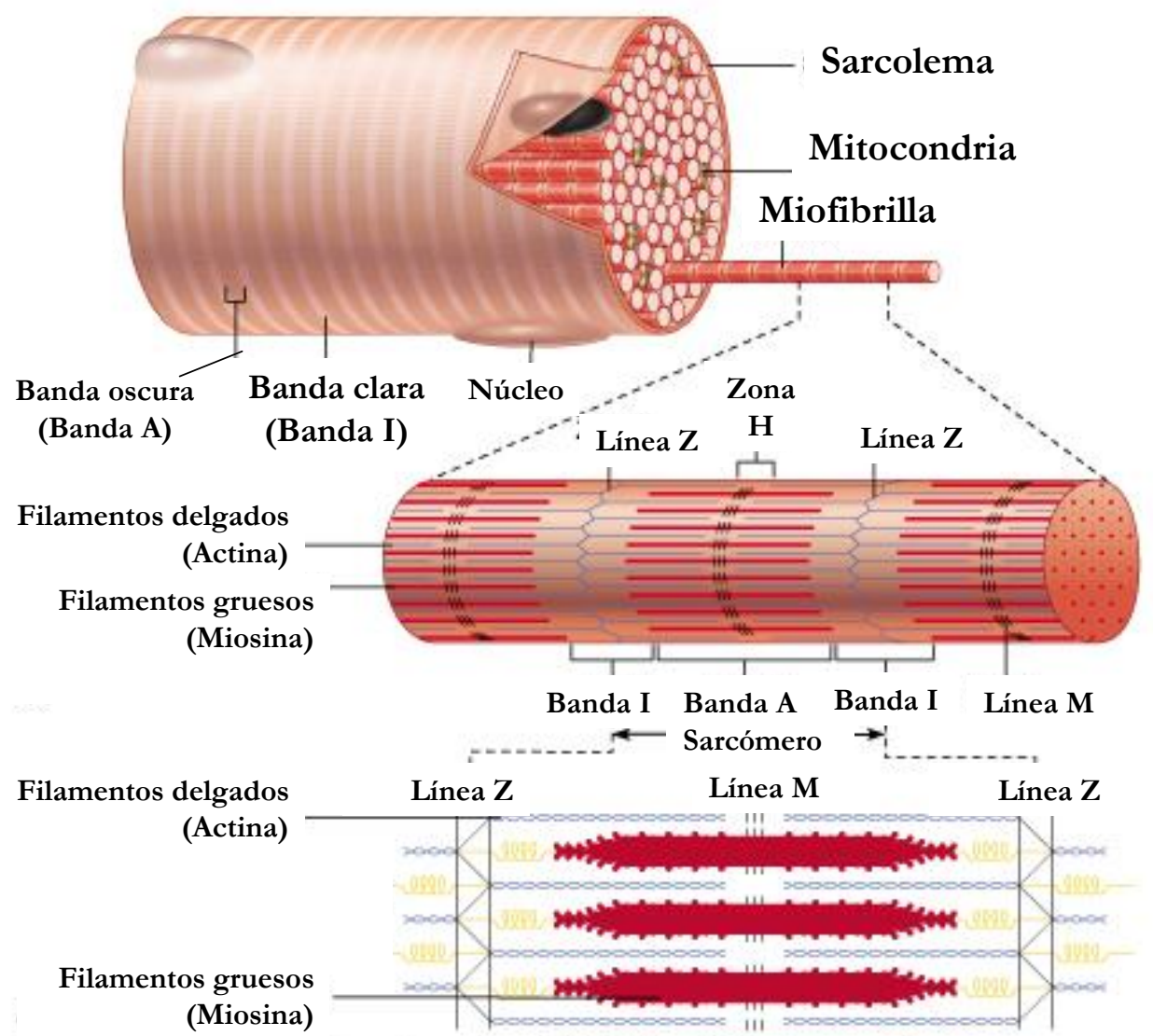

Figura 1.17. Estructura de las fibras musculares (Adaptado de Campbell y Reece, 2005).

\subsection{Estructura del tejido vegetal}

El tejido parenquimático en frutas se considera como un sistema biológico constituido por células ensambladas en una compleja estructura con conexiones intercelulares, espacios intracelulares y espacios extracelulares. Por otra parte, las frutas están compuesta fundamentalmente por: agua, sólidos insolubles, sólidos solubles y gases; estos componentes están distribuidos en cuatro fases diferentes: la matriz sólida, que está fundamentalmente integrada por las membranas 
celulares, incluyendo la pared celular (PC), el plasmalema (MP) y el tonoplasto (T), y los orgánulos celulares del citoplasma (c); la fase líquida intracelular; la fase líquida extracelular y el gas (Fito et al., 2007) (Figura 1.18).

El volumen de las células parenquimáticas está principalmente ocupado por grandes vacuolas centrales (v), que fundamentalmente son disoluciones acuosas con múltiples solutos entre los que se encuentran metabolitos como los aminoácidos, ácidos orgánicos (ácido málico) y diversos sacáridos (fructosa), e iones inorgánicos (potasio). La membrana que delimita a la vacuola es el tonoplasto, y se caracteriza por ser selectivamente permeable e intervenir en el mantenimiento de la turgencia vegetal y en el crecimiento celular (Salisbury y Ross, 1991).

Dentro de la estructura de la célula vegetal, requieren una mención especial las membranas celulares, que proporcionan una barrera efectiva frente al espacio extracelular. Tradicionalmente se pensaba que el agua era transportada a través de la bicapa lipídica por difusión simple, pero estudios recientes identificaron proteínas especializadas en el transporte de agua (aquaporins) situadas en las membranas con una intrínseca elevada permeabilidad al agua (Agre et al., 1998).

Además existe una capa rígida rodeando la membrana celular llamada pared celular, que gracias a su característica composición y estructura, proporciona a la célula vegetal fuerza mecánica y flexibilidad frente a una posible distensión de la membrana plasmática. Esta pared está formada por microfibrillas de celulosa embebidas en una matriz amorfa altamente hidratada. Entre las paredes de las células adyacentes se encuentra una fina capa de material llamada lámina media, formada por pectatos de calcio y magnesio y otros componentes con propiedades cementantes que colaboran con la adhesión entre células (Taiz y Zeiger, 2006). En la pared celular existen unos canales de unión, denominados plasmodesmos, que permiten la comunicación entre células adyacentes. 

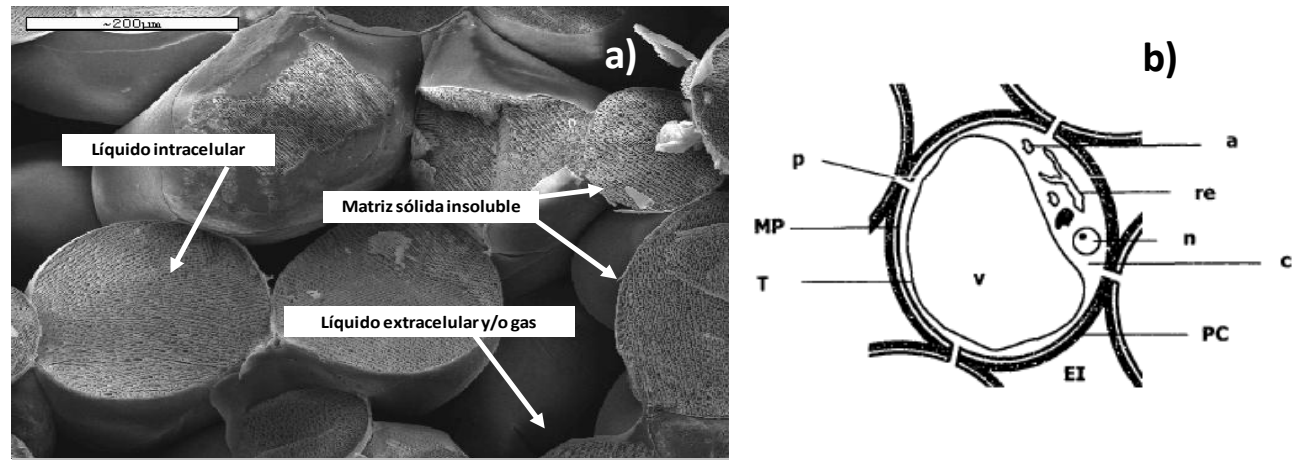

Figura 1.18. a) Tejido parenquimático de manzana "Granny Smith” observada con CryoSEM (Fito et al., 2008). b) Esquema de una célula vegetal típica del tejido parenquimático (Albors, 2002).

Es importante destacar en este apartado en el que se está describiendo la unidad estructural del tejido parenquimático, que existen tres diferentes caminos para que un soluto o solvente fluya a través del tejido cuando éste está siendo sometido a un tratamiento osmótico (Figura 1.19). El transporte apoplástico, que es externo a la membrana celular. El transporte simplástico, que permite el movimiento molecular entre células a través de los plasmodesmos. Finalmente, el transporte a través de la membrana, que puede ser descrito como un intercambio entre el protoplasto y el espacio libre compuesto por el espacio extracelular y la pared celular (Tyerman et al., 1999).

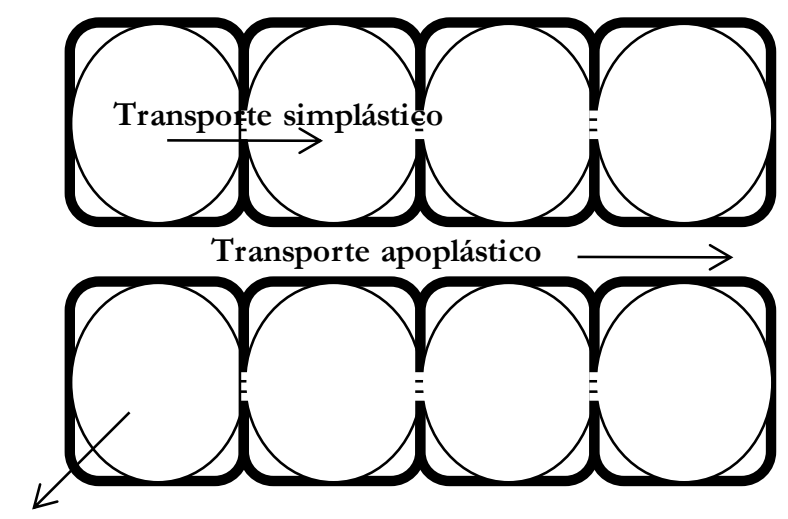

Transporte transmembrana

Figura 1.19. Representación esquemática del tejido parenquimático de manzana en el que se representan los distintos tipos de transporte que puede experimentar un soluto a través del tejido. 


\subsubsection{Técnicas de medida}

La medida de las propiedades dieléctricas ha adquirido mucha importancia debido al reciente desarrollo de sistemas de control de calidad de productos alimentarios basados en la radiación electromagnética. Existen diferentes técnicas de medida de las propiedades dieléctricas de productos (Bussey, 1967; Thompson y Zachariah, 1971; Kraszewski, 1980; Afsar et al, 1986; Nelson y Kraszewski, 1990; Andrade et al, 1992; Metaxas y Meredith, 1993; Birch et al, 1994; Jain y Voss, 1994; Nelson, 1999; Nelson y Bartley, 2000; Datta et al, 2005; Agilent Technologies, 2006)

La técnica de medida a emplear para la determinación de las propiedades dieléctricas de alimentos depende de la naturaleza física y eléctrica del mismo, la frecuencia de interés, así como el grado de precisión requerido (Datta et al, 2005; Venkatesh y Raghavan, 2005). Normalmente la permitividad no se mide directamente sino que es obtenida a partir de la medida de impedancia, pérdidas por transmisión, reflectividad, etc. (Alabaster, 2004). Los analizadores de redes disponen del software para transformar las magnitudes medidas en permitividad y, aunque resultan bastante caros, son muy versátiles y útiles si los estudios a realizar son extensos (Nelson y Kraszewski, 1990).

Los métodos de medida de propiedades dieléctricas se clasifican en métodos de reflexión o transmisión que dependen de sistemas resonantes o no resonantes, con estructuras abiertas o cerradas (Kraszewski, 1980). Las guías de onda y las líneas de transmisión coaxiales son métodos con estructuras cerradas, mientras que las técnicas de espacio libre y las sondas coaxiales terminadas en abierto son métodos con estructuras abiertas. Las estructuras resonantes pueden incluir tanto cavidades resonantes cerradas como abiertas que trabajan conectadas a dos puertos para las medidas de transmisión, o conectadas a un puerto para las medidas en reflexión (Nelson, 1999).

\subsubsection{Platos paralelos}

Este método de medida consiste en intercalar una lámina delgada de material entre dos electrodos construyendo de esta forma un condensador 
(Figura 1.20). Se suele utilizar un medidor LCR o un analizador de impedancia para obtener los parámetros capacitancia (C) y factor de disipación (D). A partir de estos parámetros se obtiene la constante dieléctrica así como el factor de pérdidas. Este método de medida exige que la muestra sea una lámina plana y lisa (Agilent Technologies, 2000), lo cual, en ciertos casos, puede resultar un inconveniente por la dificultad de preparación de la muestra.

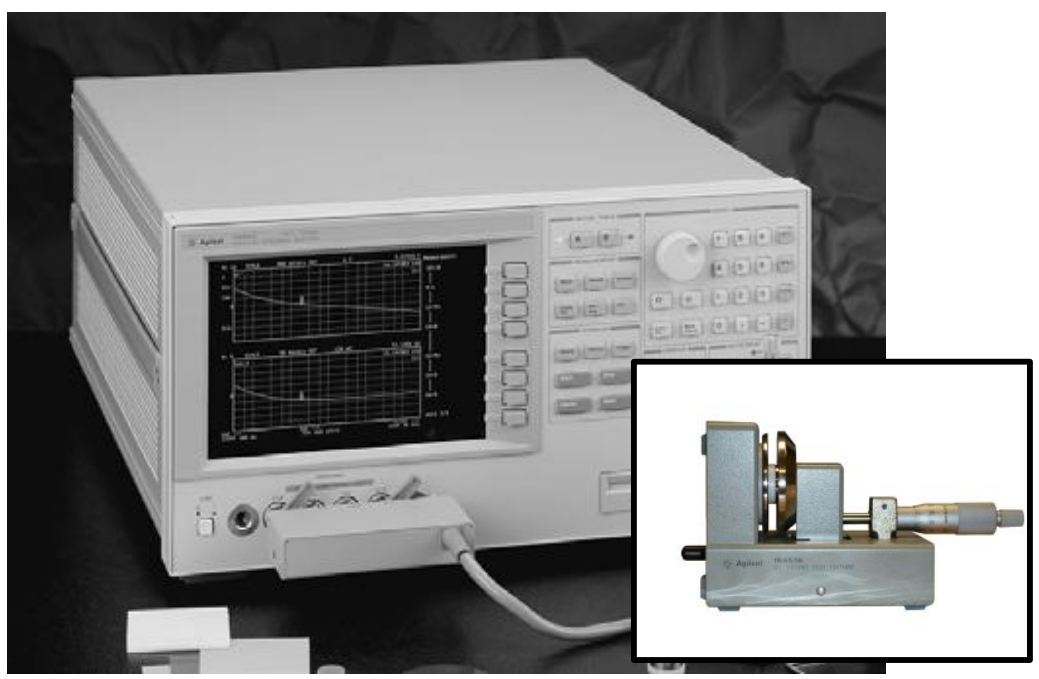

Figura 1.20. Analizador de Impedancias y sensor de platos paralelos (Agilent Technologies, EEUU).

\subsubsection{Sonda coaxial}

En este método, la constante dieléctrica y el factor de pérdidas se determinan mediante la medida de las ondas reflejadas por la muestra, la cual está localizada al final de la sonda coaxial, que consiste básicamente en una sección cortada de una línea de transmisión. Mediante esta técnica se obtienen espectros dieléctricos en un amplio rango de frecuencias $(0.2-50 \mathrm{GHz})$, y es utilizada principalmente para líquidos y semisólidos. También es posible la medida de sólidos cuya superficie sea lisa, por lo que esta técnica puede ser apropiada para muchos alimentos. Además este método es de los pocos que puede ser utilizado en animales vivos (Gabriel y Gabriel, 1996; Raicu et al, 2000). 
Las medidas se realizan introduciendo la sonda en el interior de la muestra líquida o semisólida, o mediante un íntimo contacto entre la sonda y la superficie lisa del sólido. Se asume que el material objeto del estudio es de espesor infinito y no-magnético. Este método es no destructivo y fácil de usar, además no necesita preparación de la muestra. Por otra parte, sus desventajas serían el requerimiento de un determinado espesor de la muestra, además de su menor precisión si es comparado con otros métodos de medida como pueden ser las líneas de transmisión o las cavidades resonantes (Agilent Technologies, 2004). Otra desventaja sería la posibilidad de cometer errores de medida debido a la presencia de aire entre la sonda y la muestra; además es importante destacar que para que la medida sea representativa de la muestra, ésta debe ser homogénea. Este método se utiliza para fluidos, pastas y productos triturados, como son: margarinas, productos cárnicos, y productos de la pesca (Kent, 2001).

El típico sistema de sonda coaxial consiste en un analizador de redes, una sonda coaxial, un ordenador externo y un software para calcular la permitividad a partir de la medida de los parámetros S, una vez el equipo haya sido calibrado. Existen diferentes tipos de sondas coaxiales que pueden ser conectadas a un analizador de redes. En la figura 1.21 se muestran tres posibilidades comercializadas por la casa Agilent ${ }^{\circledR}$ (Agilent Technologies, EEUU).

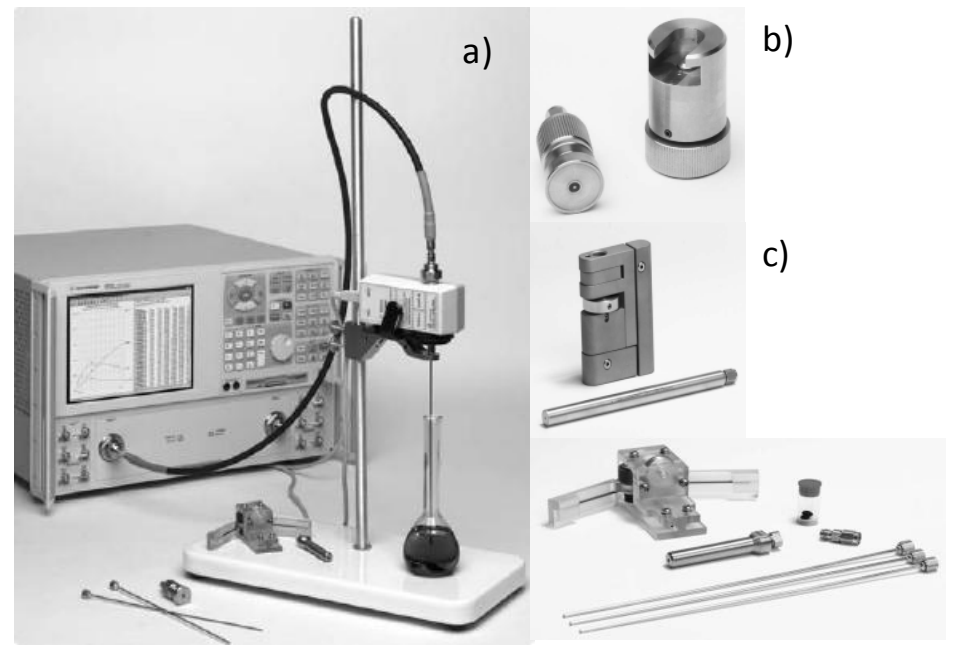

d)

Figura 1.21. a) Técnica de medida de sonda coaxial conectada a un Analizador de Redes. b) c) d) Posibles sondas que se pueden conectar al Analizador de Redes en el sistema de Sonda Coaxial (Agilent Technologies, 2008). 


\subsubsection{Línea de Transmisión}

Este método utiliza una guía de onda o una sonda coaxial en línea, conectada mediante dos puertos a un analizador de redes (Figura 1.22). Uno de los factores fundamentales de esta técnica de medida es la preparación de la muestra. Muestras rectangulares o muestras anulares deben ser preparadas tanto para la guía de onda como para la sonda coaxial, respectivamente. Mediante esta técnica es posible determinar tanto la permitividad como la permeabilidad, a partir de la amplitud y la fase de las señales de microondas reflejadas por el material o transmitidas a través del material que es objeto de estudio. Este método es útil para sólidos duros maleables y requiere una determinada forma de muestra, por ello, normalmente es un método destructivo. Por otra parte es un método más preciso que la sonda coaxial, aunque a veces presenta ciertas dificultades para materiales de bajas pérdidas.

Este método se utiliza para fluidos, pastas y productos triturados como margarinas, quesos, productos cárnicos (Kent, 2001).
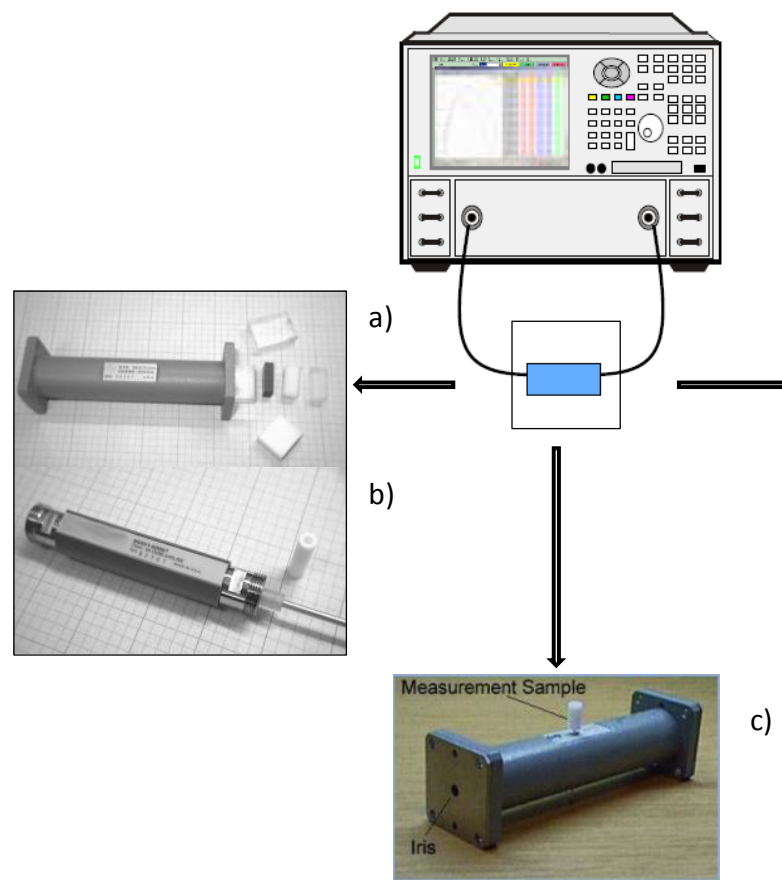

Figura 1.22. Esquema de las diferentes técnicas de medida de propiedades dieléctricas a) Fotografía de una guía de onda b) Fotografía de una línea de transmisión coaxial c) Fotografía de una cavidad resonante (Agilent Technologies, 2004, 2006) d) Fotografía de antenas para la técnica de espacio libre. 


\subsubsection{Cavidades resonantes}

Las cavidades resonantes son estructuras que suelen presentar un alto factor de calidad Q, y que resuenan a ciertas frecuencias. Cuando una muestra de material dieléctrico se introduce en el interior de la cavidad se produce una alteración de la frecuencia de resonancia, que disminuye ligeramente, así como del factor de calidad (Rzepecka, 1973). A partir de los cambios experimentados por estos parámetros, se puede calcular la permitividad compleja o la permeabilidad del material, para un valor concreto de frecuencia, precisamente la frecuencia de resonancia (Catalá, 1999). Claramente, el tamaño de la cavidad se reduce a medida que aumenta la frecuencia, pudiendo conllevar ciertos problemas técnicos a frecuencias de microondas (Alabaster, 2004). Este método es uno de los más precisos para la medida de permitividad (Jain y Voss, 1994). Por otra parte, esta técnica trabaja a una única frecuencia en vez de en un amplio espectro y presenta la desventaja de que la muestra debe presentar una geometría específica (Agilent Technologies, 2006). Normalmente se utiliza para productos fluidos como la mantequilla o la margarina (Kent, 2001). Este método ha sido utilizado para la medida de propiedades dieléctricas de tejido biológico (Campbell, 1990, Campbell y Land, 1992).

\subsubsection{Técnicas de Espacio libre}

La técnica de espacio libre es un método no destructivo y de no contacto. No requiere una preparación especial de la muestra. Es particularmente apropiada para materiales a altas temperaturas y para dieléctricos nohomogéneos. Además, puede ser fácilmente incorporada en la línea de proceso para la realización de un control continuo de algún parámetro relevante del producto, con la ventaja de que puede ser, además, monitorizado (Kraszewski et al, 1995). En esta técnica la muestra se sitúa entre una antena emisora y una receptora, midiendo la atenuación y el cambio de fase de la señal. La técnica de espacio libre permite la medida precisa de la permitividad en un amplio rango de frecuencias. En la mayoría de estos sistemas de medida, la precisión de $\varepsilon^{\prime}$ y $\varepsilon^{\prime \prime}$ 
depende principalmente de la forma de llevar a cabo el sistema de medida, así como de la validez de las ecuaciones de cálculo empleadas. Normalmente esta técnica es utilizada a altas frecuencias para poder trabajar con tamaños de muestra manejables. Por otra parte, las muestras que se utilizan en esta técnica deben poseer superficies planas paralelas (Agilent Technologies, 2005a) y además se asume la hipótesis de que el tamaño de la muestra es lo suficientemente grande como para rechazar cualquier efecto de difracción causado por los bordes de la muestra (Trabelsi et al, 1998).

Esta técnica se utiliza en alimentos principalmente para productos de humedad baja o intermedia, para materiales laminados, polvos, granos, mantequillas, crema de queso, disoluciones azucaradas, productos confitados y repostería (Kent, 2001).

\subsection{Aplicación de la espectroscopia dieléctrica al control de calidad de alimentos. Revisión bibliográfica.}

Las propiedades dieléctricas en alimentos, cuando se correlacionan con otros parámetros, como contenido en humedad o densidad, pueden ser utilizadas para medir eléctricamente estas características. Como hemos mencionado anteriormente, la frecuencia, temperatura, contenido en sal, humedad, estado del agua (congelada, libre o interaccionando con la matriz) son los principales factores que influyen en las propiedades dieléctricas en materiales biológicos y de la agricultura (Tran et al, 1984; Engelder y Buffler, 1991; Seaman y Seals, 1991; Herve et al, 1998; Berbert et al, 2001; Feng et al, 2002). Içier y Baysal (2004a) realizaron una extensa revisión sobre las propiedades dieléctricas de alimentos, haciendo especial hincapié en los principales factores que afectan a estas propiedades de los alimentos así como a sus posibles usos industriales. La segunda parte de esa revisión bibliográfica (Içier y Baysal, 2004b) se centra en las técnicas de medida de propiedades dieléctricas para este tipo de productos. Ambas revisiones ofrecen una visión global de la aplicación de la espectroscopia dieléctrica al control de calidad de alimentos. 
La utilización de las microondas de señal es una técnica que se ha aplicado a diferentes productos de la industria alimentaria para el control de muy diversos factores de calidad, incluyendo, por ejemplo, la medida del contenido en diferentes sales (Shiinoki et al, 1998; Kent et al, 2000a; De los Reyes, 2007; De los Reyes et al, 2005b, 2006b, 2007b), contenido de agua añadida en carne procesada (Kent y Anderson, 1996; Kent et al, 2001; Kent, 2003), y detección de bacterias en leche (Váczy y Semberg, 2003). Por otra parte, se han estudiado alimentos como por ejemplo el queso, para analizar el efecto de la humedad y contenido en sal en las propiedades dieléctricas (Everard et al, 2006); el yogur, para la determinación del contenido en azúcar (Bohigas et al, 2008); la mantequilla, estudiando el efecto de la temperatura y el contenido en sal (Ashmed et al, 2007); el pan, donde se observa la influencia de algunos parámetros como son el contenido en sal y humedad (Chin et al, 2005; Goedeken et al, 2006); el aceite, estudiando sus propiedades dieléctricas en función de su composición, humedad, temperatura y frecuencia (Lizhi et al, 2008); macarrones y queso, estudiando las propiedades dieléctricas en función de la frecuencia y de la temperatura (Nelson y Bartley, 2000).

También se ha aplicado esta técnica a productos líquidos, como la salsa de soja (Tanaka et al, 2005), soluciones acuosas saturadas de alfa-D-glucosa (Liao et al, 2003), en las que se miden las propiedades dieléctricas a diferentes temperaturas y concentraciones. Raveendranath y Mathew (1995) adaptaron la técnica del uso de las microondas para estudiar la calidad del agua en depuración. Nunes et al, (2006), estudiaron la variación del factor de pérdidas y la constante dieléctrica con el contenido en grasa de la leche, sugiriendo que podría ser utilizada para determinar algunos componentes de la misma (componentes iónicos, grasas, carbohidratos y proteínas). Se han utilizado las microondas también para comparar diferencias en las propiedades dieléctricas entre zumo de uva y vino (García et al, 2004). 


\subsubsection{Aplicación de la espectroscopia dieléctrica de microondas a productos de la agricultura}

Se ha estudiado la aplicación de microondas a diversas frutas y vegetales con la finalidad de correlacionar diferentes propiedades como son: humedad, contenido en almidón, y efecto de la temperatura con la variación de las propiedades dieléctricas (Nelson, 1980, 1983, 1992, 2005; Tran et al, 1984; Seaman y Seals, 1991; Nelson et al, 1993, 1994; Berbert et al, 2002; Feng et al, 2002; Sharma y Prasad, 2002; Sipahioglu y Barringer, 2003; Datta et al, 2005; Guo et al, 2007a). Se han desarrollado varios modelos predictivos que correlacionan las propiedades dieléctricas de frutas y vegetales con algunos parámetros como la humedad, sólidos solubles e insolubles y temperatura (Sun et al, 1995; Tulasidas et al, 1995; Sharma y Prasad, 2002; Nelson, 2003; Sipahioglu y Barringer, 2003; Berbert et al, 2004; Calay et al, 2007). En general, cabe destacar que las frutas y verduras poseen una fase líquida importante que provoca que la constante dieléctrica adquiera valores altos; por el contrario, en frutas y verduras deshidratadas tanto la constante dieléctrica como el factor de pérdidas toman valores menores. Como resumen se puede concluir que el comportamiento dieléctrico de las frutas y vegetales está influenciado principalmente por la conductividad iónica y el agua ligada, a bajas frecuencias, y por la relajación de las moléculas de agua libre a frecuencias mayores (Nelson et al, 1994).

De entre las aplicaciones más importantes en este tipo de productos, además del control de su composición mediante la medida de propiedades dieléctricas, cabe destacar el trabajo de De los Reyes et al (2005a, 2006a). Estos autores estudiaron las diferencias entre las propiedades dieléctricas de las semillas y zumo de mandarina, con la finalidad de poder determinar la presencia de semillas en el fruto mediante esta técnica. Este estudio obtuvo resultados muy prometedores. Por otra parte, también se ha utilizado la medida de propiedades dieléctricas para la determinación del grado de madurez de algunas frutas como son los melocotones (Nelson, 1995), la sandía (Nelson et al, 2007), o el melón (Nelson et al, 2006). 
También se han estudiado ampliamente las propiedades dieléctricas de algunos productos en grano y semillas; en este caso el principal interés reside en la determinación del contenido en humedad (Nelson, 1977, 1978a, b, 1987, 1991; Kraszewski, 1991; Kraszewski y Nelson, 1993a, b; Berbert y Stenning, 1996a, b; Kraszewski et al, 1998; Berbert et al, 2001; Trabelsi y Nelson, 2003).

\subsubsection{Aplicación de la espectroscopia dieléctrica de microondas al control de calidad de carne y pescado}

La aplicación de la espectroscopia dieléctrica en productos proteicos tiene especial interés para la presente tesis. Las propiedades dieléctricas de este tipo de productos han sido estudiadas por numerosos autores y las aplicaciones más importantes se van a resumir en esta sección.

La permitividad y la conductividad son las propiedades que determinan la propagación de una onda electromagnética en un tejido biológico. Gabriel et al (1996a, b, c) describieron estos parámetros con detalle. Es importante destacar que una de las limitaciones más importantes a tener en cuenta al trabajar con sondas dieléctricas es el volumen de muestra que interacciona con el campo. Este volumen de muestra debe ser representativo de la pieza entera de carne o de pescado, ya que los parámetros electromagnéticos en este tipo de tejidos varían a lo largo del mismo, es lo que se conoce como anisotropía y es un parámetro muy importante que hay que tener presente al trabajar con tejidos biológicos.

Una importante aplicación de las microondas de señal en alimentos es la determinación de la frescura de la carne y del pescado. Tras la muerte, el músculo no es capaz de obtener energía mediante el metabolismo aerobio, recurriendo al metabolismo anaerobio para mantener su integridad celular. Los cambios postmortem conducen hacia una rigidez temporal de los músculos conocida como rigor mortis. Por otra parte, la glicólisis produce una bajada de $\mathrm{pH}$ llevando éste próximo al punto isoeléctrico de las proteínas y disminuyendo la capacidad de retención de agua de éstas (Hullberg, 2004). El nivel de glucógeno almacenado en el animal en el momento del sacrificio afecta a la textura de la futura carne 
comercial. Debido a la gran cantidad de cambios sufridos en el músculo durante su conversión en carne, es de esperar que las propiedades dieléctricas de dicho tejido también cambien, siendo posible la determinación del grado de frescura de los productos proteicos. Basándose en este razonamiento, diversos grupos de investigación están llevando a cabo estudios. En este sentido, un sensor de microondas basado en un método polarimétrico para evaluar la estructura de los alimentos está siendo desarrollado en Clermont-Ferrand INRA Centre (French Nacional Institute for Agricultural Research). El objetivo de esas investigaciones es discriminar entre filetes de pescado frescos y aquellos que hayan sido sometidos a un proceso de congelación/descongelación. Mediante este método también se ha tratado de monitorizar el proceso de maduración de la carne. Ambas aplicaciones están basadas en la reducción de la anisotropía de los tejidos durante el procesado de los productos, así como durante el proceso de maduración de la carne, produciéndose en ambos casos un cambio detectable en las propiedades dieléctricas (Clerjon y Damez, 2007).

Otra aplicación importante es la detección del agua añadida, un fraude muy común en la industria alimentaria. Esta aplicación ha sido ampliamente desarrollada para pescado, productos de la pesca y carne (Kent et al, 2000b, 2001, 2002; Daschner y Knöchel, 2003). Asimismo, Kent y Stroud (1999), publicaron un método para la determinación del hielo añadido en alimentos congelados.

También ha sido publicado que es posible predecir la composición de grasa del pescado o de la carne picada utilizando medidas electromagnéticas (Kent, 1990; Kent et al, 1993, 2007; Borgaard et al, 2003). El contenido en grasa de estos alimentos está claramente relacionado con el contenido en agua del producto, así que si uno de ellos es conocido, el otro puede ser determinado. Un instrumento basado en las microondas que principalmente consiste en una microstripline está siendo actualmente comercializado (Distell Company®, West Lothian, Scotland). Este instrumento de medida es compacto y no destructivo, y puede medir grasa del pescado (Kent, 1990), grasa de la carne (Kent et al, 1993) y frescura de pescado (Borgaard et al, 2003).

Estudios relativamente recientes han tratado de relacionar los cambios en las propiedades dieléctricas de carne con el estado de desnaturalización de las 
proteínas. El fenómeno de desnaturalización proteica produce cambios estructurales que provocan la liberación de moléculas de agua o sales (Bircan y Barringer, 2002a). Por otra parte, como se ha estado explicando a lo largo de todo el capítulo, las propiedades dieléctricas dependen de la composición (Lyng et al, 2002; Zhang et al, 2004) y están influenciadas por el agua y el contenido iónico del alimento entre otros factores (Roebuck et al., 1972). Por lo tanto, es lógico pensar que el fenómeno de desnaturalización puede ser detectado mediante la medida de las propiedades dieléctricas. Li y Barringer (1996) monitorizaron los cambios del factor de pérdidas en muestras de jamón con un alto contenido en sal a frecuencias de microondas. Estos autores concluyeron que estos cambios se correspondían con la desnaturalización del complejo actomiosina. Además Bircam y Barringer (2002a) monitorizaron los valores que tomaban $\varepsilon$ ' y $\varepsilon^{\prime \prime}$ (a frecuencias de microondas) en muestras de carne, pescado y carne picada en un rango de temperatura de $20-120^{\circ} \mathrm{C}$. Estos autores encontraron que tanto $\varepsilon^{\prime}$ como $\varepsilon$ " aumentaban hasta una temperatura que correspondía con la temperatura de desnaturalización del colágeno en estos alimentos. Zhang et al (2004) publicaron un estudio relacionado con las propiedades dieléctricas de muestras de carne picada en un rango de temperaturas de $5-85^{\circ} \mathrm{C}$ en radiofrecuencia y microondas. Sin embargo, en este estudio las medidas se tomaron simplemente en intervalos de $20^{\circ} \mathrm{C}$ y un número de ingredientes no cárnicos formaban parte de la composición de las muestras de carne. Debido a ello, el efecto de la desnaturalización proteica sobre las propiedades dieléctricas pudo ser enmascarado por los ingredientes no cárnicos e incluso pudo ser perdido debido al gran intervalo de temperaturas empleado. Por ello, Brunton et al (2006) monitorizaron los cambios en las propiedades dieléctricas de piezas de carne enteras en un rango de temperaturas de $5-85^{\circ} \mathrm{C}$ pero en intervalos de $1^{\circ} \mathrm{C}$ para determinar si los cambios en las propiedades dieléctricas, cuando éstas se medían a intervalos de temperatura menores, podían ser relacionados con cambios en el estado de desnaturalización de las proteínas estructurales monitorizado con DSC. Además se midieron los cambios en las propiedades reológicas y la pérdida de exudado en músculo de vacuno en un intento de correlacionar los cambios de esas propiedades con la desnaturalización de las proteínas. 
Diversos estudios han concluido que el análisis de espectros es una herramienta muy útil para el control de calidad de diversos productos (Miura et al, 2003). Específicamente, estos autores han estudiado las diferencias entre pollo crudo, congelado y cocido a $25^{\circ} \mathrm{C}$. También estudiaron los espectros dieléctricos de pescado, vegetales, huevos, productos lácteos y bebidas.

Un estudio completo de las propiedades dieléctricas de diferentes tipos de carne y de ingredientes utilizados en productos cárnicos a frecuencia de microondas y radiofrecuencia fue publicado recientemente (Lyng et al, 2005). Por otra parte, Daschner et al (2000), obtuvieron un método para la determinación de la composición de diferentes tipos de carne a partir de la medida de las propiedades dieléctricas.

Las propiedades dieléctricas de carne de pavo fueron medidas a $915 \mathrm{y}$ $2450 \mathrm{MHz}$ (Sipahioglu et al, 2003b). Los autores desarrollaron ecuaciones para correlacionar la parte real e imaginaria de la permitividad con la temperatura, humedad, actividad de agua y cenizas. Otras ecuaciones se desarrollaron para modelizar las propiedades dieléctricas del jamón en función de la temperatura y la composición (Sipahioglu et al, 2003a). Por otra parte, el mismo grupo de investigación estudió el efecto de la adición de ácido láctico en carne de pavo (Sipahioglu, 2002) a frecuencias de 915 y 2450 MHz. La adición de ácido láctico produce una disminución del $\mathrm{pH}$ y la desnaturalización de las proteínas, lo que produce una disminución de la capacidad de retención de agua de las muestras y, consecuentemente, una disminución en las propiedades dieléctricas debido al menor contenido en humedad de las mismas.

Clerjon et al (2003) trataron de probar la viabilidad de un sensor de microondas en línea para la medida de la $a_{w}$. Los autores analizaron 45 muestras modelo de geles de origen animal con diferentes contenidos en agua y $\mathrm{NaCl}\left(\mathrm{a}_{\mathrm{w}}\right.$ desde 0.91 a 1) los cuales fueron caracterizados en términos de $a_{w} y$ propiedades dieléctricas. Esta investigación proporcionó buenas correlaciones entre algunas propiedades dieléctricas, como la frecuencia de relajación, y la aw.

En cuanto a los productos de la pesca, se han estudiado productos desestructurados como la pasta de surimi (Mao et al, 2003). También se midieron 
las propiedades dieléctricas de carne de arenque mediante un método de transmisión (Kent, 2007). Por otra parte, se han desarrollado modelos para describir el efecto de la temperatura en las propiedades dieléctricas de ostras peladas (Hu y Mallikarjunan, 2004). Además se ha estudiado la correlación de algunos productos de la pesca y el contenido en sal de los mismos (De los Reyes et al, 2005b, 2006b).

\subsubsection{Aplicación de la espectroscopia de impedancia eléctrica al control de calidad de carne y productos cárnicos}

En los tejidos biológicos como puede ser la carne, la impedancia depende principalmente de su estructura y de su conductividad. La gran complejidad de la estructura de la carne produce una fuerte anisotropía eléctrica como ya se ha comentado en la sección anterior (Callow, 1939). Damez et al (2008b) estudiaron la anisotropía eléctrica de la carne de vacuno durante el proceso de maduración, con el objetivo de obtener una valoración rápida del grado de madurez de la carne.

Otra de las aplicaciones más importantes de la medida de impedancia eléctrica es la evaluación del pH (Swatland, 1985; Byrne et al, 2000). Algunos autores usaron la conductividad a 45 y 60 minutos post mortem para detectar carnes Pálidas, Blandas y Exudativas (PSE, Pale Soft and Exudative) pero, debido a los elevados valores que tomaba la desviación estándar, no fue posible concluir nada (Fortin y Raymond, 1988; Warris et al, 1991). Por otra parte se encontraron relaciones entre la impedancia y la capacidad de retención de agua (Whitman et al, 1996).

En carne de vacuno, uno de los principales problemas de calidad son las carnes Oscuras Firmes y Secas (DFD, Dark Firm and Dry) que se caracterizan por su elevado $\mathrm{pH}$ y su gran susceptibilidad a los problemas microbiológicos. Este defecto de la calidad se asocia con modificaciones en las membranas celulares y cambios en el líquido extracelular. Por ello es de esperar que también se vean afectadas las propiedades eléctricas de la carne. Algunos estudios recientes en este campo no apoyaron esta teoría y demostraron que no es posible 
la rápida detección de carnes DFD mediante la medida de las propiedades eléctricas (Forrest et al, 2000; Garrido et al, 1994a; Guerrero et al, 2004; Jaud et al, 1992).

Por otra parte, el Centro de Tecnología de la Carne del Institut de Recerca i Tecnologia Agroalimentàries (IRTA, Girona, España) y la empresa NTE (NTE, S.A., Barcelona, España) llevan trabajando desde el año 1994 en el uso de la medida de impedancia eléctrica para la determinación de la calidad de la carne. El trabajo conjunto ha abarcado actividades que van desde la investigación básica hasta el desarrollo de equipos de demostración (Elvira et al, 2001). Durante el año 2001 presentaron dos equipos que utilizan la impedancia eléctrica para evaluar la calidad de la carne (detección de carnes PSE, problemas de pastosidad en jamones) (Oliver et al, 2001; Guerrero et al, 2004), así como para la clasificación de jamones en función de su grasa intramuscular. Actualmente están realizando otros estudios para la determinación de la composición de carne picada en una mezcladora, así como estudios en jamón cocido cuyos resultados no están aún disponibles (Elvira et al, 2001).

Por otra parte, desde los años 80 se han realizado numerosos estudios para la estimación del contenido en grasa en carcasas o en músculos de animales mediante el empleo de las propiedades eléctricas. La grasa es un buen aislante eléctrico y juega un papel fundamental en la impedancia de los tejidos de la carne. Se han realizado algunos estudios de la composición de carne de cerdo (Swantek et al, 1992), y en carne de vacuno y de cerdo (Marchello et al, 1999). Slanger y Marchello (1994) midieron la conductividad eléctrica en carcasas de bovino inmediatamente tras el sacrificio. Los autores obtuvieron una estimación del contenido en grasa con una excelente precisión $\left(\mathrm{R}^{2}=0.95\right)$. Esto fue posible porque justo después del sacrificio no existe modificación en las membranas o en los compartimentos extracelulares, y las medidas fueron realizadas a una temperatura estable.

La grasa intramuscular (IMF) juega un papel importante en la calidad sensorial de la carne. Madsen et al (1999) describieron un sistema de medida de impedancia compuesto por seis electrodos y 10 frecuencias entre $50 \mathrm{~Hz}$ y 50 $\mathrm{KHz}$ para la predicción de la grasa intramuscular en vacuno. Este patentado 
aparato (Estados Unidos, $\mathrm{n}^{\circ}$ Patente 6265882) utiliza electrodos insertados en el músculo para estimar la grasa intramuscular en carcasas mediante la medida a diferentes frecuencias.

Altmann y Pliquett (2006) presentaron un aparato para medir la impedancia de manera repetitiva mientras la sonda se insertaba en el músculo. Los autores examinaron diferentes tiempos post mortem y diferentes direcciones de inserción de la sonda. Un método estandarizado basado en sus resultados se utilizó para predecir la grasa intramuscular en cerdo y vacuno.

Otra aplicación fundamental de la espectroscopia de impedancia eléctrica es la evaluación de la ternura de la carne. Los procesos de maduración de la carne incluyen la acción de proteasas endógenas que afectan a la estructura de las fibras musculares, producen un incremento progresivo de la permeabilidad de la membrana y un debilitamiento del tejido conectivo. Faure et al (1972) trataron de evaluar el grado de maduración de la carne cuantificando esos efectos. Propusieron una aproximación basada en el ratio de impedancia entre baja y alta frecuencia. El ratio de impedancia decrecía durante el tiempo de almacenamiento. Trabajos similares se llevaron a cabo con el ratio de la capacitancia (el parámetro dieléctrico que reflejaba el grado de aislamiento de las membranas) y la resistencia eléctrica (Kleibel et al, 1983).

Como se ha comentado a lo largo de todo el capítulo, el músculo es eléctricamente anisotrópico, lo cual significa que el músculo y, por ello, la carne, muestra cambios en las propiedades eléctricas en función de la dirección en que se aplican los campos eléctricos en la muestra. Tras el rigor mortis, la impedancia eléctrica de la carne decrece linealmente junto con la resistencia mecánica de las fibras musculares y, por ello, la anisotropía eléctrica sirve para predecir la fuerza de las fibras musculares (Lepetit et al, 2006) y, por tanto, el grado de desestructuración del tejido.

Por otra parte, Byrne et al (2000), relacionaron las propiedades eléctricas del músculo después de ser cocinado con la ternura evaluada por la fuerza de corte Warner-Bratzler (WBSF). Sus resultados mostraron que no existía una relación directa entre la ternura de la carne y las medidas eléctricas. 
Lepetit y Hamel (1998) demostraron que es posible seleccionar carnes que maduren rápidamente si el estado de madurez se conoce a las 48 horas post mortem. Esto evitaría un almacenamiento durante largos periodos de carnes que ya han madurado. La reducción de los costes de almacenamiento sería de un 50\%. En este estudio el grado de madurez se midió con un método mecánico destructivo, aunque esta misma información puede ser obtenida mediante un sensor no destructivo Damez et al (2008a,b).

\subsection{E1 sector porcino en la Industria Agroalimentaria}

\subsubsection{Situación Actual del sector porcino}

El sector cárnico es uno de los más importantes en la Unión Europea. Este sector incluye principalmente cuatro tipos de carne: vacuno, porcino, bovino, aviar. La carne constituye el mayor aporte proteico en la dieta europea. Además una gran parte de la energía que aporta este producto se debe a su contenido graso. Otros constituyentes como pueden ser las vitaminas A y B, así como el Hierro, Fósforo y Zinc resultan positivos para la salud humana.

La Unión Europea produce 22.5 millones de toneladas anuales de carne porcina y es el segundo productor mundial de este producto tras China (46 millones de Toneladas) (M.A.R.M., 2009). La elevada producción durante la segunda mitad de los 90 produjo una bajada de los precios. Desde entonces la producción se ha estabilizado, y los precios han respondido favorablemente. Los países que tuvieron un nivel productivo mayor de este tipo de carne en la UE durante el año 2008 fueron: Alemania (22.6\%), España (15.4\%), Francia (10.1\%), Polonia (8.4\%), Dinamarca (7.6\%), Italia (7.1\%) (M.A.R.M., 2009). Por otra parte, en la Unión Europea se prevé que a medio plazo la producción del sector porcino continuará aumentando aunque a un ritmo inferior al que lo hizo en los años 90; según estas previsiones, para el año 2014 la producción se situará en 22.6 millones de toneladas. Además se estima que la carne de porcino seguirá siendo la favorita entre los consumidores. En cuanto a las exportaciones se 
espera que continúe la expansión del comercio intracomunitario (M.A.R.M., 2007).

El mercado de carne porcina en España facturó en el año 2008 aproximadamente 5.079 millones de euros, lo que supone algo más del 34\% de la producción final ganadera española y en torno al 12\% de la producción final agraria (M.A.R.M., 2009). Estas cifras configuran al sector porcino español como un líder europeo, siendo, como ya se ha comentado, el segundo productor de carne de porcino comunitario. Por otra parte, el consumo de este tipo de carne en España alcanza casi los $68 \mathrm{kgs} /$ persona/año, siendo en la Unión Europea este consumo de $43.5 \mathrm{kgs} /$ persona/año, siendo por tanto el principal epígrafe del gasto en alimentación (M.A.P.A., 2007b; M.A.R.M., 2009).

En definitiva, nuestro país se ha convertido en uno de los mayores productores de porcino en la Unión Europea. Por lo tanto, está claro que el sector porcino experimenta una expansión y que requiere, en la situación económica mundial actual, un acercamiento de sus necesidades a la elaboración y desarrollo de los planes, programas y líneas prioritarias de Investigación, Desarrollo e Innovación como un factor de competitividad, así como la aplicación de programas de transferencia de los resultados (VIC porc '06, 2006)

\subsubsection{Tendencias del mercado}

En los países desarrollados, la renta y el precio contribuyen cada vez menos a la explicación de la demanda de productos cárnicos, mientras que factores de carácter cualitativo como son los englobados bajo las siglas P.A.N., preferencias, actitudes y necesidades del consumidor (Plataforma Tecnológica Europea "Food for Life”, 2007), juegan un papel cada vez más importante. Debido al cambio que ha experimentado el modelo familiar, actualmente las tendencias en el consumo vienen marcadas fundamentalmente por jóvenes independientes y familias de pocos miembros; por ello, la demanda va encaminada hacia alimentos rápidos de preparar, que sean saludables, seguros, con elevado valor añadido y de calidad (M.A.P.A., 2007b). Debido a esto, cabe destacar el sector de elaborados cárnicos como productos que reúnen muchas de las características que el consumidor 
busca a la hora de elegir un producto. Este sector se ha asentado mucho en los últimos años, adaptándose a los nuevos requerimientos del mercado lo que se ha traducido en una diversificación de sus productos. En el año 2006, el mercado de elaborados cárnicos creció un 5.1\%, hasta los 6.091 millones de euros, en un contexto de moderado incremento de los precios. El segmento de curados absorbió el 50.3\% del valor del mercado, seguido del de cocidos (35.5\%) y otros productos (14.2\%). En este último segmento sobresale el crecimiento de los platos preparados (DBK, 2007). Cabe destacar que durante el período 2001-2006 la producción de elaborados cárnicos contabilizó un crecimiento medio anual cercano al 3.5\% en términos de volumen, hasta situarse en el año 2007 en 1.25 millones de toneladas (DBK, 2007).

En cuanto al comercio exterior, sobresale la notable progresión al aumento de las exportaciones de carne porcina de nuestro país, siendo además la tendencia a continuar en este sentido. Es importante destacar que el principal producto exportado por nuestro país es la carne fresca/congelada/refrigerada, suponiendo un $69.6 \%$ del producto exportado a la Unión Europea y un 45.3\% del producto exportado a países terceros durante el año 2008 (M.A.R.M., 2009).

\subsubsection{Principales retos de la industria cárnica}

Como se ha explicado en el apartado anterior, los productos cárnicos curados constituyen un grupo de alimentos que abarcan un gran sector de la producción. Tradicionalmente, los productos curados requieren largos tiempos de procesado, normalmente consisten en sucesivas etapas de salado, post-salado y proceso de curado. Debido a esta gran expansión del mercado de productos cárnicos curados, existe una necesidad creciente de controlar de un modo rápido, preciso y barato tanto la materia prima, como el proceso de fabricación y el producto elaborado final. El control de los productos cárnicos es importante tanto para las propias industrias de fabricación como para las grandes empresas distribuidoras. 
Por otra parte debido a la importancia de las exportaciones de carne de porcino fresca/congelada/refrigerada, también es importante en este sentido controlar el producto en fresco.

En definitiva, aparecen como principales retos del sector el control de aspectos de calidad de la carne fresca para optimizar el destino final de ésta, así como el control del proceso de fabricación de los elaborados cárnicos. Ello conllevará una mayor satisfacción tanto del consumidor como de los productores, proporcionando productos de la calidad deseada y más adaptados a los requerimientos y exigencias del consumidor, lo cual producirá una repercusión directa sobre el precio del producto cárnico. Este modelo de producción se asienta pues sobre la base de la calidad y la adecuación a la demanda, y busca sobre todo que el sistema productivo sea competitivo y eficaz.

\subsubsection{La espectroscopia dieléctrica como herramienta para el estudio y control de los procesos y de la calidad de la carne así como de los productos cárnicos}

Para tratar de responder a los principales retos del sector cárnico y producir alimentos que reúnan determinadas características de calidad, seguridad y nutricionales aparecen los sensores basados en la radiación electromagnética como una opción interesante.

Esta técnica se ha empleado ya en la industria cárnica para controlar algunos aspectos como puede ser el grado de frescura de la carne, porcentaje de agua añadida, humedad del producto, control del pH, etc. (Castro-Giráldez et al, 2009; De los Reyes et al, 2007a).

Debido a que es una técnica que tiene muchas posibilidades de aplicación dentro de la industria alimentaria, es necesaria la realización de estudios para ampliar el conocimiento en el sector cárnico.

Algunos de los campos de investigación que se pretenden estudiar en esta tesis son: 
1. Control de la materia prima. Detección de defectos en la calidad de la carne fresca para optimizar el destino de la carne. Control del proceso de maduración de la carne fresca.

2. Control de la operación de salado.

\subsection{Situación actual de la producción de manzana y kiwi}

La producción mundial de manzana durante el año 2008 fue de aproximadamente 70 millones de toneladas, de las cuales el $60 \%$ fueron producidas en Asia. Europa es el segundo productor con un 23\% del volumen, mientras que América cuenta con un 13,5\% (WAPA, 2009). Entre los países europeos, Polonia es el mayor productor con 2.830.870 toneladas durante el año 2009 (WAPA, 2009), seguido de Italia con 2.208.227 toneladas. La producción de manzanas durante el año 2009 experimentó descensos generalizados en casi todos los países productores, así en Polonia descendió un 19\% con respecto al año 2008, Italia un 2\% y España un 15\%; en Alemania la producción se mantuvo estable (WAPA, 2009). Por lo tanto, como resumen se puede concluir que para los 21 países más importantes en la producción de manzana en la Unión Europea, la producción se redujo en un $7 \%$ con respecto a los datos del año 2008, situándose la producción en 10.753 .000 toneladas.

La producción de manzanas en España, en la campaña 2009, fue de 448.000 (WAPA, 2009). En cuanto a las variedades, se aprecia un descenso de casi todas las variedades, siendo la variedad Red Delicious la que más ha descendido con respecto al año 2008 (-36\%). La variedad Golden Delicious sigue siendo la más abundante situándose en 239.000 toneladas para el año 2009. En cuanto a la variedad Granny Smith, es importante destacar que sigue siendo una de las minoritarias, situándose su producción en apenas 6.000 toneladas (WAPA, 2009). 
En cuanto a las exportaciones, simplemente cabe destacar que se ha situado en torno a 53.043 toneladas, un $2 \%$ menor que de enero a julio de 2008 , por un valor de 30 millones de euros (-7\%).

La producción mundial de kiwi, se sitúa durante el año 2008 en 1,3 millones de toneladas, de las cuales europa produce un 50\%, mientras que Oceanía es el segundo productor mundial con un $28 \%$ de la producción. De entre todos los países, Italia es el que cuenta con una mayor producción con 473.955 toneladas, lo que supone un 36\% de la producción mundial, y un $73 \%$ de la producción europea (Fuente: faostat)

Una mención especial requiere la fruta escarchada, que suele ser un producto con un mercado muy reducido y cuyo mayor volumen de producción se genera en fechas navideñas. Su producción aproximada es de $35.650 \mathrm{kgs}$ y mueve un volumen de 108.000 euros (MAPA, 2007a).

\subsubsection{Tendencias del mercado}

Según el panel de consumo publicado para el año 2007 por el ministerio de Agricultura, Pesca y Alimentación (MAPA, 2007a), a la hora de elegir un producto alimentario prima, por encima de todo, los productos fáciles de preparar y que sean productos sanos y saludables. En este sentido, las frutas y hortalizas frescas son un sector cada vez más importante en España; de hecho, el sector de las frutas frescas ha aumentado su consumo en un 39\% durante el año 2007 con respecto al valor del año 2004. Es el sector de las frutas frescas el que ha experimentado una de las mayores evoluciones en el consumo, tras las hortalizas frescas. Por otra parte, es importante destacar que el perfil del consumidor también ha cambiado notablemente, siendo ahora las parejas sin hijos y los adultos independientes el sector poblacional más relevante. Además, también es importante es sector correspondiente a la inmigración que ha sufrido 
un crecimiento exponencial, considerándose como un nuevo sector de consumidores potenciales.

Por lo tanto, debido a que las frutas y hortalizas frescas se consideran productos saludables y sanos, su consumo tiene una tendencia al alza. Este hecho provoca que sea importante el control del producto en fresco para asegurar su calidad, siendo la espectroscopia dieléctrica una buena herramienta. Por otra parte, a pesar de que el sector de frutas escarchadas no es tan relevante, el control de los procesos de este tipo de industrias tiene interés ya que estos productos presentan un mayor valor añadido con respecto al producto en fresco. Además, la aplicación de la espectroscopia como herramienta de control de este tipo de procesos puede servir como un estudio previo para futuras aplicaciones en el sector de frutas transformadas, como frutas en conserva, congeladas, mermeladas y confituras.

\subsubsection{La espectroscopia dieléctrica como herramienta para el control del grado de madurez de fruta fresca y del proceso de escarchado de manzana y kiwi}

En la presente tesis se ha tratado de determinar el grado de madurez de fruta fresca mediante la aplicación de la espectroscopia dieléctrica. Para ello se ha tomado como modelo de fruta climatérica la manzana (var. Granny Smith). La determinación del grado de madurez de la fruta permitirá optimizar los tiempos de almacenamiento de la misma, así como determinar el mejor destino de cada pieza dentro de la industria.

Por otra parte, se va a estudiar el control de la operación de deshidratación osmótica de manzana Granny Smith así como de kiwi (Actinidia deliciosa cv Hayward) mediante el empleo de las propiedades dieléctricas. 
2. Objetivas y plan de trabaja 



\subsection{Objetivos}

\subsubsection{Objetivo general}

El objetivo general de la presente tesis consiste en estudiar la viabilidad del empleo de las propiedades dieléctricas como método de control no destructivo de diferentes productos y procesos de la industria agroalimentaria.

\subsubsection{Objetivos particulares}

Para alcanzar el citado objetivo general de la tesis se plantearon los siguientes objetivos particulares:

1) Análisis de los espectros dieléctricos de carne fresca con la finalidad de discernir entre diferentes calidades de carne: Pálidas Blandas y Exudativas (PSE), Oscuras Firmes y Secas (DFD), Rojas Firmes y No Exudativas (RFN). Estudio de algunos parámetros de calidad de la carne y relación con las propiedades dieléctricas. Análisis del grado de frescura de la carne (Artículos del capítulo 4.1 de la presente tesis).

2) Análisis de la operación de salado de lomo de cerdo. Estudio termodinámico del sistema y de la operación de salado. Estudio de los espectros dieléctricos identificando las frecuencias claves que caracterizan el proceso. Desarrollo de algoritmos de control a las frecuencias claves estudiadas (Artículos del capítulo 4.2 de la presente tesis).

3) Análisis de los espectros dieléctricos de manzana fresca así como de sistemas patrón que tratan de modelizar la composición del tejido parenquimático de manzana fresca, con la finalidad de determinar mediante medidas dieléctricas el estadio de madurez de 
la manzana, así como su composición y la influencia de la estructura (Artículos del capítulo 4.3 de la presente tesis).

4) Análisis de la operación de deshidratación osmótica de manzana Granny Smith. Estudio termodinámico del sistema y de la operación de deshidratación. Estudio de los espectros dieléctricos identificando las frecuencias claves que caracterizan el proceso. Desarrollo de algoritmos de control a las frecuencias claves estudiadas (Artículos del capítulo 4.4 de la presente tesis).

5) Análisis de la operación de deshidratación osmótica de kiwi (Actinidia deliciosa cv Hayward). Estudio termodinámico del sistema y de la operación de deshidratación. Estudio de los espectros dieléctricos identificando las frecuencias claves que caracterizan el proceso. Desarrollo de algoritmos de control a las frecuencias claves estudiadas (Artículos del capítulo 4.5 de la presente tesis).

\subsection{Plan de Trabajo}

El plan de trabajo de la presente tesis se subdividió en 5 planes experimentales, correspondientes a cada uno de los objetivos particulares expuestos en el apartado anterior. Por ello, y para una mayor claridad en la exposición, los resultados del presente documento se dividen en cinco capítulos, correspondientes a los 5 planes experimentales, y un último capítulo en el que se presentan las dos patentes obtenidas durante el desarrollo de esta tesis.

1. Estudio de los espectros dieléctricos de lomo de cerdo y su relación con los parámetros de calidad de carne fresca

Este primer estudio se corresponde con el objetivo particular 1 y su plan experimental es el que a continuación se presenta: 
Puesta a punto de los métodos específicos de medida de propiedades dieléctricas para muestras de carne fresca mediante la sonda coaxial Agilent 85070E y el analizador de redes Agilent E8362B así como de los platos paralelos Agilent $16451 B$ y el analizador de impedancias Agilent $4194 A$.

> Medida y análisis de las propiedades dieléctricas de disoluciones patrón de compuestos relevantes en la bioquímica postmortem del lomo de cerdo mediante la utilización de la sonda coaxial Agilent $85070 \mathrm{E}$ y el analizador de redes Agilent E8362B.

Medida y análisis de los parámetros bioquímicos y físico-químicos de muestras de carne fresca durante el postmortem.

$>$ Medida y análisis de las propiedades dieléctricas de las muestras de carne mediante la utilización de la sonda coaxial Agilent $85070 \mathrm{E}$ y el analizador de redes Agilent E8362B. Estas medidas se realizarán en dirección y en perpendicular a las fibras de las muestras de carne.

Medida y análisis de las propiedades dieléctricas de las muestras de carne con el método de los platos paralelos Agilent $16451 B$ y el analizador de impedancias Agilent 4194A. Estas medidas se realizarán en dirección y en perpendicular a las fibras de las muestras de carne.

- Estudio de la relación entre los parámetros bioquímicos y físico-químicos con las determinaciones dieléctricas realizadas a las muestras.

2. Estudio de la cinética de salado de lomo de cerdo mediante la utilización de espectros dieléctricos

Este estudio se corresponde con el objetivo particular 2 y su plan experimental es el que a continuación se presenta:

Salado de muestras de carne en salmuera al 25\% de cloruro sódico muestreando a distintos tiempos en periodos de "salting in", "salting out" y de relajación de las fibras. Análisis de las muestras tratadas y reposadas. 
Análisis de las cinéticas de cambio fisicoquímico y estructural de las muestras tratadas y reposadas, determinando los puntos críticos en la transformación del producto cárnico.

> Medida y análisis de los espectros dieléctricos mediante la utilización de la sonda coaxial Agilent 85070E y el analizador de redes Agilent E8362B de muestras de carne tratadas y reposadas.

> Desarrollo de algoritmos de control que permitan controlar los parámetros de calidad de la carne durante la operación de salado.

3. Estudio de la influencia de la composición y estructura de la manzana Granny Smith mediante la utilización de espectros dieléctricos

Este estudio se corresponde con el objetivo particular 3 y su plan experimental es el que a continuación se presenta:

Preparación de disoluciones patrón cuya composición trate de simular la de las células parenquimáticas de la manzana fresca.

Medida y análisis físico-químico de las disoluciones patrón.

> Medida de los espectros dieléctricos de las disoluciones patrón mediante la sonda coaxial Agilent $85070 \mathrm{E}$ y el analizador de redes Agilent E8362B. Identificación de las frecuencias clave para la determinación de los componentes relevantes de la composición de manzana.

Medida y análisis de los parámetros físico-químicos de muestras de manzana fresca y de sus correspondientes licuados.

Medida y análisis de las propiedades dieléctricas de las muestras de manzana fresca y de sus correspondientes licuados mediante la utilización de la sonda coaxial Agilent $85070 \mathrm{E}$ y el analizador de redes Agilent E8362B.

Estudio de la relación entre los parámetros físico-químicos y los espectros dieléctricos. Desarrollo de algoritmos de control para la determinación del Índice de Thiault. 
4. Estudio de la cinética de escarchado de manzana Granny Smith mediante la utilización de espectros dieléctricos

Este estudio se corresponde con el objetivo particular 4 y su plan experimental es el que a continuación se presenta:

Deshidratación osmótica de manzanas Granny Smith en disolución de sacarosa de $65^{\circ}$ Brix. Análisis de las muestras tratadas y reposadas.

> Análisis de las cinéticas de cambio fisicoquímico y estructural de las muestras tratadas y reposadas, determinando los puntos críticos en la deshidratación osmótica.

Medida y análisis de los espectros dieléctricos mediante la utilización de la sonda coaxial Agilent $85070 E$ y el analizador de redes Agilent E8362B de muestras de manzana tratadas y reposadas.

Desarrollo de algoritmos de control que permitan controlar los parámetros de calidad de la manzana durante el proceso de deshidratación.

5. Estudio de la cinética de deshidratación osmótica de kiwi (Actinidia deliciosa $\underline{\text { cv Hayward) mediante la utilización de espectros dieléctricos }}$

Este estudio se corresponde con el objetivo particular 5 y su plan experimental es el que a continuación se presenta:

Deshidratación osmótica de kiwi (Actinidia deliciosa cv Hayward) en disolución de sacarosa de $65^{\circ}$ Brix. Análisis de las muestras tratadas y reposadas.

Análisis de las cinéticas de cambio fisicoquímico y estructural de las muestras tratadas y reposadas, determinando los puntos críticos en la deshidratación osmótica. 
Medida y análisis de los espectros dieléctricos mediante la utilización de la sonda coaxial Agilent 85070E y el analizador de redes Agilent E8362B de muestras de kiwi tratadas y reposadas.

Desarrollo de algoritmos de control que permitan controlar los parámetros de calidad de kiwi durante el proceso de deshidratación. 


\section{Materiales y Métados}





\subsection{Materia prima}

\subsubsection{Lomo de cerdo (Longissimus dorsi)}

Para el estudio de los parámetros de calidad de carne fresca durante el periodo postmortem se utilizó como materia prima lomo de cerdo (Longissimus dorsi) proporcionado por la empresa Cárnicas Teva S.L situada en el sector cárnico de Mercavalencia. Se utilizaron cerdos del cruce Landrace x Duroc. Se utilizaron 26 lomos de cerdo, escogidos por personal experto de la propia industria cárnica de entre un total de 200 carcasas. Los lomos se seleccionaron por su apariencia (lomos de diferentes calidades) y sexo, de forma que se trabajó con: 11 hembras, 16 machos.

Para el estudio de la cinética de salado de muestras de lomo se empleó como materia prima lomo de cerdo (Longissimus dorsi) suministrado por la industria cárnica Maxicarne, S.L. situada en Paterna. Se utilizaron los lomos con un periodo postmortem de 1.5 días y se clasificaron como RFN mediante el análisis del Drip loss.

\subsubsection{Manzana Granny Smith}

Para los estudios realizados con manzanas se empleó como materia prima manzana fresca de la variedad Granny Smith. Las muestras se adquirieron en un supermercado local, tratando de conseguir homogeneidad en cuanto al calibre; además se evitaron las piezas que contenían defectos superficiales. Las manzanas se adquirieron un día antes de su utilización y se mantuvieron en refrigeración a $6^{\circ} \mathrm{C}$. 


\subsubsection{Kiwi (Actinidia deliciosa cv Hayward)}

Para los estudios realizados con kiwi se empleó como materia prima Kiwi (Actinidia deliciosa cv Hayward). Las muestras se adquirieron en un supermercado local, tratando de conseguir homogeneidad en cuanto al calibre; además se evitaron las piezas que contenían defectos superficiales. Los kiwis se adquirieron un día antes de su utilización y se mantuvieron en refrigeración a $6^{\circ} \mathrm{C}$

\subsubsection{Disoluciones patrón}

Para la preparación de las disoluciones patrón que trataban de simular las concentraciones de algunos componentes relevantes de la bioquímica postmortem del lomo de cerdo fresco se emplearon aditivos de la empresa Sigma Chemical Co. (St Louis, Mo., E.E.U.U.). Todas las disoluciones patrón se prepararon con agua bidestilada.

Para la preparación de las disoluciones patrón que trataban de simular las concentraciones de algunos componentes relevantes del proceso de maduración de manzana se emplearon aditivos de la empresa Vidrafoc, S.A. (Barcelona, España). Todas las disoluciones patrón se prepararon con agua bidestilada.

\subsection{Medida de los espectros dieléctricos}

\subsubsection{Sonda coaxial}

Los espectros dieléctricos se midieron mediante la sonda coaxial Agilent 85070E conectada a un analizador de redes Agilent E8362B, ubicada en el Instituto Universitario de Ingeniería de Alimentos para el Desarrollo (IuIAD). Este analizador de redes mide en el rango de frecuencias de $10 \mathrm{MHz}$ a $20 \mathrm{GHz}$, a uno de sus dos puertos está unido un cable flexible modelo 85131F que lleva acoplada una transición de dieléctrico teflón para unir un cable coaxial modelo 85070-60006 conectado a la sonda dieléctrica 85070E. Se preparó también un 
elevador mecánico de acero inoxidable para acercar la muestra a la sonda y, de esta forma, evitar errores debido al movimiento de los cables durante la realización de las medidas (cambios de fase) (Figura 3.1).

La sonda coaxial Agilent 85070E puede medir en el rango de frecuencias de $500 \mathrm{MHz}$ a $50 \mathrm{GHz}$. La sonda utilizada es el modelo Slim Form Probe, cuyo diámetro externo es de $2.2 \mathrm{~mm}$ y su longitud de $200 \mathrm{~mm}$ (Figura 3.2). Por tanto, según las especificaciones de ambos equipos, la utilización de la sonda coaxial Agilent 85070E conectada al analizador de redes Agilent E8362B abarcaba un rango de medida de $500 \mathrm{MHz}$ a $20 \mathrm{GHz}$.
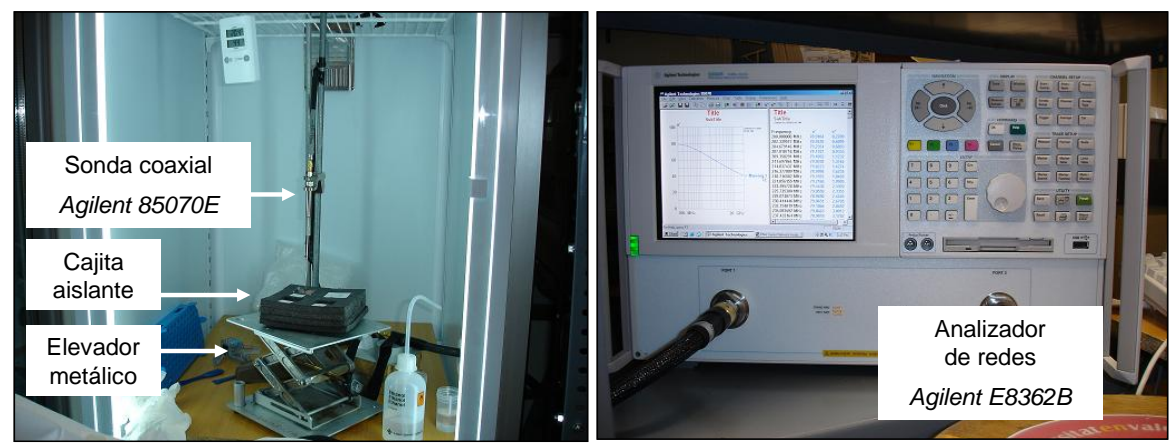

Figura 3.1. Sonda coaxial Agilent 85070E y analizador de redes Agilent E8362B.

La sonda puede operar a temperaturas en un rango de 0 a $125^{\circ} \mathrm{C}$. Se utiliza para medir sustancias líquidas y semisólidos pero también es capaz de medir sólidos deformables.

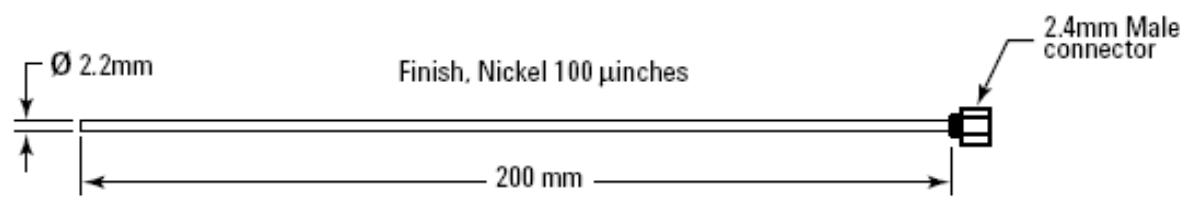

Figura 3.2. Esquema de la sonda Slim Form Probe Agilent E85070 (Agilent Technologies, 2005b).

La sonda se calibra midiendo primero el aire, seguidamente se acopla un accesorio formado por un polímero conductor en la parte final de la sonda que 
provoca un cortocircuito, y finalmente se procede a la calibración con agua Milli®-Q a $25^{\circ} \mathrm{C}$ (Figura 3.3).

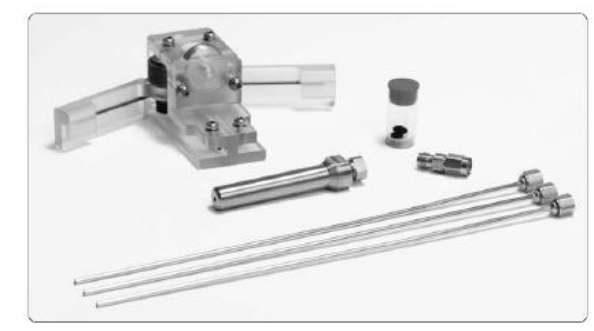

Figura 3.3. Kit para el montaje y calibración de la sonda coaxial Slim Form Probe Agilent E85070 (Agilent Technologies, 2005b).

En los estudios de lomo de cerdo todas las medidas de las propiedades dieléctricas se realizaron a $4^{\circ} \mathrm{C}$. Para asegurar esa temperatura en las muestras de carne fresca, se utilizaron cajitas aislantes en las que se introducían los cubos de metacrilato que contenían las muestras de carne (Figura 3.1). Por otra parte, las medidas en manzana y kiwi se realizaron a la temperatura de $30^{\circ} \mathrm{C}$.

\subsubsection{Platos paralelos}

La medida de las propiedades dieléctricas a baja frecuencia se realizó mediante la técnica de platos paralelos Agilent 16451 B conectados a un analizador de impedancias Agilent 4194A (Figura 3.4). 

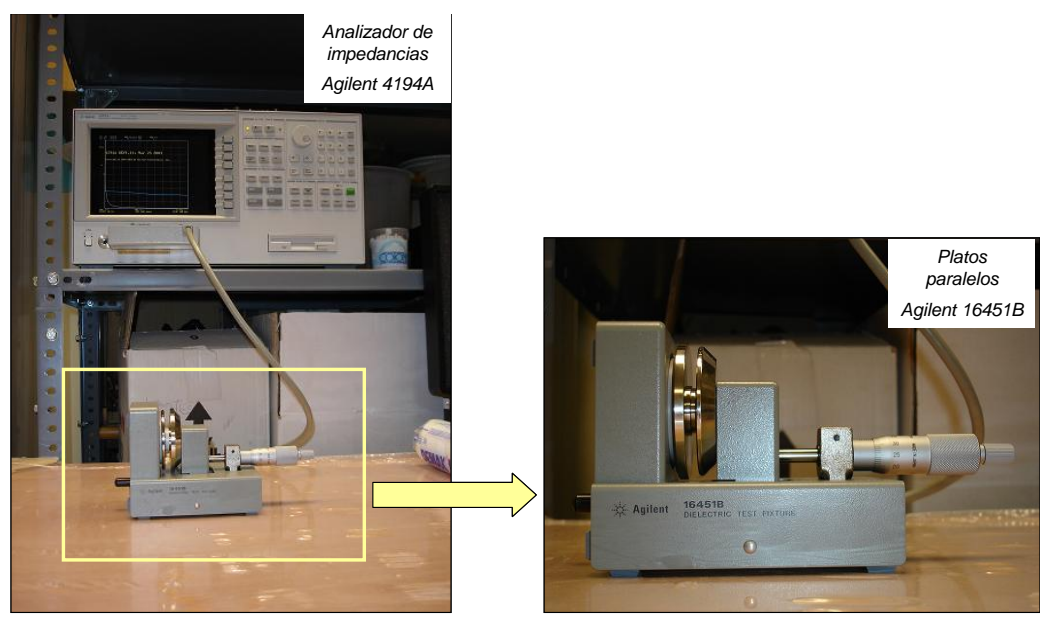

Figura 3.4. Platos paralelos Agilent $16451 \mathrm{~B}$ y analizador de impedancias Agilent 4194A.

Entre los dos posibles electrodos que se pueden conectar al equipo de placas paralelas Agilent 16451B, se eligió el electrodo A. La figura 3.5 muestra la forma y dimensiones de dicho electrodo.

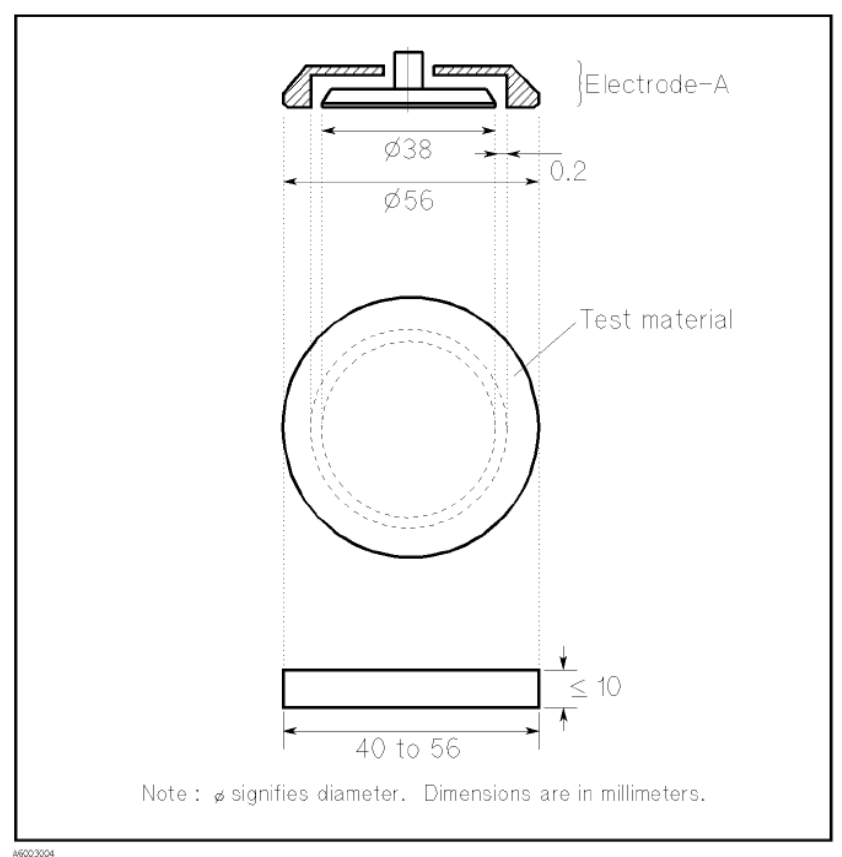

Figura 3.5. Características del electrodo A (Agilent Technologies, 2000).

Además se utilizó el método de contacto de los dos electrodos (placas) de metal rígido con la muestra tal y como se muestra en la figura 3.6. Este método 
utiliza dos electrodos rígidos en contacto directo con la superficie de la muestra. Se aplica para muestras finas y materiales ligeramente compresibles. Lo más importante a tener en cuenta es que no existan huecos de aire entre los electrodos y la superficie del material.

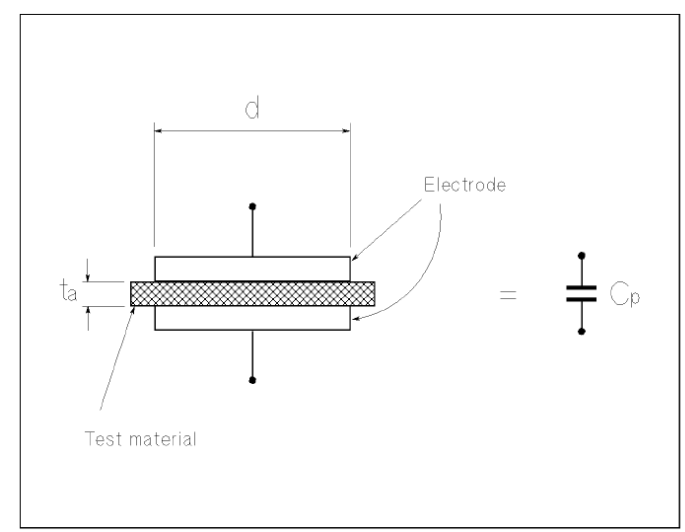

Figura 3.6. Método de contacto directo de la muestra con los dos electrodos (placas) de metal (Agilent Technologies, 2000).

El equipo de placas paralelas se calibró conforme a las especificaciones proporcionadas por la empresa Agilent (Agilent Technologies, 2000). Fundamentalmente consistía en asegurar el paralelismo de las placas, y se utilizó el open/short proporcionado con el equipo.

La constante dieléctrica y el factor de pérdidas se obtuvieron a partir de la capacitancia y el factor de disipación que proporcionaba el equipo tras cada medida. Se utilizaron las ecuaciones siguientes (Agilent Technologies, 2000):

$$
\begin{aligned}
& \varepsilon^{\prime}=\frac{t_{a} \times C_{p}}{\pi \times\left(\frac{d}{2}\right)^{2} \times \varepsilon_{0}} \\
& D_{t}=D=\tan \delta
\end{aligned}
$$


Donde:

$\varepsilon^{\prime}:$ Constante dieléctrica

$\mathrm{C}_{\mathrm{p}}$ : Capacitancia equivalente en paralelo $(\mathrm{F})$

D: Factor de disipación

$\mathrm{D}_{\mathrm{t}}$ : Factor de disipación de la muestra

$\tan \delta:$ tangente de pérdidas

$\mathrm{t}_{\mathrm{a}}:$ Espesor medio de la muestra $(\mathrm{m})$

$\mathrm{d}$ : Diámetro del electrodo superior $(\mathrm{m})\left[38 \times 10^{-3} \mathrm{~m}\right]$

$\varepsilon_{0}=8.854 \times 10^{-12}(\mathrm{~F} / \mathrm{m})$

\subsection{Determinación de propiedades físico-químicas}

\subsubsection{Determinación de la actividad de agua}

La actividad de agua se determinó con un higrómetro de punto de rocío Decagón de la marca Aqualab®, modelo serie $3 \mathrm{TE}$ a $25^{\circ} \mathrm{C}$ (Decagon Devices, Inc., Washington, E.E.U.U.). La precisión del equipo es de \pm 0,003. Para comprobar la correcta calibración del equipo se emplearon disoluciones de referencia proporcionadas por la casa Aqualab ${ }^{\circledR}$.

Se considera que la actividad de agua obtenida corresponde con la $a_{w}$ superficial debido a que las medidas se realizaron sin una desestructuración previa de las muestras (Figura 3.7).

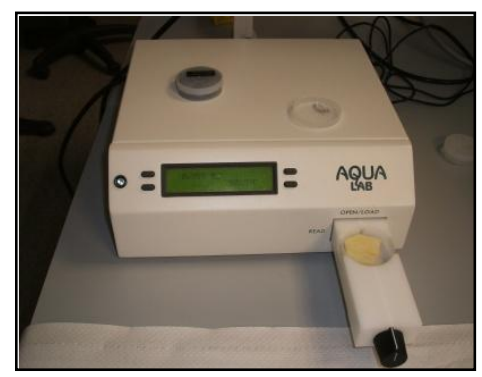

Figura 3.7. Equipo utilizado para medir la $a_{w}$ 


\subsubsection{Determinación de la humedad}

Para la determinación de la humedad se emplearon diferentes métodos en función del tipo de muestra:

- La determinación de la humedad en las experiencias de lomo de cerdo se realizó mediante pérdida de masa de las muestras desestructuradas tras secado en estufa a $110{ }^{\circ} \mathrm{C}$ a presión atmosférica ISO 1442 (1997). La fracción másica de agua $\left(\mathrm{x}_{\mathrm{w}}\right)$ se obtuvo a partir de la ecuación 3.3.

$$
x_{w}=\frac{M_{p+m h}-M_{p+m s}}{M_{p+m h}-M_{p}}
$$

Siendo,

$\mathrm{M}_{\mathrm{p}}=$ masa del recipiente de vidrio $(\mathrm{g})$

$\mathrm{M}_{\mathrm{p}+\mathrm{mh}}=$ masa del recipiente de vidrio y la muestra húmeda $(\mathrm{g})$

$\mathrm{M}_{\mathrm{p}+\mathrm{ms}}=$ masa del recipiente de vidrio y la muestra seca $(\mathrm{g})$

- Para la determinación de la humedad en muestras de frutas se empleó el método AOAC 22.013 (1984). Este método consiste en el secado de la muestra hasta peso constante en estufa a vacío, a $60{ }^{\circ} \mathrm{C}$. La fracción másica de agua $\left(\mathrm{x}_{\mathrm{w}}\right)$ se obtuvo a partir de la ecuación 3.3.

\subsubsection{Determinación de los sólidos solubles}

\subsubsection{Determinación del contenido de $\mathrm{NaCl}$}

El análisis de la concentración de cloruros se realizó mediante una valoración argentiométrica de $500 \mu \mathrm{l}$ de un extracto obtenido a partir de las muestras. Para ello se empleó un analizador de cloruros Sherwood modelo 926 Chloride Analyser (Figura 3.8).

Para su preparación, la muestra se trituró, se diluyó convenientemente en agua destilada y se homogeneizó en un Ultraturrax modelo T25 a 10000 rpm. Una vez la muestra estuvo desestructurada por completo, se centrifugó a 4000 rpm durante 10 minutos separando después el sobrenadante. 
Dado que en este experimental las muestras sufrieron distintos tiempos de deshidratación osmótica, la cantidad de sal presente en las muestras no fue siempre la misma. Por ello, se tomó $500 \mu$ del sobrenadante y se realizó un primer análisis. En el caso de que el valor fuese superior al límite de seguridad de medida máximo del analizador, se realizó una segunda dilución a partir de dicho sobrenadante que permitiera alcanzar el rango de medida del instrumento.

Una vez obtenida la concentración de cloruros, se calculó la concentración de $\mathrm{NaCl}$ de la muestra mediante balances de masa a partir del valor de concentración de iones $\mathrm{Cl}^{-}$, la masa de muestra y las disoluciones empleadas.

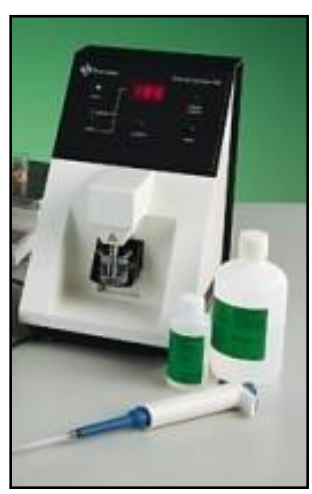

Figura 3.8. Analizador de cloruros, Sherwood 926 Chloride Analyser

\subsubsection{Determinación del contenido de sólidos solubles en fruta}

El contenido en sólidos solubles se determinó a partir del índice de refracción de las muestras. La obtención del índice de refracción se realizó con un refractómetro (ABBE, ATAGO, Modelo 3-T, Japón) termostatado a $20^{\circ} \mathrm{C}$ (Figura 3.9). A partir de la lectura de ${ }^{\circ}$ Brix es posible obtener la fracción másica en solutos de la muestra analizada aplicando la ecuación 3.4.

$$
x_{s}=\frac{x_{w} \cdot z_{s}}{1-z_{s}}
$$

(Ecuación 3.4) 
Donde,

$\mathrm{x}_{\mathrm{s}}$ : fracción másica de solutos.

$\mathrm{x}_{\mathrm{w}}$ : fracción másica de agua.

Zs: contenido en sólidos solubles de la fracción líquida de la muestra expresada en tanto por uno.

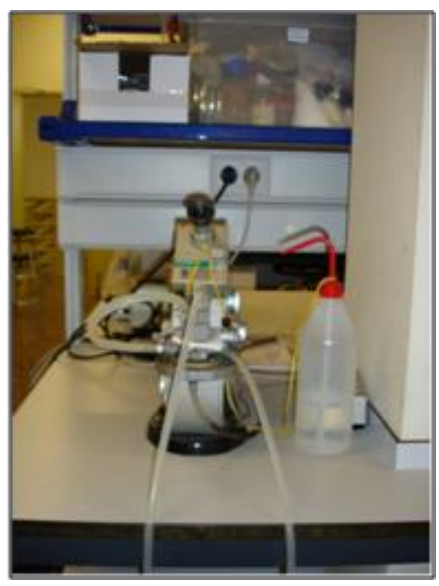

Figura 3.9. Refractómetro ABBE ATAGO, 3-T

\subsubsection{Determinación de la masa}

Para realizar las medidas de masa se utilizó una balanza analítica de precisión de la marca Mettler Toledo®, modelo AB304-S.

\subsubsection{Determinación del volumen}

Las medidas de volumen se realizaron, mediante una técnica de análisis de imagen, tanto del alzado como del perfil de las muestras (Figura 3.10), usando el software Adobe Photoshop CS2 (Adobe Systems Inc., San José, CA, E.E.U.U.). 
Sobre una superficie plana, se colocó un fondo de color negro mate para evitar que el flash pudiera reflejarse en él y distorsionar la imagen, situando además una tira de papel milimetrado al lado de las mismas. Se usó un soporte para cámaras que se colocó a $40 \mathrm{~cm}$ de la superficie, de modo que el objetivo quedó en un plano paralelo al de las muestras.

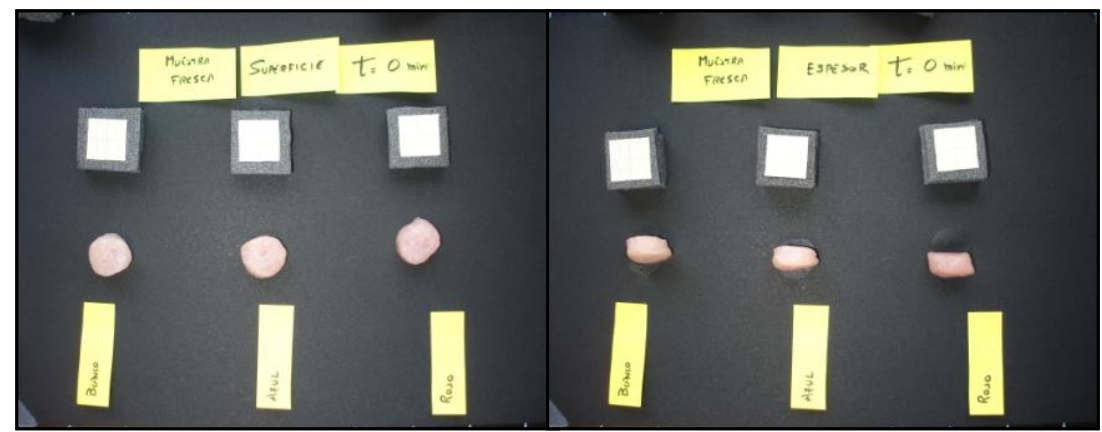

Figura 3.10. Detalle del montaje utilizado para la obtención de la superficie y espesor de las muestras de carne.

\subsubsection{Determinación del pH}

La medida del $\mathrm{pH}$ de las muestras se realizó mediante un $\mathrm{pH}$-metro de punzón portátil CRISON PH25® (CRISON Instruments S.A., España)

\subsubsection{Determinación de la acidez valorada}

En el caso de manzana, la acidez se determinó mediante una valoración con solución de $\mathrm{NaOH} 0.1 \mathrm{~N}$, considerando que todo el ácido presente era ácido málico y utilizando el factor de conversión 0.067 para ácido málico (AOAC 22.008, 1984). La fórmula utilizada se presenta a continuación (ecuación 3.5). 


$$
A c_{\text {Valorada }}=\frac{V_{\mathrm{NaOH}} \times 0.1 \times 0.067 \times 100}{V_{\text {Zumo }}}
$$

Siendo,

- Ac Valorada la acidez del zumo expresada como (g ác. Málico/100mL zumo)

- $\mathrm{V}_{\mathrm{NaOH}}$ el volumen de hidróxido sódico utilizado en la valoración expresado en $\mathrm{mL}$

- VZumo el volumen de zumo pipeteado, que en este caso fue de $5 \mathrm{~mL}$

En el caso de kiwi, la acidez se determinó mediante una valoración con solución de $\mathrm{NaOH} 0.1 \mathrm{~N}$, considerando que todo el ácido presente era ácido cítrico y utilizando el factor de conversión 0.064 para ácido cítrico (AOAC 942.15, 2000).

\subsubsection{Determinación del contenido catiónico en frutas}

El contenido catiónico en muestras de kiwi se analizó mediante cromatografía (Methrom Ion Analysis, Herisau, Switzerland), utilizando una columna universal (Metrosep C2-150, $4.0 \times 150 \mathrm{~mm}$ ) con un elyuente compuesto por ácido tartárico (4.0 mmol/L) y ácido dipicolítico $(0.75 \mathrm{mmol} / \mathrm{L})$, equipado por detectores electrónicos. En cada caso, las muestras de kiwi se homogeneizaron previamente a $9000 \mathrm{rpm}$ en un ULTRATURRAX T25 durante 5 minutos y se centrifugaron (J.P. Selecta S.A., Medifriger-BL, Barcelona, Spain) a 4000 rpm durnate 20 minutos. Después, se tomó $1 \mathrm{~mL}$ del sobrenadante y se enrasó hasta $50 \mathrm{~mL}$ con agua Milli®-Q. Se filtró en filtros de jeringa de $0.45 \mu \mathrm{m}$ de nylon. De ese filtrado se tomaron $15 \mathrm{~mL}$ para analizar el contenido catiónico. 


\subsection{Microscopía Electrónica de Barrido a bajas Temperaturas (Cryo-SEM)}

Las muestras se sumergen en $\mathrm{N} 2$ nieve a temperatura $\leq-210^{\circ} \mathrm{C}$, y se transfieren rápidamente a un Cryo-Trans CT1x500C (Oxford Instruments, Witney, UK), acoplado a un microscopio electrónico de barrido Jeol JSM-5410 (Jeol, Tokyo, Japan), que trabaja en condiciones de congelación $\left(\mathrm{T}<-130^{\circ} \mathrm{C}\right)$ a vacío $(1 \mathrm{kPa})$.

En el Cryo-Trans la muestra se fractura a $-180^{\circ} \mathrm{C}$ con ayuda de un pequeño punzón. La muestra se introduce en la cámara del microscopio para ser sublimada a $-95^{\circ} \mathrm{C}$, con el fin de eliminar el posible exceso de escarcha superficial que pueda enmascarar la adecuada observación de la muestra.

Finalmente, antes de proceder a su estudio, la muestra se recubre con Au en el mismo Cryo-Trans $(0.2 \mathrm{kPa}$ y $2 \mathrm{~mA})$. La observación se produce a $15 \mathrm{kV}$ y a una distancia de trabajo de $15 \mathrm{~mm}$ para la obtención de imágenes.

\subsection{Determinación de las pérdidas de exudado en lomo de cerdo (Drip loss)}

A las 24 horas post mortem se cortaron tres lonchas por lomo de aproximadamente $100 \mathrm{~g}$, se pesaron en una balanza de precisión, se introdujeron en una bolsa de polietileno previamente pesada y se mantuvieron suspendidas en una cámara a $4^{\circ} \mathrm{C}$ durante 72 horas. Se prestó especial atención a que la bolsa permaneciera cerrada para evitar pérdidas por evaporación y que no ejerciera presión sobre la loncha para evitar el exudado por presión. Una vez transcurrido ese tiempo, se descolgaron y se pesó por un lado la carne y por otro lado la bolsa con el exudado liberado durante este periodo, expresándose las pérdidas por goteo como el porcentaje de pérdida de peso de la muestra con respecto a su peso a las 24 horas post mortem (Figura 3.11). 


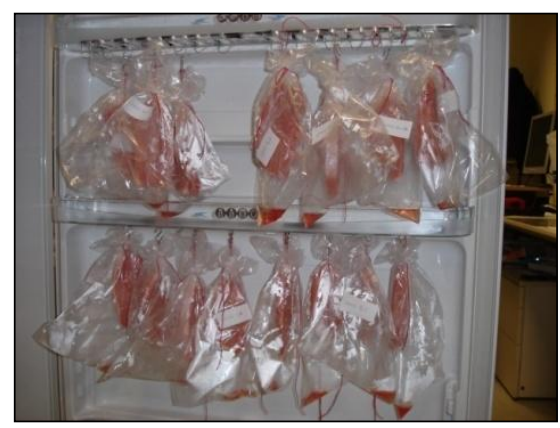

Figura 3.11. Lomos colgados en refrigeración a $4^{\circ} \mathrm{C}$ para la determinación del Drip loss.

\subsection{Análisis de color}

Para el análisis de color se utilizó un espectrocolorímetro Minolta modelo CM-3600D (Minolta Co. Ltd., Tokio, Japón) (Figura 3.12), mediante el que se obtuvo el espectro de reflexión de las muestras de carne. Se realizaron tres medidas por cada loncha en cada tiempo seleccionado. El equipo mide el espectro de reflexión entre 400 y $700 \mathrm{~nm}$ a intervalos de $10 \mathrm{~nm}$. Las coordenadas de color CIE $L^{*} a b^{*}$ (CIE, 1978), el Croma $\left[\left(a^{* 2}+b^{* 2}\right)^{1 / 2}\right]$ y el tono $\left[\operatorname{Tan}^{-1}\left(\mathrm{~b}^{*} / \mathrm{a}^{*}\right)\right]$ fueron calculadas por el software del equipo, utilizando como referencia el observador $10^{\circ}$ y el iluminante D65.

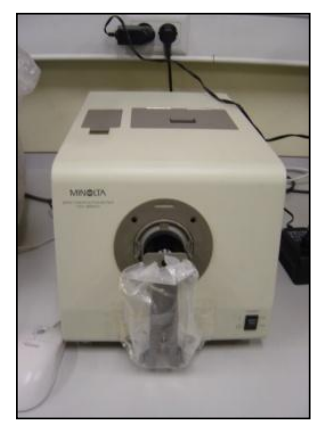

Figura. 3.12. Colorímetro Minolta CM-3600D

Los ratios K/S se calcularon utilizando el software SpectraMagic ver. 3.6 (Minolta Co., Ltd., Osaka, Japón). La cantidad relativa de Desoximioglobina $(\mathrm{DMb})$ se estimó a partir del ratio $\mathrm{K} / \mathrm{S}_{474} \div \mathrm{K} / \mathrm{S}_{525}$, la cantidad relativa de 
Oximioglobina $\left(\mathrm{MbO}_{2}\right)$ a partir del ratio $\mathrm{K} / \mathrm{S}_{610} \div \mathrm{K} / \mathrm{S}_{525}$ y la cantidad relativa de Metamioglobina (MetMb) a partir del ratio $\mathrm{K} / \mathrm{S}_{572} \div \mathrm{K} / \mathrm{S}_{525}$ (Hunt et al, 1991; Mancini et al, 2003). Estos ratios decrecen cuando la cantidad relativa de las especies de mioglobina se incrementan; por ello, los $\mathrm{K} / \mathrm{S}$ ratios se multiplicaron por (-1) para obtener la impresión correcta al observar las figuras. Los valores de $\mathrm{K} / \mathrm{S}$ a las longitudes de onda que no vienen proporcionadas por el equipo (474, 525 y $572 \mathrm{~nm}$ ) fueron obtenidas mediante interpolación.

\subsection{Determinación de parámetros bioquímicos del lomo de cerdo}

\subsubsection{Nucleótidos y nucleósidos}

La determinación de nucleótidos y nucleósidos se realizó mediante cromatografía líquida de alta resolución (HPLC) en fase inversa utilizando un cromatógrafo Agilent modelo 1100 (Agilent Technologies, Palo Alto, CA), provisto de una bomba cuaternaria, horno para columnas y detector U.V (Figura 3.13). La separación se realizó en una columna C18 Synergi $4 \mu \mathrm{m}$ MAX-RP 80A 150 x 4,6 mm (Phenomenex, Torrance, CA) y detección UV a 254 nm. Durante la preparación de la muestra para el análisis de nucleótidos y nucleósidos fue esencial mantener la cadena de frío, especialmente hasta que se añadió ácido perclórico $\left(\mathrm{HClO}_{4}\right)$ que actuó simultáneamente como desproteinizante y disolvente de extracción. Así, la muestra que había sido congelada con nitrógeno líquido se trituró, y $4 \mathrm{~g}$ se homogeneizaron con $15 \mathrm{~mL}$ de $\mathrm{HClO}_{4} 0.6 \mathrm{M}$ en un masticador (IUL Instruments GMBH, Barcelona, España) en frío durante cuatro minutos y se centrifugó durante 20 minutos a 10.000 x g en una centrífuga refrigerada Sorvall ${ }^{\circledR}$ RC-5B (Du Pont Instruments, Chadds Ford, PA). El sobrenadante se filtró a través de fibra de vidrio y se neutralizó con carbonato potásico hasta $\mathrm{pH} 6,5-7,5$. El extracto obtenido se mantuvo congelado a $-20^{\circ} \mathrm{C}$ 
hasta su uso. Previamente a la inyección, el extractofue descongelado y filtrado a través de filtros de $0.45 \mu \mathrm{m}$.

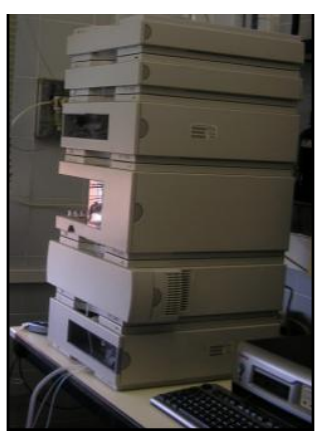

Figura 3.13. Cromatógrafo (HPLC) utilizado en la determinación de nucleótidos, nucleósidos y aminoácidos.

Las fases móviles empleadas fueron dos: una fase A formada por fosfato monopotásico 0,1 M pH 6 y una fase B formada por fase A: metanol (75:25) (v/v) empleándose un caudal de fase móvil de $1 \mathrm{~mL} / \mathrm{min}$. El gradiente utilizado se detalla en la tabla 3.1 .

Tabla 3.1. Gradiente utilizado en el análisis de nucleótidos y nucleósidos.

\begin{tabular}{|ccc|} 
Tiempo (min) & Fase A (\%) & Fase B (\%) \\
\hline 0.00 & 100 & 0 \\
5.00 & 100 & 0 \\
22.00 & 15 & 85 \\
\hline
\end{tabular}

Después de cada análisis, se lavó la columna con 100\% de fase B durante 8 minutos y se equilibró con 100\% de A durante 10 minutos antes de la siguiente inyección.

Los nucleótidos/nucleósidos analizados fueron: 5'-adenosín trifosfato (ATP), 5'-adenosín difosfato (ADP), 5'-adenosín monofosfato (AMP), 5'-inosín monofosfato (IMP), inosina e hipoxantina. La identificación de los picos cromatográficos se realizó comparando los tiempos de retención y los espectros 
con los de los correspondientes patrones, y la cuantificación se realizó mediante rectas de calibrado.

\subsubsection{Aminoácidos}

Los aminoácidos libres y los dipéptidos naturales se analizaron por HPLC utilizando el cromatógrafo descrito en el apartado anterior, en una columna de fase inversa Nova Pack C18 de 300 x 3.9 mm (Waters Co., Milford, MA, USA) y detección UV a $254 \mathrm{~nm}$. Para el análisis se partió del extracto perclórico neutralizado obtenido previamente para la determinación de nucleótidos (apartado 3.6.1.). Previo al análisis, los aminoácidos y dipéptidos se derivatizaron con fenilisocianato según el método descrito por (Bidlingmeyer et al, 1987). A 200 $\mu \mathrm{L}$ del extracto se le añadió $50 \mu \mathrm{L}$ de patrón interno, norleucina $0.01 \mathrm{M} \mathrm{HCl}$, y se secó en un evaporador centrífugo a vacío Jouan, modelo RC.10.10 (Figura 3.14), una vez seco se le añadió $15 \mu \mathrm{L}$ de "reactivo de secado" formado por metanol: acetato sódico 1M: trietilamina (2:2:1), se agitó y se volvió a secar, cuando ya estuvo seco se le añadió $15 \mu \mathrm{L}$ de "reactivo de derivatización" compuesto por metanol: agua: trietilamina: fenilisotiocianato (7:1:1:1), se agitó, se dejó reaccionar durante 20 minutos y se volvió a secar en el evaporador. Las muestras derivatizadas y secas se mantuvieron en congelación a $-20^{\circ} \mathrm{C}$ hasta su análisis.

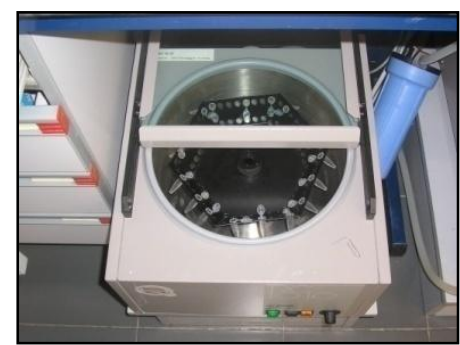

Figura 3.14. Evaporador centrífugo a vacío utilizado para evaporar los reactivos de derivatización. 
Previamente a su inyección en el cromatógrafo, las muestras se diluyeron en $200 \mu \mathrm{L}$ de reactivo de dilución compuesto por tampón fosfato $5 \mathrm{mM} \mathrm{pH} \mathrm{7,4}$ conteniendo el 5\% de acetonitrilo, se centrifugaron durante 5 minutos a 14000 $\mathrm{rpm}$, en frío, en una centrífuga para eppendorf Microfuge ${ }^{\circledR} 22 \mathrm{R}$ Centrifuge (Beckman Coulter ${ }^{\mathrm{TM}}$ ) y se inyectaron $20 \mu \mathrm{L}$ al cromatógrafo manteniendo la temperatura de columna en $40^{\circ} \mathrm{C}$.

Las fases móviles empleadas fueron dos: una fase A formada por tampón acetato sódico $70 \mathrm{mM}$ a pH 6.55 con 2.5\% (v/v) de acetonitrilo y una fase B formada por acetonitrilo: agua: metanol (45:40:15) (v/v), empleándose un caudal de fase móvil de $1 \mathrm{~mL} / \mathrm{min}$ y el gradiente descrito en la tabla 3.2.

Tabla 3.2. Gradiente utilizado en el análisis de aminoácidos

\begin{tabular}{|ccc|}
\hline Tiempo (min) & Fase A (\%) & Fase B ( $/ \mathbf{0})$ \\
\hline 0.0 & 100.0 & 0.0 \\
13.5 & 97.0 & 3.0 \\
16.5 & 96.9 & 3.1 \\
19.0 & 96.5 & 3.5 \\
21.0 & 95.5 & 4.5 \\
40.0 & 67.0 & 33.0 \\
50.0 & 60.0 & 40.0 \\
60.0 & 40.0 & 60.0 \\
\hline
\end{tabular}

Después de cada análisis se lavó la columna durante 10 minutos con 100\% de fase B y se equilibró la columna con 100\% de fase A durante 20 minutos antes de la siguiente inyección.

Se analizaron un total de 21 aminoácidos : ácido aspártico (Asp), ácido glutámico (Glu), serina (Ser), asparagina (Asn), glicina (Gly), glutamina (Gln), $\beta$ alanina ( $\beta-\mathrm{Ala}$ ), histidina (His), treonina (Thr), alanina (Ala), arginina (Arg), prolina (Pro), tirosina (Tyr), valina (Val), metionina (Met), isoleucina (Ile), leucina (Leu), triptófano (Trp), ornitina (Orn), lisina (Lys) y la taurina (Tau) y dos dipéptidos naturales; carnosina (Car) y anserina (Ans). 
La identificación se realizó comparando los tiempos de retención con los de los correspondientes patrones y la cuantificación se realizó mediante patrón interno (Norleucina) construyendo previamente las rectas de calibrado relativas a dicho patrón. Los resultados se expresaron en mg de aminoácidos/ 100 g de músculo.

\subsection{3. Ácido láctico}

La determinación del contenido de ácido láctico en carne se realizó mediante HPLC en el cromatógrafo anteriormente descrito. En este caso se utilizó una columna Rezex ROA -Organic Acid $\mathrm{H}^{+}$de 300 x 7.8 mm (Phenomenex) y detección UV a $210 \mathrm{~nm}$.

La separación se hizo de modo isocrático utilizando como fase móvil ácido sulfúrico $0.005 \mathrm{~N}$ a caudal de $0.5 \mathrm{~mL} / \mathrm{min}$ y manteniéndose la columna a $40{ }^{\circ} \mathrm{C}$.

Para este análisis también se utilizaron las muestras de extracto desproteinizado utilizadas en los otros análisis, de las que se inyectó $20 \mu \mathrm{L}$.

La identificación se realizó comparando el tiempo de retención con el del patrón de ácido láctico y la cuantificación se realizó mediante una recta de calibrado. Los resultados se expresaron en g de ácido láctico/ 100 g de músculo.

\subsection{Estudio de los espectros dieléctricos de lomo de cerdo y su relación con los parámetros de calidad de carne fresca}

\subsubsection{Estudio de disoluciones patrón}

Previamente a la realización del experimental con muestras de lomo de cerdo, se realizaron análisis de disoluciones patrón con diferentes concentraciones de algunos componentes clave en el proceso de maduración de 
la carne. Se prepararon disoluciones de ácido láctico de 850 a $250 \mathrm{mg} / 100 \mathrm{~g}$ de carne, ATP de 24 a $0.5 \mu \mathrm{mol} / \mathrm{g}$ carne, AMP de 6 a $0.15 \mu \mathrm{mol} / \mathrm{g}$ carne, IMP de 40 a $1 \mu \mathrm{mol} / \mathrm{g}$ carne, inosina de 20 a $0.5 \mu \mathrm{mol} / \mathrm{g}$ carne e hipoxantina de 4 a 0.1 $\mu \mathrm{mol} / \mathrm{g}$ carne. Las disoluciones patrón se prepararon con agua bidestilada para analizar exclusivamente el efecto del elemento en cuestión sin que el eluyente interfiriese en las medidas.

\subsubsection{Estudio de muestras de lomo fresco}

El presente estudio forma parte de un proyecto multidisciplinar en el que colaboraron el Instituto de Ingeniería de Alimentos para el Desarrollo de la Universidad Politécnica de Valencia (IuIAD.) y el Instituto de Agroquímica y Tecnología de Alimentos (IATA). Las determinaciones físicas y físico-químicas de los lomos de cerdo se realizaron en el IuIAD mientras que las determinaciones bioquímicas se realizaron en el IATA., tal como se especifica a continuación en el diagrama de flujo de las experiencias realizadas (Figura 3.15). 


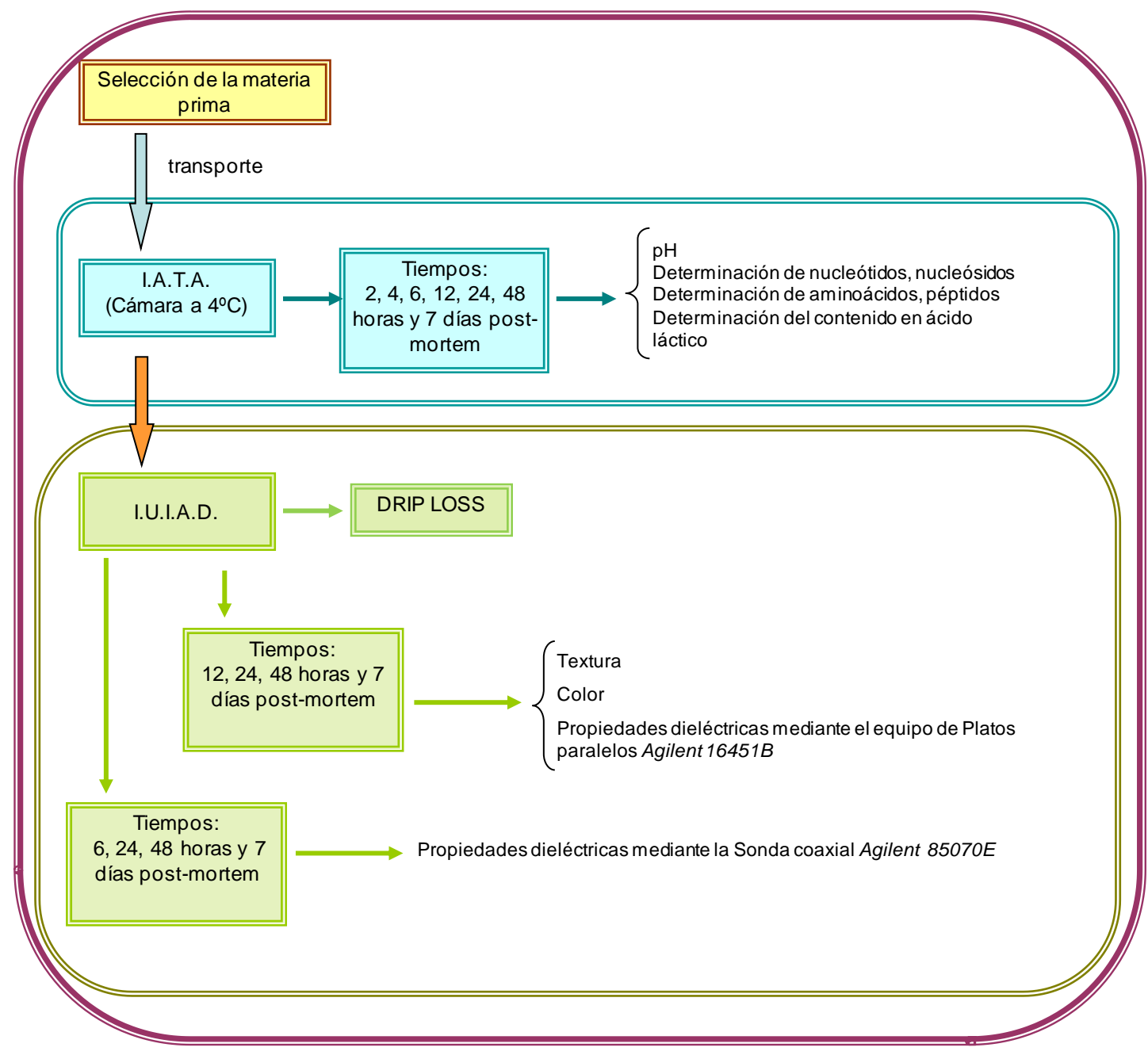

Figura 3.15. Diagrama de flujo de las experiencias realizadas para el estudio de maduración del lomo de cerdo.

Los animales fueron sacrificados a las 6:50 horas. Tras el sacrificio, se llevaron a la cámara de oreo a $0^{\circ} \mathrm{C}$ y allí se separaron los cerdos (Figura 3.16).

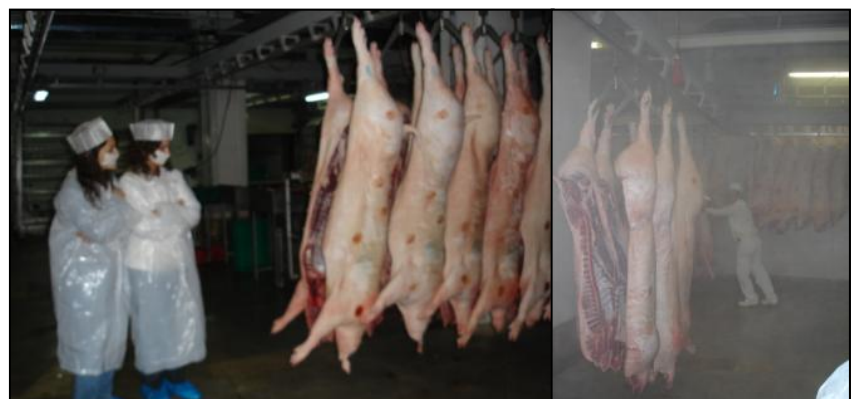

Figura 3.16. Selección de la materia prima. 
Una vez seleccionados los animales se procedió al despiece de los mismos en una cámara a $8^{\circ} \mathrm{C}$ (Figura 3.17). Los lomos se embalaron debidamente, cubriéndolos con film transparente, para su transporte al IATA.

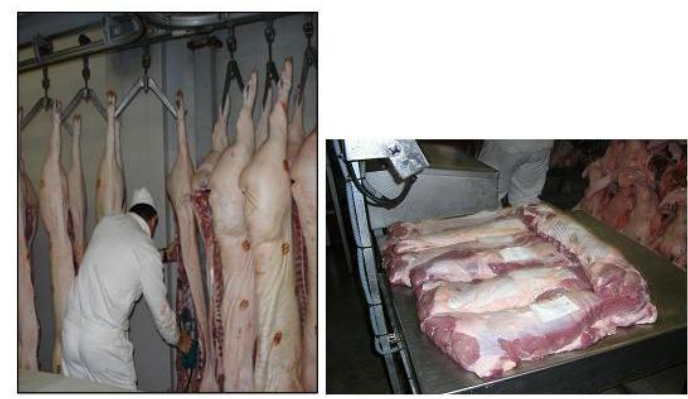

Figura 3.17. Despiece y preparación de lomos para el transporte al IATA.

A la llegada al IATA la temperatura de los lomos era de $21^{\circ} \mathrm{C} \pm 1$. Seguidamente se midió el pH de los mismos, se cortaron virutas que se congelaron inmediatamente con nitrógeno líquido y se envasaron a vacío para evitar la degradación de los componentes de la carne (Figura 3.18) Las muestras así obtenidas se almacenaron a $-80^{\circ} \mathrm{C}$ hasta el momento de los análisis bioquímicos (nucleótidos, nucleósidos, aminoácidos y dipéptidos). Este primer muestreo correspondió a carne de 2 horas postmortem.

Los lomos, cubiertos con film, se introdujeron en una cámara a $4^{\circ} \mathrm{C}$ y una vez alcanzada esta temperatura cada uno de ellos se dividió en dos partes. La mayor de ellas se trasladó al IuIAD con el fin de realizar las medidas de las propiedades dieléctricas, textura y color; la otra parte del lomo se mantuvo en refrigeración, realizando muestreos a las 4, 6, 12, 24, 48 horas y 7 días post mortem, tal y como se describió anteriormente, para realizar los análisis bioquímicos. Se midió además el pH de las muestras a esos tiempos. 


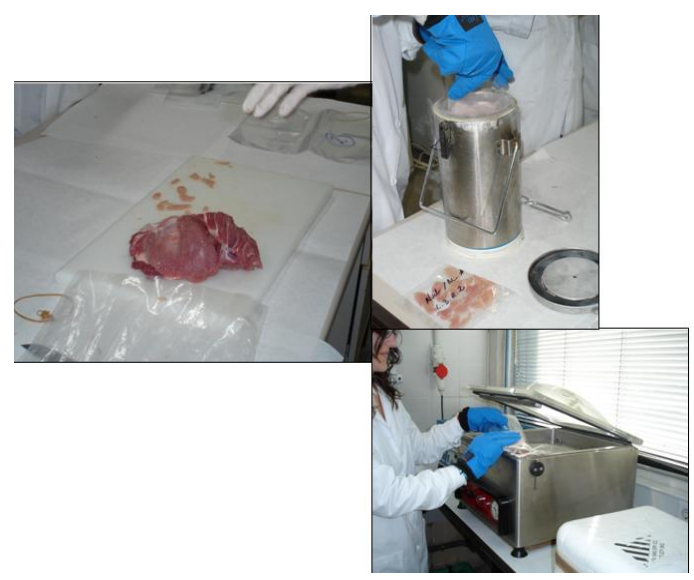

Figura 3.18. Congelación de muestras con nitrógeno líquido y envasado a vacío.

Una vez en el IuIAD, se cortaron tres cubos por cada lomo de $3 \mathrm{~cm}$ de lado y se cosió un hilo en la cara de la dirección de las fibras para su correcta identificación. Las muestras se introdujeron en cubos de las mismas dimensiones realizados con metacrilato y previamente rotulados (Figura 3.19), se taparon con parafilm para evitar su deshidratación y se introdujeron en una incubadora Hotcold-M (JP Selecta $\left.{ }^{\circledR}\right)$ a $4^{\circ}$ C. Con estos cubos se midieron las propiedades dieléctricas con la sonda coaxial Agilent 85070 unida a un analizador de redes Agilent E8362B.

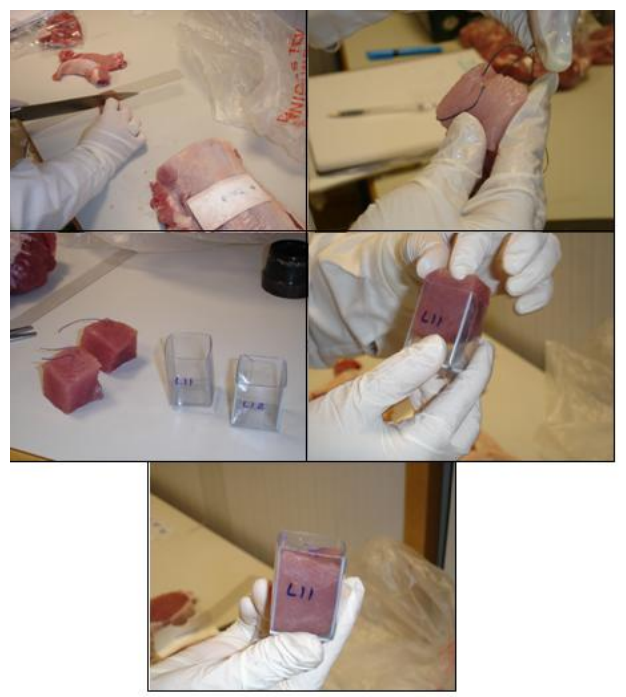

Figura 3.19. Detalle de las muestras de carne utilizadas para las medidas de espectros dieléctricos mediante la sonda coaxial Agilent 85070, identificación de la dirección de las fibras e introducción de los mismos en los cubos de metacrilato. 
Para la medida de las propiedades dieléctricas mediante los platos paralelos Agilent $16451 B$ conectados a un analizador de impedancias Agilent $4194 A$, se loncheó mediante una loncheadora seis lonchas por lomo (3 cortadas en la dirección de las fibras, 3 cortadas en perpendicular a las fibras) con $3 \pm 1 \mathrm{~mm}$ de espesor y, a partir de esas lonchas, utilizando un sacabocados cilíndrico de 4.6 cm de diámetro, se obtuvieron las muestras (Figura 3.20).
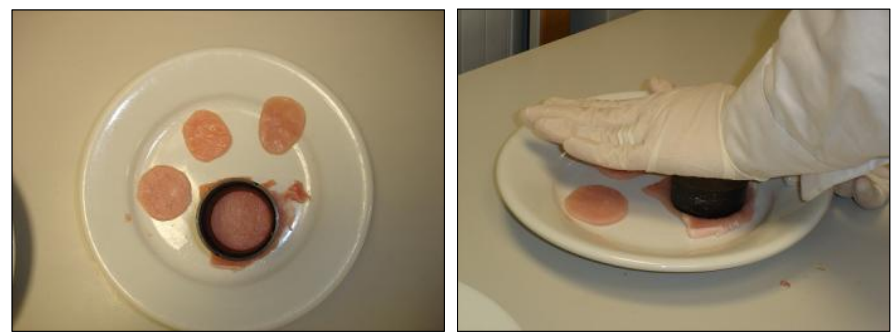

Figura 3.20. Detalle de la preparación de las muestras para la medida mediante los platos paralelos Agilent 16451B.

Posteriormente, se cortaron tres cubos por lomo de $2 \mathrm{~cm}$ de lado para la medida de la textura y lonchas de $2 \mathrm{~cm}$ de espesor para la medida del color.

Todas estas medidas (propiedades dieléctricas a baja frecuencia, textura, color) se realizaron a las 12 horas, a las 24 horas, a las 48 horas y a los 7 días postmortem. Las medidas de las propiedades dieléctricas mediante la sonda coaxial Agilent 85070 se realizaron a las 6, 24, 48 horas y 7 días postmortem.

Todas las medidas se realizaron por triplicado.

Además se determinaron las pérdidas por goteo o Drip loss.

\subsection{Estudio de la cinética de salado de lomo de cerdo mediante la utilización de espectros dieléctricos}

El diagrama del plan experimental se muestra en la figura 3.21. Para la operación de salado se empleó salmuera al 25\% (p/p) de $\mathrm{NaCl}$. La relación entre las muestras y la disolución durante la deshidratación fue de 1:20 (p/p) para evitar 
cambios significativos en la concentración de la disolución durante el proceso. El tratamiento se realizó a la temperatura controlada de $4^{\circ} \mathrm{C}$. Se cortaron 54 cilindros de carne (15 mm de diámetro y $10 \mathrm{~mm}$ de espesor). Las muestras se introdujeron en la disolución durante $0,5,10,15,25,30,40,50,60,90$ minutos y $2,2.5,3,4,5,8$ y 12 horas. Tras el tratamiento, las muestras se equilibraron en una cámara Hotcold-M (JP Selecta ${ }^{\circledR}$ ) a $4^{\circ} \mathrm{C}$ durante 16 horas. La muestra fresca se caracterizó determinando su masa, volumen, $a_{w}$, espectro dieléctrico, humedad y cloruros. A cada muestra, previamente al tratamiento de deshidratación osmótica, se le determinó la masa y el volumen. Inmediatamente tras la realización del tratamiento se determinó la masa, volumen, $\mathrm{a}_{\mathrm{w}} \mathrm{y}$ espectro dieléctrico de las muestras; como estos ensayos son no destructivos, se dejó reposar las muestras durante 16 horas en las cajas de Decagon precintadas con parafilm y se determinó la masa, el volumen, $a_{w}$, espectro dieléctrico, humedad y cloruros de las muestras reposadas.

Para cada tiempo de deshidratación osmótica se iban extrayendo muestras de la salmuera para realizar medidas de $a_{w}$, espectro dieléctrico y cloruros. 


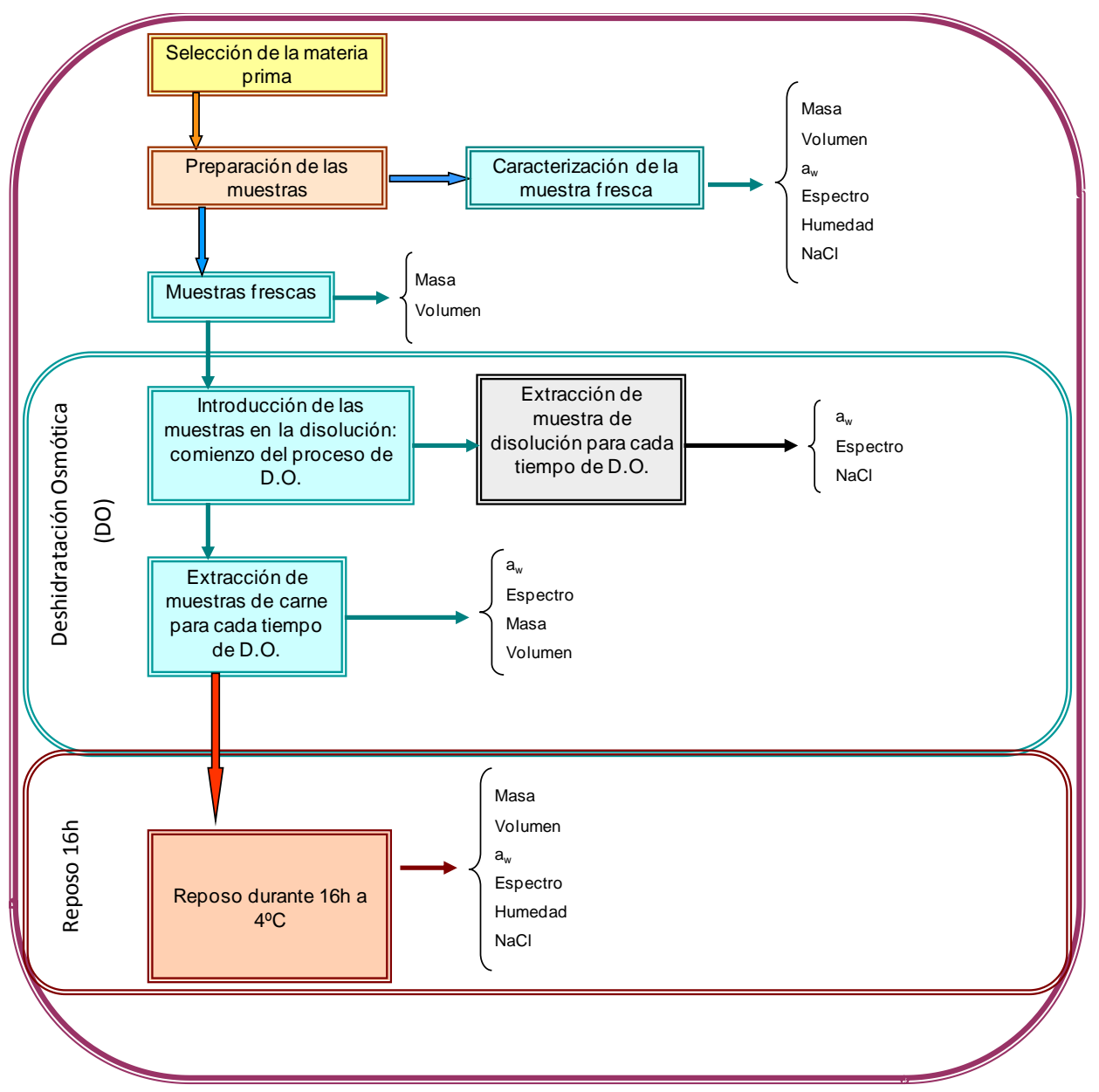

Figura 3.21. Diagrama de flujo de las experiencias realizadas para el estudio de salado de lomo de cerdo.

\subsection{Estudio de la influencia de la composición y la estructura en el análisis de las propiedades dieléctricas de manzana Granny Smith}

La metodología experimental se realizó en dos etapas tal y como se puede observar en el diagrama de flujo (Figura 3.22), una primera etapa realizada mediante disoluciones patrón tratando de simular la fase líquida de la manzana, y una segunda etapa realizada con muestras de manzana. 


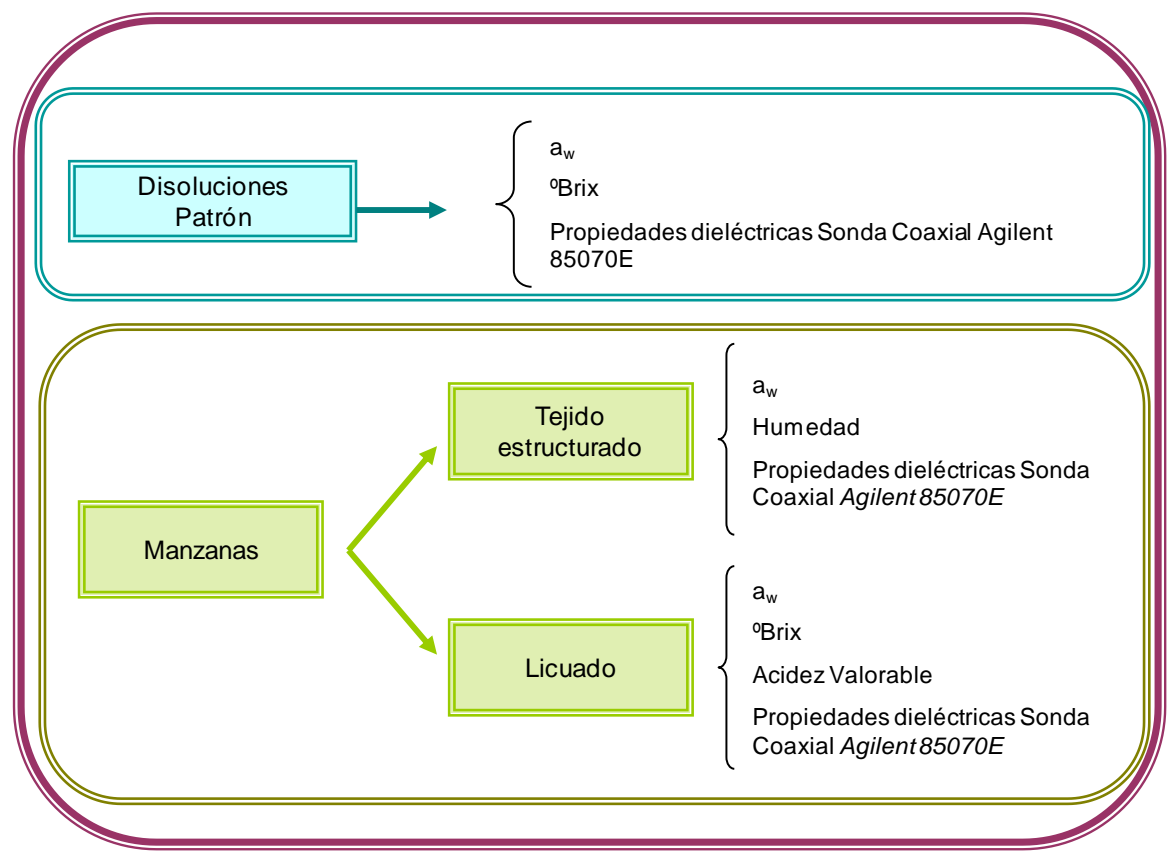

Figura 3.22. Diagrama de flujo de las experiencias realizadas para el experimental de manzana fresca.

La primera etapa se realizó sobre disoluciones patrón que simulaban la fase líquida de manzana (Tablas 3.3.a, b, c). La composición de dichas disoluciones se basó en distintas fuentes bibliográficas (Eisele y Drake, 2005; Ansorena, 2003). Además, la composición de los distintos azúcares se obtuvo teniendo en cuenta que la relación entre los azúcares mayoritarios de la manzana (sacarosa, glucosa y fructosa) es de 1:1:3, respectivamente (Eisele y Drake, 2005).

A dichas disoluciones se les determinó la actividad de agua y se midieron los ${ }^{\circ}$ Brix. Además se les midió el espectro dieléctrico mediante la sonda coaxial Agilent 85070E conectada al analizador de redes Agilent E8362B.

En la segunda etapa el estudio se realizó sobre tejido parenquimático de manzana y sobre el licuado procedente de las mismas manzanas. Para las experiencias se utilizaron 20 manzanas Granny Smith. Cada una de ellas se dividió en dos partes, una de las cuales se utilizó para extraer el licuado, y la otra parte para las determinaciones sobre tejido parenquimático de manzana fresca. Para cada una de las 40 muestras obtenidas se determinó la $a_{w}$ y propiedades dieléctricas. Además a las muestras de manzana se les determinó la humedad, y a los licuados extraídos de éstas los ${ }^{\circ}$ Brix y la acidez valorada. 
Tabla 3.3.a. Composición de las disoluciones patrón de agua y ácido málico empleadas en el presente estudio.

\begin{tabular}{|c|c|}
\hline Identificador & málico $(\mathrm{g} / 100 \mathrm{~mL})$ \\
\hline w & 0 \\
\hline $\mathrm{m} 4$ & 0.4004 \\
\hline $\mathrm{m} 5$ & 0.4996 \\
\hline $\mathrm{m} 6$ & 0.5998 \\
\hline $\mathrm{m} 7$ & 0.7 \\
\hline $\mathrm{m} 8$ & 0.7994 \\
\hline $\mathrm{m} 9$ & 0.8998 \\
\hline $\mathrm{m} 10$ & 1.0002 \\
\hline $\mathrm{m} 11$ & 1.1005 \\
\hline
\end{tabular}

Tabla 3.3.bI. Composición de las disoluciones patrón de agua y ácido málico a diferentes ${ }^{\circ}$ Brix empleadas en el presente estudio.

\begin{tabular}{|c|c|c|}
\hline Identificador & 9Brix & málico $\mathbf{( g / 1 0 0 m L )}$ \\
\hline $\mathrm{B} 7 \mathrm{~m} 0$ & 7 & 0 \\
\hline $\mathrm{B} 7 \mathrm{~m} 5$ & 7 & 0.5006 \\
\hline $\mathrm{B} 7 \mathrm{~m} 6$ & 7 & 0.5999 \\
\hline $\mathrm{B} 7 \mathrm{~m} 7$ & 7 & 0.6999 \\
\hline $\mathrm{B} 7 \mathrm{~m} 8$ & 7 & 0.8001 \\
\hline $\mathrm{B} 7 \mathrm{~m} 9$ & 7 & 0.8996 \\
\hline $\mathrm{B} 7 \mathrm{~m} 1$ & 7 & 1.0001 \\
\hline $\mathrm{B} 9 \mathrm{~m} 0$ & 9 & 0 \\
\hline $\mathrm{B} 9 \mathrm{~m} 5$ & 9 & 0.4999 \\
\hline $\mathrm{B} 9 \mathrm{~m} 6$ & 9 & 0.5998 \\
\hline $\mathrm{B} 9 \mathrm{~m} 7$ & 9 & 0.7 \\
\hline $\mathrm{B} 9 \mathrm{~m} 8$ & 9 & 0.7992 \\
\hline $\mathrm{B} 9 \mathrm{~m} 9$ & 9 & 0.9003 \\
\hline $\mathrm{B} 9 \mathrm{~m} 1$ & 9 & 1.0002 \\
\hline $\mathrm{B} 11 \mathrm{~m} 0$ & 11 & 0 \\
\hline $\mathrm{B} 11 \mathrm{~m} 5$ & 11 & 0.5001 \\
\hline $\mathrm{B} 11 \mathrm{~m} 6$ & 11 & 0.6002 \\
\hline $\mathrm{B} 11 \mathrm{~m} 7$ & 11 & 0.7 \\
\hline $\mathrm{B} 11 \mathrm{~m} 8$ & 11 & 0.8001 \\
\hline $\mathrm{B} 11 \mathrm{~m} 9$ & 11 & 0.8998 \\
\hline $\mathrm{B} 11 \mathrm{~m} 1$ & 11 & 1.0001 \\
\hline
\end{tabular}


Tabla 3.3.bII. Composición de las disoluciones patrón de agua y ácido málico a diferentes ${ }^{\circ}$ Brix empleadas en el presente estudio.

\begin{tabular}{|c|c|c|}
\hline \multicolumn{2}{|c|}{ Identificador } & \multicolumn{2}{c|}{ 'Brix } & málico $\mathbf{( g / 1 0 0 m L})$ \\
\hline $\mathrm{B} 13 \mathrm{~m} 0$ & 13 & 0 \\
\hline $\mathrm{B} 13 \mathrm{~m} 5$ & 13 & 0.5003 \\
\hline $\mathrm{B} 13 \mathrm{~m} 6$ & 13 & 0.5997 \\
\hline $\mathrm{B} 13 \mathrm{~m} 7$ & 13 & 0.6999 \\
\hline $\mathrm{B} 13 \mathrm{~m} 8$ & 13 & 0.7996 \\
\hline $\mathrm{B} 13 \mathrm{~m} 9$ & 13 & 0.8998 \\
\hline $\mathrm{B} 13 \mathrm{~m} 1$ & 13 & 1.0001 \\
\hline $\mathrm{B} 15 \mathrm{~m} 0$ & 15 & 0 \\
\hline $\mathrm{B} 15 \mathrm{~m} 5$ & 15 & 0.4996 \\
\hline $\mathrm{B} 15 \mathrm{~m} 6$ & 15 & 0.5999 \\
\hline $\mathrm{B} 15 \mathrm{~m} 7$ & 15 & 0.7002 \\
\hline $\mathrm{B} 15 \mathrm{~m} 8$ & 15 & 0.8002 \\
\hline $\mathrm{B} 15 \mathrm{~m} 9$ & 15 & 0.8997 \\
\hline $\mathrm{B} 15 \mathrm{~m} 1$ & 15 & 0.9998 \\
\hline
\end{tabular}


Tabla 3.3.c. Composición de las disoluciones patrón de agua, ácido málico y $\mathrm{K}^{+}$a 0 y $13^{\circ}$ Brix.

\begin{tabular}{|c|c|c|c|c|}
\hline Identificador & $\begin{array}{c}\mathbf{z}_{\mathbf{s}} \\
\text { 'Brix }\end{array}$ & $\begin{array}{c}\text { gluconato potásico } \\
\text { (g/100mL) }\end{array}$ & $\begin{array}{c}\text { málico } \\
\text { (g/100mL) }\end{array}$ & K+ (g/100mL) \\
\hline B0m0K10 & 0 & 0.100 & 0.000 & 0.017 \\
\hline B0m5K10 & 0 & 0.100 & 0.500 & 0.017 \\
\hline B0m7K10 & 0 & 0.100 & 0.700 & 0.017 \\
\hline B0m10K10 & 0 & 0.100 & 1.000 & 0.017 \\
\hline B0m0K15 & 0 & 0.150 & 0.000 & 0.025 \\
\hline B0m5K15 & 0 & 0.150 & 0.500 & 0.025 \\
\hline B0m7K15 & 0 & 0.150 & 0.700 & 0.025 \\
\hline B0m10K15 & 0 & 0.150 & 1.000 & 0.025 \\
\hline B0m0K20 & 0 & 0.200 & 0.000 & 0.033 \\
\hline B0m5K20 & 0 & 0.200 & 0.500 & 0.033 \\
\hline B0m7K20 & 0 & 0.200 & 0.700 & 0.033 \\
\hline B0m10K20 & 0 & 0.200 & 1.000 & 0.033 \\
\hline B0m0K25 & 0 & 0.250 & 0.000 & 0.042 \\
\hline B0m5K25 & 0 & 0.250 & 0.500 & 0.042 \\
\hline B0m7K25 & 0 & 0.250 & 0.700 & 0.042 \\
\hline B0m10K25 & 0 & 0.250 & 1.000 & 0.042 \\
\hline B13m0K10 & 13 & 0.100 & 0.000 & 0.017 \\
\hline B13m5K10 & 13 & 0.100 & 0.500 & 0.017 \\
\hline B13m7K10 & 13 & 0.100 & 0.700 & 0.017 \\
\hline B13m10K10 & 13 & 0.100 & 1.000 & 0.017 \\
\hline B13m0K15 & 13 & 0.150 & 0.000 & 0.025 \\
\hline B13m5K15 & 13 & 0.150 & 0.500 & 0.025 \\
\hline B13m7K15 & 13 & 0.150 & 0.700 & 0.025 \\
\hline B13m10K15 & 13 & 0.150 & 1.000 & 0.025 \\
\hline B13m0K20 & 13 & 0.200 & 0.000 & 0.033 \\
\hline B13m5K20 & 13 & 0.200 & 0.500 & 0.033 \\
\hline B13m7K20 & 13 & 0.200 & 0.700 & 0.033 \\
\hline B13m10K20 & 13 & 0.200 & 1.000 & 0.033 \\
\hline B13m0K25 & 13 & 0.250 & 0.000 & 0.042 \\
\hline B13m5K25 & 13 & 0.250 & 0.500 & 0.042 \\
\hline B13m7K25 & 13 & 0.250 & 0.700 & 0.042 \\
\hline B13m10K25 & 13 & 0.250 & 1.000 & 0.042 \\
\hline & & & & \\
\hline
\end{tabular}




\subsection{Estudio de la cinética de escarchado de manzana mediante la utilización de espectros dieléctricos}

El diagrama del plan experimental se muestra en la figura 3.23. Para la operación de escarchado se empleó una disolución de sacarosa de $65^{\circ} \mathrm{Brix}$. La relación entre la fruta y la disolución durante la deshidratación fue de 1:20 (p/p) para evitar cambios significativos en la concentración de la disolución durante el proceso. El tratamiento se realizó a la temperatura controlada de $30^{\circ} \mathrm{C}$. Se cortaron 36 cilindros de manzana (20 $\mathrm{mm}$ de diámetro y $10 \mathrm{~mm}$ de espesor). Las muestras se introdujeron en la disolución durante 0, 180, 360, 480, 720, 1463, 1577, 1722, 3375, 4320, 7200, 8540, 10270 minutos. Tras el tratamiento, las muestras se equilibraron en una cámara Hotcold-M (JP Selecta ${ }^{\circledR}$ ) a $30^{\circ} \mathrm{C}$ durante 24 horas.

La muestra fresca se caracterizó determinando su masa, volumen, $\mathrm{a}_{\mathrm{w}}$, espectro dieléctrico, humedad y ${ }^{\circ}$ Brix. A cada muestra, previamente al tratamiento de deshidratación osmótica, se le determinó la masa y el volumen. Inmediatamente tras la realización del tratamiento se determinó la masa, volumen, $a_{\mathrm{w}} \mathrm{y}$ espectro dieléctrico de las muestras; como estos ensayos son no destructivos, se dejó reposar las muestras durante 24 horas en las cajas de Decagon precintadas con parafilm y se determinó la masa, el volumen, $\mathrm{a}_{\mathrm{w}}$, espectro dieléctrico, humedad y ${ }^{\circ}$ Brix de las muestras reposadas. 
Para cada tiempo de Deshidratación Osmótica se iban extrayendo muestras de la disolución osmótica para realizar medidas de $\mathrm{a}_{\mathrm{w}}$, espectro dieléctrico y ${ }^{\circ} \mathrm{Brix}$.

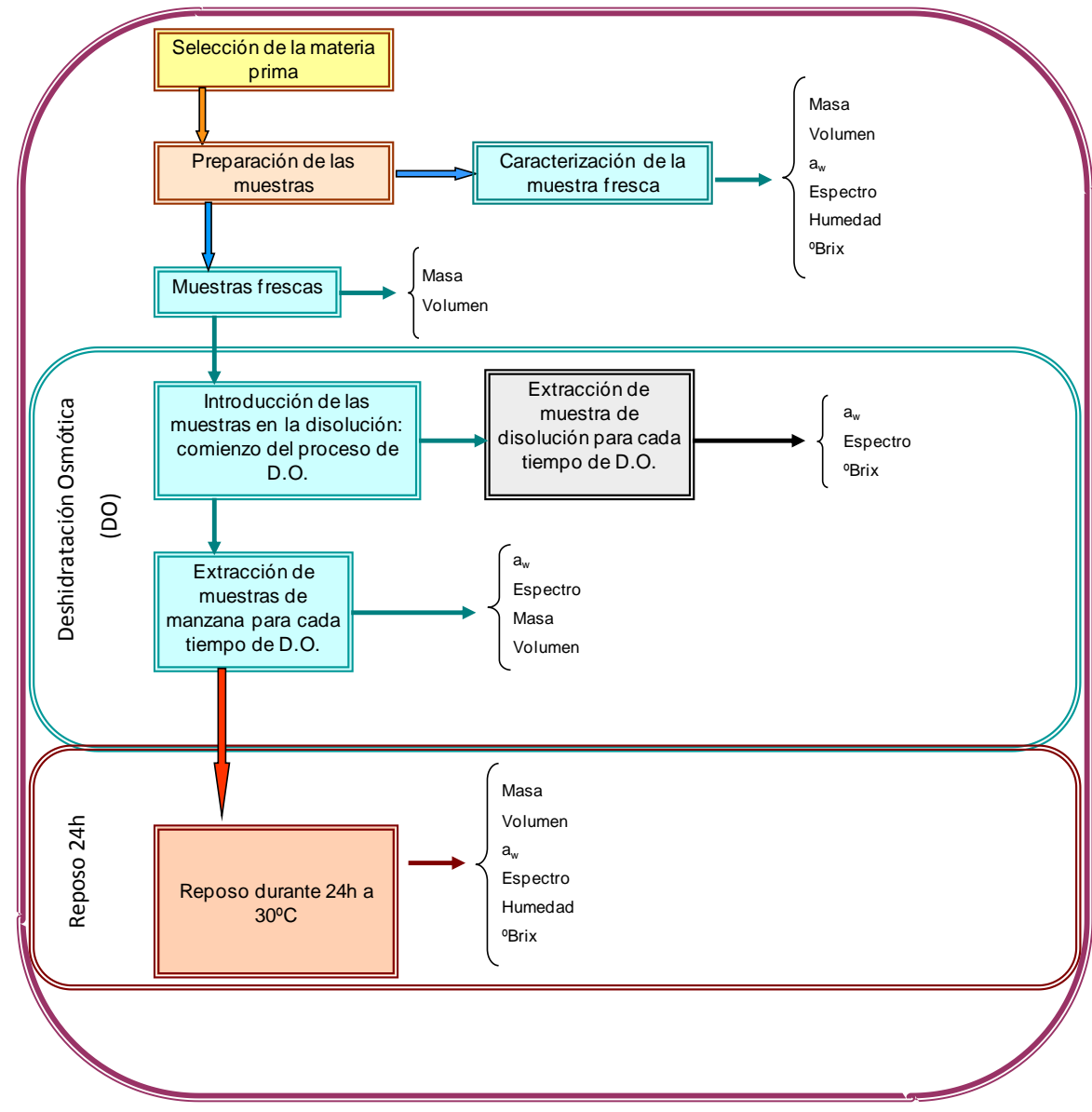

Figura 3.23. Diagrama de flujo de las experiencias realizadas para el experimental de deshidratación osmótica de manzana.

\subsection{Estudio de la cinética de deshidratación de kiwi} (Actinidia deliciosa cv Hayward) la utilización de espectros dieléctricos

El diagrama del plan experimental se muestra en la figura 3.24. Para la operación de escarchado se empleó una disolución de sacarosa de $65^{\circ} \mathrm{Brix}$. La relación entre la fruta y la disolución durante la deshidratación fue de 1:20 (p/p) 
para evitar cambios significativos en la concentración de la disolución durante el proceso. El tratamiento se realizó a la temperatura controlada de $30^{\circ} \mathrm{C}$. Se cortaron 90 medias rodajas de kiwi (espesor 10mm). Las muestras se introdujeron en la disolución durante $0,5,10,15,20,30,45,60,90,120,180,250,320,400$, 720, 1440 minutos. Tras el tratamiento, las muestras se equilibraron en una cámara Hotcold-M (JP Selecta ${ }^{\circledR}$ ) a $30^{\circ} \mathrm{C}$ durante 24 horas.

La muestra fresca se caracterizó determinando su masa, volumen, $a_{w}$, espectro dieléctrico, humedad, ${ }^{\circ}$ Brix, ácido cítrico y contenido catiónico. A cada muestra, previamente al tratamiento de deshidratación osmótica, se le determinó la masa y el volumen. Inmediatamente tras la realización del tratamiento se determinó la masa, volumen, $a_{w}$ y espectro dieléctrico de las muestras; como estos ensayos son no destructivos, se dejó reposar las muestras durante 24 horas en las cajas de Decagon precintadas con parafilm y se determinó la masa, el volumen, $a_{w}$, espectro dieléctrico, humedad, ${ }^{\circ}$ Brix, ácido cítrico y contenido catiónico de las muestras reposadas. Además, se realizaron fotografías de Cro-SEM durante los primeros 60 minutos de tratamiento.

Para cada tiempo de Deshidratación Osmótica se iban extrayendo muestras de la disolución osmótica para realizar medidas de $\mathrm{a}_{\mathrm{w}}$, espectro dieléctrico $\mathrm{y}{ }^{\circ} \mathrm{Brix}$. 


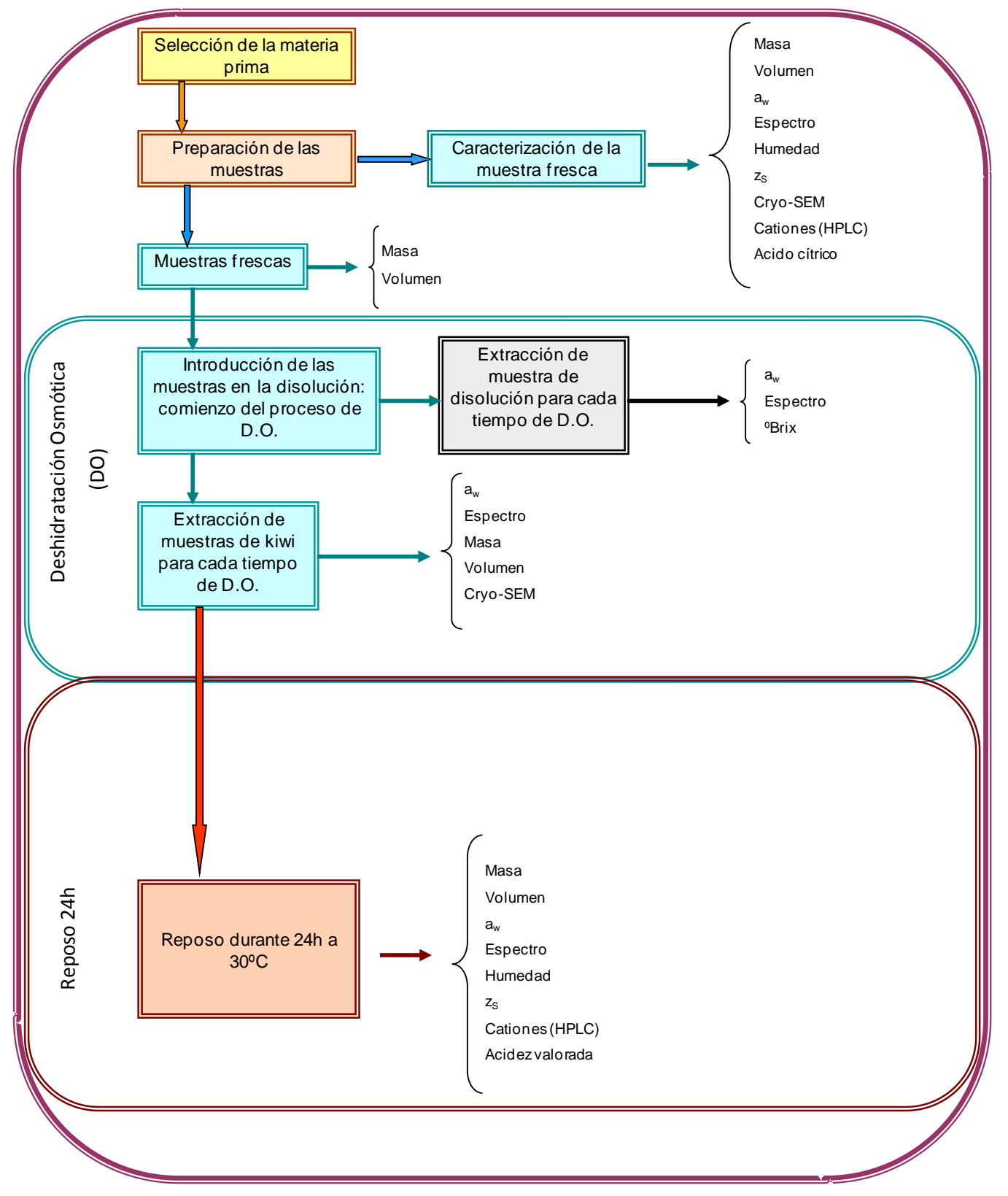

Figura 3.24. Diagrama de flujo de las experiencias realizadas para el experimental de deshidratación osmótica de kiwi. Las medidas de Cryo-SEM en las muestras tratadas se realizaron únicamente durante los primeros 60 minutos de tratamiento. 
4. Resultados 

Los resultados abtenidos en esta tesis se presentan en forma de publicaciones y patentes. It continuación se incluyen los textas correspondientes a las publicaciones cientificas (SCI) asi coma un resumen de las patentes internacionales solicitadas.

En el apartado de Anexas, se incluyen los capitulas de libro de editorial internacional, las presentaciones a congresses internacionales de gran relewancia, asi coma una ciltima publicación cientifica internacional. 

4.1. Estudia de las espectras dieléctricas de loma de cerda y su relación con los paraimetros de calidad de carme fresca

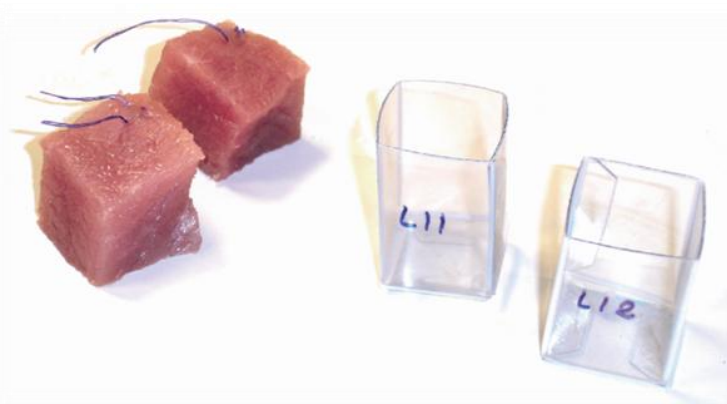





\title{
Development of a dielectric spectroscopy technique for the determination of key biochemical markers of meat quality
}

\author{
Marta Castro-Giráldez ${ }^{a}$ Laura Dols ${ }^{b}$, Fidel Toldráb, Pedro Fito ${ }^{a^{*}}$ \\ aInstituto Universitario de Ingeniería de Alimentos para el Desarrollo, Universidad Politécnica de Valencia, Camino de Vera, s/n, 46022, Valencia, Spain
} bInstituto de Agroquímica y Tecnología de los Alimentos(CSIC), PO Box 73, 46100 Burjassot (Valencia), Spain

\section{A RT ICLE INFO}

Article history:

Received 26 February 2009

\section{Keywords:}

Dielectric spectroscopy

Dielectric spectra

Dielectric properties

Biological meat markers

Sensor

Nucleotides

Lactic acid

\begin{abstract}
A B S T R A C T
Dielectric measurements of different standard solutions (nucleotides, nucleosides, lactic acid and myoglobin) were assayed simulating the concentrations of these substances in early postmortem meat. These assays were performed for considering the potential use of dielectric spectra for the quality control of meat. Good correlations among Adenosine Triphosphate (ATP), Inosine Monophosphate (IMP) and lactic acid with loss factor at punctual frequencies $(0.5,0.915$ and $1 \mathrm{GHz})$ were found. The other assayed substances did not present a marked effect over the electromagnetic spectra. Good correlations of dielectric properties with IMP and lactic acid content of real pork meat samples were also found at $0.5 \mathrm{GHz}$. This work is presenting prospective data of dielectric spectra for certain key biochemical markers in order to consider its potential application as a non-destructive control sensor for the prediction of pork meat quality.
\end{abstract}

(C) 2010 Elsevier Ltd. All rights reserved.

\section{Introduction}

One of the most important objectives for the food industry is to develop and control the processes in order to produce foods with high quality, safety and nutrition as demanded by consumers. In this context, non contact and non invasive control methods based in electromagnetic radiation appear as a useful tool. Specifically, the application of microwave dielectric measurements to the food quality control is a relatively novel technique which is still being developed. Its main advantage with respect to the infrared spectroscopy is that it can measure the bulk properties of the material and not just its surface (Kent, 2001). This characteristic is important for heterogeneous materials like foods.

One of the main problems of the pork meat industry is the variability in exudation, color and firmness, all of them defining different meat quality: PSE (Pale, Soft and Exudative), RSE (Red, Soft and Exudative), DFD (Dark, Firm and Dry), RFN (Red, Firm and Non-exudative) (Greaser, 1986, Toldrá, 2006). Exudative meats produce important losses in the meat sector due to the

*Corresponding author. Tel.: +3496387 7369

E-mail address: pfito@tal.upv.es (P.Fito). consumer refuse, while DFD meats may cause microbiological concerns to the manufacture industry. For this reason, pork meat industry needs rapid and effective systems to classify carcasses according to its technological quality. Currently, there are some biochemical methods to analize the level of several biological markers which are generated during postmortem glycolisis and can be used for detecting meat quality. Among this methods, the determination of the nucleotide and nucleoside metabolites (Honikel and Fischer, 1977; Batlle et al, 2000, 2001; Aristoy and Toldrá, 2008), lactate (Kocwin-Podsiadla et al., 1995) or mioglobine content (Greaser, 2008) during postmortem are successful but have some disadvantages (destruction of sample, tedious and time consuming, etc.) in comparison to dielectric sensors.

Dielectric spectra can be used to describe physicochemical aspects, components interactions and structural changes in foodstuffs (CastroGiráldez et al., 2009, Içier and Baysal, 2004). Due to this fact, accurate measurements of the dielectric properties can provide scientists and engineers with valuable information for monitoring manufacturing processes to improve meat quality control. In this context, the dielectric properties 
measurements, especially the dielectric spectra in a wide range of frequencies, appear as a useful method in processing quality control and for optimizing some processes in the meat industry. On the other hand, measurements are setup in minutes providing real time data. These measurements are non-destructive and very fast, and some of these techniques can be even non-contacting. These latest characteristics made the dielectric properties measurements even more attractive for the on line control of food processes. Moreover, this quality control system can be considered a clean technology because it does not generate any residues or require water consumption. On the other hand, the main disadvantage of the use of the dielectric spectroscopy technique in the microwave band is the high initial investment (expensive equipment). Due to this fact, preliminary studies are needed in order to define the key frequencies and try to reduce sensor costs before considering its transfer to the meat industry.

Dielectric spectroscopy is a relatively new research field that is advancing very fast in recent years. Nowadays microwave dielectric spectroscopy is a technique already used to analyze different properties of meat and meat products, for example to evaluate meat structure (Clerjon and Damez, 2007), to evaluate meat freshness (Damez et al., 2008a); to detect added water (Kent et al., 2001, 2002); to determine fat composition of minced meat (Kent et al., 1993; Borgaard et al., 2003); to relate dielectric properties of meat and meat products with meat structural proteins denaturation (Bircan and Barringer, 2002; Brunton et al., 2006; Li and Barringer, 1996). Some of these applications are already transfered to meat industry.

Dielectric spectroscopy determines the dielectric properties of the sample as a function of frequency. Complex permittivity $\left(\varepsilon^{*}\right)$ (Equation 1$)$ is the dielectric property that describes food behaviour when is subjected under an electromagnetic field (Nelson and Datta, 2001). The real part of complex permittivity is called the dielectric constant $\left(\varepsilon^{\prime}\right)$ and the imaginary part is called loss factor $\left(\varepsilon{ }^{\prime \prime}\right)$. The dielectric constant is related with the material ability to store energy, and the dielectric loss factor is related to the absorption and dissipation of the electromagnetic energy in other kinds of energy.

$$
\left.\varepsilon^{*}=\varepsilon^{\prime}+i \varepsilon^{\prime \prime} \quad \text { (Equation } 1\right)
$$

Permittivity decrease with frequency increase in different steps called dispersions. In biological systems, there are four relaxation regions: $\alpha, \beta, \delta$ and $\gamma$ (Gabriel, 2006). Each relaxation process occurs in a specific frequency range and allows to identifying different phenomena. At the frequencies used in present work, the $\gamma$ - is the main dispersion (Figure 1). The $\gamma$-dispersion, also called orientation polarization, is located at $\mathrm{GHz}$ region, and it is due to the polarization dipoles, fundamentally free water molecules. In some cases it could be interesting to analyze the loss factor spectra. Loss factor can be expressed by the equation 2, which reflects the different contribution phenomena to the loss factor spectrum in the frequency range of the present study.

$$
\varepsilon^{\prime \prime}=\varepsilon_{d}^{\prime \prime}+\frac{\sigma}{\varepsilon_{0} \omega}
$$

where:

$\varepsilon_{d}$ " represents the loss factor caused by the dipolar orientation or dipolar relaxation.

$\sigma / \varepsilon_{0} \omega$ represents the loss factor due to effect of ionic conductivity, where $\sigma, \varepsilon_{0}$ and $\omega$ are the conductivity of the material, the dielectric constant in vacuum and the angular frequency, respectively. It is important to highlight that ionic conductivity only introduces losses into the material when exposed to electromagnetic energy.

The main objective of this research is to optimize dielectric spectra for the detection of specific biological markers in fresh meat for a subsequent on-line quality control of this product by using dielectric spectroscopy.

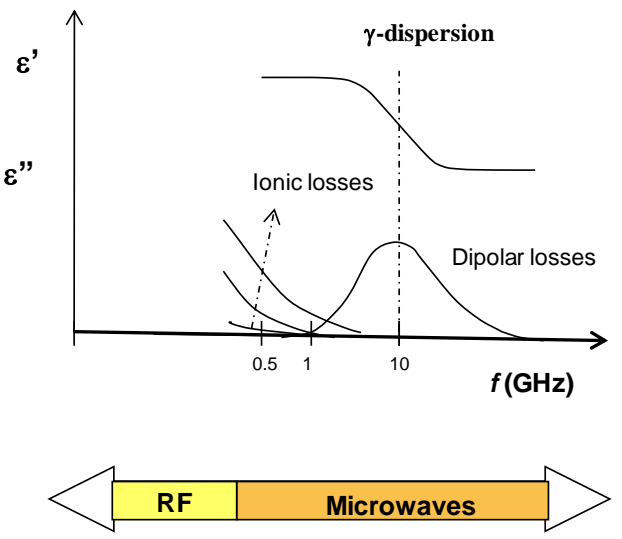

Figure 1. Ideal representation of dielectric constant and loss factor spectra in biological tissue.

\section{Materials and Methods}

Standard solutions.- The lactic acid solutions were prepared considering $850 \mathrm{mg}$ lactic acid/100 g meat as the highest concentration of lactic acid in fresh meat (Greaser, 1986) that would correspond to $11.3 \mathrm{mg} / \mathrm{mL}$. Five dilutions were made within the range 3.33 down to $11.3 \mathrm{mg} / \mathrm{mL}$. The nucleotides solutions were prepared simulating the largest concentrations in meat: Adenosine Triphosphate (ATP) (6 $\mu \mathrm{mol} / \mathrm{g}$ meat), Adenosine Monophosphate (AMP) (1.5 $\mu \mathrm{mol} / \mathrm{g}$ meat), Inosine Monophosphate (IMP) (10 $\mu \mathrm{mol} / \mathrm{g}$ meat), Inosine (5 $\mu$ mol / g meat) and Hypoxanthine (1 $\mu$ mol / g meat) (Battle et al, 2000) that would correspond to $5 \mathrm{mg} / \mathrm{mL}, 1$ $\mathrm{mg} / \mathrm{mL}, 5 \mathrm{mg} / \mathrm{mL}, 2 \mathrm{mg} / \mathrm{mL}$ and $0.2 \mathrm{mg} / \mathrm{mL}$, respectively. Five dilutions and two solutions with double and four times the highest concentrations in fresh meat were also prepared. ADP nucleotide was not assayed because it was consider an intermediate compound in post-mortem metabolism and its degradation is produced very fast. Myoglobin solutions were prepared simulating typical meat concentrations around $2 \mathrm{mg}$ myoglobin/ g meat corresponding to $3 \mathrm{mg}$ myoglobin/mL (Aberle et al, 2001) and also the double amount: $6 \mathrm{mg}$ myoglobin $/ \mathrm{mL}$. 
Reagents were from Sigma Chemical Co. (St Louis, Mo. USA). The standard solutions were prepared with bidistilled water and it was considered a mean moisture meat content of $0.75 \mathrm{~g} \mathrm{H}_{2} \mathrm{O} / \mathrm{g}$ meat (Lawrie, 2006) to do the calculations. All the measurements were made at $4^{\circ} \mathrm{C}$ and by triplicate.

Meat analysis.- After standard solutions measurements, the dielectric spectra were also measured in meat samples (longissimus dorsi) at $6 \mathrm{~h}$ and $24 \mathrm{~h}$ postmortem. These samples corresponded to 11 different carcasses (Landrace $\mathrm{x}$ Duroc) taken at two hours after slaughter from a local industry. The samples were introduced rapidly in a $4^{\circ} \mathrm{C}$ chamber and three cubes $(3 \times 3 \times 3 \mathrm{~cm})$ of each pork loin were cut for dielectric spectra measurements. The fiber direction was correctly identified and meat samples were introduced in metacrilate cubes to avoid superficial dehydration and maintained in a $4^{\circ} \mathrm{C}$ chamber.

Small meat pieces were cut at 6 and 24 hours postmortem, introduced in plastic bags and immediately frozen with liquid nitrogen. The samples were storage at $80^{\circ} \mathrm{C}$ for the biochemical analysis. Before nucleotides, nucleosides and lactic acid analysis, frozen samples were minced. Four grams were added with $1.5 \mathrm{~mL} 0.6 \mathrm{M}$ perchloric acid and homogenised in a stomacher (IUL Instruments GMBH, Barcelona, Spain) under cold conditions $\left(4^{\circ} \mathrm{C}\right)$. The solution was then centrifuged $(10,000 \mathrm{xg}$ for $20 \mathrm{~min})$, and the supernatant collected neutralised to $\mathrm{pH} 7.0$ and then was ready for the chromatographic analysis.

Nucleotides and nucleosides chromatographic analysis.- Nucleotides and nucleosides were analysed by reverse phase HPLC using an Agilent 1100 system equipped with diode array detection at $254 \mathrm{~nm}$. The chromatographic separation was developed using C-18 Synergi column $(4.6 \times 150 \mathrm{~mm}, 4 \mu \mathrm{m}$ MAX-RP $80 \mathrm{~A})$ from Phenomenex (Torrance, CA) at room temperature. Mobile phases consisted of solvent A, containing $0.1 \mathrm{M}$ monopotassium phosphate, $\mathrm{pH}$ 6.0, and solvent $\mathrm{B}$, containing phase A:methanol (75:25). The solvents were filtered through a $0.22 \mu \mathrm{m}$ membrane filter and degassed prior to the analytical run. The separation conditions were a linear gradient from $0 \%$ to $100 \%$ of phase A in 5 minutes and then down to $15 \%$ of phase A from 5 to 22 min. The flow rate was $1.0 \mathrm{~mL} / \mathrm{min}$. Peak areas were correlated to compound concentration by interpolation in the corresponding calibration curve. Results were expressed as $\mu \mathrm{g}$ nucleotide/ $100 \mathrm{~g}$ muscle. The column was washed with phase B for $8 \mathrm{~min}$ and equilibrated under the initial conditions for $10 \mathrm{~min}$ before each injection.
Lactic Acid analysis.- The content of lactic acid was analysed in the deproteinised extracts of meat. The analysis was carried out in a HPLC 1100 system equipped with diode array detection at $210 \mathrm{~nm}$. The separation was achieved with a Rezex ROA -Organic Acid $\mathrm{H}^{+}$column $(7.8 \times 300 \mathrm{~mm})$ from Phenomenex (Torrance, $\mathrm{CA}$ ) at $40^{\circ} \mathrm{C}$. The separation was performed isocratically using $0.005 \mathrm{~N}$ sulfuric acid solution at a flow rate of $0.5 \mathrm{~mL} / \mathrm{min}$. Lactic acid was detected by comparison with pure standards. Results were expressed as g lactic acid/ $100 \mathrm{~g}$ muscle.

Dielectric properties measurement.- Dielectric properties were measured with an Agilent $85070 \mathrm{E}$ openended coaxial probe connected to an Agilent E8362B Vector Network Analyzer. The software of the Network Analyzer calculates the dielectric constant and loss factor as a reflected signal function. For these measurements the probe was fixed to a stainless steel support, and an elevation platform brings the sample near the probe to avoid possible phase changes due to cable movements after calibration.

The system was calibrated by using three different types of loads: air, short-circuit and $25^{\circ} \mathrm{C}$ Milli $\circledast$ - $Q$ water. Once the calibration was made, $25^{\circ} \mathrm{C}$ Milli $\circledast$ - $Q$ water was measured again to check calibration suitability.

The dielectric properties were measured by introducing the open-ended probe at least, $5 \mathrm{~mm}$ deep in the aqueous solutions. For deformable solids (pork loin), the dielectric properties were measured by attaching the probe to the surface of the samples. Dielectric spectra of meat samples were measured in perpendicular to fiber direction avoiding fat phase of the meat. The Mean values of ten replicates of the pork loin samples are reported in this article. All determinations were made at $4{ }^{\circ} \mathrm{C}$ from $500 \mathrm{MHz}$ to $20 \mathrm{GHz}$.

\section{Results and discussion}

\section{Standard solutions}

Lactic acid is in lactate form when dissolved in water and contributes to ionic losses due to its negative charge. Lactic acid effect can be observed at low frequencies of the spectrum. Figure 2 shows the dielectric spectra of lactic acid at the studied concentrations. Lactic acid concentration in fresh meat is small and its effect is lower than that produced by water molecules; only a small contribution at the beginning of the dipolar dispersion can be appreciated in figure 2 . In the same figure, it can be observed that loss factor $\left(\varepsilon^{\prime \prime}\right)$ increases when lactic acid concentration of standard solutions increases at low

Table 1. Correlations among loss factor at punctual frequencies $(0.5,0.9$ and $1 \mathrm{GHz})$ with lactic acid, ATP and IMP content.

\begin{tabular}{|c|c|c|}
\hline$f(\mathbf{G H z})$ & $\begin{array}{c}\text { Lactic acid correlations } \\
\mathbf{x}(\mathrm{mg} \mathrm{lactic} \text { acid} / \\
\left.\mathrm{mLH}_{2} \mathrm{O}\right)\end{array}$ & $\mathbf{R}^{2}$ \\
\hline 0.5 & $\varepsilon^{\prime \prime}=0.3473 x+5.1698$ & 0.9822 \\
\hline 0.915 & $\varepsilon^{\prime \prime}=0.2062 x+6.9620$ & 0.9537 \\
\hline 1 & $\varepsilon " '=0.1855 x+7.219$ & 0.9003 \\
\hline$f(\mathbf{G H z})$ & $\begin{array}{c}\text { ATP correlations } \\
\times\left(\mathrm{mg} \mathrm{ATP} / \mathrm{mLH}_{2} \mathrm{O}\right)\end{array}$ & $\mathbf{R}^{2}$ \\
\hline 0.5 & $\varepsilon^{\prime \prime}=0.7109 x+2.6024$ & 0.9905 \\
\hline 0.915 & $\varepsilon^{\prime \prime}=0.4149 x+5.4063$ & 0.9867 \\
\hline 1 & $\varepsilon^{\prime \prime}=0.3843 x+5.6653$ & 0.9808 \\
\hline$f(\mathbf{G H z})$ & $\begin{array}{c}\text { IMP correlations } \\
\left.\text { x (mg IMP/ } \mathbf{m L H}_{2} \mathrm{O}\right)\end{array}$ & $\mathbf{R}^{2}$ \\
\hline 0.5 & $\varepsilon^{\prime \prime}=0.4304 x+3.3807$ & 0.9658 \\
\hline 0.915 & $\varepsilon^{\prime \prime}=0.2409 x+5.9138$ & 0.9618 \\
\hline 1 & $\varepsilon "=0.2192 x+6.2579$ & 0.9453 \\
\hline
\end{tabular}




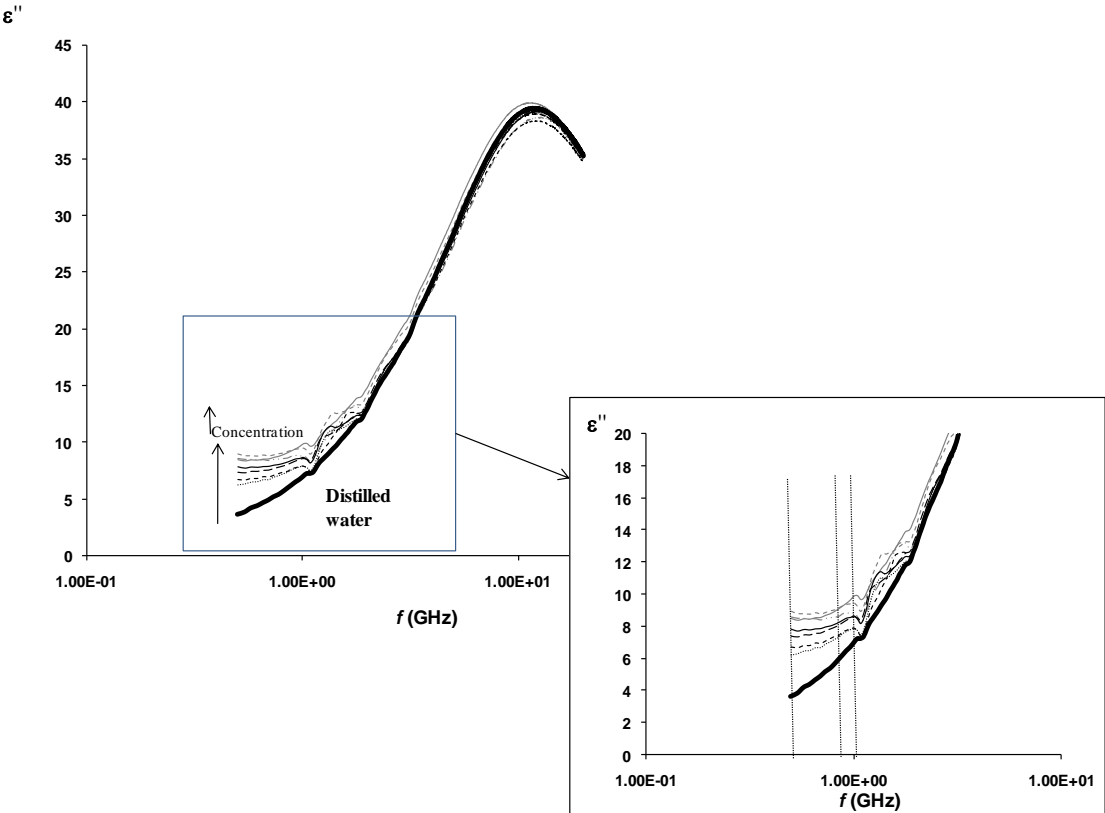

Figure 2. Loss factor electromagnetic spectra for lactic acid standard solution in bi-distilled water at different concentrations where ( - -) $11.3 \mathrm{mg}$ lactic acid/mL, (---) $10 \mathrm{mg}$ lactic acid / mL, (-) $8.67 \mathrm{mg}$ lactic acid /mL, (-) $7.33 \mathrm{mg}$ lactic acid /mL, (_ _ $) 6 \mathrm{mg}$ lactic acid /mL, (- - -) $4.67 \mathrm{mg}$ lactic acid /mL, (․) $3.33 \mathrm{mg}$ lactic acid / mL and (_) bi-distilled water. Measurements were made at $4{ }^{\circ} \mathrm{C}$.

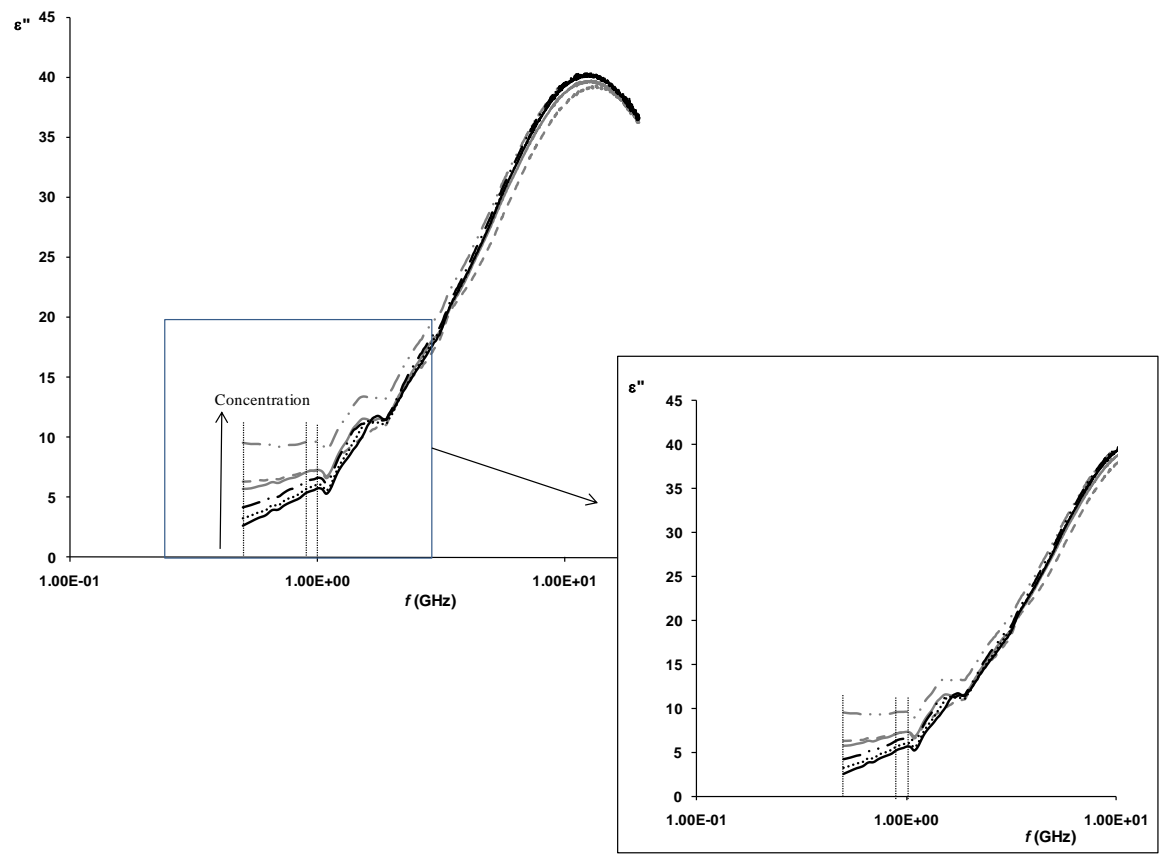

Figure 3. Loss factor electromagnetic spectra for ATP standard solutions in bi-distilled water at different concentrations where (-•-•-) $10 \mathrm{mg}$ ATP/mL, (- -) $5 \mathrm{mg} \mathrm{ATP} / \mathrm{mL}$, (_) $4 \mathrm{mg} \mathrm{ATP} / \mathrm{mL},(-\cdot-\cdot-) 2 \mathrm{mg} \mathrm{ATP} / \mathrm{mL}$, (....) $1 \mathrm{mg} \mathrm{ATP} / \mathrm{mL}$ y (__) $0.5 \mathrm{mg} \mathrm{ATP} / \mathrm{mL}$. Measurements were made at $4^{\circ} \mathrm{C}$. 
frequencies. Linear correlations between loss factor at different frequencies and lactic acid concentration were made and good correlation coefficients were found (Table 1). Moreover, in table 2, the mean values and the relative standard deviation (RSD) values are shown. RSD values are low, so dielectric properties measurement method can be considered precise.

Figure 3 shows the loss factor spectra for ATP standard solutions. As occurred in lactic acid, ATP molecule produces a marked effect over ionic losses due to the negative charges of the phosphate groups. Some correlations between loss factor at different frequencies and ATP content were made and good correlation coefficients were found (Table 1). Again, the RSD values are low, confirming that the dielectric properties measurement is precise (Table 3 ).

It was not appreciated a marked effect of AMP over electromagnetic spectra at typical meat concentrations, only the highest concentration $\left(4 \mathrm{mg} / \mathrm{mL} \mathrm{H}_{2} \mathrm{O}\right.$ ) has a slightly effect in ionic losses with regard to pure water spectra (Figure 4a). This molecule hardly presents ionic effect when compared with ATP because of the lost of two phosphate groups in the degradation reactions.

On the other hand IMP, which also has a phosphate group, produces a more noticeable effect on ionic losses than AMP (Figure 5). This may be due to the fact that IMP is present at higher concentration in fresh meat than AMP. In figure 5, it can also be appreciated that the highest IMP concentration, the highest loss factor at low frequencies is observed. Good correlations between IMP concentration and loss factor at $0.5,0.915$ and $1 \mathrm{GHz}$ frequencies were found (Table 1) and also low RSD values were obtained (Table 4). It is important to highlight that the correlations between loss factor and biochemical markers were better at $0.5 \mathrm{GHz}$ than at $0.915 \mathrm{GHz}$ and at $1 \mathrm{GHz}$ (Table 1); this phenomenon can be explained because, as figure 1 shows, the effect of ionic conductivity is the dominant at lower frequencies $(0.5 \mathrm{GHz})$ while when the frequency increases the dipolar losses also influenced the loss factor spectra. Therefore, at higher frequencies, not only the ionic compounds have an influence on the loss factor but also the water dipoles.

Standard solutions of inosine and hypoxantine do not produce a sensible effect over electromagnetic spectra at typical meat concentrations (Figure 4b and c); an alteration of water spectra continuity can be observed at low frequencies of the spectra, but no clear dispersion and no specific effect is produced. Moreover, no linear correlations were found at punctual frequencies between loss factor and inosine and hypoxantine concentrations. These two components do not posses net charge in their chemical structure and, for this reason, ionic effect is not expected.

Myoglobin solutions had the same behavior as inosine and hypoxantine solutions. So, there was no marked effect over the electromagnetic spectra at typical meat concentrations (Figure 4d).

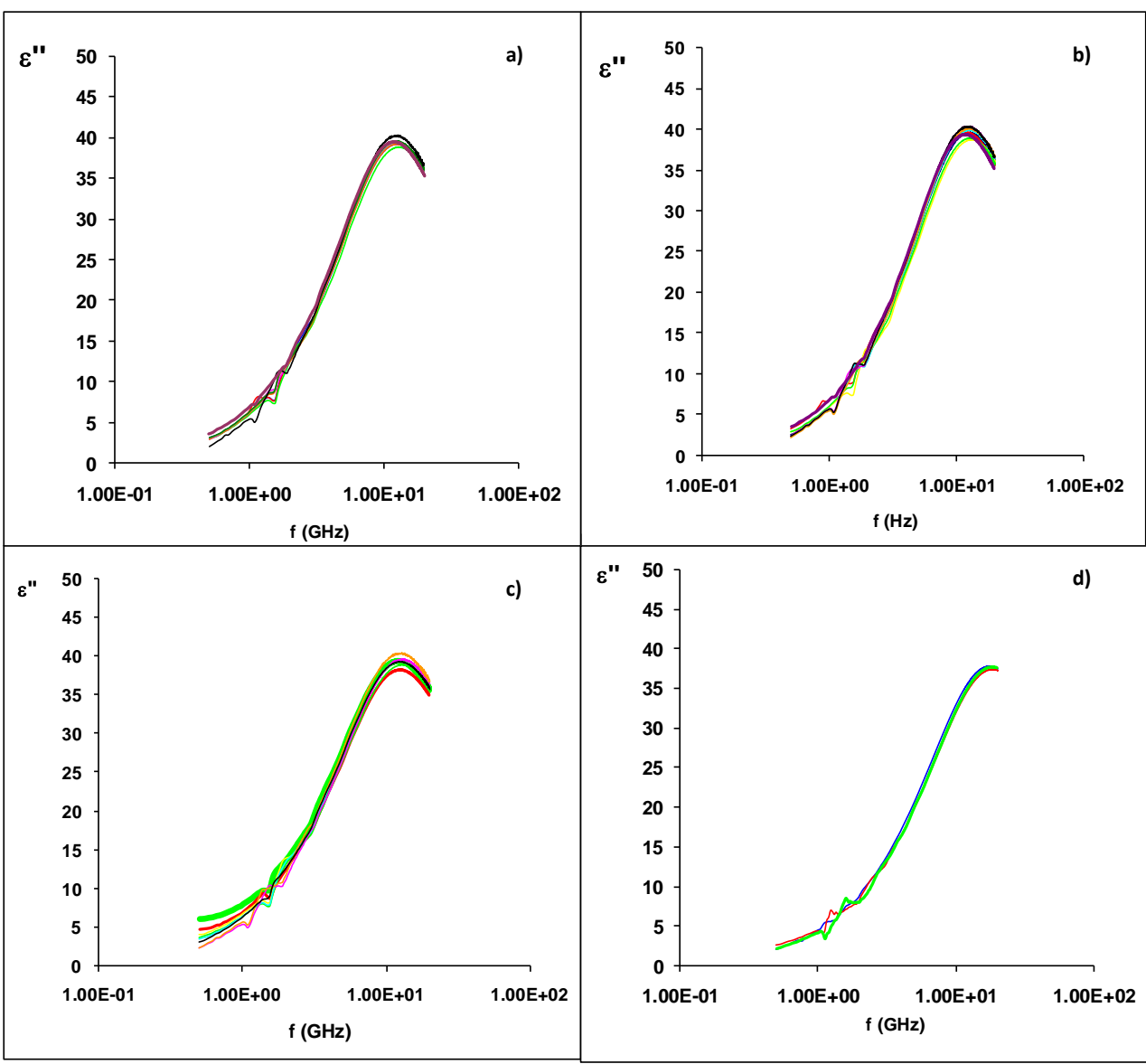

Figure 4. Loss factor spectra of a) AMP at different concentrations in bi-distilled water where (-) $4 \mathrm{mg} \mathrm{AMP} / \mathrm{mL}$ (-) $2 \mathrm{mg} \mathrm{AMP} / \mathrm{mL},(-) 1 \mathrm{mg} \mathrm{AMP} / \mathrm{mL}$, (-) $0.8 \mathrm{mg} \mathrm{AMP} / \mathrm{mL}$, (-) $0.6 \mathrm{mg} \mathrm{AMP} / \mathrm{mL},(-) 0.4 \mathrm{mg} \mathrm{AMP} / \mathrm{mL}$, (-) $0.2 \mathrm{mg}$ AMP/ $\mathrm{mL}$ and $(-) 0.1 \mathrm{mg} \mathrm{AMP} / \mathrm{mL}$ and $(-)$ bi-distilled water at $4^{\circ} \mathrm{C}$. b) Inosine at different concentrations where (-) $8 \mathrm{mg}$ inosine/ mL, (-) $4 \mathrm{mg}$ inosine/ $\mathrm{mL},(-) 2 \mathrm{mg}$ inosine/ $\mathrm{mL},(-) 1.6 \mathrm{mg}$ inosine/ $\mathrm{mL},(-) 1.2 \mathrm{mg}$ inosine/ mL (-) $0.8 \mathrm{mg}$ inosine/ $\mathrm{mL},(-) 0.4 \mathrm{mg}$ inosine/ $\mathrm{mL},(-) 0.2 \mathrm{mg}$ inosine/ $\mathrm{mL}$ and (-) bidistilled water at $4^{\circ} \mathrm{C}, \mathrm{c}$ ) Hypoxantine at different concentrations where (-) $8 \mathrm{mg}$ hypoxantine/ $\mathrm{mL},(-) 4 \mathrm{mg}$ hypoxantine/ $\mathrm{mL}$, (-) $2 \mathrm{mg}$ hypoxantine / mL, (-) $1.6 \mathrm{mg}$ hypoxantine / $\mathrm{mL}$, (-) $1.2 \mathrm{mg}$ hypoxantine / $\mathrm{mL},(-) 0.8 \mathrm{mg}$ hypoxantine / $\mathrm{mL}$, (-) 0.4 mg hypoxantine / $\mathrm{mL},(-) 0.2 \mathrm{mg}$ hypoxantine/ $\mathrm{mL} \mathrm{H}_{2} \mathrm{O}$ and (-) bidistilled water at $4^{\circ} \mathrm{C}$, d) Myoglobine at different concentrations where (-) $3 \mathrm{mg}$ myoglobine/ $\mathrm{mL},(-) 6 \mathrm{mg}$ myoglobine/ $\mathrm{mL},(-)$ bidistilled water at $4^{\circ} \mathrm{C}$. 
Table 2.. Means and Relative Standard Deviation (\%) of the dielectric loss factor at 0.5, 0.915 and $1 \mathrm{GHz}$ for the different standard solutions of lactic acid.

\begin{tabular}{ccccccc}
\hline $\begin{array}{c}\text { Standard Solutions of } \\
\text { Lactic acid }\end{array}$ & \multicolumn{3}{c}{ MEANS } & \multicolumn{3}{c}{ Relative Standard Deviation $(\%)$} \\
\hline$\left(\mathrm{mg} / \mathrm{mL} \mathrm{H}_{2} \mathrm{O}\right)$ & $\mathrm{e} "(0,5 \mathrm{GHz})$ & $\mathrm{e} "(0,915 \mathrm{GHz})$ & $\mathrm{e} "(1 \mathrm{GHz})$ & $\mathrm{e} "(0,5 \mathrm{GHz})$ & $\mathrm{e} "(0,915 \mathrm{GHz})$ & $\mathrm{e} "(1 \mathrm{GHz})$ \\
\hline 11.33 & 8.9437 & 9.3742 & 9.4572 & 0.2859 & 0.3770 & 0.3905 \\
10.00 & 8.599 & 8.8623 & 8.8413 & 0.2126 & 0.3229 & 0.1826 \\
8.67 & 8.3661 & 8.7711 & 8.7959 & 0.1380 & 0.1990 & 0.2542 \\
7.33 & 7.8196 & 8.5123 & 8.6427 & 0.2546 & 0.2679 & 0.2399 \\
6.00 & 7.3746 & 8.3739 & 8.5797 & 0.1660 & 0.2369 & 0.2550 \\
4.67 & 6.6927 & 7.7329 & 7.8624 & 0.3205 & 0.4494 & 0.4422 \\
3.33 & 6.2227 & 7.6932 & 7.8739 & 0.2924 & 0.3680 & 0.2060 \\
\hline
\end{tabular}

Table 3. Means and Relative Standard Deviation (\%) of the dielectric loss factor at 0.5, 0.915 and $1 \mathrm{GHz}$ for the different standard solutions of ATP.

\begin{tabular}{ccccccc}
\hline $\begin{array}{c}\text { Standard Solutions of } \\
\text { ATP }\end{array}$ & \multicolumn{3}{c}{ MEANS } & \multicolumn{3}{c}{ Relative Standard Deviation $(\%)$} \\
\hline$\left(\mathrm{mg} / \mathrm{mL} \mathrm{H}_{2} \mathrm{O}\right)$ & $\varepsilon^{\prime \prime}(0,5 \mathrm{GHz})$ & $\varepsilon^{\prime \prime}(0,915 \mathrm{GHz})$ & $\varepsilon^{\prime \prime}(1 \mathrm{GHz})$ & $\varepsilon^{\prime \prime}(0,5 \mathrm{GHz})$ & $\varepsilon^{\prime \prime}(0,915 \mathrm{GHz})$ & $\varepsilon^{\prime \prime}(1 \mathrm{GHz})$ \\
\hline 10.00 & 9.5046 & 9.5717 & 9.5829 & 0.2690 & 0.3693 & 0.3854 \\
5.00 & 6.3453 & 7.2715 & 7.2819 & 0.2881 & 0.3936 & 0.2218 \\
4.00 & 5.6922 & 7.1865 & 7.2842 & 0.2028 & 0.2428 & 0.3069 \\
2.00 & 4.2134 & 6.4799 & 6.6726 & 0.4726 & 0.3519 & 0.3107 \\
1.00 & 3.2427 & 5.8078 & 6.0848 & 0.3775 & 0.3416 & 0.3596 \\
0.50 & 2.6103 & 5.4547 & 5.7319 & 0.8217 & 0.6371 & 0.6065 \\
\hline
\end{tabular}

Table 4. Means and Relative Standard Deviation (\%) of the dielectric loss factor at 0.5, 0.915 and $1 \mathrm{GHz}$ for the different standard solutions of IMP.

\begin{tabular}{ccccccc}
\hline $\begin{array}{c}\text { Standard Solutions of } \\
\text { IMP }\end{array}$ & \multicolumn{3}{c}{ MEANS } & \multicolumn{3}{c}{ Relative Standard Deviation (\%) } \\
\hline$\left(\mathrm{mg} / \mathrm{mL} \mathrm{H}_{2} \mathrm{O}\right)$ & $\mathrm{e} "(0,5 \mathrm{GHz})$ & $\mathrm{e} "(0,915 \mathrm{GHz})$ & $\mathrm{e} "(1 \mathrm{GHz})$ & $\mathrm{e} "(0,5 \mathrm{GHz})$ & $\mathrm{e} "(0,915 \mathrm{GHz})$ & $\mathrm{e} "(1 \mathrm{GHz})$ \\
\hline 20 & 11.6189 & 10.4939 & 10.3589 & 0.2115 & 0.2496 & 0.2302 \\
10 & 8.1008 & 8.621 & 8.9309 & 0.3034 & 0.2880 & 0.2535 \\
5 & 6.0977 & 7.4795 & 7.5857 & 0.3911 & 0.3401 & 0.2975 \\
3 & 5.3689 & 6.9472 & 7.1221 & 0.4653 & 0.3341 & 0.3010 \\
2 & 3.8094 & 6.1798 & 6.4749 & 0.6067 & 0.3579 & 0.3047 \\
1 & 3.0271 & 5.6474 & 5.9011 & 0.7732 & 0.4036 & 0.3483 \\
0.5 & 3.5025 & 6.0267 & 6.5278 & 0.7248 & 0.3485 & 0.3134 \\
\hline
\end{tabular}

\section{Meat samples}

Pork meat samples were classified following the criteria adopted by Flores et al. (1999) as 5 aceptable-normal RFN (Red Firm and Non-Exudative) loins, 3 PSE (Pale, Soft and Exudative) loins and 3 DFD (Dark Firm and Dry) loins, based on $\mathrm{pH}$ at $2 \mathrm{~h}$ post-mortem, $\mathrm{L}^{*}$ value, and drip loss.

Figure 6 shows the loss factor and the dielectric constant spectra of RFN samples at 6 hours post-mortem in a frequency range of $0.5 \mathrm{GHz}$ to $20 \mathrm{GHz}$. In foodstuffs it can be assumed that, at microwave frequencies, dielectric behavior is mainly determined by free water and ionic conductivity (Mudgett, 1985). Many authors have studied biological tissues dispersions (Foster and Schwan, 1996, Gabriel and Gabriel, 1996; Gabriel, 2006; Gabriel et al., 1996a, b, c; Grant et al., 1978; Pething, 1979). In figure 6a it is possible to appreciate the $\gamma$ dispersion which is caused by dipolar molecules relaxation of free water that have a relaxation frequency of approximately $10.5 \mathrm{GHz}$ at $4^{\circ} \mathrm{C}$. This dispersion mainly corresponds to extracellular 


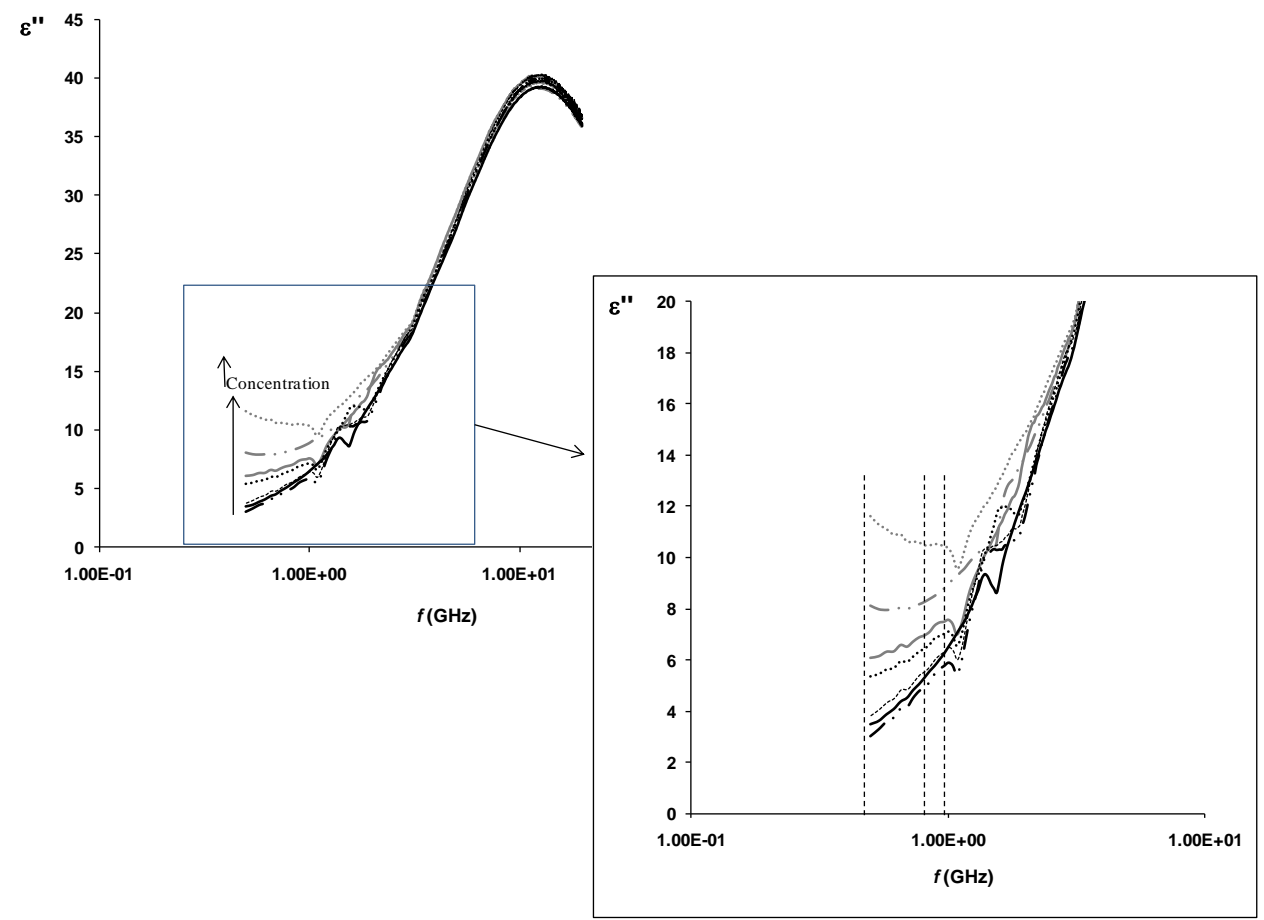

Figure 5. Loss factor electromagnetic spectra for IMP standard solutions in bi-distilled water at different

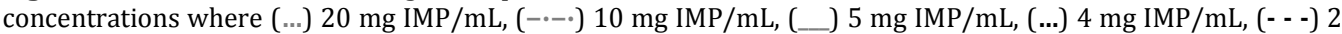
$\mathrm{mg} \mathrm{IMP} / \mathrm{mL}$, (-•-·) $1 \mathrm{mg} \mathrm{IMP} / \mathrm{mL}$ and (_) $0.5 \mathrm{mg} \mathrm{IMP} / \mathrm{mL}$.

water which contains salts, nutrients and remaining substances. Figure 6.b shows more in detail the loss factor spectrum. In this figure it is possible to appreciate at low frequencies the meat ions contribution to the ionic losses, and at higher frequencies the dipolar losses caused by water molecules.

After slaughter, some intramuscular changes are produced as a consequence of the transformation of muscle into meat. ATP energy is used to maintain muscle temperature and cellular integrity against its natural degradation. When oxygen contribution stops and phosphocreatine reserves are finished, anaerobic glycolisis starts to consume ATP by this alternative way. Muscle glycogen is converted into lactic acid, resulting in a pH decrease that continues till reaching approximately 5.4-5.5 (Toldrá, 2007). Due to the post-mortem metabolism, lactic acid and ATP related compounds appear as key components which are involved in the conversion of muscle to meat.

After standard solutions analysis, the effect of lactic acid ATP and IMP at $0.5,0.915$ and $1 \mathrm{GHz}$ was demonstrated For this reason, some correlations were made at different key frequencies in order to analyze the effect of these compounds over the electromagnetic spectrum during the 24 hours after slaughter.

Good correlations of IMP, lactic acid and both components together $\left(\mathrm{R}^{2}=0.9594, \mathrm{R}^{2}=0.9506\right.$ and $\mathrm{R}^{2}=0.9576$, respectively) with loss factor at $0.5 \mathrm{GHz}$ were found at 6 hours postmortem (Table 5). A good correlation $\left(\mathrm{R}^{2}=\right.$ 0.9239) was also found between ATP content of meat samples and loss factor at $0.5 \mathrm{GHz}$, but, in this case, the relation was negative. This means that when ATP decreases, the loss factor increases; after slaughtering ATP is the source of energy used to maintain cellular integrity. ATP is regenerated by glycogen breakdown through glycolysis with the simultaneous accumulation of lactic acid (Marieb, 2004). ATP depletion provokes the accumulation of IMP which is the end-product of the ATP breakdown (Marieb, 2004). Thus, at 6 hours after slaughter, lactic acid and IMP are progressively generated while ATP is depleted. This phenomenon explains the positive good relation between IMP and lactic acid with loss factor at $0.5 \mathrm{GHz}$. On the other hand, the correlations between the loss factor at 0.915 and at $1 \mathrm{GHz}$ with IMP and lactic acid were worse than at $0.5 \mathrm{GHz}$ (Table 5); as was explained for standard solutions, this phenomenon can be explained because the effect of ionic conductivity is the dominant at lower frequencies $(0.5 \mathrm{GHz})$ while, when the frequency increases, the dipolar losses also influenced the loss factor spectra. Moreover, other components of meat such as water bound to proteins, amino acids or small proteins can produce effects on the spectra at higher frequencies (Craig, 1995, Feldman et al., 2003).

The correlations between the loss factor at 0.5, 0.9 and 1 $\mathrm{GHz}$ with IMP, lactic acid and both components together at 6 and 24 hours post-mortem are shown in table 6 . These correlations are worse than those obtained using only the data of 6 hours postmortem. This phenomenon can be explained because most of the changes in IMP and lactic acid are produced during early postmortem $(<6$ $\mathrm{hpm}$ ), and the data at 24 hours postmortem can be influenced by other meat changes which include the generation of free amino acids caused by proteolysis process, changes in meat structure...

It is important to highlight that ATP at 24 hours postmortem was almost depleted (levels of ATP around $0.15 \mu \mathrm{mol} / \mathrm{g}$ meat); for this reason, it is not included in table 6 .

RSD (\%) values of dielectric loss factor at $0.5,0.915$ and 1 $\mathrm{GHz}$ in meat samples were obtained at 6 and 24 hours postmortem. Obviously, the precision of loss factor in real meat samples was lower $(1-5 \%)$ than that of standard solutions $(<1 \%)$. Meat is a structured complex material which suffers lots of changes after slaughtering. The complexity of meat composition and structure affects the precision of the proposed method, being lower than in standard solutions. 

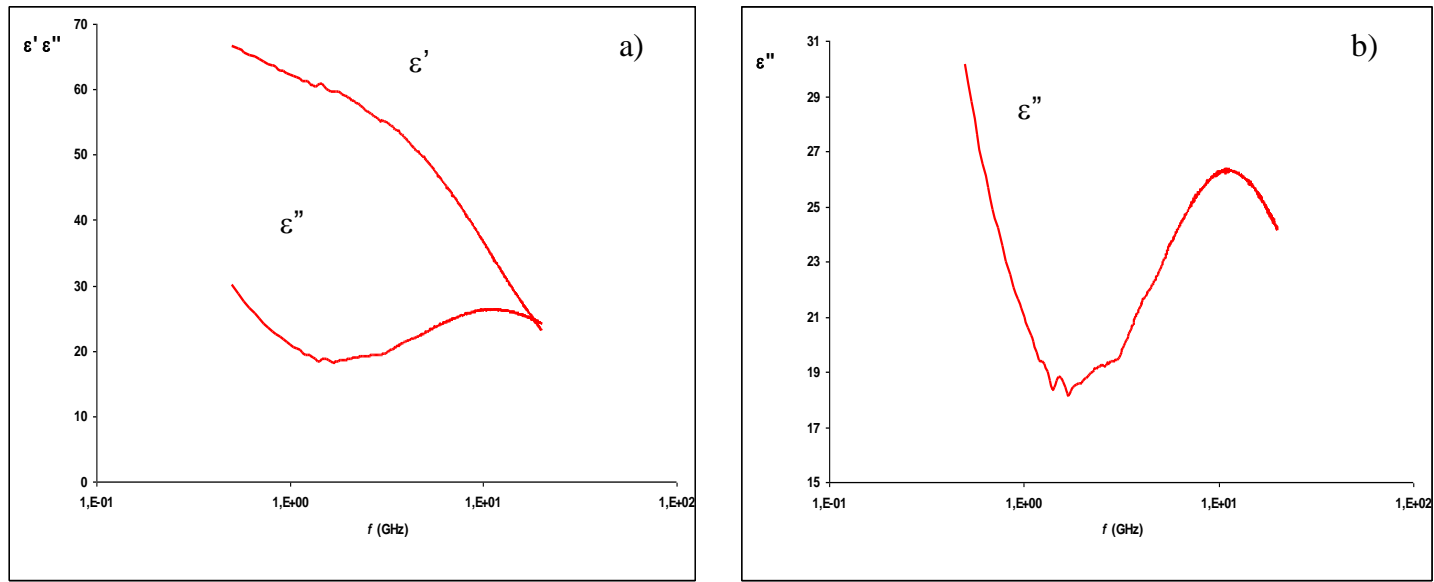

Figure 6. a) Dielectric constant spectrum (above curve) and loss factor spectrum (below curve) of RFN sample at 6 hours post-mortem in a frequency range of $0.5 \mathrm{GHz}$ to $20 \mathrm{GHz}$. b) Detail of loss factor spectra of the sample.

Table 5. Correlations between loss factor measured perpendicular to the meat fibers at punctual frequencies $(0.5,0.9$ and $1 \mathrm{GHz})$ with IMP, ATP and lactic acid content at 6 hours post-mortem.

\begin{tabular}{|c|c|c|}
\hline$f(\mathbf{G H z})$ & $\mathrm{x}=\mathrm{IMP}(\mu \mathrm{mol} / \mathrm{g}$ meat $)$ & $\mathbf{R}^{2}$ \\
\hline 0.5 & $\varepsilon^{\prime \prime}(f)=1.3449 x+23.552$ & 0.9594 \\
\hline 0.915 & $\varepsilon^{\prime \prime}(f)=0.7941 x+17.814$ & 0.9234 \\
\hline 1 & $\varepsilon ",(f)=0.7448 x+17.378$ & 0.9213 \\
\hline$f(\mathbf{G H z})$ & $\mathrm{x}=\mathrm{ATP}(\mu \mathrm{mol} / \mathrm{g}$ meat $)$ & $\mathbf{R}^{2}$ \\
\hline 0.5 & $\varepsilon^{\prime \prime}(f)=-2.4112 x+30.25$ & 0.9239 \\
\hline 0.915 & $\varepsilon " \prime(f)=-1.458 x+21.794$ & 0.9328 \\
\hline 1 & $\varepsilon ",(f)=-1.371 \quad x+21.111$ & 0.9301 \\
\hline$f(\mathbf{G H z})$ & $\begin{array}{c}x=\text { Lactic acid } \\
(\mu \mathrm{mol} / \mathrm{g} \text { meat })\end{array}$ & $\mathbf{R}^{2}$ \\
\hline 0.5 & $\varepsilon^{\prime \prime}(f)=0.0924 x+20.89$ & 0.9506 \\
\hline 0.915 & $\varepsilon^{\prime \prime}(f)=0.0546 x+16.241$ & 0.9155 \\
\hline 1 & $\varepsilon, '(f)=0.0511 x+15.905$ & 0.9120 \\
\hline$f(\mathbf{G H z})$ & $\mathbf{x}=\underset{(\mu \mathrm{mol} / \mathrm{g} \text { meat })}{\text { Lactic acid + IMP }}$ & $\mathbf{R}^{2}$ \\
\hline 0.5 & $\varepsilon^{\prime \prime}(f)=0.0871 \mathrm{x}+21.01$ & 0.9576 \\
\hline 0.915 & $\varepsilon " '(f)=0.0514 x+16.312$ & 0.9222 \\
\hline 1 & $\varepsilon " \prime(f)=0.0482 x+15.972$ & 0.9188 \\
\hline
\end{tabular}

Table 6. Correlations between loss factor measured perpendicular to the meat fibers at punctual frequencies $(0.5,0.9$ and $1 \mathrm{GHz})$ with IMP and lactic acid content at 6 and 24 hours post-mortem.

\begin{tabular}{|c|c|c|}
\hline$f(\mathbf{G H z})$ & $\mathrm{x}=\mathrm{IMP}(\mu \mathrm{mol} / \mathrm{g}$ meat $)$ & $\mathbf{R}^{2}$ \\
\hline 0.5 & $\varepsilon \varepsilon^{\prime \prime}(f)=1.2569 x+23.75$ & 0.9172 \\
\hline 0.915 & $\varepsilon " \prime(f)=0.7584 x+17.839$ & 0.8892 \\
\hline 1 & $\varepsilon ",(f)=0.7322 x+17.349$ & 0.8983 \\
\hline$f(\mathbf{G H z})$ & $\begin{array}{c}\mathrm{x}=\text { Lactic acid } \\
(\mu \mathrm{mol} / \mathrm{g} \text { meat })\end{array}$ & $\mathbf{R}^{2}$ \\
\hline 0.5 & $\varepsilon^{\prime \prime}(f)=0.0816 x+21.719$ & 0.8939 \\
\hline 0.915 & $\varepsilon^{\prime \prime}(f)=0.0497 x+16.573$ & 0.8833 \\
\hline 1 & $\varepsilon^{\prime \prime}(f)=0.0479 x+16.138$ & 0.8876 \\
\hline$f(\mathbf{G H z})$ & $\begin{array}{c}\mathrm{x}=\underset{ }{(\mu \mathrm{mol} / \mathrm{g} \text { meat })} \\
\end{array}$ & $\mathbf{R}^{2}$ \\
\hline 0.5 & $\varepsilon^{\prime \prime}(f)=0.0773 x+21.787$ & 0.9025 \\
\hline 0.915 & $\varepsilon^{\prime \prime}(f)=0.047 x+16.616$ & 0.8908 \\
\hline 1 & $\varepsilon "(f)=0.0453 x+16.179$ & 0.8954 \\
\hline
\end{tabular}




\section{Conclusions}

The analysis of different concentrations of key biochemical markers in standard solutions lead to good correlations among lactic acid, ATP and IMP content with loss factor at punctual frequencies $(0.5$ 0.915 and $1 \mathrm{GHz}$ ). Good correlations were also found in meat samples at 6 hours postmortem among lactic acid and IMP content with loss factor at $0.5 \mathrm{GHz}$. Meat is a structured food with a large number of compounds interacting and changing during post-mortem time. For this reason, there are other compounds like amino acids or water bound to proteins influencing the dielectric measurements at higher frequencies $(0.915$ and $1 \mathrm{GHz})$ Thus, worse correlations were found at these frequencies. The results obtained in standard solutions were more precise than those obtained in real meat samples. Meat is a structured complex material which suffers lots of changes after slaughtering. The complexity of meat composition and structure affects the precision of the proposed method, being lower than in standard solutions. Thus, more studies are needed in order to optimize dielectric sensors as an effective tool for the control of meat quality. Although all these drawbacks, first results are promising and confirm the viability of using this technique for the determination of key biochemical markers of meat quality. The use of this technique could result very interesting for meat industry because this kind of sensors are non-destrutive and can be implemented in slaughter line; moreover the measurements are made very fast.

\section{Acknowledgements}

Grant from Agroalimed (Conselleria de Agricultura, Pesca y Alimentación, Valencia, Spain) and FPU grant to MC from Ministry of Science and Innovation (Madrid, Spain) are fully acknowledged. Work prepared within the Unidad Asociada IAD (UPV)-IATA (CSIC) framework.

\section{References}

Aberle, E.D., Forrest, J.C., Gerrald, D.E \& Mills, E.W. (2001) Properties of fresh meat. In Principles of Meat Science. Chapter 6: pp. 112. 4⿳亠丷厂 Edition. Kendall/hunt Publishing Company. Iowa (E.E.U.U.).

Aristoy, MC \& Toldrá, F. (2008). Nucleotides and its derived compounds. In: Handbook of Muscle Foods Analysis (L.M.L. Nollet y F. Toldrá, Eds.), CRC Press, BocaRaton FL, USA, 2008, pp 279-288.

Battle N., Aristoy, M.C. \& Toldrá, F. (2001). ATP metabolites during aging of exudative and non exudative pork meats. Journal of Food Science, 66(1), 68-71.

Battle, N., Aristoy, M.C. \& Toldrá, F. (2000). Early postmortem detection of exudative pork meat based on nucleotide content. Journal of Food Science, 65(3), 413-416.

Bircan, C. \& Barringer, S.A. (2002a). Determination of protein denaturation of muscle foods using the dielectric properties. Journal of Food Science, 67(1), 202-205.

Borgaard, C., Christensen, L.B. \& Jespersen, Bo L. (2003) Reflection mode microwave spectroscopy for on-line measurement of fat in trimmings. In 49th ICoMST, 31 august- 5 september, Campinas, Brazil.

Brunton, N.P., Lyng, J.G., Zhang, L. \& Jacquier, J.C. (2006). The use of dielectric properties and other physical analyses fo assessing protein denaturation in beef biceps femoris muscle during cooking from 5 to $85{ }^{\circ} \mathrm{C}$. Meat Science, 72(2), 236-244.

Castro-Giráldez, M, Fito, P J , Toldrá, F \& Fito, P. (2009). Physical sensors and techniques. In Handbook of Processed Meats and Poultry Analysis. (Leo ML Nollet and Fidel Toldrá Eds.), CRC Press, BocaRaton FL, USA, pp. 7-33.

Clerjon, S. \& Damez, J.L. (2007). Microwave sensing for meat and fish structure evaluation. Measurement Science and Technology, 18(4), 1038-1045.
Craig D.Q.M. (1996). Dielectric analysis of biological systems. In Dielectric analysis of pharmaceutical systems. Editorial Taylor y Francis, Ltd. London, UK. pp179-208.

Damez, J.L., Clerjon, S., Abouelkaram, S. \& Lepetit, J. (2008a). Electrical impedance probing of the muscle food anisotropy for meat ageing control. Food Control, 19(10), 931-939.

Feldman, Y., Ermolina, I. \& Hayashi, Y. (2003). Time domain dielectric spectroscopy study of biological systems. In IEEE Transactions on Dielectrics and Electrical Insulation, $10(5), 728-733$

Flores, M., Armero, E., Aristoy, M.C. \& Toldrá, F. (1999). Sensory characteristics of cooked pork loin as affected by nucleotide content and post-mortem meat quality, Meat Science, 51(1), 53-59.

Foster, K.R. \& Schwan, H.P. (1996). Dielectric properties of tissues. In Handbook of Biological Effects of Electromagnetic Fields. Editors: Charles Polk and Elliot Postow, CRC Press, $2^{\text {nd }}$ ed., USA, pp. 25-102.

Gabriel, C. \& Gabriel, S. (1996). Compilation of the Dielectric Properties of Body Tissues at RF and Microwave Frequencies. Internet Document. URL: http://www.emfdosimetry.org/dielectric/Report/Repor t.html. Accesed on $21^{\text {st }}$ of July, 2008.

Gabriel, C. (2006). Dielectric properties of biological materials. In Bioengineering and biophysical aspects of electromagnetic fields, Handbook of biological effects of electromagnetic fields, third edition. Edited by: F.S. Barnes and B. Greenebaum, CRC Press, Boca Raton (U.S.A), pp.51-101

Gabriel, C., Gabriel, S. \& Corthout, E. (1996a). The dielectric properties of biological tissues: I. Literature survey. Physics in Medicine and Biology. 41(11),2231-2249.

Gabriel, S., Lau, R.W. \& Gabriel, C. (1996b). The dielectric properties of biological tissues: II. Measurements in the frequency range $10 \mathrm{~Hz}$ to $20 \mathrm{GHz}$. Physics in Medicine and Biology. 41(11), 2251-2269.

Gabriel, S., Lau, R.W. \& Gabriel, C. (1996c). The dielectric properties of biological tissues: III. Parametric models for the dielectric spectrum of tissues. Physics in Medicine and Biology. 41(11), 2271-2293.

Grant, E.H., Sheppard, R.J. \& South, G.P. (1978). Dielectric Behaviour of Biological Molecules in Solutions. Clarendon Press, Oxford. 145-184.

Greaser, M.L. (1986). Conversion of muscle to meat. In Muscle as food. Edited by P.J. Bechtel, Academic Press, Orlando, USA, pp. 37-102.

Greaser, M.L. (2008) Nucleotides and its derived compounds. In: Handbook of Muscle Foods Analysis (L.M.L. Nollet and F. Toldrá, Eds.), CRC Press, BocaRaton FL, USA, pp 57-73.

Honikel, K.O. \& Fischer, C. (1977). A rapid method for the detection of PSE and DFD porcine muscle. Journal of Food Science, 42(6), 1633-1636.

Içier, F. \& Baysal, T. (2004a). Dielectric properties of food materials-1: factors affecting and industrial uses. Critical reviews in food science and nutrition, 44: 465-471.

Kent, M. (2001). Microwave measurements of product variables. In Instrumentations and sensors for the food industry. Edited by: Erika Kress-Rogers and Christopher J.B. Brimelow, second edition, CRC Press, USA, pp. 233-279.

Kent, M., Knöchel, R., Daschner, F. \& Berger, U.K. (2001). Composition of foods including added water using microwave dielectric spectra. Food Control, 12(7), 467482.

Kent, M., Lees, A. \& Roger, A. (1993). Estimation of the fat content of minced meat using a portable microwave fat meter. Food Control. 4, 222

Kent, M., Peymann, A., Gabriel, C. \& Knight, A. (2002). Determination of added water in pork products using microwave dielectric spectroscopy. Food Control. 13, 143.

Kocwin-Podsiadla, M., Przybylski, W., Kuryl, J., Talmant, A. \& Monin, G. (1995). Muscle glycogen level and meat quality in pigs of different halothane genotypes. Meat Science, 40(1),121-125.

Lawrie, R.A. (2006). Lawrie's Meat Science. 6th edition Technomic Publishing Co.,Lancaster, PA.

Li, A. \& Barringer, S. (1996). Effects of protein denaturation on the dielectric properties for ham, egg and milk. IFT Annual Meeting Book of Abstracts, 60(2), 141

Marieb, E.N. (2004). Human anatomy and physiology, 5thedition, Redwood City: Benjamin Cummings.

Mudgett, R.E. (1985). Dielectric Properties of Foods. In: Microwaves in the Food Processing Industry. Editor: Decareau. Academic Press, Orlando, pp. 15-37. 
Nelson, S.O. \& Datta, A.K. (2001). Dielectric properties of Food Materials and Electric Field Interactions. In: Handbook of Microwave Technology for Food Applications. Editors A.K. Datta, R.C. Anantheswaran. Marcel Dekker, New York, pp. 69-114.

Pethig, R. (1979). Dielectric and Electrical Properties of Biological Materials. John Wiley and Sons Ltd., New York, U.S.A.

Toldrá, F. (2006) Meat: Chemistry and biochemistry. In: Handbook of Food Science, Technology and Engineering (YH Hui, JD
Culbertson, S Duncan, I Guerrero-Legarreta, ECY LiChan, CY Ma, CH Manley, TA McMeekin, WK Nip, LML Nollet, MS Rahman, F Toldrá, YL Xiong, Eds.), vol. 1, CRC Press, Boca Raton, FL, USA, pp 28-1 to 28-18.

Toldrá, F. (2007) Biochemistry of muscle and fat. In: Handbook of fermented meat and poultry (F. Toldrá, YH. Hui, I. Astiasarán, WK. Nip, JG. Sebranek, ETF. Silveira, LH Stahnke \& R. Talon Eds.), Blackwell Publishing, Ames, Iowa, USA, pp 51-58. 


\title{
Original article
}

\section{Use of visible spectroscopy to assess colour development during ageing of fresh pork from different quality classes}

\author{
Marta Castro-Giráldez ${ }^{1}$, Pedro J. Fito ${ }^{1}$, Fidel Toldrá ${ }^{2} \&$ Pedro Fito $^{1, *}$ \\ ${ }^{1}$ Instituto Universitario de Ingeniería de Alimentos para el Desarrollo, Universidad Politécnica de Valencia, \\ Camino de Vera s/n, 46022 Valencia, Spain and ${ }^{2}$ Instituto de Agroquímica y Tecnología de Alimentos (CSIC), \\ PO Box 73, 46100 Burjassot (Valencia), Spain
}

(Received 9 November 2009, Accepted in revised form 24 May 2010)

\begin{abstract}
Summary
The objective of the present research was to study the entire visible spectra evolution during meat ageing in different pork meat quality classes (PSE, DFD and RFN). The potential use of the visible spectra for discriminating low meat quality classes during the 24 hours postmortem was also analyzed. For these purposes, 26 pork loins were used: 3 PSE (Pale, Soft and Exudative), 3 DFD (Dark, Firm and Dry) and 20 RFN (Red, Firm and Non-exudative). At 12, 24, 48 hours and 7 days postmortem, reflectance spectra (from 400 to $700 \mathrm{~nm}$ ) were obtained by a spectrocolorimeter Minolta CM-3600D after one and a half hour of blooming time. It was demonstrated that the ageing time has an influence in colour parameters and in blooming ability of RFN loins. The evolution of visible spectra was influenced by ageing time in PSE and RFN loins, while the visible spectra of DFD loins showed no variation with postmortem time. The results showed the possibility of separating PSE meats from the other classes by using visible reflectance spectra at 24 hours postmortem.
\end{abstract}

Keywords Quality, colour, visible spectroscopy, PSE meats, DFD meats, reflectance spectra, colour development.

\section{Introduction}

Colour is one of the most important meat characteristics that consumers consider before buying, and is also related to the sensory characteristics of meat (Norman et al, 2003). The colour of pork is influenced by the pigment content, the different redox states of hemoprotein myoglobin: deoxymyoglobin (DMb) (purple colour), oxymyoglobin $\left(\mathrm{MbO}_{2}\right)$ (bright red colour) and metmyoglobin (MetMb) (brown colour), and by meat structure (Lindahl et al, 2001). During meat ageing, any factor that acts on the myoglobin or indirectly changes the $\mathrm{pH}$ and its rate of decline can affect meat colour evolution (Honikel, 1997).

Abnormal postmortem glycolysis during the conversion of muscle to meat produces extreme progress in $\mathrm{pH}$ which affects negatively to water holding capacity and colour (Bendall and Swatland, 1988), defining the main low quality classes in pork meat. Dark, Firm and Dry (DFD) meats are characterized by an ultimate $\mathrm{pH}$ higher than the isoelectric point of proteins which

*Correspondent: Email: pfito@tal.upv.es produces a high water holding capacity, which is associated with greater translucence and less scatter of incident light, making the meat appear darker (MacDougall and Jones, 1981; MacDougall, 1982). Moreover, at high $\mathrm{pH}(>6)$ mitochondrial oxygen consumption is high and remains so during some time post-rigor (Bendall and Taylor, 1972); consequently, in meat exposed to air the purple colour of deoxymyoglobin predominates, being the surface oxymyoglobin layer thin (Ashmore et al, 1972). On the other hand, Pale, Soft and Exudative (PSE) meats are characterized by the fast decline of $\mathrm{pH}$ after slaughtering with a simultaneous high muscle temperature, producing severe proteins denaturation (Offer et al, 1989) and, consequently, high exudation which produces a high light scattering and reflection over moist surface, giving the pale colour to this kind of meats. With regard to the myoglobin forms in this quality class, the $\mathrm{pH}$ decline promotes the inactivation of oxygen-consuming enzymes which causes the oxygenation of myoglobin yielding to more oxymyoglobin formation (Govindarajan, 1973). These low quality classes contrast to RFN (Red Firm and Non-exudative) 
meats, which are the desirable class to consumers. These meats have a slower $\mathrm{pH}$ decline than PSE meats, which affects positively to their texture and colour. The macromolecular structure is less dense than DFD meats, increasing the light scattering in a desirable way and the oxymyoglobin is the predominant pigment (Offer et al, 1989).

Recently, lots of studies have been made with regard to colour and colour stability of pork. Some parameters have been studied such as the pre-slaughter stress (Rosenvold and Andersen, 2003), diet (Hoving-Bolink et al, 1998; Rosenvold and Andersen, 2003; Tikk et al, 2008), blooming time (Skrlep and CandekPotokar, 2007; Lindahl et al, 2006a; Brewer et al, 2001). However, the influence of ageing on colour development of different quality classes has not been widely evaluated.

The aim of this paper has been to study the entire visible spectra of different meat classes and the evolution of these spectra during meat ageing in order to evaluate meat colour development. The relative amounts of the three myoglobin species have been also studied in order to compare the ability of these quality classes to bloom during ageing. Moreover, the potential use of visible spectroscopy for discriminating low meat quality classes during the 24 hours after slaughter has been analyzed.

\section{Material and Methods}

\subsection{Raw material}

26 pigs (Landrace $\mathrm{x}$ Duroc, 16 males and 10 females) were slaughtered in a commercial slaughterhouse located near the Institute of Agrochemistry and Food technology (Valencia, Spain). These carcasses were selected by trained employee from a total of 200 hundred carcasses, trying to obtain loins from the different quality classes. Carcasses were rapidly chilled at $-10^{\circ} \mathrm{C}$ for $45 \mathrm{~min}$ and the L.Dorsi muscle removed. The muscle was kept at $4^{\circ} \mathrm{C}$ until sampled.

\subsection{Technological Classification}

Meat

Quality

The pork loins were classified based on $\mathrm{L}_{24 \mathrm{~h}}{ }^{*}$ coordinate, $\mathrm{pH}_{2 \mathrm{~h}}, \mathrm{pH}_{24 \mathrm{~h}}$ and drip loss, according to the classification of Table 1. Samples pH was measured through a portable $\mathrm{pH}$-meter CRISON PH25® (CRISON Instruments, S.A., Barcelona, Spain) at 2, 4, 6, 8, 24, 48 hours and 7 days postmortem.

A thick slice (about $100 \mathrm{~g}$ ) was excised $24 \mathrm{~h}$ after slaughter, suspended within a net in a plastic bag and stored at $4{ }^{\circ} \mathrm{C}$. The percent change in weight over the subsequent $48 \mathrm{~h}$ was taken as the drip loss, following the method described by Honikel (1998).

\subsection{Reflectance Spectra Measurements}

The entire pork loins were wrapped with an oxygen permeable film during storage at $4^{\circ} \mathrm{C}$ until sampled. One and a half

hour before each colour measuring time, a chop (2 cm thickness) from each loin was sliced, covered with thin oxygen permeable film and maintained at $4^{\circ} \mathrm{C}$ in order to allow the meat to bloom fully. The colour measuring times were 12, 24, 48 hours and 7 days postmortem.

The colour of the samples was measured through the surface reflectance spectra in a spectrocolorimeter Minolta CM-3600D (Minolta Co. Ltd., Japan). Three measurements were made for each sample at each time. The instrument measures reflectance spectrum between 400 and $700 \mathrm{~nm}$ at $10 \mathrm{~nm}$ intervals. The colour coordinates CIE $L^{*} a^{*} b^{*}$ (CIE, 1978), chroma [( $\left.\left.\mathrm{a}^{*^{2}}+\mathrm{b}^{*^{2}}\right)^{1 / 2}\right]$, hue angle $\left[\operatorname{Tan}^{-1}\left(\mathrm{~b}^{*} / \mathrm{a}^{*}\right)\right]$ were instrumentally calculated based on D65 illuminant and $10^{\circ}$ observer. A white tile and a black chamber supplied by the manufacturer were used for calibration. The Kubelka-Munk K/S ratios were calculated using SpectraMagic ver. 3.6 software (Minolta Co., Ltd., Osaka, Japan). The relative content of $\mathrm{DMb}$ was estimated by the ratio $\mathrm{K} / \mathrm{S}_{474} \div \mathrm{K} / \mathrm{S}_{525}$, the relative content of $\mathrm{MbO}_{2}$ by the ratio $\mathrm{K} / \mathrm{S}_{610} \div$ $\mathrm{K} / \mathrm{S}_{525}$ and the relative content of MetMb by the ratio $\mathrm{K} / \mathrm{S}_{572} \div \mathrm{K} / \mathrm{S}_{525}$ (Hunt et al, 1991; Mancini et al, 2003). These ratios decrease when the relative content of the corresponding myoglobin species increases. Therefore, the K/S-ratios were multiplied by (-1) in figure 4 for obtaining the right impression when looking at it and as K/S values at wavelengths are not proportioned by the equipment $(474,525$ and $572 \mathrm{~nm})$, they were calculated by linear interpolation.

\subsection{Statistical analysis}

Statistical analysis was carried out with the Statgraphic ® Plus, version 5.1 (Statpoint Technologies, Inc, Warrenton, VA, U.S.A.). Multifactor ANOVA analyses for colour parameters and for myoglobin species were made in order to find significant interaction amongst postmortem time and the pork quality classes. Fischer's LSD intervals at $95 \%$ confidence intervals were used for this purpose.

One-way ANOVA analyses for reflectance at each measured wavelength were made in order to find significant differences among the three pork quality classes at each postmortem time. Moreover, in each pork quality class, one-way ANOVA analyses for reflectance at each 
Table 1. Meat classification based upon $\mathrm{pH}_{2 \mathrm{~h}}, \mathrm{pH}_{24 \mathrm{~h}}$, drip loss and $\mathrm{L}_{24 \mathrm{~h}}$ * coordinate.

\begin{tabular}{lcccc}
\hline Meat Quality Classes & $\mathrm{pH}_{2 \mathrm{~h}}$ & $\mathrm{pH}_{24 \mathrm{~h}}$ & Drip Loss & $\mathrm{L}_{24 \mathrm{~h}}{ }^{*}$ \\
\hline Pale Soft Exudative (PSE) & $<5.8$ & - & $\geq 6$ & $>56$ \\
Red Firm Non exudative (RFN) & $>5.8$ & $<5.8$ & $<6 \%$ & $50-56$ \\
Dark Firm Dry (DFD) & - & $>5.8$ & $<3 \%$ & $<50$ \\
\hline
\end{tabular}

wavelength were made in order to find significant differences among postmortem times. Fischer's LSD intervals at $95 \%$ confidence intervals were used for these purposes.

\section{Results and Discussion}

The pork loins were classified according to the classification of table 1. Based on this classification, 3 pork loins were classified as PSE (Pale, Soft and Exudative), 3 as DFD (Dark Firm and Dry) and 20 as RFN (Red Firm and Nonexudative) (Table 2).

The $\mathrm{pH}$ evolution during postmortem period is shown in figure 1 . The rapid drop of $\mathrm{pH}$ suffered by PSE samples immediately after slaughter, from a $\mathrm{pH}$ near the neutrality (in the living animal) to 5.58 at 2 hours postmortem (hpm), can be appreciated in figure 1 . RFN samples showed a $\mathrm{pH}$ at $2 \mathrm{hpm}$ of 5.99, indicating a progressive $\mathrm{pH}$ decline from slaughter. DFD samples showed the highest $\mathrm{pH}$ at $2 \mathrm{hpm}$, which value was 6.22 . These animals are characterized because the glycogen reserves are depleted before slaughter, and thus, these muscles produce little lactic acid during the conversion of muscle to meat. Furthermore, in the figure it can be appreciated that the $\mathrm{pH}$ decrease continues until approximately $8 \mathrm{hpm}$ in the three quality classes, reaching a final $\mathrm{pH}$ close to 5.4 for PSE samples, 5.63 for RFN samples and close to 5.90 for DFD samples. The decrease of $\mathrm{pH}$ from 2 to $24 \mathrm{hpm}$ is more pronounced in RFN and DFD samples than in PSE samples, which highest decrease is experimented during the two first hours postmortem.

\section{Colour evolution during ageing}

$\mathrm{L}^{*}$ coordinate with regard to postmortem time is represented in figure $2 \mathrm{a}$. The Least Significance Difference (LSD) intervals (95\% confidence) are also shown. L* coordinate represents lightness, where $\mathrm{L}^{*}=0$ is completely black, and $\mathrm{L}^{*}=100$ is completely white. $\mathrm{L}^{*}$ coordinate at 24 hours postmortem is one of the parameters usually used for meat quality classification. PSE samples showed a significantly higher $(\mathrm{p}<0.05)$ $\mathrm{L}_{24 \mathrm{~h}}$ * value with respect to the other two quality classes. In the figure, it can also be observed that $\mathrm{L}^{*}$ value of PSE meats remains higher than the $\mathrm{L}^{*}$ value of DFD and RFN during the 48 hours postmortem. In PSE meats, the $\mathrm{pH}$ decreases rapidly during the first hours after slaughter while temperature is still high, resulting in excessive protein denaturation (Offer and Knight, 1988), so the water-holding capacity is decreased (Ledward, 1992), light scattering is increased (Bendall and Swatland, 1988) and L* coordinate is increased (Joo et al, 1999). On the other hand, DFD meats present an $\mathrm{L}^{*}$ coordinate similar to RFN meats during the 24 hours after slaughter as it was reported by Zhu and Brewer (1998). Above 24 hours postmortem, RFN meats present higher $\mathrm{L}^{*}$ coordinate than DFD meats, which remains almost constant and lower. $L^{*}$ coordinate increases gradually during ageing for RFN meats.

In figure 2, the Hue mean angle, $\mathrm{a}^{*}$ and $\mathrm{b}^{*}$ coordinates are represented for each meat quality class during ageing. In the CIE L*a*b* space, a* represents the red-green colour and $b^{*}$ the yellow-blue colour of the sample. DFD and PSE quality classes do not show important variations in $a^{*}$ and $b^{*}$ colour coordinates during ageing. On the contrary, RFN quality class shows variations in both $\mathrm{a}^{*}$ and $\mathrm{b}^{*}$ coordinates. The value of $\mathrm{a}^{*}$ coordinate increases significantly $(\mathrm{p}<0.05)$ from 48 hours to 7 days postmortem; this fact means that RFN samples showed more red colour after 7 days of ageing than during the 2 days after slaughter. The $b^{*}$ coordinate shows an increase from 24 hours to 7 days postmortem.

Table 2. Meat quality measurements by quality classes for assayed pork loins

\begin{tabular}{llll}
\hline Technologic parameters & PSE $(\mathrm{n}=3)$ & DFD $(\mathrm{n}=3)$ & $\mathrm{RFN}(\mathrm{n}=20)$ \\
\hline Drip Loss $(\%)$ & $6.0^{\mathrm{a}} \pm 0.3$ & $1.5^{\mathrm{b}} \pm 0.3$ & $3.5^{\mathrm{c}} \pm 0.4$ \\
$\mathrm{~L}_{24 \mathrm{~h}}{ }^{*}$ & $56.7^{\mathrm{a}} \pm 0.8$ & $49.4^{\mathrm{b}} \pm 0.2$ & $51.8^{\mathrm{b}} \pm 1.8$ \\
$\mathrm{pH} 2 \mathrm{~h} \mathrm{pm}$ & $5.58^{\mathrm{a}} \pm 0.13$ & $6.22^{\mathrm{b}} \pm 0.09$ & $5.99^{\mathrm{c}} \pm 0.05$ \\
$\mathrm{pH} 24 \mathrm{~h} \mathrm{pm}$ & $5.37^{\mathrm{a}} \pm 0.10$ & $5.90^{\mathrm{b}} \pm 0.06$ & $5.63^{\mathrm{c}} \pm 0.04$ \\
\hline$n=$ number of pork loins \\
$\begin{array}{l}\text { a,b,c = means in a row with different superscripts are significantly different }(p<0.05) \\
p m=\text { postmortem }\end{array}$
\end{tabular}




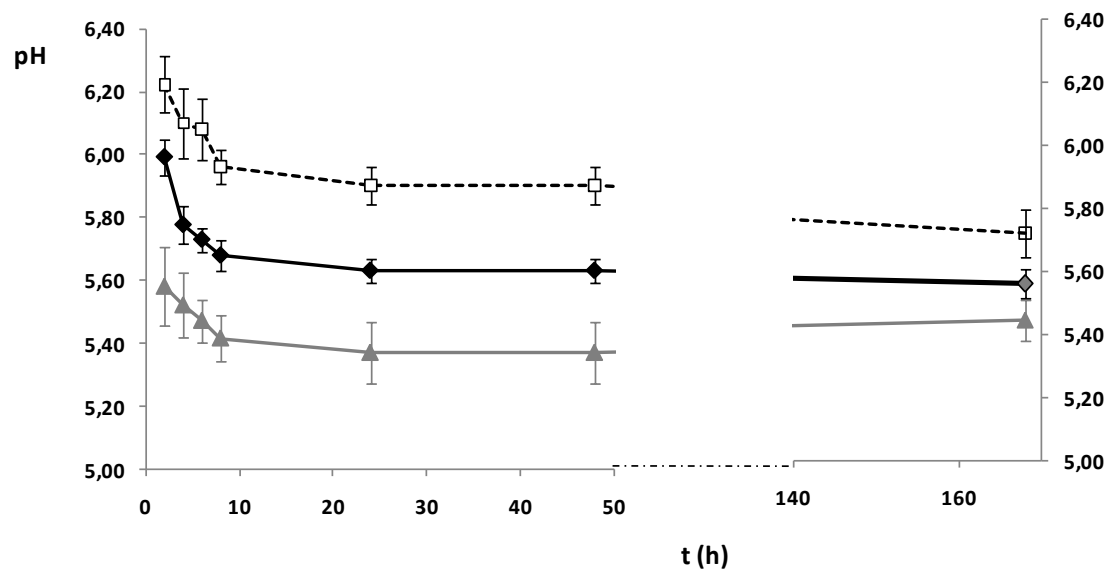

Figure 1. Evolution of $\mathrm{pH}$ means during ageing, where DFD samples ( $\square$ ), RFN samples ( $\bullet$ ), PSE samples $(\Delta)$. The standard deviation of each $\mathrm{pH}$ is shown.
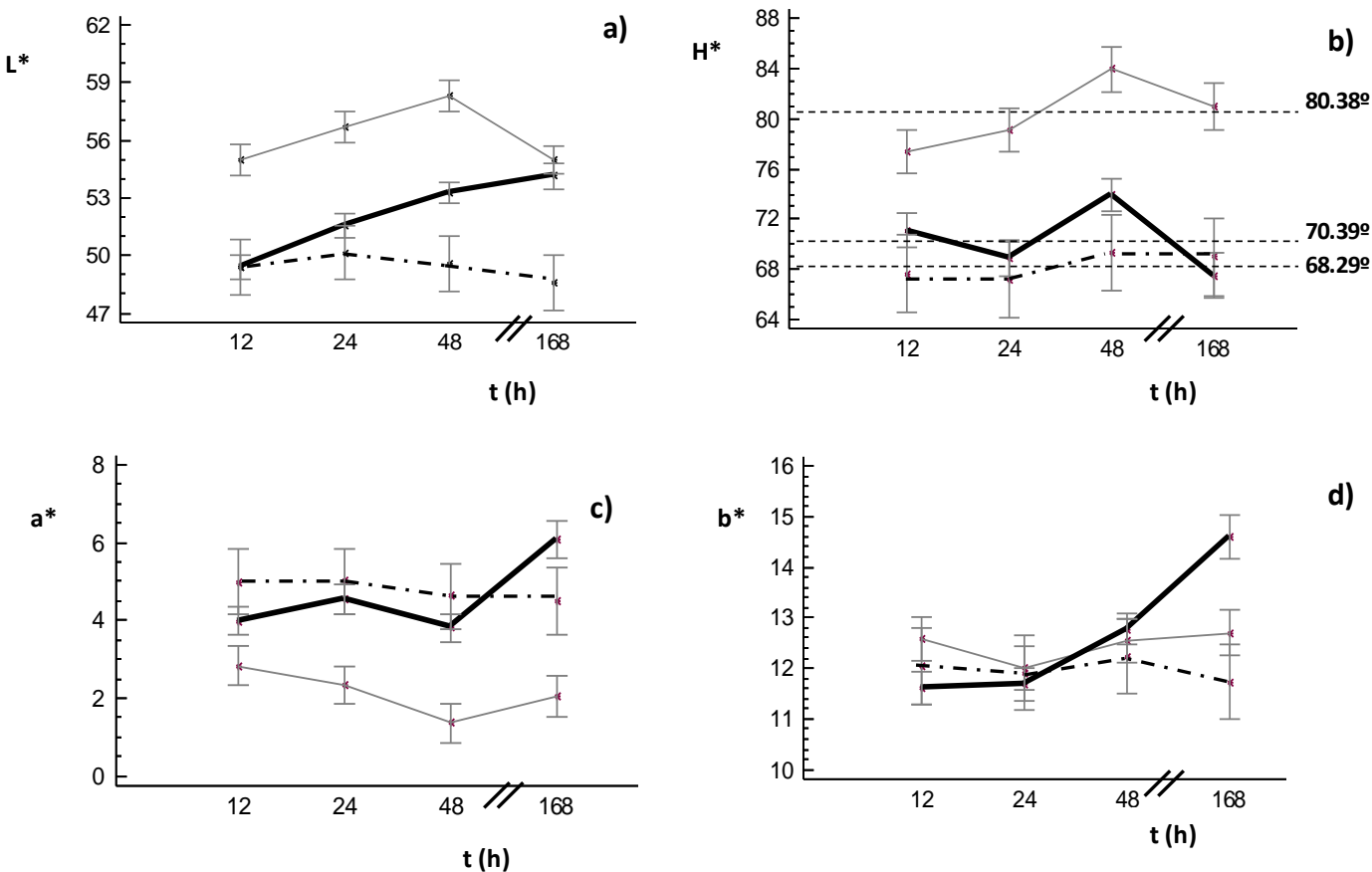

d)

Figure 2. Evolution of a) $L^{*}$ mean values, b) Hue mean angles, c) $a^{*}$ coordinate, c) $\mathrm{b}^{*}$ coordinate, during ageing where RFN (-), DFD (-.-.), and PSE (-). In all figures the Least Significance Difference (LSD) intervals (with 95\% confidence) are represented. 
Both coordinates, $\mathrm{a}^{*}$ and $\mathrm{b}^{*}$, were used to calculate the hue mean angle during ageing in order to obtain more information about the effect of ageing in meat colour. In the figure $2 b$, it can be observed that RFN and DFD meats have similar hue mean angles during ageing $\left(70.39^{\circ}\right.$ and $68,29^{\circ}$, respectively). On the other hand, PSE samples showed a hue mean angle $\left(80.38^{\circ}\right)$ significantly higher $(\mathrm{p}<0.05)$ than $\mathrm{RFN}$ and DFD meats. Hue angle measures the degree of departure from the red axis of the CIE colour space (Brewer et al., 2006). Lower hue angle is related with higher visually perceived redness. So, RFN and DFD samples, which have a significantly lower $(\mathrm{p}<0.05)$ hue mean angle, are characterized by redder colour than PSE meats. Moreover, from 48 hours to 7 days postmortem, the RFN samples showed a significantly $(p<0.05)$ decrease in hue angle, which is related with higher perceived red colour in those samples after 7 days of ageing.

In figure 3 , the average reflectance spectra between 400 and 700nm were represented for the studied meat quality classes at 12, 24, 48 hours and 7 days postmortem. It can be observed that at 12 hours postmortem the PSE meats reflectance spectrum is significantly higher $(\mathrm{p}<0.05)$ than that of DFD and RFN meats at wavelengths above $430 \mathrm{~nm}$. It might be due to the accelerated metabolism that characterizes the exudative meats which produces a fast $\mathrm{pH}$-decline while temperature is still high; this situation produces a decrease in the water holding capacity and an excessive protein denaturation, increasing light scattering. The same behaviour can be observed at 24 and 48 hours postmortem. It is important to remark that RFN meats spectrum is being progressively increasing with ageing, approaching to PSE spectrum. This is due to the fact that these kind of samples have a higher $\mathrm{pH}$ at early postmortem when compared to the PSE samples; moreover, its $\mathrm{pH}$ decline is gradual, approaching progressively to isoelectric point of myosin with meat ageing, leading to the loss of water-binding capacity of the protein and affecting muscle structure; due to these factors, more incident light is scattered and RFN meat reflectance spectrum is approaching to PSE spectrum. This phenomenon is reflected in the 48 hours postmortem spectra (Figure 3), which show differences statistically significant among the three quality classes. Otherwise, DFD samples are characterized by a little production of lactic acid and, consequently, by a very low $\mathrm{pH}$ decrease $\left(\mathrm{pH}_{24}\right.$ near 6,0), higher water holding capacity and dark colour (Lawrie, 1998). The figure 3 shows that, at 24 hours postmortem, the reflectance spectra can be used to discriminate only the PSE meats, not being useful to the discrimination of DFD meats. For this discrimination, 48 hours postmortem are needed.
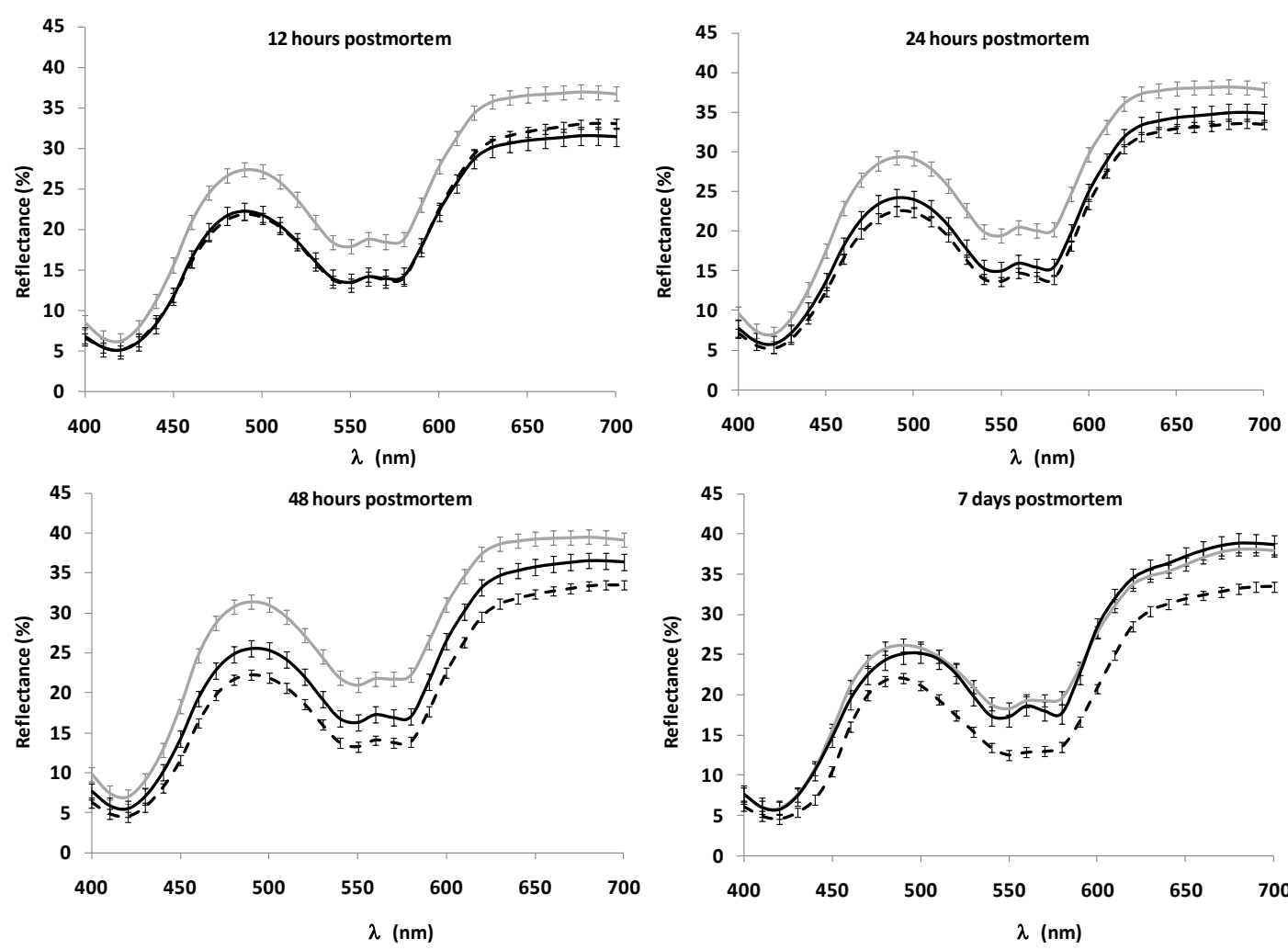

Figure 3. Mean reflectance spectra $(400 \mathrm{~nm}-700 \mathrm{~nm})$ and Least Significance Difference (LSD) intervals (with 95\% confidence) at different postmortem times, where: RFN (-), DFD (- - -), and PSE (一). 

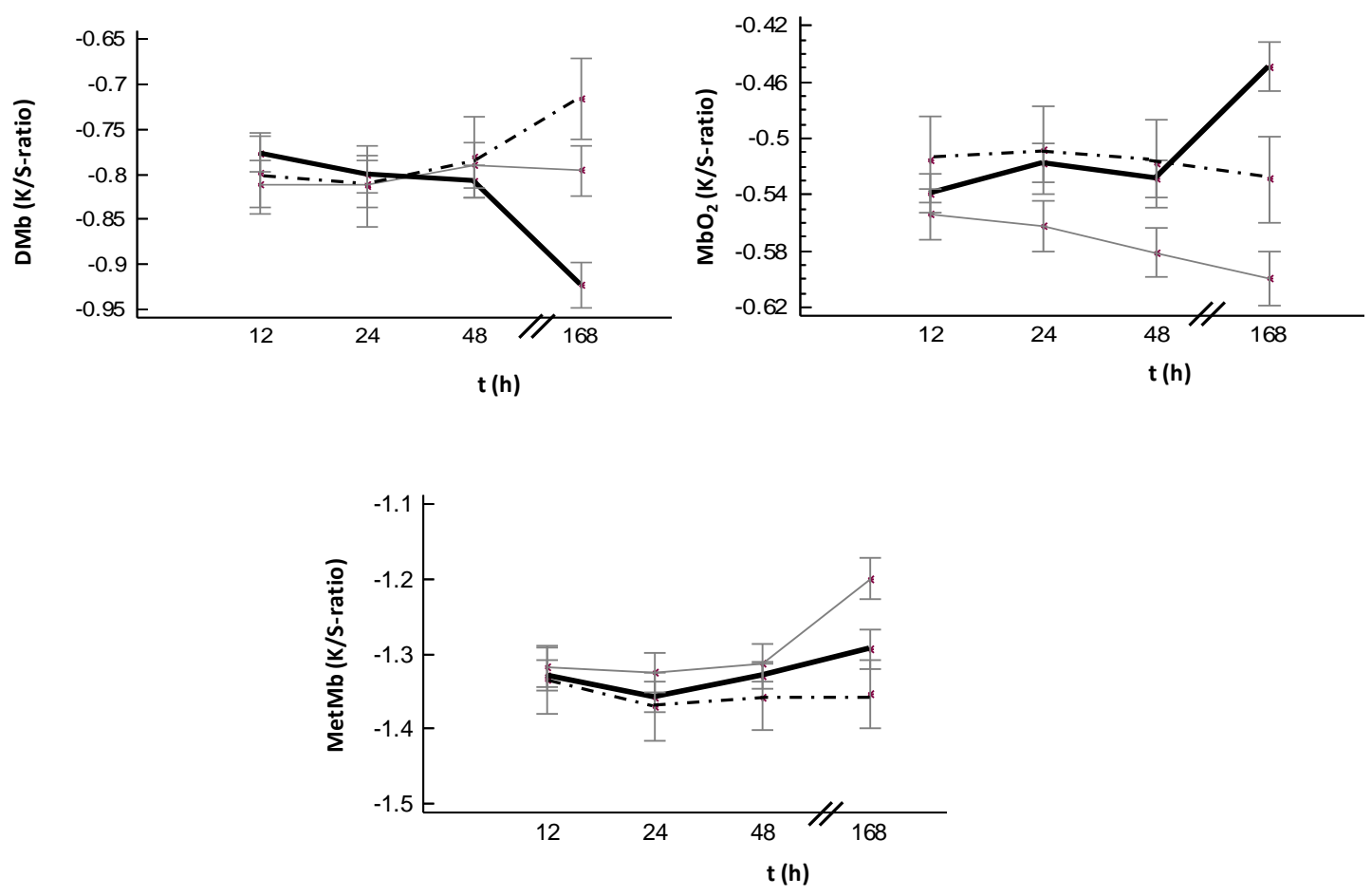

Figure 4. Effect of ageing on the relative concentration of $\mathrm{DMb}, \mathrm{MbO}_{2}$ and $\mathrm{MetMb}$, calculated from K/S-ratio for RFN (-), DFD (-.-.), and PSE (-) samples. The mean values and the Least Significance Difference (LSD) intervals (with $95 \%$ confidence) are represented.

\section{Evolution of myoglobin species during ageing}

The evolution of myoglobin species of different pork classes was investigated (Figure 4). The relative amounts of $\mathrm{DMb}, \mathrm{MbO}_{2}$ and MetMb in meat depend on the oxygen availability, the autoxidation rate of myoglobin and the MetMb reducing capacity (Leward, 1992). In figure 4, it can be observed that oxymyoglobin is significantly higher $(\mathrm{p}<0.05)$ at 7 days postmortem than during the 48 hours after slaughter in RFN meats. After slaughtering, the muscle continues consuming oxygen in cell respiration (Lanari and Cassens, 1991; Madavi and Carpenter, 1993). Meat ageing in normal meats promotes a decrease in respiration due to the loss of structural integrity and consequently, the oxygen consumption decrease, allowing it to penetrate into the muscle (Millar et al, 1994) and thus a more pronounced blooming occurs (Zhu et al, 2001; Lindahl et al, 2006a,b), leading to a more red colour (Rosenvold and Andersen, 2003; Lindahl et al, 2006a,b). On the other hand, deoxymyoglobin decrease significantly $(\mathrm{p}<0.05)$ from 48 to 7 days postmortem for RFN meats; this phenomenon can be related to the increase in oxymyoglobin at 7 days postmortem due to the increased oxygenation (blooming ability) at this time. Moreover, metmyoglobin suffers a slight increase at 7 days postmortem in RFN meats; this slight accumulation of MetMb can be due to the decrease of metmyoglobin reductase activity as time postmortem progresses (Mancini and Hunt, 2005). These significant changes in myoglobin species of RFN meats were reflected in a significant increase of $\mathrm{L}^{*}, \mathrm{a}^{*}$ and $\mathrm{b}^{*}$ coordinates, and a decrease in the hue angle at 7 days postmortem. Thus, more blooming can be associated with lighter and redder colour as was previously reported by Lindahl et al (2001).

On the other hand, low quality meats do not have a significant increase in oxymyoglobin during meat ageing. PSE meats have a rapid $\mathrm{pH}$ decline while samples are still at high temperatures; this situation favors the autooxidation of myoglobin (Gotoh and Shikama, 1974) to metmyoglobin which increase significantly $(\mathrm{p}<0.05)$ at 7 days postmortem (Figure 4). DFD meats are characterized by high $\mathrm{pH}$ ( $\mathrm{pH}$ near 6), at which oxygen consuming enzymes remain active, so less oxygen is available to the oxygenation of myoglobin (Figure 4). On the other hand, this meat class has a very stable colour, and no significant variations on myoglobin states are produced. 

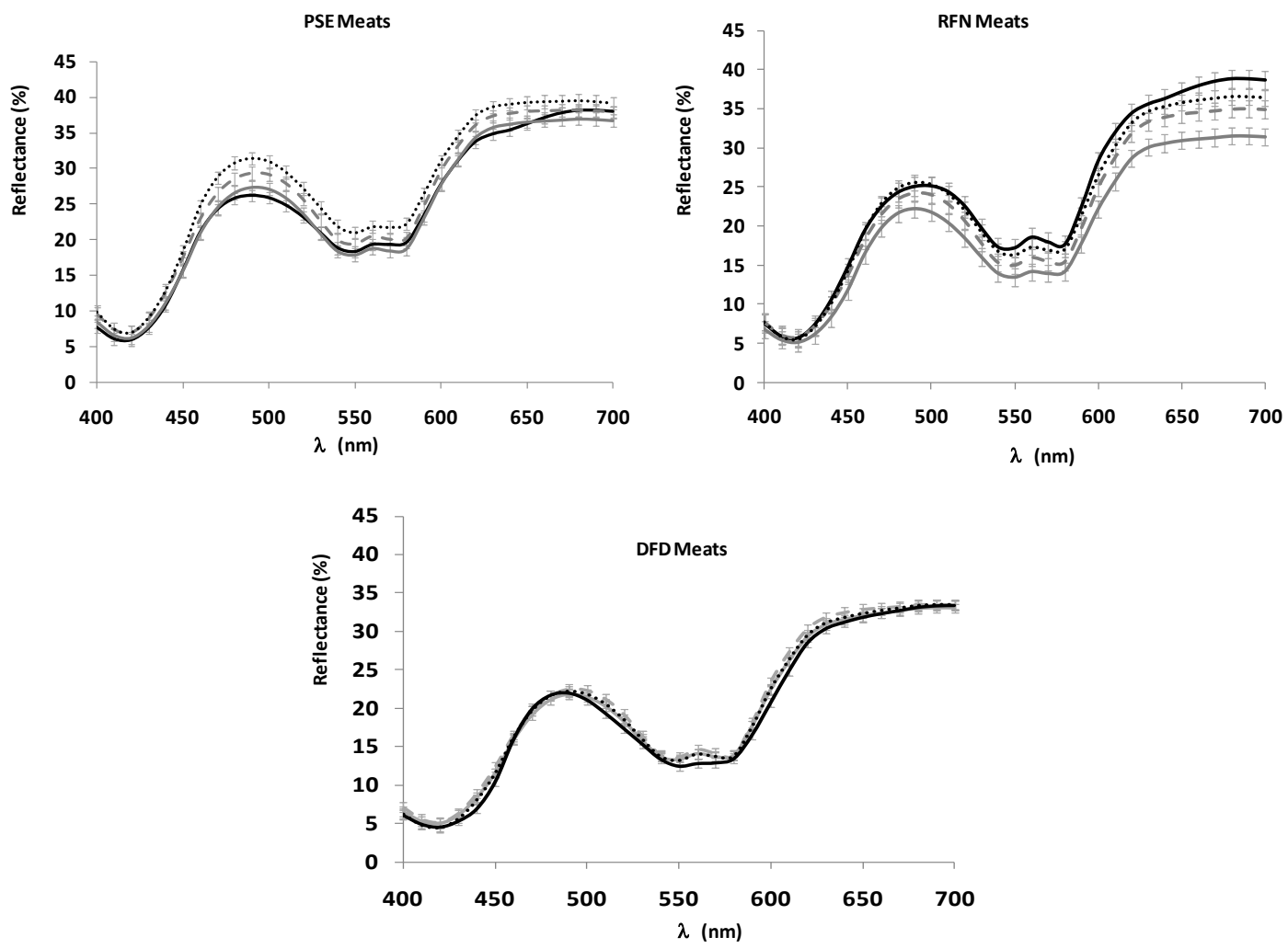

Figure 5. Mean reflectance spectra $(400 \mathrm{~nm}-700 \mathrm{~nm})$ for each meat quality class during ageing, where: 12 hours postmortem (-), 24 hours postmortem (- - ), 48 hours postmortem (...), 7 days postmortem (-). The Least Significance Difference (LSD) intervals (with 95\% confidence) are represented.

When compared the three quality classes in figure 4 it can be observed that $\mathrm{DMb}$ is similar during the 48hours postmortem in the three classes, while there are significantly differences $(\mathrm{p}<0.05)$ at 7 days postmortem, being higher in DFD meats than in PSE meats, which are higher than RFN meats. $\mathrm{MbO}_{2}$ is significantly higher $(\mathrm{p}<0.05)$ in RFN meats than in the low quality classes at 7 days postmortem, which is related with the significantly $(\mathrm{p}<0.05)$ higher values of $a^{*}$ and $b^{*}$ coordinates at 7 days postmortem in RFN meats than in the low quality classes, indicating a brighter red colour of this samples at 7 days postmortem. On the other hand, PSE meats have less $\mathrm{MbO}_{2}$ than the other two classes from 24 hours to 7 days postmortem. With regard to the MetMb, PSE samples have higher MetMb at 7 days postmortem than the other two quality classes.

In figure 5 the evolution of the mean reflectance spectra $(400 \mathrm{~nm}-700 \mathrm{~nm})$ for each meat quality during ageing are shown. It can be observed that the reflectance of RFN samples is increasing with postmortem time. The 7 days postmortem spectrum has a different shape from the other spectra. It can be observed that the bump at around $560 \mathrm{~nm}$ is more pronounced at 7 days postmortem which can be associated with an increase in $\mathrm{MbO}_{2}$ which is typically observed at such wavelength (Lindahl, 2005). Moreover, a little decrease in reflectance is observed at around $630 \mathrm{~nm}$, which can be associated to the slight increase in MetMb (Lindahl, 2005). On the contrary, DFD samples spectra remain almost constant during the postmortem, which can be interpreted as very stable colour characteristics of this pork meat quality class. There exist only differences at 7 days postmortem spectrum in which the bump at around 560nm disappears; it can be associated with the decrease in $\mathrm{MbO}_{2}$ observed at this time, although this decrease was not significant (see figure 4). PSE samples presented an increase in reflectance during the 48 hours after slaughter, but the reflectance at 7 days postmortem decreases significantly $(\mathrm{p}<0.05)$. The 7 days postmortem spectrum presents a different behaviour between 600-700 $\mathrm{nm}$, which can be associated to the significant $(p<0.05)$ increase of MetMb (Lindahl, 2005). 


\section{Conclusions}

The evolution of visible spectra was influenced by ageing time in PSE and RFN loins, while the visible spectra of DFD loins showed no variation with postmortem time.

A more pronounced blooming was observed in RFN meats at 7 days postmortem than during the 48 hours after slaughter. This phenomenon was reflected in a significantly $(\mathrm{p}<0.05)$ higher oxymyoglobin content, $\mathrm{L}^{*}, \mathrm{a}^{*}$ and $\mathrm{b}^{*}$ coordinates and a significantly $(p<0.05)$ lower deoxymyoglobin content, and hue angle at 7 days postmortem with regard to the values of these parameters in this quality class during the 48 hours after slaughter. Thus, it is possible to conclude that ageing time affects positively to the colour of RFN meats. PSE samples showed a significantly $(p<0.05)$ increase in metmyoglobin at 7 days postmortem, and a significantly $(\mathrm{p}<0.05)$ decrease in $\mathrm{L}^{*}$ coordinate while DFD meats did not show significant variation on colour parameters or on myoglobin states.

Additionally, the results showed the possibility of separating PSE meats from the other classes by using visible reflectance spectra at 24 hours postmortem. However, at this time, it was also demonstrated that discriminating DFD meats by this method is not possible.

\section{Acknowledgements}

Grant from Agroalimed (Conselleria de Agricultura, Pesca y Alimentación, Valencia, Spain) and FPU grant to MC from Ministry of Science and Innovation (Madrid, Spain) are fully acknowledged. Work prepared within the Unidad Asociada IIAD (UPV)-IATA (CSIC) framework.

\section{References}

Ashmore, C.R., Parker, W. \& Doerr, L. (1972). Respiration of mitochondria isolated from dark-cutting beef: postmortem changes. Journal of Animal Science, 34, 46-53.

Bendall, J.R. \& Taylor, A.A. (1972). Consumption of oxygen by the muscles of beef animals and related species. II. Consumption of oxygen by post-rigor muscle. Journal of the Science of Food and Agricultural, 23, 707-711.

Bendall, J.R. \& Swatland, H.J. (1988). A review of the relationships of $\mathrm{pH}$ with physical aspects of pork quality. Meat Science, 24,85-126.

Brewer, M.S., Zhu, L.G., Bidner, B., Meisinger, D.J. \& McKeith, F.K. (2001). Measuring pork color: effects of bloom time, muscle, $\mathrm{pH}$ and relationship to instrumental parameters. Meat Science, 57, 169176.

Brewer, M.S., Novakofski, J. \& Freise,K. (2006) Instrumental evaluation of $\mathrm{pH}$ effects on ability of pork chops to bloom. Meat Science, 72, 596-602.

CIE. (1978). International Commission on Illumination, recommendations on uniform colour spaces, colour, difference equations, psychometric colour terms. CIE publication No. 15 (Suppl.2), (E-1.31) 1971/(TC-1.3). Bureau Central de la CIE, Paris, France.
Gotoh, T. \& Shikama, K. (1974). Autoxidation of oxymyoglobin from bovine heart muscle. Archives Biochemistry and Biophysics, 163, 476-478.

Govindarajan, S. (1973). Fresh meat colour. CRC Critical Reviews in Food Technology, 4,117-140.

Honikel, K.O. (1997). Reference methods supported by OECD and their use in Mediterranean meat products. Food Chemistry, 59 (4), 573-582.

Honikel, K.O. (1998). Reference methods for the assessment of physical characteristics of meat. Meat Science, 49(4),447-457.

Hoving-Bolink, A.H., Eikelenboom, G., van Diepen, J.Th.M., Jongbloed, A.W. \& Houben, J.H. (1998). Effect of dietary vitamin E supplementation on pork quality. Meat Science, 49 (2), 205-212.

Hunt, M.C., Acton, J.C., Benedict, R.C., Calkins, C.R., Cornforth, D.P., Jeremiah, L.E., et al (1991). Guidelines for meat colour evaluation. In Proceedings $44^{\text {th }}$ annual reciprocal meat conference June 9-12, Kansas City University, Manhattan, KS., pp.1-17. Chicago, IL, U.S.A.: Publ. National Live Stock and Meat Board.

Joo, S.T., Kauffman, R.G., Kim, B.C. \& Park, G.B. (1999). The relationship of sarcoplasmic and myofibrillar protein solubility to colour and water-holding capacity in porcine longissimus muscle. Meat Science, 52, 291-297.

Lanari, M.C. \& Cassens, R.G. (1991). Mitochondrial activity and beef muscle colour stability. Journal of Food Science, 56, 1476-1479.

Lawrie, R.A. (1998). Lawrie's Meat Science. Cambridge, UK: Woodhead Publishing Limited, sixth edition.

Ledward, D.A. (1992). Colour of raw and cooked meat. In: The chemistry of muscle-based foods (edited by D.E Johnston, M.K. Knight and D.A. Ledward). Pp. 128-144. Cambridge, UK: Royal Society of Chemistry.

Lindahl, G. (2005). Colour characteristics of fresh pork. Doctoral Thesis, Swedish University of Agricultural Sciences, Uppsala (Sweden).

Lindahl, G., Lundström, K. \& Tornberg, E. (2001). Contribution of pigment content, myoglobin forms and internal reflectance to the colour of pork loin and ham from pure breed pigs. Meat Science, 59, 141-151.

Lindahl, G., Karlsson, A.H., Lundström, K. \& Andersen, H. J. (2006a). Significance of storage time on degree of blooming and colour stability of pork loin from different crossbreeds. Meat Science, 72, 603-612.

Lindahl, G., Enfält, A.C., Andersen, H.J. \& Lundström, K. (2006b). Impact of RN genotype and ageing time on colour characteristics of the pork muscles longissimus dorsi and semimembranosus. Meat Science, 74, 746-755.

MacDougall, D.B. \& Jones, S.J. (1981). Translucency and colour defects of dark-cutting meat and their detection. In: The Problem of the Dark-cutting in Beef (edited by D.E. Hood and P.V. Tarrant). Pp. 328-339. Hague, Netherlands: Martinus Nijhoff Publishers

MacDougall, D.B. (1982). Changes in the colour and opacity of meat. Food Chemistry, 9,75-80.

Madavi, D.L. \& Carpenter, C.E. (1993). Ageing and processing affect colour, metmyoglobin reductase and oxygen consumption of beef muscles. Journal of Food Science, 58, 939- 947.

Mancini, R. A., Hunt, M.C. \& Kropf, D.H. (2003). Reflectance at $610 \mathrm{~nm}$ estimates oxymyoglobin content on the surface of ground beef. Meat Science, 64, 157-162.

Mancini, R.A. \& Hunt, M.C. (2005). Current research in meat colour. Meat Science, 71,100-121.

Millar, S., Wilson, R., Moss, B.W. \& Ledward, D.A. (1994). Oxymyoglobin formation in meat and poultry. Meat Science, 36, 397-406. 
Norman, J.L., Berg, E.P., Heymann, H. \& Lorenzen, C.L. (2003). Pork loin colour relative to sensory and instrumental tenderness and consumer acceptance. Meat Science, 65(2), 927-933.

Offer, G. \& Knight, P. (1988). The structural basis of waterholding in meat. Part 2: Drip losses. In: Development in meat science (edited by $\mathrm{R}$. Lawrie). Vol. 4, pp. 172-243. London: ElSevie Applied Science.

Offer, G., Knight, P., Jeacoke, R., Almond, R., Cousins, T., Elsey, J., et al (1989). The structural basis of waterholding, appearance and toughness of meat and meat products. Food Microstructure, 8,151170.

Rosenvold, K. \& Andersen, H.J. (2003). The significance of pre-slaughter stress and diet on colour and colour stability. Meat Science, 63, 199-209.
Skrlep, M. \& Candek-Potokar, M. (2007). Pork color measurement as affected by bloom time and measurement location. Journal of Muscle Foods, $18,78-87$.

Tikk, K., Lindahl, G., Karlsson, A.H. \& Andersen, H.J. (2008). The significance of diet, slaughter weight and ageing time on pork colour and colour stability. Meat Science, 79, 806-816.

Zhu, L.G. \& Brewer, M.S. (1998). Discoloration of fresh pork as related to muscle and display conditions. Journal of Food Science, 63, 763-767.

Zhu, L.G., Bidner, B. \& Brewer, M.S. (2001). Postmortem $\mathrm{pH}$, muscle, and refrigerated storage effects on ability of vacuum-packaged pork to bloom. Journal of Food Science, 66, 1230-1235. 



\title{
Microwave dielectric spectroscopy for the determination of pork meat quality
}

\author{
Marta Castro-Giráldeza ${ }^{\mathrm{a}}$ M-Concepción Aristoyb, Fidel Toldráb, Pedro Fito ${ }^{\mathrm{a}^{*}}$ \\ aInstituto Universitario de Ingeniería de Alimentos para el Desarrollo, Universidad Politécnica de Valencia, Camino de Vera, s/n, 46022, Valencia, Spain \\ Instituto de Agroquímica y Tecnología de los Alimentos(CSIC), PO Box 73, 46100 Burjassot (Valencia), Spain
}

A R T I C LE INFO

Article history:

Received 16 October 2009

\section{Keywords:}

Dielectric spectroscopy

Dielectric properties

PSE meats

DFD meats

Quality

Ageing

\begin{abstract}
A B S T R A C T
The use of dielectric spectra to detect quality defects in porcine muscle during postmortem period was evaluated. The changes in dielectric spectra during meat ageing were also studied. For these purposes, dielectric spectra were measured by using an Agilent 85070E Open-ended Coaxial Probe connected to an Agilent E8362B Vector Network Analyzer from $500 \mathrm{MHz}$ to $20 \mathrm{GHz}$ parallel and perpendicular to muscle fiber direction. This study reveals that dielectric properties at two punctual frequencies $(0.5 \mathrm{GHz}$ and $10 \mathrm{GHz}$ ) are a useful tool to determine meat quality classes (RFN, PSE, DFD) soon (6 hours) after slaughter. Based on these results, it is possible to develop control algorithms in order to discriminate low quality pork meats and to decide their best uses. Moreover, the evolution of dielectric spectra during meat ageing showed important variations only in DFD meats, while in PSE and RFN meats the variations were observed only at some punctual frequencies of the spectrum during the 24 hours after slaughter.
\end{abstract}

(C) 2010 Elsevier Ltd. All rights reserved.

\section{Introduction}

Rapid on-line techniques to discriminate low quality classes of pork meat are of great interest for both consumers and industry. Among the low quality classes, Pale, Soft and Exudative (PSE) and Dark, Firm and Dry (DFD) present a 10\% and 4\% of incidence respectively (Morgan, Smith, Cannon, McKeith and Heavner, 1994). PSE meats present bad appearance for consumers and cause high economic losses for the industry (Stetzer and McKeith, 2003). These meats are caused by an accelerated rate of postmortem glycolysis resulting in low muscle $\mathrm{pH}$ while carcass temperature remains high, causing sarcoplasmic and myofibrillar proteins denaturation and an accelerated rigor mortis process (Sosnicki, Greaser, Pietrzak, Pospiech and Sante, 1998). The accelerated postmortem metabolism results in meats with pale lean, soft texture and low water holding capacity (Bowker, Grant, Forrest and Gerrard, 2000). On the other hand, DFD meats are prone to microbial contamination during its processing (Lawrie, 1998); these meats are

${ }^{*}$ Corresponding author. Tel.: +34 963877369

E-mail address: pfito@tal.upv.es (P.Fito). characterized by a dark, unattractive appearance and a firm, dry, less palatable and sticky texture due to enhanced water binding capacity (Wulf, Emnet, Leheska and Moeller, 2002; Scheffler and Gerrard, 2007). Red, Firm and Non-exudative (RFN) is the desirable meat quality which is considered ideal for producers and consumers. Dielectric spectroscopy technique presents some advantages with regard to traditional methods for discriminating low meat quality classes; it can be considered a relatively inexpensive and rapid technique, applied in the slaughter line and non destructive. This technique has shown potential uses for food quality control and meat composition measurements; it has been used to detect the fraudulent addition of water in meat products (Kent, Knökel, Daschner and Berger, 2000, 2001; Kent, Peymann, Gabriel and Knight, 2002), to measure water activity in proteic gels (Clerjon, Daudin and Damez, 2003), to control meat freshness (Clerjon and Damez 2007), to predict the fat content in minced meat (Kent, Lees and Roger, 1993; Borgaard, Christensen and Jespersen, 2003), for controlling meat salting process (CastroGiráldez, Fito and Fito, 2010d), and for determining 
meat ageing (Damez, Clerjon, Abouelkaram and Lepetit, 2008; Castro-Giráldez, Botella, Toldrá and Fito, 2010c).

The complex permittivity $\left(\varepsilon_{r}\right)$ is the dielectric property which describes the behaviour of the food when is subjected to an electromagnetic field (Metaxas and Meredith, 1993; Nelson and Datta, 2001). Complex permittivity is defined by the next equation:

$$
\varepsilon_{\mathrm{r}}=\varepsilon^{\prime}-\mathrm{j} \cdot \varepsilon^{\prime \prime}
$$

(Equation 1)

In this equation, $j=\sqrt{-1}$. The real part of complex permittivity is called dielectric constant $\left(\varepsilon^{\prime}\right)$ and the imaginary part is called loss factor $\left(\varepsilon^{\prime \prime}\right)$. The dielectric constant is related with the capacitance of the material and its ability to store energy. This capacity of the material to store energy is called polarization (Nelson and Datta, 2001). This phenomenon is mainly due to the displacement of positive and negative charges from their equilibrium position, under the influence of the applied electromagnetic field and against the atomic and molecular attraction. Foods are nonideal dielectrics and polarization has associated dissipation phenomena producing energy absorptions and the decay of dielectric constant. The parameter which reflects the absorption and dissipation of electromagnetic energy is the loss factor (Metaxas and Meredith, 1993).

The interaction of the electric field with biological tissue in the range of microwaves and radio frequencies produces four main relaxations: $\alpha, \beta, \delta$ and $\gamma$. Each relaxation occurs in a specific frequency range and allows to identifying different phenomena (Gabriel, 2006). The interaction of microwaves and meat products produces the socalled $\gamma$-dispersion which is closely related with the water content and its state (Kent and Jason, 1975). But dielectric spectrum at these frequencies depends also on food composition which obviously influences the water state. Moreover, the presence of ions produces ionic conductivity that affects the loss factor spectrum. The electrical charges of proteins, the presence of free amino acids or the $\mathrm{pH}$ variations are some of the factors that can affect the dielectric spectrum at these frequencies (Gabriel, 2006).

The aim of this paper was to analyze the possibility of determining the fresh meat quality classes by using dielectric spectra in the microwave range during the 24 hours after slaughter. The evolution of these spectra during ageing was also analyzed. This study is the first step for further development of an accurate method to discriminate low quality meats in a rapid and non-destructive way.

\section{Materials and Methods}

\subsection{Raw material}

26 pigs (Ladrance $\mathrm{x}$ Duroc, 16 males and 10 females) were slaughtered in a commercial slaughterhouse located near the Institute. Carcasses were rapidly chilled at $-10^{\circ} \mathrm{C}$ for $45 \mathrm{~min}$ and the Longissimus Dorsi muscle removed. The muscle was kept at $4^{\circ} \mathrm{C}$ until sampled.

\subsection{Technological Quality Analysis}

pH was measured through a portable pH-meter CRISON PH25 $\AA$ at 2 and 24 hours after slaughtering.

The colour was measured through the surface reflectance spectra in a spectrocolorimeter Minolta CM-3600D (Minolta Co. Ltd., Tokio, Japan) at 24 hours postmortem. Chops of $2 \mathrm{~cm}$ of thickness perpendicular to the fiber direction were used for this determination. Three measurements were made for each sample. The instrument measures reflectance spectrum between 400 and $700 \mathrm{~nm}$ at $10 \mathrm{~nm}$ intervals. The colour coordinates CIE L*a*b* (CIE, 1978) were instrumentally calculated based on D65 illuminant and $10^{\circ}$ observer.

Drip loss was determined by the method of Honikel (1998).

\subsection{Dielectric properties measurement}

Three cubes of each loin $(\mathrm{L}=3 \mathrm{~cm})$ were cut from the entire pork loins just one hour before each selected time $(6,24,48$ hours and 7 days postmortem). The fiber direction was correctly identified by sewing with black thread on the perpendicular to fiber direction surface (Figure 1). Meat samples were introduced in metacrilate cubes to avoid superficial dehydration and maintained in a $4^{\circ} \mathrm{C}$ chamber until the measurements (less than one hour).

Dielectric properties were measured with an Agilent 85070E Open-ended Coaxial Probe connected to an Agilent E8362B Vector Network Analyzer (Figure 1). The software of the Network Analyzer calculates the dielectric constant and loss factor as a reflected signal function. For these measurements the probe was fixed to a stainless steel support, and an elevation platform brings the sample near the probe to avoid possible phase changes due to cable movements after calibration.

The system was calibrated by using three different types of loads: air, short-circuit and $25^{\circ} \mathrm{C}$ Milli ${ }^{\circledR}-\mathrm{Q}$ water. Dielectric spectra of meat samples were measured at 6, 24, 48 hours and 7 days postmortem by contacting the sample surface with the probe, following the direction of the fibers and perpendicular to them avoiding fat phase of the meat. The Mean values of at least six replicates of the pork loin samples in each direction were made. All determinations were made at $4{ }^{\circ} \mathrm{C}$ from $500 \mathrm{MHz}$ to $20 \mathrm{GHz}$. 


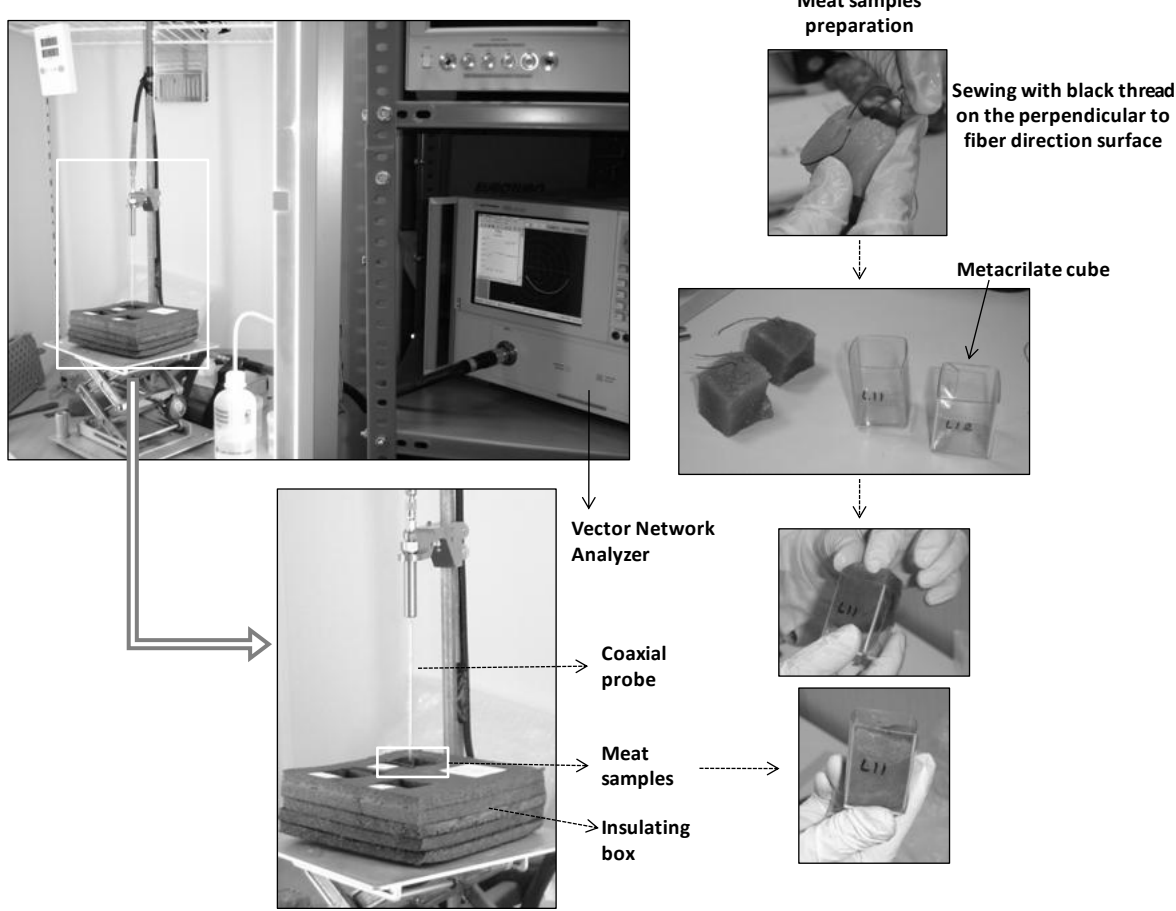

Figure 1. Measurement of the dielectric properties of pork loin samples with an Agilent 85070E openended coaxial probe connected to an Agilent E8362B Vector Network Analyzer. The preparation of meat samples can be also appreciated.

\subsection{Biochemical analysis}

For Adenosine Triphosphate (ATP) analysis, smal pieces were cut at each sampling time $(2,4,6,8$ and 24 hours postmortem), introduced in plastic bags and immediately frozen with liquid nitrogen The samples were stored at $-80^{\circ} \mathrm{C}$ for further analysis.

\subsubsection{Sample extract preparation}

For ATP analysis, the samples were prepared from the liquid nitrogen frozen samples without thawing. Thus, $4 \mathrm{~g}$ of frozen sample was ground and homogenized with $15 \mathrm{~mL}$ of cold $\left(4^{\circ} \mathrm{O} C\right) 0.6 \mathrm{M}$ perchloric acid using a stomacher (IUL Instruments GMBH, Barcelona, Spain) for $4 \mathrm{~min}$ at $4^{\circ} \mathrm{C}$. Homogenate was centrifuged for $20 \mathrm{~min}$ at $10,000 \mathrm{x} \mathrm{g}$ in a refrigerated $\left(4^{\circ} \mathrm{C}\right)$ centrifuge and the supernatant filtered through glass wool. Extracts were neutralized by adding potassium carbonate $2 \mathrm{M}$ and frozen at $-20{ }^{\circ} \mathrm{C}$ until used.

\subsubsection{Adenosine Triphosphate analysis}

ATP was directly analyzed in the deproteinized extract by reverse phase HPLC using an Agilent 1100 system (Agilent Te chnologies, Palo Alto, Ca, USA) equipped with diode array detection at 254 $\mathrm{nm}$. The chromatographic separation was achieved in a Synergi C- 18 column $(4.6 \times 150 \mathrm{~mm}, 4 \mu \mathrm{m}$ MAXRP 80 A) from Phenomenex (Torrance, CA) at room temperature. Mobile phases consisted of solvent A, containing $0.1 \mathrm{M}$ monopotassium phosphate, $\mathrm{pH}$ 6.0 , and solvent $B$, containing phase $A$ : methanol (75:25). The solvents were filtered through a 0.22 $\mu \mathrm{m}$ membrane filter. The separation conditions include a $5 \mathrm{~min}$ of isocratic elution with solvent $\mathrm{A}$ followed by a linear gradient to $15 \%$ of solvent B to $22 \mathrm{~min}$, at a flow rate of $1.0 \mathrm{~mL} / \mathrm{min}$. The column was washed with phase $B$ for $8 \mathrm{~min}$ and equilibrated under the initial conditions for $10 \mathrm{~min}$ before each injection. ATP was identified by comparing the retention time and spectra with its respective standard. Peak area was correlated to compound concentration by interpolation in the corresponded calibration curve.

\subsection{Statistical analysis}

Statistical analysis was carried out with the Statgraphic ® Plus, version 5.1 (Statpoint Technologies, Inc, Warrenton, VA, U.S.A.). Multifactor ANOVA analyses for dielectric parameters were made in order to find significant interaction amongst postmortem time and the pork quality classes. Each particular quality class was studied at different time periods. Fischer's LSD intervals at $95 \%$ confidence intervals were used for this purpose.

\section{Results and Discussion}

The pork loins were classified based on $\mathrm{pH}_{2} \mathrm{~h}, \mathrm{pH}_{24 \mathrm{~h}}$, $\mathrm{L}^{*}$ value and drip loss, as was previously described (Toldrá and Flores, 2000). Based on this criterion, 3 pork loins were classified as PSE (Pale, Soft and 
Exudative), 3 as DFD (Dark Firm and Dry) and 20 as RFN (Red Firm and Non-exudative).

\subsection{Rigor Mortis Development}

The rigor mortis development was evaluated by ATP determination, assuming that rigor onset starts when ATP is depleted (Jaworek, Gruber and Bergmeyer, 1974; Hamm, 1982; Greaser, 1986). Figure 2 shows the evolution of ATP content for the three quality classes studied during ageing. PSE samples were in broad rigor mortis at approximately 4 hours postmortem (hpm), RFN samples at 6-8 hpm, and DFD samples later than 8 hpm.

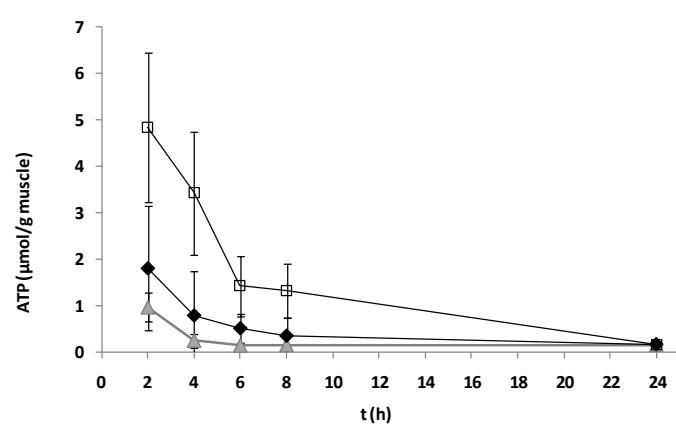

Figure 2. Progression of the ATP content during ageing of L. dorsi muscle from DFD samples ( $\square$ ), RFN samples ( $\bullet$ ), PSE samples ( $\mathbf{\Delta})$.

\subsection{Dielectric spectra analysis}

\subsubsection{Differences between measurements made in the direction of the fibers and perpendicular to them}

The dielectric spectra of meat samples were measured at $6,24,48$ hours and 7 days postmortem in the direction of the fibers and also in perpendicular to them in order to analyze if there exist any difference between both directions. Figure 3 shows the dielectric loss factor spectra measured in both directions during postmortem for the three quality classes studied. In this figure, it is possible to appreciate that there are some differences between both measurement directions. Some punctual frequencies were analyzed (Figure 4 and 5) in order to determine if these differences were significant. In figures 4 and 5 , it is possible to appreciate that only DFD samples showed differences between both ways of measure mainly at $24 \mathrm{hpm}$. At $6 \mathrm{hpm}$ these samples were in prerigor state and thus the intercellular spaces between fiber bunches and the perimysium, and the spaces between the fibers in each bunch had not appeared. This can explain that there were no differences in dielectric properties. At $24 \mathrm{hpm}$, the drip channels have been formed because samples reached the rigor mortis state (Offer and Cousin, 1992). The difference between the dielectric properties measured in parallel and in perpendicular to fiber direction can be explained
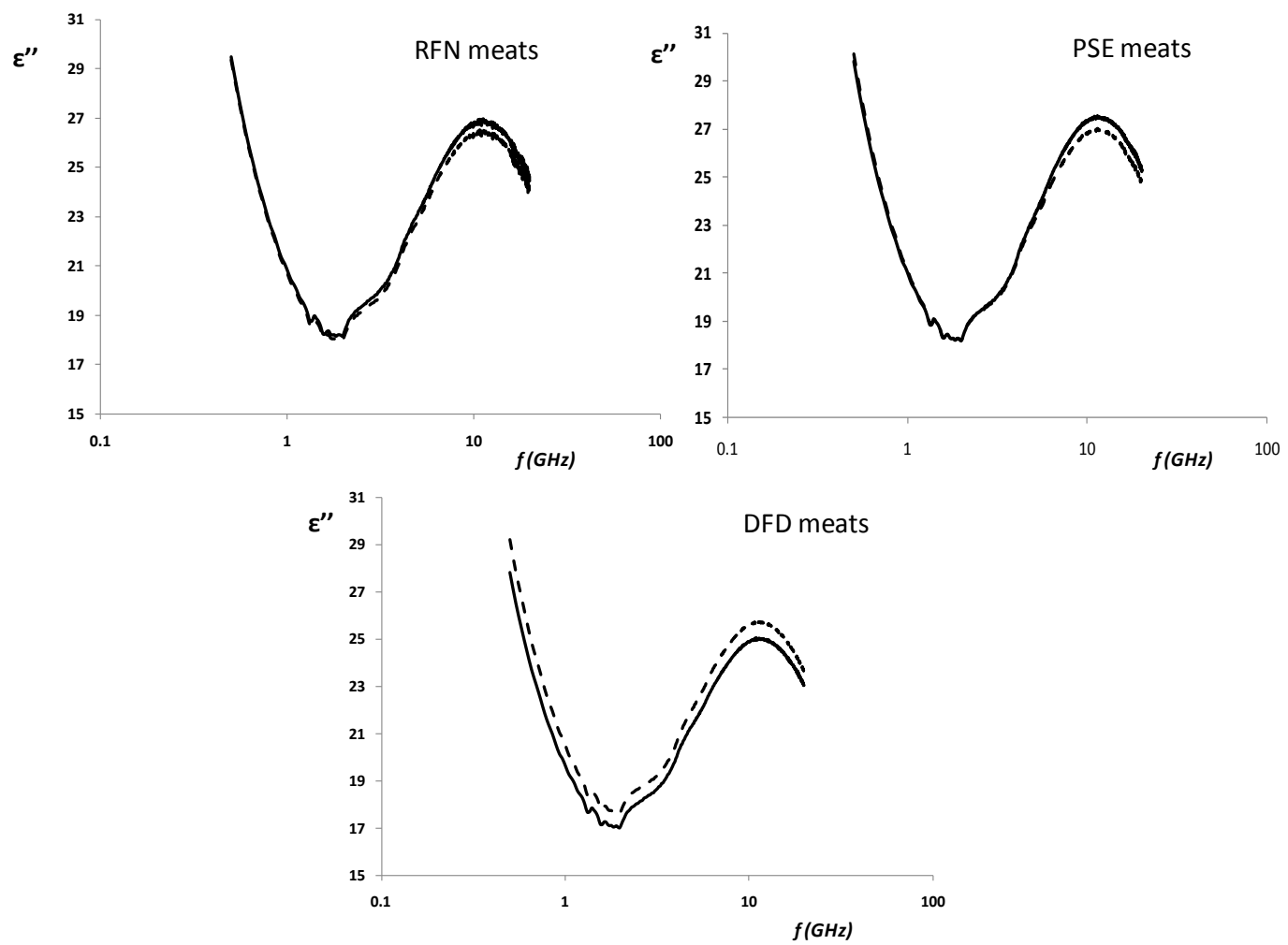

Figure 3.Dielectric loss factor spectra at 24 hours postmortem, where: measurements made perpendicular to the fiber direction $(-)$, and in the direction of the fibers $(---)$. 

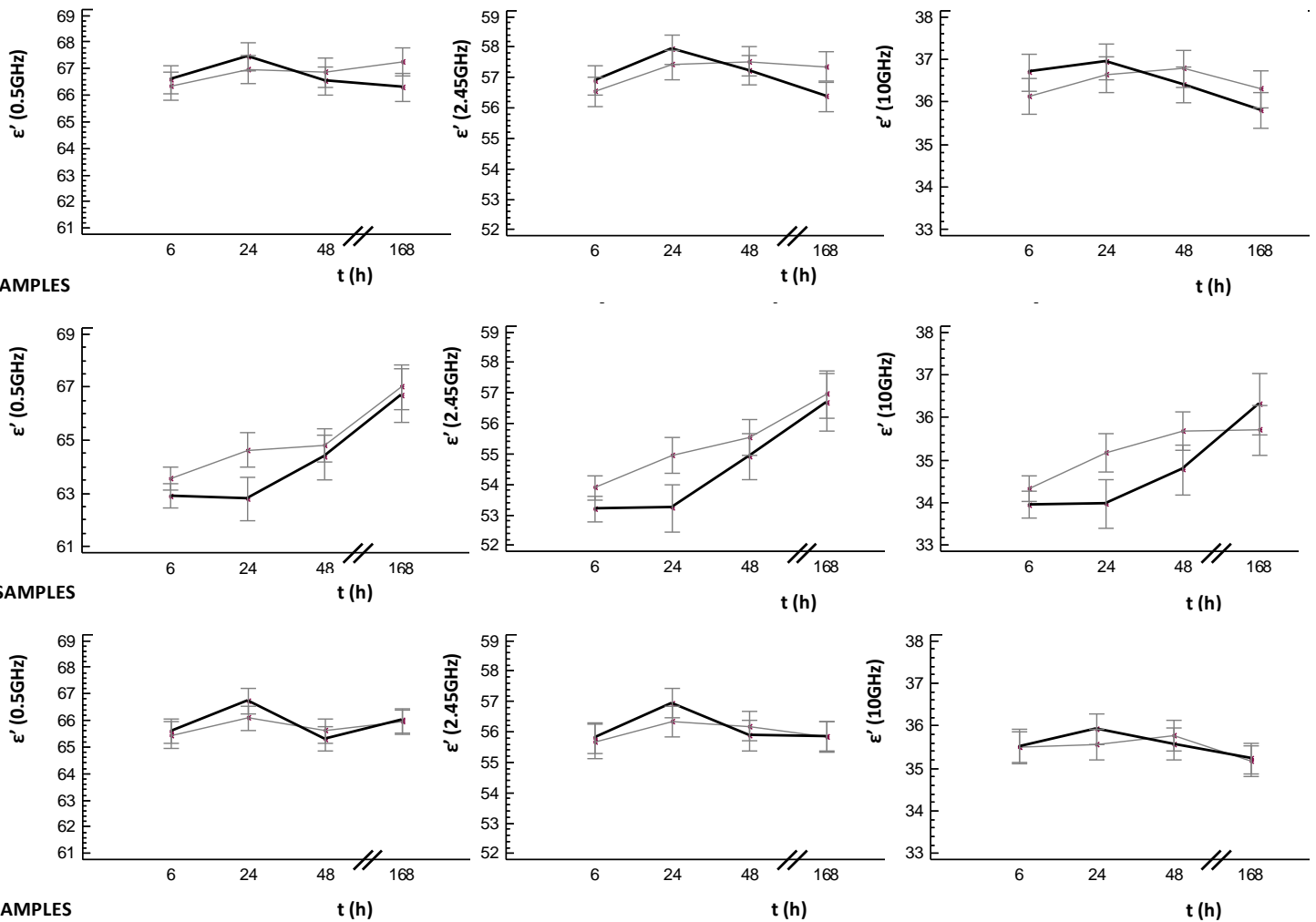

Figure 4 . Dielectric constant means and Least Standard Deviation (LSD) intervals at punctual frequencies $(0.5,2.45$ and $10 \mathrm{GHz})$ of meat samples during ageing, where: a) PSE, b) DFD, c) RFN.

Dielectric measurements were done in the direction of the fibers $(-)$ and perpendicular to them

(一).
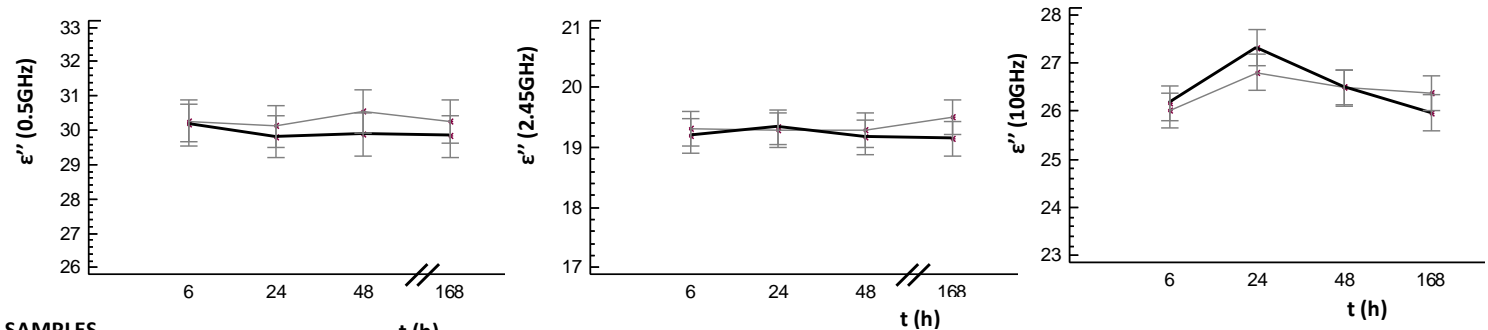

a) PSE SAMPLES

$t$ (h)
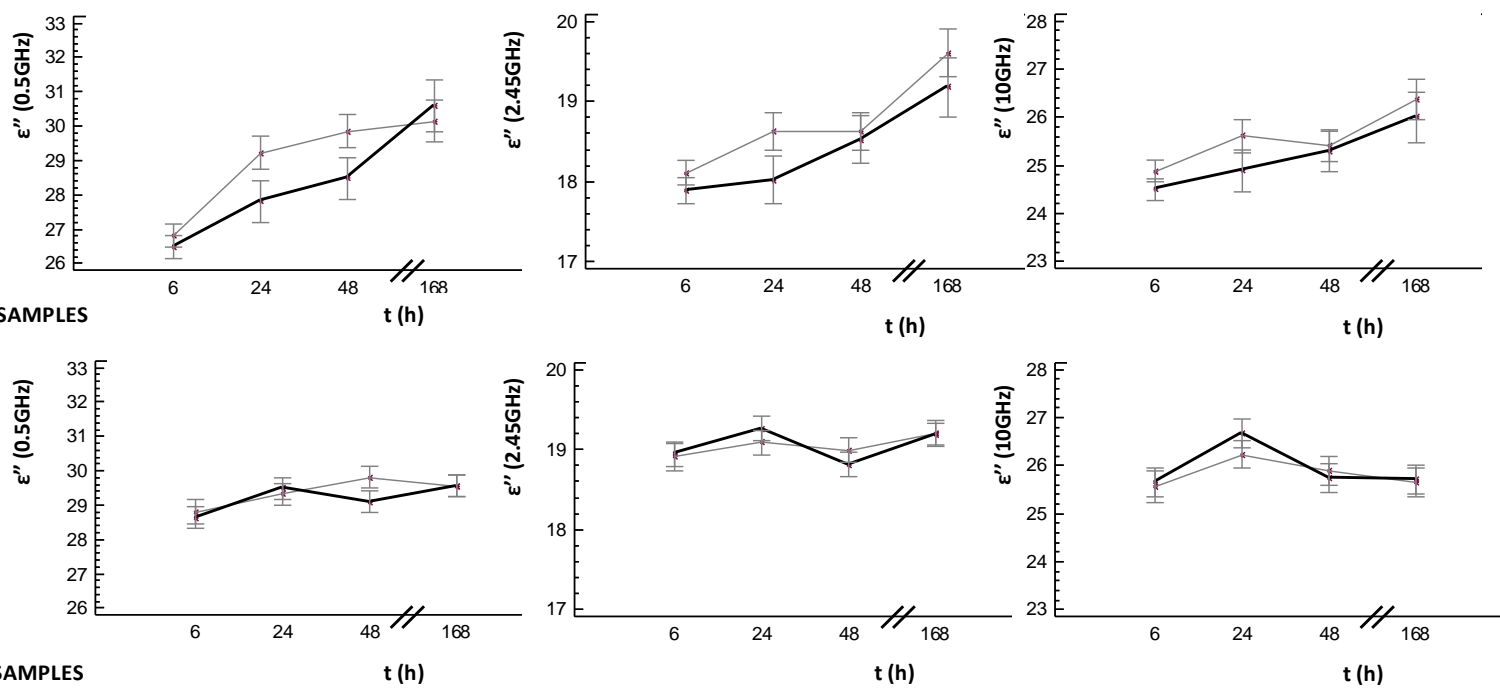

Figure 5. . Dielectric loss factor means and Least Standard Deviation (LSD) intervals at punctual frequencies $(0.5,2.45$ and $10 \mathrm{GHz})$ of meat samples during ageing, where: a) PSE, b) DFD, c) RFN.

Dielectric measurements were done in the direction of the fibers $(-)$ and perpendicular to them 
because meat exudates more in the parallel fiber direction and for this reason the dielectric spectra of DFD samples take higher values in the direction of the fibers than in perpendicular to them. The fact that no differences were observed between both measurement directions in PSE and RFN samples can be related with the protein denaturation with accompanies the $\mathrm{pH}$ decrease and the faster tissue disorganization which is produced in PSE and RFN with regard to DFD samples.

\subsubsection{Differences among pork meat qualities spectra}

The possibility of using the dielectric spectra in the microwave region for discriminating low meat qualities (DFD and PSE) was studied. In figures 6 and 7 the evolution of the dielectric spectra for RFN, PSE and DFD samples is shown for the measurements made in perpendicular to fiber direction. There were differences in the spectra among the qualities and there were analysed some punctual frequencies (Figure 8) in order to determine if the differences among pork quality meats were significant.

In the figure 8 , it is possible to appreciate that only during the 24 hours after slaughter the discrimination of low quality meats is possible. At low frequencies, the loss factor was more useful than dielectric constant to discriminate among quality classes. This phenomenon is due to the fact that the postmortem metabolism involves key metabolites which appear at the early postmortem, such as lactate or nucleotides, which are charged and produce an increase of ionic losses at low frequencies of the spectrum (Fito, personal communication). For this reason, significant differences $(\mathrm{p}<0.05)$ at early postmortem $(6 \mathrm{hpm})$ were found in the loss factor at $0.5 \mathrm{GHz}$. After slaughtering, muscle cells are deprived of nutrients and oxygen, and both ionic force and osmotic pressure increase from animal death to rigor mortis caused by the increase in metabolites and by the free inorganic ions (Bonnet, Ouali and Kopp, 1992). It is important to highlight that when $\mathrm{pH}$ approach to myofibrillar proteins isoelectric point (near pH of 5.4), the proteins charges tend to be cancelled and their capacity to absorb cations (mainly $\mathrm{Mg}^{+2}$ and $\mathrm{Ca}^{+2}$ ) decreases, increasing the free ions in the sarcoplasm (Damez, Clerjon, Abouelkaram and Lepetit, 2008) and therefore the ionic conductivity. ATP depletion in PSE meats occurs at around 4 hours postmortem, when the onset of rigor mortis is produced (see 3.1 section). Moreover, $\mathrm{pH}$ decrease occurs very fast in this kind of meats. For both reasons, free ions are expected to be higher in this kind of meats at early postmortem. On the other hand, the accelerated metabolism of these meats produces also an increase in metabolites. Thus, the increase in osmotic pressure caused by metabolites and free ions during the early postmortem can be the cause
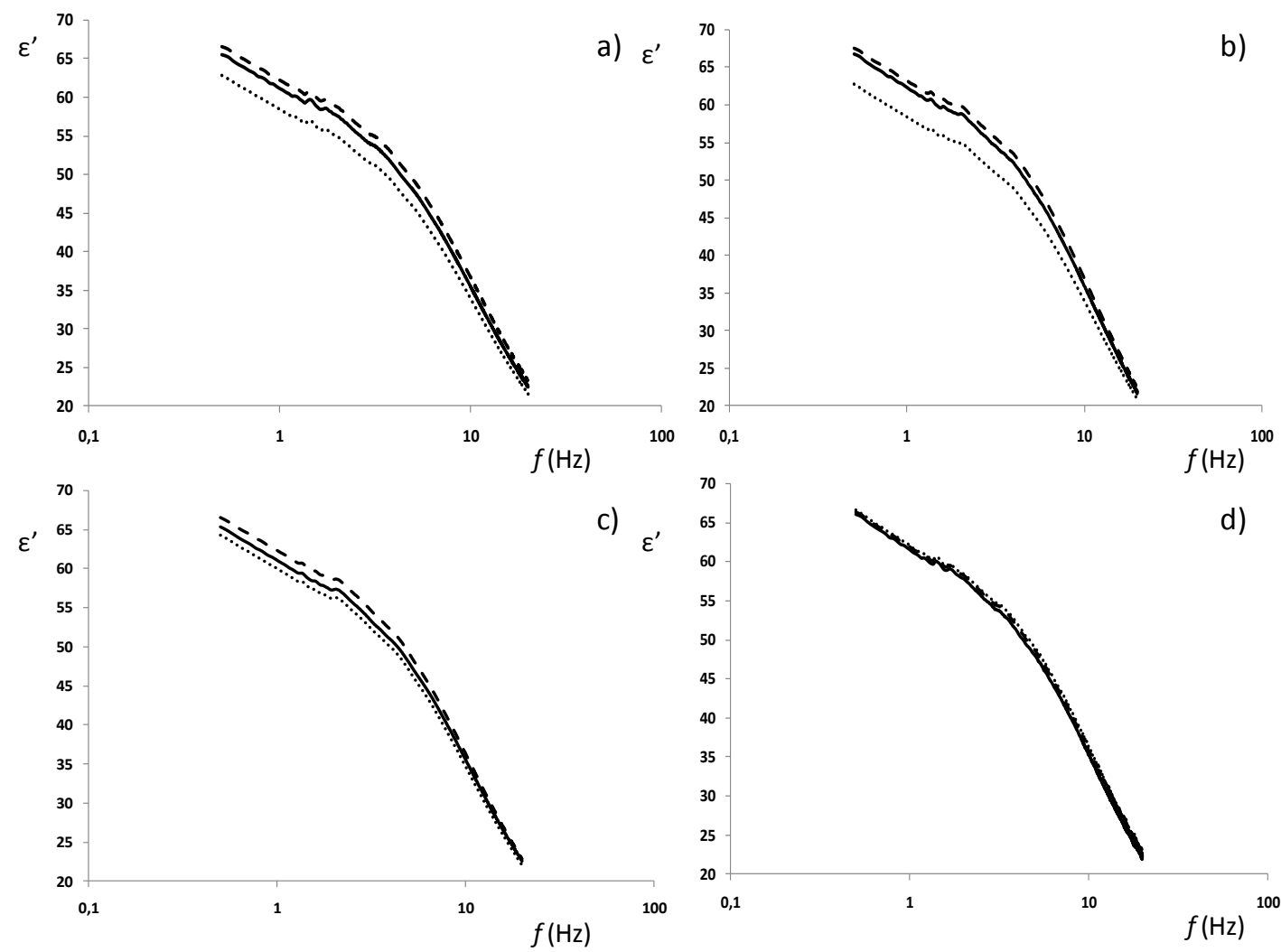

Figure 6. Dielectric constant spectra measured in perpendicular to fiber direction for RFN (一), PSE (- - ) and DFD (...) samples at: a) 6hpm, b) 24hpm, c) $48 \mathrm{hpm}, \mathrm{d}) 168 \mathrm{hpm}$. 

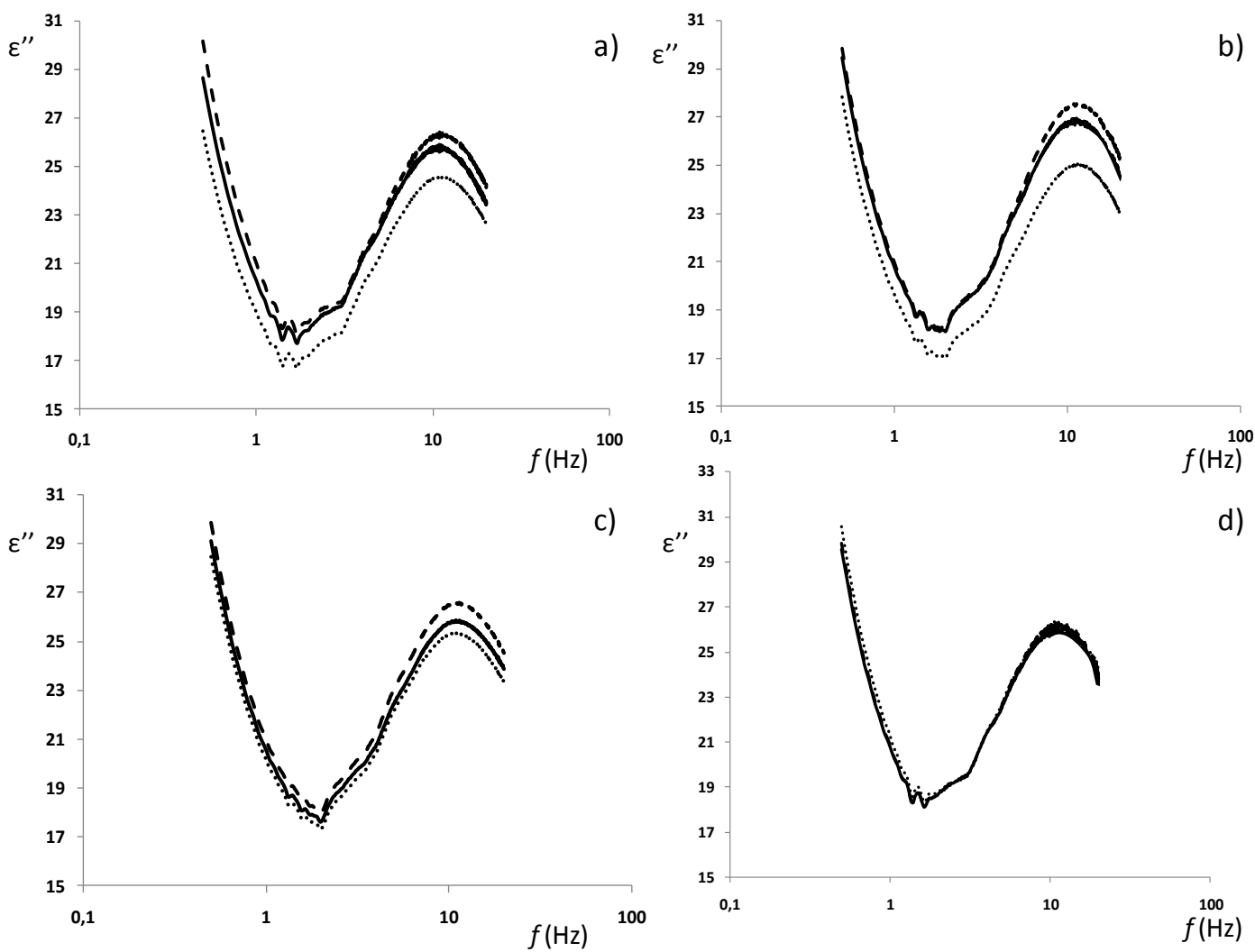

Figure 7. Dielectric loss factor spectra measured in perpendicular to fiber direction for RFN (- ), PSE (- - -) and DFD (...) samples at: a) 6hpm, b) $24 \mathrm{hpm}, \mathrm{c}) 48 \mathrm{hpm}, \mathrm{d}) 168 \mathrm{hpm}$.

of the higher ionic losses at 6hours postmortem in PSE meats. Loss factor at $0.5 \mathrm{GHz}$ was significantly higher than those of RFN and DFD samples. The onset of rigor mortis in RFN samples was around 68hours postmortem when ATP was depleted. Loss factor at $0.5 \mathrm{GHz}$ increased significantly $(\mathrm{p}<0.05)$ from 6 to 24 hours postmortem in this kind of meats, it can be due to the increase in free ions and metabolites until rigor mortis (Herrera-Mendez, Becila, Boudjellal and Ouali, 2006). Moreover, the $\mathrm{pH}$ decrease of the RFN meats is produced gradually and also causes free ions release from proteins. On the other hand, the onset of rigor mortis in DFD samples was produced later than in RFN samples, so at 6 hours postmortem the DFD samples were in pre-rigor state (see 3.1 section). Moreover low lactic acid is generated by these samples; both reasons can explain the significant $(p<0.05)$ lower loss factor of these meats at $0.5 \mathrm{GHz}$ with regard to the RFN and PSE samples.
On the other hand, dielectric constant presents higher differences among classes than loss factor at higher frequencies of the spectrum (Figure 8). The frequency of $10 \mathrm{GHz}$ presents significant $(\mathrm{p}<0.05)$ differences among classes at 6 hours postmortem, being the dielectric constant of PSE higher than that of RFN. In the same way, the dielectric constant of RFN samples is higher than that of DFD samples. At these frequencies of the spectrum the most relevant phenomenon is the dipolar relaxation. In lean muscle, water molecules are the main dipole.

During the conversion of muscle to meat, lactic acid is produced and $\mathrm{pH}$ decreases causing the disappearance of electric charges and the shrinkage of the protein network, resulting in a reduction of the water holding capacity (Offer and Trinick, 1983). This phenomenon is combined by the lateral shrinkage caused mainly by the formation of irreversible cross-bridges between 

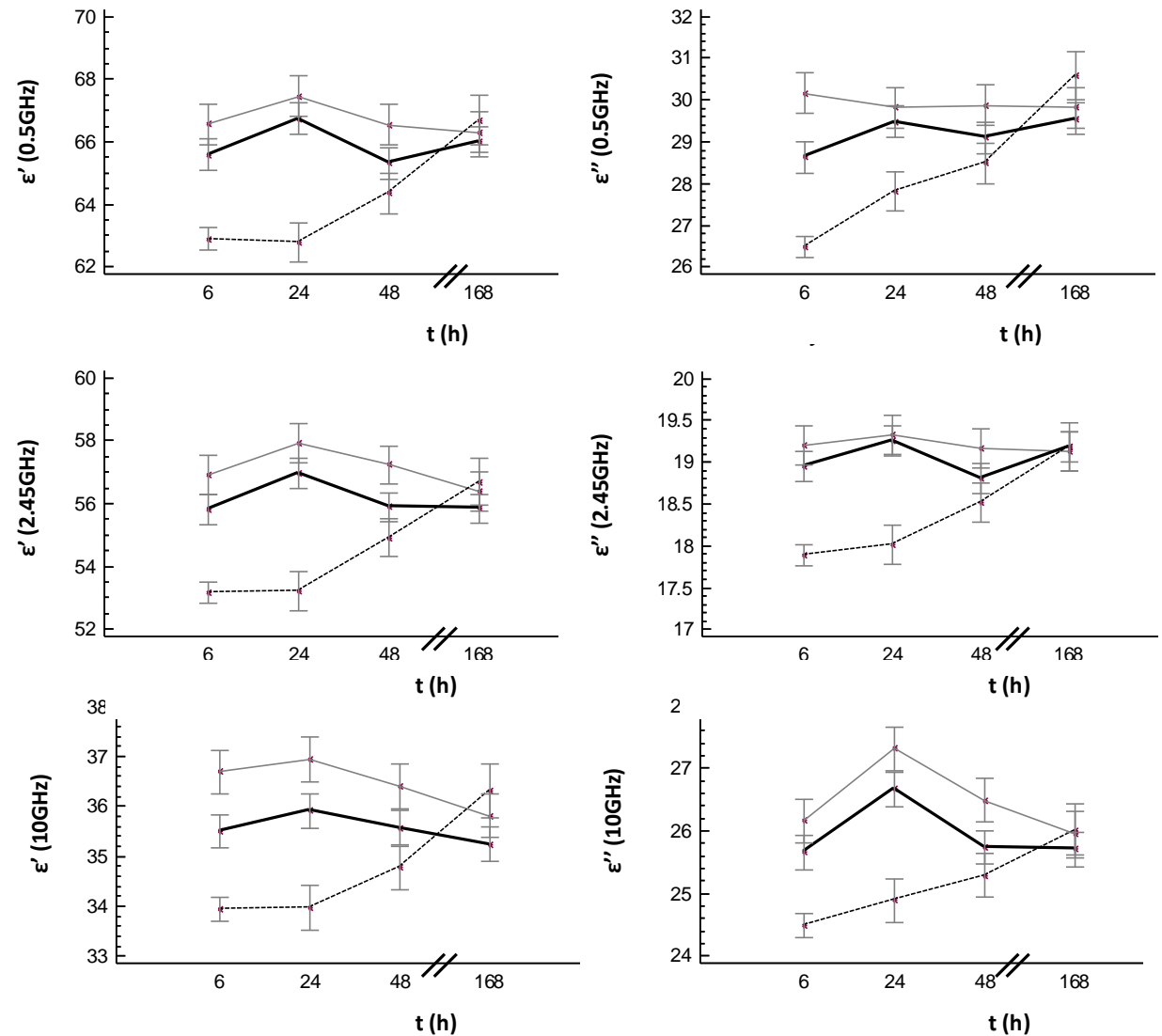

Figure 8. Evolution of dielectric constant and loss factor means and Least Standard Deviation (LSD) intervals (with $95 \%$ confidence) at punctual frequencies $(0.5,2.45,10 \mathrm{GHz}$ ) measured in perpendicular to fiber direction during the postmortem $(6,24,48$ and $168 \mathrm{hpm})$ for the three quality classes studied, where: RFN $(-)$, DFD $(---)$, and PSE $(-)$.

actin and myosin during rigor development (HuffLonergan and Lonergan, 2005). So, as rigor progresses, the space in the myofibrils is reduced and fluid can be forced into the extramyofibrillar spaces where it is more easily lost as drip (Offer and Trinick, 1983; Huff-Lonergan and Lonergan, 2005). The free water is lost as drip when postmortem time increases. This process is affected by postmortem proteolysis which favors the rupture of proteinaceous connection between muscle structures, and allows the myofibrils to shrinkage without transferring this shrinkage to the entire muscle, and creating channels between cells and between bundles of cells (Huff-Lonergan and Lonergan, 2005). The exudation of drip from the meat surfaces is a slow process which takes many days (Offer and Cousins, 1992). These phenomena are developed in different ways in the different quality classes and can explain some of the dielectric properties behaviours.

In PSE muscles, the rapid $\mathrm{pH}$ decline while the temperature is still high produces the denaturation of many proteins; this phenomenon combined with the early instauration of rigor mortis causes that the gaps between fibre bundles and between fibres appear faster than in the other two quality classes. Thus, in PSE meat samples, the water remains poorly retained and it is easily lost as drip. This phenomenon can explain the fact that the dielectric constant at $10 \mathrm{GHz}$ (which is directly related with free water relaxation) in PSE meat samples was higher than in RFN samples and than in DFD samples (Figure 8). The differences in dielectric constant at $10 \mathrm{GHz}$ are only significant during the 24 hours after slaughter; after this time, the high drip loss of PSE samples can be the cause of the decrease in dielectric constant value at $10 \mathrm{GHz}$, taking values similar as the other two quality classes. DFD samples have a slow $\mathrm{pH}$ decline during the 24 hours after slaughter; due to this fact, the proteins do not reach its isoelectric point and the water remains better retained at early postmortem. Moreover, the rigor mortis onset appears later and less water can flow outside the cells due to the higher charges of proteins. These two phenomena can explain the low values that dielectric constant takes during the 24 hours after slaughter. After this time, the dielectric constant increases 

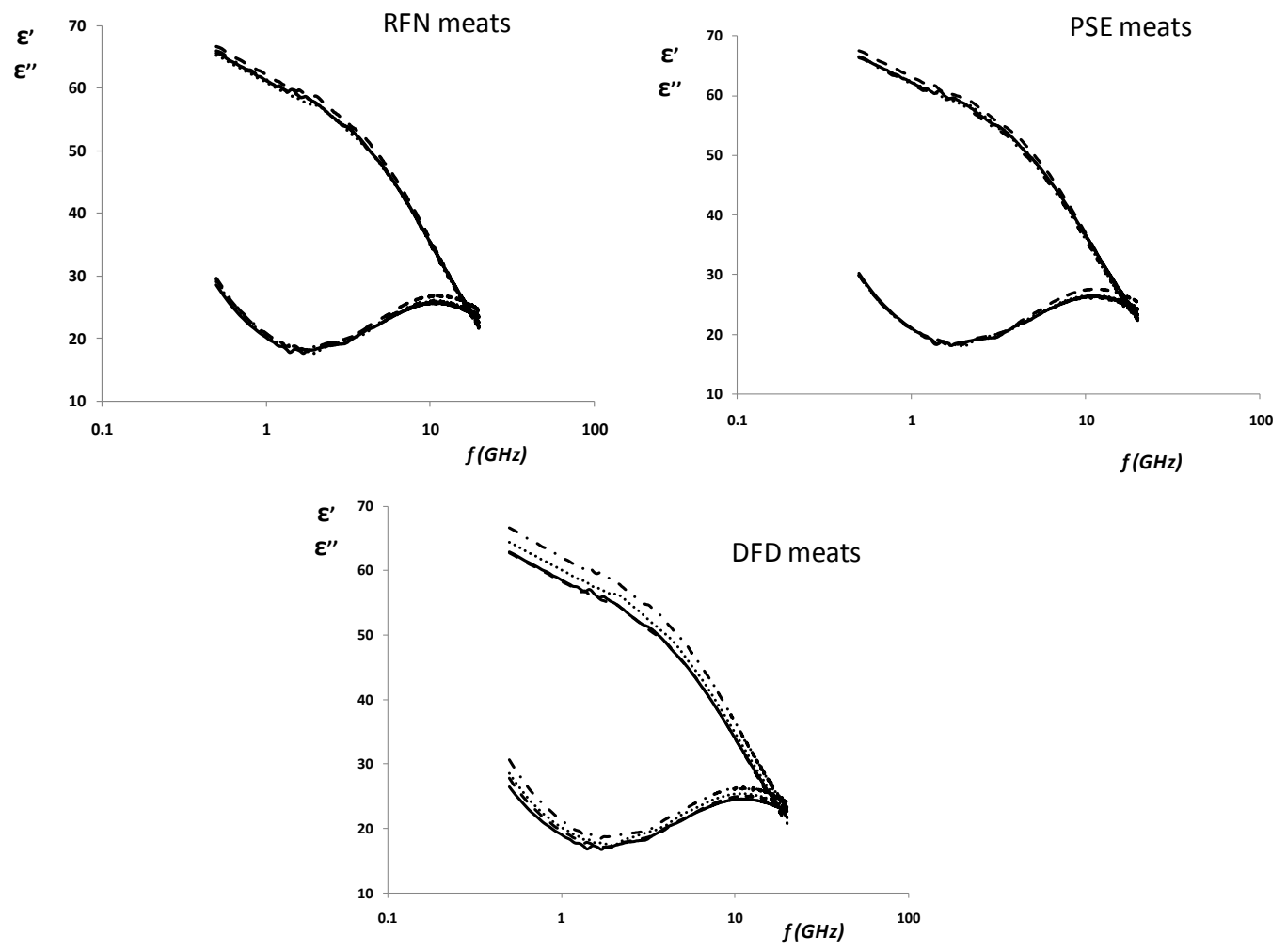

Figure 9. Evolution of dielectric constant and loss factor spectra of RFN, PSE and DFD samples measured

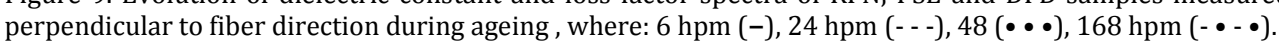

gradually approaching to those values of PSE and RFN, being not useful for distinguishing among classes after this time.

\subsubsection{Evolution of dielectric spectra during ageing}

PSE and RFN spectra showed slight differences during postmortem time (Figure 9). Both quality classes only showed differences during the 24 hours after slaughter at some punctual frequencies (Figure 8). The most important variations in the spectra evolution with postmortem time were found in DFD samples, which spectra increased significantly $(\mathrm{p}<0.05)$ during ageing (Figure 9) These variations can be explained because, as was explained before, in this quality class, the changes attributed to rigor onset and the $\mathrm{pH}$ decrease are produced later than in the other two quality classes. These phenomena affect to ionic conductivity and also to the dipolar relaxation phenomenon, affecting as well to the dielectric properties. In PSE samples and also in RFN samples, the postmortem changes associated to $\mathrm{pH}$ decrease and to the rigor mortis process are produced faster, and consequently, the changes of dielectric properties associated to these phenomena are also produced early. More studies are needed in order to determine exactly the phenomena that affect directly to dielectric spectra in the different quality classes.

\section{Conclusions}

Dielectric spectra of meat samples showed differences among the three quality classes: PSE, DFD and RFN. These differences were significant at frequencies of $0.5 \mathrm{GHz}$ and at $10 \mathrm{GHz}$ during the 6 hours after slaughter. The differences may be attributed to the different development of the postmortem metabolism of pork meat quality classes. The results obtained in this work allow confirming the viability of developing an industrial method for evaluating pork loins quality during few hours postmortem.

Moreover, the evolution of dielectric spectra during meat ageing showed important variations only in DFD meats, while in PSE and RFN meats the variations were observed only at some punctual requencies of the spectrum during the 24 hours after slaughter. 


\section{Acknowledgements}

Grant from Agroalimed (Conselleria de Agricultura, Pesca y Alimentación, Valencia, Spain) and FPU grant to MC from Ministry of Science and Innovation (Madrid, Spain) are fully acknowledged. Work prepared within the Unidad Asociada IAD (UPV)-IATA (CSIC) framework.

\section{References}

Bonnet, M., Ouali, A. \& Kopp, J. (1992). Beef muscle osmotic pressure as assessed by differential scaning calorimetry (DSC). International Journal of Food Science and Technology, 27, 399-408.

Borgaard, C., Christensen, L.B. \& Jespersen, Bo L. (2003) Reflection mode microwave spectroscopy for online measurement of fat in trimmings, in 49th ICoMST, 31 august-5 september, Campinas, Brazil.

Bowker, B.C., Grant, A.L., Forrest, J.C. \& Gerrard, D.E (2000). Muscle metabolism and PSE pork. Journal of Animal Science, 79,1-8.

Castro-Giráldez, M., Botella, P., Toldrá, F. \& Fito, P. (2010c). Low-frequency dielectric spectrum to determine pork meat quality. Innovative Food Science and Emerging Technologies, 11, 376-386.

Castro-Giráldez, M., Fito, P.J. \& Fito, P. (2010d).Application of microwaves dielectric spectroscopy for controlling pork meat (Longissimus dorsi) salting process. Journal of Food Engineering, 97, 484-490.

CIE. (1978). International Commission on Illumination, recommendations on uniform color spaces, color difference equations, psychometric color terms CIE publication No. 15 (Suppl.2), (E-1.31) 1971/(TC-1.3). Bureau Central de la CIE, Paris, France.

Clerjon, S. \& Damez, J.L. (2007). Microwave sensing for meat and fish structure evaluation. Meat Science and Technology, 18(4), 1038-1045.

Clerjon, S., Daudin, J.D. \& Damez, J.L. (2003). Water activity and dielectric properties of gels in the frequency range $200 \mathrm{MHz}-6 \mathrm{GHz}$. Food Chemistry 82(1),87-97.

Damez, J.L., Clerjon, S., Abouelkaram \& S., Lepetit, J. (2008). Beef meat electrical impedance spectroscopy and anisotropy sensing for noninvasive early assessment of meat ageing. Journal of Food Engineering, 85,116-122.

Gabriel, C. (2006). Dielectric properties of biological materials. In F.S. Barnes \& B. Greenbaum (Eds.) Bioengineering and biophysical aspects of electromagnetic fields, Handbook of biological effects of electromagnetic fields (pp. 51-100). Boca Raton, U.S.A.: CRC Press.

Greaser, M.L. (1986). Conversion of muscle to meat. In P.J. Bechter (Ed.), Muscle as food (pp.37-102), Orlando, Flo, U.S.A: Academic Press.
Hamm, R. (1982). Post mortem changes in muscle with regard to processing of hot-boned beef. Food Technology, 36(11), 105-115.

Herrera-Mendez, C.H., Becila, S., Boudjellal, A. \& Ouali, A. (2006). Meat ageing: Reconsideration of the current concept. Trends in Food Science and Technology, 17(8), 394-405.

Honikel, K.O. (1998). Reference methods for the assessment of physical characteristics of meat. Meat Science, 49(4), 447-457.

Huff-Lonergan, E. \& Lonergan, S.M. (2005). Mechanism of water-holding capacity of meat: the role of postmortem biochemical and structural changes. Meat Science. 71,194-204.

Jaworek, D., Gruber, W. \& Bergmeyer, H.U. (1974). Adenosine 5'-triphosphate determination with 3phosphoglycerate kinase. In H.U. Bergmeyer (Ed.), Methods of Enzymatic Analysis. Vol. 4. (pp. 2097-2101). New York: Academic Press.

Kent, M. \& Jason, A.C. (1975). Dielectric properties of foods in relation to interactions between water and the substrate. In R.B. Duckworth (Ed.), Water relations of foods (pp.211-231). New York, U.S.A.: Academic Press.

Kent, M., Lees, A. \& Roger, A. (1993). Estimation of the fat content of minced meat using a portable microwave fat meter. Food Control, 4, 222-227.

Kent, M., Knökel, R., Daschner, F. \& Berger, U.K. (2000). Composition of foods using microwave dielectric spectra. European Food Research and Technology, 210, 359-366.

Kent, M., Knökel, R., Daschner, F. \& Berger, U.K. (2001). Composition of foods including added water using microwave dielectric spectra. Food Control, $12,467-482$

Kent, M., Peymann, A., Gabriel, C. \& Knight, A. (2002). Determination of added water in pork products using microwave dielectric spectroscopy. Food Control, 13(3), 143-149.

Lawrie, R.A. (1998). Lawrie's Meat Science (6 th $^{\text {ed.). }}$ Lancaster, PA: Technomic Publishing Co.

Metaxas, A.C. \& Meredith, R.J. (1993). Industrial Microwave Heating. IEE Power Engineering series 4. London, UK: Peter Peregrinus LTD.

Morgan, J.B., Smith, G.C., Cannon, J., McKeith, F.K., \& Heavner, J.L. (1994). Pork Distribution Channel Audit Report, Pork Chain Quality Audit. National Pork Producers Council, Des Moines, IA.

Nelson, S.O. \& Datta, A.K. (2001). Dielectric properties of Food Materials and Electric Field Interactions. In A.K. Datta \& R.C. Anantheswaran (Eds), Handbook of Microwave Technology for Food Applications (pp. 69-114). New York: Marcel Dekker.

Offer, G. \& Trinick, J. (1983). On the mechanism of water holding in meat: the swelling and shrinking of myofibrils. Meat Science, 8, 245-281.

Offer, G. \& Cousins, T. (1992). The mechanism of drip production: formation of two compartments of extracellular space in muscle post mortem. Journal of the Science of Food and Agriculture, 58 (1), 107-116. 
Scheffler, T.L. \& Gerrard, D.E. (2007). Mechanism controlling pork quality development: the biochemistry controlling postmortem energy metabolism. Meat Science, 77,7-16.

Sosnicki, A.A., Greaser, M.L., Pietrzak, M., Pospiech, E. \& Sante, V. (1998). PSE-like syndrome in breast muscle of domestic turkeys: a review. Journal of Muscle Foods, 9,13-23.

Stetzer, A.J. \& McKeith, F.K. (2003). Benchmarking value in the pork supply chain: Quantitative strategies and opportunities to improve quality. Savoy, $I L$ : American Meat Science Association.

Toldrá, F. \& Flores, M. (2000). The use of muscle enzymes as predictors of pork meat quality. Food Chemistry, 69, 387-395.

Wulf, D.M., Emnet, R.S., Leheska, J.M. \& Moeller, S.J. (2002). Relationships among glycolytic potential, dark cutting (dark, firm and dry) beef, and cooked beef palatability. Journal of Animal Science, 80,1895-1903. 



\title{
Low-frequency dielectric spectrum to determine pork meat quality
}

\author{
Marta Castro-Giráldez ${ }^{a}$, Patricia Botellaa ${ }^{a}$ Fidel Toldráb, Pedro Fito ${ }^{a^{*}}$ \\ anstituto Universitario de Ingeniería de Alimentos para el Desarrollo, Universidad Politécnica de Valencia, Camino de Vera, s/n, 46022, Valencia, Spain
} ${ }^{b}$ Instituto de Agroquímica y Tecnología de los Alimentos(CSIC), PO Box 73, 46100 Burjassot (Valencia), Spain

\section{A RT I C LE INFO}

Article history:

Received 6 November 2009

Accepted 24 January 2010

Keywords:

Dielectric properties

Dielectric spectra

Postmortem

Anisotropy

Ageing

Meat Quality

\begin{abstract}
A B S T R A C T
The use of dielectric spectra to determine meat quality classes (PSE, DFD, RFN) in porcine muscle during postmortem period was evaluated. The changes in dielectric properties during meat ageing were also analyzed for each meat quality class. For these purposes, dielectric spectra were measured from $100 \mathrm{~Hz}$ to $0.4 \mathrm{MHz}$ in parallel and in perpendicular to muscle fiber directions. Significant differences $(\mathrm{p}<0.05)$ in dielectric constant and loss factor among classes were observed at 24 and 48 hours post-mortem. Thus, the use of dielectric properties to detect low meat qualities is more reliable at 24 hours after slaughtering. Moreover, two indexes for evaluating meat ageing were developed from dielectric properties with good results. This research is the first step for developing a sensor based on electromagnetic waves at radio frequencies for controlling pork meat quality. The results are promising and some definite frequencies are demonstrated to be useful for these purposes.

Industrial Relevance: The results of this research article are demonstrated to be useful for discriminating low meat qualities (PSE and DFD meats). Thus, the industrial relevance is clear in this case because the detection of low meat qualities is identified as one of the most important challenges of meat industry nowadays. On the other hand, basing on the results of the present paper it is possible to develop a prototype for industrial applications. Moreover, two possible Indexes are developed in the present paper for determining meat freshness which also can be considered important from an industrial point of view. All this determinations were made by using dielectric spectroscopy which can be considered an emerging technology. For all these reasons we are sending to this journal "Innovative Food Science and Emerging Technologies" our results.
\end{abstract}

(C) 2010 Elsevier Ltd. All rights reserved.

\section{Introduction}

The incidence of pork meat quality problems such as PSE (Pale, Soft and Exudative) or DFD (Dark, Firm and Dry), are still one of the main meat industry challenges (Stetzer \& McKeith, 2003). PSE meats have pale color, soft texture and high exudation; these characteristics make this kind of meats unsuitable for processing (Damez, Clerjon, Abouelkaram, \& Lepetit, 2008b). On the other hand, DFD meats have high ultimate $\mathrm{pH}$, and thus, are very susceptible to spoiling (Lawrie, 1998; Damez et al., 2008b). The early detection of low quality meats is an important issue for meat industry in order to reduce economic losses and to proportionate the best destination to meat carcasses. Many efforts are being made in the search for accurate and non-destructive methods of

*Corresponding author. Tel.: +34 963877369

E-mail address: pfito@tal.upv.es (P.Fito). meat quality assessment (Damez \& Clerjon, 2008; Tan, 2004; Bertram, Andersen \& Karlsson, 2001; Byrne, Downey, Troy \& Buckley, 1998; Monin, 1998). In this context, sensors based on electromagnetic radiation appear as an interesting option which fulfils these requirements and can provide important information about biological tissues such as meats.

The complex permittivity $\left(\varepsilon_{r}\right)$ is the dielectric property which describes the behavior of the food when it is subjected to an electromagnetic field (Metaxas \& Meredith, 1993; Nelson \& Datta, 2001). Complex permittivity is defined by the next equation:

$$
\varepsilon_{\mathrm{r}}=\varepsilon^{\prime}-\mathrm{j} \cdot \varepsilon^{\prime \prime}
$$

In this equation, $j=\sqrt{-1}$. The real part of complex permittivity is called dielectric constant $\left(\varepsilon^{\prime}\right)$ and the imaginary part is called loss factor $\left(\varepsilon^{\prime \prime}\right)$. The 
dielectric constant is related with the capacitance of the material and its ability to store energy (polarization). Foods are non-ideal dielectrics and polarization has associated dissipation phenomena producing energy absorptions and the decay of dielectric constant. The parameter which reflects the absorption and dissipation of electromagnetic energy is the loss factor (Castro-Giráldez, Fito, Toldrá \& Fito, 2010a).

Biological tissues can be considered nonmagnetic materials which electrical properties are a consequence of their composition and their structure. The most important components which influence the dielectric properties of tissues are mainly ions, and the most important source of dipolar moments are the water tissue molecules and also the proteins and lipids which form the membranes and cell interfaces (Rigaud, Morucci \& Chauveau, 1996). The movement of the charges induces a conduction effect, and the polarization of the dipoles results in dielectric relaxation phenomena (Rigaud et al., 1996). The conductivity of most tissues rises from low values at low frequencies that depend strongly on the volume fraction of extracellular fluid up to a plateau in the 10-100 $\mathrm{MHz}$ frequency range which mainly corresponds to conductivity of intra and extracellular ions (Castro-Giráldez et al., 2010a). Then, conductivity rises dramatically due to the dielectric relaxation of water (Rigaud et al., 1996) (Figure 1). This increase in conductivity is associated with a decrease in permittivity from very high values at low frequencies in different steps called dispersions. It is important to highlight that these dispersions are not produced instantaneously and are characterized by the correspondent relaxation phenomena (Schwan, 1988). In biological systems, there are three main dispersions $(\alpha, \beta, \gamma)($ Schwan, 1957) (Figure 1).
The dispersions are related to three relaxation phenomena and determine three frequency ranges (Pethig and Kell, 1987). The $\gamma$-dispersion is located at high frequencies $(>100 \mathrm{MHz})$ and is mainly due to the permanent dipole relaxation of small molecules, mainly free water which is the main constituent of muscle tissues. The $\beta$-dispersion, from few $\mathrm{KHz}$ to $\mathrm{MHz}$, is mainly caused by the Maxwell-Wagner effect. This phenomenon is typical of inhomogeneous materials and is due to interface polarization of biological membrane systems. It can be postulated that it is a measure of cell membrane integrity during meat ageing due to the decrease of its insulating properties (Ghatass, Soliman, \& Mohamed, 2008). The $\alpha$-dispersion, from few $\mathrm{Hz}$ to few $\mathrm{KHz}$, is associated with the polarization phenomena in the electrical double layer of the tissues (Foster and Schwan, 1989). Moreover, another mechanism associated with membrane permeability (ion passage in tissue) was investigated (Kuang, 1996).

Muscle ageing involves lot of complex biochemical and physicochemical processes which influence its structure. These processes include the action of proteases, an increase in membrane permeability and the weakening of connective tissue (Damez et al, 2008b). These physical changes during postmortem time are expected to change the dielectric properties of the samples, so studying the electrical behavior of biological tissues can provide unique information about the meat state (Schwan, 1957; Pething and Kell, 1987; Kuang and Nelson, 1997). On the other hand, low quality meats are characterized by different postmortem metabolisms from RFN (Red Firm and Nonexudative) meats (Bowker, Grant, Forrest \& Gerrard, 2000; Lawrie, 1998). PSE muscle is related to fast $\mathrm{pH}$ decrease, cellular breakdown, and an increase in extracellular fluid, thus, conductivity of

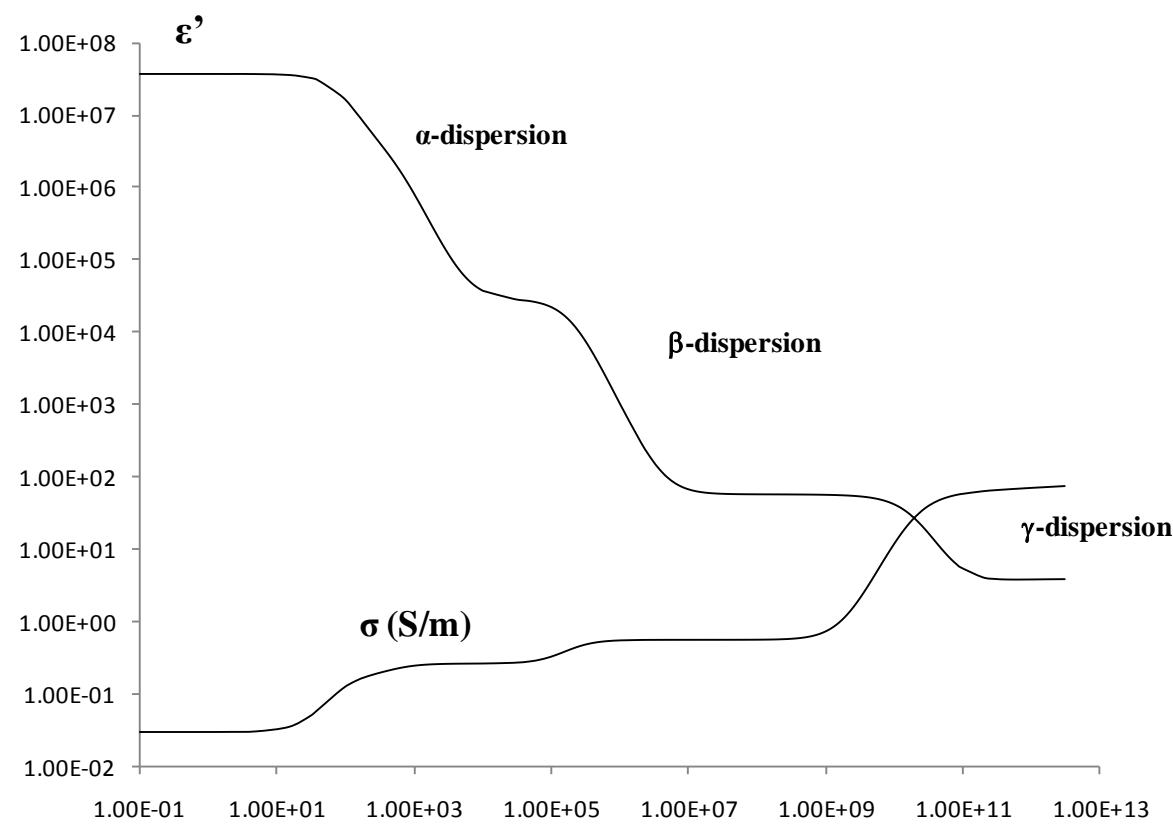

$f(\mathrm{~Hz})$

Figure 1. Ideal representation of electric conductivity $(\mathrm{S} / \mathrm{m})$ and dielectric constant spectra in biological tissue. 
this kind of meats is expected to be higher than normal muscle (Guerrero et al., 2004; Oliver, Gispert, Tibau \& Diestre, 1991). On the other hand, DFD meats are characterized by an abnormal $\mathrm{pH}$ evolution which directly affects the muscle structure (Wulf, Emnett, Leheska, Moeller, 2002) and therefore, the dielectric properties. So, studying the dielectric properties of fresh meat is expected to be a useful tool to discriminate low meat qualities.

Some applications of dielectric spectroscopy at low frequencies have been reported in meat and meat products. Damez et al. (2008b) reported a method to early assessment of beef meat ageing by studying the electrical anisotropy behavior of the product. Other authors (Gómez-Sánchez, Aristizábal-Botero, Barragán-Arango \& Felice, 2009) propose an index (inherent electrical anisotropy: IEA) to quantify the degradation of the muscle due to the aging process. Some studies were made in order to discriminate DFD meats by using electrical measurements but the results were non promising (Guerrero et al., 2004; Forrest, Morgan, Borggaard, Rasmussen, Jespersen, \& Andersen, 2000; Garrido, Pedauye, Banon, \& Laencina, 1994a Jaud, Weisse, Gehlen, \& Fischer, 1992). PSE detection was very difficult during early postmortem because of the rapid metabolic modifications which affect structure and therefore the electrical properties (Kleibel, Pfüzner \& Krause, 1983; Bendall \& Swatland, 1988). These measurements were also used in order to evaluate fat content (Swantek, Crenshaw, Marchello, \& Lukaski, 1992; Marchello, Slanger, \& Carlson, 1999; Slanger \& Marchello, 1994; Bejerholm \& BartonGade, 1986; Madsen, Borggaard, Rasmussen \& Christensen, 1999; Altmann \& Pliquett, 2006) and to evaluate the level of aging (Faure, Flachat, Jenin, Lenoir, Roullet \& Thomasset, 1972 ; Lepetit, Salé, Favier \& Dalle, 2002; Lepetit and Hamel, 1998; Damez, Clerjon, Abouelkaram \& Lepetit, 2006; Lepetit, Damez, Clerjon, Favier, Abouelkaram \& Dominguez, 2006) or to evaluate meat tenderness (Byrne, Troy \& Buckley, 2000).

The aim of the present work was to analyze the low frequency spectra of the different meat quality classes, trying to further understand each dispersion phenomenon. Moreover, the viability of using electric properties of meat to discriminate low meat qualities (PSE and DFD) was analyzed due to the fact that these properties are influenced by interfacial phenomenon and consequently by meat structure integrity. The electric properties evolution of each kind of meat during aging was also analyzed in order to study the possibility of determining a meat ageing index by using the electric properties of meat at two definite frequencies of the spectra.

\section{Materials and Methods}

2.1. Meat analysis

\subsubsection{Raw material}

26 pigs (Ladrance $\mathrm{x}$ Duroc, 16 males and 10 females) were slaughtered in a commercial slaughterhouse located near the Institute. Carcasses were rapidly chilled at $-10^{\circ} \mathrm{C}$ for $45 \mathrm{~min}$ and the L.Dorsi muscle removed. The muscle was kept at $4^{\circ} \mathrm{C}$ until sampled.

\subsubsection{Sample preparation}

Six slices (diameter $46 \mathrm{~mm}$, thickness ranging from 2 to $4 \mathrm{~mm}$ ) were used for the dielectric spectra measurements with the parallel plates Agilent $16451 B$ connected to an Impedance Analyser Agilent 4194A. Three slices were cut in the direction of the fibers and the other three were cut in perpendicular to them. The slices were cut half an hour before each measurement time. The dielectric properties measurements were made at 4 ${ }^{\circ} \mathrm{C} \pm 1{ }^{\circ} \mathrm{C}$ at $12,24,48$ hours and 7 days post mortem.

\subsubsection{Analysis for the classification of pork quality classes}

The pork loins were classified based on $\mathrm{pH}_{2 \mathrm{~h}}, \mathrm{pH}_{24 \mathrm{~h}}$, $\mathrm{L}^{*}$ value and drip loss, according to the classification of Toldrá and Flores (2000).

Samples $\mathrm{pH}$ was measured through a portable $\mathrm{pH}$ meter CRISON PH25® at 2 and 24 hours after slaughtering. Drip loss was determined by the method of Honikel (1998).

The color of the samples was measured through the surface reflectance spectra in a spectrocolorimeter Minolta CM-3600D (Minolta Co. Ltd., Japan) at 24 hours postmortem. Three measurements were made for each sample at each time. The instrument measures reflectance spectrum between 400 and $700 \mathrm{~nm}$ at $10 \mathrm{~nm}$ intervals. The colour coordinates CIE L*a*b* (CIE, 1978) were instrumentally calculated based on D65 illuminant and $10^{\circ}$ observer. A white tile and a black chamber supplied by the manufacturer were used for calibration.

\subsubsection{Dielectric Properties Measurement by the Parallel Plate Fixture}

The system used to measure dielectric spectra at low frequencies consists of an Agilent $16451 B$ parallel plate fixture connected to an Agilent 4194A impedance analyzer (Figure 2).

The electrode A of the fixture, which has a $38 \mathrm{~mm}$ guarded/guard electrode, was used. The diameter of the samples used was $46 \mathrm{~mm}$ and the thickness was determined individually for each meat sample with an accuracy of $\pm 0.01 \mathrm{~mm}$. The thickness of the samples was in the range $2-4 \mathrm{~mm}$ due to the limitations in the slicing system. Preliminary experiments demonstrated that, in this thickness range, the dielectric properties of each loin do not present significant differences.

The Contacting Electrode Method (Rigid Metal Electrode) was used. This method consists in setting the sample between the electrodes, ensuring good contact between the electrodes and the sample.

The dielectric properties were measured by performing an OPEN/SHORT correction.

Dielectric spectra of meat samples were measured in perpendicular to fiber direction and also in the 
direction of the fibers. The Mean values of three replicates of the pork loin samples are reported in this article. The frequency range of the measurements was from $40 \mathrm{~Hz}$ to $4 \mathrm{MHz}$.

The software of the impedance analyzer calculates the capacitance $\left(\mathrm{C}_{\mathrm{P}}\right)$ and dissipation factor $(\mathrm{D})$ and then the dielectric constant $\left(\varepsilon^{\prime}\right)$ and Dissipation factor $\left(D_{t}\right)$ of test material were calculated by using the following equations:

$$
\begin{gathered}
\varepsilon^{\prime}=\frac{t_{a} \times C_{p}}{\pi \times\left(\frac{d}{2}\right)^{2} \times \varepsilon_{0}} \\
D_{t}=D=\tan \delta
\end{gathered}
$$

where,

$\varepsilon^{\prime}$ : Dielectric constant

D: Dissipation factor

$\mathrm{D}_{\mathrm{t}}$ : Dissipation factor of the test material $\tan \delta$ : loss tangent

$\mathrm{C}_{\mathrm{p}}$ : Equivalent parallel capacitance $(\mathrm{F})$

$\mathrm{t}_{\mathrm{a}}$ : Sample thickness $(\mathrm{m})$

$\mathrm{d}$ : Diameter of Guarded electrode (m) $\left[38 \times 10^{-3} \mathrm{~m}\right]$ $\varepsilon_{0}=8.854 \times 10^{-12}(\mathrm{~F} / \mathrm{m})$

\subsubsection{Statistical analysis}

Statistical analysis was carried out with the Statgraphic ® Plus, version 5.1 (Statpoint
Technologies, Inc, U.S.A.). Multifactor ANOVA analyses for dielectric parameters were made in order to find significant interaction amongst postmortem time and the pork quality classes. Each particular quality class was studied at different time periods.

\section{Results and Discussion}

Table 1 shows the classification of the pork loins used in the present study; 3 pork loins were classified as PSE, 3 as DFD and 20 as RFN.

\subsection{Evolution of pork meat dielectric spectra during ageing}

The dielectric constant spectra of RFN, PSE and DFD meats measured in perpendicular to fiber direction during postmortem time are shown in figure 3. Meat is a very heterogeneous material and the interfacial processes are very important. All interfaces give rise to Maxwell-Wagner $(\beta$ dispersion) and electrical double layer $(\alpha-$ dispersion) polarization effects (Grimnes \& GrØttem-Martinsen, 2008).

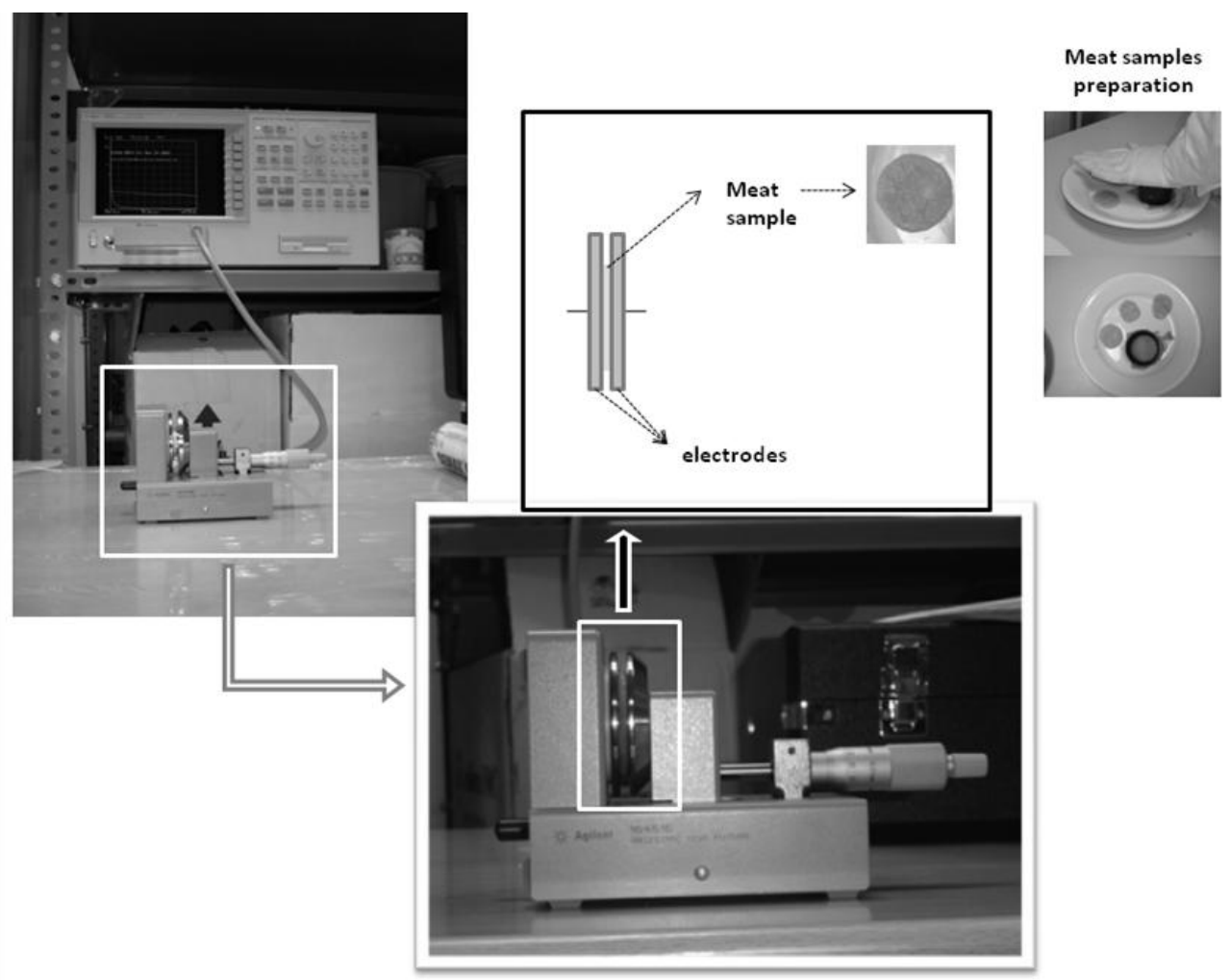

Figure 2. Equipment for measuring meat dielectric properties which consists on an Agilent $16451 B$ parallel plate fixture connected to an Agilent 4194A impedance analyzer. Meat samples preparation and a diagram of the contacting electrode method can also be appreciated. 
Table 1. Meat quality measurements by quality classes for assayed pork loins

\begin{tabular}{|c|c|c|c|}
\hline $\begin{array}{l}\text { Technologic } \\
\text { parameters }\end{array}$ & PSE $(n=3)$ & DFD $(n=3)$ & RFN $(n=20)$ \\
\hline Drip Loss (\%) & $6.0 \pm 0.3$ & $1.5 \pm 0.3$ & $3.5 \pm 0.4$ \\
\hline $\mathrm{L}^{*}$ & $56.7^{a} \pm 0.8$ & $49.4^{b} \pm 0.2$ & $51.8^{\mathrm{b}} \pm 1.8$ \\
\hline $\mathrm{pH} 2 \mathrm{~h} \mathrm{pm}$ & $5.58^{a} \pm 0.13$ & $6.22^{b} \pm 0.09$ & $5.99^{c} \pm 0.05$ \\
\hline $\mathrm{pH} 24 \mathrm{~h} \mathrm{pm}$ & $5.37^{a} \pm 0.10$ & $5.90^{\mathrm{b}} \pm 0.06$ & $5.63^{c} \pm 0.04$ \\
\hline
\end{tabular}

In biological systems, the most important dielectric interface is the cell membrane, which can be assimilated to the two armatures of a capacitor and, when an electric field is applied, the ions can accumulate to both sides of the membrane; when the frequency increases, a polarization relaxation phenomenon (Maxwell-Wagner effect or $\beta$ dispersion) occurs because they do not have enough time to accumulate. This dispersion occurs from few $\mathrm{kHz}$ to $\mathrm{MHz}$. The $\alpha$-dispersion is around few $\mathrm{Hz}$ to few $\mathrm{KHz}$, and it could be related with membrane pores (ion-channels) and membrane permeability (Kuang \& Nelson, 1997). The same authors demonstrated that this dispersion is affected by membrane structure characteristics such as thickness and size and number of pores. So, at frequencies of the $\alpha$-dispersion, the dielectric phenomena can be interpreted as a measure of cell membrane integrity. During postmortem time, some physicochemical processes occur which include the action of endogenous proteases on the muscle fibers, a progressive increase of membrane permeability, the lost of their insulating power and the weakening of connective tissues. As it can be observed in figure 3 , the dielectric constant at $\alpha$ dispersion tends to increase while the dielectric constant at $\beta$-dispersion tends to decrease with postmortem time progression. These spectra were measured perpendicular to fiber direction and it is important to remark that the spectra measured in the direction of the fiber showed the same tendency (Figure 4). The $\alpha$-dispersion increase is associated with the decrease of membrane properties and integrity with postmortem progression. Moreover, the $\beta$-dispersion decreases with postmortem time, which indicates a decrease in membrane capacitance with ageing as was previously reported by Swatland (1980) and also indicates a decrease in the insulating properties of cell membranes (Pliquett, Altmann, Pliquett \& Schöberlein, 2003).

As it is well known, at these frequencies the measurements are affected by two sources of systematic errors: electrode polarization and lead inductance errors (Gabriel, Lau \& Gabriel, 1996b). Both effects increase with increasing sample conductivity and its consequences are more pronounced on the capacitance than on the conductance in biological samples (Schwan, 1992). The high permittivity values at low frequencies are a manifestation of electrode polarization whereas negative permittivity values at high frequency show the effect of the stray inductance (Gabriel et al., 1996b). Many authors reported different ways to correct both sources of errors (Gabriel et al., 1996b; Kuang and Nelson, 1997).

In the present study, the parallel plate does not

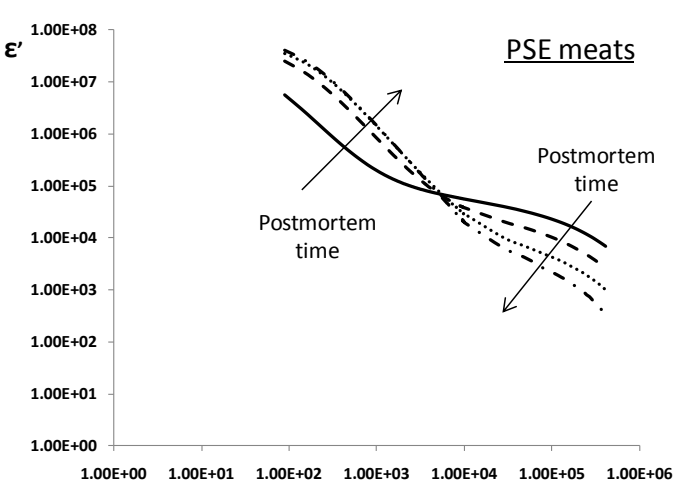

$f(H z)$

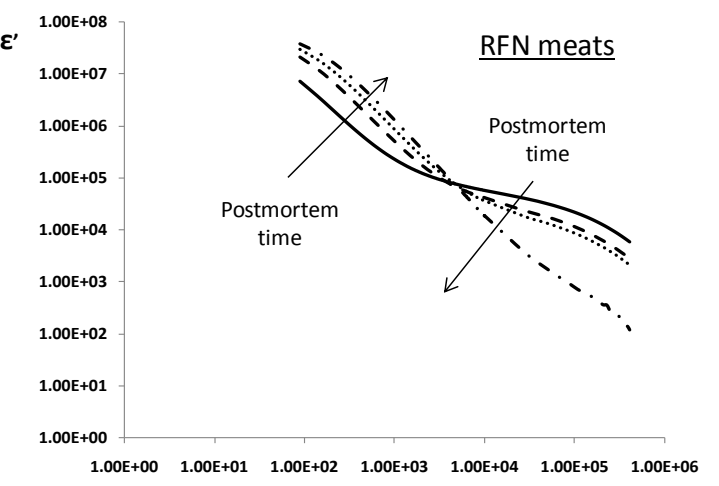

$f(H z)$

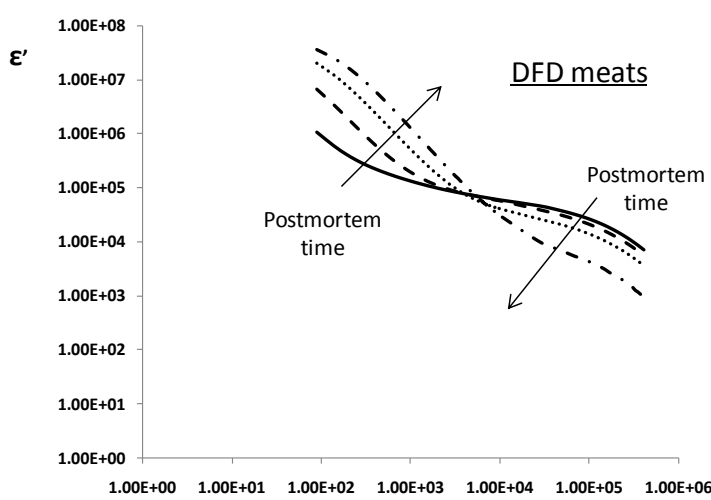

$f(H z)$

Figure 3. Dielectric constant spectra of RFN, PSE and DFD meats during postmortem time measured perpendicular to fiber direction, where: 12 hours post-mortem (-), 24 hours post-mortem (- - ), 48 hours post-mortem (...), 7 days post-mortem (- . -. ). 
allow an easy way to correct the extreme values of our measurement frequency range $(40 \mathrm{~Hz}$ to 4 $\mathrm{MHz}$ ). In this first approach of the determination of the quality classes of pork meat by using dielectric properties at low frequencies of the spectrum, it can be expected that both sources of errors are small because of the large surface of contact between the samples and the electrodes. Anyway, the extreme values of our frequency range of measurement were refused, considering only in the present study the values from $100 \mathrm{~Hz}$ to $0.4 \mathrm{MHz}$ in order to avoid the problems caused by the electrode polarization and the lead inductance errors.

In the present study the loss factor was also analyzed in terms of electric conductivity in order to study the possibility of using these measurements to discriminate the different quality classes and to analyze meat ageing. The figure 5 shows the evolution of conductivity during postmortem time for each quality class.

The cell membranes are considered to have a high capacitance and a low complicated pattern of conductivity (Grimnes \& Grottem-Martinsen, 2008). At low frequencies the current passes around the cells, and cell interior have a low contribution to the conductivity. At higher frequencies, the membrane effect disappears and cell interior contributes to the tissue conductivity. The figure shows that when increasing postmortem time, the conductivity increases; this behavior can be explained by the fact that degradations in sarcoplasmic reticulum membranes during meat ageing cause a decrease in the insulating power of membranes increasing conductivity as was explained by Damez et al (2008b). This behavior can be also influenced by the rigor mortis process which generates gaps between fibers (Offer and Cousins, 1992) increasing the extracellular space and increasing the conductivity of tissue.

The possibility of developing an Index which defines de ageing of meat by using some frequencies of the dielectric spectrum was analyzed. Two Ageing Indexes $(A I)$ are proposed in the present research article. Both indexes are dimensionless. The first Ageing Index $\left(A \varepsilon^{\prime}\right)$ utilizes the measurement of dielectric constant at two frequencies in perpendicular of fiber direction (equation 4); one of them is a lower frequency $(140 \mathrm{~Hz})$ which belongs to the $\alpha$-dispersion; the other frequency is a higher frequency $(300 \mathrm{kHz})$ in the $\beta$-dispersion.

$$
A I_{X}^{\varepsilon^{\prime}}=\left[\frac{\left(\varepsilon_{140 \mathrm{~Hz}}-\varepsilon^{\prime}{ }_{300 \mathrm{kHz}}\right)_{12 \mathrm{hpm}}}{\left(\varepsilon_{140 \mathrm{~Hz}}-\varepsilon^{\prime}{ }_{300 \mathrm{kHz}}\right)_{x h p m}}\right] \times 100
$$

Where: hpm is referred to hours postmortem.

This $A I^{\prime}$ was defined with regard to the $12 \mathrm{hpm}$ samples in order to analyze the evolution of the samples ageing. In the equation, the suffix $x$ represents each measurement time $(24,48$ and 168 $\mathrm{hpm})$. The equation was defined in this way because, as it can be observed in figure 3 , the difference between the dielectric constant at 140 $\mathrm{Hz}$ and at $300 \mathrm{kHz}$ is increasing with postmortem
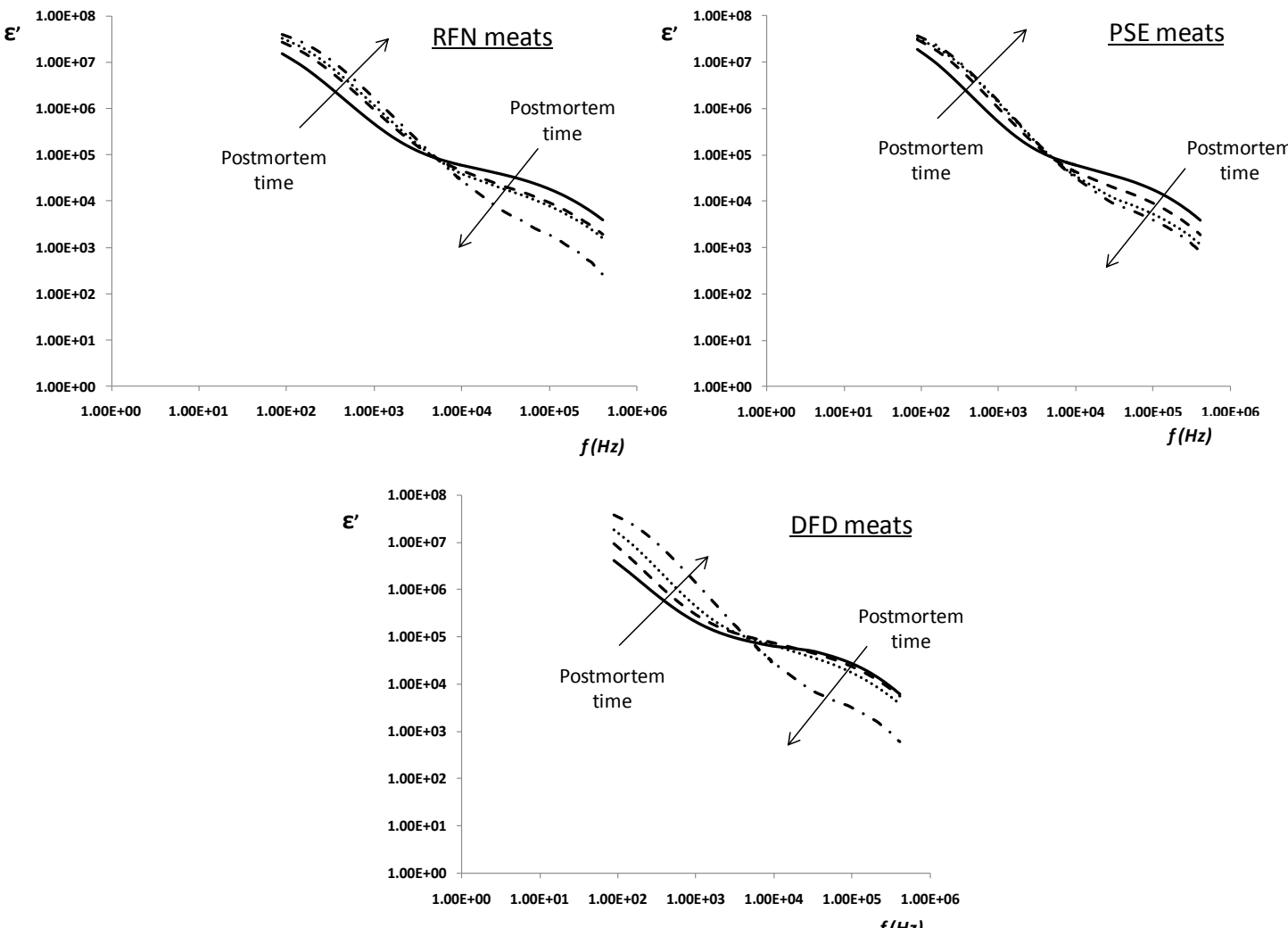

Figure 4. Dielectric constant spectra of RFN, PSE and DFD meats during postmortem time measured in the direction of the fibers, where: 12 hours post-mortem (-), 24 hours post-mortem (- - -), 48 hours post-mortem (...), 7 days post-mortem $(-.$.$) .$ 

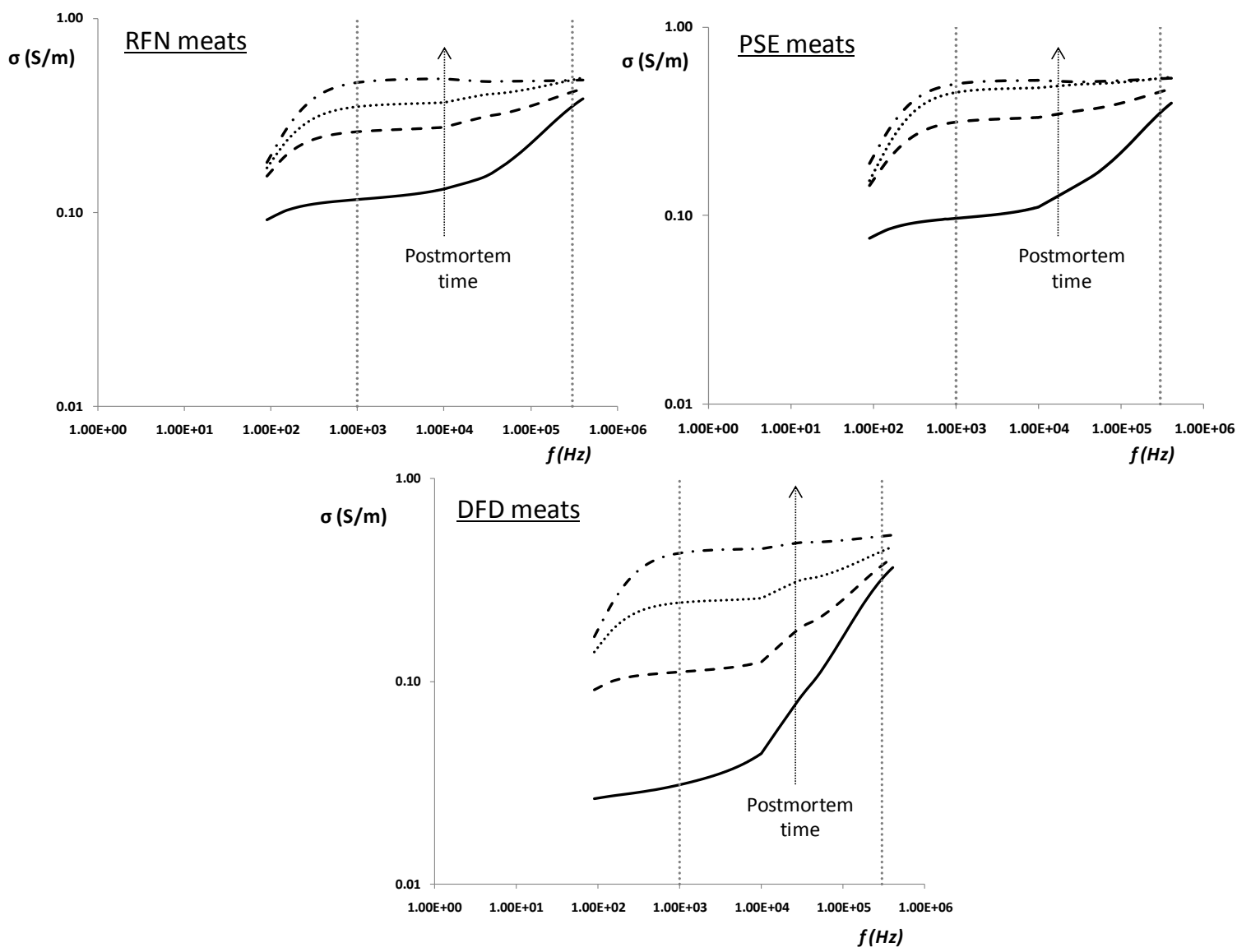

Figure 5. Conductivity spectra of RFN, PSE and DFD meats during post-mortem time measured perpendicular to fiber direction, where: 12 hours post-mortem (-), 24 hours post-mortem (- - -), 48 hours post-mortem (...), 7 days post-mortem $\left(-.-\right.$ ) . The frequencies of $1 \mathrm{kHz}$ and $300 \mathrm{kHz}$ used for the calculation of the Ageing Index $\left(\mathrm{A} I^{\sigma}\right)$ are marked with dotted vertical lines.

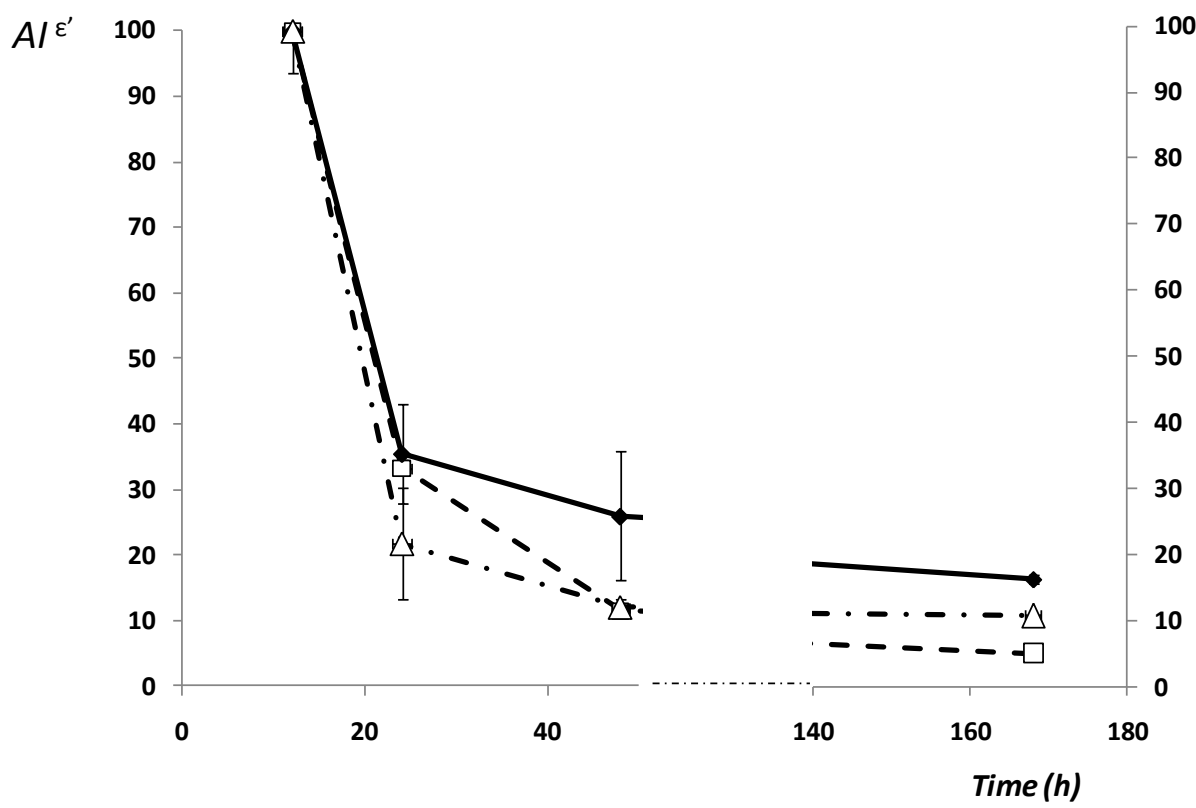

Figure 6. Ageing Index $\left(A \varepsilon^{\prime}\right)$ for RFN samples (一), DFD samples (- - -), PSE samples (- . - ) during postmortem time. 
time. The $A \varepsilon^{\prime}$ at each studied time was represented in the figure 6 . The figure shows that low quality meats decrease faster than the RFN meats. For low quality meats, the $A I^{\prime}$ is already very low at $48 \mathrm{hpm}$. It can be also appreciated that the $A I^{\prime}$ is reduced very fast during the first $24 \mathrm{hpm}$.

The increase in conductivity spectrum with postmortem time can be attributed to the increase in cell membrane permeability due to the meat ageing. A new index to analyze the integrity of cell membranes was defined based on the conductivity at two frequencies of the present study. The frequency of $300 \mathrm{kHz}$ was taken as an indicator of the conductivity of the intra an extracellular electrolytes; and $1 \mathrm{kHz}$ as the frequency at which more changes occur when the permeability of the cell increases. The Ageing Index based on the conductivity $\left(A I^{\sigma}\right)$ was defined like:

$$
A I^{\sigma}=\left[\frac{\sigma_{300 \mathrm{kHz}}-\sigma_{1 \mathrm{kHz}}}{\sigma_{300 \mathrm{kHz}}}\right] \times 100
$$

(Equation 5)

This index is similar than the parameter Py which was developed by Pliquett and collaborators in 2003 but using, in the present study, data from the measured spectrum instead of the limit values in the modeled $\beta$-dispersion. Obviously, the subtraction of conductivity at $300 \mathrm{kHz}$ and $1 \mathrm{kHz}$ will be lower when the membrane of the cells losses its insulating properties and therefore, the liquid intra and extracellular contribute to the conductivity spectra.

Figure 7 represents the values of the $A I^{\sigma}$ for the different quality classes studied. It can be appreciated that the Index decreases when postmortem time increases for each quality class. It is important to remark that this index is good to determinate meat ageing in each quality class, but it is important to highlight that it is not directly related to pork quality because the $A I^{\sigma}$ is higher in DFD samples which are low quality class. This is because this kind of meats have lower conductivity and more resistance, for this reason, a quality factor based on conductivity is not adequate to discriminate low quality classes although it is good to determine meat ageing in each quality class.

\subsection{Dielectric spectra anisotropy}

Meat can be described as a network of muscle fibers surrounded by connective tissues. So meat is characterized by different organized levels which form the high complex meat structure and have strong contrasting dielectric properties (Gulino et al., 2005); thus there exist differences between the measurements carried out perpendicular to fiber direction and those carried out in the same direction of the fibers; this property is called anisotropy. During the rigor mortis and the maturation process, structural damage appears (Koohmaraie, 1996; Marsh and Carse, 1974) and meat anisotropy is reduced (Clerjon and Damez, 2007).

In figure 8, it is possible to observe that the three quality classes showed anisotropy in the permittivity and also in the conductivity at 12 hours postmortem. As it can be appreciated in the figure, the $\alpha$-dispersion is higher when measurements were made in the direction of the fibers, while the Maxwell-Wagner effect is higher when measurements are made perpendicular to fiber direction.

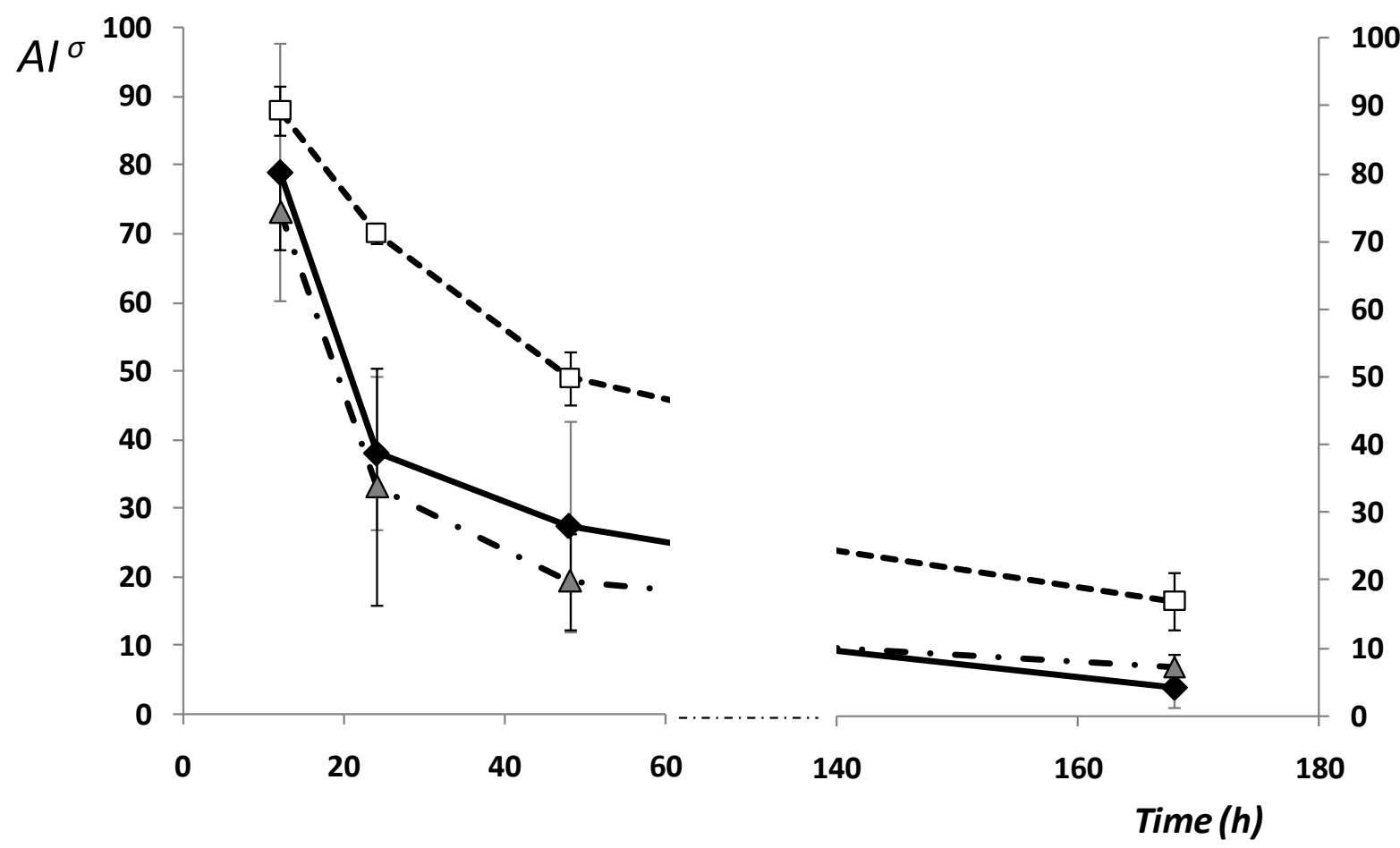

Figure 7. Ageing Index $\left(A I^{\sigma}\right)$ for RFN samples (-), DFD samples (- - ), PSE samples (- . - ) during postmortem time. 


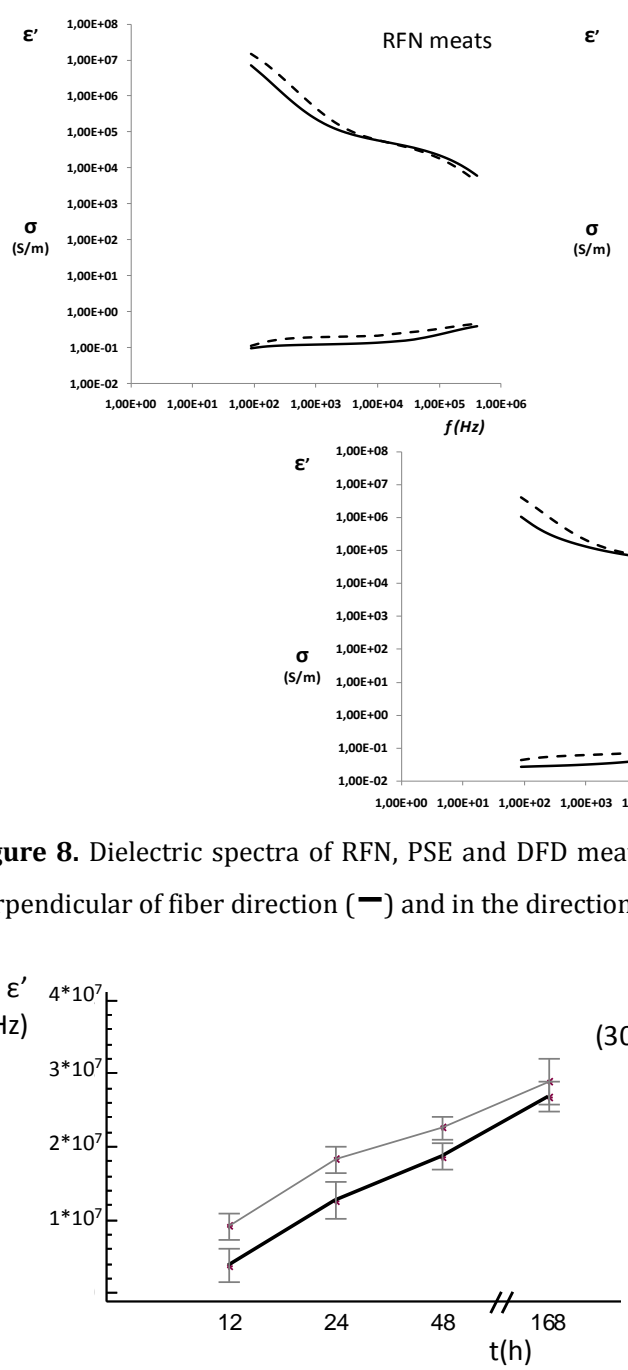

a)

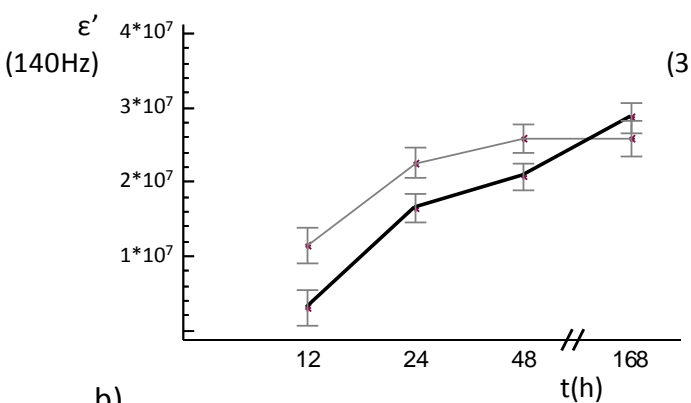

b)

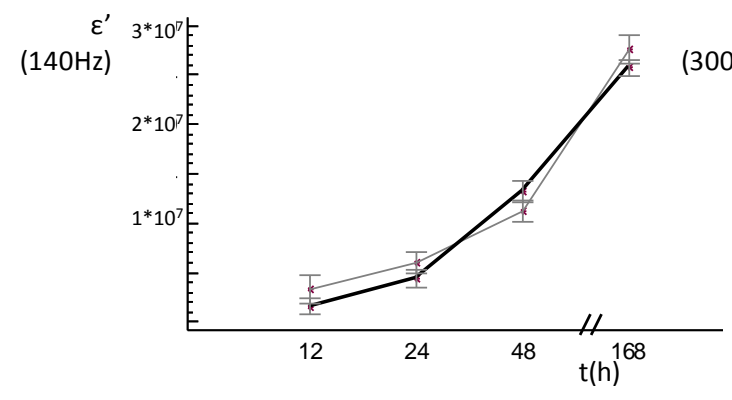

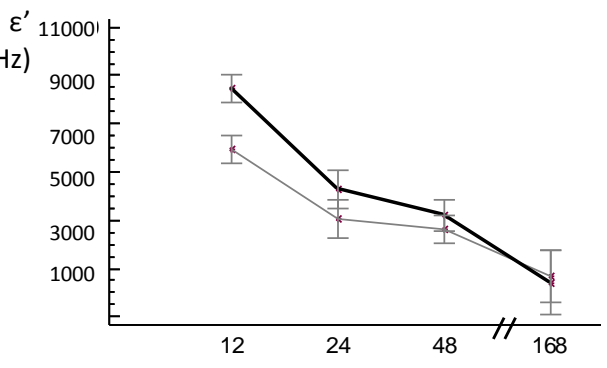

$t(h)$

c)

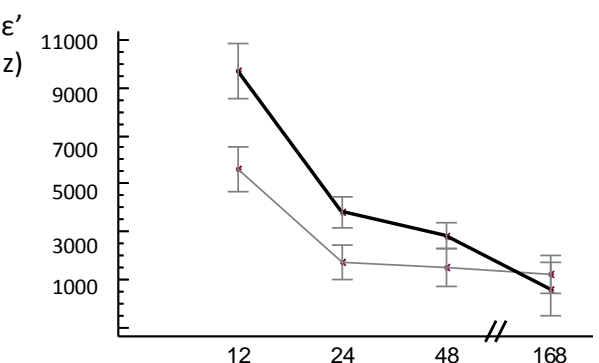

$\mathrm{t}(\mathrm{h})$

Figure 9. Dielectric constant values at $140 \mathrm{~Hz}$ and $300 \mathrm{kHz}$ measured in the direction ( - ) and perpendicular to the fibers ( - ) during postmortem time, for: a) RFN, b) PSE, c) DFD. At each postmortem time the mean values of the dielectric constant and the LSD (Least Standard Deviation) intervals are shown. 
Figure 9 showed some examples of the evolution of dielectric constant at different definite frequencies measured in the direction of the fibers and perpendicular to them. It can be appreciated that the anisotropy of the samples is reduced with postmortem time in RFN and PSE samples; the difference between measuring in perpendicular and in the direction of the fibers decreases when postmortem time increases. It can be appreciated in the figure that DFD samples showed less anisotropy than PSE and RFN samples.

\subsection{Differences among the three quality classes at each postmortem time}

The possibility of employing the dielectric spectra for discriminating low meat qualities (DFD and PSE) was studied. In figure 10 the evolution of the dielectric constant spectra for RFN, PSE and DFD samples is shown for the measurements made in perpendicular to fiber direction. There are differences in the spectra among the qualities and there were analysed some definite frequencies (Figure 11) in order to determine if the differences among pork quality meats were significant. Figure 11 shows that the most significant differences $(\mathrm{p}<0.05)$ in dielectric constant and loss factor among classes are at 24 and 48 hours postmortem. At 12 hours postmortem there were no differences among classes; this behaviour can be explained because during the first 24 hours post-mortem the metabolic changes are produced rapidly, affecting structure and therefore electrical properties. So, it can be affirmed that the use of dielectric properties to detect low meat qualities is more reliable when the final $\mathrm{pH}$ has been reached and the metabolic changes have been occurred. On the other hand, when the maturation process advances, the differences among the dielectric properties of the quality classes are reduced as it can be appreciated in figure 11.
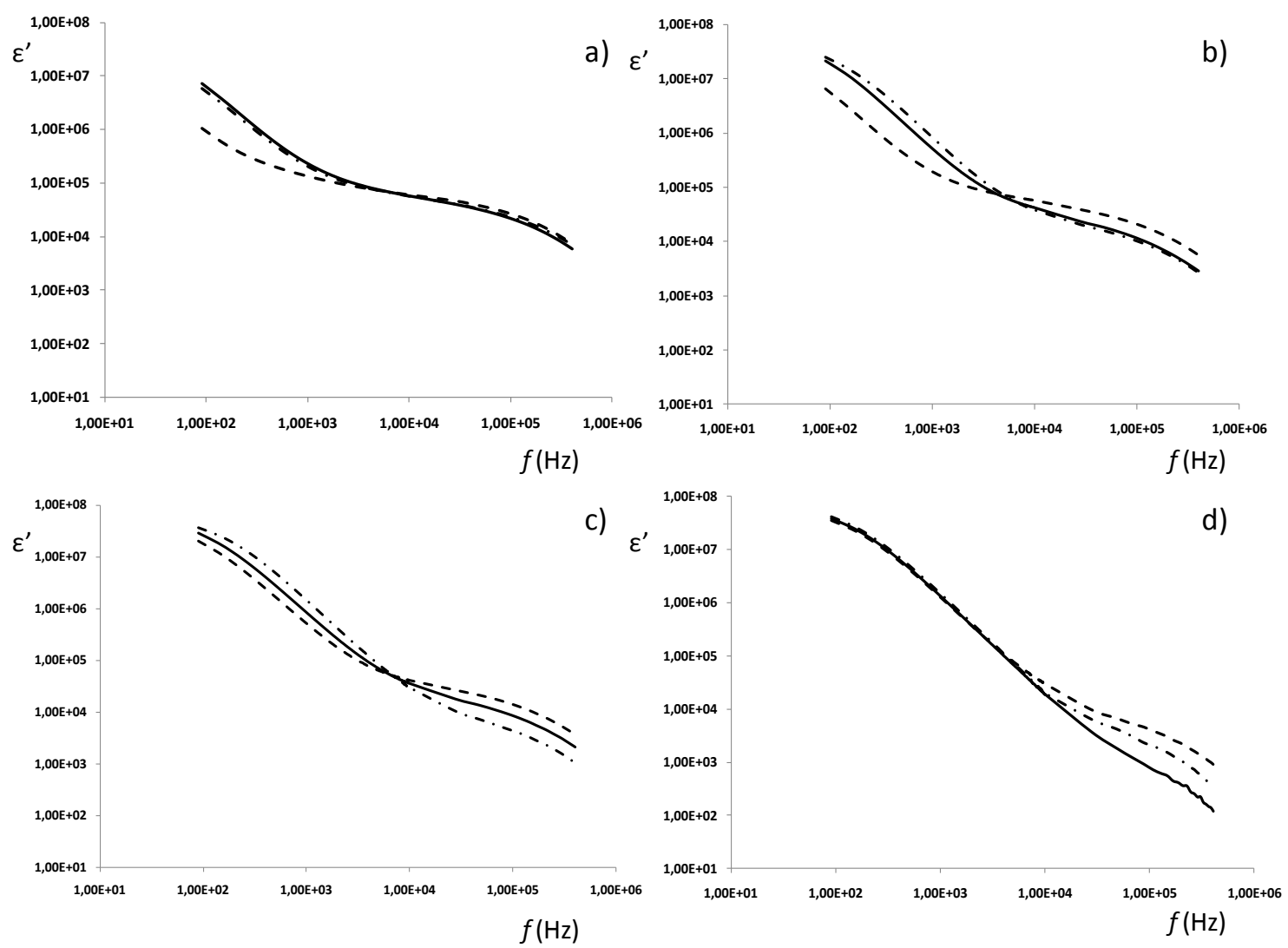

Figure 10. Dielectric constant spectra measured in perpendicular to fiber direction for RFN ( samples at: a) $12 \mathrm{hpm}, \mathrm{b}) 24 \mathrm{hpm}, \mathrm{c}) 48 \mathrm{hpm}, \mathrm{d}) 168 \mathrm{hpm}$. 
$(140 \mathrm{~Hz})$

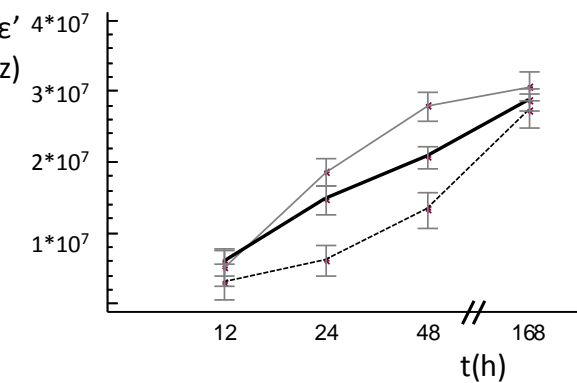

$(140 \mathrm{~Hz})$

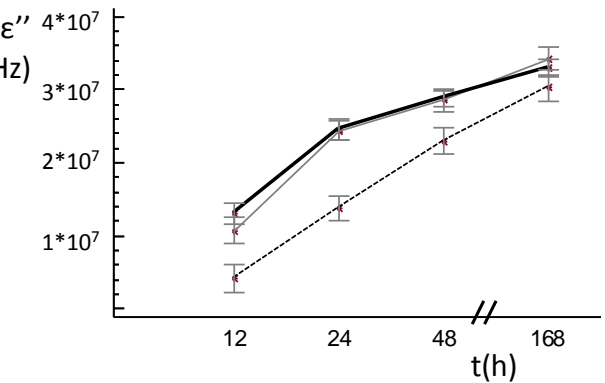

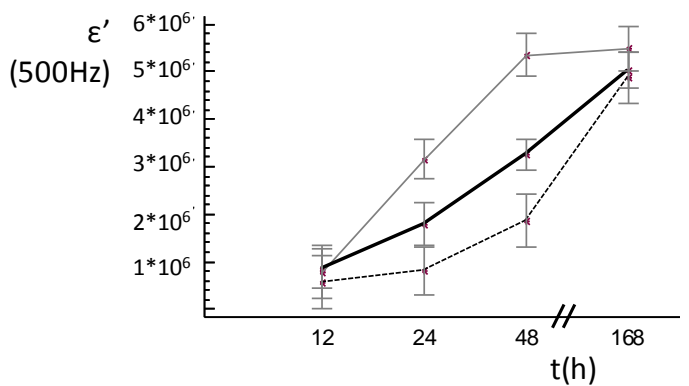

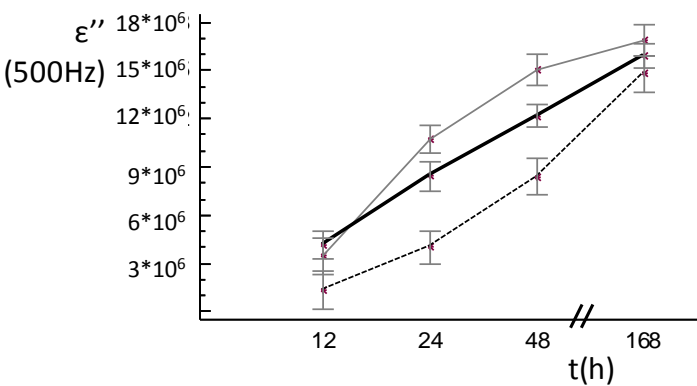

$(300 \mathrm{kHz})$

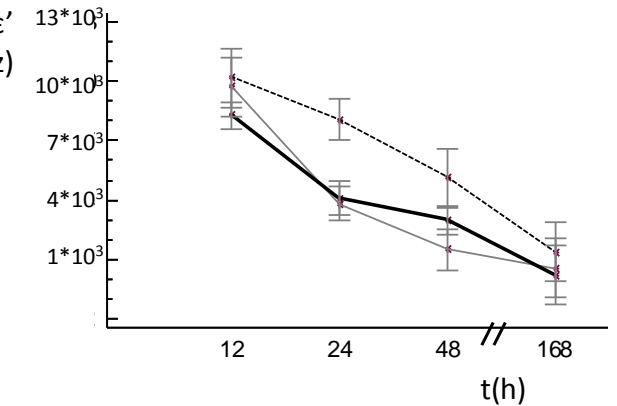

$(300 \mathrm{kHz})$

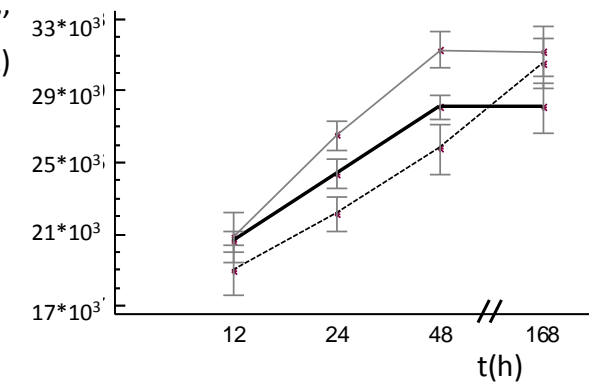

Figure 11. Mean values and LSD (Least Standard Deviation) intervals of dielectric constant and loss factor at definite frequencies $(140 \mathrm{~Hz}, 500 \mathrm{~Hz}, 300 \mathrm{kHz}$ ) for RFN samples (一), DFD samples (- - -), PSE samples $(-)$ during postmortem time.

\section{Conclusions}

There were developed two Ageing Indexes $\left(A I^{\varepsilon}\right.$ and $A I^{\sigma}$ ) based on different frequencies of the meat dielectric spectra. Both indexes are good indicators of meat ageing.

The results showed anisotropy in the permittivity and also in the conductivity in PSE and RFN samples. The $\alpha$-dispersion is higher when measurements were made in the direction of the fibers, while the Maxwell-Wagner effect is higher when measurements are made perpendicular to fiber direction. The anisotropy of the samples was reduced with postmortem time in RFN and PSE samples. Less anisotropy was observed for DFD samples.

The most significant differences $(\mathrm{p}<0.05)$ in dielectric constant and loss factor among classes were observed at 24 and 48 hours post-mortem. So it can be concluded that the use of dielectric properties to detect low meat qualities is more reliable at 24 hours after slaughtering.

The results of this research are promising and some definite frequencies $(140 \mathrm{~Hz}, 500 \mathrm{~Hz}$ and 300 $\mathrm{kHz}$ ) are demonstrated to be useful for discriminating low meat qualities which is identified as one of the most important challenges of meat industry nowadays. The next step in this research will be to develop a prototype for industrial applications based in those interesting frequencies obtained in this research.

\section{Acknowledgements}

Grant from Agroalimed (Conselleria de Agricultura, Pesca y Alimentación, Valencia, Spain) and FPU grant to MC from Ministry of Science and Innovation (Madrid, Spain) are fully acknowledged. Work prepared within the Unidad Asociada IAD (UPV)-IATA (CSIC) framework.

\section{References}

Altmann, M., \& Pliquett, U. (2006). Prediction of intramuscular fat by impedance spectroscopy. Meat Science, 72 (4), 666-671. Bejerholm, C., \& Barton-Gade, P. A. (1986). Effect of intramuscular fat level on eating quality of pig meat. In Proceedings of the 
32nd European Meeting of Meat Research Workers, Ghent 24-29 August, Vol. II (pp.389-391)

Bendall, J.R., \& Swatland, H.J. (1988). A review of the relationships of $\mathrm{pH}$ with physical aspects of pork quality. Meat Science, 24(1), 85-126.

Bertram, H.C., Andersen, H.J. \& Karlsson, A.H. (2001). Comparative study of low-field NMR relaxation measurements and two traditional methods in the determination of water holding capacity of pork. Meat Science, 57(2), 125-132.

Bowker, B.C., Grant, A.L., Forrest, J.C. \& Gerrard, D.E. (2000) Muscle metabolism and PSE pork. Journal of Animal Science, 79, 1-8.

Byrne, C., Troy, D. \& Buckley, D. (2000). Postmortem changes in muscle electrical properties of bovine $\mathrm{m}$. longissimus dors and their relationship to meat quality attributes and $\mathrm{pH}$ fall. Meat Science, 54, 23-34

Byrne, C.E., Downey, G., Troy, D.J. \& Buckley, D.J. (1998). Nondestructive prediction of selected quality attributes of bee by near-infrared reflectance spectroscopy between 750 $1098 \mathrm{~nm}$. Meat Science, 49 (4), 399-409.

Castro-Giráldez, M, Fito, P.J., Toldrá, F., \& Fito, P. (2010a). Physical sensors for quality control during processing. In Fidel Toldrá (Ed.), Handbook of Meat Processing (443-456) U.S.A.: Wiley-Blackwell Publishing.

CIE. (1978). International Commission on Illumination, recommendations on uniform color spaces, color, difference equations, psychometric color terms. CIE publication No. 15 (Suppl.2), (E-1.31) 1971/(TC-1.3) Bureau Central de la CIE, Paris, France.

Clerjon, S. \& Damez, J.L. (2007). Microwave sensing for meat and fish structure evaluation. Measurement Science and Technology, 18, 1038-1045.

Damez, J. L., Clerjon, S., Abouelkaram, S \& Lepetit, J. (2006). Polarimetric ohmic probes for the assessment of meat ageing. In Proceedings of the 52nd international congress of meat science and technology, Dublin, Ireland, 13-18 August (pp.637-638).

Damez, J.L., Clerjon, S., Abouelkaram, S., \& Lepetit, J. (2008b). Beef meat electrical impedance spectroscopy and anisotropy sensing for non-invasive early assessment of meat ageing Journal of Food Engineering, 85(1), 116-122.

Damez, J.L., Clerjon, S. (2008). Meat quality assessment using biophysical methods related to meat structure. Meat Science, 80, 132-149.

Faure, N., Flachat, C., Jenin, P., Lenoir, J., Roullet, C., \& Thomasset A. (1972). Contribution a l'étude de la tendreté et de la maturation des viandes par la méthode de la conductibilité électrique en basse et haute fréquence. Revue de médecine vétérinaire, 123, 1517-1527.

Forrest, J.C., Morgan, M.T., Borggaard, C., Rasmussen, A.J. Jespersen, B.L., \& Andersen, J.R. (2000). Development of technology for the early post mortem prediction of water holding capacity and drip loss in fresh pork. Meat Science, $55,115-122$.

Foster, K.R., \& Schwan, H.P. (1989). Dielectric properties of tissues and biological materials: a critical review. In J.R. Bourn (Ed.), Critical Reviews in Biomedical Engineering (17(1) 25-104). Boca Raton, Fla.: CRC Press.

Gabriel, S., Lau, R.W. \& Gabriel, C. (1996b). The dielectric properties of biological tissues: II. Measurements in the frequency range $10 \mathrm{~Hz}$ to $20 \mathrm{GHz}$. Physics in Medicine and Biology, 41, 2251-2269.

Garrido, M.D., Pedauye, J., Banon, S., \& Laencina, J. (1994a) Objective assessment of pork quality. Meat Science, 37(3), 411-420.

Ghatass, Z.F., Soliman, M.M., \& Mohamed, M.M. (2008). Dielectric technique for quality control of beef meat in the range $10 \mathrm{kHz}-1 \mathrm{MHz}$. American-Eurasian Journal of Scientific Research, 3(1), 62-69.

Gómez-Sánchez, J.A., Aristizábal-Botero, W., Barragán-Arango, P.J., \& Felice, C.J. (2009). Introduction of a muscular bidirectional electrical anisotropy index to quantify the structural modifications during aging in raw meat. Measurement Science and Technology, 20, 1-9.

Grimnes, S. \& GrØttem-Martinsen, 0. (2008). Passive tissue electrical properties. In S. Grimnes, 0. GrØttem-Martinsen (Eds), Bioimpedance and bioelectricity basics (pp. 93-138) Second edition. Great Britain: Academic Press.

Guerrero, L., Gobantes, I., Oliver, M.A., Arnau, J., Guàrdia, M.D., Elvira, J., Riu, P., Grèbol, N., \& Monfort, J.M. (2004). Green hams electrical impedance spectroscopy (EIS) measures and pastiness prediction of dry cured hams. Meat Science, 66, 289-294.

Gulino, M., Bellia, P., Falciglia, F., Musumeci, F., Pappalardo, A., Scordino, A. \& Triglia, A. (2005). Role of water content in dielectric properties and delayed luminiscence of bovine Achilles tendon. FEBS Letters, 579, 6101-6104

Honikel, K.O. (1998). Reference methods for the assessment of physical characteristics of meat. Meat Science. 49(4),447457.

Jaud, D., Weisse, K., Gehlen, K.H., \& Fischer, A. (1992). pH and conductivity - Comparative measurements on pig carcasses and their relationship to drip loss. Fleischwirtschaft, 72 (10), 1416-1418.

Kleibel, A., Pfüzner, H. \& Krause, E (1983). Measurement of dielectric loss factor a routine method of recognizing PSE muscle. Fleischwirtsch, 63(7), 1183-1185.

Koohmaraie, M. (1996). Biochemical factors regulating the toughening and tenderization processes of meat. Meat Science, 43, 193-201.

Kuang, W. 1996. Low-frequency dielectric properties of biological tissues: electrical double layer on membranes and ionic conduction through membrane pores. M.S. thesis., Athens, Ga., The University of Georgia.

Kuang, W., \& Nelson, S.O. (1997). Low-frequency dielectric dispersion from ion permeability of membranes. Journal of colloid and interface science, 193, 242-249.

Lawrie, R.A. (1998). Lawrie's Meat Science. $6^{\text {th }}$ edition Technomic Publishing Co., Lancaster, PA.

Lepetit, J. \& Hamel, C. (1998). Correlations between successive measurements of myofibrillar resistance of raw longissimus dorsi muscle during ageing. Meat Science, 49(2), 249-254.

Lepetit, J., Damez, J. L., Clerjon, S., Favier, R., Abouelkaram, S. \& Dominguez, B. (2006). Multi-electrode sensor for measuring the electric anisotropy of a biological material and the use of said sensor. French Patent FR2880124 W02006070169.

Lepetit, J., Salé, P., Favier, R. \& Dalle, R. (2002). Electrical impedance and tenderisation in bovine meat. Meat Science, 60(1), 51-62.

Madsen, N. T., Borggaard, C., Rasmussen, A. J., \& Christensen, L. B. (1999). On-line measurement of intramuscular fat/marbling in beef carcasses using electric impedance. In Proceeding of the 45th International Congress of Meat Science and Technology, Yokohama, Japan, 1-6 August (pp.378-379).

Marchello, M.J., Slanger, W.D., \& Carlson, J.K. (1999). Bioelectrical impedance: Fat content of beef and pork from different size grinds. Journal of Animal Science, 77(9), 2464-1468.

Marsh, B.B. \& Carse, W.A. (1974). Meat tenderness and the slidingfilament hypothesis. Journal of Food Technology, 9, 129139.

Metaxas, A.C., \& Meredith, R.J. (1993). Industrial Microwave Heating. IEE Power Engineering series 4, Peter Peregrinus LTD, London, UK.

Monin, G. (1998). Recent methods for predicting quality of whole meat. Meat Science, 49(1), 231-243.

Nelson, S.O., \& Datta, A.K. (2001). Dielectric properties of Food Materials and Electric Field Interactions. In A.K. Datta, R.C. Anantheswaran (Eds), Handbook of Microwave Technology for Food Applications (pp. 69-114). New York: Marcel Dekker.

Offer, G. \& Cousin, T. (1992). The mechanism of drip productionformation of two compartments of extracellular-space in muscle post-mortem. Journal of the Science of Food and Agricultural, 58, 107-116.

Oliver, M.A., Gispert, M., Tibau, J. \& Diestre, A. (1991).The measurement of light scattering and electrical conductivity for the prediction of PSE pig mea tat various times postmortem. Meat Science, 29, 141-151.

Pethig, R., \& Kell, D. B. (1987). The passive electrical properties of biological systems: Their significance in physiology, biophysics and biotechnology. Physics in Medicine and Biology, 32,933-937.

Pliquett, U., Altmann, M., Pliquett, F. \& Schöberlein, L. (2003). Py-a parameter for meat quality. Meat Science, 65, 1429-1437.

Rigaud, B., Morucci, J. P., \& Chauveau, N. (1996). Bioelectrical impedance techniques in medicine. Part I: Bioimpedance measurement. Critical Reviews in Biomedical Engineering, 24(4-6), 257-351.

Schwan, H.P. (1992). Linear and nonlinear electrode polarization and biological materials. Annals of Biomedical Engineering, 20, 269-288.

Schwan, H. P. (1988). Biological effects of nonionizing radiations: Cellular properties and interactions. Annals of Biomedical Engineering, 16,245-263.

Schwan, H. P. (1957). Electrical properties of tissues and cell suspensions. Advances in biological and medical physics, 5, 147-209. 
Slanger, W.D., \& Marchello, M.J. (1994). Bioelectrical impedance can predict skeletal muscle and fat-free skeletal muscle of beef cows primal cuts. Journal of Animal Science, 72(12), 3124-3130.

Stetzer, A.J. \& McKeith, F.K. (2003). Benchmarking value in the pork supply chain: Quantitative strategies and opportunities to improve quality. Savoy, IL: American Meat Science Association.

Swantek, P.M., Crenshaw, J.D., Marchello, M.J., \& Lukaski, H.C. (1992). Bioelectrical impedance: A nondestructive method to determine fat-free mass of live market swine and pork carcasses. Journal of Animal Science, 70(1), 169-177.
Swatland, H.J. (1980). Postmortem changes in electrical capacitance and resistivity of pork. Journal of Animal Science, 51, 1108-1112.

Tan, J. (2004). Meat quality evaluation by computer vision. Journal of Food Engineering, 61 (1), 27-35.

Toldrá, F. \& Flores, M. 2000. The use of muscle enzymes as predictors of pork meat quality. Food Chemistry, 69, 387395.

Wulf, D.M. Emnett, R.S., Leheska, J.M., Moeller, S.J. (2002) Relationships among glycolytic potential, dark cutting (dark, firm and dry) beef, and cooked beef palatability. Journal of Animal Science, 80, 1895-1903. 



\title{
Low frequency dielectric measurements for evaluating the extent of postmortem ageing of pork meat
}

\author{
Marta Castro-Giráldeza, Fidel Toldráb, Pedro Fito ${ }^{*}$ \\ a Instituto Universitario de Ingeniería de Alimentos para el Desarrollo, Universidad Politécnica de Valencia, Camino de Vera, s/n, 46022, Valencia, Spain
} ${ }^{b}$ Instituto de Agroquímica y Tecnología de los Alimentos(CSIC), PO Box 73, 46100 Burjassot (Valencia), Spain

\section{ARTICLE INFO}

\section{Article history:}

Received 8 April 2010

Keywords:
Ageing
Pork meat
Principal Component Analysis
Dielectric properties
Conductivity

\begin{abstract}
A B S T R A C T
The use of dielectric properties at low frequency to estimate the progress of pork meat (Longissimus dorsi) ageing was evaluated. Dielectric measurements were perfomed at $140 \mathrm{~Hz}, 1 \mathrm{kHz}$ and $300 \mathrm{kHz}$ in perpendicular to the long axis of the meat muscle fibers at 12, 24, 48 and 168 hours postmortem. Principal Component Analysis (PCA) was used to describe the relationships between meat physical/biochemical parameters and dielectric parameters of pork meat. Good correlations were found between the ageing indexes ( $\mathrm{AI} \sigma$ and $\mathrm{AI}^{\varepsilon^{\prime}}$ ) calculated from dielectric properties and some parameters of texture such as hardness and chewiness. Moreover, both indexes correlated well with free amino acids content, and with $\mathrm{K}$ value. The high degree of correlation confirms the viability of using the ageing indexes obtained from dielectric measurements to evaluate the degree of ageing of pork meat, giving information about some important eating quality parameters.
\end{abstract}

(C) 2010 Elsevier Ltd. All rights reserved.

\section{Introduction}

Pale, Soft and Exudative (PSE) meats constitute an important defect in pork industry because of its bad appearance for consumers and also because of the considerable economic losses for the industry (Stetzer and McKeith, 2003). PSE meats are caused by an accelerated rate of postmortem glycolysis resulting in low muscle $\mathrm{pH}$ while carcass temperature remains high, causing sarcoplasmic and myofibrillar proteins denaturation and an accelerated rigor mortis process (Sosnicki et al., 1998). The accelerated postmortem metabolism results in meats with pale lean, soft texture and low water holding capacity (Bowker et al., 2000). Other important quality defect in pork meat are the Dark, Firm and Dry (DFD) meats, which are prone to microbial contamination during its processing (Lawrie,1998). These meats are characterized by a dark, unattractive appearance and a firm, dry, less palatable and sticky texture due to enhanced water binding capacity (Scheffler and Gerrard, 2007; Wulf et al., 2002). On the other hand, Red, Firm and Nonexudative (RFN) is the desirable meat quality which is considered ideal for producers and consumers.

*Corresponding author. Tel.: +34 963877369

E-mail address: pfito@tal.upv.es (P.Fito).
Meat quality describes the attractiveness of meat to consumers. Two of the main eating quality aspects are the tenderness and flavour (Wood et al., 1996). Meat ageing involves biochemical and physicochemical processes which affect meat tenderization and increase its palatability (Nishimura, Rhyu, Okitani, and Kato, 1988). These processes include the increase of membrane water permeability, the weakening of connective tissues and the changes in myofibrillar protein structure of muscle (Damez, Clerjon, Abouelkaram and Lepetit, $2008 \mathrm{~b})$. The changes in myofibrillar proteins in muscle are caused by proteolytic enzymes: endopeptidases, calpains and cathepsins, which affect to muscle texture increasing meat tenderness (Nishimura, 1998) and exopeptidases, which act over polypeptides and proteins generating smaller peptides and free amino acids which are responsible of flavour development (Aristoy and Toldrá, 1995).

Due to the influence of postmortem ageing in meat tenderness and flavour, the evaluation of the degree of ageing is important to satisfy the quality requirements of consumers. Moreover, studying the ageing process allows optimizing storage times of meat pieces (Damez et al., 2008b) and therefore improving meat eating quality. Currently, meat ageing is evaluated by complicated procedures which 
include conventional physical and chemical analysis such as texture evaluation and the amount of free amino acids (FAA). Another way of determining the meat ageing is by calculating the $\mathrm{K}$ index. This term was introduced by Saito, Arai and Matuyoshi (1959) as an indicator of fish freshness. Since then, it has been widely used in fish products industry (Ehira and Uchiyama, 1974; Uchiyama and Kato, 1974; Ryder, 1985, Matsumoto and Yamanaka, 1990; Yokoyama, Sakaguchi, Kawai and Kanamori, 1992; Vázquez-Ortiz, Pacheco-Aguilar, Lugo-Sanchez and Villegas-Ozuna, 1997; Raatikainen et al., 2005). Subsequently, the viability of using this index for determining beef, rabit, chicken and porcine muscle freshness was demonstrated (Nakatani, Fujita, Sawa, Otani, Hori and Takagahara, 1986; Fujita et al., 1988). $\mathrm{K}$ value is defined by the ratio of inosine $(\mathrm{HxR})+$ hypoxantine $(\mathrm{Hx})$ to the total amount of ATP (adenosine 5-triphosphate) related compounds when expressed as a percentage (Saito et al., 1959). All these methods are tedious and expensive, and, obviously can not be implemented in process line. On the other hand, the complex processes which occur during postmortem time change the electric properties of the samples (Castro-Giráldez, Botella, Toldrá and Fito, 2010c); therefore, the study of meat electric properties during the postmortem period could be a useful tool for evaluating meat ageing process in a rapid and non-expensive way. Some authors studied the ageing process by using measurements of the electrical properties. Pliquett defined a parameter called Py which was related to membrane integrity (Pliquett, Altmann, Pliquett and Schöberlein, 2003). Other authors developed a ratio of anisotropy based on the bovine muscle electrical properties during the ageing process along the longitudinal and transverse directions (Lepetit, Salé, Favier and Dalle, 2002; Damez et al., 2008b). GómezSánchez, Aristizábal-Botero, Barragán-Arango and Felice (2009) proposed an index IEA (Inherent Electrical Anisotropy) to quantify the changes of the electrical properties of bovine muscles during the ageing process. In previous work, Castro-Giráldez et al. (2010c) reported two indexes for evaluating pork meat ageing process based in meat dielectric constant $\left(A I^{\varepsilon}\right)$ and in meat electric conductivity $\left(A I^{\sigma}\right)$. Both indexes used two different frequencies of the low frequency spectra; one frequency of the $\alpha$ dispersion region and one frequency of the $\beta$ dispersion region. The $\alpha$-dispersion is around few $\mathrm{Hz}$ to few $\mathrm{kHz}$, and it could be related with membrane permeability (Kuang and Nelson, 1997). The $\alpha$ dispersion increases with the decrease of membrane properties and integrity with postmortem progression. The $\beta$-dispersion occurs from few $\mathrm{kHz}$ to $\mathrm{MHz}$ and proportionates information about the integrity of muscle membranes and the gradual rupture of structures in the tissue (Bodakian and Hart, 1994). In previous work, Castro-Giráldez et al. (2010c) demonstrated the evolution of both indexes $\left(A I^{\prime}\right.$ and $A I^{\sigma}$ ) with postmortem time, but their relation with meat quality parameters was not analyzed. The objective of this paper is to analyze the relationship between both ageing indexes and some indicators of meat quality such as texture and free amino acids content. The relation between both ageing indexes with the well-known K-value was also analyzed.

\section{Material and Methods}

\subsection{Raw material}

20 pigs (Landrace $\mathrm{x}$ Duroc) were slaughtered in a commercial slaughterhouse located near the Institute. Carcasses were rapidly chilled at $-10^{\circ} \mathrm{C}$ for $45 \mathrm{~min}$ and the Longissimus dorsi muscle removed. The muscle was kept at $4^{\circ} \mathrm{C}$ until sampled. The pork loins were classified as RFN (Red Firm and Nonexudative) according to the classification of Flores, Moya, Aristoy and Toldrá (2000).

\subsection{Biochemical analysis}

Small pieces were cut at each sampling time $(2,4,6$, $12,24,48$ hours and 7 days postmortem), introduced in plastic bags and immediately frozen with liquid nitrogen. The samples were stored at $-80^{\circ} \mathrm{C}$ for further analysis.

\subsubsection{Sample extract preparation}

The samples for nucleosides, nucleotides, free amino acids and dipeptides were prepared from the liquid nitrogen frozen samples without thawing. Thus, $4 \mathrm{~g}$ of frozen sample was ground and homogenized with 15 $\mathrm{mL}$ of cold $0.6 \mathrm{M}$ perchloric acid using a stomacher (IUL Instruments GMBH, Barcelona, Spain) for $4 \mathrm{~min}$ in cold $\left(4^{\circ} \mathrm{C}\right)$. Homogenate was centrifuged for 20 $\min$ at $10.000 \mathrm{x} \mathrm{g}$ in a refrigerated $\left(4^{\circ} \mathrm{C}\right)$ centrifuge and the supernatant filtered through glass wool. Extracts were neutralized by adding potassium carbonate and frozen at $-20{ }^{\circ} \mathrm{C}$ until used.

\subsubsection{Nucleotides and nucleosides analysis}

Nucleotides and nucleosides were directly analyzed in the deproteinized extract by reverse phase HPLC using an Agilent 1100 system (Agilent Technologies, Palo Alto, Ca, USA) equipped with diode array detection at $254 \mathrm{~nm}$. The chromatographic separation was achieved in a Synergi C-18 column ( $4.6 \times 150 \mathrm{~mm}, 4 \mu \mathrm{m}$ MAX-RP $80 \mathrm{~A})$ from Phenomenex (Torrance, $\mathrm{CA}$ ) at room temperature. Mobile phases consisted of solvent A, containing $0.1 \mathrm{M}$ monopotassium phosphate, $\mathrm{pH}$ 6.0, and solvent $\mathrm{B}$, containing phase A:methanol $(75: 25)$. The solvents were filtered through a $0.22 \mu \mathrm{m}$ membrane filter. The separation conditions include a $5 \mathrm{~min}$ of isocratic elution with solvent A followed by a linear gradient to $15 \%$ of solvent B to $22 \mathrm{~min}$, at a flow rate of 1.0 $\mathrm{mL} / \mathrm{min}$. The column was washed with phase B for 8 min and equilibrated under the initial conditions for $10 \mathrm{~min}$ before each injection. Nucleotides and nucleosides were identified by comparing the retention times and spectra with their respective standards. Peak areas were correlated to compound concentrations by interpolation in the corresponded calibration curve.

$\mathrm{K}$ value was calculated from the concentrations of the degradation products of ATP by using the following equation (Saito et al., 1959):

$$
K-\text { value }=\frac{[H \times R]+[H x]}{[A T P]+[A D P]+[A M P]+[I M P]+[H \times R]+[H x]} \times 100
$$


Where the symbols in the brackets mean the metabolites of ATP.

\subsubsection{Free amino acids and natural dipeptides analysis}

Free amino acids and natural dipeptides were analyzed in the deproteinized sample extracts. To this aim, $200 \mu \mathrm{L}$ of thawed extract plus $50 \mu \mathrm{L}$ of 10 $\mathrm{mM}$ norleucine in $0.01 \mathrm{M} \mathrm{HCl}$ (internal standard) were mixed and submitted to derivatization with phenylthioisocyanate by the method of Bidlingmeyer, Cohen, Tarvin and Frost (1987). Derivatized amino acids were separated by RP-HPLC (1100 Agilent system) in a Waters Nova-Pack C18 column (300x3.9 $\mathrm{mm}$ ) (Waters Co. Milford, MA, USA), as described by Flores, Aristoy, Spanier and Toldrá (1997) and detected at $254 \mathrm{~nm}$. The results (mean of three determinations) were expressed as $\mathrm{mg} / 100 \mathrm{~g}$ of muscle.

\subsection{Texture profile analysis (TPA)}

Textural properties were measured by double compression using a Texture Analyzer TA.XT2 (Stable MicroSystems, UK) equipped with a flatended cylindrical plunger (SMS-P/75). The force $(\mathrm{N})$ was recorded continuously during compression in a texture profile curve with a load cell of $250 \mathrm{~N}$. Determinations were carried out on three cubes. Cubical samples $(20 \times 20 \times 20 \mathrm{~mm})$ were compressed axially ( $20 \%$ compression), with a constant crosshead speed of $1 \mathrm{~mm} / \mathrm{s}$. The holding time between both compressions was $5 \mathrm{~s}$ (Tabilo, Flores, Fiszman, and Toldrá, 1999). From the TPA curves, the following texture parameters were calculated as was previously reported by Tabilo et al (1999): hardness (g), cohesiveness (dimensionless), springiness (dimensionless), adhesiveness ( $\mathrm{g} \times \mathrm{s}$ ) and chewiness (g).

\subsection{Dielectric properties measurement}

The system used to measure the dielectric properties consists on an Agilent 16451B parallel plate fixture connected to an Agilent 4194A impedance analyzer.

Dielectric properties were measured at $12,24,48$ hours and 7 days postmortem, in perpendicular to fiber direction at $4^{\circ} \mathrm{C}$. The Contacting Electrode Method (Rigid Metal Electrode) was used. The Mean values of three replicates of the pork loin samples are reported in this article. The frequency range of the measurements was from $40 \mathrm{~Hz}$ to $4 \mathrm{MHz}$. The software of the impedance analyzer calculates the capacitance $\left(\mathrm{C}_{\mathrm{P}}\right)$ and dissipation factor (D). The measurement procedure was widely explained in previous work (Castro-Giráldez et al., 2010c).

The Ageing Indexes based on dielectric properties were defined as follows (Castro-Giráldez et al., 2010c):

$$
\begin{aligned}
& A I_{X}^{\varepsilon \prime}=\left[\frac{\left(\varepsilon^{\prime}{ }_{140 \mathrm{~Hz}}-\varepsilon^{\prime}{ }_{300 \mathrm{kHz}}\right)_{12 \mathrm{hpm}}}{\left(\varepsilon^{\prime}{ }_{140 \mathrm{~Hz}}-\varepsilon^{\prime}{ }_{300 \mathrm{kHz}}\right)_{x h p m}}\right] \times 100 \\
& A I^{\sigma}=\left[\frac{\sigma_{300 \mathrm{kHz}}-\sigma_{1 \mathrm{kHz}}}{\sigma_{300 \mathrm{kHz}}}\right] \times 100
\end{aligned}
$$

In equation 2 , hpm is referred to hours postmortem, $\varepsilon^{\prime} 140 \mathrm{~Hz}$ and $\varepsilon^{\prime} 300 \mathrm{kHz}$ are the dielectric constant at 140 $\mathrm{Hz}$ and $300 \mathrm{kHz}$, respectively. The $A \varepsilon^{\prime}$ was defined with regard to the $12 \mathrm{hpm}$ samples in order to analyze the evolution of the samples ageing. In the equation 2, the suffix $x$ represents each measurement time $(24,48$ and $168 \mathrm{hpm})$.

In equation $3, \sigma_{300 \mathrm{kHz}}$ and $\sigma_{1 \mathrm{kHz}}$ are the electric conductivity at $300 \mathrm{kHz}$ and at $1 \mathrm{kHz}$, respectively.

\subsection{Statistical analysis}

The meat metabolites content (nucleotides, nucleosides, amino acids, peptides), the $\mathrm{K}$ value and the texture parameters evaluated at different postmortem times were analyzed by the ANOVA test using the statistical package Statgraphic ${ }^{\circledR}$ Plus, version 5.1 (Statpoint Technologies, Inc, U.S.A.). The Fischer's least significant difference (LSD) was used to discriminate between the means of the different parameters during ageing.

Principal Component Analysis (PCA) was performed on the different meat parameters such as FAA, $\mathrm{K}$ value, Balenine, textural parameters (hardness, cohesiveness, springiness and chewiness) and the ageing indexes obtained from dielectric measurements $\left(A I^{\prime}\right.$ and $\left.A I^{\sigma}\right)$ in order to study the relationships among variables. PCA is a commonly used chemometric method and its most important use is to compress the k-dimensional data into a smaller number of dimensions. The projection of data into lower dimensions helps to observe grouping of objects, variables and outliers. The reduction of dimensions can also be used to reduce the noise in a data set (Raatikainen et al., 2005).

Correlation coefficients and PCA were performed using the SPSS package for Windows Version 18 (SPSS Inc., USA).

\section{Results and Discussion}

\subsection{Nucleotide and nucleoside evolution during ageing}

The nucleotide and nucleoside evolution during ageing was studied at 2, 4, 6, 12, 24, 48 hours and 7 days postmortem. The respective mean values and standard deviations of the ATP-related compounds were calculated and their evolution during postmortem period is shown in figure 1 .

ATP, ADP and AMP contents decrease gradually during ageing. These components are degraded rapidly during the first 24 hours after slaughter.

The IMP content has a marked increase during the 24 hours after slaughter, and then gradually decreases. This decrease is very slow, and the value remained at a high level of $3.38 \pm 0.27 \mu \mathrm{mol} / \mathrm{g}$ muscle at 7 days postmortem, against approximately 2.58 \pm 0.45 $\mu \mathrm{mol} / \mathrm{g}$ muscle after slaughter.

The HxR content increases gradually during the postmortem period from a value of $1.35 \pm 0.29 \mu \mathrm{mol} / \mathrm{g}$ muscle until $3.38 \pm 0.31 \mu \mathrm{mol} / \mathrm{g}$ muscle at 7 days postmortem. The $\mathrm{Hx}$ content increases slightly during the 7 days postmortem. 


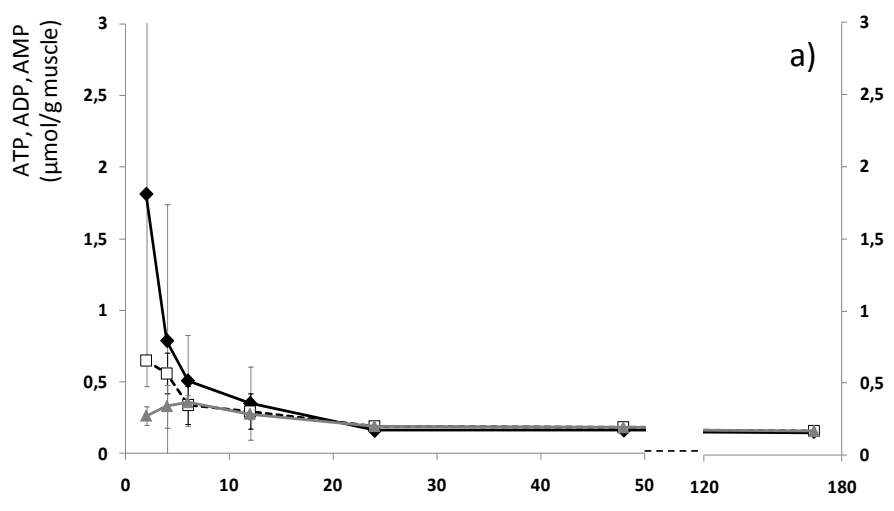

$\mathrm{t}(\mathrm{h})$

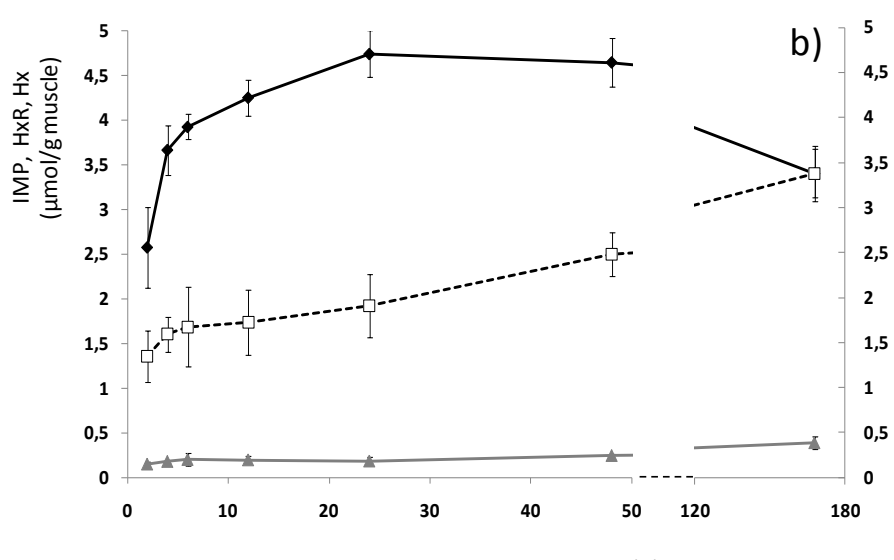

$\mathrm{t}(\mathrm{h})$

Figure 1. Changes in the ATP-related compounds of Longissimus dorsi muscle during ageing at $4^{\circ} \mathrm{C}$, where: a) $\rightarrow$ ATP content, $\square$ ADP content, $\triangle$ AMP content; b) IMP content, $\square$ HxR content, $\Delta$ Hx content.

K value was calculated from ATP-related compounds at $12,24,48$ hours and 7 days postmortem. The evolution of this ageing index with postmortem time is shown in figure 2. As can be appreciated in the figure, $\mathrm{K}$ value can be considered a good indicator of meat ageing after the first 24 hours after slaughter. The usefulness of this index to control pork meat ageing was previously demonstrated by other authors (Fujita et al., 1988).

\subsection{Peptides and free amino acids evolution during ageing}

It was also study the proteolytic breakdown process through the analysis of the nitrogen compounds of meat such as peptides and free amino acids in meat. This enzymatic process has an important effect in meat tenderness and therefore in meat quality (Wood et al., 1996; Flores, Armeros, Aristoy and Toldrá, 1999). The enzymatic systems responsible of the protelytic breakdown of myofibrillar proteins are calpain and lysosomal cathepsins. After the action of endopeptidases, the exopeptidases act over polypeptides and proteins generating smaller peptides and free amino acids which are responsible of flavour changes in meat and meat products (Nishimura and Kato, 1988; Kato, Rhue and Nishimura, 1989; Aristoy and Toldrá, 1995).

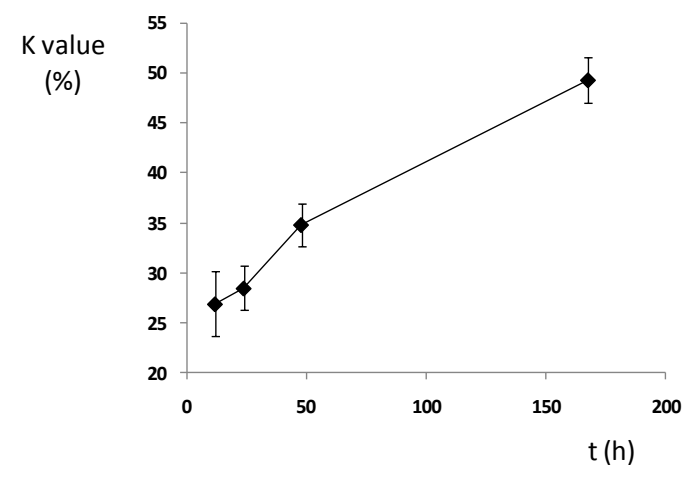

Figure 2. Changes in K value with postmortem time. 
Table 1. Concentration of free amino acids and dipeptides in Longissimus dorsi samplesa.

\begin{tabular}{|c|c|c|c|c|c|c|c|c|c|c|c|c|c|c|}
\hline \multirow[b]{3}{*}{ Amino acids } & \multicolumn{14}{|c|}{ hours postmortem } \\
\hline & \multicolumn{2}{|c|}{2} & \multicolumn{2}{|c|}{4} & \multicolumn{2}{|l|}{6} & \multicolumn{2}{|c|}{12} & \multicolumn{2}{|l|}{24} & \multicolumn{2}{|c|}{48} & \multicolumn{2}{|c|}{168} \\
\hline & $\mathrm{M}^{\mathrm{b}}$ & SE & $M$ & SE & $M$ & $\mathrm{SE}$ & $M$ & $\mathrm{SE}$ & $M$ & $\mathrm{SE}$ & $M$ & SE & $\mathrm{M}$ & $\mathrm{SE}$ \\
\hline Asp & 0.15 & 0.10 & 0.25 & 0.09 & 0.33 & 0.10 & 0.30 & 0.11 & 0.54 & 0.22 & 0.77 & 0.22 & 0.96 & 0.21 \\
\hline Glu & 0.85 & 0.19 & 1.08 & 0.21 & 1.47 & 0.18 & 1.61 & 0.44 & 2.99 & 0.63 & 3.57 & 0.40 & 4.99 & 1.07 \\
\hline Ser & 1.74 & 0.21 & 1.82 & 0.22 & 2.04 & 0.15 & 2.41 & 0.43 & 3.17 & 0.31 & 4.69 & 0.65 & 5.33 & 0.43 \\
\hline Asn & 1.11 & 0.17 & 1.20 & 0.20 & 1.32 & 0.21 & 1.47 & 0.21 & 1.85 & 0.36 & 2.60 & 0.54 & 2.94 & 0.51 \\
\hline Gly & 4.30 & 0.41 & 4.55 & 0.43 & 5.15 & 0.62 & 5.51 & 1.05 & 7.44 & 1.32 & 9.74 & 1.88 & 11.39 & 1.49 \\
\hline Gln & 12.03 & 2.81 & 14.28 & 3.80 & 15.08 & 3.37 & 17.41 & 3.56 & 20.91 & 3.75 & 29.55 & 7.14 & 33.80 & 6.57 \\
\hline B-Ala & 3.17 & 1.35 & 3.90 & 2.26 & 3.55 & 1.81 & 3.50 & 0.97 & 4.05 & 1.41 & 4.74 & 2.16 & 4.05 & 2.12 \\
\hline Tau & 18.29 & 5.54 & 18.77 & 2.87 & 21.79 & 7.17 & 20.47 & 11.05 & 25.19 & 8.46 & 26.36 & 2.44 & 15.56 & 5.31 \\
\hline His & 1.04 & 0.23 & 1.10 & 0.20 & 1.22 & 0.20 & 1.42 & 0.26 & 1.79 & 0.28 & 2.58 & 0.53 & 2.85 & 0.37 \\
\hline Thr & 2.58 & 0.55 & 2.99 & 0.37 & 3.35 & 0.57 & 3.80 & 0.83 & 4.73 & 0.53 & 6.82 & 1.60 & 7.67 & 1.26 \\
\hline Ala & 12.04 & 2.89 & 12.72 & 2.87 & 13.98 & 2.33 & 15.98 & 3.64 & 20.06 & 2.98 & 28.66 & 7.10 & 32.64 & 5.61 \\
\hline Arg & 2.39 & 0.31 & 2.52 & 0.31 & 2.82 & 0.26 & 3.25 & 0.57 & 4.53 & 0.43 & 5.98 & 0.98 & 6.97 & 0.82 \\
\hline Pro & 1.69 & 0.20 & 2.00 & 0.31 & 2.16 & 0.30 & 2.39 & 0.35 & 3.04 & 0.34 & 4.21 & 0.83 & 5.01 & 0.89 \\
\hline Tyr & 1.65 & 0.17 & 1.78 & 0.17 & 1.96 & 0.23 & 2.27 & 0.47 & 3.04 & 0.38 & 4.34 & 0.64 & 5.03 & 0.89 \\
\hline Val & 3.55 & 0.73 & 3.79 & 0.71 & 4.14 & 0.67 & 4.67 & 0.69 & 5.81 & 0.88 & 8.32 & 1.99 & 9.37 & 1.50 \\
\hline Met & 1.04 & 0.15 & 1.16 & 0.17 & 1.29 & 0.19 & 1.60 & 0.47 & 2.05 & 0.34 & 3.55 & 0.71 & 4.28 & 1.06 \\
\hline Ile & 2.25 & 0.46 & 2.44 & 0.57 & 2.53 & 0.55 & 3.02 & 0.55 & 3.66 & 0.59 & 5.42 & 1.31 & 6.31 & 0.80 \\
\hline Leu & 3.20 & 0.93 & 3.52 & 0.62 & 3.78 & 0.46 & 4.40 & 0.75 & 5.21 & 0.79 & 8.35 & 1.47 & 9.67 & 1.50 \\
\hline Phe & 2.04 & 0.40 & 2.18 & 0.37 & 2.39 & 0.48 & 2.60 & 1.08 & 3.47 & 0.77 & 5.36 & 1.35 & 5.79 & 1.55 \\
\hline Trp & 0.29 & 0.05 & 0.32 & 0.02 & 0.36 & 0.03 & 0.37 & 0.06 & 0.49 & 0.12 & 0.70 & 0.19 & 0.96 & 0.31 \\
\hline Lys & 2.46 & 0.23 & 2.62 & 0.23 & 2.84 & 0.19 & 3.33 & 0.54 & 4.60 & 0.73 & 6.04 & 0.99 & 7.11 & 0.72 \\
\hline $\begin{array}{l}\text { FAA } \\
\text { Dipeptides }\end{array}$ & \multicolumn{13}{|c|}{ Dipeptides } & 12.59 \\
\hline Car & $1187.23 a$ & 218.44 & $1317.75 a$ & 280.27 & $1236.25 a$ & 90.58 & $1409.75 a b$ & 412.02 & $1757.22 \mathrm{bc}$ & 238.67 & $2001.02 \mathrm{c}$ & 483.59 & $1276.85 a$ & 375.77 \\
\hline Ans & $26.32 a$ & 4.47 & $30.52 a$ & 5.00 & $30.90 a$ & 5.17 & $32.10 \mathrm{ab}$ & 8.72 & $36.04 a b$ & 6.48 & $42.32 \mathrm{~b}$ & 10.86 & $28.13 a$ & 11.46 \\
\hline Bal & $35.52 a$ & 8.15 & $39.29 a$ & 6.19 & $42.34 a b$ & 6.50 & $46.66 \mathrm{bc}$ & 4.18 & $49.67 c$ & 4.75 & $67.72 \mathrm{~d}$ & 6.38 & $81.39 \mathrm{e}$ & 5.49 \\
\hline
\end{tabular}

${ }^{a}$ Results are expressed as means (M) in mg/100g of meat and Standard Error (SE).

bMeans in a row with different letters are significantly different $(\mathrm{P}<0.05)$

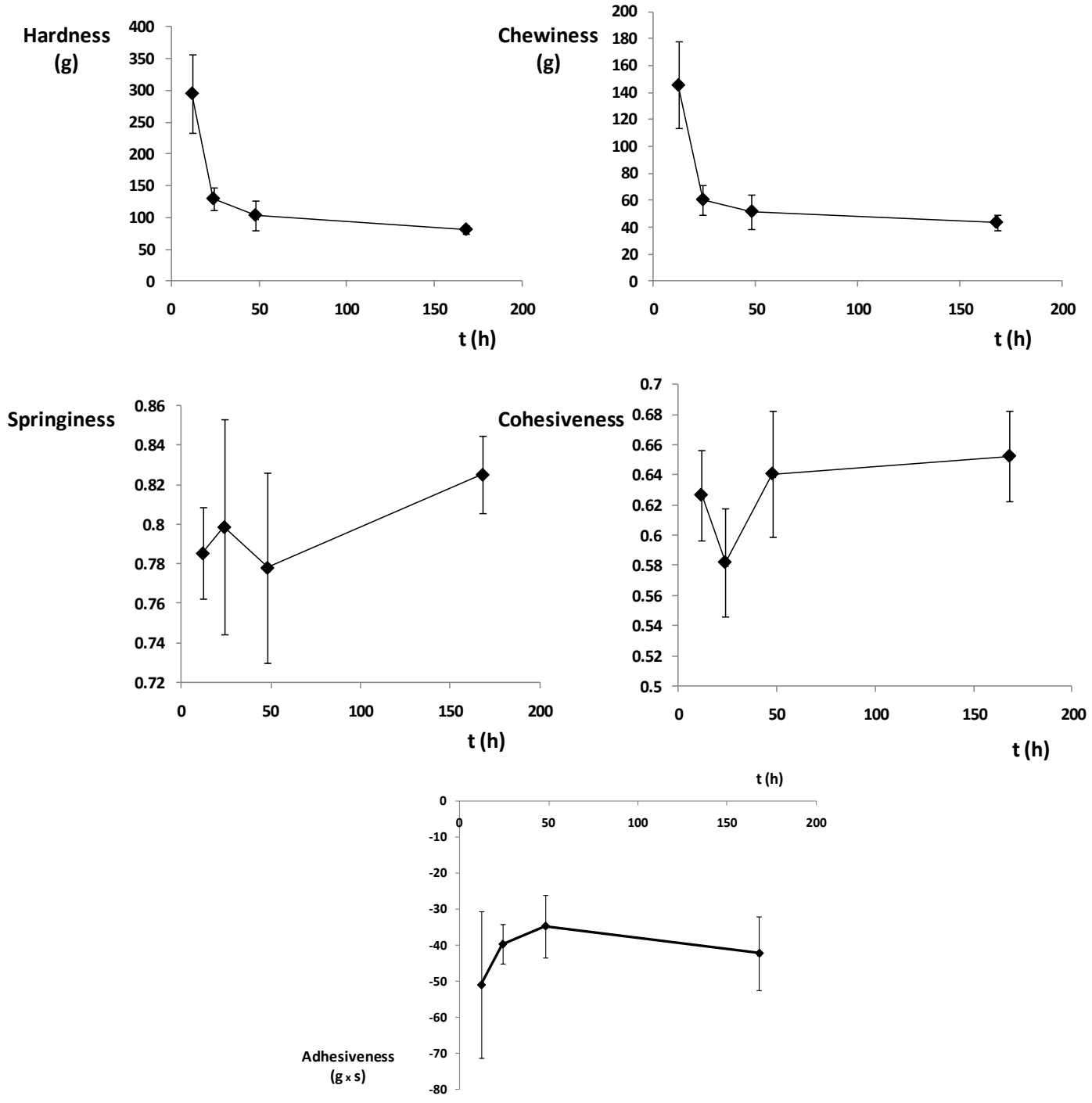

Figure 3. Evolution of texture parameters with postmortem time. 
In table 1, the evolution of the amino acids and dipeptides studied is shown. It can be observed that the ageing of pork meats produced a general increase in all free amino acid concentrations except for $\beta$ alanine which remains almost constant, and taurine which suffers a decrease at 7 days postmortem. The FAA content showed a significant $(\mathrm{P}<0.05)$ increase during ageing. On the other hand, the natural dipeptides carnosine and anserine did not show a marked tendency; these dipeptides showed a slight increase during the 48 hours postmortem, but their values at 7 days after slaughter were similar to the initials. On the contrary, the concentration of the dipeptide balenine shows a significant $(\mathrm{P}<0.05)$ increase during ageing.

\subsection{Texture parameters during ageing}

Textural characteristics of the pork loins are shown in figure 3 . The hardness and chewiness values of the samples at $12 \mathrm{hpm}$ were significantly $(\mathrm{P}<0.05)$ higher than those obtained at 7 days postmortem. So, ageing process produces a large decrease in meat hardness, becoming soft in terms of consumer perception. Chewiness is defined as the energy required for masticating a solid food to a state ready for swallowing (Civille and Szczesniak, 1973). In terms of consumer sensory perception, it defines the degree of meat tenderness (Szczesniak, 1963). So, ageing process produces a large decrease in chewiness, becoming tender in terms of consumer perception. The texture parameters cohesiveness, springiness and adhesiveness do not suffer significant $\quad(\mathrm{P}<0.05)$ changes during ageing. Cohesiveness is related to the degree to which a substance is compressed between the teeth before it breaks, and springiness (originally called elasticity) is related to the degree to which a product returns to its original shape once it has been compressed between the teeth. The last parameter, the adhesiveness, is the force required to remove the material that adheres to the palate during the eating process (Civille and Szczesniak, 1973).

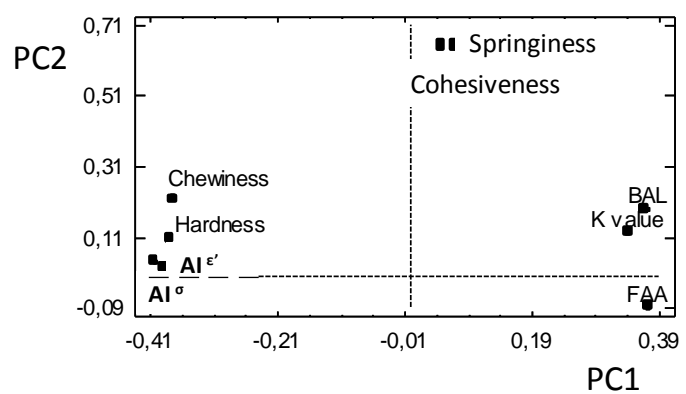

Figure 5. Plot of the two PC loading vectors.

\subsection{Ageing Indexes based on dielectric properties}

The evolution of both ageing indexes $\left(\mathrm{AI}^{\varepsilon^{\prime}}\right.$ and $\left.\mathrm{AI}{ }^{\sigma}\right)$ during ageing were calculated as was previously explained in material and methods section. Its evolution is shown in figure 4, in which the LSD (Least Standard Deviation) intervals at each postmortem time are also shown. In the figure it can be appreciated that the $\mathrm{AI}^{\varepsilon}$ 'showed significant $(\mathrm{P}<0.05)$ differences between all the postmortem hours analyzed. By contrast, the $\mathrm{AI}^{\sigma}$ showed a general decrease during the postmortem time but this decrease was not significant between 24 and 48 hours postmortem.

\subsection{Principal Component Analysis}

The conversion of muscle to meat involves complex biochemical processes developed during postmortem period (Ouali, 1992; Koohmaraie, 1996). Among these processes, the fragmentation of myofibrils during postmortem storage has been related to the tenderness of aged meat (Koohmaraie, 1992). Thus, ageing process affects some meat texture parameters such as hardness and chewiness (Figure 3). Moreover, meat ageing produce a marked increase in free amino acids and in some peptides such as
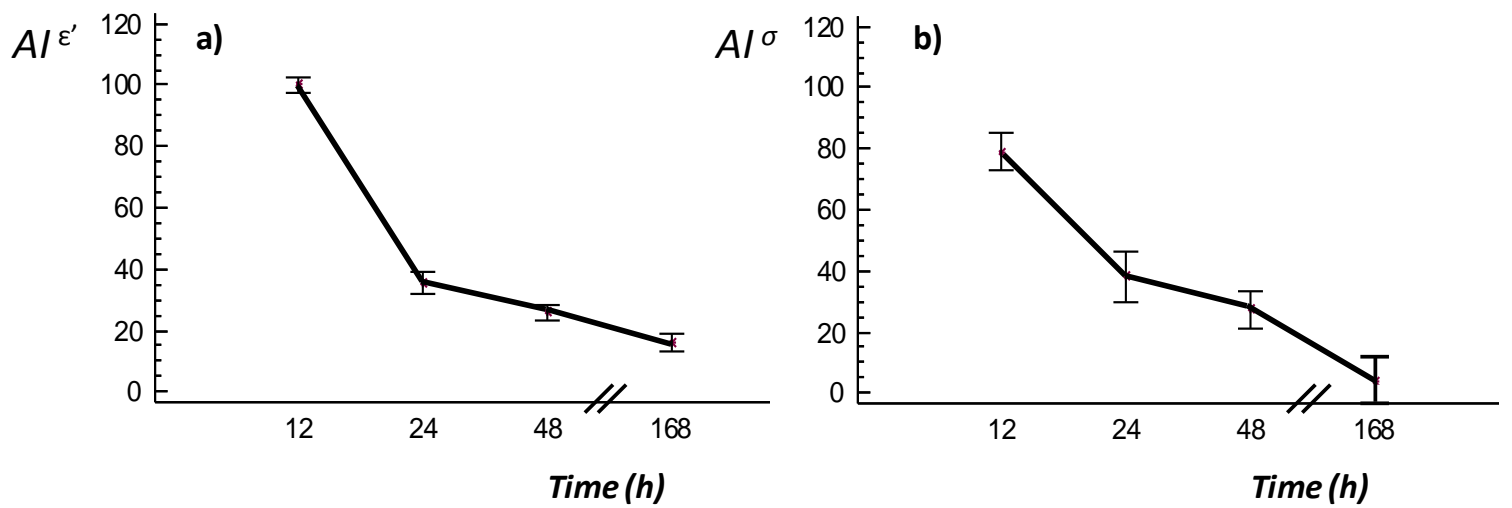

Figure 4. a) Ageing Index based on dielectric constant $\left(A \varepsilon^{\prime}\right)$ and b) Ageing Index based on electric conductivity $\left(A I^{\sigma}\right)$ during postmortem time. At each postmortem time the mean values of both ageing indexes and the LSD (Least Standard Deviation) intervals are shown. 
balenine (Table 1), improving taste and flavour. The changes in ATP-related compounds are also important during ageing; these changes are reflected in changes in the $\mathrm{K}$ value (Figure 2).

Principal Component Analysis was performed to study the relationship between physical/biochemical parameters and dielectric Ageing Indexes. There were used some texture parameters which were observed to vary during ageing such as hardness and chewiness; the parameters cohesiveness and springiness were also included in the analysis because they influenced the chewiness parameter. $\mathrm{K}$ value, free amino acids content and balenine were also included in the analysis because they showed a marked variation during postmortem time.

Factor analysis of texture parameters, $\mathrm{K}$ value, free amino acids content and balenine identified two principal components accounting for $78.6 \%$ of the total variance. PC1 accounted for $61.1 \%$ of the total variance, and PC2 accounted for $17.5 \%$. Table 2 shows the principal component loadings. These results show that hardness, chewiness, $\mathrm{K}$ value, free amino acids content and balenine were highly significant in the PC1. So, the first PC is defined by meat ageing indicators. In fact, in the loading plot (Figure 5), these variables are placed far from the origin of the first PC. In particular, chewiness, hardness, and both dielectric ageing indexes, placed on the left in the loading plot, are positively correlated; so, a decrease in both dielectric ageing indexes is related to a decrease in meat hardness and chewiness, and a increase of FAA, BAL and $\mathrm{K}$ value, which are in the opposite part of the plot. The texture parameters of cohesiveness and springiness are highly significant in the second PC. Both parameters are not related with the ageing process as was demonstrated with figure 3 , in which their evolution had not a marked tendency with postmortem evolution.

The score plot (Figure 6) shows the location of the objects in the multivariate space of the two principal components score vectors. It can be appreciated that the score vectors of PC1 are substantially arranged by postmortem time, leading from hard and tough meat with low content of FAA and low $\mathrm{K}$ value, to soft and tender meat with high FAA and $\mathrm{K}$ value. The variation in PC1 score vectors with postmortem time can be better appreciated in figure 7, in which the score vectors are increasing their value when postmortem time increases. The variation of PC2 score vectors does not show any tendency with postmortem time evolution.

The relationships between the Ageing Indexes calculated from dielectric properties and the selected biochemical/physical parameters used in the PC analysis were analyzed (Table 3). Dielectric Ageing Indexes were highly correlated $(\mathrm{P}<0.01)$ with free amino acids content, dipeptide balenine, $\mathrm{K}$ value, and some parameters of texture such as hardness and chewiness. The highest correlation coefficients were found between $\mathrm{AI}^{\prime}(\mathrm{r}=0.87, \mathrm{r}=0.86, \mathrm{P}<0.01$ ) with those texture parameters of hardness and chewiness, respectively.

These results show that both Ageing Indexes based on low frequency dielectric measurements can determine the extent of ageing of muscle and give an indication of meat eating quality because they are related with some important biochemical and texture meat parameters.

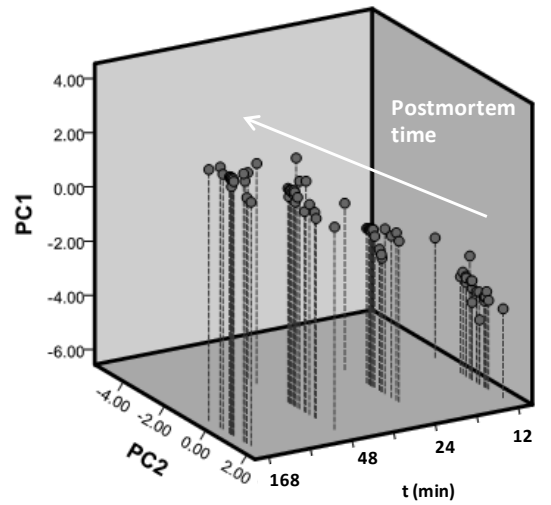

Figure 7. Plot of the first two PC score vectors with regard to postmortem time.

Table 2. Principal components loadings

\begin{tabular}{lcc}
\cline { 2 - 3 } & PC1 & PC2 \\
\hline BAL & 0.3719 & 0.1896 \\
FAA & 0.3701 & -0.0897 \\
Hardness & -0.3841 & 0.1017 \\
Chewiness & -0.3766 & 0.2266 \\
Cohesiveness & 0.0724 & 0.6697 \\
Springiness & 0.0421 & 0.6539 \\
K value $^{{ }^{\prime}}$ & 0.3382 & 0.1236 \\
AI $^{\prime}$ & -0.4014 & 0.0396 \\
AI $^{\sigma}$ & -0.3910 & 0.0380 \\
\hline
\end{tabular}

Figure 6. Plot of the first two PC score vectors, where: $\square 12$ hpm, $\triangle 24 \mathrm{hpm}, \bullet 48 \mathrm{hpm}, \diamond 168 \mathrm{hpm}$. 


\section{Conclusions}

Currently, the methods used for determining meat ageing are based in tedious analysis and therefore can not be implemented in process line. In this study, it has been demonstrated that low frequency measurements can be used for indicating the extent of postmortem ageing of meat and provide important information of the proteolysis process evaluated by the free amino acids content and by meat hardness/chewiness.

Moreover, the evolution of both indexes shows great potential for use as indicators of meat eating quality because they are well related with hardness and chewiness, which are related with the degree of meat tenderness in terms of consumer perception; both indexes are also well related with the amounts of free amino acids and dipeptide balenine, which are related with the taste and flavour of fresh meat; and, moreover, both indexes are also well related with the $\mathrm{K}$ value, which is an indicator of meat ageing based in the ATP related compounds.

Table 3. Simple correlation coefficients obtained between dielectric Ageing Indexes and selected biochemical/physical parameters of pork meat Longissimus dorsi.

\begin{tabular}{lcc}
\cline { 2 - 3 } & $\mathrm{Al}^{\varepsilon^{\prime}}$ & $\mathrm{Al}^{\sigma}$ \\
\hline BAL & $-0.7671 * *$ & $-0.7690 * *$ \\
FAA & $-0.7687 * *$ & $-0.7614 * *$ \\
Hardness & $0.8748 * *$ & $0.7643 * *$ \\
Chewiness & $0.8590 * *$ & $0.7730 * *$ \\
Cohesiviness & -0.0994 & -0.0417 \\
Springiness & -0.1166 & -0.117 \\
K value & $-0.6312 * *$ & $-0.6898 * *$ \\
\hline
\end{tabular}

**P $<0.01$

\section{Acknowledgements}

Grant from Agroalimed (Conselleria de Agricultura, Pesca y Alimentación, Valencia, Spain) and FPU grant to MC from Ministry of Science and Innovation (Madrid, Spain) are fully acknowledged. Work prepared within the Unidad Asociada IAD (UPV)IATA (CSIC) framework.

\section{References}

Aristoy, M.C. \& Toldrá, F. (1995). Isolation of flavor peptides from raw pork meat and dry-cured ham. In G. Charalambous, Food flavors: generation, analysis and process influence (pp. 1323-1344) Amsterdam, The Netherlands: Elsevier Science.

Bidlingmeyer, B.A., Cohen, S.A., Tarvin, T.L. \& Frost, B.A. (1987). A new, rapid, high sensitivity analysis of amino acids in food type samples. Journal of the Association of Official Analytical Chemists, 70, 241-247.
Bodakian, B. \& Hart, F.X. (1994). The dielectric properties of the meat. IEEE Transactions on Dielectrics and electrical insulation, 1, 181-187.

Castro-Giráldez, M., Botella, P., Toldrá, F. \& Fito, P. (2010c). Low-frequency dielectric spectrum to determine pork meat quality. Innovative Food Science and Emerging Technologies, 11(2), 376-386.

Civille, G.V. \& Szczesniak, A.S. (1973). Guidelines to training a texture profile panel. Journal of Texture Studies, 4, 204-223.

Damez, J.L., Clerjon, S., Abouelkaram, S. \& Lepetit, J. (2008b). Beef meat electrical impedance spectroscopy and anisotropy sensing for non-invasive early assessment of meat ageing. Journal of Food Engineering, 85, 116-122.

Ehira, S. \& Uchiyama, H. (1974). Freshness-Lowering rates of cod and sea bream viewed from changes in bacterial count, Total Volatile Base- and Trimethylamine Nitrogen, and ATP related compounds. Bulletin of the Japanese Society of Scientific Fisheries, 40(5), 479-487.

Flores, M., Aristoy, M-C, Spanier, A.M \& Toldrá, F. (1997). Non-volatile components effects on quality of Serrano dry-cured ham as related to processing time. Journal of Food Science, 62, 1235-1239.

Flores, M., Armeros, E., Aristoy, M.C. \& Toldrá, F. (1999). Sensory characteristics of cooked pork loin as affected by nucleotide content and post-mortem meat quality. Meat Science, 51,53-59.

Flores, M., Moya, V.J., Aristoy, M.C. \& Toldrá, F. (2000). Nitrogen compounds as potential biochemical markers of pork meat quality. Food Chemistry, 69,371-377.

Fujita, T., Hori,Y., Otani, T., Kunita, Y., Sawa, S., Sakai, S., Tanaka, Y., Takagahara, I \& Nakatani, Y. (1988). Applicability of the $\mathrm{K}_{0}$ value as an Index of Freshness for porcine and Chicken muscles, Agricultural Biology and Chemistry, 52 (1),107112.

Gómez-Sánchez, J.A., Aristizábal-Botero, W., BarragánArango, P.J., \& Felice, C.J. (2009). Introduction of a muscular bidirectional electrical anisotropy index to quantify the structural modifications during aging in raw meat. Measurement Science and Technology, 20, 1-9.

Kato, H., Rhue, MR. \& Nishimura, T. (1989). Role of free amino acids and peptides in food taste. In R.Teranishi, R.G. Buttery, \& F. Shahidi, Flavor Chemistry. Trends and development (pp. 158174). ACS Symposium Series 388. Washington DC: ACS.

Koohmaraie, M. (1992). The role of $\mathrm{Ca}^{+2}$-dependent proteases (calpains) in postmortem proteolysis and meat tenderness. Biochimie, 74, 239-245.

Koohmaraie, M. (1996). Biochemical factors regulating the toughening and tenderization process of meat. Meat Science, 43, S193-S201.

Kuang, W., \& Nelson, S.O. (1997). Low-frequency dielectric dispersion from ion permeability of membranes. Journal of colloid and interface science, 193, 242249.

Lepetit, I., Salé, P., Favier, R. \& Dalle, R. (2002). Electrical impedance and tenderisation in bovine meat. Meat Science, 60(1), 51-62.

Matsumoto, M. \& Yamanaka, H. (1990). Postmortem biochemical changes in the muscle of Kuruma Prawn during storage and evaluation of the freshness. Nippon Suisan Gakkaishi, 56(7), 11451149.

Nakatani, Y., Fujita, T., Sawa, S., Otani, T., Hori, Y. \& Takagahara, I. (1986). Changes in the ATP-related compounds of beef and rabbit muscles and a new index of freshness of muscle. Agricultural Biology and Chemistry, 50(7), 1751-1756. 
Nishimura, T. \& Kato, H. (1988). Taste of free amino acids and peptides. Food Reviews International, 4,175194.

Nishimura, T. (1998). Mechanism involved in the improvement of meat taste during postmortem aging. Food Science Technology International, 4(4), 241-249.

Nishimura, T., Rhyu, M.R., Okitani, A. \& Kato, H. (1988) Components contributing to the improvement of meat taste during storage. Agricultural Biology and Chemistry, 52, 2323-2330.

Ouali, A. (1992). Proteolytic and physicochemical mechanism involved in meat texture development. Biochimie, 74, 251-265.

Pliquett, U., Altmann, M., Pliquett, F. \& Schöberlein, L. (2003). Py-a parameter for meat quality. Meat Science, 65, 1429-1437.

Raatikainen, O., Reinikainen, V., Minkkinen, P., Ritvanen, T., Muje, P., Pursiainen, J., Hiltunen, T., Hyvönen, P. von Wright, A. \& Reinikainen, S. (2005). Multivariate modelling of fish freshness index based on ion mobility spectrometry measurements. Analytica Chimica Acta, 544, 128134.

Ryder, J.M. (1985). Determination of adenosine triphosphate and its breakdown products in fish muscle by High-Performance Liquid Chromatography. Journal of Agricultural and Food Chemistry, 33,678-680.

Saito, T., Arai, K. \& Matuyoshi, M. (1959). A new method for estimating the freshness of fish. Bulletin of the Japanese Society of Scientific Fisheries, 24, 749750.

Szczesniak, A.S. (1963). Classification of textural characteristics. Journal of Food Science, 28, 385389.

Tabilo, G., Flores, M., Fiszman, S.M. \& Toldrá, F. (1999). Postmortem meat quality and sex affect textura properties and protein breakdown of dry-cured ham. Meat Science, 51, 255-260.
Uchiyama, H. \& Kato, N. (1974). Partial freezing as a means of preserving fish freshness-1. Changes in free amino acids, TMA-N, ATP and its related compounds, and nucleic acids during storage. Bulletin of the Japanese Society of Scientific Fisheries, 40(11), 1145-1154.

Vázquez-Ortiz, F.A., Pacheco-Aguilar, R., Lugo-Sanchez, M.E. \& Villegas-Ozuna, R.E. (1997). Application of the freshness quality index ( $\mathrm{K}$ value) for fresh fish to canned sardines from Northwestern Mexico. Journal of Food Composition and Analysis, 10, 158165.

Wood, J.D., Brown, S.N., Nute, G.R., Whittington, F.M., Perry, A.M., Johnson, S.P. \& Enser, M. (1996). Effects of breed, feed level and conditioning time on the tenderness of pork. Meat Science, 44,105-112.

Yokoyama, Y., Sakaguchi, M., Kawai, F. \& Kanamori, M. (1992). Changes in concentration of ATP-related compounds in various tissues of Oyster during ice storage. Nippon Suisan Gakkaishi, 58(11),21252136. 

4.2. Estudia de la cinética de salado de lama de cerda mediante la utilizacion de los espectros dieléctricas

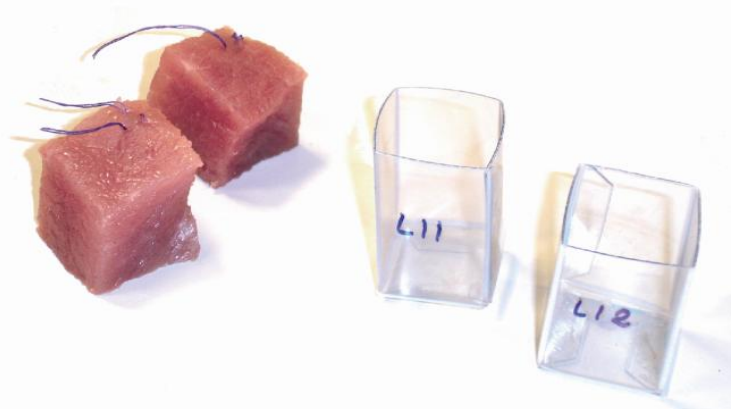





\title{
Non-equilibrium thermodynamic approach to analyze the pork meat (Longissimus dorsi) salting process
}

\author{
M. Castro-Giráldez, P.J. Fito*, P. Fito \\ Instituto Universitario de Ingeniería de Alimentos para el Desarrollo, Universidad Politécnica de Valencia, Camino de Vera, s/n, 46022, Valencia, Spain
}

ARTICLE INFO

Article history:

Received 10 September 2009

Received in revised form

November 2009

Accepted 23 January 2010

Available online 29 January 2010

Keywords:

Thermodynamic approach

Meat salting

Mass transfer

\begin{abstract}
A B S T R A C T
Salting treatment is a common operation in high quality meat production, which main objectives are to conserve the product by water activity depression and to transform the sensorial properties of fresh meat to the final meat products (like salted, cured, dried or cooked meat products). One of its main problems is the difficulty to control the simultaneous water and salt fluxes into the product and the protein fibers transformation throughout process. Water and salt transport during osmotic treatment of pork meat (longissimus dorsi) immersed in saturated salt solution, were investigated by using a thermodynamic approach. In this work the effect of rigor mortis state in the salting treatment has been demonstrated. A thermodynamic model in nonequilibrium has been developed for describing the different behaviors involved in salting process.
\end{abstract}

(C) 2010 Elsevier Ltd. All rights reserved.

\section{Introduction}

Salting is one of the oldest treatments for food preservation. One of the most common methods for salting process consists in the immersion of food in an aqueous solution with salt as osmotic agent (Colligan et al., 2001). During this osmotic treatment, simultaneous fluxes of salt and water can occur. In the case of raw meat, the treated samples can gain or lose water, producing the food hydration or dehydration (Le Meste et al., 2002; Offer and Trinick, 1983; Schmidt, 2006; Volpato et al., 2007).

Sodium chloride ( $\mathrm{NaCl}$ ) has several important roles in meat salting processes (Gilbert and Heiser, 2004). Salt reduces the water activity of the solution producing a preservative effect in salted meat; moreover, it produces an increase in water-holding capacity and also generates specific texture characteristics in some meat products when added as saturated solution, due to the fact that actin and myosin become soluble in these conditions. It also plays an important role in enhancing sensory properties (Matthews and Strong, 2005).

Meat is a cellular system with a very high biochemical and structural complexity. From a structural point of view, muscle is formed by a network of muscular fibers surrounded by connective tissue. Fibers contain specialized contractile organelles, the myofibrils. A thin layer of connective tissue, the

*Corresponding author. Tel.: +34 963877369

E-mail address: pedfisu@tal.upv.es (P.J.Fito). endomysium, surrounds the muscle cells themselves. The cells are grouped into bundles (or fasciculi) which are surrounded by another sheath of connective tissue, the perimysium. Groups of bundles form the muscle which is entirely enclosed by the epimysium, a relatively thick sheath of connective tissue (Huff-Lonergan and Lonergan, 2005). The spaces between the thick (myosin) and thin (actin) filaments of myofibrils are not constant and vary with $\mathrm{pH}$, ionic strength, osmotic pressure and with the muscle state (in rigor mortis or in the relaxation state) (April et al., 1972; Elliot, 1968; Goldman et al., 1979; Matsubara and Elliott, 1972; Millman and Nickel, 1980; Millman et al., 1981; Millman, 1981; Offer and Trinick, 1983; Rome, 1967, 1968, 1972).

Hamm $(1960,1975,1981)$ emphasized the fact that proteins have an electrostatic charge and therefore repel one another; increasing the electrostatic charge produces an increase in the repulsive force and leads to swelling. At meat $\mathrm{pH}$ (5.5-6), the charge of thick and thin filaments is negative and the addition of $\mathrm{NaCl}$ tends to enlarge the lattice and to swell the sample. In their experiments, Offer and Trinick (1983) demonstrated that the $\mathrm{NaCl}$ concentration for maximal swelling of myofibrils was from $0.8 \mathrm{M}$ to $1 \mathrm{M}$ and in that case, a substantial part of the A-band was extracted. The same authors 


\section{Nomenclature}

$a_{j} \quad$ activity of the chemical specie $\mathrm{j}(-)$.

$\mathrm{G}$ Gibbs free energy, (J/mol).

Gj partial Gibbs molar free energy of the specie $j$, (J/molj).

$\mathrm{S}$ entropy $(\mathrm{J} / \mathrm{mol} \mathrm{K})$

Jj molar flux of the specie $\mathrm{j},\left(\mathrm{mol} / \mathrm{m}^{2} \mathrm{~s}\right)$.

$\mathrm{Lj}$ phenomenological coefficient of the specie $\mathrm{j}$, $\left(\mathrm{mol}^{2} / \mathrm{s} \mathrm{m}^{2} \mathrm{~J}\right)$.

$\mathrm{Mr}$ molecular weight, $(\mathrm{g} / \mathrm{mol})$

$\mathrm{N} \quad$ Number of moles, (mol)

$\mathrm{P}$ absolute pressure (atm)

$\mathrm{R}$ Ideal gases universal constant, $\left(\mathrm{g} \mathrm{m}^{3} / \mathrm{mol} \mathrm{K}\right)$.

S Surface, $\left(\mathrm{m}^{2}\right)$.

T Temperature, $\left({ }^{\circ} \mathrm{C}\right.$ or $\left.\mathrm{K}\right)$.

$\mathrm{t}$ Time, (s or min).

$\mathrm{V}$ Volume, $\left(\mathrm{m}^{3}\right)$.

$X \quad$ Mass fraction $(-)$.

X Molar fraction (-).

Z Mass or molar fraction of the liquid fraction (-).

$\mu \mathrm{j} \quad$ chemical potential of the specie $\mathrm{j},(\mathrm{J} / \mathrm{mol})$

$\rho$ Density, $\left(\mathrm{kg} / \mathrm{m}^{3}\right)$.

V Specific volume (L/mol).

$\varepsilon \quad$ Permittivity (-).

$\varepsilon^{\prime} \quad$ dielectric constant (-).

$\varepsilon^{\prime \prime} \quad$ loss factor $(-)$.

$\gamma \quad$ activity coefficient $(-)$. demonstrated that for higher values of $\mathrm{NaCl}$ concentration, muscle tends to shrink. So, osmotic treatment of fresh meat can lead to myofibril swelling, which is accompanied by the correspondent volume of water uptake by the intercellular spaces (Le Meste et al., 2002) or can lead to muscle shrinking, with the correspondent water flow out the cells (Offer and Trinick, 1983; Schmidt et al., 2008). Thus the direction of water flow when meat is immersed in salt solution is related to the osmotic solution concentration (Schmidt et al., 2008).

It may be worthwhile highlighting the fact that the biochemistry of postmortem muscle can also affect the salting process. In this context, the rigor mortis process constraints swelling because of the crosslinks between actin and myosin (Hamm, 1960).

The objective of this work is to describe the salting meat process by using a thermodynamic approach, taking into account the influence of meat structure (ex: myofibrils swelling, shrinking phenomena or electrical interactions) in the water and salt transport.

\section{Materials and Methods}

Experiments were done using pork meat (Longissimus dorsi) collected at 1,5 days postmortem. Experimental flowchart is shown in figure 1, where it is possible to observe the salting treatment conditions using $25 \%(\mathrm{w} / \mathrm{w}) \mathrm{NaCl}$ brine at $4^{\circ} \mathrm{C} .54$ meat cylinders (15 mm diameter and $10 \mathrm{~mm}$ thick) were cut. Samples were dipped in solution for 0,5 , $10,15,25,30,40,50,60,90$, min, 2, 2.5, 3, 4, 5, 8 and 12 hours; later they were equilibrated in an isothermal chamber at $4^{\circ} \mathrm{C}$ for 16 hours.

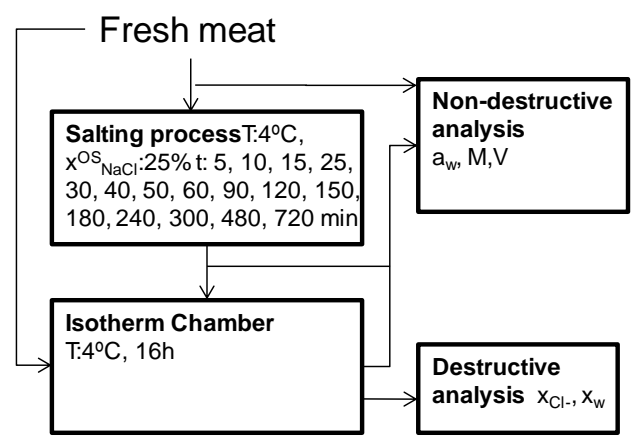

Figure 1. Diagram of the experimental procedure
The surface water activity was determined by a dew point hygrometer Decagon (Aqualab®), series $3 \mathrm{TE}$ ), with precision $\pm 0,003$. Measurements were done in structured samples (not minced), thus aw obtained is considered to be surface $\mathrm{a}_{\mathrm{w}}$.Water content was determined by drying at $110^{\circ} \mathrm{C}$ at atmospheric pressure, following the ISO 1442 (1997), for meat products. The weight of samples was determined by a precision balance Mettler Toledo AB304-S ( \pm 0.001$)$. Volume was determined by Image analysis (Sony T90, Carl Zeiss optics), using Adobe Photoshop (C) software, obtaining surface and height by triplicate. Ion chloride content was obtained by argentometric titration of $500 \mu \mathrm{l}$ of the sample extract with a Sherwood model 926 Chloride Analyser.

\section{Results and discussion}

Meat samples were analyzed just after the salting treatment, a non-equilibrium internal system, and after 16 hours of the salting operation. During the 16 hours of repose, the samples were in decagon containers preserved in an isothermal chamber and closed with parafilm in order to isolate the samples and to reach the internal equilibrium.

The salting operation with chloride salt in postmortem muscle produces compression and relaxation behaviours of muscle fibers (Shmidt et al., 2008). These mechanisms could be observed by analyzing the mass and volume variation; these variations could be estimated by the following equations:

$$
\begin{gathered}
\Delta \mathrm{M}^{\mathrm{j}}=\frac{\mathrm{M}_{\mathrm{t}}-\mathrm{M}_{\mathrm{o}}}{\mathrm{M}_{\mathrm{o}}} \\
\Delta \mathrm{V}^{\mathrm{j}}=\frac{\mathrm{V}_{\mathrm{t}}-\mathrm{V}_{\mathrm{o}}}{\mathrm{V}_{\mathrm{o}}}
\end{gathered}
$$

where $M$ represents the mass $(\mathrm{kg}), \mathrm{V}$ the volume $\left(\mathrm{m}^{3}\right)$, the subscripts $t$ represent the treatment time being 0 the initial value, and superscript $j$ the variation through the treatment $(0 \mathrm{~h})$ (non-equilibrated sample) or in repose (16h) (equilibrated).

Figure 2 shows the mass and volume variation through the osmotic treatment, where it is possible to observe an initial increase of mass and volume, and a second step with losses of mass and volume. The initial increase of volume is related to the interaction 


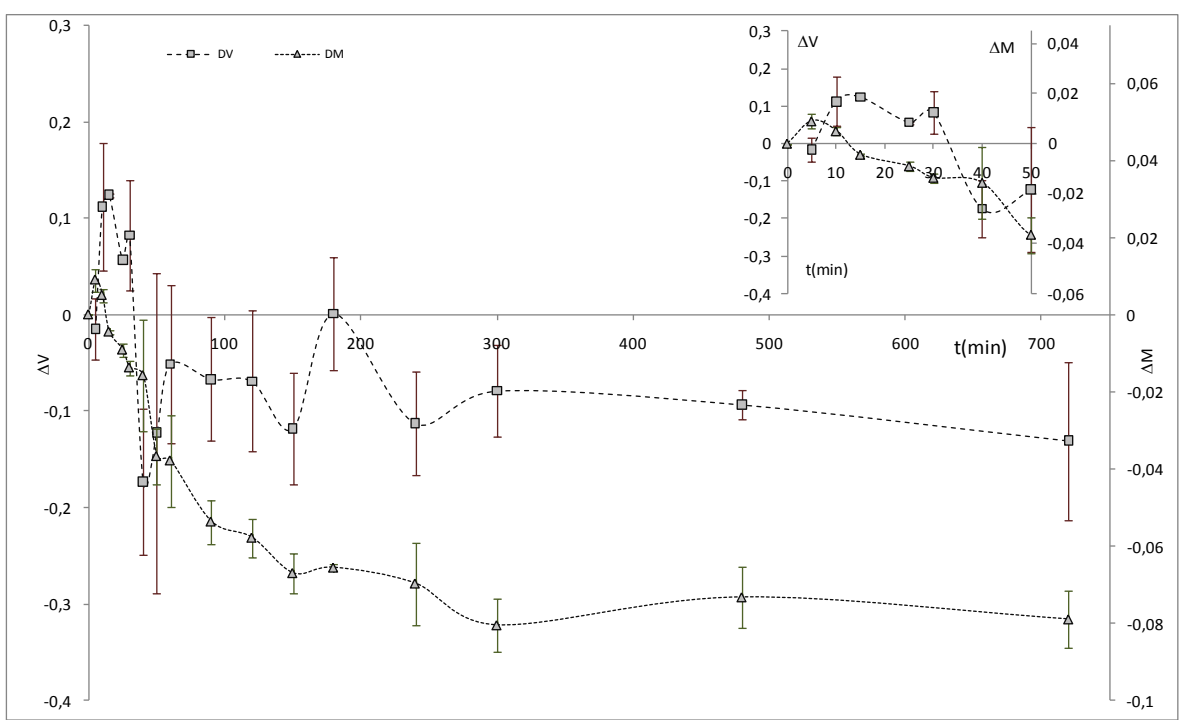

Figure 2. Mass $(\Delta)$ and volume $(\square)$ variation during the salting treatment $(0 \mathrm{~h})$. On the top right a detail of the beginning of the treatment can be appreciated.

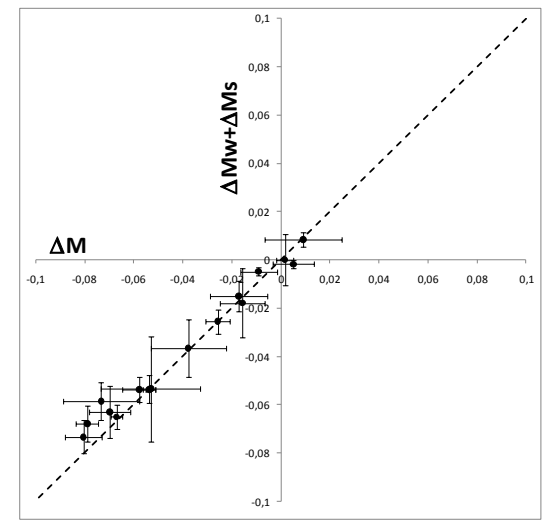

Figure 3. Relation between the overall meat mass variation and the water and sodium chloride mass variation during the osmotic treatment.

between ion chloride with the myosin and the actin filaments of the muscle fibers sites, the accumulation of anions produces repulsion in the actin-myosin system expanding the perimysium and endomysium (Offer and Cousin, 1992). Thus the immersion of the sample in the solution produces an initial enlargement of the lattice, swelling the sample. Then, the high water flux leaving the tissue reduces the overall mass of the system. This behaviour produces weight and volume loss.

Figure 3 shows the relation between the overall meat mass variation and the water and sodium chloride mass variation; a line with slope one shows the mass balance through the salting operation as $\Delta \mathrm{M}=\Delta \mathrm{M}_{\mathrm{w}}+\Delta \mathrm{M}_{\mathrm{s}}$. The fact that the data are located on the line with slope one confirms that the meat mass variation is only due to the variation of water and sodium chloride.

The mass and volume variation through the repose of samples (equilibrated samples) shows two steps (see figure 4). The first step shows a low loss of mass and high volume gained; the second step shows higher loss of mass and neglected volume variation throughout the repose, the samples were involved in isolated air, and then only mechanical mechanism could affect the samples. The potential energy (gravity mechanism) affects to all samples, but samples salted during short time suffer expansion in the fibers due to the mechanical energy stored in the tissue, these samples are relaxing during the repose time.

It is possible to obtain the salt concentration in the interface between the muscle and the external solution using the amount of water and salt losses through the repose (see equation 3 ), because liquid phase flows together by mechanical mechanism:

$$
\mathrm{x}_{\mathrm{s}}^{\mathrm{i}}=\frac{\Delta \mathrm{M}_{\mathrm{s}}^{16 \mathrm{~h}}}{\Delta \mathrm{M}_{\mathrm{s}}^{16 \mathrm{~h}}+\Delta \mathrm{M}_{\mathrm{w}}^{16 \mathrm{~h}}}
$$

where $\mathrm{Xs}_{\mathrm{s}}^{\mathrm{i}}$ is the sodium chloride mass fraction in the liquid phase of the meat side of the interface (see figure 6).

Water and salt fluxes analysis are fundamental to understand the relaxation-compression behaviours. The water and salt fluxes promoted in the osmotic treatment can be calculated by the mass variation, the process time and the variation of the samples surface (see next equations).

$$
\begin{aligned}
& \mathrm{J}_{\mathrm{w}}^{\mathrm{oh}}=\frac{-\Delta \mathrm{M}_{\mathrm{w}}^{0 \mathrm{~h}} \cdot \mathrm{M}_{\mathrm{o}}}{\Delta \mathrm{t} \cdot \mathrm{S} \cdot \mathrm{Mr}_{\mathrm{w}}} \\
& \mathrm{J}_{\mathrm{s}}^{\mathrm{Oh}}=\frac{\Delta \mathrm{M}_{\mathrm{s}}^{0 \mathrm{~h}} \cdot M_{o}}{\Delta \mathrm{t} \cdot \mathrm{S} \cdot \mathrm{Mr}_{\mathrm{s}}}
\end{aligned}
$$

Where, $\mathrm{J}$ is the flux $\left(\mathrm{mol} / \mathrm{s} \mathrm{m}^{2}\right), \Delta \mathrm{t}$ is the process time, $\mathrm{S}$ is the average measured surface of the sample during treatment $\left(\mathrm{m}^{2}\right), \mathrm{Mr}$ is the molecular weight of each compound $(18 \mathrm{~g} / \mathrm{mol}$ for water and $58.4 \mathrm{~g} / \mathrm{mol}$ for sodium chloride), the subscripts $\mathrm{w}$ represents water and s salt.

In figure 5 it is possible to observe the water and salt fluxes estimated with the equations 4 and 5, both expressed in molar quantity. Water flux is promoted by diffusional mechanisms (high gradient of water activity between salt solution and samples) and mechanical mechanisms (relaxation and compression of the samples). 


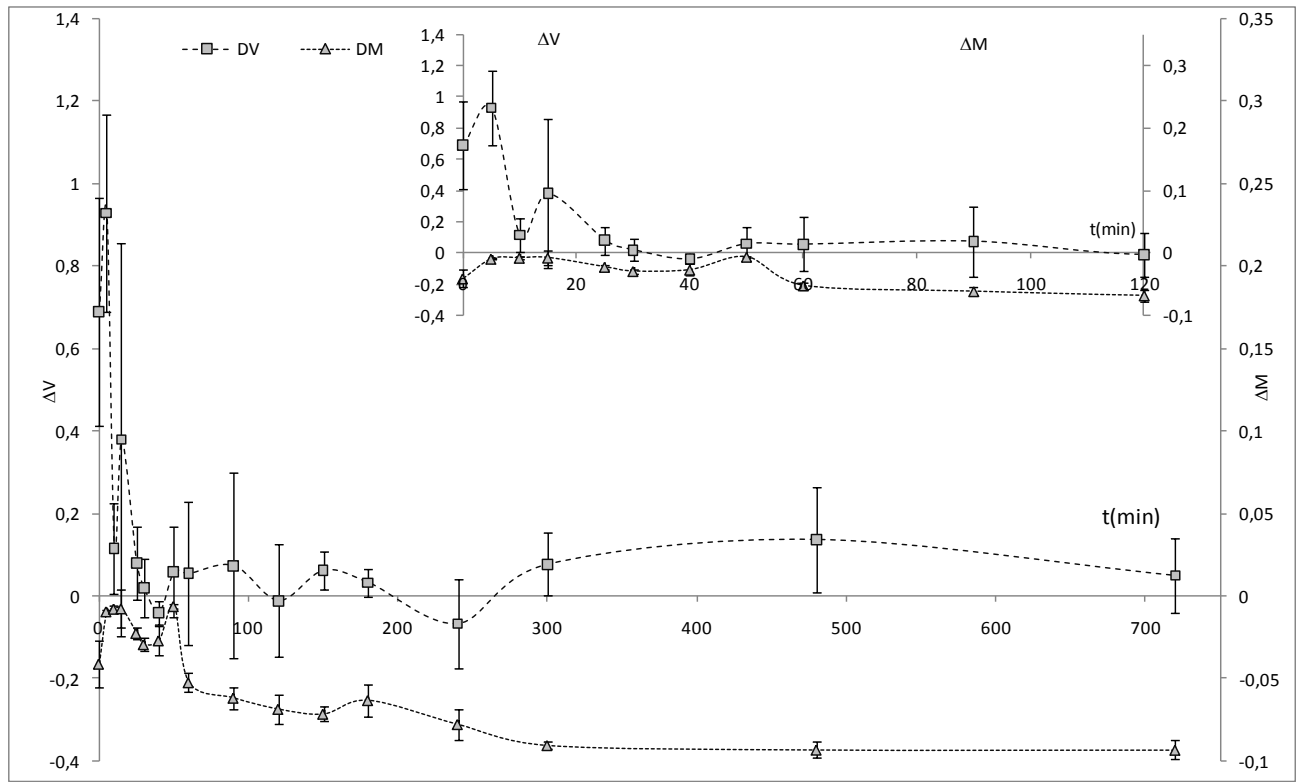

Figure 4. Mass $(\Delta)$ and volume $(\square)$ variation of the reposed samples (16h). On the top right, a detail of the beginning of the treatment can be appreciated.

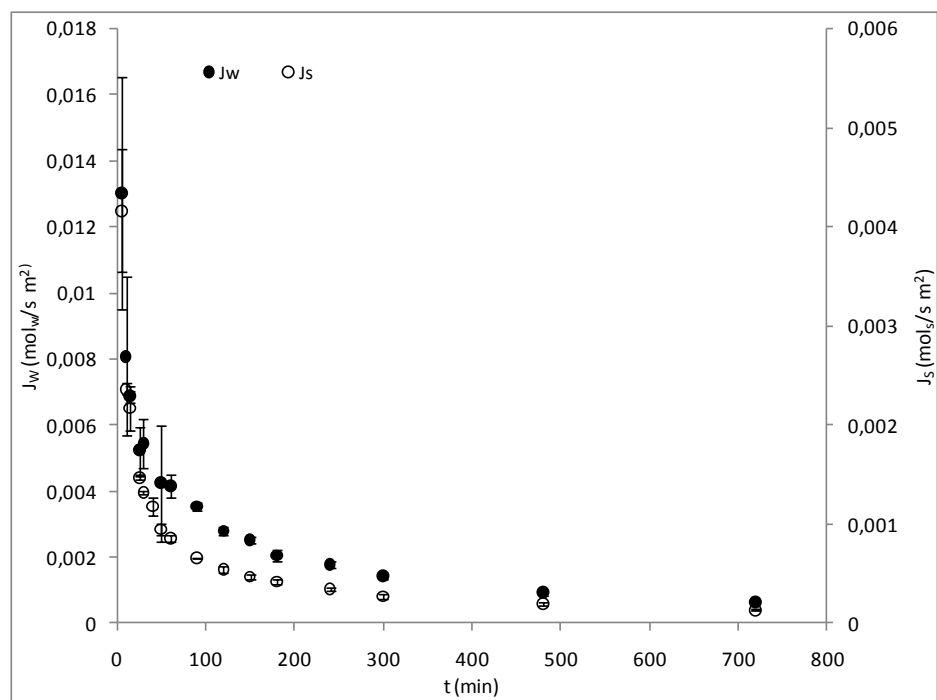

Figure 5. Water $(\bullet)$ and salt $(\circ)$ fluxes of the osmotic treatment $(0 \mathrm{~h})$

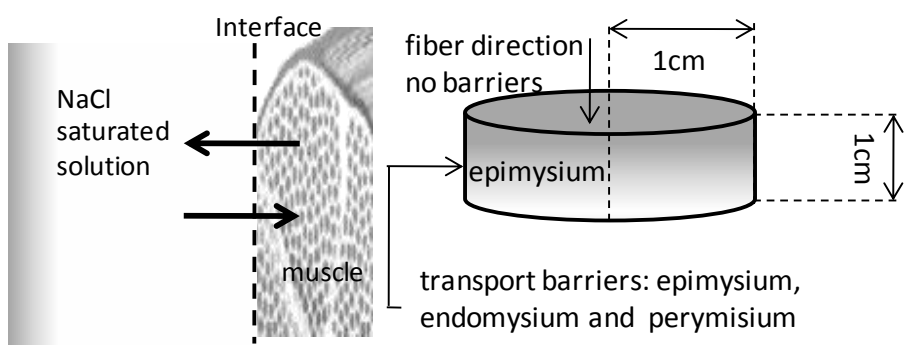

Figure 6. Scheme representing the interaction between meat sample and salt solution. 


\subsection{Non equilibrium thermodynamic approach}

In order to describe the different behaviours involved in the meat salting process, it has been developed a non-equilibrium thermodynamic approach considering the meat system as it is shown in the figure 6 . Meat samples were cut as cylinders with plane sides perpendicular to the fibers, performing the mass transfer in the way of the fibers through the internal continuous liquid phase.

In order to understand and to estimate the molecular transport through the interface, it is necessary to determine the free energy variation across the interface per mol of any chemical specie in motion. Gibbs free energy variation could be estimated in a biological tissue as is shown in the equation 6 (Demirel, 2002).

$$
\mathrm{dG}=-\mathrm{SdT}+\mathrm{VdP}+\mathrm{Fdl}+\psi \mathrm{de}+\sum_{\mathrm{i}} \mu_{\mathrm{i}} \mathrm{dn}_{i}
$$

where the effect of the electric field term depends on the valence of the ions per electric charge. In salt case the valence of chloride and sodium are annulled together, thus the term is null. The system is isotherm then the entropic term is neglected.

$$
\mathrm{dG}=\mathrm{VdP}+\mathrm{Fdl}+\sum_{\mathrm{i}} \mu_{\mathrm{i}} \mathrm{dn}_{\mathrm{i}}
$$

It is possible to develop the free energy variation per water mol (extended chemical potential of water) as (see equation 8):

$$
\Delta \mu_{w}^{e x t}=\frac{\Delta \mathrm{G}}{\Delta \mathrm{n}_{\mathrm{w}}}=\nu_{\mathrm{w}}^{-} \Delta \mathrm{P}+\mathrm{F}_{\mathrm{w}} \Delta \mathrm{l}+\mu_{\mathrm{s}} \frac{\Delta \mathrm{n}_{\mathrm{s}}}{\Delta \mathrm{n}_{\mathrm{w}}}+\mu_{\mathrm{w}}
$$

Developing the chemical potential of sodium chloride in equation 8 , it is obtained:

$$
\Delta \mu_{w}^{e x t}=\overline{v_{\mathrm{w}}} \Delta \mathrm{P}+\mathrm{F}_{\mathrm{w}} \Delta \mathrm{l}+\mathrm{R} T \ln \frac{x_{s}^{e} \cdot \gamma_{s}^{e}}{x_{s}^{i} \cdot \gamma_{s}^{i}} \frac{\Delta \mathrm{n}_{\mathrm{s}}}{\Delta \mathrm{n}_{\mathrm{w}}}+\mathrm{R} T \operatorname{Ln} \frac{a_{w}^{e}}{a_{w}^{i}}
$$

where $\gamma_{\mathrm{s}}$ was obtained from the bibliography (Lide, 2004); superscript $i$ represents the liquid phase of meat in the interface, and superscript $e$ represents the salt solution. The activity factor variation with the sodium chloride molar faction is shown in figure

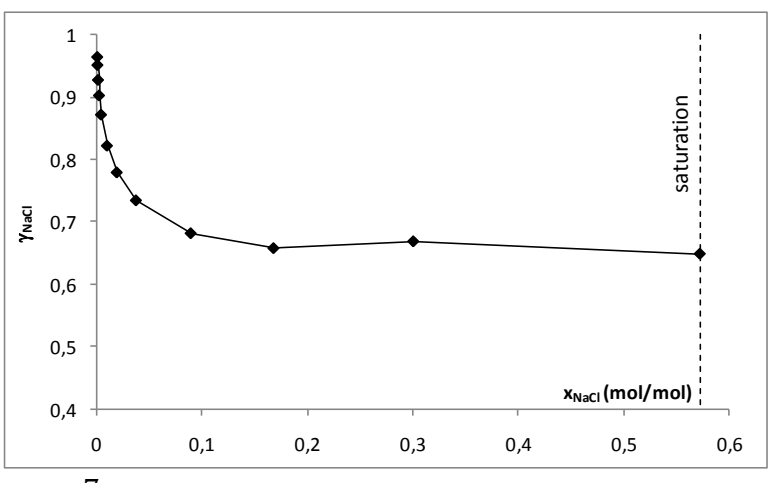

Figure 7. Activity factor variation versus sodium chloride molar fraction (Lide, 2004).
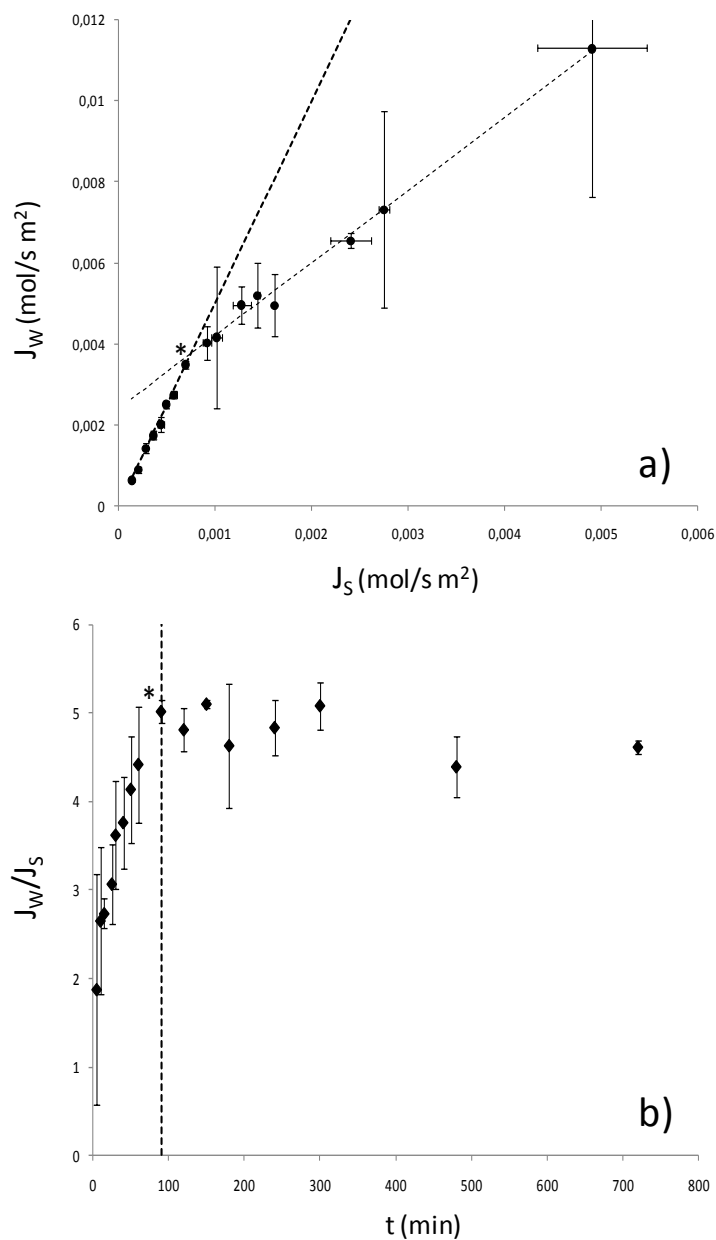

Figure 8. Relationship between salt and water molar fluxes. a) Water molar flux evolution with regard to the salt molar flux; b) ratio water/ salt molar flux variation though the salting process. (*) Critical Point (CP), represent the same time process when the water/salt ratio is steady.

The relation between the water and sodium chloride moles variation are proportional to the molar flux relation, then it is possible to use this relation in the equation 9 , obtaining:

$\Delta \mu_{w}^{e x t}=\overline{\nu_{\mathrm{w}}} \Delta \mathrm{P}+\mathrm{F}_{\mathrm{w}} \Delta \mathrm{l}+\mathrm{R} T \ln \frac{x_{s}^{e} \cdot \gamma_{s}^{e}}{x_{s}^{i} \cdot \gamma_{s}^{i}} \frac{\mathrm{J}_{\mathrm{s}}}{\mathrm{J}_{\mathrm{w}}}+\mathrm{R} T \operatorname{Ln} \frac{a_{w}^{e}}{a_{w}^{i}}$

Following the same development for the salt solute, the gradient of chemical potential extended for sodium chloride is presented in equation 11.

$$
\Delta \mu_{s}^{e x t}=\overline{v_{\mathrm{s}}} \Delta \mathrm{P}+\mathrm{F}_{\mathrm{s}} \Delta \mathrm{l}+\mathrm{R} T \ln \frac{x_{s}^{i} \cdot \gamma_{s}^{i}}{x_{s}^{e} \cdot \gamma_{s}^{e}}+\mathrm{R} T \operatorname{Ln} \frac{a_{w}^{i}}{a_{w}^{e}} \frac{\mathrm{J}_{\mathrm{w}}}{\mathrm{J}_{\mathrm{s}}}
$$


Applying the first relation of Onsager (Demirel, 2002; Gekas, 2001) water and salt fluxes may be related with the chemical potential extended, as an engine of the water and salt transport, with a phenomenological coefficients showed in equations 12 and 13

$$
\begin{aligned}
& J_{w}=L_{w} \cdot \Delta \mu_{w}^{e x t} \\
& J_{s}=L_{s} \cdot \Delta \mu_{s}^{e x t}
\end{aligned}
$$

Following the relation between water and salt fluxes it is possible to observe two different tendencies (Figure 8); these tendencies are related with the proportion between the mechanical and compositional behaviors, because mechanical behaviors involve fluid motions and the compositional mechanisms involve the motion of each chemical compound. Thus the critical point where the fluxes relation changes marks where the mechanical behaviors change relaxing or compressing the tissue.

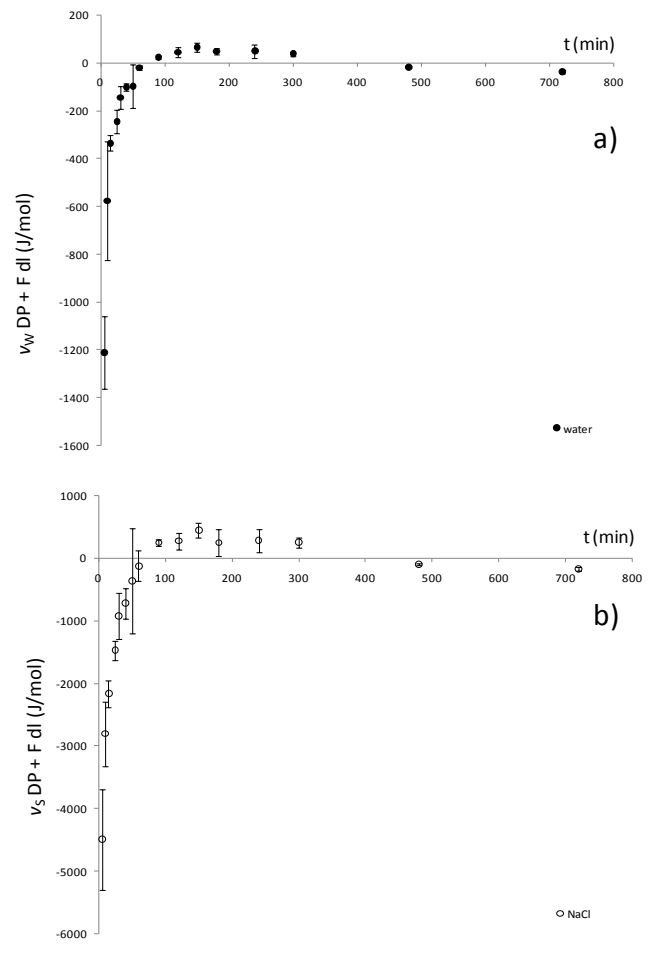

Figure 9. Variation of the mechanical part of the chemical potential for a) water and b) sodium chloride through the salting operation (Oh).

Then in this critical point the transport engine are the compositional components of the chemical potentials, so it must be estimated in this critical point as:

$$
\left.\Delta \mu_{w}^{e x t}\right|_{C P}=\mathrm{R} T \ln \frac{x_{s}^{e} \cdot \gamma_{s}^{e}}{x_{s}^{i} \cdot \gamma_{s}^{i}} \frac{\mathbf{J}_{\mathrm{s}}}{\mathbf{J}_{\mathrm{w}}}+\mathrm{R} T \operatorname{Ln} \frac{a_{w}^{e}}{a_{w}^{i}}
$$

$$
\left.\Delta \mu_{s}^{e x t}\right|_{C P}=\mathrm{R} T \ln \frac{x_{s}^{i} \cdot \gamma_{s}^{i}}{x_{s}^{e} \cdot \gamma_{s}^{e}}+\mathrm{R} T \operatorname{Ln} \frac{a_{w}^{i}}{a_{w}^{e}} \frac{\mathbf{J}_{\mathrm{w}}}{\mathbf{J}_{\mathrm{s}}}
$$

Consequently it is possible to estimate the phenomenological coefficient for each compound in motion, with the equations 14 and 15, obtaining for water $(2.7 \pm 0.5) \cdot 10^{-5} \mathrm{~mol}^{2} \mathrm{~s}^{-1} \mathrm{~m}^{-2} \mathrm{~J}^{-1}$ and for sodium chloride $(1.1 \pm 0.5) \cdot 10^{-6} \mathrm{~mol}^{2} \mathrm{~s}^{-1} \mathrm{~m}^{-2} \mathrm{~J}^{-1}$. Applying these phenomenological coefficients it is possible to estimate the mechanical behaviors involved in the interface interactions (Figure 9).

Animal was slaughtered 36 hours before the salting operation. In pork muscles, the rigor mortis process lasts between 4 and 18 hours at $4^{\circ} \mathrm{C}$ (Toldrá and Reig, 2006). In Red, Firm and Nonexudative meats the onset of rigor mortis is around 6-8 hours postmortem (Batlle et al., 2001). Rigor mortis process compresses the tissue storing mechanical energy in the fibers. The chloride ions bounded to the actin/myosin system (Offer and Trinick, 1983; Schmidt et al., 2008) relax the tissue, reducing the effect of the rigor mortis.

Mechanical free energy, developed in the thermodynamic approach, is plotted in figure 9, for water and for sodium chloride compounds. Three steps can be appreciated: an initial relaxation of the tissue, compressed throughout the rigor mortis; a contraction of muscle promoted for the fast relaxation of the elastic fibers; finally, salted samples reach the mechanical equilibrium.

\section{Conclusions}

The rigor mortis state affects the mechanical properties of meat tissue, and therefore determines the salting behaviours during salting treatment. It is possible to determine the different mechanisms involved in the salting process by using a non-equilibrium thermodynamic approach. There were determined three steps during the salting treatment of meat with saturated solution of sodium chloride: an initial relaxation of the tissue, compressed throughout the rigor mortis; a contraction of muscle promoted for the fast relaxation of the elastic fibers; finally, salted samples reach the mechanical equilibrium.

\section{Acknowledgements}

The authors acknowledge Valencian Government and the Conselleria d'Educació for the financial support of the project (GVPRE/2008/132).

\section{References}

April, E. W., Brandt, P.W. \& Elliot, G.F. (1972). The myofilament lattice: studies on isolated fibers II. The effects of osmotic strength, ionic concentration, and $\mathrm{pH}$ upon the unit-cell volume. J.Cell. Biol., 53, 53

Batlle, N., Aristoy, M.C. \& Toldrá, F. (2001). ATP metabolites during aging of exudative and nonexudative pork meats. Journal of Food Science, 66 (1), 68-71. 
Colligan, A., Bohuon, P., Deumier, F. \& Poligné, I. (2001). Osmotic treatment of fish and meat products. Journal of Food Engineering, 49, 153-162.

Demirel, Y. (2002). Chapter 1: Fundamentals of Equilibrium Thermodynamics, and Chapter 11: Thermodynamics and Biological Systems. In Y. Demirel (Ed.), Nonequilibrium Thermodynamics. Transport and Rate Processes in Physical, Chemical and Biological Systems (pp. 1-52, and pp. 541-598). Elsevier Science \& Technology Books, USA.

Elliot, G.F. (1968). Force-balances and stability in hexagonallypacked polyelectrolyte systems. J. Theoret. Biol., 21, 71-87.

Gekas, V. (2001). Mass transfer modeling. Journal of Food Engineering, 49, 97-102.

Gilbert, P.A. \& Heisler, G. (2004). Salt and health. Nutrition Bulletin, 30,62-69.

Goldman, Y.E., Matsubara, I.\& Simmons, R.M. (1979). Lateral filamentary spacing in frog skinned fibres in the relaxed and rigor states. Journal of Physiology, 295, 80-81P.

Hamm, R. (1960). Biochemistry of meat hydration. Advanced Food Research, 10, 355-463.

Hamm, R. (1975). Water-holding capacity of meat. In D.J.A. Cole, R.A. Lawrie (Eds), Meat (pp. 321-338). Butterworth \&co., London, UK.

Hamm, R. (1981).Post-mortem changes in muscle as affecting the quality of comminuted meat products. In R.A. Lawrie (Ed.) Developments in Meat Science - 2, (pp. 93-124). Pergamon press, London .

Huff-Lonergan, E. \& Lonergan, S.M. (2005). Mechanisms of water holding capacity of meat: the role of postmortem biochemical and structural changes. Meat Science, 71, 194-204.

ISO 1442:1997. (1997). Methods of test for meat and meat products. Determination of moisture content. BS 4401-3:1997

Le Meste, M., Lorient, D.\& Simatos,D. (2002). L'eua dans aliments. Editions Tec \& Doc, Paris.

Lide, D.R. (2004). Thermochemistry, Electrochemistry, and Kinetics. In D.R. Lide (Ed.), CRC Handbook of chemistry and physics, 84th edition (pp.5-100). Boca Raton, FL: CRC Press, USA.

Matsubara, I. \& Elliott, G.F. (1972). X-ray diffraction studies on skinned single fibres of frog skeletal muscle. J.Mol.Biol, 72, 657669.

Matthews, K. \& Strong, M. (2005). Salt-its role in meat products and the industry's action plan to reduce it. British Nutrition Foundation Nutrition Bulletin, 30,55-61.
Millman, B.M. \& Nickel, B.G. (1980). Electrostatic forces in muscle and cylindrical gel systems. Biophysical Journal, 32, 49-63.

Millman, B.M. (1981). Filament lattice forces in vertebrate striated muscle: relaxed and in rigor. J. Physiol, 320,118P.

Millman, B.M., Racey, T.J., \& Matsubara,I. (1981). Effects of hyperosmotic solutions on the filament lattice of intact frog skeletal muscle. Biophysical Journal, 33, 189-202.

Offer, G. \& Trinick, J. (1983). On the mechanism of water holding in meat-the swelling and shrinking of myofibrils. Meat Science, 8, 245-281.

Offer, G. \& Cousin, T. (1992). The mechanism of drip productionformation of two compartments of extracellular-space in muscle post-mortem. Journal of the Science of Food and Agricultural, 58, 107-116.

Rome, E. (1967). Light and x-ray diffraction studies of the filament lattice of glycerol-extracted rabbit muscle. Journal of Molecular Biology, 27, 591-602.

Rome, E. (1968). X-ray diffraction studies of the filament lattice of striated muscle in various bathing media. Journal of Molecular Biology, 37(2), 331-344.

Rome, E. (1972). Relaxation of glycerinated muscle:low-angle x-ray diffraction studies. Journal of Molecular Biology, 65(2), 331-345.

Schmidt, F.C. (2006). Estudo das trocas de massa durante o tratamento de cortes de peito de frango com soluções salinas.In Dissertação (mestre em Engenharia de Alimentos). Universidade Federal de Santa Catarina, Brazil.

Schmidt, F.C., Carciofi, B.A.M. \& Laurindo, J.B. (2008). Salting operational diagrams for chicken breast cuts: hydrationdehydration. Journal of Food Engineering, 88, 36-44.

Toldrá, F. \& Reig. M. (2006). Biochemistry of raw meat and Poultry. In Y. H. Hui, Wai-Kit Nip, Leo M. L. Nollet, Gopinadhan Paliyath, Benjamin K. Simpson (Eds.), Food Biochemistry and Food Processing (pp. 293-314). Blackwell Publishing, USA

Volpato, G. Michielin, E.M.Z., Ferreira, S.R.S.\& Petrus, J.C.C. (2007) Kinetics of the diffusion of sodium chloride in chicken breast (Pectoralis major) during curing. Journal of Food Engineering, 79, 779-785. 



\title{
Application of microwaves dielectric spectroscopy for controlling pork meat (Longissimus dorsi) salting process
}

\author{
M. Castro-Giráldez, P.J. Fito*, P. Fito \\ Instituto Universitario de Ingeniería de Alimentos para el Desarrollo, Universidad Politécnica de Valencia, Camino de Vera, s/n, 46022, Valencia, Spain
}

ARTICLE INFO

Article history:

Received 10 September 2009

Received in revised form October

2009

Accepted 15 November 2009

Available online 18 November 2009

Keywords:

Dielectric properties

Dielectric spectra

Microwaves

Sensor

Salting process

Pork meat

\begin{abstract}
A B S T R A C T
Salting treatment is a common operation in the production of high quality meat products, one of its main problems is the difficulty to control the simultaneous water and salt fluxes into the product and control the protein fibers transformation throughout process. Dielectric properties of salted porcine meat are strongly related to its structure and composition. Thus, dielectric properties measurement appears as a promising method for controlling on-line the salting process in meat industry. Dielectric spectroscopy studies have been performed on raw and salted longissimus dorsi pork samples. Dielectric spectra were measured in the frequency range from $500 \mathrm{MHz}$ to $20 \mathrm{GHz}$ by an Agilent 85070E open-ended coaxial probe connected to an Agilent E8362B Vector Network Analyzer immediately after salting process and also 16 hours. Salt content, moisture, water activity and volume were also measured. It has been demonstrated that the dielectric properties are a good tool to analyze the share of the added sodium chloride molecules in the muscle tissue during the salting treatment (bounded and solved ions).
\end{abstract}

(c) 2010 Elsevier Ltd. All rights reserved.

\section{Introduction}

Currently food industries are subjected to important challenges such as the market internationalization and economy globalization, which provokes a high competency and forces the industries to constant innovation, technological evolution and to respond with efficiency to habits changes of an exigent consumer. Thus, the industries have to concentrate its efforts in two main areas: process innovations and product innovations. Process innovation leads to the application of novel technologies. Process improvements produce safety and high quality products which are directly related to consumer exigencies. In this context, modern sensors play an important role and suppose a great advance for controlling concrete properties of foods. These sensors are based on electromagnetic radiation, ultrasounds and resonance techniques. Some industrial applications are being developed and lots of efforts are being made in order to obtain sensors for controlling food quality directly in process-line and in a non-destructive way.

${ }^{*}$ Corresponding author. Tel.: +34 963877369

E-mail address: pedfisu@tal.upv.es (P.J.Fito).
Dielectric spectroscopy is one of the most important techniques for chemical and physical material analysis in some research fields: medicine (Aimoto and Matsumoto, 1996; Fear et al., 2002, 2003; Peebles et al., 1992), pharmaceutical industry (Smith et al., 1995), science of materials (Adous et al., 2006; Goy et al., 1992; Martín et al., 2004). It has also been widely used in food technology for controlling some quality factors: salt content (De los Reyes et al., 2006b, 2007b; Kent et al., 2000a; Shiinoki et al., 1998), detection of milk bacteria (Váczy and Semberg, 2003). This technique has also been used in the microwave region for controlling meat and fish products. In this direction, one of the main applications which is being developed in the Clermont-Ferrand INRA Centre (French National Institute for Agricultural Research) is the determination of meat and fish freshness (Clerjon and Damez, 2007). It was also employed to detect added water in fish and meat products (Daschner et al., 2000; Daschner and Knöchel, 2003; Kent et al., 2000a, 2001, 2002). Kent and Stroud (1999) reported a method for determining added glaze in frozen foods. This method has also been employed to predict fat composition in fish and meat products (Borgaard et al., 2003; Kent, 1990; Kent et al., 1993, 2007). It 
was also studied the application of dielectric spectroscopy technique to discriminate the different pork meat quality classes (Pale Soft and Exudative, Dark Firm and Dry and Red Firm and Non-exudative) (Castro-Giráldez et al., 2007). In conclusion, dielectric spectroscopy is a useful tool for controlling the quality of food products and processes (Miura et al, 2003).

Dielectric spectroscopy determines the dielectric properties of the sample as a function of frequency. Complex permittivity $\left(\varepsilon^{*}\right)$ (Equation 1$)$ is the dielectric property that describes food behaviour when is subjected under an electromagnetic field (Metaxas and Meredith, 1993; Nelson and Datta, 2001). The real part of complex permittivity is called the dielectric constant $\left(\varepsilon^{\prime}\right)$ and the imaginary part is called loss factor $(\varepsilon ")$. The dielectric constant is related with the material ability to store energy, and the dielectric loss factor is related to the absorption and dissipation of the electromagnetic energy in other kinds of energy.

$$
\varepsilon^{*}=\varepsilon^{\prime}+i \varepsilon^{\prime \prime}
$$

Permittivity decrease with frequency increase in different steps called dispersions. It is important to highlight that these dispersions are not produced instantaneously and are characterized by the correspondent relaxation phenomena (Schwan, 1988). Relaxation phenomena are produced at microwave and radio frequencies and characterize, with the conductivity, the dielectric behavior of biological tissues at these frequencies (CastroGiráldez et al., 2010a). In biological systems, there are four relaxation regions: $\alpha, \beta, \delta$ and $\gamma$ (Gabriel, $2006)$. Each relaxation process occurs in a specific frequency range and allows to identifying different phenomena. At the frequencies employed in present work, the $\gamma$ - is the main dispersion (Figure 1). The $\gamma$-dispersion, also called orientation polarization, is located at $\mathrm{GHz}$ region, and it is due to the polarization dipoles, fundamentally free water molecules.

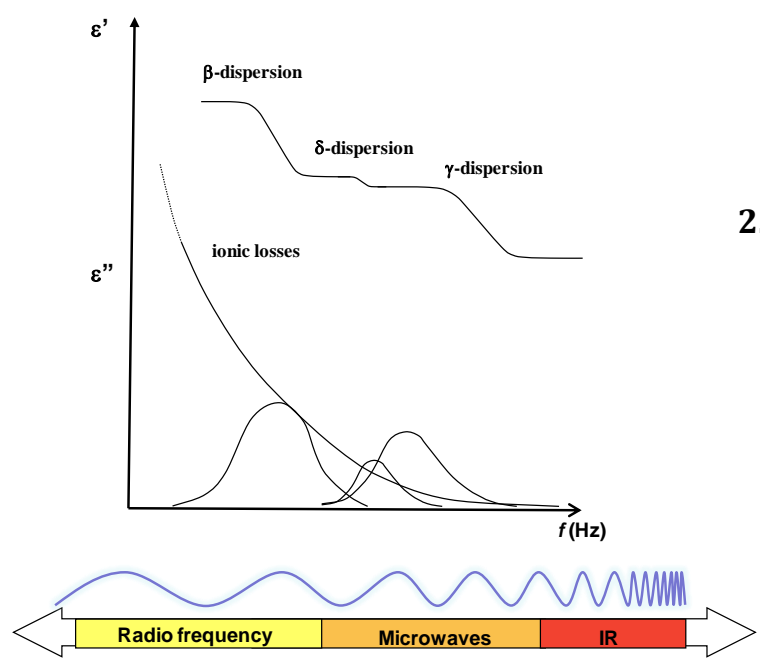

Figure 1. Ideal representation of dielectric constant and loss factor spectra in biological tissue.
The $\delta$-dispersion is located between the $\beta$, and $\gamma$, and is mainly due to the rotation of amino acids, rotation of charged side groups of proteins, and the relaxation of water interacting with proteins (Schwan, 1981; Castro-Giráldez et al., 2010a). The $\beta$ dispersion or interfacial polarization is mainly due to Maxwell-Wagner effect. This effect is produced due to interfacial phenomena on heterogeneous materials (Feldman et al. 2003).

In some cases it could be interesting to analyze the energy dissipation of these relaxation phenomena in terms of loss factor spectra. Loss factor can be expressed by the equation 2 , which reflects the different contribution phenomena to the loss factor spectrum in the frequency range of the present study.

$$
\varepsilon^{\prime \prime}=\varepsilon_{d}^{\prime \prime}+\frac{\sigma}{\varepsilon_{0} \omega}
$$

where, $\varepsilon d$ " represents the loss factor caused by the dipolar orientation or dipolar relaxation.

$\sigma / \varepsilon_{0} \omega$ represents the loss factor due to effect of ionic conductivity, where $\sigma, \varepsilon_{0}$ and $\omega$ are the conductivity of the material, the dielectric constant in vacuum and the angular frequency, respectively. It is important to highlight that ionic conductivity only introduces losses into the material when exposed to electromagnetic energy. This effect could be important in meat salting processes due to the fact that ionic losses could hide dipolar losses effect (Figure 2). In figure 2 it can be appreciated the effect of $\mathrm{NaCl}$ in water solutions with regard to pure water spectra. It was also represented the Cole\&Cole diagram.

As it has been explained along the whole introduction dielectric spectroscopy occupies an important place among the moderns measurement methods employed for chemical and physical analysis of materials. Theoretically, there could be a correlation between water and salts content with the electromagnetic characteristics of the pork meat. Measuring the dielectric properties of the product could result as an appropriate method to control the salting processes. So the objective of this work is to analyze the viability of controlling salting meat processes by using dielectric properties measurements at microwaves frequencies.

\section{2. Material and Methods}

Experiments were done using pork meat (Longissimus dorsi) samples. The meat was collected at 1,5 days postmortem. A diagram of the experimental procedure is shown in figure 3 . For the salting treatment it was employed $25 \%(\mathrm{w} / \mathrm{w}) \mathrm{NaCl}$ brine, the treatment was made at the controlled temperature of $4{ }^{\circ} \mathrm{C}$. 54 meat cylinders $(15 \mathrm{~mm}$ diameter and $10 \mathrm{~mm}$ thick) were cut. Samples were dipped in solution for $0,5,10,15,25,30,40,50,60$, 90, min, 2, 2.5, 3, 4, 5, 8 and 12 hours. After treatment, samples were equilibrated in an isothermal chamber at $4^{\circ} \mathrm{C}$ during 16 hours. 
The surface water activity was determined by a dew point hygrometer Decagon (Aqualab®, series $3 \mathrm{TE}$ ), with precision $\pm 0,003$. Measurements were done in structured samples (not minced), thus $\mathrm{a}_{\mathrm{w}}$ obtained is considered to be surface $\mathrm{a}_{w}$.Water content was determined by drying at $110^{\circ} \mathrm{C}$ at atmospheric pressure, following the ISO 1442 (1997), for meat products. Samples weight was determined by a precision balance Mettler Toledo AB304-S ( \pm 0.001$)$. Volume was determined by Image analysis (Sony T90, Carl Zeiss optics), using Adobe Photoshop (C) software, obtaining surface and height by triplicate. Ion chloride content was obtained by argentometric titration of $500 \mu \mathrm{l}$ of the sample extract with a Sherwood model 926 Chloride Analyser.

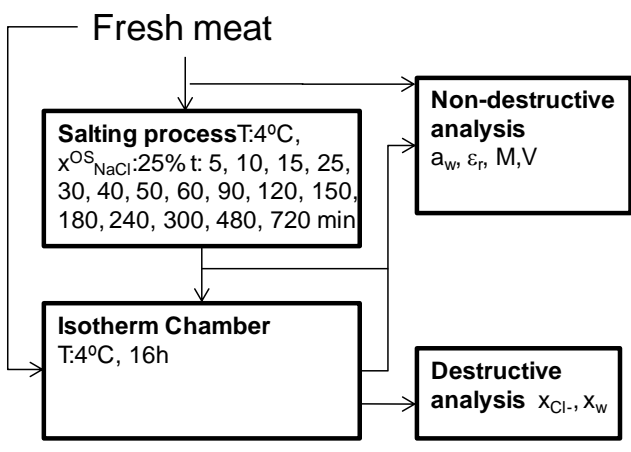

Figure 3. Experimental flowchart

\subsection{Dielectric properties measurement}

The system used to measure dielectric properties consists on an Agilent 85070E Open-ended Coaxial Probe connected to an Agilent E8362B Vector Network Analyzer (Figure 4). The software of the Network Analyzer calculates the dielectric constant and loss factor as a reflected signal function. For these measurements the probe was fixed to a stainless steel support, and an elevation platform brings the sample near the probe to avoid possible phase changes due to cable movements after calibration.

The system was calibrated by using three different types of loads: open circuit (air), short-circuit and $25^{\circ} \mathrm{C}$ distilled water. Once the calibration was made, $25^{\circ} \mathrm{C}$ distilled water was measured again to check calibration suitability.

The dielectric properties were measured by attaching the probe to the surface of the samples. Dielectric spectra of meat samples were measured following the direction of the fibers and avoiding fat phase of the meat. The Mean values of three replicates of the pork loin samples are reported in this article. All determinations were made at $4{ }^{\circ} \mathrm{C}$ from $500 \mathrm{MHz}$ to $20 \mathrm{GHz}$.

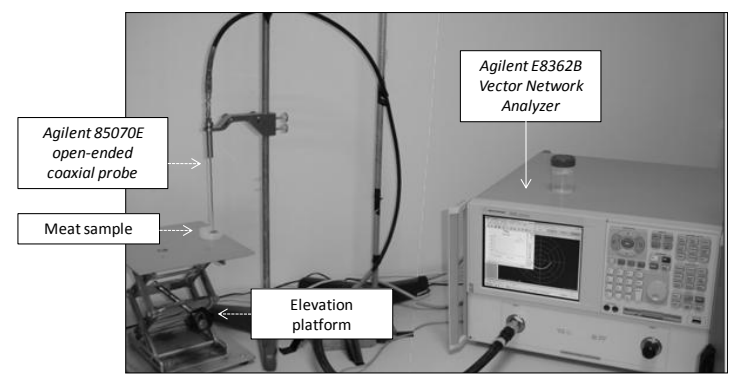

Figure 4. Measurement of fresh and salted meat samples dielectric properties with an Agilent $85070 E$ open-ended coaxial probe connected to an Aailent E8362B Vector Network Analvzer.

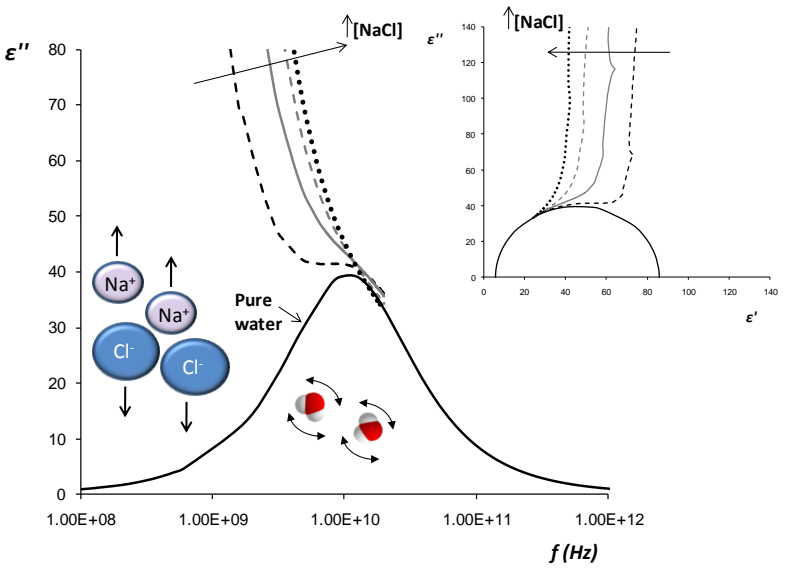

Figure 2. Loss factor spectra of Sodium Chloride solutions. It is also represented in the right top the Cole\&Cole diagram.

\section{Results and discussion}

Meat samples were analyzed just after the salting treatment, a non-equilibrium internal system, and after 16 hours of the salting operation. During the 16 hours of repose, the samples were in decagon containers preserved in an isothermal chamber and closed with parafilm in order to isolate the samples and to reach the internal equilibrium.

The salting operation with chloride salts in postmortem muscle produces compression and relaxation behaviours of muscle fibers (Schmidt et al., 2008). These mechanisms could be observed by using the next equations:

$$
\begin{aligned}
& \Delta \mathrm{M}^{\mathrm{j}}=\frac{\mathrm{M}^{\mathrm{t}}-\mathrm{M}^{0}}{\mathrm{M}^{0}} \\
& \Delta \mathrm{M}_{\mathrm{i}}^{\mathrm{j}}=\frac{\mathrm{M}^{\mathrm{t}} \cdot \mathrm{x}_{\mathrm{i}}^{\mathrm{t}}-\mathrm{M}^{0} \cdot \mathrm{x}_{\mathrm{i}}^{0}}{\mathrm{M}^{0}}
\end{aligned}
$$

where $\mathrm{M}$ represents the mass $(\mathrm{kg}), \mathrm{x}$ is the mass fraction $(\mathrm{kg} / \mathrm{kg})$, the superscript $\mathrm{t}$ is treatment time and 0 is initial value, and superscript $j$ is the variation though the treatment $(0 \mathrm{~h})$ (nonequilibrated sample) or in repose (16 h) (equilibrated).

Figure 5 shows total, water and salt mass variation through the osmotic treatment.

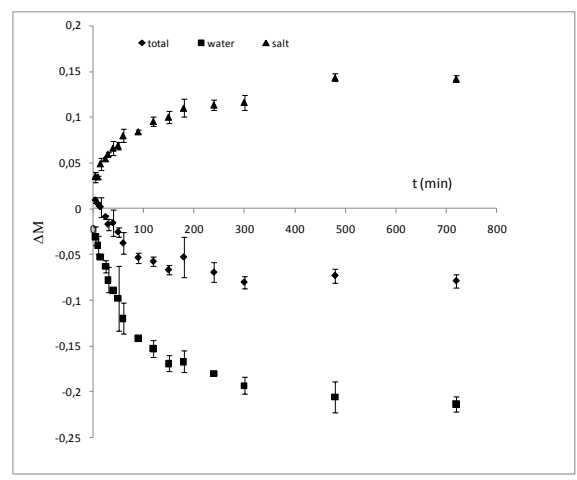

Figure 5. Total mass variation of meat samples during the osmotic treatment. The water and salt mass variation through the osmotic treatment are also shown. 


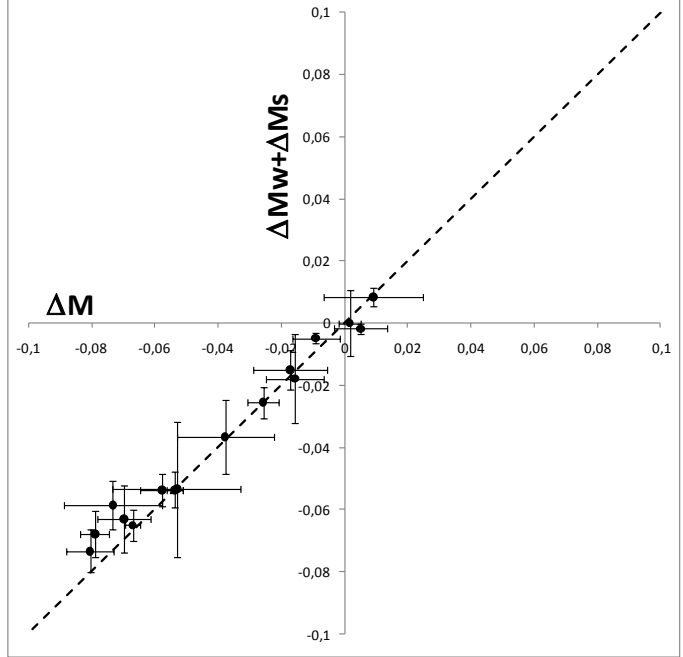

Figure 6. Mass balance of meat samples through the osmotic treatment.

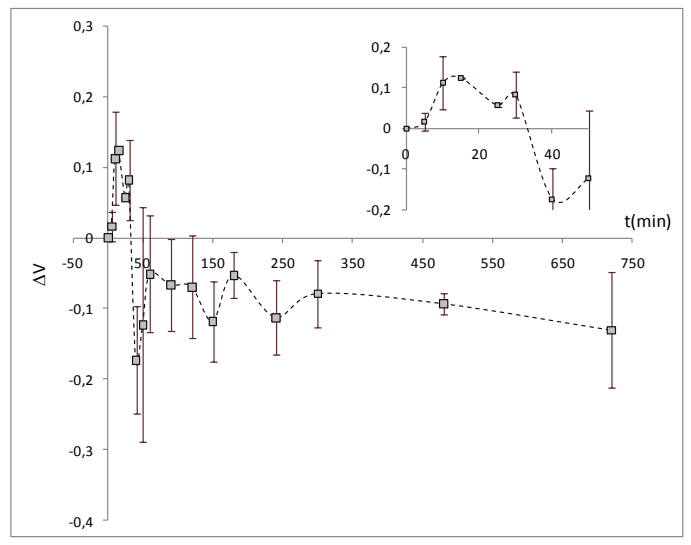

Figure 7. Volume variation through the salting process

It is possible to observe an initial increase of the total mass and a second step of total weight lost. These two steps do not appear in the water and the salt variation curves, which decrease and increase respectively with the osmotic treatment time.

Figure 6 shows the relation between the overall meat mass variation and the water and sodium chloride mass variation; a line with slope one shows the mass balance through the salting operation as $\Delta \mathrm{M}=\Delta \mathrm{M}_{\mathrm{w}}+\Delta \mathrm{M}_{\mathrm{s}}$. The fact that the data are located on the line with slope one confirms that the meat mass variation is only due to the variation of water and sodium chloride.

It was also studied the volume variation during the salting treatment (Figure 7) by using the equation 5 .

$$
\Delta \mathrm{V}^{\mathrm{j}}=\frac{\mathrm{V}^{\mathrm{t}}-\mathrm{V}^{0}}{\mathrm{~V}^{0}}
$$

where $\mathrm{V}$ represents the volume $\left(\mathrm{m}^{3}\right)$ the superscript $\mathrm{t}$ is treatment time and 0 is initial value, and superscript $\mathrm{j}$ is the variation though the treatment (0h).

In figure 7, it can be appreciated an initial increase of volume, and a second step with losses of volume. These two steps are accompanied by the same steps in total mass variation as was exposed in figure 5 . The initial increase of volume is related to the interaction between ion chloride with the myosin and the actin filaments of the muscle fibers sites, the accumulation on anions produces repulsion in the actin-myosin system expanding the perimysium and endomysium (Offer and Cousin, 1992). So the immersion of the sample in the solution produces an initial enlargement of the lattice, producing mechanical bulk flow of salt solution, swelling the sample; this behaviour is known as "salting in". Then, the high water flux leaving the tissue by diffusion mechanism reduces the overall mass of the system. This behaviour produces weight and volume lost.

Water and salt fluxes analysis are fundamental to understand the relaxation-compression behaviours. The water and salt fluxes promoted in the osmotic treatment can be calculated with the mass variation, the process time and the variation of the samples surface (see next equations).

$$
\begin{aligned}
& \mathrm{J}_{\mathrm{w}}^{0 \mathrm{~h}}=\frac{-\Delta \mathrm{M}_{\mathrm{w}}^{0 \mathrm{~h}} \cdot \mathrm{M}_{\mathrm{o}}}{\Delta \mathrm{t} \cdot \mathrm{S} \cdot \mathrm{Mr}_{\mathrm{w}}} \\
& \mathrm{J}_{\mathrm{s}}^{0 \mathrm{~h}}=\frac{\Delta \mathrm{M}_{\mathrm{s}}^{0 \mathrm{~h}} \cdot M_{o}}{\Delta \mathrm{t} \cdot \mathrm{S} \cdot \mathrm{Mr}_{\mathrm{s}}}
\end{aligned}
$$

Where, $\mathrm{J}$ is a flux $\left(\mathrm{mol} / \mathrm{s} \mathrm{m}^{2}\right)$, ? $\mathrm{t}$ is the process time, $\mathrm{S}$ is the average measured surface of the sample during treatment $\left(\mathrm{m}^{2}\right), \mathrm{Mr}$ is the molecular weight of compound $(18 \mathrm{~g} / \mathrm{mol}$ for water and $58.4 \mathrm{~g} / \mathrm{mol}$ for sodium chloride), the subscripts $\mathrm{w}$ represents water and s salt, respectively.

In figure 8 it is possible to observe the water and salt molar fluxes estimated with the equations 6 and 7 Water flux is promoted by diffusional mechanisms (high gradient of water activities between salt solution and samples) and mechanical mechanisms (relaxation and compression of the samples tissue).

Water and sodium chloride cross the interface (salt solution/meat system) and both compounds produce accumulation in the samples, water negative and salt positive. The water accumulation is distributed in moles involved in adsorption behaviours in the tissue (ADS), and in molecules of the liquid phase (LP). It can be estimated with the water flow rate $\left(\mathrm{J}^{0 \mathrm{~h}_{\mathrm{w}}} \mathrm{S}_{\mathrm{i}}\right)$ (see equation 8).

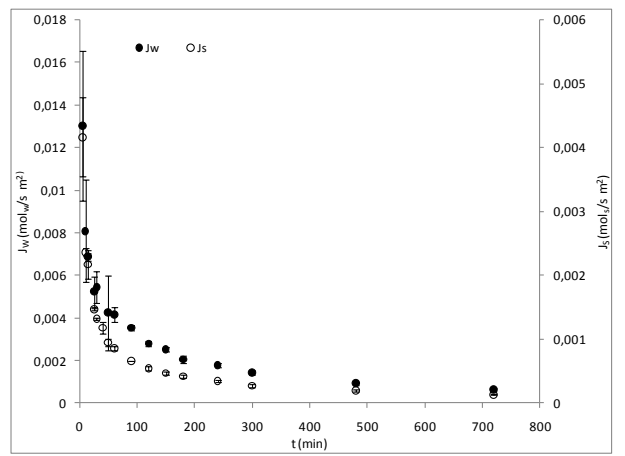

Figure 8. Water and salt fluxes of the osmotic treatment (0h) 


$$
\mathrm{J}_{\mathrm{w}}^{\mathrm{Oh}} S_{i}=\left|\frac{\partial n_{w}}{\partial t}\right|^{L P}+\left|\frac{\partial n_{w}}{\partial t}\right|^{A D S}
$$

In the range of the water activity of the samples, the variation of the quantity of water molecules adsorbed with regard to the overall water lost in samples is neglected, thus the molecular water flux comes from the liquid phase water accumulation.

The sodium chloride molar flux is divided in the accumulation of salt in the liquid phase (LP), and sodium and chloride ions interacting with the active sites of the meat tissue proteins (BN) (see equation 9).

$$
\mathbf{J}_{\mathrm{s}}^{0 \mathrm{~h}} S_{i}=\left|\frac{\partial n_{s}}{\partial t}\right|^{L P}+\left|\frac{\partial n_{s}}{\partial t}\right|^{B N}
$$

In order to distribute the salt molecules in the liquid phase and the salt molecules in bounding interactions with the tissue, the dielectric spectra of meat samples during the osmotic treatment were analyzed.

Figure 9, left plot, shows the loss factor spectra of meat samples through the salting process. It is possible to observe, at low frequencies, the higher loss factor values, corresponding this range of frequency with the contribution of ionic conductivity to loss factor spectrum. At high frequencies of the spectrum, low loss factor values can be observed, decreasing with treatment progression. In this range of frequencies the main effect is the dipolar orientation, mainly caused by water molecules orientation. The fact that at these frequencies the loss factor spectra decrease with treatment progression is due to the decrease in water mobility when ion content increases.

In figure 9, right plot, it is shown the variation of loss factor at four frequencies, where it is possible to observe higher differences at low frequencies (500 and $900 \mathrm{MHz}$ ). Moreover, it can be also observed an steady values in the loss factor in the middle of the salting process.

Water molecules interact with the electric field in the frequency range of the dipolar orientation phenomenon (near to $10 \mathrm{GHz}$ ), but water molecules are the solvent of the meat liquid phase and their motion hold the ions motion in the liquid phase solution. For this reason, the molar water flux that cross the interface salt solution/meat fibers could be related with the dielectric losses at frequencies of the ionic conductivity phenomenon.

Figure 10 shows the relation between molar water flux and the loss factor at $500 \mathrm{MHz}$, confirming the linear relation of water molecules flowing and the motion of ions in the liquid phase of meat samples.

Figure 11 shows the salt molar flux with regard to loss factor at the punctual frequency of $500 \mathrm{MHz}$. It can be appreciated in the figure two different tendencies: a linear relation at long treatment times (II), and an exponential relationship at the beginning of the salting treatment (I).

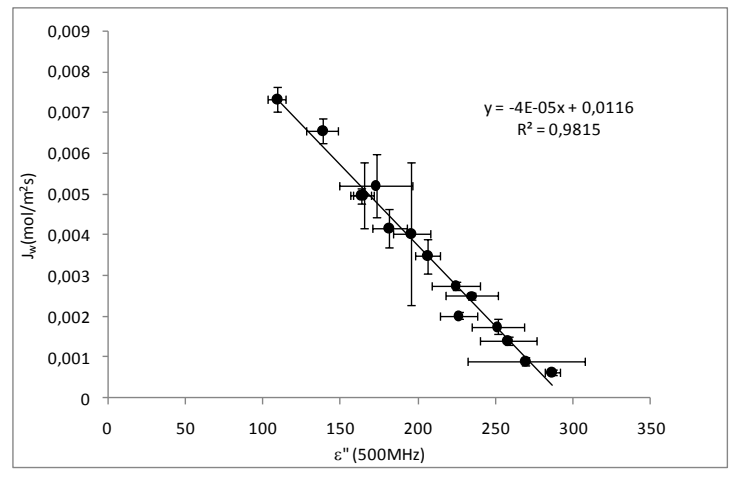

Figure 10. Water molar flux versus loss factor at $500 \mathrm{MHz}$ and at $4^{\circ} \mathrm{C}$.

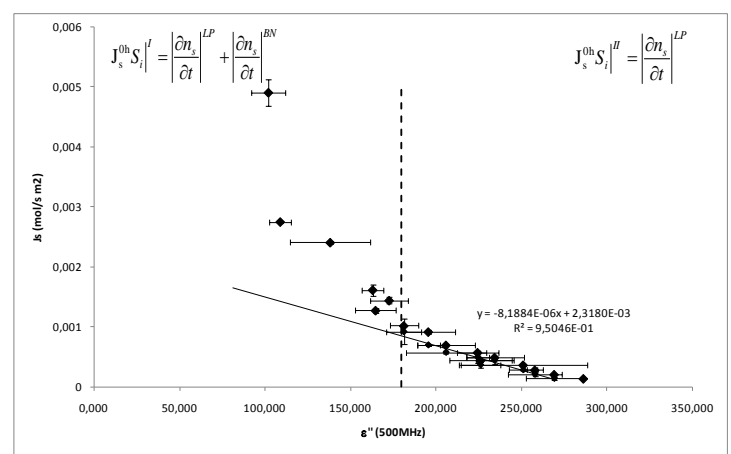

Figure 11. Salt molar flux versus loss factor at $500 \mathrm{MHz}$ and $4^{\circ} \mathrm{C}$
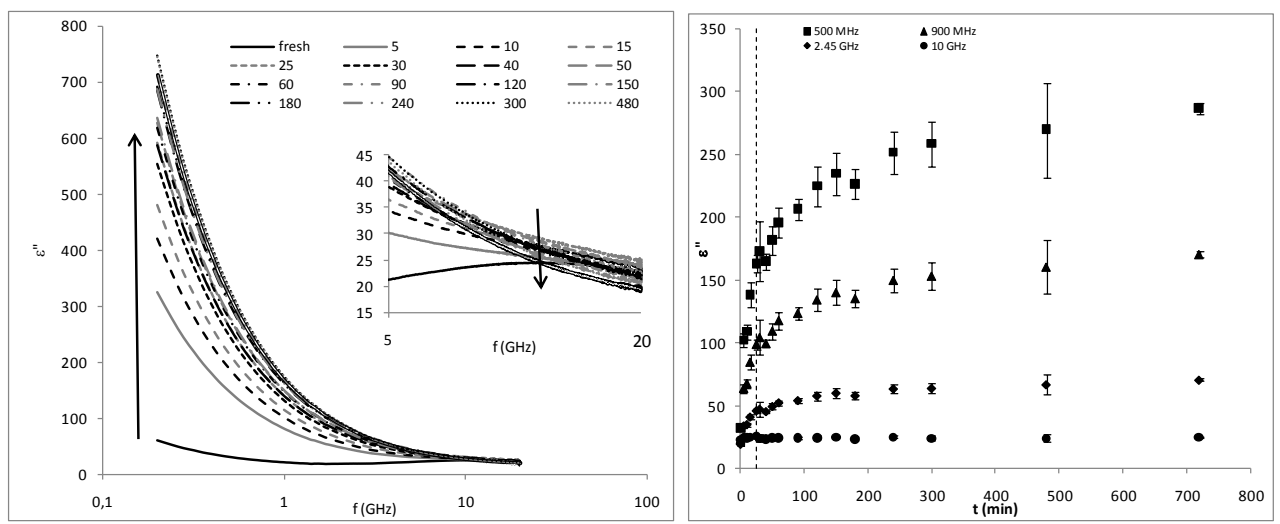

Figure 9. Dielectric properties of fresh and salted samples during the salting process. Left plot shows the loss factor spectra of samples, and right plot shows the evolution of the loss factor at punctual frequencies $(500 \mathrm{MHz}, 900 \mathrm{MHz}, 2.45 \mathrm{GHz}$ and $10 \mathrm{GHz})$ during the salting process. 
The ions bounded to active charges of the proteins can not be orientated by the electrical field. These bounds are produced at the beginning of the process, decreasing the ions present in the liquid phase and therefore the loss factor values. At long treatment times, all the active charges of proteins are already occupied by the ions, thus all the salt flux goes to the liquid phase of meat, being related directly with the loss factor values. Extending this linear relation between the salt molar flux and the loss factor from the stage II to the stage I, it is possible to determine the accumulation of ions bounded in the actine/miosine protein fibers. These two stages are defined by the different equations exposed in the figure 11 .

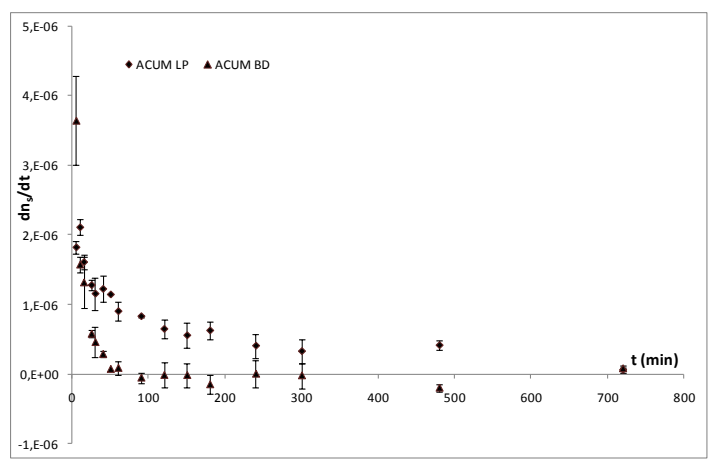

Figure 12. Evolution of the salt accumulation in samples.

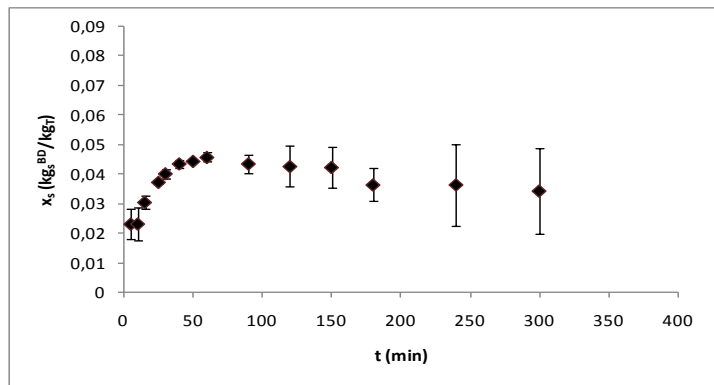

Figure 13. Evolution of the bounded ions concentration $(w / w)$ estimated with the accumulation term.

Consequently, it is possible to estimate the salt accumulation in the liquid phase with a linear regression in the second range of figure 11 , explained before. The rest of the accumulation is the salt accumulation in bounding processes with the fibers. Figure 12 shows the accumulation terms of salt in liquid phase and salt bounded in fibers. It can be appreciated that the salt accumulation of ions bounded in the actine/miosine protein fibers is produced in the first 60 minutes of salting treatment. Figure 13 shows the evolution of the bounded ions concentration estimated with the equation 10 , where salt maximum concentration $(0.045 \pm 0.006)$ has been reached in 60 minutes.

$$
\left.\mathrm{x}_{\mathrm{s}}^{\mathrm{BN}}\right|^{\mathrm{t}}=\left.\mathrm{x}_{\mathrm{s}}^{\mathrm{BN}}\right|^{\mathrm{t}-1} \cdot \frac{\mathrm{M}_{\mathrm{t}-1}}{\mathrm{M}_{\mathrm{t}}}+\left|\frac{\partial \mathrm{n}_{\mathrm{s}}}{\partial \mathrm{t}}\right|^{\mathrm{BN}} \cdot \frac{(t-(t-1)) \cdot \mathrm{M}_{\mathrm{rS}}}{\mathrm{M}_{\mathrm{t}}}
$$

Where $\mathrm{x}^{\mathrm{BN}}{ }_{\mathrm{S}}{ }^{\mathrm{t}}$ is the mass fraction of ions of sodium and chloride bounded to the fibers in t time, $\left.\mathrm{x}^{\mathrm{BN}}\right|_{\mathrm{s}} ^{\mathrm{t}-1}$ is the same mass fraction obtained in the previous time $\mathrm{t}, \mathrm{M}_{\mathrm{rs}}$ is the molecular weight and $\mathrm{m}$ is the corresponding overall mass of $\mathrm{t}$ and $\mathrm{t}-1$.

\section{Conclusions}

The sodium chloride, gained in the salting treatment, is divided in that of the liquid phase inside and outside the fiber cells; and that which is interacting to meat fibers proteins, myosin/actin system. Therefore, water molecules lost through the treatment come from the liquid phase. The motion of sodium chloride molecules is related to the motion of water molecules, being possible to correlate the water flux with the loss factor at frequencies of ionic conductivity phenomena $(500 \mathrm{MHz})$. The same occurs with the salt molecules from the liquid phase which can be determined by using dielectric properties. Subtracting them to the overall salt molecules, it is possible also to determine the bounded salt molecules to the myosin/actin system.

It has been demonstrate that the dielectric properties are a good tool to analyze the share of the sodium chloride molecules in the muscle tissue during the salting treatment.

\section{Acknowledgements}

The authors acknowledge Valencian Government and the Conselleria d'Educació for the financial support of the project (GVPRE/2008/132).

\section{References}

Adous, M., Quéffélec,P. \& Laguerre, L. (2006). Coaxial/cylindrical transition line for broadband permittivity measuremento civil engineering materials. Meas. Sci. Technol., 8,22412246.

Aimoto, A. \& Matsumoto, T. (1996). Non-invasive method for measuring the electrical properties of deep tissues using an open-ended coaxial probe. Med. Eng. Phys., 18, 641-646.

Borgaard, C., Christensen, L.B. \& Jespersen, Bo L. (2003) Reflection mode microwave spectroscopy for on-line measurement of fat in trimmings. In 49th ICoMST, 31 august- 5 september, Campinas, Brazil.

Castro-Giráldez, M, Fito, P.J., Toldrá, F. \& Fito, P. (2010a). Physical sensors for quality control during processing. In Fide Toldrá (Ed.), Handbook of Meat Processing (443-456) Wiley-Blackwell Publishing, U.S.A.

Castro-Giráldez, M., Toldrá, F. \& Fito, P. (2007). Dielectric spectroscopy studies as a tool for quality control in meat industry. In Proceedings of Food-New Options for the Industry Congress (EFFOST 2007), Lisbon, Portugal.

Clerjon, S. \& Damez, J.L. (2007). Microwave sensing for meat and fish structure evaluation. Measurement Science and Technology, 18(4), 1038-1045. 
Daschner, F. \& Knochel, R. (2003). Dielectric microwave sensors with multivariate calibration. Advances in Radio Science, 1 , 9-13

Daschner, F., Kent, M., Knochel, R. \& Berger, U.K. (2000) Optimization of the microwave determination of water in foods using principal component analysis. In Instrumentation and Measurement Technology Conference, 2000. IMTC 2000. Proceedings of the 17th IEEE. 1,12-16.

De los Reyes, R., Haas, C., Andrés, A., Fito, P. \& De los Reyes, E. (2006b). Dielectric Spectroscopy Studies of "Salted Cod Water" systems during the Desalting Process. In Proceedings of "International Microwave Power Institute's 40th Annual Symposium", Agoust 9-11, Boston, Massachusetts, U.S.A

De Los Reyes, R., Heredia, A., Fito, P., De los Reyes, E. \& Andrés, A (2007b). Dielectric spectroscopy of osmotic solutions and osmotically dehydrated tomato products. Journal of food engineering, 80(4),1218-1225.

Fear, E.C., Hagness, S.C., Meaney, P.M., Okoniewski, M. \& Stuchly, M.A. (2002). Enhancing breast tumor detection with nearfield imaging. IEEE Microwave magazine, 3(1), 48-56.

Fear, E.C., Meaney, P.M. \& Stuchly, M.A. (2003). Microwaves for breast cancer detection?. IEEE Potentials, 22(1), 12-18.

Feldman, Y., Ermolina, I. \& Hayashi, Y. (2003). Time domain dielectric spectroscopy study of biological systems. IEEE Transactions on Dielectrics and Electrical Insulation, $10(5), 728-753$

Gabriel, C. (2006). Dielectric properties of biological materials. In F.S. Barnes, B. Greenebaum (Eds.), Bioengineering and biophysical aspects of electromagnetic fields, Handbook of biological effects of electromagnetic fields (pp. 51-100), CRC Press, Boca Raton, third edition, U.S.A.

Goy, B., Martin, P. \& Leban, J.M. (1992). The measurement of wood density by microwave sensor. Holz Als Roh-Und Werkstoff., 50,163-166.

ISO 1442:1997. (1997). Methods of test for meat and meat products. Determination of moisture content. BS 44013:1997

Kent, M. \& Stroud, G. (1999). A new method for the measurement of added glaze on frozen foods. Journal of Food Engineering 39(3),313-321.

Kent, M. (1990). Hand-held instrument for fat/water determination in whole fish. Food Control, 1,47-53.

Kent, M., Knökel, R., Daschner, F. \& Berger, U.K. (2000a). Composition of foods using microwave dielectric spectra. Eur Food Res Technol., 210,359-366.

Kent, M., Knökel, R., Daschner, F. \& Berger, U.K. (2001) Composition of foods including added water using microwave dielectric spectra. Food Control, 12, 467-482.

Kent, M. Lees, A. \& Christie, R.H. (2007). Seasonal variation in the calibration of a microwave fat: water content meter for fish flesh. International Journal of Food Science \& Technology, $27(2), 137-143$
Kent, M., Lees, A. \& Roger, A. (1993). Estimation of the fat content of minced meat using a portable microwave fat meter. Food Control, 4, 222-227.

Kent, M., Peymann, A., Gabriel, C. \& Knight, A. (2002) Determination of added water in pork products using microwave dielectric spectroscopy. Food Control, 13(3), 143-149.

Martín, P., Moroño, A. \& Hodgson, E.R. (2004). Cuarzo KU1 de alta resistencia a la radiación. Boletín de la Sociedad Española de Cerámica y Vídrio, 43(2), 452-454.

Metaxas, A.C. \& Meredith, R.J. (1993). Industrial Microwave Heating. IEE Power Engineering series 4, Peter Peregrinus LTD, London, UK.

Miura, N., Yagihara, S. \& Mashimo, S. (2003). Microwave Dielectric Properties of Solid and Liquid Foods Investigated by Time-domain Reflectometry. Journal of Food Science, 68(4), 1396-1403.

Nelson, S.O. \& Datta, A.K. (2001). Dielectric properties of Food Materials and Electric Field Interactions. In A.K. Datta, R.C. Anantheswaran (Eds), Handbook of Microwave Technology for Food Applications (pp. 69-114). Marcel Dekker, New York

Offer, G. \& Cousin, T. (1992). The mechanism of drip production-formation of two compartments of extracellular-space in muscle post-mortem. Journal of the Science of Food and Agricultural, 58, 107-116.

Peebles, D.M., Edwards, A.D., Wyatt, J.S., Bishop, A.P., Cope, M. \& Delpy, D.T. (1992). Changes in human fetal cerebral hemoglobin concentration and oxygenation during labor measured by near-infrared spectroscopy. American Journal of Obstetrics and Gynecology, 166, 1369-1373.

Schwan, H.P. (1981). Dielectric properties of biological tissue and physical mechanisms of electromagnetic field interaction. In Karl H. Illinger (Ed.), Biological Effects of Nonionizing Radiation, ACS Symposium Series 157. American Chemical Society, Washington, DC.

Schwan, H.P. (1988). Biological effects of non-ionizing radiations: cellular properties and interactions. Annals of Biomedical Engineering, 16,245-263.

Shiinoki, Y., Motouri, Y. \& Ito, K. (1998). On-line monitoring of moisture and salt contents by the microwave transmission method in a continuous salted buttermaking process. Journal of food engineering, 38(2),153167

Smith, G., Duffy, A.P., Shen, J. \& Olliff, C.J. (1995). Dielectric relaxation spectroscopy and some applications in the pharmaceutical sciences. J. Pharma. Sci, 84,1029-1044.

Schmidt, F.C., Carciofi, B.A.M. \& Laurindo, J.B. (2008). Salting operational diagrams for chicken breast cuts: hydrationdehydration. Journal of Food Engineering, 88, 36-44.

Váczy, G. \& Semberg, P. (2003). Microwave milk testing. In Milk and dairy products, European dairy congress, 15-18 of November 2003, Portaro, Slovenia. 

4.3. Estudia de la influencia de la compasición y estructura de la manzana Granny Smith mediante la utilización de espectros dieléctricas 



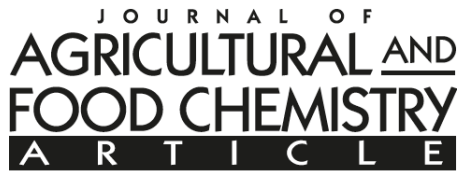

\title{
Development of a Dielectric Spectroscopy Technique for Determining Key Chemical Components of Apple Maturity
}

\author{
Marta Castro-Giráldez, Pedro J. Fito*, Creu Chenoll, and Pedro Fito \\ Instituto Universitario de Ingeniería de Alimentos para el Desarrollo, Universidad Politécnica de \\ Valencia, Camino de Vera s/n, 46022, Valencia, España.
}

\begin{abstract}
Dielectric measurements (from $500 \mathrm{MHz}$ to $20 \mathrm{GHz}$ ) on different standard solutions ( $\mathrm{K}^{+}$, malic acid) with different sugar contents were assayed simulating concentrations of these substances during apple ripening. These assays were performed for considering the potential use of dielectric spectra $(500 \mathrm{MHz}-20 \mathrm{GHz})$ to determine the optimal time for eating the fruit. Good correlations between a newly defined Dielectric Maturity Index and the Thiault Index were found. This work is presenting prospective data of dielectric spectra for certain apple key chemical components in order to consider its potential application as a nondestructive control sensor for the prediction of climacteric fruit maturity.
\end{abstract}

KEYWORDS: dielectric spectroscopy, dielectric spectra, dielectric properties, apple ripening, climacteric fruits, Thiault Index.

\section{INTRODUCTION}

The physiological pathways that take part in fruit ripening, which are controlled and/or modified in the confection processes of post-harvesting lines, mark the sensorial quality and the shelf life of the fruit. During the ripening, a series of chemical and biochemical changes occur, and mainly affect sugar, organic acids and pectines composition, among others (Taiz and Zeiger, 2002). Thus, sugar content and acid concentration are the properties generally utilized to determine fruit maturity, but currently they require destructive and tedious measurements that can not be implemented in post-harvest lines (Liu et al., 2007). In this context, dielectric spectroscopy appears as an interesting technique for controlling the basic aspects of fruit quality in a rapid and non destructive way; moreover, it can be directly applied in postharvesting lines.

Cells are the functional units of parenchimatic apple tissue and their state determines mainly the chemical and biochemical transformation of apple during the maturation process. Cell volume is constituted by a big central vacuole, formed by aqueous solutions of amino acids, organic acids (malic acid), some saccharides (fructose), and inorganic ions (potassium). Mean chemical composition of Granny Smith apple is shown in Table 1. A detailed chemical composition of apple juice is also shown (Table 2).

In Table 1, it can be observed that carbohydrates are, except for water, the major components.

*Corresponding author. pedfisu@tal.upv.es (P.J.Fito).

(c) 2010 American Chemical Society
Glucose, fructose and sucrose are the main sugars (Table 2). It is important to highlight the importance of organic acids in apple composition, malic acid being the most important. Of the inorganic fraction, the main mineral is potassium (Eisele and Drake, 2005).

Table 1. Mean chemical composition and standard deviation of Granny Smith apple (Ansorena, 2003)*.

\begin{tabular}{lc}
\hline Energy content (kcal) & $58 \pm 4$ \\
Water content (g) & $84 \pm 1$ \\
Proteins (g) & $0.3 \pm 0.1$ \\
Lipids (g) & $0.6 \pm 0.2$ \\
Carbohydrates (g) & $15 \pm 2$ \\
\hline${ }^{*}$ composition per 100g &
\end{tabular}

Table 2. Mean chemical composition and standard deviation of Apple juice (Eisele and Drake, 2005).

\begin{tabular}{cc}
\hline Water $(\mathrm{g} / 100 \mathrm{~g})$ & $85.8 \pm 1.8$ \\
Carbohydrates $(\mathrm{g} / 100 \mathrm{~mL})$ & $2.16 \pm 0.73$ \\
Sucrose & $2.01 \pm 0.53$ \\
Glucose & $5.7 \pm 0.8$ \\
Fructose & \\
Minerals (ppm) & $1511 \pm 267$ \\
Potassium & $41.9 \pm 13.6$ \\
Calcium & $64.9 \pm 9.9$ \\
$\quad$ Magnesium & $252 \pm 73$ \\
Phosphates & \\
Organic acids $(\mathrm{mg} / 100 \mathrm{~mL})$ & $847 \pm 280$ \\
Malic & $11.9 \pm 5.4$ \\
Citric & $42 \pm 24$ \\
Quinic &
\end{tabular}


There is an increasing interest in determining fruit maturity in a rapid and non-destructive way. In recent years, dielectric spectroscopy is a novel technique which is being employed for determining numerous quality attributes in food products (De los Reyes et al., 2007a). More concretely, it has been employed in determining fruit maturity based on soluble solids content in honeydew melons (Nelson et al., 2006; Nigmatullin et al., 2006) and watermelons (Nelson et al., 2007) with promising results. It was also employed to study the dielectric properties of apples during storage but no high correlations were found between the dielectric properties and soluble solids content (Guo et al., 2007a).

Complex permittivity ( $\mathrm{rr}$ ) (Equation 1) is the dielectric property that describes food behaviour under an electromagnetic field (Metaxas and Meredith, 1993; Nelson and Datta, 2001). The real part of complex permittivity is called the dielectric constant $\left(\varepsilon^{\prime}\right)$ and the imaginary part is called loss factor $\left(\varepsilon^{\prime \prime}\right)$. The subscript $r$ indicates that values are relative to air, and therefore the variable is dimensionless.

$$
\varepsilon_{\mathrm{r}}=\varepsilon^{\prime}-\mathrm{j} \cdot \varepsilon^{\prime \prime}
$$

The dielectric constant reports the ability of the food to store the electromagnetic energy. Only a perfect dielectric can store and release wave energy without absorbing it. Loss factor is related to absorption and dissipation of electromagnetic energy from the field (Decareau, 1985). Such energy absorptions are caused by different factors that depend on structure, composition and measurement frequency (De los Reyes et al. 2007a). Table 3. Standard solutions of water, malic acid and $\mathrm{K}+$ at different ${ }^{\circ}$ Brix used at present research.

At microwave frequencies the main mechanisms that contribute to the loss factor spectra are the ion conductivity and the dipole polarization (mainly free water molecules). Moreover, sugars content also contribute to dielectric spectra of fruits. Sugars can form hydrogen bonds to water molecules which produce the reduction of water mobility and the displacement of the relaxation frequency of free water to lower frequencies (Kaatze, 2005). This phenomenon is higher when higher is the concentration of solute (Kaatze, 1995, 1997; Kaatze et al.,2002).

The aim of this research was to analyze the viability of using dielectric spectra $(500 \mathrm{MHz}$ to $20 \mathrm{GHz})$ for determining the content of specific key molecules of apple maturity (soluble solids content and free acids concentration) for a subsequent on-line quality control of this product by using dielectric spectroscopy.

\section{MATERIALS AND METHODS}

Standard solutions.- Standard solutions were prepared with Brix values of $0,7,9,11,13$, and 15 and malic acid concentrations of 0 and 0.5 to $1.0 \mathrm{~g} / 100 \mathrm{ml}$ in increments of $0.1 \mathrm{~g} / 100 \mathrm{ml}$. There were also prepared standard solutions of water, malic acid, and $\mathrm{K}+$ with different Brix values of 0 and 13 (Table 3). The composition of the standard solutions was based in bibliographic sources (Ansorena, 2003; Eisele and Drake, 2005) trying to simulate the apple liquid phase. Moreover, sugar composition was obtained mixing sucrose, glucose and fructose taking into account that the relationship among this three main apple sugars is 1:1:3, respectively (Eisele and Drake, 2005) (Table 2).

The additives used for preparing standard solutions were: DL-malic acid (E-296, F.C.C.), aditio quality (Panreac Quimica S.A.U., Barcelona, Spain); Potassium D-gluconate, aditio quality, puriss p.a. $\geq$ 99.0\% (NT) (Sigma-Aldrich®, Germany). Standard solutions were prepared with distilled water.

The water activity and ${ }^{\circ}$ Brix of the standard solutions were determined. All the measurements were made at controlled temperature of $30^{\circ} \mathrm{C}$.

Table 3. Standard Solutionsof Water, Malic Acid and $\mathrm{K}^{+}$at Different ${ }^{\circ}$ Brix Used in the Present in the Present Research

\begin{tabular}{|c|c|c|c|}
\hline${ }^{\circ}$ Brix & $\begin{array}{c}\text { Potassium D- } \\
\text { gluconate } \\
(\mathrm{g} / 100 \mathrm{~mL})\end{array}$ & $\begin{array}{l}\text { Malic acid } \\
(\mathrm{g} / 100 \mathrm{~mL})\end{array}$ & $\begin{array}{c}\mathrm{K}^{+} \\
(\mathrm{g} / 100 \mathrm{~mL})\end{array}$ \\
\hline 0 & 0.100 & 0.000 & 0.017 \\
\hline 0 & 0.100 & 0.500 & 0.017 \\
\hline 0 & 0.100 & 0.700 & 0.017 \\
\hline 0 & 0.100 & 1.000 & 0.017 \\
\hline 0 & 0.150 & 0.000 & 0.025 \\
\hline 0 & 0.150 & 0.500 & 0.025 \\
\hline 0 & 0.150 & 0.700 & 0.025 \\
\hline O & 0.150 & 1.000 & 0.025 \\
\hline 0 & 0.200 & 0.000 & 0.033 \\
\hline 0 & 0.200 & 0.500 & 0.033 \\
\hline 0 & 0.200 & 0.700 & 0.033 \\
\hline 0 & 0.200 & 1.000 & 0.033 \\
\hline O & 0.250 & 0.000 & 0.042 \\
\hline 0 & 0.250 & 0.500 & 0.042 \\
\hline 0 & 0.250 & 0.700 & 0.042 \\
\hline 0 & 0.250 & 1.000 & 0.042 \\
\hline 13 & 0.100 & 0.000 & 0.017 \\
\hline 13 & 0.100 & 0.500 & 0.017 \\
\hline 13 & 0.100 & 0.700 & 0.017 \\
\hline 13 & 0.100 & 1.000 & 0.017 \\
\hline 13 & 0.150 & 0.000 & 0.025 \\
\hline 13 & 0.150 & 0.500 & 0.025 \\
\hline 13 & 0.150 & 0.700 & 0.025 \\
\hline 13 & 0.150 & 1.000 & 0.025 \\
\hline 13 & 0.200 & 0.000 & 0.033 \\
\hline 13 & 0.200 & 0.500 & 0.033 \\
\hline 13 & 0.200 & 0.700 & 0.033 \\
\hline 13 & 0.200 & 1.000 & 0.033 \\
\hline 13 & 0.250 & 0.000 & 0.042 \\
\hline 13 & 0.250 & 0.500 & 0.042 \\
\hline 13 & 0.250 & 0.700 & 0.042 \\
\hline 13 & 0.250 & 1.000 & 0.042 \\
\hline
\end{tabular}


Dielectric properties measurement.- The system used to measure dielectric properties consisted on an Agilent 85070E open-ended coaxial probe connected to an Agilent E8362B Vector Network Analyzer. The software of the network analyzer calculates the dielectric constant and loss factor as a reflected signal function. For these measurements the probe was fixed to a stainless steel support, and an elevation platform brought the sample near the probe to avoid possible phase changes due to cable movements after calibration.

The system was calibrated by using three different types of loads: air, short-circuit and $25^{\circ} \mathrm{C}$ Milli ${ }^{\circledR}-Q$ water. Once the calibration was made, $25^{\circ} \mathrm{C}$ Milli $($ $\mathrm{Q}$ water was measured again to check calibration suitability.

The dielectric properties were measured by introducing the open-ended probe at least $5 \mathrm{~mm}$ deep in the aqueous solutions. The mean values of three replicates of each solution are reported in this article. The dielectric properties were measured from $500 \mathrm{MHz}$ to $20 \mathrm{GHz}$.

Physical-Chemical analysis.- The water activity of standard solutions was determined by using a dew point hygrometer Aqualab® series 3 TE (Decagon Devices, Inc., Washington, USA). Sugar content was determined by a refractometer (ABBE, ATAGO Model 3-T, Japan).

\section{RESULTS AND DISCUSSION}

In figure 1, the dielectric constant and loss factor spectra $(500 \mathrm{MHz}-20 \mathrm{GHz})$ of solutions of water and sugar at different concentrations can be observed.

In figure 1 it can be observed that sugar molecules produce a decrease in dielectric constant and loss factor spectra with regard to dielectric spectra of pure water at dipolar dispersion frequencies. This effect is due to the fact that sugar molecules can form hydrogen bonds with water dipoles, limiting its movement and decreasing its polarization capacity. For this reason, dipolar dispersion is displaced to minor frequencies of the spectrum, decreasing dipolar relaxation frequency as can be appreciated in figure 1 . On the other hand, due to the fact that there no existed ions in the prepared standard solutions, any effect cannot be appreciated at low frequencies due to ionic losses, only the effect of the displacement of dipolar dispersion to lower frequencies produced by sugars can be observed also at low frequencies, being the higher sugar content the higher loss factor.

Dielectric spectra $(500 \mathrm{MHz}-20 \mathrm{GHz})$ of malic acid standard solutions at different ${ }^{\circ}$ Brix are shown in figure 2 .

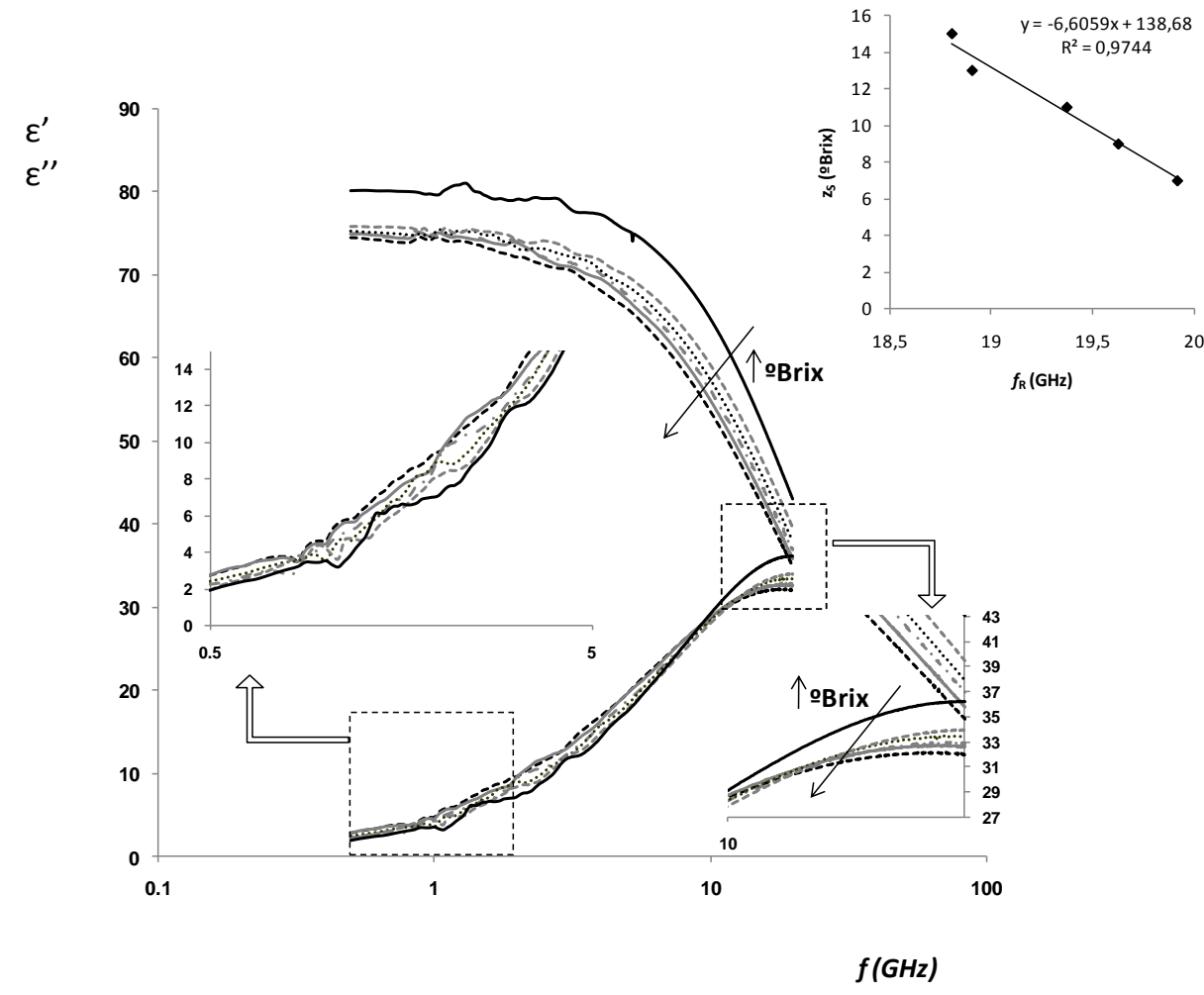

Figure 1. Dielectric spectra of water and sugar (glucose, fructose and sucrose at 1:1:3 proportions) with different

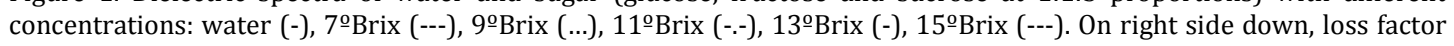
spectra at frequencies near the dipolar relaxation frequency could be observed in detail. On right side up, the relation between sugars concentration and the relaxation frequency can be observed. In left side, loss factor spectra at low frequencies are shown in detail. 

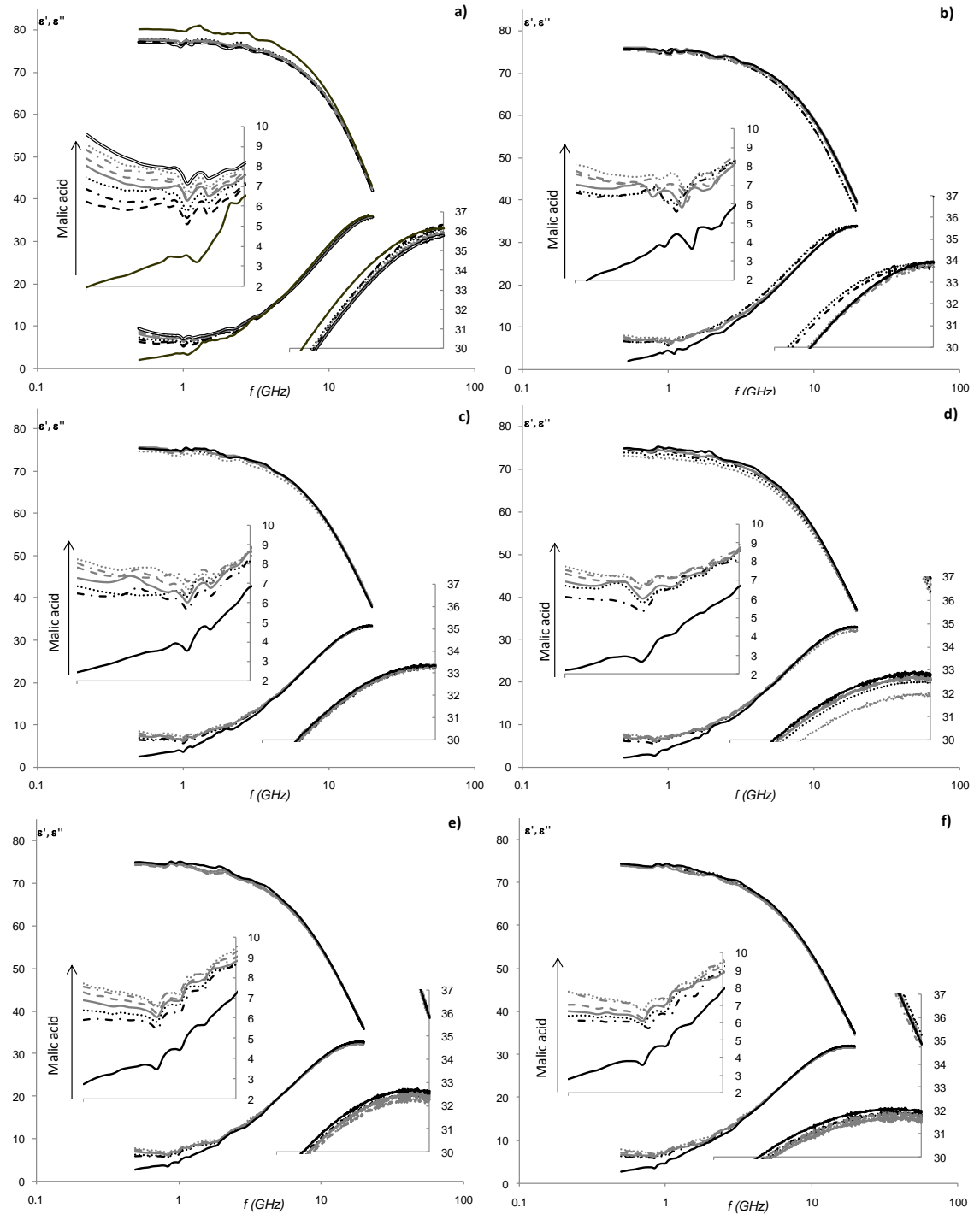

Figure 2. Dielectric spectra of experimental standard solutions at different malic acid concentrations $(\mathrm{g} / \mathrm{mL})$, where: $0(-$ ), $0.4(--), 0.5(-.-), 0.6(\ldots), 0.7(-), 0.8(--), 0.9(--), 1(\ldots), 1.1(=)$; a) distilled water and malic acid, b) $7^{\text {ooBrix }}$ sugar

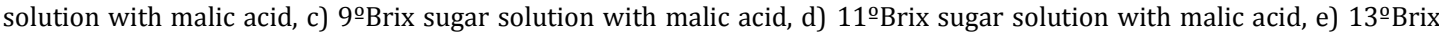
sugar solution with malic acid, f) $15^{\circ}$ Brix sugar solution with malic acid. It can be observed in all graphs: on right side, a detail of loss factor variations around the dipolar relaxation frequency; on left side, a detail of solutions ionic behavior at low frequencies $(0.5-1.5 \mathrm{GHz})$.

Figure 2 shows that the effect of malic acid can be detected at low frequencies. At these frequencies of the spectrum, the ionic conductivity phenomena is the main contribution to loss factor; for this reason, it is possible to affirm that malic acid is in malate form, a strongly anionic molecule which increase markedly ionic losses. This effect can be clearly appreciated in figure 2a, in which distilled water and malic acid solutions spectra are represented with no sugar presence. The sugar addition to the solution produces an increase of solution viscosity with the subsequent decrease of loss factor spectra due to the dipolar and ionic mobility reduction.

This decrease can be appreciated in the figures from $2 \mathrm{~b}$ to $2 \mathrm{f}$ which have an increasing sugar concentration.
Figure 3 represents the malate and sugar content effect on the loss factor at $500 \mathrm{MHz}$ frequency. In the same figure, malate chemical structure can be also appreciated.

Figure 3 shows that malate molecule has two negative electrical charges which generate a strong ionic behavior when the molecule is subjected to electromagnetic radiation. Higher malate content produces higher loss factor at 500MHz. The sugar content effect on the loss factor at this frequency can also be observed. For equal malate content, loss factor value is minor when sugar content is increased. This phenomenon is due to the reduction of malate mobility when sugar concentration increase.

The effect of $\mathrm{K}+$ on the dielectric spectrum, in frequency range from $500 \mathrm{MHz}$ to $20 \mathrm{GHz}$, was also studied because of its importance in apple 
composition (Eisele and Drake, 2005) (Figure 4) Potassium ion generates an increase in loss factor spectrum at low frequencies (Figure 4a). This effect is lower when sugar is added to the standard solution (Figure 4b). Moreover, sugar produces also a decrease in loss factor on dipolar zone (frequencies near $10 \mathrm{GHz}$ ). On the other hand, malate ion effect is shown in figures $4 \mathrm{c}$ and $4 \mathrm{~d}$, where, at low frequencies, an increase in loss factor can be appreciated due to the addition of malate to the potassium ion losses. The effect of sugars in loss factor spectrum can also be observed, which produces an increase in viscosity and a reduction in molecules mobility, decreasing both ionic and dipolar losses.

In figure 5 the additive effect of malate and potassium ions on loss factor at $500 \mathrm{MHz}$ are presented for water and $13^{\circ}$ Brix solutions.

Figure 5 corroborate that both ions have an additive effect on loss factor at $500 \mathrm{MHz}$, increasing its value when both ions increase. Moreover, the effect of sugars on loss factor at low frequencies of the spectrum can be observed again, provoking a decrease in ion mobility due to the presence of these macromolecules.

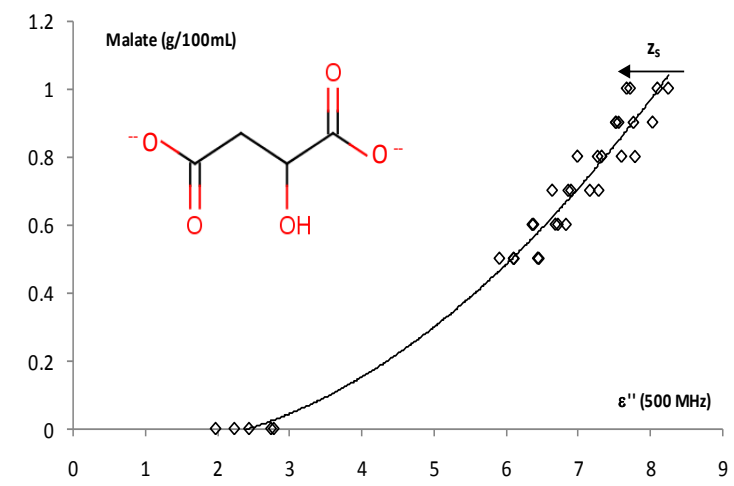

Figure 3. Malate $(\mathrm{g} / 100 \mathrm{~mL})$ and sugars content effect (zS, ${ }^{-B}$ Brix) on the loss factor at the punctual frequency of $500 \mathrm{MHz}$.
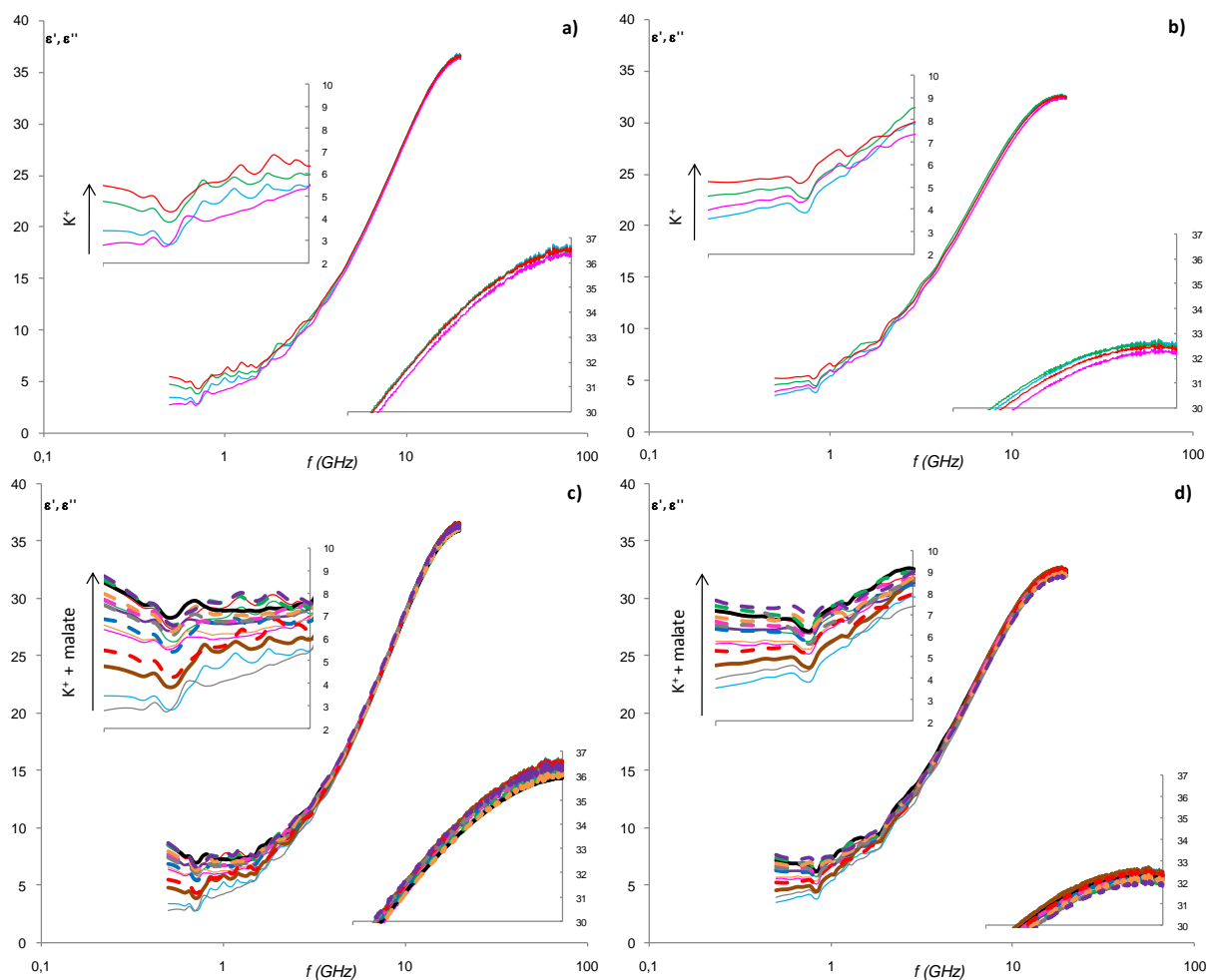

Figure 4. Loss factor spectra of standard solutions at different concentrations of malic acid $(\mathrm{g} / 100 \mathrm{~mL})$, potassium $(\mathrm{g} / 100 \mathrm{~mL})$ and sugars $\left({ }^{\circ} \mathrm{Brix}\right)$, where: a) Distilled water and $\mathrm{K}+$ at different concentrations: $0.017(-)$, $0.025(-), 0.033(-), 0.042(-)$, b) 13 Borix solution with $\mathrm{K}+$ at the same concentrations as in preceding case, c) Solutions of malic acid and $\mathrm{K}+$, where: 0 malic acid and $0.017 \mathrm{~K}+(-), 0.5$ malic acid and $0.017 \mathrm{~K}+(-), 0.7$ malic acid and $0.017 \mathrm{~K}+(-), 1$ malic acid and $0.017 \mathrm{~K}+(-), 0$ malic acid and $0.025 \mathrm{~K}+(-), 0.5$ malic acid and $\mathrm{K}+(-), 0.7$ malic acid and $0.025 \mathrm{~K}+(-), 1$ malic acid and $0.025 \mathrm{~K}+(-), 0$ malic acid and $0.033 \mathrm{~K}+(-), 0.5$ malic acid and $0.033 \mathrm{~K}+(-$ $--), 0.7$ malic acid and $0.033 \mathrm{~K}+(---), 1$ malic acid and $0.033 \mathrm{~K}+(---), 0$ malic acid and $0.042 \mathrm{~K}+(---), 0.5$ malic acid and $0.042 \mathrm{~K}+(---), 0.7$ malic acid and $0.042 \mathrm{~K}+(---), 1$ malic acid and $0.042 \mathrm{~K}+(---)$. d) $13^{\circ}$ Brix solution with malic acid and $\mathrm{K}+$ at the same concentrations as in preceding case. 


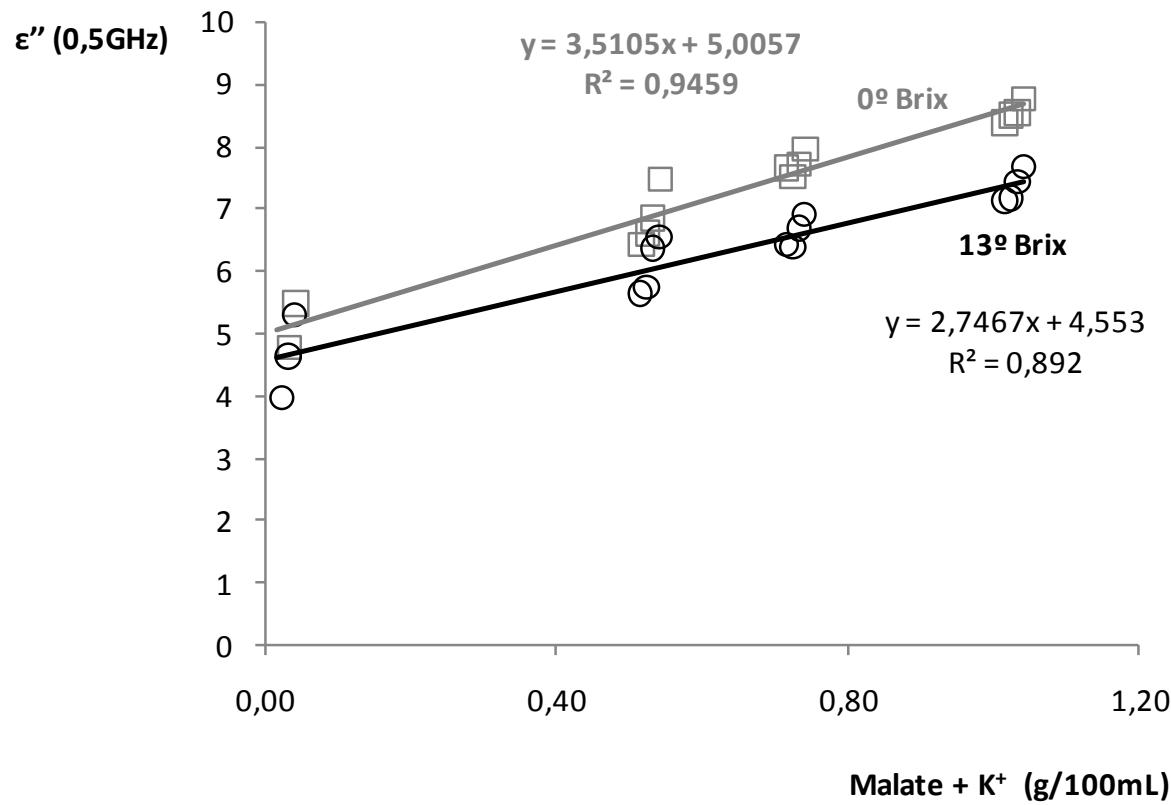

Figure 5. Malate and Potassium ions $(\mathrm{g} / 100 \mathrm{~mL})$ versus loss factor at $500 \mathrm{MHz}$ for pure water and $13^{\circ}{ }^{\circ} \mathrm{Brix}$ solution.

Maturity Index. Thiault Index (TI) was used as an indicator of apple maturity. The Thiault Index is defined by equation 2 (Thiault, 1970).

$$
\mathrm{TI}=\mathrm{cs}_{\mathrm{s}}+10 \times \mathrm{Ac}
$$

Where, $\mathrm{c}_{\mathrm{s}}$ represents the sugar concentration $(\mathrm{g} / \mathrm{L})$ measured by refractometry, Ac represents the $\mathrm{NaOH}$ estimated acidity (expressed as g/L). The Lewis expression of sugar solutions density (Lewis, 1987) was used to transform the sugar mass fraction $(\mathrm{g} / \mathrm{g})$ to sugar concentration $(\mathrm{g} / \mathrm{L})$ (equation 3).

$$
c_{s}=z_{s} \times \rho_{s s}
$$

In apple, if TI is equal to 170 , is the minimum to an acceptable fruit quality; if TI is equal to 180 , is recommended to harvest the fruit; if TI is more than 180, the fruit quality is excellent (Porro et al., 2002 ; Varela et al., 2005).

As it can be observed in equation 2, Thiault Index is an indicator of soluble solids content and acid concentration. Both soluble solids content and acidity are quantified in the same order, for this reason the acidity is multiplied by 10 .

Due to the fact that malic acid concentration is positively related to loss factor at $500 \mathrm{MHz}$, and the concentration in soluble solids is negatively related to loss factor at relaxation frequency, it could be possible to define a new Maturity Index based on dielectric properties (equation 4).

$$
\mathrm{MI}_{\text {dielectric }}=\varepsilon^{\prime \prime}\left(f_{\text {relaxation })}-\varepsilon^{\prime \prime}\left(f_{0.5 \mathrm{GH}}\right)\right.
$$

It is important to highlight that the loss factor at $500 \mathrm{MHz}$ is directly related to malic acid concentration and an increase in malic acid produces an increase in loss factor at this frequency; on the contrary, an increment in sugar content produces a decrease in the loss factor at relaxation frequency. As it was explained above, Thiault Index quantify both soluble solids content and acid concentration; for this reason, to define a Dielectric Maturity Index it is necessary to subtract the loss factor at relaxation frequency to loss factor at $500 \mathrm{MHz}$. It could be interesting to remark that loss factor at relaxation frequency is higher than loss factor at $500 \mathrm{MHz}$, and for this reason and to avoid negative signs the subtraction was define as specified in equation 3. Moreover, it is also important to denote that an increase in Thiault Index will produce a decrease in Dielectric Maturity Index; thus, when Dielectric Maturity Index takes lower values more quality is present the fruit.

Figure 6 represents the Dielectric Maturity Index from standard solutions of different malic acid and sugar concentrations as a function of the Thiault Index, where the good correlations coefficients obtained for each sugar concentration are shown. 


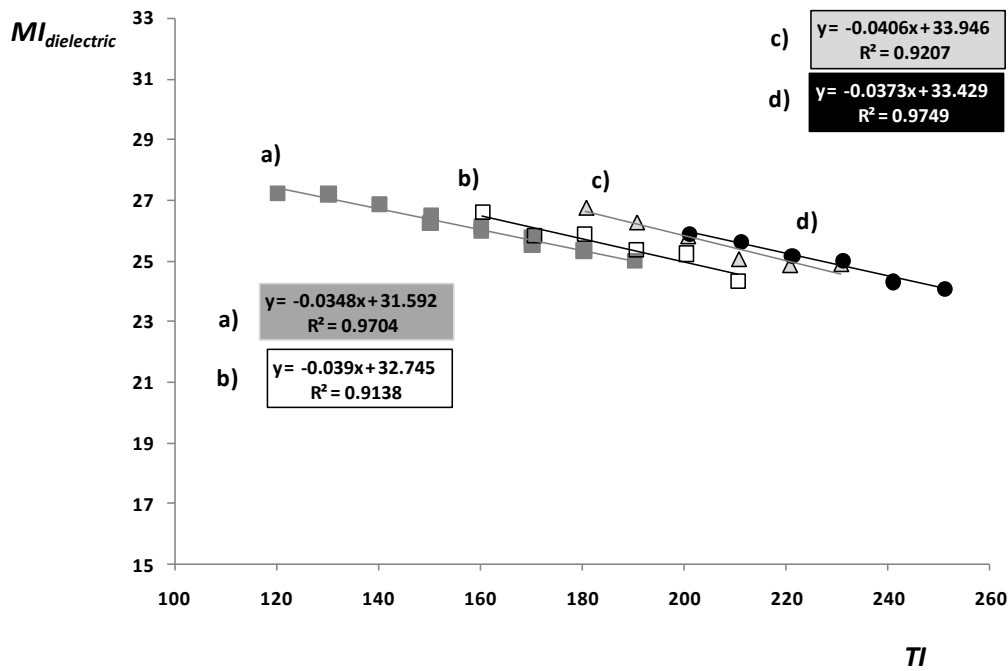

Figure 6. Maturity Index obtained from dielectric properties versus Thiault Index from standard solutions of different malic acid concentrations $(0.5,0.6,0.7,0.8,0.9,1 \mathrm{~g} / 100 \mathrm{~mL})$ at different sugar concentrations of $\boldsymbol{\square} 7$ and 9º̈Brix, $\mp 11^{\circ}$ Brix, $\Delta$ 13ํㅡㅁix, $\bullet 15^{\circ}$ Brix.

\section{LITERATURE CITED}

Ansorena, D. Frutas y Frutos Secos. In Alimentos Composición y Propiedades; Astiasarán, I., Martínez, J.A., Eds.; McGraw-Hill International, New York, 2003, pp. 191-211.

De los Reyes, R.; Castro-Giráldez, M.; Fito, P.; De los Reyes, E. Application of microwaves for in-line quality assessment. In Advances in Food Diagnostics; Nollet, Leo ML; Toldrá, F., Eds.; Blackwell Publishing, Iowa, 2007a, pp. 49-80.

Decareau, R.V. Microwaves in the Food Processing Industry. Academic Press, series of Food Science and Technology, New York, 1985.

Eisele T. A.; Drake S.R. The partial compositional characteristics of apple juice from 175 apple varieties. J. Food Compos. Anal. 2005, 18(2-3), 213221.

Guo, W.; Nelson, S.; Trabelsi, S.; Kays, S.J. 10-1800$\mathrm{MHz}$ dielectric properties of fresh apples during storage. J.Food Eng. 2007a, 83(4), 562-569.

Kaatze, U. Electromagnetic wave interactions with water and aqueous solutions. In Electromagnetic aquametry; Kupfer, K., Ed. ; Springer, New York, 2005; pp. 15-37.

Kaatze, U. Microwave dielectric properties of liquids. Rad. Phys. Chem. 1995, 45, 549-566.

Kaatze, U. The dielectric properties of water in its different states of interaction. J.Solution Chem. 1997, 26, 1049-1112.

Kaatze, U.; Behrends, R.; Pottel, R. Hydrogen network fluctuations and dielectric spectrometry of liquids. J. Non-crystalline solids. 2002, 305,19-28.

Lewis, M.J. Physical properties of foods and food processing systems. Ellís Horwood Ltd, Chichester, England, 1987; Chapter 2, pp. 61-62.

Liu, Y.d.; Yin-bin Y.; Xiaping F.; Huisan L. Experiments on predicting sugar content in apples by FT-NIR Technique. J. Food Eng. 2007, 80, 986989.

Metaxas, A.C.; Meredith, R.J. Industrial Microwave Heating. IEE Power Engineering series 4, Peter Peregrinus LTD, London, UK., 1993.

Nelson, S.O.; Datta, A.K. Dielectric properties of Food Materials and Electric Field Interactions. In Handbook of Microwave Technology for Food Applications; Datta, A.K., Anantheswaran, R.C., Eds.; Marcel Dekker, New York, 2001; pp. 69-114.

Nelson, S.O.; Guo, W.; Trabelsi, S.; Kays, S.J. Dielectric spectroscopy of watermelons for quality sensing. Meas. Sci. Technol. 2007, 18,1887-1892.

Nelson, S.O.; Trabelsi, S.; Kays, S.J. Dielectric spectroscopy of honeydew melons from $10 \mathrm{MHz}$ to $1.8 \mathrm{GHz}$ for quality sensing. Trans. ASAE, 2006, 49(6),1977-1982.

Nigmatullin, R.R.; Arbuzov, A.; Nelson, S.O.; Trabelsi, S. Dielectric relaxation in complex systems: quality sensing and dielectric properties of honeydew melons from $10 \mathrm{MHz}$ to $1.8 \mathrm{GHz}$. Published by Institute of physics publishing and sissa. 2006, pp.1-19.

Porro, D.; Datlaserra, M.; Dorigatti, C.; Zatelli, A. Fitoregolatori efitormoni: risposta produttiva ed económica di Golden Delicious. Terra Trentina. 2002, 6,28-33.

Taiz, L.; Zeiger, E. Ethylene: the gaseous hormone. In Plant Physiology; Taiz, L., Zeiger, E., Eds.; Sinauer Associates, Inc., Publishers, Sunderland, Massachusetts, 2002, pp. 519-538.

Thiault, J. Etude de criteres objectifs de la qualite gustative de pommes Golden Delicious. Bull. Tech. Inf. Minist. Agric. Paris. 1970, 248,191-201.

Varela, P.; Salvador, A.; Fiszman, S. Shelf-life estimation of 'Fuji' apples: sensory characteristics and consumer acceptability. Postharvest Biol Tec. 2005, 38, 18-24.

Received for review September 22, 2009. Revised manuscript received January 11, 2010. Accepted February 3, 2010. 



\title{
Development of a dielectric spectroscopy technique for the determination of apple (Granny Smith) maturity
}

\author{
Marta Castro-Giráldez, Pedro J. Fito*, Creu Chenoll, Pedro Fito \\ Instituto Universitario de Ingeniería de Alimentos para el Desarrollo, Universidad Politécnica de Valencia, Camino de Vera, s/n, 46022, Valencia, Spain
}

A R T I C L E I N F O

Article history:

Received 17 January 2010

Keywords:

Dielectric spectroscopy

Dielectric spectra

Dielectric properties

Maturity Index

Climateric fruits

Malic acid

\begin{abstract}
A B S T R A C T
Dielectric measurements of apple were done during its maturity in order to find relations with apple physiological compounds (sugar content, malic acid). An Agilent 85070E open-ended coaxial probe connected to an Agilent E8362B vector network analyzer were used in these experiments. All determinations were made at $30^{\circ} \mathrm{C}$ from $500 \mathrm{MHz}$ to $20 \mathrm{GHz}$. These assays were performed in order to consider the potential use of dielectric spectroscopy for determining the state of fruit maturity. Good correlations among apples Thiault Index with a new defined Dielectric Maturity Index were found. The Dielectric Maturity Index was related to loss factor at two punctual frequencies $0.5 \mathrm{GHz}$ and dipolar relaxation frequency). This work is presenting a non-destructive control method for the prediction of climacteric fruits maturity.

Industrial Relevance: The results of this research article are demonstrated to be useful for determining apple maturity. Thus, the industrial relevance is clear because the determination of fruit maturity is important to decide the best uses and storage time of the fruit. In the paper, a Maturity Index based on dielectric properties was developed. The results are obtained for the concrete application of apple fruit but they can be extended to other climacteric fruits although more studies are necessary. Dielectric spectroscopy, which can be considered an emerging technology, has the advantage of being an objective and a non destructive technique. For all these reasons we are sending to this journal "Innovative Food Science and Emerging Technologies" our results.
\end{abstract}

(C) 2010 Elsevier Ltd. All rights reserved.

\section{Introduction}

Apple industry has progressed recently because of its advances in production, storage, product development and marketing efficiencies (Sinha, 2006). To further improve of apple industry competitiveness, objective techniques for determining fruit maturity are needed in order to decide the best uses and storage time of the fruit. Immature fruits are more subject to shriveling and mechanical damage; and overripe fruits become soft and mealy with insipid flavor soon after harvest (Kader \& Barret, 1996).

Figure 1 presents an overview of the most relevant metabolic processes and changes during the growing, ripening and senescence in climacteric fruits. Apple is a climacteric fruit and is characterized by the starch accumulation during

*Corresponding author. Tel.: +3496387 7369

E-mail address: pedfisu@tal.upv.es (P.J.Fito). fruit growth, which is hydrolysed to monosaccharides, mainly glucose and fructose, during the ripening process. Starch hydrolysis is a process that requires high energy consumption and it is related to an increase of fruit respiration rate (climacteric crisis), until reaching its maximum at the end of ripening (climacteric peak). Finally, respiration rate decreases during senescence (Lal Kaushal \& Sharma, 1995). The main biochemical changes of fruit maturity are produced during the climacteric crisis.

Ethylene effect on fruit maturity is also important in climacteric fruits. A climacteric rise in ethylene production precedes the increase in respiration rate (Figure 1), suggesting that ethylene is the hormone that triggers the ripening process (Lanahan, Black \& Ecker, 1996).

Organic acids are also strongly related to maturity process of climacteric fruits, in which ethylene is produced from 1-amine-1carboxyl ciclopropane 


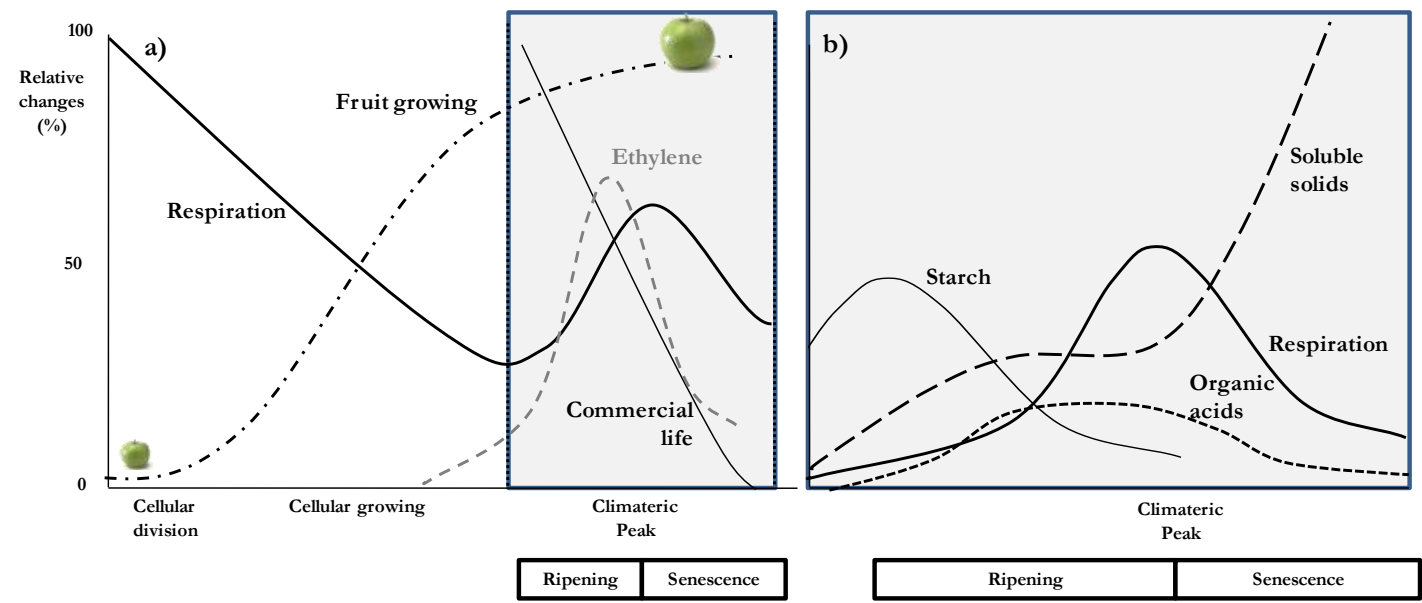

Figure 1. a) Qualitative evolution of respiration rate, fruit growing, ethylene levels and commercial life of Granny Smith apple; b) Qualitative evolution of starch, soluble solids and organic acids content during the ripening and senescence (Elaborated by the authors from data of different sources: Hulme, 1958; Pearson \& Roberson, 1954; Taiz \& Zeiger, 2002).

acid (Mansour, Latche, Vaillant, Pech \& Reid, 1986); moreover, the intense respiratory activity consumes malic acid in an oxidative descarboxilation (Hulme, Dones, \& Wooltorton, 1963). Malic acid can also be used in gluconeogenesis (Ribereau-Gayon \& Peynaud, 1971).

The relationship between soluble solids content and organic acid concentration is called Maturity Index and is usually used in industry as a reference parameter of fruit state (Harker, Marsh, Young, Murray, Gunson \& Walker, 2002). Thiault Index (TI) is one of the maturity indexes

frequently employed in apple fruit; it is related to soluble solids content and malic acid concentration (Varela, Salvador, \& Fiszman, 2005). Therefore, there exist an increasing interest in determining organic acid and sugar composition of apple because of the possibility of employing these determinations for predicting fruit maturity index There exist numerous instrumental techniques to carry out these determinations but require samples from fruit internal tissues and, therefore, are destructive tests. On the other hand, recent researches are developing nondestructive techniques to measure food quality attributes; these techniques are mainly based in electrical properties of foods, known as dielectric properties. They were recently used to predict soluble solids content in honeydew melons (Nelson, Trabelsi \& Kays, 2006) and watermelons (Nelson, Guo, Trabelsi, Kays, 2007) with promising results. On the other hand, no good correlations were obtained in apple during storage at frequencies between 10$1800 \mathrm{MHz}$ (Guo, Nelson, Trabelsi \& Kays, 2007a) More studies are needed for determining the real possibility of sensing apples quality from their dielectric properties.

Dielectric spectroscopy determines the dielectric properties of a medium as a function of frequency. It is based on the interaction of an electric external field with the sample (Metaxas \& Meredith, 1993; Nelson \& Datta, 2001); complex permittivity $\left(\varepsilon^{*}\right)$
(Equation 1) is the dielectric property that describes this interaction (Metaxas \& Meredith, 1993; Nelson \& Datta, 2001). The real part of complex permittivity is called dielectric constant $\left(\varepsilon^{\prime}\right)$ and the imaginary part is called loss factor $\left(\varepsilon^{\prime \prime}\right)$. The dielectric constant is related with the capacitance of the material and its ability to store energy, and the dielectric loss factor is related to the absorption and dissipation of the electric field energy in other kinds of energy such as the termic one.

$$
\varepsilon^{*}=\varepsilon^{\prime}+i \varepsilon^{\prime \prime}
$$

There are different mechanisms affecting the dielectric behaviour of biological tissue. Relaxation phenomena are produced at microwave and radio frequencies and characterize, with the conductivity, the dielectric behaviour of practically all tissues at these frequencies. Permittivity decreases with the frequency increase in different steps called dispersions. It is important to highlight that these dispersions are not produced instantaneously and are characterized by the correspondent relaxation phenomena (Schwan, 1988). In biological systems, there are four main relaxation regions: $\alpha, \beta, \delta$ and $\gamma$ (Gabriel, 2006). Each of these steps characterizes a type of relaxation that occurs in a specific frequency range and which allows to identifying different phenomena. At the frequencies employed in present work, the $\gamma$ is the main dispersion (Figure 2). The $\gamma$-dispersion, also called orientation polarization, is located at $\mathrm{GHz}$ region, and it is due to the orientation of dipoles, fundamentally free water molecules (Feldman, Ermolina \& Hayashi, 2003). Relaxation frequency is that in which the loss factor reaches its maximum value in $\gamma$ dispersion (Figure 2).

In some cases, to analyze the energy dissipation of these relaxation phenomena in terms of loss factor spectra could be useful. Loss factor can be expressed by the equation 2, which reflects the different contribution phenomena to the loss factor 
spectrum in the frequency range of the present study.

$$
\varepsilon^{\prime \prime}=\varepsilon_{d}^{\prime \prime}+\sigma / \varepsilon_{0} \omega
$$

where:

$\varepsilon_{\mathrm{d}}$ " represents the loss factor caused by the dipolar orientation or dipolar relaxation.

$\sigma / \varepsilon_{0} \omega$ represents the loss factor due to effect of ionic conductivity, where $\sigma, \varepsilon_{0}$ and $\omega$ are the conductivity of the material, the dielectric constant in vacuum and the angular frequency, respectively. In previous work, the high correlation of dielectric properties with soluble solids and malic acid content was demonstrated in standard solutions which simulate the apple liquid phase (CastroGiráldez, Fito, Chenoll \& Fito, 2010b). The objective of the present study was a further step in the use of dielectric spectroscopy to determine the harvested apples maturity in a rapid and nondestructive way.

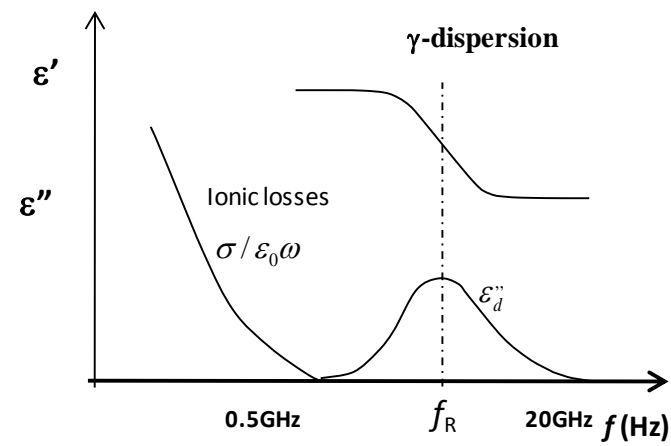

Figure 2. Ideal representation of dielectric constant and loss factor spectra in biological tissue, where: $f_{\mathrm{R}}$ is the relaxation frequency; $\varepsilon_{\mathrm{d}}$ " represents the loss factor caused by the dipolar relaxation; $\sigma / \varepsilon_{0} \omega$ represents the loss factor due to effect of ionic conductivity, where: $\sigma, \varepsilon_{0}$ and $\omega$ are the conductivity of the material, the dielectric constant in vacuum and the angular frequency, respectively.

\section{Material and Methods}

\subsection{Raw material}

20 Granny Smith apples were used, trying to get homogeneity in size. Pieces with superficial defects were refused. Apples were acquired one day before starting the experimental and were stored at $6^{\circ} \mathrm{C}$ until the measurements. At each storage duration interval, four apples were taken and allowed to warm to $30^{\circ} \mathrm{C}$ overnight in a controlled temperature chamber. Measurements were taken at one week intervals during five weeks storage period.

\subsection{Experimental procedure}

Apples were removed from $6^{\circ} \mathrm{C}$ storage the night before the experimental and allowed to equilibrate to $30^{\circ} \mathrm{C}$. Apples were cut into two halves. One of them was used to structured tissue measurements which consisted in water activity, moisture and dielectric spectra. The other half was liquidized and paper filtered, and the clarified juice obtained was used to the measurements of water activity, sugar concentration (orix), estimated acidity and dielectric spectra.

\subsection{Dielectric properties measurement}

The system used to measure dielectric properties consists of an Agilent 85070E open-ended coaxial probe connected to an Agilent E8362B vector network analyzer. The software of the network analyzer calculates the dielectric constant and loss factor as a reflected signal function. For these measurements the probe was fixed to a stainless steel support, and an elevation platform brings the sample near the probe to avoid possible phase changes due to cable movements after calibration. The system was calibrated by using three different types of loads: air, short-circuit and $25^{\circ} \mathrm{C}$ Milli $\AA-Q$ water. Once the calibration was made, $25^{\circ} \mathrm{C}$ Milli ${ }^{\circledR}$ $\mathrm{Q}$ water was measured again to check calibration suitability.

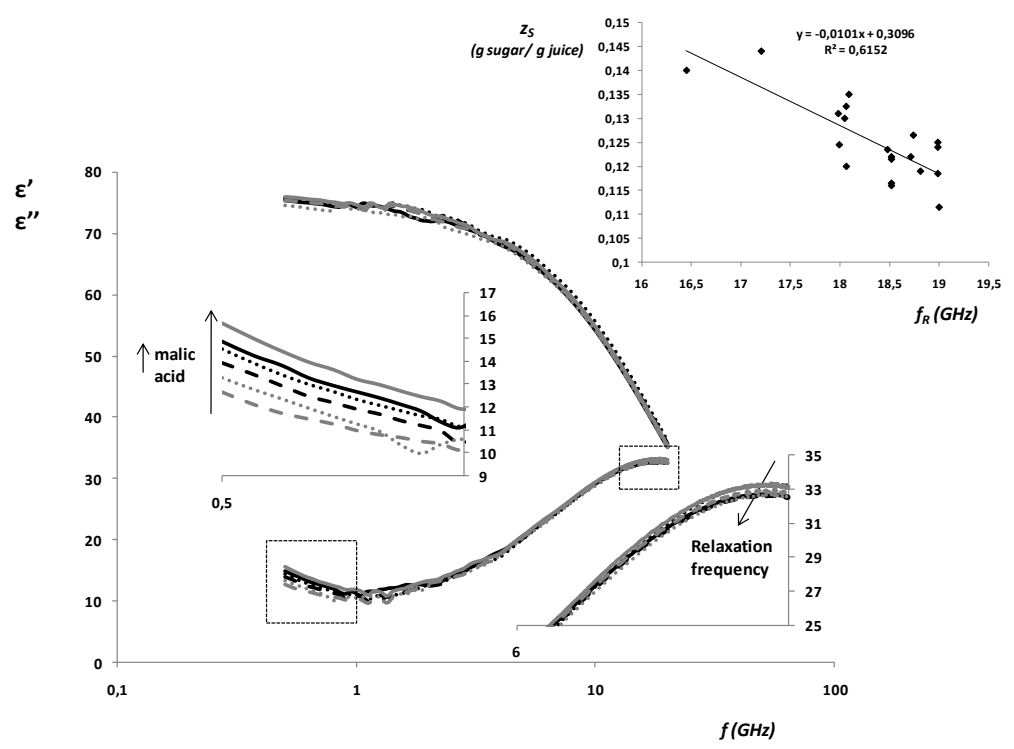

Figure 3. Dielectric spectra of clarified apple juices. At right side down, loss factor spectra at frequencies near the dipolar relaxation frequency could be observed in detail. At right side up, the relation between sugars concentration and the relaxation frequency can be observed. At left side, loss factor spectra at low frequencies are shown in detail. 
The dielectric properties were measured by contacting the sample surface with the probe and by introducing the open-ended probe at least $5 \mathrm{~mm}$ deep in the clarified apple juice. The Mean values of ten replicates are reported in this article. All determinations were made at $30^{\circ} \mathrm{C}$ from $500 \mathrm{MHz}$ to $20 \mathrm{GHz}$

\subsection{Physical-Chemical analysis.}

The water activity was determined by using a dew point hygrometer Aqualab ${ }^{\circledR}$ series 3 TE (Decagon Devices, Inc., Washington, USA). Water activity was measured in clarified liquid and in structured apple tissue.

Sugar content was determined by a refractometer (ABBE, ATAGO Model 3-T, Japan).

Moisture content and titrable acidity (expressed as malic acid) were determined according to the AOAC (1984) methods 22.013, 22.008, respectively.

Analytical determinations described above were obtained by triplicate.

\subsection{Maturity Index}

Thiault Index (TI) was used as an indicator of apple maturity. The Thiault Index is defined by equation 3 (Thiault, 1970).

$$
\mathrm{TI}=\mathrm{c}_{\mathrm{s}}+10 \times \mathrm{Ac}
$$

Where, $c_{s}$ represents the sugar concentration $(g / L)$ measured by refractometry, Ac represents the $\mathrm{NaOH}$ estimated acidity (expressed as $\mathrm{g} / \mathrm{L}$ ). The Lewis expression of sugar solutions density (Lewis, 1987) was used to transform the sugar mass fraction $(\mathrm{g} / \mathrm{g})$ to sugar concentration $(\mathrm{g} / \mathrm{L})$ (equation 4).

$$
\mathrm{c}_{\mathrm{s}}=\mathrm{z}_{\mathrm{s}} \times \rho_{\mathrm{ss}}
$$

In apple, if TI is equal to 170, is the minimum to an acceptable fruit quality; if TI is equal to 180 , is recommended to harvest the fruit; if TI is more than 180, the fruit quality is excellent (Porro,
Datlaserra, Dorigatti, \& Zatelli, 2002; Varela et al., 2005).

\section{Results and Discussion}

In figure 3 , some dielectric spectra of clarified apple juices can be observed. The figure shows that the ionic losses are the main contribution to loss factor at low frequencies. Ionic losses are directly related to malic acid content (Castro-Giráldez et al., $2010 \mathrm{~b}$ ). At the higher frequencies of the spectra, a slightly decrease in dipolar relaxation frequency can be observed; it can be attributed to differences in sugar content (Castro-Giráldez et al., 2010b). In figure 4 the relation between malic acid concentration and the loss factor at $0.5 \mathrm{GHz}$ can be observed. In the same figure, the relation between soluble solids content and the loss factor at relaxation frequency is also shown.

Figure 4 shows that the increase in malic acid produces an increase in the loss factor value at $0.5 \mathrm{GHz}$ due to the increase in ionic losses. It can be affirm that malic acid is in malate form in apple juice, and the strong negative charges of the molecule have an important effect on loss factor at low frequencies of the spectrum. The negative relation of soluble solids content with loss factor at dipolar relaxation frequency can also be observed. The increase of viscosity caused by the presence of sugar molecules reduces water mobility and displaces dipolar relaxation frequency to lower frequencies of the spectrum (Figure 5), decreasing also the loss factor value at the relaxation frequency (Figure 4).

In figure 5, dielectric spectra of apple tissue are shown. If compared apple juice spectra to apple tissue spectra (Figures 3 and 5, respectively), it can be observed that apple juices spectra take higher values than apple tissue spectra; these differences can be due to the compartimentation of apple tissue and the effect of the matrix on the dielectric spectra. At these frequencies, insoluble matrix does
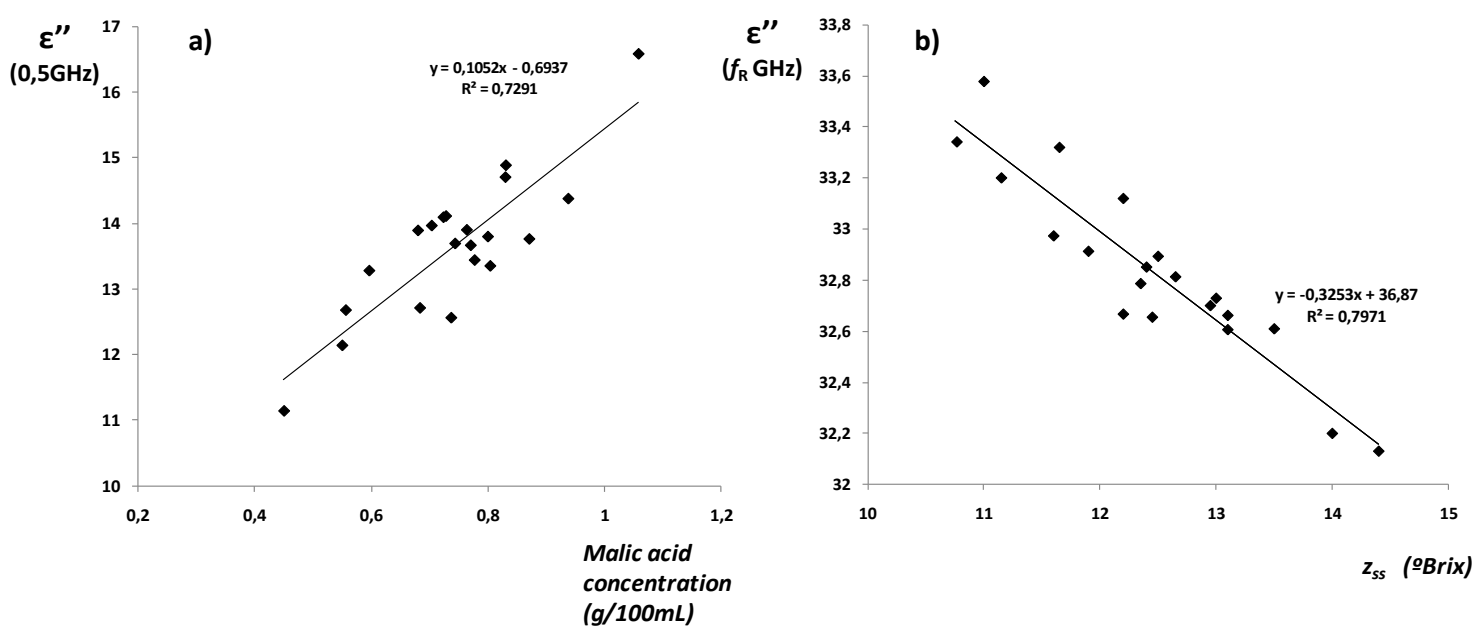

Figure 4. a) Relation of malic acid concentration with loss factor of apple juice at $0,5 \mathrm{GHz}$; b) Relation of soluble solids content with loss factor of apple juice at dipolar relaxation frequency. 


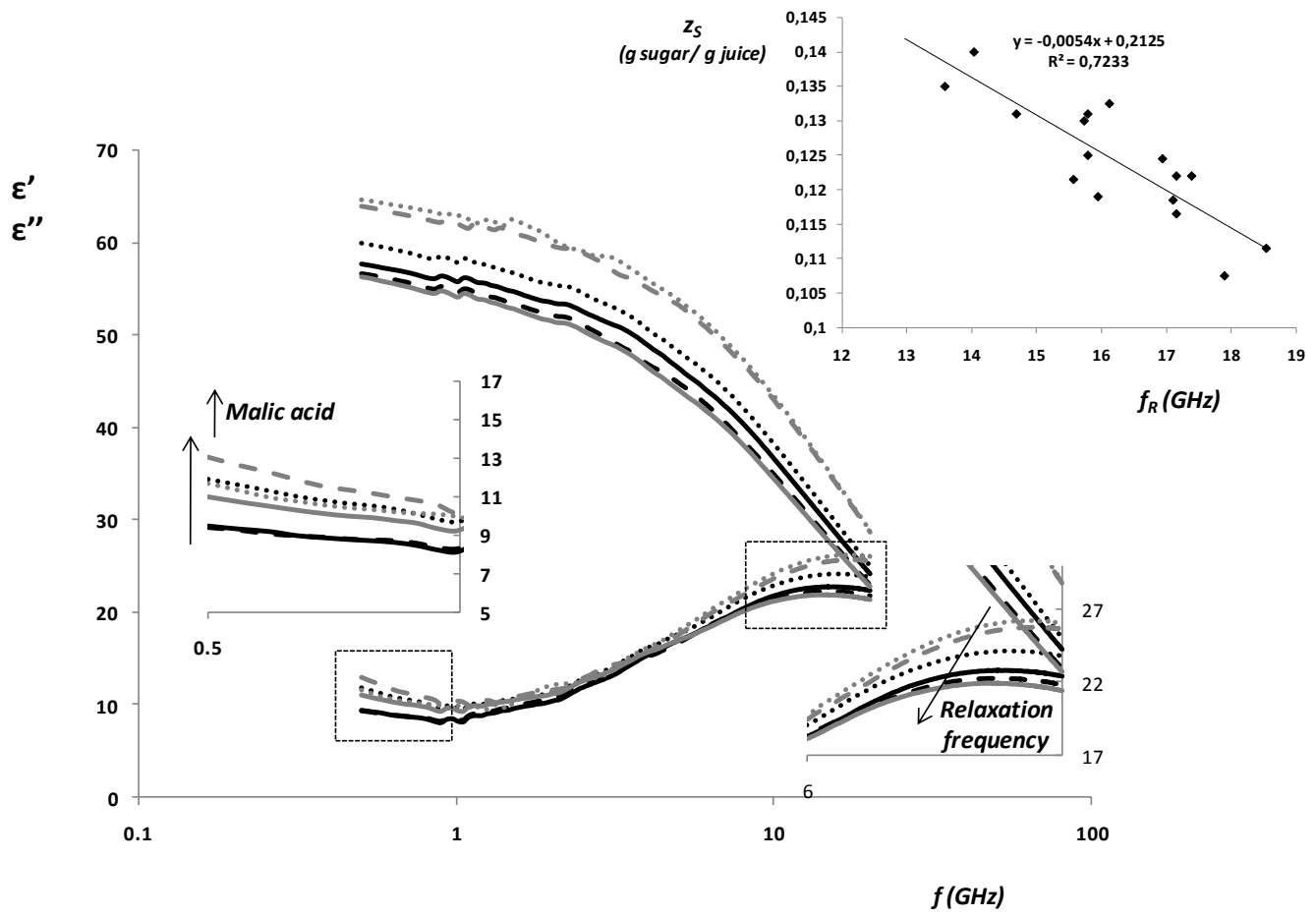

Figure 5. Dielectric spectra of Granny Smith apples. At right side down, loss factor spectra at frequencies near the dipolar relaxation frequency could be observed in detail. At right side up, the relation between sugars concentration and the relaxation frequency can be observed. At left side, loss factor spectra at low frequencies are shown in detail.

not interact with radiation producing a concrete polarization, but its presence, taking part of a highly ordered structure, has the effect of limiting the mobility of water and solutes molecules. In the same figure, the relation between sugars concentration and the relaxation frequency can be observed. The increase in sugars content decreases relaxation frequency as can be observed in this figure.

\subsection{Maturity Index}

As it can be observed in equation 3, Thiault Index is an indicator of soluble solids content and malic acid concentration. Both soluble solids content and acidity are quantified in the same order, for this reason the acidity is multiplied by 10 .

Due to the fact that malic acid concentration is positively related to loss factor at $0.5 \mathrm{GHz}$, and the concentration of soluble solids is negatively related to loss factor at the relaxation frequency, a new Maturity Index based on dielectric properties (MIdielectric) can be defined (equation 5).

$$
M I_{\text {dielectric }}=\varepsilon^{\prime \prime}\left(f_{\text {relaxation }}\right)-\varepsilon^{\prime \prime}\left(f_{0.5 \mathrm{GHz}}\right)
$$

It is important to highlight that an increase in malic acid produces an increase in loss factor at $0.5 \mathrm{GHz}$; on the contrary, an increase in sugar content produces a decrease in the loss factor at relaxation frequency. As it was explained above, Thiault Index quantify both soluble solids content and malic acid concentration; for this reason, to define a Dielectric Maturity Index it is necessary to subtract the loss factor at relaxation frequency from the loss factor at $0.5 \mathrm{GHz}$. It could be interesting to remark that loss factor at relaxation frequency is higher than loss factor at $0.5 \mathrm{GHz}$, for this reason and to avoid negative signs, the subtraction was define as specified in equation 5. Moreover, it is also important to denote that an increase in Thiault Index will produce a decrease in Dielectric Maturity Index.

In figure 6, the Dielectric Maturity Index was represented as a function of the Thiault Index. It can be appreciated that there exist a linear correlation between both Indexes.

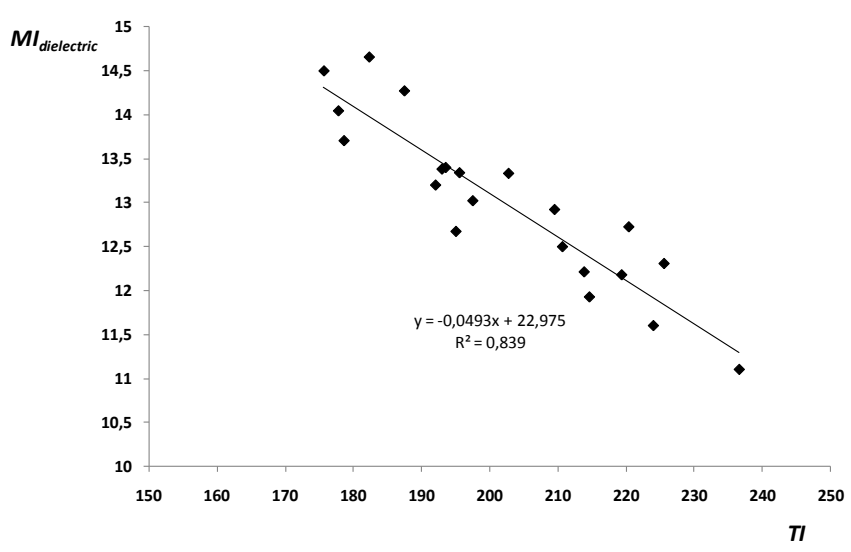

Figure 6. Dielectric Maturity Index $\left(M I_{\text {dielectric }}\right)$ as a function of the Thiault Index (TI) for Granny Smith apple tissue. 


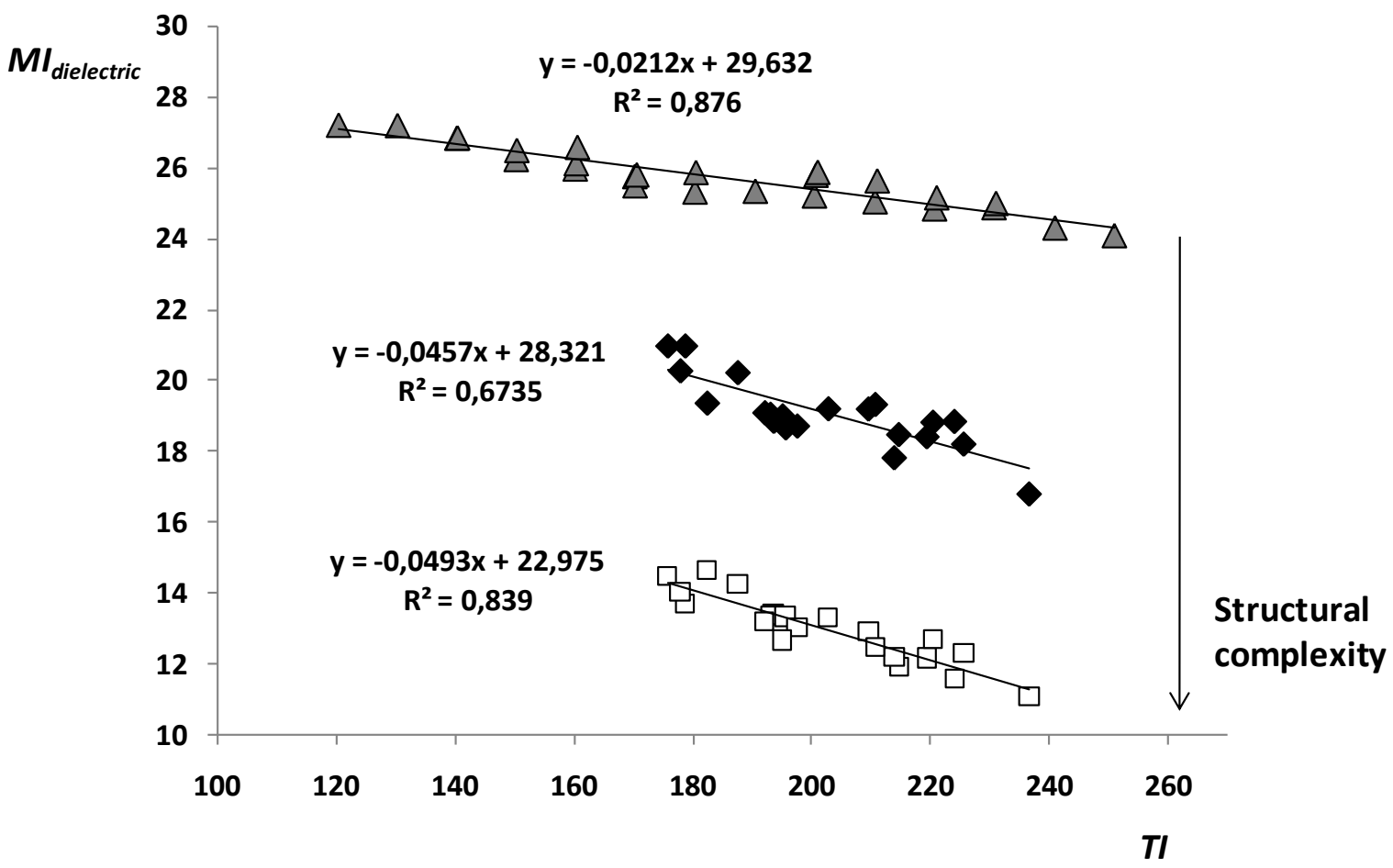

Figure 7. Dielectric Maturity Index (MI dielectric) as a function of the Thiault Index (TI) for standard solutions ( $\Delta$ ) (CastroGiráldez et al., 2010b), apple juice ( $\bullet$ and Granny Smith apple tissue ( $\square$ ).

In figure 7 , the Dielectric Maturity Index was represented as a function of the Thiault Index for standard solutions (Castro-Giráldez et al., 2010b), apple juice and Granny Smith apple tissue. Standard solutions have higher Dielectric Maturity Indexes than apple juice which also has higher values than apple tissue. Obviously, in apple juice there exist other compounds that do not interact with electromagnetic radiation at these frequencies but which reduce the mobility of dipoles or ions. In apple tissue this effect is accented due to the high structured organization of the cells. Beside this fact, it can be affirmed that the fruit maturity can be good predicted with the Maturity Index calculated from dielectric properties of apple tissue. On the other hand worse correlation was found between Thiault Index and the Maturity Index calculated from dielectric properties of apple juice. It might be due to the fact that the liquidized operation produces a destructuration of tissue and thus compositional changes and biochemical reactions can occur, mainly oxidation reactions.

\section{Conclusions}

The possibility to develop a prediction system of Thiault Index for Granny Smith apples based on dielectric measurements at two punctual frequencies of $0.5 \mathrm{GHz}$ and dipolar relaxation frequency was demonstrated. This prediction system utilizes the subtraction between loss factor at relaxation frequency and at $0.5 \mathrm{GHz}$. This subtraction was used due to the fact that apple maturation produces an increase in sugar content (decreasing loss factor at relaxation frequency) and an increase in malate content (increasing loss factor at $0.5 \mathrm{GHz}$ ).

\section{References}

AOAC (1984). Official methods of analysis (14th ed.). Washington, DC: Association of Official Analytical Chemists.

Castro-Giráldez, Fito, P.J., Chenoll, C. \& Fito, P., (2010b). Development of a dielectric spectroscopy technique for determining key chemical components of apple maturity. Journal of Agricultural and Food Chemistry. In press.

Feldman, Y., Ermolina, I. \& Hayashi, Y. (2003). Time domain dielectric spectroscopy study of biological systems. IEEE Transactions on Dielectrics and Electrical Insulation, 10(5),728-753.

Gabriel, C. (2006). Dielectric properties of biological materials. In F.S. Barnes \& B. Greenebaum, Bioengineering and biophysical aspects of electromagnetic fields, Handbook of biological effects of electromagnetic fields (pp.51-100). Boca Raton: CRC Press.

Guo, W., Nelson, S., Trabelsi, S. \& Kays, S.J. (2007a). 10-1800-MHz dielectric properties of fresh apples during storage. Journal of Food Engineering, 83(4), 562-569.

Harker, F.R., Marsh, K.B., Young, H., Murray, S.H., Gunson, F.A. \& Walker, S.B., (2002). Sensory interpretation of instrumental measurements 2: sweet and acid taste of apple fruit. Posthasvest Biology and Technology, 24, 241250.

Hulme, A.C. (1958). Some aspects of the biochemistry of apple and pear fruits. In E.M. Mrak, G.F. Stewart \& C.O. Chichester, Advances in Food Research (pp. 297-413). New York: Academic Press.

Hulme, A.C., Dones, J.D. \& Wooltorton, L.S. (1963). The respiration climacteric in apple fruits. Proceedings of the Royal Society $B, 158,514-535$.

Kader, A.A. \& Barret, D.M. (1996). Classification, composition of fruits and postharvest maintenance of quality. In L.P. Somogyi, H.S. Ramaswamy, Y.H. Hui, Processing fruits: Science and Technology Vol I. Biology, principles and 
applications (pp. 1-24). Lancaster, Pennsylvania: Technomic Pub. Co. Inc.

Lal Kaushal, B.B. \& Sharma, P.C. (1995). Apple. In D.K. Salunkhe, S.S. Kadam, Handbook of fruit science and technology: production, composition, storage and processing (pp. 91122). New York: Marcel Dekker.

Lanahan,A., Black, R. \& Ecker, J.R.(1996). Hookless1, an ethylene response gene, is required for differential cell elongation in the Arabidopsis hook. Cell, 85,183-194.

Lewis, M.J. (1987). Physical properties of foods and food processing systems (pp. 61-62). Chichester, England: Ellís Horwood Ltd.

Mansour, R., Latche, A., Vaillant, V., Pech, J.C. \& Reid, M.S. (1986) Metabolism of 1-aminocyclopropane-1-carboxylic acid in ripening apple fruits. Physiology Plant, 66,495-502.

Metaxas, A.C. \& Meredith, R.J. (1993). Industrial Microwave Heating. IEE Power Engineering series 4, London, UK Peter Peregrinus LTD.

Nelson, S.O. \& Datta, A.K. (2001). Dielectric properties of Food Materials and Electric Field Interactions. In A.K. Datta \& R.C. Anantheswaran, Handbook of Microwave Technology for Food Applications (pp.69-114). New York: Marcel Dekker.

Nelson, S.O., Trabelsi, S. \& Kays, S.J. (2006). Dielectric spectroscopy of honeydew melons from $10 \mathrm{MHz}$ to $1.8 \mathrm{GHz}$ for quality sensing. Transactions of the ASAE, 49(6),19771982.
Nelson, S.O., Guo, W., Trabelsi, S. \& Kays, S.J. (2007). Dielectric spectroscopy of watermelons for quality sensing. Measurement Science and Technology, 18,1887-1892.

Pearson, J.A. \& Roberson, R.N. (1954). The physiology of growth in apple fruits. VI. The control of respiration rate and synthesis. Australian Journal of Biological Sciences, 7(1),117.

Porro, D., Datlaserra, M., Dorigatti, C. \& Zatelli, A. (2002). Fitoregolatori efitormoni: risposta produttiva ed económica di Golden Delicious. Terra Trentina, 6,28-33.

Ribereau-Gayon, J. \& Peynaud, E. (1971). Physiologie et biochimie de la vigne. Biochimie de la vigne et du raisin. In Dunod, Sciences et Techniques de la Vigne, Vol.1 (pp. 456), Paris.

Schwan, H.P. (1988). Biological effects of non-ionizing radiations: cellular properties and interactions. Annals of Biomedical Engineering, 16, 245-263.

Sinha, N.K. (2006). Apples. In Yiu H.Hui, Handbook of fruits and fruit processing (pp. 265-278). U.S.A: Blackwell Publishing.

Taiz, L. \& Zeiger, E. (2002). Ethylene: the gaseous hormone. In L. Taiz \& E. Zeiger, Plant Physiology (pp. 519-538). Sunderland, Massachusetts: Sinauer Associates, Inc. Publishers.

Thiault, J. (1970). Etude de criteres objectifs de la qualite gustative de pommes Golden Delicious. Bulletin Technique d'Information (Ministère de l'Agriculture), 248,191-201.

Varela, P., Salvador, A. \& Fiszman, S. (2005). Shelf-life estimation of 'Fuji' apples: sensory characteristics and consumer acceptability. Postharvest Biology and Technology, 38, 18- 

4.4. Estudia de la cinética de escarchada de manzana Granny Smith mediante la cutilización de espectros dieléctricas 



\title{
Nonlinear thermodynamic approach to analyze long time osmotic dehydration of parenchymatic apple tissue
}

\author{
M. Castro-Giráldez, P.J. Fito*, P. Fito \\ Instituto Universitario de Ingeniería de Alimentos para el Desarrollo, Universidad Politécnica de Valencia, Camino de Vera, s/n, 46022, Valencia, Spain
}

\section{ARTICLE INFO}

\section{Article history:}

Received 29 April 2010

Received in revised form 29 June

2010

Accepted 27 July 2010

Keywords:

Osmotic dehydration

Thermodynamic model

Mass transfer

Nonlinear model

\section{Introduction}

Dehydration process has been used for centuries as a way to preserve foods. This process should be contemplated not only as a unit operation but also as a potent method to produce unique food structures (Aguilera et al., 2003a). Particularly, osmotic treatment is a dehydration technique which produces a dewatering-impregnation effect (Ferrando and Spiess, 2002). Nowadays, it is very important in the transformation and conservation of foodstuffs, improving the quality, stability and, the nutritional and organoleptic characteristics of the products if compared with traditional drying methods (Lenart and Lewicki, 1988; Lerici et al., 1988; Nanjundaswamy and Madhakrishniak, 1989; Lazarides and Mavroudis, 1995).

The osmotic process consists in the immersion of food in hypertonic solutions which exhibit an osmotic pressure. Moreover, a release of water from the food with a simultaneous impregnation of the material with the solute will take place

*Corresponding author. Tel.: +34 963877369

E-mail address: pedfisu@tal.upv.es (P.J.Fito).
(Ferrando and Spiess, 2001). There is an additional loss of product native solutes. Osmotic dehydration in a multiphase system as apple produces mass transfer phenomena simultaneously with physical and structural changes. For this reason, the mass transfer phenomena that occur in plant tissue in osmotic dehydration involve complex mechanisms which are difficult to understand and which are controlled mainly by the plant cell structure (Le Maguer, 1988) such as loss of turgid, plasmolysis, membrane lysis, etc. While the tissue membranes are intact, the transport through the membrane is the main one and it is responsible of mass transfer (Le Maguer and Yao, 1995, Seguí et al., 2006). For this reason, the structure can be considered one of the main factors for understanding osmotic dehydration (Mavroudis et al., 1998).

Parenquimatic tissue of apple is considered as a biological system constituted by cells ensembled in a complex structure with intercellular connexions, intracellular spaces and extracellular spaces. Apple composition is constituted by many components which can be grouped in: water, non-soluble solids, soluble solids, gases, and are distributed in four 


\section{Nomenclature}

$a_{j} \quad$ activity of the chemical specie $\mathrm{j}(-)$.

G Gibbs free energy, (J/mol).

Gj Partial Gibbs molar free energy of the specie j, (J/molj).

M mass (g)

Jj molar flux of the specie $\mathrm{j},\left(\mathrm{mol} / \mathrm{m}^{2} \mathrm{~s}\right)$

$\mathrm{Lj}$ phenomenological coefficient of the specie $\mathrm{j}$, $\left(\mathrm{mol}^{2} / \mathrm{s} \mathrm{m}^{2} \mathrm{~J}\right)$.

$\mathrm{Mr}$ molecular weight, $(\mathrm{g} / \mathrm{mol})$.

$\mathrm{n} \quad$ Number of moles, (mol)

$\mathrm{P}$ absolute pressure (atm)

$\mathrm{R}$ Ideal gases universal constant, $(\mathrm{J} / \mathrm{mol} \mathrm{K})$.

S Surface area, $\left(\mathrm{m}^{2}\right)$.

$\mathrm{T}$ Temperature, $\left({ }^{\circ} \mathrm{C}\right.$ or $\left.\mathrm{K}\right)$.

$\mathrm{t}$ Time, (s or min).

V Volume, $\left(\mathrm{m}^{3}\right)$.

X Mas or molar fraction (-).

F Force $(\mathrm{N})$

l Displaced distance $(\mathrm{m})$

$\bar{F} \quad$ Molecular force (N/mol)

Z Mass or molar fraction of the liquid fraction $(-)$.

\section{Greek alphabet:}

$\mu \mathrm{j} \quad$ Chemical potential of the specie $\mathrm{j},(\mathrm{J} / \mathrm{mol})$

$\mu_{j}^{0} \quad$ Chemical potential of reference of the specie $j$, (J/mol)

V Specific volume (L/mol).

$\Delta \quad$ Variation of a variable.

\section{Subscript y superscript:}

0 Initial time

24 Time 24 hours after the treatment.

LP Liquid phase.

max Maximum

s sucrose

w water

$\mathrm{t}$ Time, (s or min). different phases: solid matrix, which is mainly integrated by the cell membranes including the cell wall, plasmalemma, tonoplast and the cellular organules in the cytoplasm; intracellular liquid phase; extracellular liquid phase and gas (Fito et al., 2007). Parenquimatic cells volume is mainly occupied by large central vacuoles, which allow the cells to store nutrients and water. Special attention has to be taken to cell membranes which provide an effective barrier to the extracellular environment. The water transmembrane transport consists in diffusion of water by lipid bilayers or by water channels (specialized water transport proteins, aquaporins) (Agre et al., 1998). There is a fairly rigid layer surrounding the cell membrane called cell wall, which provides the structural support and mechanical protection. In the cell wall there are linking channels, the plasmodesmata, which allow the communication between adjacent cells. It is important to highlight that there are three different ways for a solute or solvent to flow through an osmotically treated cellular tissue. The apoplastic transport is external to the cell membrane. The simplastic transport allows the molecular movement between cells through the plasmodesmata. Finally, the transport through the membrane that can be described as an interchange between the protoplasm and the free space composed by extracellular space and the cell wall (Tyerman et al., 1999).

When foods are osmotically dehydrated, the mass fluxes lead to changes in the structural and transport properties such as volume, dimension, viscosity, density, porosity, among others, affecting the subsequent mass flows. It has been observed that the changes of volume and porosity occurred during the osmotic dehydration process promote the action of non-diffusional forces, such as the pressure gradients. These gradients are caused by the relaxation of the cellular tissue (Barat et al., 2001). Moreover, the shrinking of the tissue because of the water lost can damage the osmotically dehydrated cells (Ferrando and Spiess, 2003). This can happen by plasmolysis or by lysis of the connection between the membrane and the cellular wall (Rastogi et al., 2000).

The final properties of food products are the result of the changes produced in raw materials due to process treatments (Aguilera and Stanley, 1999). These changes may be observed as differences in quality factors such as: food composition, nutritional facts, taste and flavour, aspect, shape \& size, colour, texture, etc (Aguilera et al, 2003a, b).

Although osmotic treatment is not a new operation, the mass transfer phenomena involved are not yet fully understood. Simple and non-real models based on Fick's law can not be enough exact in order to describe complex systems dehydration processes. The use of an effective diffusion coefficient (Deff) reduces all structural effects and concomitant mechanisms to a single parameter (Aguilera et al., 2003b). These models usually oversimplify both the food system description and the mechanisms and kinetic equations of changes (Fito et al., 2008). Typically the food system is supposed to be isotropous, homogeneous and continuous, with only two or three components distributed in one or two phases (Crank, 1985). Currently, for modelling osmotic processes in modern engineering, the heterogeneous properties of the tissue must be considered (Ferrando and Spiess, 2002) and also the development of advanced concepts and methodologies are necessary (Marcotte and Le Maguer, 1991; Zhiming and Le Maguer, 1996). The new models for food and processes development must incorporate enough information about all these aspects (thermodynamic, structural, chemical and biochemical, and even mechanisms) (Fito et al., 2008). Only in this way, the prediction of real changes in the quality of food products in line with the process progression could be possible. A new food approaches, based on the real structures of 
foods, as SAFES methodology (Systematic Approach to Food Engineering Systems), recognize the complexity of food system and allows, coordinating the information about food structure, composition, thermodynamic, etc., to analyse real food and processes and to predict its behaviour (Fito et al, 2007).

The objective of this work is to describe candying apple process by using a nonlinear thermodynamic approach, taking into account the influence of tissue structure (ex: swelling and shrinking tissue phenomena or structural changes) in the water and sucrose transport.

\section{Materials and methods}

Sucrose solution $\left(65 \% \mathrm{w} / \mathrm{w}, 30^{\circ} \mathrm{C}\right)$, prepared with commercial sugar and distilled water, was used as an osmotic agent. Before the experiment, apples (var. Granny Smith) with the same size and ripeness were bought from a local supermarket and kept refrigerated until use. The apples were cut with a calimeter and a cork borer in cylinders $(1 \mathrm{~cm}$ thickness, $2 \mathrm{~cm}$ diameter) from the parenquimatic tissue. There were prepared 47 samples which were immersed in a vessel containing the osmotic solution with continuous stirring. The relation between the fruit and the solution was of 1:20 $(\mathrm{w} / \mathrm{w})$ to avoid changes in the solution during the process. The system was maintained at $30^{\circ} \mathrm{C}$ in a constant-temperature chamber. To prevent evaporation the vessel was covered with a sheet of plastic wrap.

Preliminary kinetic studies were done at the same working conditions in order to select the osmotic dehydration times. Osmotic dehydration was conducted over several time periods: 180, 360,
480, 720, 1463, 1577, 1722, 3375, 4320, 7200, 8540 and 10270 minutes. Three samples were used at each dehydration time.

A flow-diagram of the experimental procedure is presented in figure 1 .

Each sample treated was reposed at $30^{\circ} \mathrm{C}$ for 24 hours, on Decagon containers, closed with parafilm $\AA$, in order to eliminate the concentration profiles in samples.

Mass, volume and surface water activity was analyzed for each fresh, treated and reposed samples. Representative fresh samples were used to determine the initial moisture and solute content

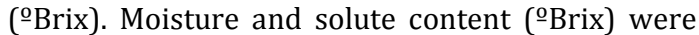
measured for each reposed sample. At each osmotic time, an aliquot of sucrose solution was also taken from the vessel. Water activity and ${ }^{\circ}$ Brix of the solution were measured at each time.

Mass was determined by using a Mettler Toledo Balance $( \pm 0.0001)$ (Mettler-Toledo, Inc., U.S.A.).

Volume measurements were analysed by using a photographic treatment of the samples and the software Adobe Photoshop ${ }^{\circledR}$ (Adobe Systems Inc., San Jose, CA, U.S.A.) to get the diameter and the thickness of the samples.

Surface water activity was measured in the structured samples with a dew point hygrometer Aqualab ${ }^{\circledR}$ series 3 TE (Decagon Devices, Inc., Washington, USA).

Moisture content was determined by drying in a vacuum oven at $60^{\circ} \mathrm{C}$ till constant weight was reached (AOAC method 934.06 (2000)). Sugar content was determined in a refractometer (ABBE, ATAGO Model 3-T, Japan). Analytical determinations described above were obtained by triplicate.

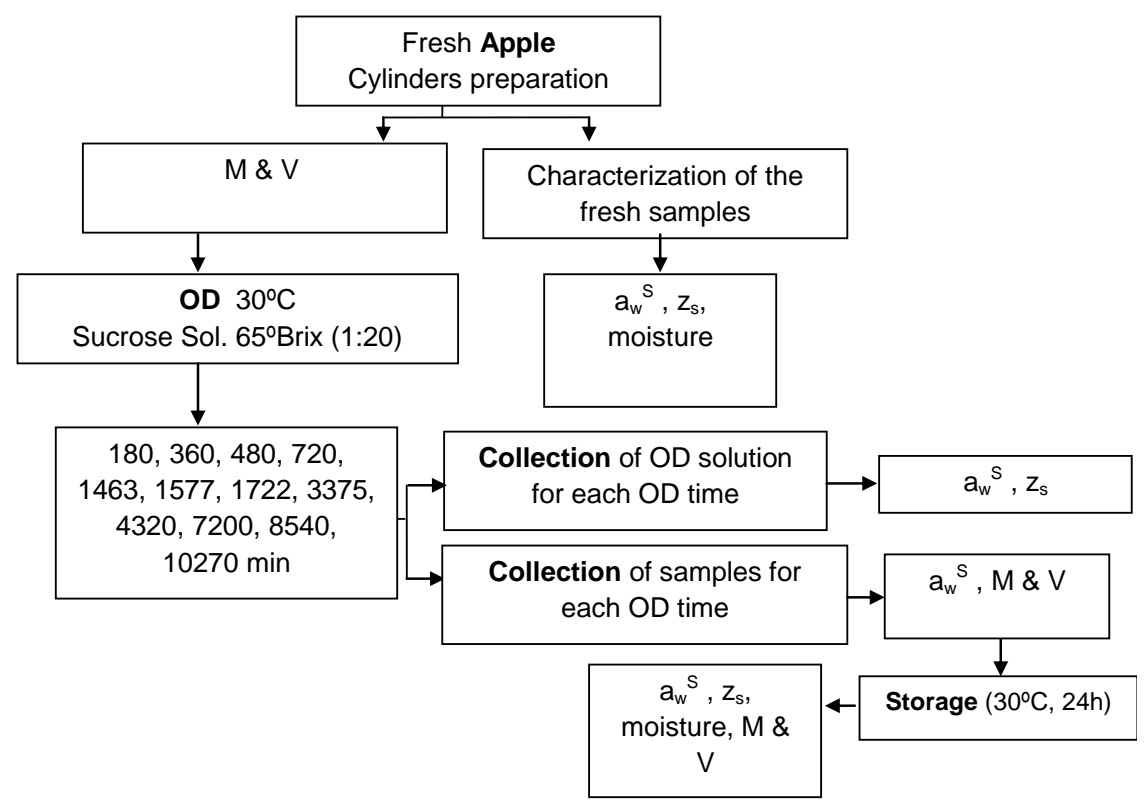

Figure 1. Flow diagram of the experimental procedure. 


\section{Results and discussion}

The osmotic dehydration operation with $65^{\circ}$ Brix solution produces compression and relaxation phenomena (Fito and Chiralt, 1997). These mechanisms could be observed by analyzing the mass and volume variation; these variations could be estimated by the following equations:

$$
\begin{array}{ll}
\Delta \mathrm{M} & =\frac{\mathrm{M}_{\mathrm{t}}-\mathrm{M}_{\mathrm{o}}}{\mathrm{M}_{\mathrm{o}}} \quad \text { (Equation 1) } \\
\Delta \mathrm{V} & =\frac{\mathrm{V}_{\mathrm{t}}-\mathrm{V}_{\mathrm{o}}}{\mathrm{V}_{\mathrm{o}}} \quad \text { (Equation 2) }
\end{array}
$$

where $\mathrm{M}$ represents the mass $(\mathrm{kg}), \mathrm{V}$ the volume $\left(\mathrm{m}^{3}\right)$, the subscripts $t$ represent the treatment time, being 0 the initial value.

Moreover, the sucrose and water mass evolution can be observed applying equation 1 for the specific compounds as follows:

$$
\begin{aligned}
& \Delta \mathrm{M}_{\mathrm{w}}=\frac{\mathrm{M}_{\mathrm{t}} \mathrm{x}_{\mathrm{wt}}-\mathrm{M}_{0} \mathrm{x}_{\mathrm{w} 0}}{\mathrm{M}_{0}} \\
& \Delta \mathrm{M}_{\mathrm{s}}=\frac{\mathrm{M}_{\mathrm{t}} \mathrm{x}_{\mathrm{st}}-\mathrm{M}_{0} \mathrm{x}_{\mathrm{s} 0}}{\mathrm{M}_{0}}
\end{aligned}
$$

(Equation 3)

(Equation 4)

where $\mathrm{x}_{0}$ is the mass fraction of water $\left(\mathrm{x}_{\mathrm{w} 0}\right)$ or soluble solids $\left(\mathrm{x}_{\mathrm{s} 0}\right)$ of the sample at initial time $\left(\mathrm{kg} / \mathrm{kg}_{\mathrm{T}}\right)$ and $\mathrm{xt}_{\mathrm{t}}$ is the same after dehydration process $\left(\mathrm{kg} / \mathrm{kg}_{\mathrm{T}}\right)$.

Figure 2 shows the mass, volume, water and sucrose mass variation through the osmotic treatment. In the figure, the decrease in total mass and volume is appreciated. The decrease in mass is explained by the water losses while the sucrose mass increases during the osmotic treatment.
The water and solute fluxes promoted in the osmotic treatment can be calculated with the mass variation, the process time and the variation of the samples surface.

$$
\begin{aligned}
& \mathrm{J}_{\mathrm{w}}=\frac{-\Delta \mathrm{M}_{\mathrm{w}} \cdot \mathrm{M}_{\mathrm{o}}}{\Delta \mathrm{t} \cdot \mathrm{S} \cdot \mathrm{Mr}_{\mathrm{w}}} \quad \text { (Equation 5) } \\
& \mathrm{J}_{\mathrm{s}}=\frac{\Delta \mathrm{M}_{\mathrm{s}} \cdot M_{o}}{\Delta \mathrm{t} \cdot \mathrm{S} \cdot \mathrm{Mr}_{\mathrm{s}}} \quad \text { (Equation 6) }
\end{aligned}
$$

where $J_{w}$ is the water flux $\left(\mathrm{mol}_{\mathrm{w}} / \mathrm{s} \mathrm{m} \mathrm{m}^{2}\right), J_{\mathrm{s}}$ is the sucrose flux $\left(\mathrm{mol}_{\mathrm{s}} / \mathrm{s} \mathrm{\textrm {m } ^ { 2 } )}\right.$ during the treatment, $\mathrm{t}$ is the process time, $\mathrm{S}$ is the measured surface area of the sample $\left(\mathrm{m}^{2}\right), \mathrm{Mr}_{\mathrm{w}}$ is the molecular weight of water $(18 \mathrm{~g} / \mathrm{mol})$ and $\mathrm{Mr}_{\mathrm{s}}$ is the molecular weight of sucrose $(342 \mathrm{~g} / \mathrm{mol})$. It is possible to observe in figure 3 that the flux of solutes is reduced faster than the water flux, this is possible because the cell membrane is semi-permeable and only water compound may cross the membrane.

Figure 4 shows a detail of surface water activity measured in the fresh, treated and reposed samples; these measurements represent the water activity of the surface of each sample. After the repose time, the moisture was analyzed in whole sample. The moisture of treated samples was estimated by balances. Figure 4 shows the relationship between the moisture in dry basis and the surface water activity of the treated, reposed samples and data from pure solutions of water and sucrose (Starzak \& Mathlouthi, 2006). In this figure it is possible to observe that the reposed samples maintain the same relationship surface water activity/moisture as the pure sucrose solution at different concentrations. Therefore, the water and sucrose concentration is homogeneous in the reposed samples, been negligible the concentration profiles through the tissue. Treated samples show

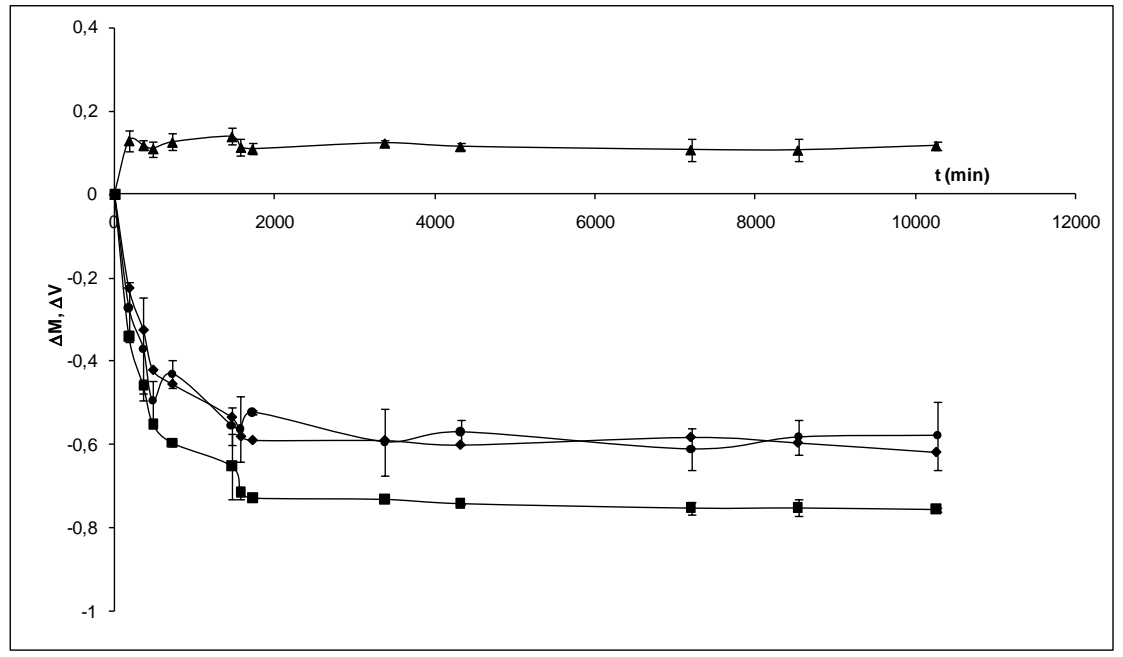

Figure 2. Evolution of overall mass $(\boldsymbol{\nabla})$, water mass $(\boldsymbol{\square})$, sucrose mass $(\boldsymbol{\Delta})$ and volume $(\bullet)$ through the osmotic treatment. 


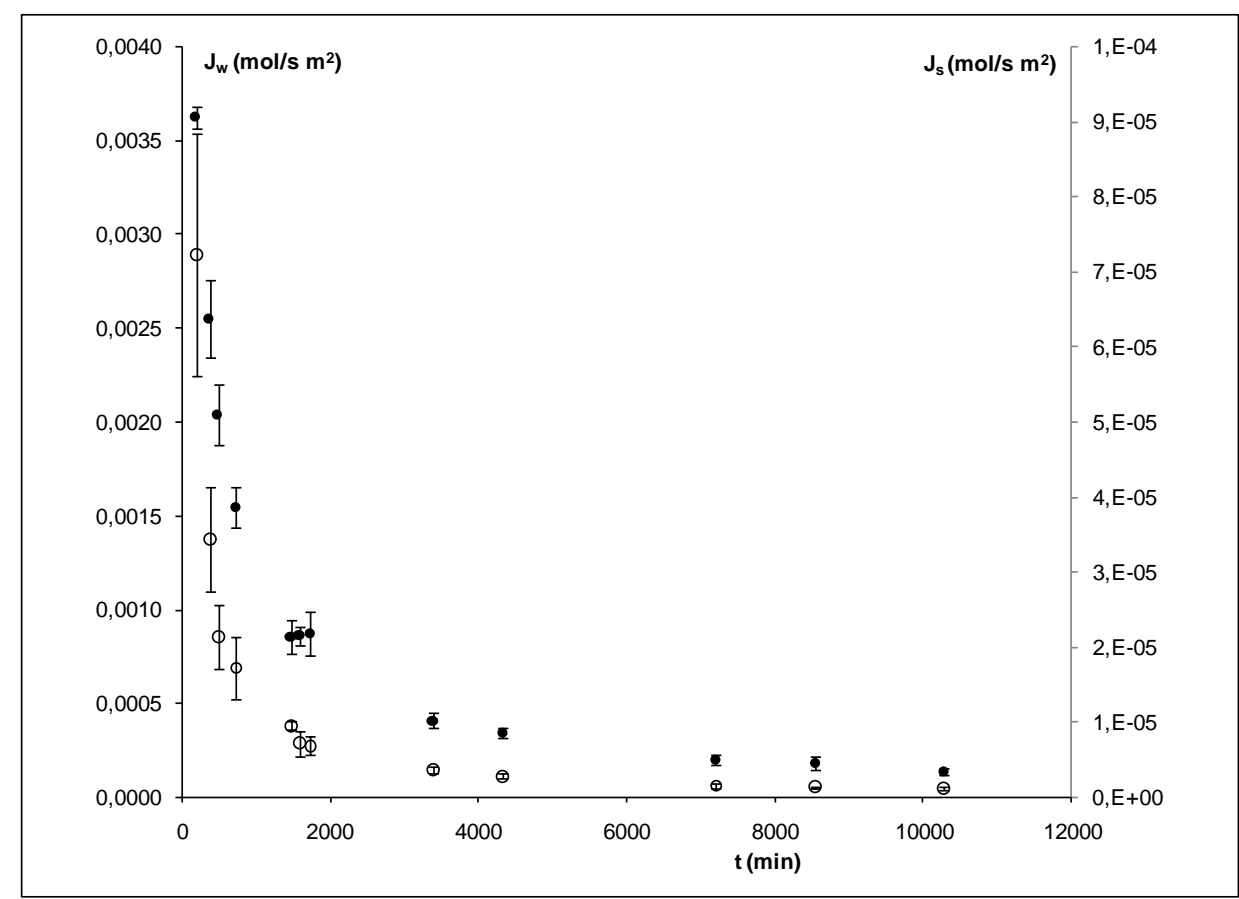

Figure 3. Variation of water $(\bullet)$ and sucrose $(O)$ fluxes versus time through the treatment.

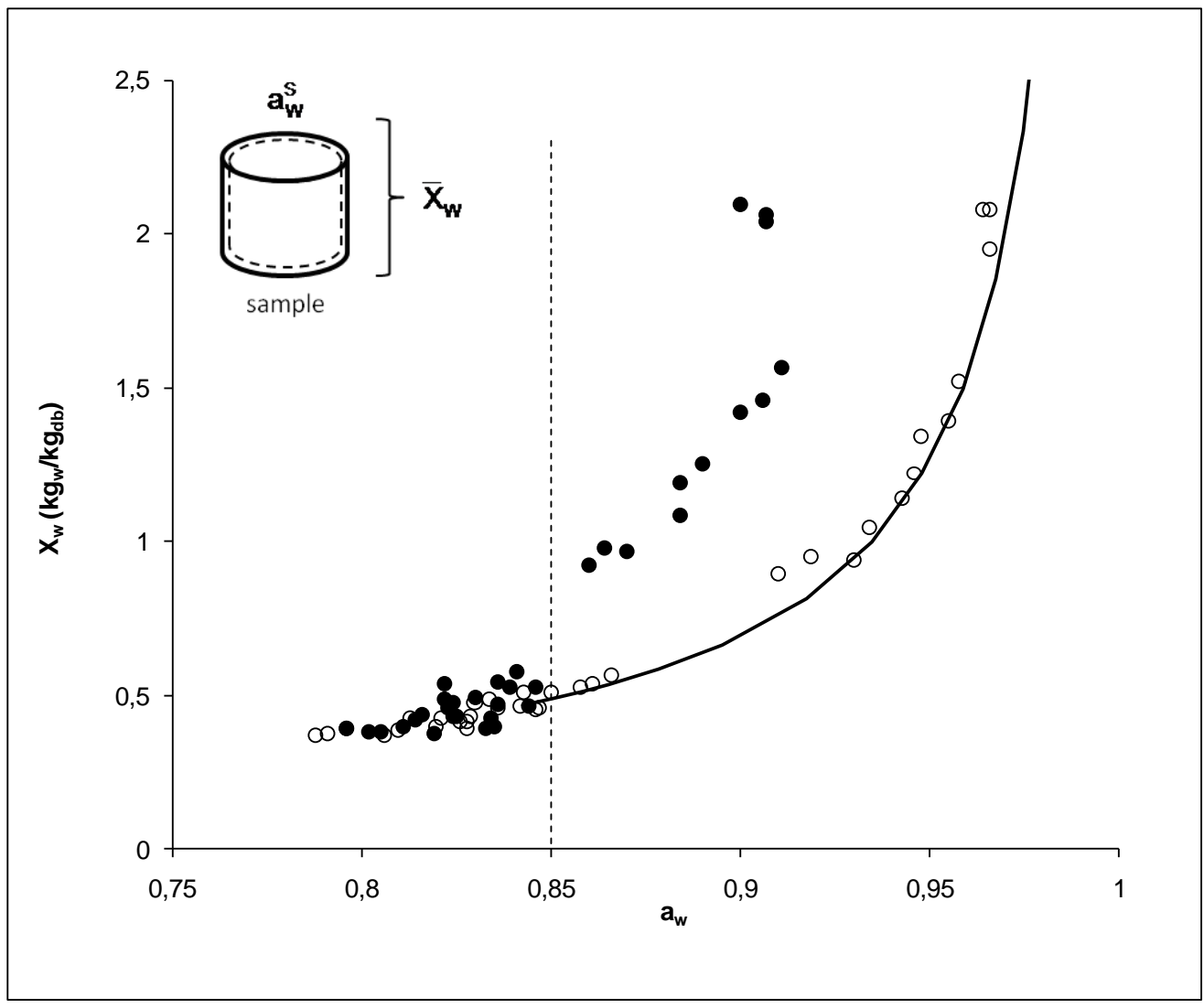

Figure 4. Relationship between the moisture in dry basis and the water activity for samples dehydrated $(\bullet)$, reposed 24h (O), and sucrose solutions (-) obtained from Starzak \& Mathlouthi (2006). A detail of surface water activity measurement and the average moisture measurement necessary to determine the internal transport is shown. 
two steps. At the beginning of the treatment, the surface water activity of treated samples is lower than that of the reposed samples; it denotes concentration profiles in the apple tissue and an important internal transport is driven by diffusion mechanisms. When surface water activity reaches the value of 0.85 , the treated and the reposed values concur with the pure solution values; this fact denotes the disappearance of concentration profiles in the tissue and the predominance of the mechanical behaviours driving the mass transfer.

\section{Non equilibrium approach to determine the water transport between the osmotic solution and the apple surface}

The thermodynamic analysis of the energy, equilibrium and fluxes in food systems is usually made in terms of the Gibbs Free Energy (Nicolis and Prigogine, 1977a,b).

In order to understand and to estimate the molecular transport through the interface (see figure $5 a$ ), it is necessary to determine the free energy variation across the interface per mol of any chemical specie in motion. Gibbs free energy variation could be estimated in a biological tissue as equation 7 shows (Demirel, 2002, CastroGiráldez et al., 2010).

$$
d G=-S d T+V d P+F d l+\psi d e+\sum_{i} \mu_{i} d n_{i}
$$

(Equation 7)

where the effect of the electric field term depends on the valence of the ions per electric charge. The effect in the free energy variations of the amount of native ions is negligible, thus the term is null. The system is isotherm, then the entropic term is negligible. So, the equation 7 is transformed in equation 8 .

$$
d G=V d P+F d l+\sum_{i} \mu_{i} d n_{i}
$$

(Equation 8)

Therefore it is possible to develop the free energy variation per water mol (extended chemical potential of water) as follows:

$$
\Delta \mu_{w}^{e x t}=\frac{\Delta \mathrm{G}}{\Delta \mathrm{n}_{\mathrm{w}}}=\nu_{\mathrm{w}} \Delta \mathrm{P}+\overline{\mathrm{F}}_{\mathrm{w}} \Delta \mathrm{l}+\mu_{\mathrm{s}} \frac{\Delta \mathrm{n}_{\mathrm{s}}}{\Delta \mathrm{n}_{\mathrm{w}}}+\mu_{\mathrm{w}}
$$

Where the $\overline{v_{\mathrm{w}}}$ represent the molar partial volume and $F_{w}$ the mechanical storage force expressed by mol. Figure $5 \mathrm{a}$ shows the simplification scheme used to apply the thermodynamic model. Applying equation 9 in the interface, defined in figure $5 \mathrm{a}$ as osmotic solution/extracellular space (apoplastic way), the water chemical potential results as follows:

$$
\Delta \mu_{w}^{e x t}=\bar{v}_{\mathrm{w}} \Delta \mathrm{P}+\overline{\mathrm{F}}_{\mathrm{w}} \Delta \mathrm{l}+\mathrm{R} T \ln \frac{a_{s}^{O S}}{a_{s}^{e}} \frac{\Delta \mathrm{n}_{\mathrm{s}}}{\Delta \mathrm{n}_{\mathrm{w}}}+\mathrm{R} T \operatorname{Ln} \frac{a_{w}^{O S}}{a_{w}^{e}}
$$

where as is obtained from the bibliography (Lide, 2004) (Figure 6); superscript $e$ represents the external liquid phase (apoplastic way) close to the interface, and superscript $O S$ represents the sucrose solution.

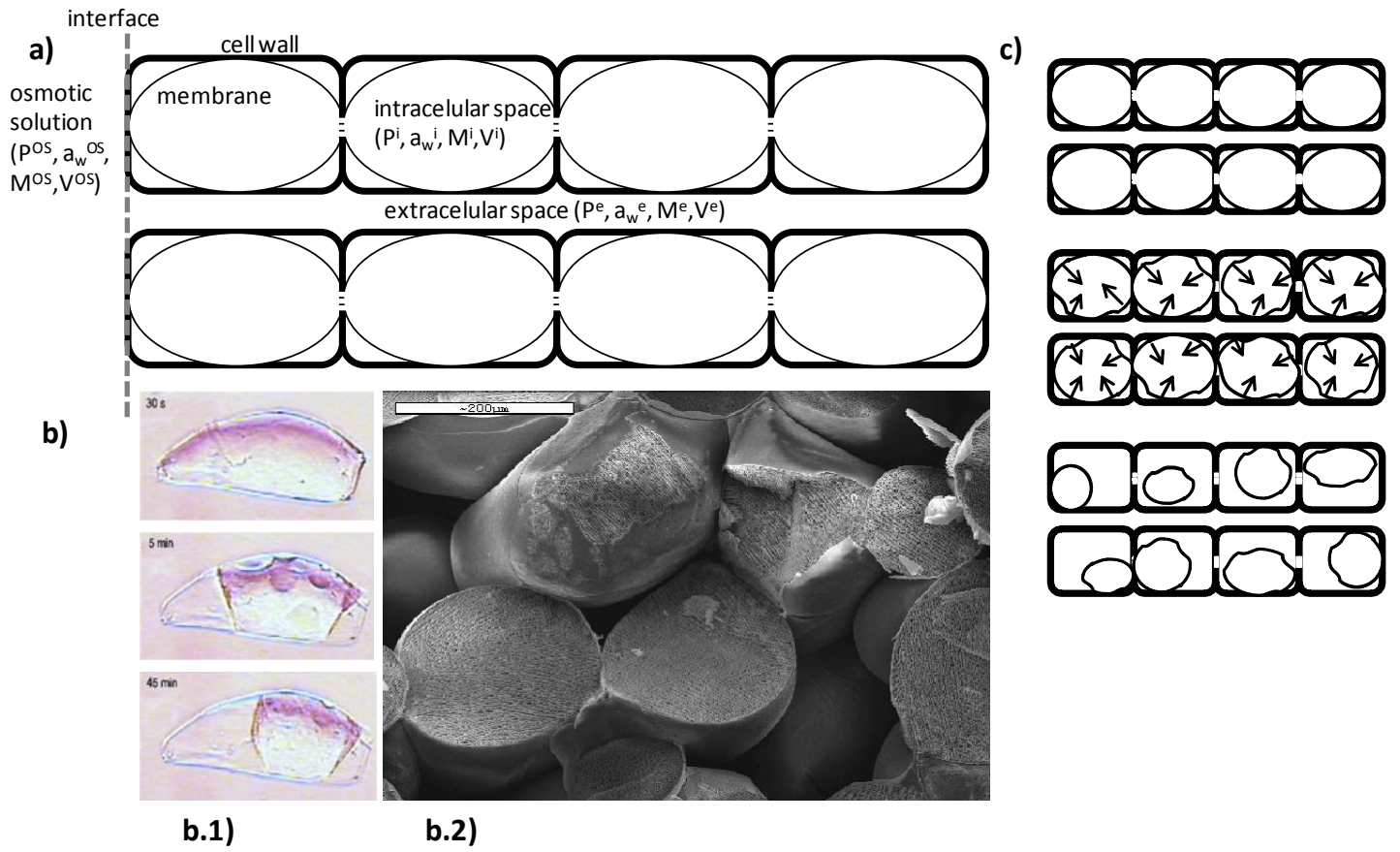

Figure 5. Evolution of apple tissue through the osmotic treatment. a) scheme of cell tissue, with the simplified phases used in the thermodynamic model; b) pictures of apple tissue, b.1) evolution of isolated apple cell through the osmotic treatment in sucrose solution ( $30^{\circ} \mathrm{C}, 35^{\circ} \mathrm{Brix}$ ) (adapted from Seguí et al, 2010), b.2) fresh apple tissue (Fito et al., 2007); c) Scheme of the parenquimatic tissue deformation through the osmotic treatment and the plasmolysis process. 


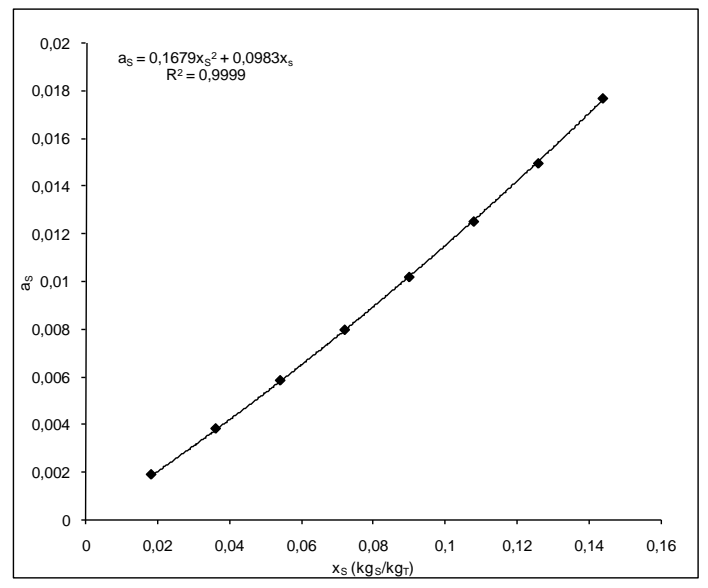

Figure 6. Sucrose activity versus sucrose mass fraction in a pure sucrose solution (adapted from Lide, 2004).

The relation between the water and sucrose moles in motion is the same as the molar flux relation, then it is possible to use this relation in the equation 10, obtaining:

$$
\Delta \mu_{w}^{e x t}=\bar{\nu}_{\mathrm{w}}^{-} \Delta \mathrm{P}+\overline{\mathrm{F}}_{\mathrm{w}} \Delta \mathrm{I}+\mathrm{R} T \ln \frac{a_{s}^{o s}}{a_{s}^{e}} \frac{\mathrm{J}_{\mathrm{s}}}{\mathrm{J}_{\mathrm{w}}}+\mathrm{R} T \operatorname{Ln} \frac{a_{w}^{o s}}{a_{w}^{e}}
$$

Applying the first relation of Onsager (Demirel, 2002; Gekas, 2001), water fluxes may be related with the chemical potential extended, as a driving force of the water transport, with a phenomenological coefficient showed in equation 12.

$$
J_{w}=L_{w} \cdot \Delta \mu_{w}^{e x t} \quad \text { (Equation 12) }
$$

As explained before, figure 4 shows a first step of dehydration where the concentration profiles show the predominance of the activity terms in the transport driving forces. Figure 7 represents the activity terms of equation 11 with regard to the molecular water flux, where it is possible to observe a linear relation in the beginning of the osmotic treatment corresponding with the first step explained before in figure 4. First data is out of the linearity because the apple tissue is turgid (high internal pressure) at the initial time and the internal and external water transport need time to be coupled. Thus, it is possible to consider, in this first step, the mechanical terms of the equation 11 negligible. In this step of the treatment the chemical potential will be defined as follows:

$$
\Delta \mu_{w}^{e x t}=\mathrm{R} T \ln \frac{a_{s}^{o s}}{a_{s}^{e}} \frac{\mathrm{J}_{\mathrm{s}}}{\mathrm{J}_{\mathrm{w}}}+\mathrm{R} T \operatorname{Ln} \frac{a_{w}^{o s}}{a_{w}^{e}}
$$

(Equation 13)

Applying the equation 12 , the phenomenological coefficient obtained is $\mathrm{L}_{\mathrm{w}}=1,095 \cdot 10^{-5} \mathrm{~mol}^{2} / \mathrm{J} \mathrm{s} \mathrm{m}^{2}$. Different values of phenomenological coefficients of water transport through the protoplast membrane, in fruits, have been published; Ferrando and Spiess (2002 and 2003) showed in osmotic dehydration treatments with sucrose solution at $30^{\circ} \mathrm{C}, 1 \cdot 10^{-6} \mathrm{~mol}^{2} / \mathrm{J} \mathrm{s} \mathrm{m}^{2}$ for onions, $5.2 \cdot 10^{-6} \mathrm{~mol}^{2} / \mathrm{J} \mathrm{s} \mathrm{m}^{2}$ for carrots and $6.8 \cdot 10^{-6} \mathrm{~mol}^{2} / \mathrm{J}$ $\mathrm{s} \mathrm{m}^{2}$ for potatos. Seguí et al. (2006) reported the value of $4.5 \cdot 10^{-5} \mathrm{~mol}^{2} / \mathrm{J} \mathrm{s} \mathrm{m}^{2}$ for apple (var Fuji). Phenomenological coefficients for transmembrane transport have been published, working with isolated protoplasts or cells, but not for the apoplastic transport. Apoplastic transport is so relevant in the overall water transport in the tissue because it is coupled with the transmembrane and symplastic transport.

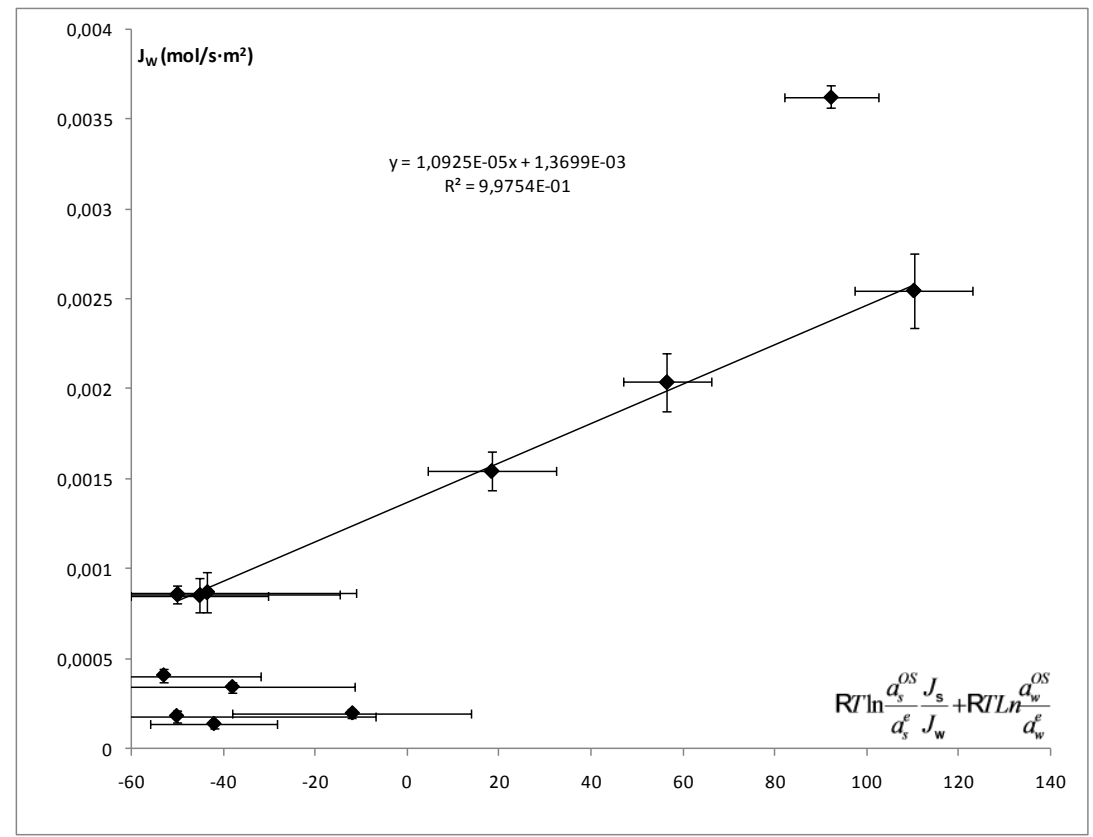

Figure 7. Molar water flux versus activity terms obtained from equation 11. 


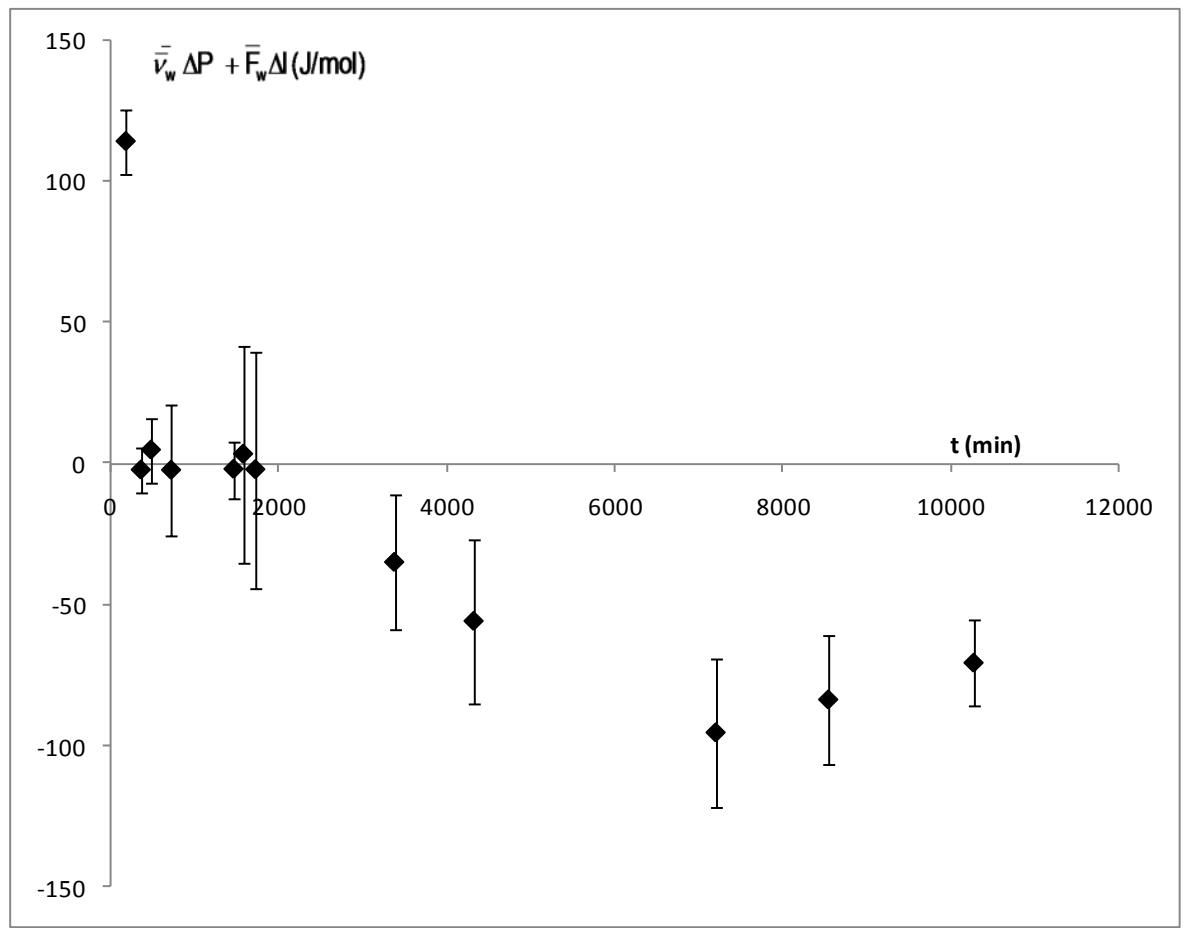

Figure 8. Evolution of the mechanical terms (see equation 15) involved in the water transport through the treatment time.

With the phenomenological coefficient and the molar water flux it is possible to estimate the extended chemical potential in all the treatment range, as follows;

$$
\Delta \mu_{\mathrm{w}}^{\mathrm{ext}}=\frac{\mathrm{J}_{\mathrm{w}}}{\mathrm{L}_{\mathrm{w}}}
$$

(Equation 14)

Then, the mechanical terms of the equation 11 , may be estimated as follows:

$$
\overline{v_{\mathrm{w}}} \Delta \mathrm{P}+\overline{\mathrm{F}}_{\mathrm{w}} \Delta \mathrm{l}=\Delta \mu_{w}^{e x t}-\left(\mathrm{R} T \ln \frac{a_{s}^{O S}}{a_{s}^{e}} \frac{\mathrm{J}_{\mathrm{s}}}{\mathrm{J}_{\mathrm{w}}}+\mathrm{R} T \operatorname{Ln} \frac{a_{w}^{O S}}{a_{w}^{e}}\right)
$$

(Equation 15)

Figure 8 shows the evolution of the mechanical terms involved in the water and sucrose transport through the treatment time, where is possible to observe three steps. Initial step shows a decreasing of the mechanical terms, it could occur because fresh cells (see figure 5b.2) are turgid and high level of mechanical energy is stored in the wall/membrane system, the shrinkage promoted by the water lost in the protoplast produces a relaxation in this system, affecting to the $\overline{\mathrm{F}}_{\mathrm{w}} \Delta \mathrm{l}$ term. The initial contraction of the wall/membrane system with shrinkage of the tissue produces a variation in the absolute pressure in the external phase (affecting to the $\mathrm{v}_{\mathrm{w}} \mathrm{dP}$ term). When the wallmembrane system reaches the minimum tension (relaxed), the internal and external pressure are the same and wall-membrane shrink together, reducing the overall volume, thus, the mechanical terms are negligible; being the activity terms the driving forces of the water transport through the apoplastic way. In step three, a structural change occurs, the total separation between wall and membrane (end of plasmolysis, as figure 5c represents) followed by an expansion of the wall (Seguí et al., 2010) with the continuous shrinkage of the protoplast, as the figure $5 \mathrm{~b} .1$ shows. Those phenomena produce an increase in the mechanical terms with negative values, which produce an inversion in the way of the transport in opposite sense with the activity term. Graphing the mechanical terms by the structural deformation (Figure 9), a $30 \%$ of deformation in first 180 minutes is observed, where the mechanical terms are maximum and positives in sense of the water flux. It is produced because the maximum shrinkage per minute of the tissue in whole treatment occurs. Next step shows shrinkage with neglected effect of the mechanical behaviours in the apoplastic way. In this step, deformation reaches the maximum shrinkage level of $60 \%$ (maximum mechanical energy stored in the contracted middle lamina and cell wall). Finally, this mechanical energy stored in the tissue is released to the external liquid phase driving the transport behaviours in the overall mass transfer. No significant changes on the overall volume are observed (see figure 2); the increase in the mechanical terms must to be produced by internal changes in the tissue, as plasmolysis (Seguí et al., 2010), the shrinkage of the protoplast produce a decrease in the external absolute pressure. 


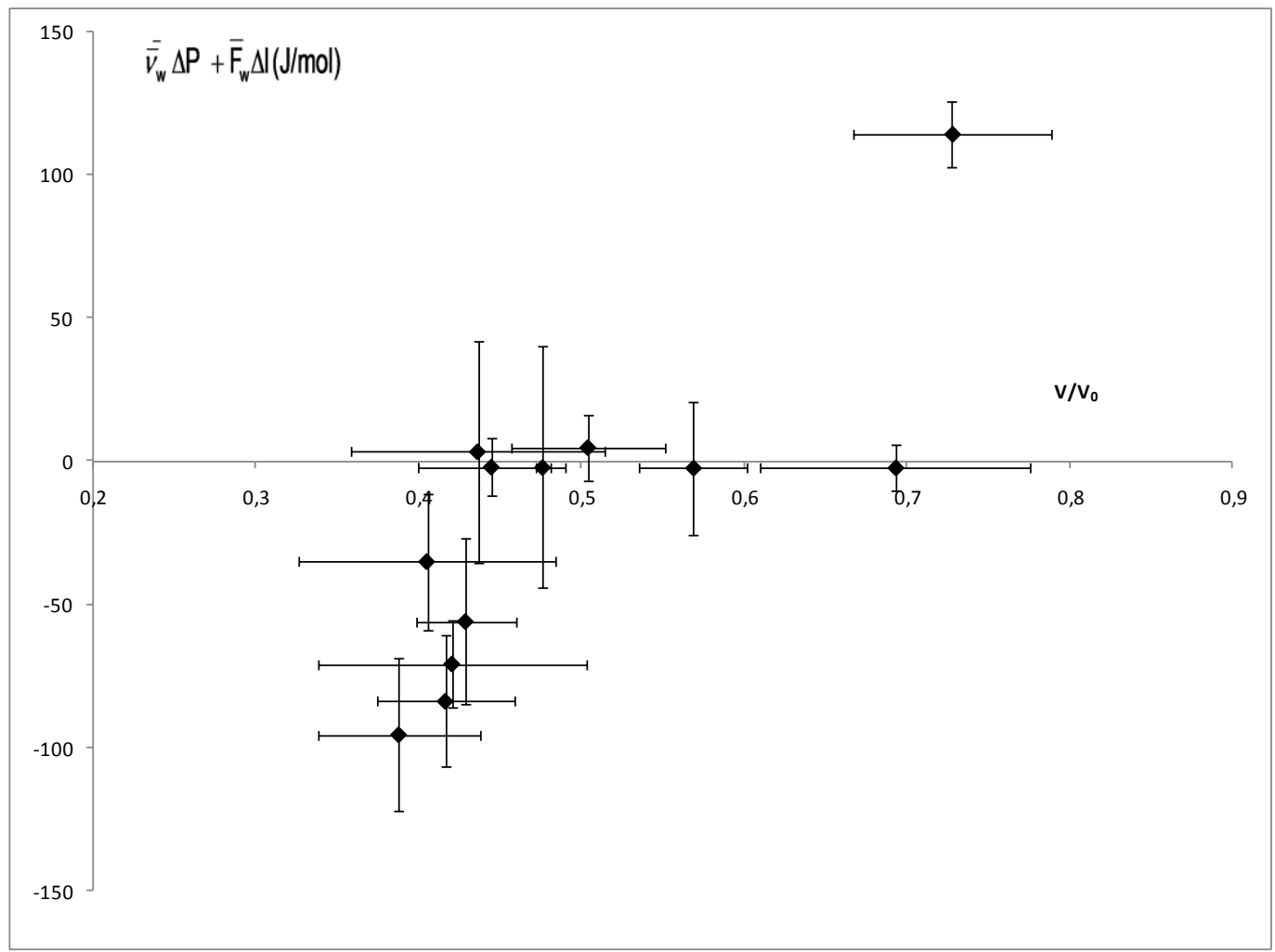

Figure 9. Relationship between the mechanical terms and the structural deformation.

\section{Conclusions}

Is possible to develop a nonlinear thermodynamic approach to determine the different behaviours involved in the osmotic dehydration of parenchymatic apple tissue, determining the apparition of concentration profiles and the structural changes.

It has been demonstrated that at the beginning of the treatment, turgid cells lost mechanical energy due to the high water transport promoted by activity gradients (high velocity of shrinkage). When the tissue lost the cell turgor, the mass transport reaches a new step with predominance of diffusional driving forces; where the tissue contraction, reaches the maximum shrinkage level of $60 \%$, at approximately 0,85 of water activity. It produces an important structural change, general plasmolysis, removing the concentration profiles and changing the mechanism driving forces. In the last step the mechanical forces are predominant in the mass transport.

\section{References}

Agre, P., Bonhivers, M. \& Borgnia, M.J. (1998). The aquaporins, blueprints for cellular plumbing systems. The Journal of Biological Chemistry, 273(24):14659-14662.

Aguilera, J.M. \& Stanley, D.W. (1999). Microstructural principles of Food Processing and Engineering. Elsevier Science, Gaithersburg, MD.

Aguilera, J.M., Chiralt, A. \& Fito, P. (2003a). Food dehydration and product structure. Trends in Food Science and Technology, 14, 432-437.
Aguilera, J.M., Chiralt, A. \& Fito, P. (2003b). Process, structrure and functionality. Special Issue on the International Conference Iberdesh 2002, Food Science and Technology International, 9,135.

Barat, J.M., Fito, P. \& Chiralt, A. (2001). Modelling of simultaneous mass transfer and structural changes in fruit tissues. Journal of Food Engineering, 49, 77-85.

Castro-Giráldez, M., Fito, P.J. \& Fito, P. (2010). Non-equilibrium thermodynamic description to analyze the pork meat (Longissimus dorsi) salting process. Journal of Food Engineering, 99(1), 24-30.

Crank, J. (1985). In Mathematics of Diffusions, Oxford University Press, New York.

Demirel, Y. (2002). Chapter 1: Fundamentals of Equilibrium Thermodynamics, and Chapter 11: Thermodynamics and Biological Systems. In Y. Demirel (Ed.), Nonequilibrium Thermodynamics. Transport and Rate Processes in Physical, Chemical and Biological Systems (pp. 1-52, and pp. 541-598). Elsevier Science \& Technology Books, USA.

Ferrando, M. \& Spiess, W.E.L. (2001). Cellular response of plant tissue during the osmotic treatment with sucrose, maltose, and trehalose solutions. Journal of Food Engineering, 49,115-127.

Ferrando, M. \& Spiess, W.E.L. (2002). Transmembrane mass transfer in carrot protoplasts during osmotic treatment. Food Engineering and Physical Properties, 67(7), 2673-2680

Ferrando, M. \& Spiess, W.E.L. (2003). Effect of osmotic stress on microstructure and mass transfer in onion and strawberry tissue. Journal of the Science of Food and Agriculture, 83, 951-959.

Fito, P., \& Chiralt, A. (1997). Osmotic dehydration: an approach to the modelling of solid food-liquid operations. In $\mathrm{P}$. Fito, E. Ortega-Rodríguez, \& G. V. Barbosa-Cánovas (Eds.), Food engineering 2000 (pp. 231-252), Chapman \& Hall, New York.

Fito, P., LeMaguer, M., Betoret, N., Fito, P.J. (2007). Advanced food process engineering to model real foods and 
processes: The "SAFES" methodology. Journal of Food Engineering, 83(2), 173-185.

Fito, P., Le Maguer, M., Betoret, N. \& Fito, P.J. (2008). Advanced food products \& process engineering (SAFES) Concepts \& methodology. In G.F. Gutiérrez-López, G.V. Barbosa-Cánovas, J. Welti-Chanes \& E. Parada-Arias (Eds.), Food engineering integrated approaches (pp. 117-137), Food Engineering Series, Springer, U.S.A.

Gekas, V. (2001). Mass transfer modeling. Journal of Food Engineering, 49, 97-102.

Lazarides, H.N. \& Mavroudis, N.E. (1995). Freeze/thaw effects on mass transfer rates during osmotic dehydration. Journal of Food Science, 60(4), 826-828.

LeMaguer, M. (1988). Osmotic dehydration: review and future directions. In Proceedings of the Internationa symposium on progress in food preservation processes (pp. 283-309). Brussels, CERIA.

LeMaguer, M. \& Yao, Z. (1995). Mass transfer during osmotic dehydration at the cellular level. In G. V. BarbosaCánovas \& J. Welti-Chánes (Ed.), Food preservation by moisture control. Fundamentals and applications (pp. 325-350). Technomic Publisher Co. Inc., Lancaster.

Lenart, A. \& Lewicki, P.P. (1988). Energy consumption during osmotic and convective drying of plant tissue. Acto Alimentaria Polonica, 14 (1), 65-72.

Lerici, C.R., Mastrocola, D., Sensidoni, A. \& Dalla Rosa, M. (1988). Osmotic concentration in food processing. In S. Bruin (Ed.), Preconcentration and Drying of Food Materials (pp. 123). ElSevier Science, Amsterdam.

Lide, D.R. (2004). Thermochemistry, Electrochemistry, and Kinetics. In D.R. Lide (Ed.), CRC Handbook of chemistry and physics, $84^{\text {th }}$ edition (pp.5-100). Boca Raton, FL: CRC Press, USA

Marcotte, M. \& Le Maguer, M. (1991). Mass transfer in cellular tissues. Part I: the mathematical model. Journal of Food Engineering, 13, 199-220.

Mavroudis, N.E., Gekas, V. \& Sjöholm, I. (1998). Osmotic dehydration of apples. Shrinkage phenomena and the significance of initial structure on mass transfer rates. Journal of Food Engineering, 38, 101-123.

Nanjundaswamy, A.M. \& Madhakrishniak, S.G. (1989). Advances in dehydration processes for fruits, vegetables and their products. In Ragavenfra Rao M.R. et al. (Eds.),

Trends in Food Science and Technology (pp. 369), India.

Nicolis, G. \& Prigogine, I. (1977a). Self organization in non equilibrium systems from dissipative structures to order through fluctuations, John Wiley and Sons, Inc.

Nicolis, G. \& Prigogine, I. (1977b). Die erforschung des komplexen. auf dem weg zu einem neuen verständnis der naturwissenschaften, R. Piper $\mathrm{GmbH}$ and Co. KG. München.

Rastogi, N.K., Angersbach, A., \& Knorr, D. (2000). Evaluation of mass transfer mechanisms during osmotic treatment of plant materials. Journal of Food Science, 65,10161019.

Seguí, L., Fito, P.J., Albors, A. \& Fito, P. (2006). Mass transfer phenomena during the osmotic dehydration of apple isolated protoplasts (Malus domestica vas. Fuji). Journal of Food Engineering, 77(1), 179-187.

Seguí, L., Fito, P.J., Fito, P. (2010). Analysis of structure-property relationships in isolated cells during OD treatments. Effect of initial structure on the cell behavior. Journal of Food Engineering, 99(4), 417-423.

Starzak, M. \& Mathlouthi, M. (2006). Temperature dependence of water activity in aqueous solutions of sucrose. Food Chemistry, 96(3), 346-370.

Tyerman, S.D., Bohnert, H.J., Maurel, C., Steudle, E. \& Smith, J.A.C. (1999). Plant aquaporins: their molecular biology, biophysics and significance for plant water relations. Journal of Experimental Botany, 50, special issue, 1055-1071.

Zhiming, Y. \& Le Maguer, M. (1996). Mathematical Modelling and Simulation of Mass Transfer in Osmotic Dehydration Processes. Part I: Conceptual and Mathematical Models. Journal of Food Engineering, 29 (3): 349-360. 


\title{
Application of microwaves dielectric spectroscopy for controlling long time osmotic dehydration of parenchymatic apple tissue
}

\author{
M. Castro-Giráldez, P.J. Fito*, P. Fito \\ Instituto Universitario de Ingeniería de Alimentos para el Desarrollo, Universidad Politécnica de Valencia, Camino de Vera, s/n, 46022, Valencia, Spain
}

A R T I C L E IN F O

Article history:

Received 8 Jul 2010

Keywords:

Osmotic dehydration

Dielectric spectroscopy

Dielectric properties

Microwaves

\begin{abstract}
A B S T R A C T
Dielectric spectroscopy studies have been performed on fresh and osmotically dehydrated Granny Smith apples. The osmotic treatment consisted on immerse the samples into $65 \%(\mathrm{w} / \mathrm{w})$ sucrose aqueous solution at $30^{\circ} \mathrm{C}$ during 180,360 , $480,720,1463,1577,1722,3375,4320,7200,8460,10270,14590$ and 23230 minutes. Some physical-chemical parameters were measured in fresh, treated and reposed $\left(24 \mathrm{~h}\right.$ at $\left.30^{\circ} \mathrm{C}\right)$ samples. Dielectric spectra were measured in the frequency range from $500 \mathrm{MHz}$ to $20 \mathrm{GHz}$ by an Agilent $85070 \mathrm{E}$ Open-ended Coaxial Probe connected to an Agilent E8362B Vector Network Analyzer in the fresh, treated and reposed samples. It has been demonstrated that the dielectric properties are a good tool to control the surface water activity by using the loss factor at relaxation frequency, and also to control the internal transport. This relation of dielectric properties with the water activity allows controlling the shrinkage level and determines the moment when the driving forces change from diffusional to mechanical behaviors. This value corresponds to $12,25 \pm 0,16$ and represents a practical control value to decide if the final dehydrated samples shrank or swell.
\end{abstract}

(C) 2010 Elsevier Ltd. All rights reserved.

\section{Introduction}

Currently, food industry is developing modern physical sensors in order to improve the quality of its products. In this context, sensors based on microwaves play an important role because they are non destructive and can be even noncontacting. Dielectric spectroscopy requires an important equipment investment, and due to this fact, for the industry application, it is necessary a preliminary study in order to delimit the range of frequencies and to reduce the sensor cost (Castro-Giráldez et al., 2010a). This technique has been already used to describe the salting operation in meat products (Castro-Giráldez et al., 2010d) and to analyze the apple maturity process (Castro Giráldez et al., 2010b); in both cases good results were obtained.

Dielectric spectroscopy determines the dielectric properties of a medium as a function of frequency. Complex permittivity $\left(\varepsilon^{*}\right)$ (Equation 1 ) is the dielectric property that describes food behaviour when is subjected under an electromagnetic field

*Corresponding author. Tel.: +34963877369 E-mail address: pedfisu@tal.upv.es (P.J.Fito).
(Metaxas and Meredith, 1993; Nelson and Datta, 2001). The real part of complex permittivity is called the dielectric constant $\left(\varepsilon^{\prime}\right)$ and the imaginary part is called loss factor $(\varepsilon ")$. The dielectric constant is related with the material ability to store energy, and the dielectric loss factor is related to the absorption and dissipation of the electromagnetic energy in other kinds of energy such as the termic one.

$$
\varepsilon^{*}=\varepsilon^{\prime}+i \varepsilon^{\prime \prime} \quad \text { (Equation 1) }
$$

Foods are heterogeneous material which contains water, organic molecules, macromolecules, ions, and insoluble matrix. In some foods, these constituents are highly organized in cellular and subcellular structures forming the macroscopic structure of tissues. Dielectric properties of food tissues will reflect the contribution of some polarizations at different levels (Gabriel, 2006). It includes basically four dispersions: $\alpha, \beta, \delta, \gamma$. In microwave region, the $\gamma$ - is the main dispersion. It is called orientation polarization, is located at $\mathrm{GHz}$ region, and it is due to the polarization of dipoles, fundamentally free water molecules (Castro-Giráldez et al., 2010a). It is also important to analyze the energy dissipation of these relaxation phenomena in terms of loss factor spectra. 


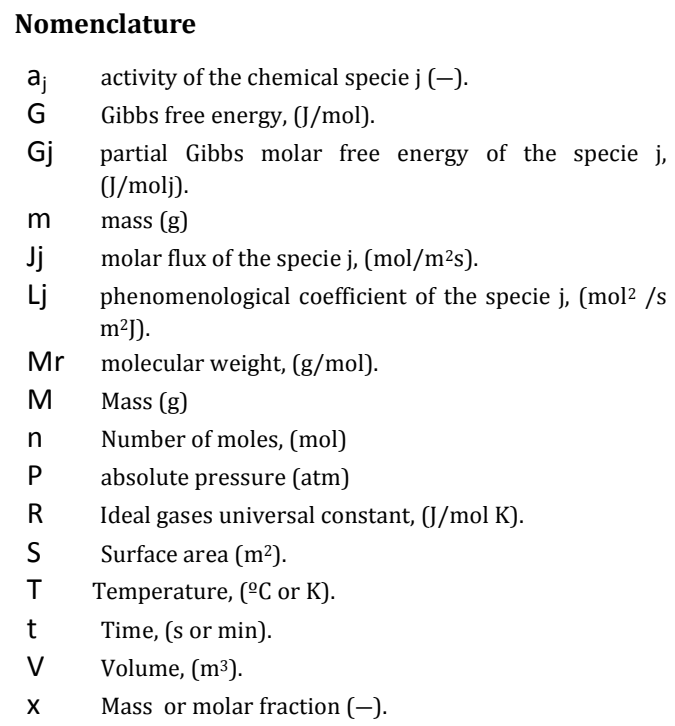

X Molar fraction (-)

$\mathrm{Z} \quad$ Mass or molar fraction of the liquid fraction (-). Dielectric constant (-)

Loss factor $(-)$.

\section{Greek alphabet:}

$\mu \mathrm{j} \quad$ Chemical potential of the specie $\mathrm{j},(\mathrm{J} / \mathrm{mol})$

$\mu_{j}^{0} \quad$ Chemical potential of reference of the specie $\mathrm{j},(\mathrm{J} / \mathrm{mol})$

V Specific volume (L/mol)

$\Delta \quad$ Variation of a variable.

\begin{tabular}{ll} 
& \multicolumn{1}{c}{ Subscript y superscript: } \\
0 & Initial time \\
24 & Time 24 hours after the treatment. \\
LP & Liquid phase. \\
max & Maximum \\
S & sucrose \\
w & water \\
t & Time, (s or min).
\end{tabular}

Loss factor can be expressed by the equation 2 , which reflects the different contribution phenomena to the loss factor spectrum in the frequency range of the present study. The relaxation frequency can be defined as the frequency at which the loss factor is maximum in a given dispersion.

$$
\varepsilon^{\prime \prime}=\varepsilon_{d}^{\prime}+\frac{\sigma}{\varepsilon_{0} \omega}
$$

(Equation 2)

where:

$\varepsilon d$ " represents the loss factor caused by the dipolar orientation or dipolar relaxation;

$\sigma / \varepsilon_{0} \omega$ represents the loss factor due to effect of ionic conductivity, where $\sigma, \varepsilon_{0}$ and $\omega$ are the conductivity of the material, the dielectric constant in vacuum and the angular frequency, respectively. Osmotic dehydration is one of the oldest techniques of food preservation. It consists in the immersion of foodstuffs in hypertonic solutions, giving rise to at least two simultaneous countercurrent flows: an important water flow out of the food into the solution and a simultaneous transfer of solute from the solution into the food (Salvatori et al., 1999). Nowadays, it is very important in the transformation and conservation of alimentary products. As the name itself induces, the objective is to reduce the water content of a product to stop the enzymatic activity and microbiological growth. In the last twenty years, in a period of successful food engineering research activities, this process received special interest with regard to its principles, potentials and industrial applications (Spiess et al., 2001). Currently, for modelling osmotic processes in modern engineering, the heterogeneous properties of the tissue must be considered (Ferrando and Spiess, 2002) and also the development of advanced concepts and methodologies are necessary (Marcotte and Le Maguer, 1991; Zhiming and Le Maguer, 1996). The new models for food and processes development must incorporate enough information about some aspects such as the structure of the product, chemical and biochemical changes, implied mechanisms, thermodynamics...(Fito et al., 2008). In this context, the dielectric properties could also give important information of the product real changes during process progression. So, the objective of this work is to analyze the viability of controlling apple candying process by using dielectric properties measurements at microwaves frequencies.

\section{Materials and methods}

Sucrose solution $\left(65 \% \mathrm{w} / \mathrm{w}, 30^{\circ} \mathrm{C}\right)$, prepared with commercial sugar and distilled water, was used as an osmotic agent. Before the experiment, apples (var. Granny Smith) with the same size and ripeness were bought from a local supermarket and kept refrigerated until use. The apples were cut with a calimeter and a cork borer in cylinders $1 \mathrm{~cm}$ thickness, $2 \mathrm{~cm}$ diameter) from the parenquimatic tissue. There were prepared 42 samples which were immersed in a vessel containing the osmotic solution with continuous stirring. The relation between the fruit and the solution was of 1:20 $(\mathrm{w} / \mathrm{w})$ to avoid changes in the solution during the process. The system was maintained at $30^{\circ} \mathrm{C}$ in a constant-temperature chamber. To prevent evaporation, the vessel was covered with a sheet of plastic wrap.

Preliminary kinetic studies were done at the same working conditions in order to select the osmotic dehydration times. Osmotic dehydration was conducted over several time periods: 180,360 , 480, 720, 1463, 1577, 1722, 3375, 4320, 7200, $8460,10270,14590$ and 23230 minutes. Three samples were used at each dehydration time.

A flow-diagram of the experimental procedure is presented in figure 1.

Each sample treated was reposed at $30^{\circ} \mathrm{C}$ for 24 hours, on Decagon containers, closed with 
parafilm ${ }^{\circledR}$, in order to eliminate the concentration profiles in samples.

Mass, volume, surface water activity and dielectric spectrum was analyzed for each fresh, treated and reposed samples. Representative fresh samples were used to determine the initial moisture and solute content ( ${ }^{\circ}$ Brix). Moisture and solute content (-Brix) were measured for each reposed sample. At each osmotic time, an aliquot of sucrose solution was also taken from the vessel. Water activity, oBrix and dielectric spectrum of the solution were measured at each time.

Mass was determined by using a Mettler Toledo Balance $\quad( \pm 0.0001) \quad$ (Mettler-Toledo, Inc., Schwarzenbach, Switzerland).

Volume measurements were analysed by using a photographic treatment of the samples and the software Adobe Photoshop ${ }^{\circledR}$ (Adobe Systems Inc., San Jose, CA, U.S.A.) to get the diameter and the thickness of the samples.

Surface water activity was measured in the structured samples with a dew point hygrometer Aqualab® series 3 TE (Decagon Devices, Inc., Washington, USA).

Moisture content was determined by drying in a vacuum oven at $60^{\circ} \mathrm{C}$ till constant weight was reached (AOAC method 934.06 (2000)). Sugar content was determined in a refractometer (ABBE,
ATAGO Model 3-T, Japan). Analytical determinations described above were obtained by triplicate.

\section{Dielectric properties measurement.-}

The system used to measure dielectric properties consists on an Agilent 85070E Open-ended Coaxial Probe connected to an Agilent E8362B Vector Network Analyzer. The software of the Network Analyzer calculates the dielectric constant and loss factor as a reflected signal function. For these measurements the probe was fixed to a stainless steel support, and an elevation platform brings the sample near the probe to avoid possible phase changes due to cable movements after calibration.

The system was calibrated by using three different types of loads: air, short-circuit and $25^{\circ} \mathrm{C}$ Milli ${ }^{\circ}-\mathrm{Q}$ water. Once the calibration was made, $25^{\circ} \mathrm{C}$ Milli ${ }^{\circledR}$ $\mathrm{Q}$ water was measured again to check calibration suitability.

The dielectric properties were measured by attaching the probe to the surface of the samples. The Mean values of three replicates of apple samples are reported in this article. All determinations were made at $30{ }^{\circ} \mathrm{C}$ from $500 \mathrm{MHz}$ to $20 \mathrm{GHz}$.

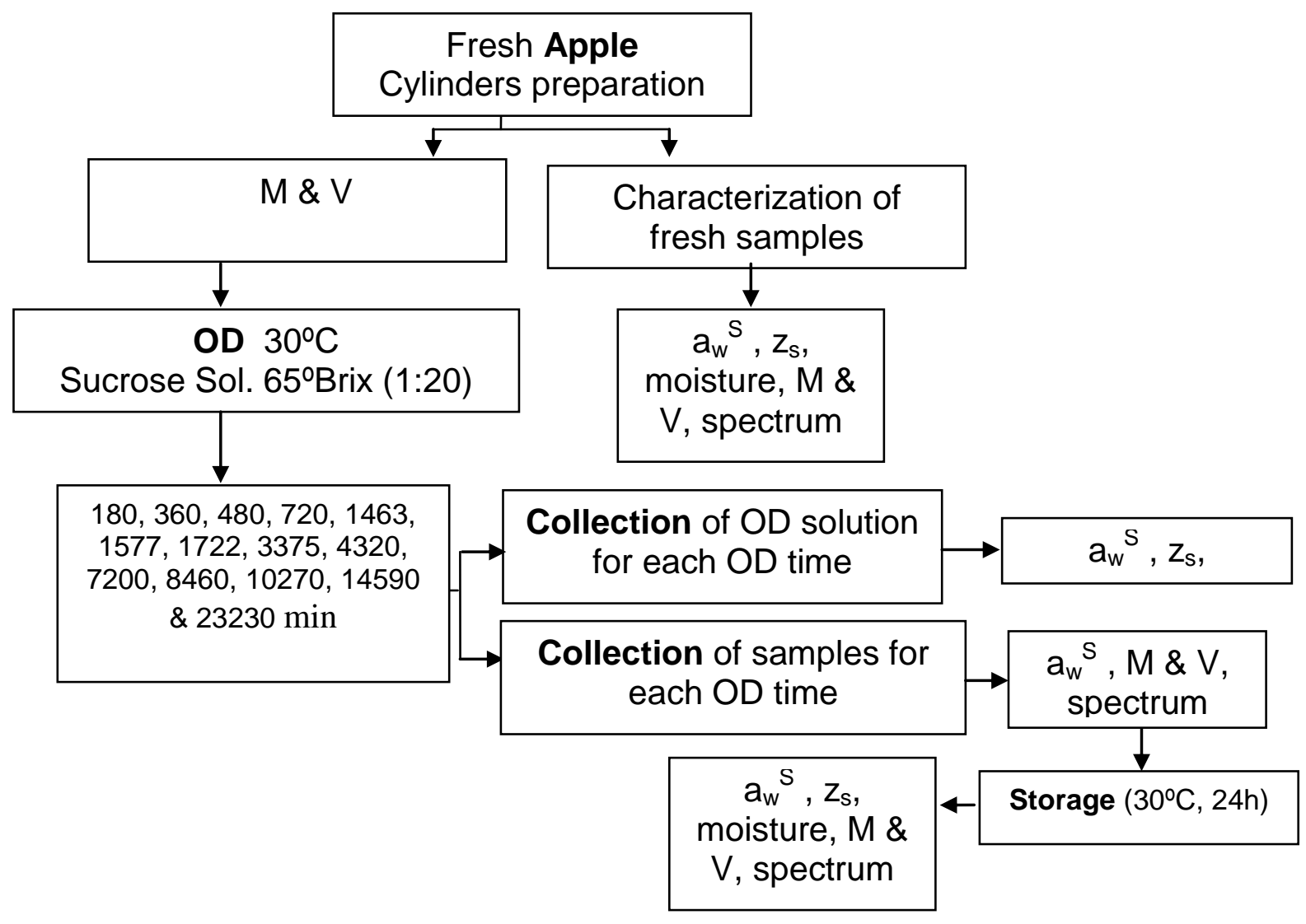

Figure 1. Flux diagram of the experimental procedure 


\section{Results}

The osmotic dehydration operation with $65^{\circ}$ Brix solution produces compression and relaxation phenomena (Fito and Chiralt, 1997). These mechanisms could be observed by analyzing the mass and volume variation; these variations could be estimated by the following equations:

$$
\begin{aligned}
& \Delta \mathrm{M}=\frac{\mathrm{M}_{\mathrm{t}}-\mathrm{M}_{\mathrm{o}}}{\mathrm{M}_{\mathrm{o}}} \\
& \Delta \mathrm{V}=\frac{\mathrm{V}_{\mathrm{t}}-\mathrm{V}_{\mathrm{o}}}{\mathrm{V}_{\mathrm{o}}}
\end{aligned}
$$

(Equation 3)

(Equation 4)

where $\mathrm{M}$ represents the mass $(\mathrm{kg}), \mathrm{V}$ the volume $\left(\mathrm{m}^{3}\right)$, the subscripts $t$ represent the treatment time, being 0 the initial value.

Moreover, the sucrose and water mass evolution can be observed applying equation 3 for the specific compounds as follows:

$$
\begin{aligned}
& \Delta M_{w}=\frac{M_{t} x_{w t}-M_{0} x_{w 0}}{M_{0}} \\
& \Delta M_{s}=\frac{M_{t} x_{s t}-M_{0} x_{s 0}}{M_{0}}
\end{aligned}
$$

(Equation 5)

(Equation 6)

where $\mathrm{x}_{0}$ is the mass fraction of water $\left(\mathrm{x}_{\mathrm{w} 0}\right)$ or soluble solids $\left(\mathrm{x}_{\mathrm{s} 0}\right)$ of the sample at initial time $\left(\mathrm{kg} / \mathrm{kg}_{\mathrm{T}}\right)$ and $\mathrm{xt}_{\mathrm{t}}$ is the same after dehydration process $\left(\mathrm{kg} / \mathrm{kg}_{\mathrm{T}}\right)$.

Figure 2 shows the mass, volume, water and sucrose mass variation through the osmotic treatment. In the figure, the decrease in total mass and volume is appreciated. The decrease in mass is explained by the water losses while the sucrose mass increases during the osmotic treatment.

The water and solute fluxes promoted in the osmotic treatment can be calculated with the mass variation, the process time and the variation of the samples surface (Equations 7 and 8).

$$
\begin{aligned}
& \mathrm{J}_{\mathrm{w}}=\frac{-\Delta \mathrm{M}_{\mathrm{w}} \cdot \mathrm{M}_{\mathrm{o}}}{\Delta \mathrm{t} \cdot \mathrm{S} \cdot \mathrm{Mr}_{\mathrm{w}}} \quad \text { (Equation 7) } \\
& \mathrm{J}_{\mathrm{s}}=\frac{\Delta \mathrm{M}_{\mathrm{s}} \cdot M_{o}}{\Delta \mathrm{t} \cdot \mathrm{S} \cdot \mathrm{Mr}_{\mathrm{s}}} \quad \text { (Equation 8) }
\end{aligned}
$$

where $J_{w}$ is the water flux $\left(\mathrm{mol}_{\mathrm{w}} / \mathrm{s} \mathrm{m} \mathrm{m}^{2}\right), \mathrm{J}_{\mathrm{s}}$ is the sucrose flux $\left(\mathrm{mol}_{\mathrm{s}} / \mathrm{s} \mathrm{m}^{2}\right)$ during the treatment, $\mathrm{t}$ is the process time, $S$ is the measured surface of the sample $\left(\mathrm{m}^{2}\right), \mathrm{Mr}_{\mathrm{w}}$ is the molecular weight of water (18 $\mathrm{g} / \mathrm{mol}$ ) and $\mathrm{Mr}_{\mathrm{s}}$ is the molecular weight of sucrose $(342 \mathrm{~g} / \mathrm{mol})$. It is possible to observe in figure 3 that the flux of solutes is reduced faster than the water flux, this is possible because the cell membrane is semi-permeable and only water compound may cross the membrane.

In figure 4, the spectra of fresh and treated samples can be appreciated. In the left side of the figure, the evolution of the spectra during the beginning of the treatment can be observed; the osmotic treatment decreases the relaxation frequency and the spectra are being flattened as treatment progresses. This phenomenon occurs until the surface water activity reaches the value of 0.85 , in which the spectra remain almost constant (right figure 4).

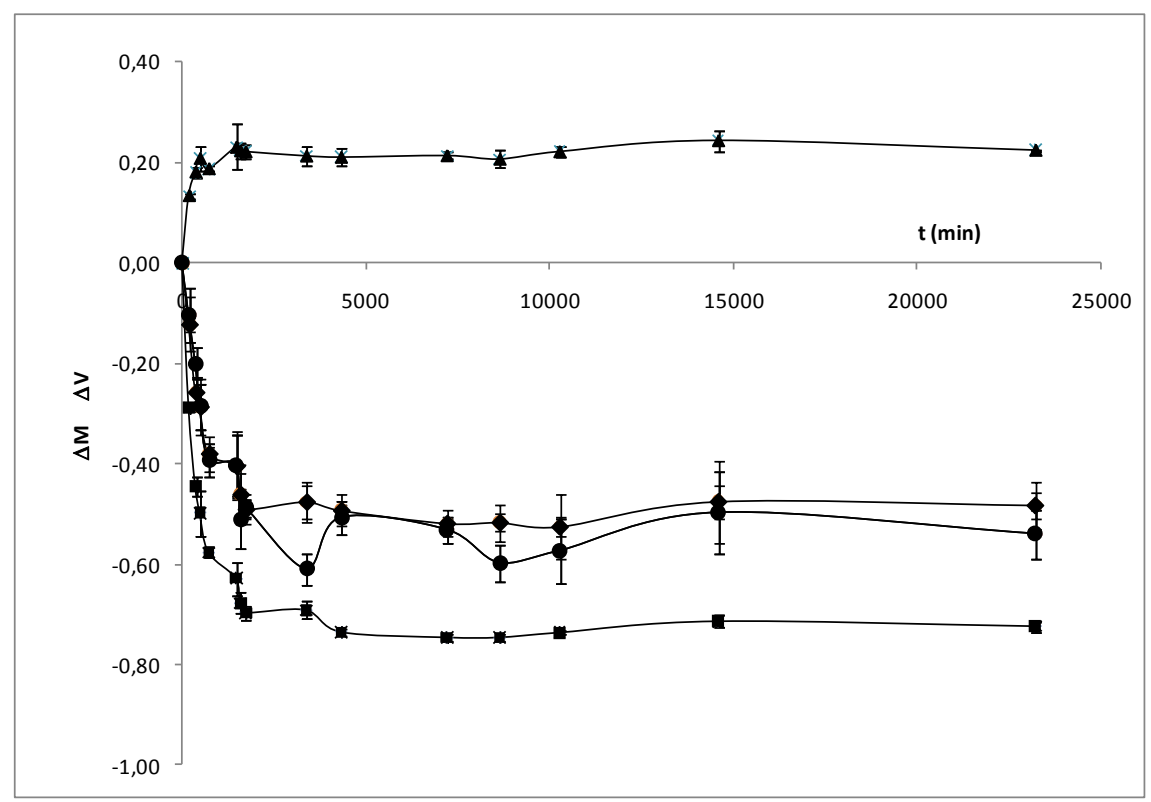

Figure 2. Evolution of overall mass $(\diamond)$, water mass $(\boldsymbol{\square})$, sucrose mass $(\boldsymbol{\Delta})$ and volume $(\bullet)$ through the osmotic treatment. 


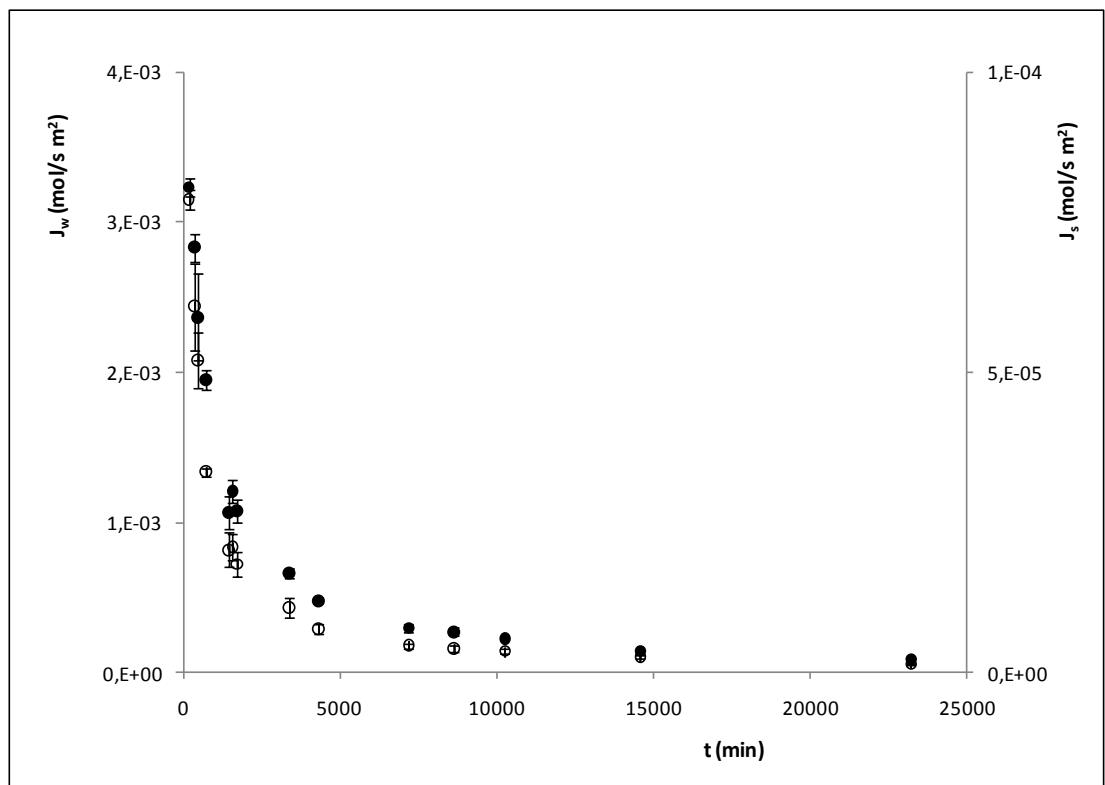

Figure 3. Variation of water $(\bullet)$ and sucrose $(0)$ fluxes versus time through the treatment.

In figure 5, the treated and the reposed samples spectra are observed. As was explained previously (Castro-Giráldez et al., 2010e), the water and sucrose concentration is homogeneous in the reposed samples, been negligible the concentration profiles through the tissue. Treated samples show two steps. At the beginning of the treatment, the surface water activity of treated samples is lower than that of the reposed samples; it denotes concentration profiles in the apple tissue and an important internal transport is driven by diffusion mechanisms. When surface water activity reaches the value of 0.85 , the treated and the reposed values concur; this fact denotes the disappearance of concentration profiles in the tissue and the predominance of the mechanical behaviours driving the mass transfer. These different phenomena can be observed by using the dielectric properties. At the beginning of the treatment, the dielectric spectra of the reposed samples are higher than those of the treated samples; this means that during the repose time, important internal transport occurs by diffusion mechanisms, equilibrating the samples and disappearing the concentration profiles (left figure 5). When surface water activity reaches the value of 0.85 , the treated and the reposed spectra concur because of the disappearance of concentration profiles and the predominance of the mechanical behaviours driving the mass transfer.

Castro-Giráldez et al., (2010e) explained the water transport driving forces through the surface of apple tissue in an osmotic treatment with sucrose as follows:
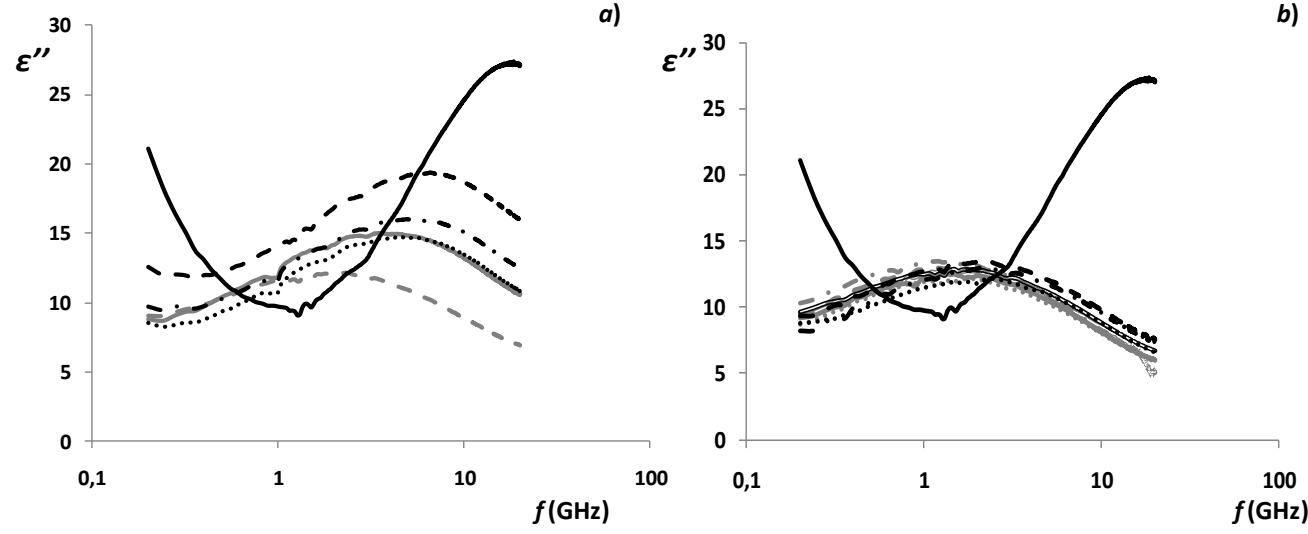

Figure 4. Dielectric loss factor spectra from fresh $(-)$ and treated samples at different times of osmotic dehydration: a) $180 \min (---), 360 \min (-.-$.), $480 \min (. .),. 720 \min (-), 1463 \min (--$-); b) 1577 min (- $-), 1722 \min (-.-),. 3375 \min (\ldots), 4320 \min (=), 7200 \min (-), 8640 \min (--), 10270 \min (-$. - ), 14590 $\min (\ldots), 23230 \min (=)$. 


$$
\frac{\Delta G_{w}}{\Delta n_{w}}=\mathrm{R} T \ln \frac{a_{s}^{O S}}{a_{s}^{e}} \frac{\mathrm{J}_{\mathrm{s}}}{\mathrm{J}_{\mathrm{w}}}+\mathrm{R} T \operatorname{Ln} \frac{a_{w}^{O S}}{a_{w}^{e}}+v_{\mathrm{w}}^{-} \Delta \mathrm{P}+\overline{\mathrm{F}}_{\mathrm{w}} \Delta \mathrm{l}
$$

(Equation 9)

Where the driving forces have been divided in two blocks, the first block is composed by compositional mechanisms (activity of the chemical species involved in mass transport) and the second block involves mechanical mechanisms. On figure $6 \mathrm{a}$ it is possible to observe the relationship between the moisture in dry basis and the surface water activity of the treated, reposed samples and data from pure solutions of water and sucrose (Starzak \& Mathlouthi, 2006). This figure shows that the reposed samples maintain the same relationship surface water activity/moisture as the pure sucrose solution at different concentrations. Therefore, the water and sucrose concentration is homogeneous in the reposed samples, being negligible the concentration profiles through the tissue. At the beginning of the treatment, the surface water activity of treated samples is lower than that of the reposed samples; it denotes concentration profiles in the apple tissue and an important internal transport is driven by diffusion mechanisms (affect the activity terms of equation 9). When surface water activity reaches a water activity value of chemical pseudoequilibrium (Castro-Giráldez et al., 2010e), the treated and the reposed values concur with the pure solution values; this fact denotes the disappearance of concentration profiles in the tissue and the predominance of the mechanical behaviours driving the mass transfer. Figure $6 \mathrm{~b}$ shows the relationship between the moisture in dry basis and the loss factor at frequency of relaxation of pure solution of sucrose and treated and reposed samples, where it can be observed the same blocks exposed in figure 6a. Loss factor at relaxation frequency in the $\gamma$-dispersion expresses the maximum effect of the motion of water molecules, because in the tissue, water represents the most important dipole. Thus, at the beginning of the treatment, the treated and reposed samples show differences in loss factor; treated samples increase loss factor value through the 24 hours of the repose time reaching closed values of those of the pure solution. In range with predominance of diffusional driving forces, loss factor of pure solution takes higher values than those of reposed apple samples because the adsorbed water can not be induced, because those molecules are without motion capacity. Therefore, the loss factor of water molecules in liquid phase must be the same as loss factor of pure solution. Following this point of view, the water adsorbed $\left(\mathrm{X}_{\mathrm{W}^{\mathrm{ADS}}}\right)$ can be estimated by the subtraction between the overall moisture $\left(\overline{X_{W}}\right)$ and the water content of liquid phase $\left(\mathrm{X}_{\mathrm{W}^{\mathrm{LP}}}\right)$. Figure $7 \mathrm{~b}$ relates the loss factor with the moisture (in dry basis) of pure solution. Fitting these data, equation 10 is obtained $\left(R^{2}=0,9998\right)$.

$$
X_{W}=0.0092 \times \varepsilon^{\prime \prime 2}+0.2072 \times \varepsilon^{\prime \prime}+1,5516
$$

(Equation 10)

This equation allows obtaining the water content of molecules in motion. Using the loss factor measured in reposed samples, the water content of liquid phase is obtained. Using equation 11 it is possible to estimate the adsorbed water.

$$
X_{W}{ }^{A D S}=\overline{X_{W}}-X_{W}{ }^{L P}
$$

(Equation 11)

In figure $7 \mathrm{a}$, the relation between the overall moisture (in dry basis), the water content of liquid phase (in dry basis) and the adsorbed water (in dry basis) with the surface water activity of the
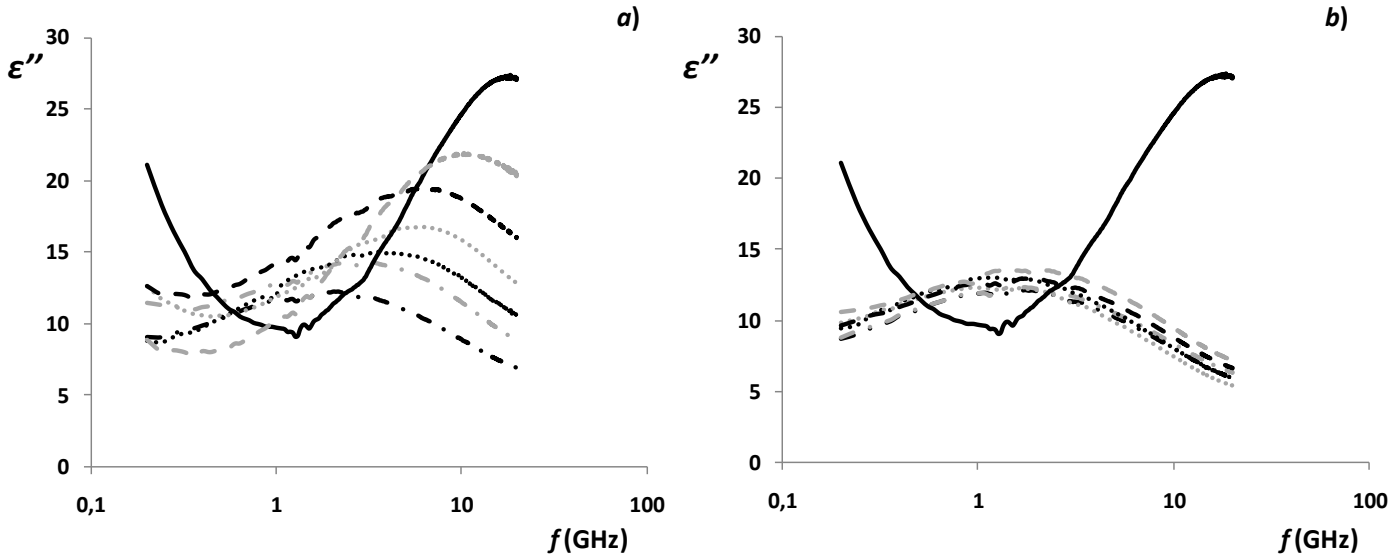

Figure 5. Dielectric loss factor spectra from fresh (-), treated (black lines) and reposed (grey lines) samples at different times of osmotic dehydration: a) $180 \mathrm{~min}(---), 720 \mathrm{~min}(.),. 1463 \mathrm{~min}(-.-$.); b) $4320 \mathrm{~min}(--$ $-), 8640 \min (\ldots), 14590 \min (-.-$.$) .$ 

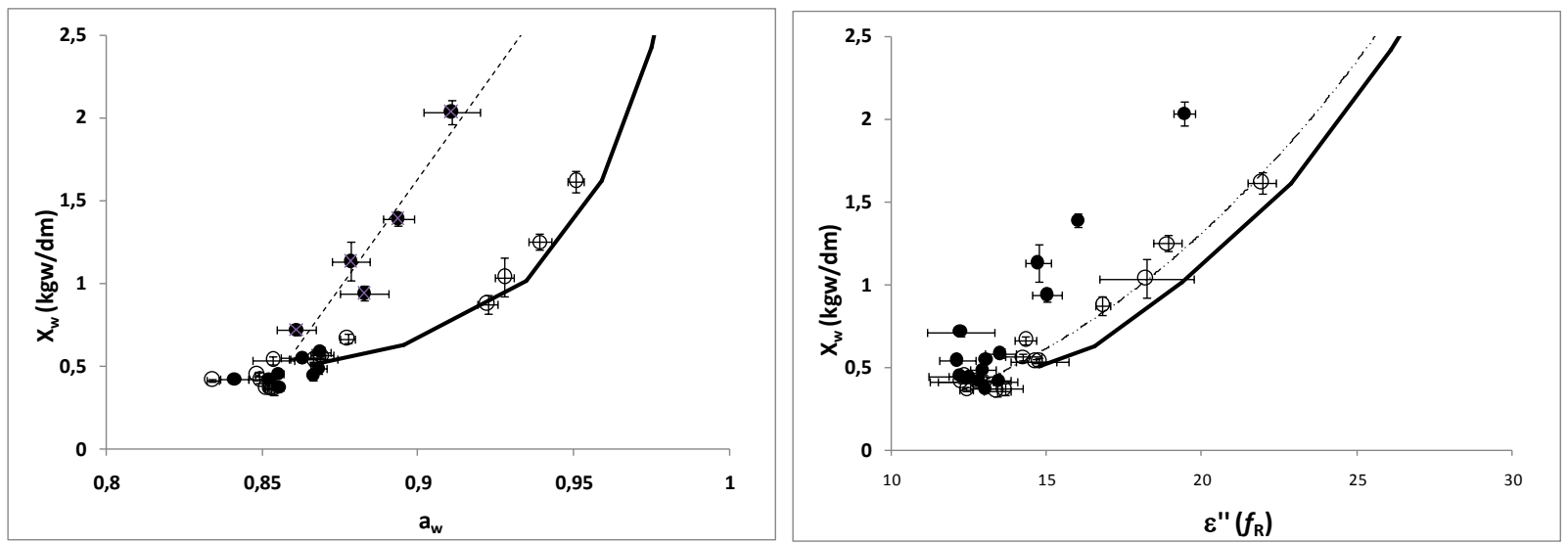

Figure 6. a) Relationship between the moisture in dry basis and the surface water activity for treated samples $(\bullet)$, reposed 24h (o), and sucrose solutions (-) obtained from Starzak \& Mathlouthi (2006).b) Relationship between the moisture in dry basis and the loss factor at relaxation frequency for treated samples $(\bullet)$, reposed $24 \mathrm{~h}(\mathrm{o})$, and pure sucrose solutions (-).

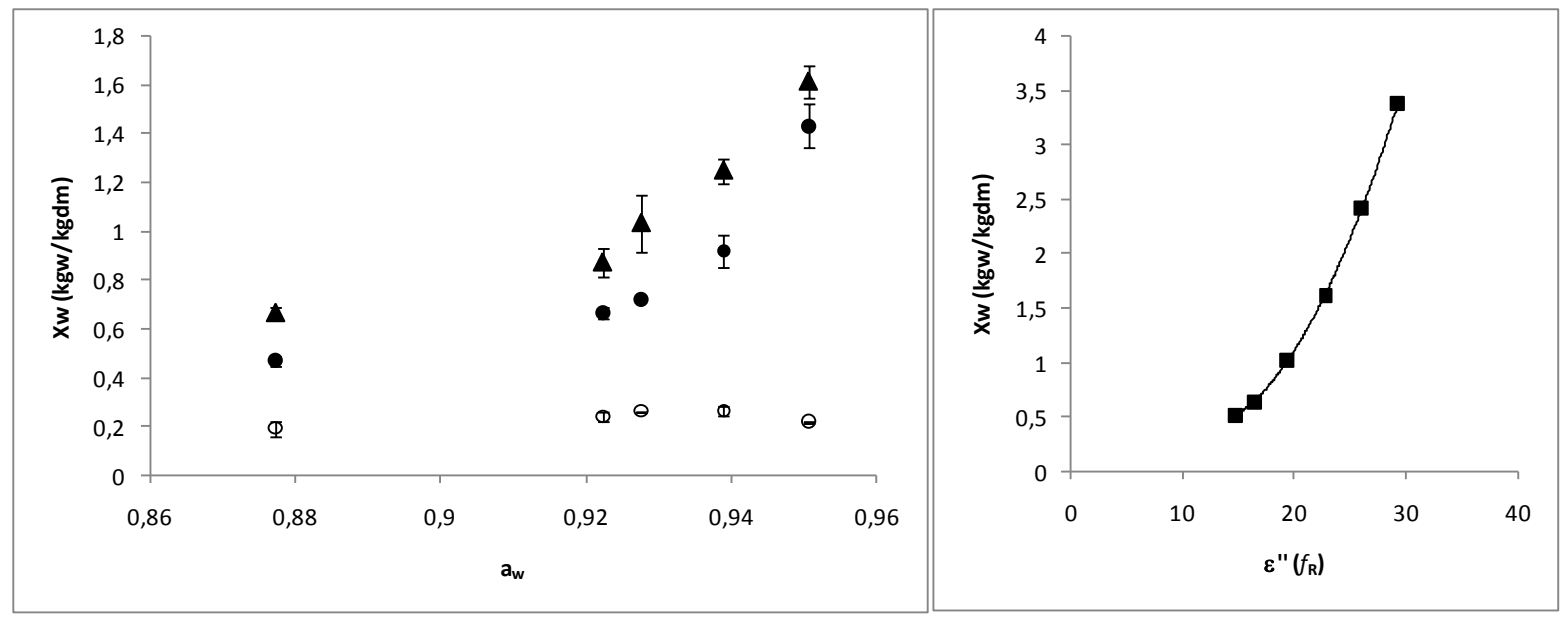

Figure 7. a) Relationship between the moisture in dry basis and the surface water activity for reposed samples, where $(\bullet)$ moisture of liquid phase, adsorbed water (o), and overall moisture ( $\boldsymbol{\Delta})$. b) Relationship between the moisture in dry basis and loss factor at relaxation frequency for pure sucrose solution.

reposed samples is shown for the range with predominance of diffusional driving forces. It is possible to observe in this figure that the amount of adsorbed water remains almost constant with the dehydration treatment.

Taking the mechanical terms of the equation 9, estimated by Castro-Giráldez (2010e) and plotting them with regard to the structural deformation (Figure 8a), it can be observed that the $60 \%$ of deformation is the limit of the tissue corresponding with the maximum mechanical energy stored in the contracted middle lamina and cell wall. This limit corresponds to the change of transport mechanisms, where the driving forces change from the activity terms to the mechanical terms. Thus, the mechanical energy stored in the tissue is released to the external liquid phase driving the transport behaviours in the overall mass transfer. No significant changes on the overall volume are observed because the increase in the mechanical terms must be produced by internal changes in the tissue, as plasmolysis (Seguí et al., 2010). Therefore, comparing the overall structure deformation with the loss factor at relaxation frequency (Figure 8b), it is possible to observe a good correlation in all shrinkage stage because this stage corresponds with the first stage where the activity terms drive the mass transport. 

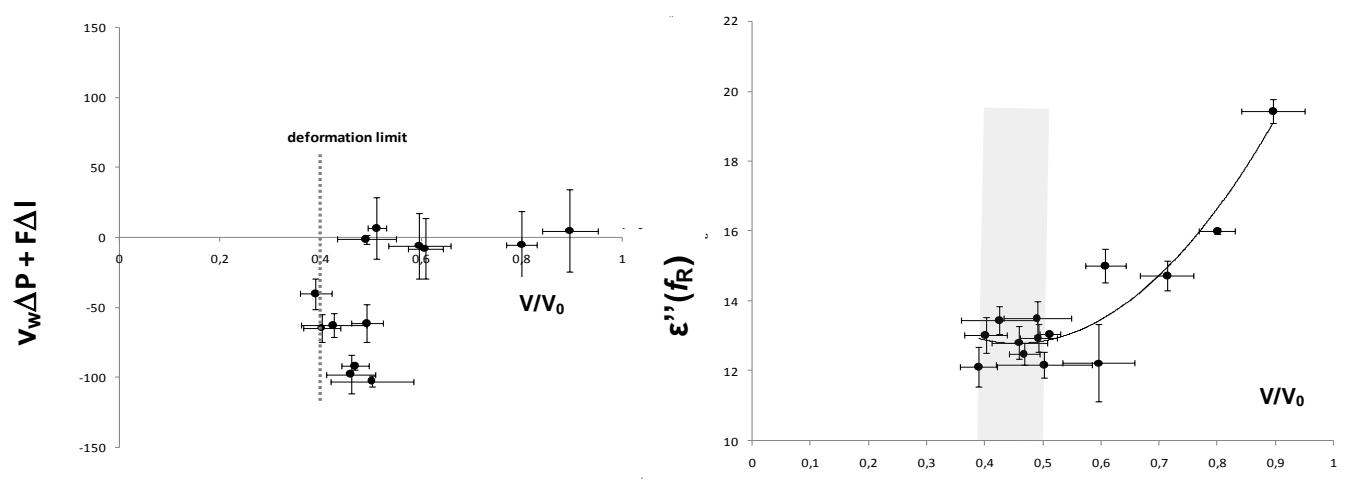

Figure 8. a) Mechanical terms of the equation 9 (estimated by Castro-Giráldez, 2010d) by the structure deformation of treated samples. b) Structure deformation by the loss factor at relaxation frequency of treated samples.

Consequently, it is possible to determine the final stage of shrinkage of apple tissue and the beginning of the stage with predominance of mechanical mechanisms driving the transport in apple dehydration, determining the threshold of loss factor changes at the relaxation frequency. Figure 9 shows the relationship between the mechanical terms of equation 9 estimated following CastroGiráldez (2010e) where it is possible to observe how the loss factor changes when the mechanical terms are negligible reaching a constant value of loss factor when the shrinkage stops. At that instant the mechanical terms are becoming important, driving the mass transport. The threshold value of loss factor where the driving forces change is $12,25 \pm 0,16$ and represents a practical control value to decide if the final dehydrated samples shrink or swell.

\section{Conclusions}

In osmotic treatment two stages were identifying the first stage which is composed by compositional

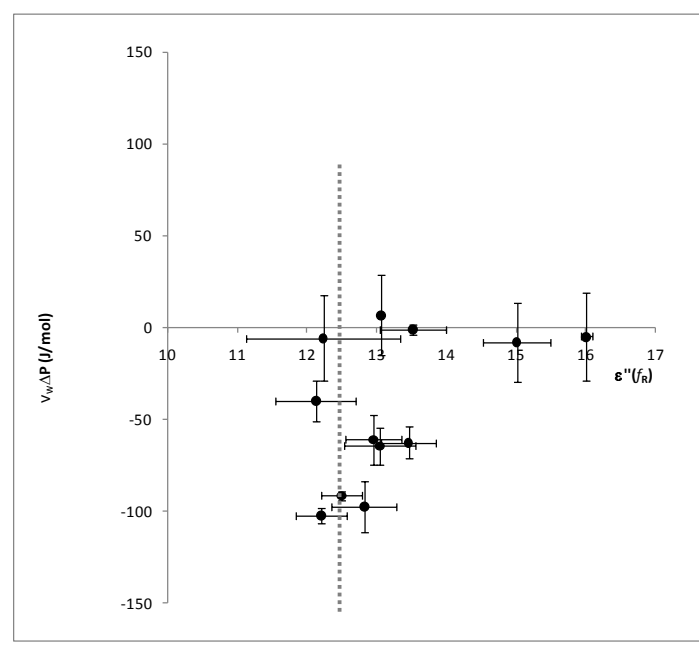

mechanisms and the second stage which involves mechanical mechanisms. It was demonstrated that the measurement of dielectric spectra allows controlling the water transport when the terms of activity are the driven force. In this stage, loss factor of pure solution takes higher values than those of reposed apple samples because the adsorbed water can not be induced. This phenomenon allows estimating the quantity of adsorbed water by the subtraction between the overall moisture and the water content of liquid phase estimated by using dielectric loss factor at relaxation frequency. Moreover, since the deformation (shrinkage) occurs during the stage driven by the activity terms, then the loss factor at relaxation frequency allows controlling the shrinkage level and determines the moment when the driving forces change from diffusional to mechanical behaviors. This value corresponds to $12,25 \pm 0,16$ and represents a practical control value to decide if the final dehydrated samples shrank or swell.

Figure 9. Mechanical terms of the equation 9 by the loss factor at relaxation frequency of treated samples. 


\section{References}

Castro-Giráldez, M, Fito, P.J., Toldrá, F. \& Fito, P. (2010a). Physical sensors for quality control during processing. In Leo ML Nollet, Fidel Toldrá (Eds.), Handbook of Meat Processing (pp. 7-34). FL: CRC Press, U.S.A.

Castro-Giráldez, M., Fito, P.J., Chenoll, C. \& Fito, P. (2010b). Development of a dielectric spectroscopy technique for determining key chemical components of apple maturity. Journal of Agricultural and Food Chemistry, 58, 3761-3766.

Castro-Giráldez, M., Fito, P.J. \& Fito, P. (2010d). Application of microwaves dielectric spectroscopy for controlling pork meat (Longissimus dorsi) salting process. Journal of Food Engineering, 97(4), 484-490.

Castro-Giráldez, M., Fito, P.J. \& Fito, P. (2010e). Nonlinear thermodynamic approach to analyze long time osmotic dehydration of parenchymatic apple tissue. Journal of Food Engineering, in press.

Ferrando, M. \& Spiess, W.E.L. (2001). Cellular response of plant tissue during the osmotic treatment with sucrose, maltose, and trehalose solutions. Journal of Food Engineering, 49,115-127.

Ferrando, M. \& Spiess, W.E.L. (2002). Transmembrane mass transfer in carrot protoplasts during osmotic treatment. Food Engineering and Physical Properties, 67(7), 2673-2680.

Fito, P., Le Maguer, M., Betoret, N. \& Fito, P.J. (2008). Advanced food products \& process engineering (SAFES) I: Concepts \& methodology. In G.F. Gutiérrez-López, G.V. Barbosa-Cánovas, J. Welti-Chanes \& E. Parada-Arias (Eds.), Food engineering integrated approaches (pp. 117-137), Food Engineering Series, Springer, U.S.A.
Gabriel, C. (2006). Dielectric properties of biological materials. In F.S. Barnes, B. Greenebaum (Eds.), Bioengineering and biophysical aspects of electromagnetic fields, Handbook of biological effects of electromagnetic fields (pp. 51-100), CRC Press, Boca Raton, third edition, U.S.A

Marcotte, M. \& Le Maguer, M. (1991). Mass transfer in cellular tissues. Part I: the mathematical model. Journal of Food Engineering, 13, 199-220.

Metaxas, A.C. \& Meredith, R.J. (1993). Industrial Microwave Heating. IEE Power Engineering series 4, Peter Peregrinus LTD, London, UK.

Nelson, S.O. \& Datta, A.K. (2001). Dielectric properties of Food Materials and Electric Field Interactions. In A.K. Datta, R.C. Anantheswaran (Eds), Handbook of Microwave Technology for Food Applications (pp. 69-114). Marcel Dekker, New York.

Salvatori, D., Andrés, A., Chiralt, A. \& Fito, P. (1999). Osmotic dehydration progression in apple tissue I : spatial distribution of solutes and moisture content. Journal of Food Engineering, 42(3), 125-135.

Seguí, L., Fito, P.J., Fito, P. (2010). Analysis of structureproperty relationships in isolated cells during OD treatments. Effect of initial structure on the cell behavior. Journal of Food Engineering, 99(4):417-423.

Starzak, M. \& Mathlouthi, M. (2006). Temperature dependence of water activity in aqueous solutions of sucrose. Food Chemistry, 96(3), 346-370.

Zhiming, Y. \& Le Maguer, M. (1996). Mathematical Modelling and Simulation of Mass Transfer in Osmotic Dehydration Processes. Part I: Conceptual and Mathematical Models. Journal of Food Engineering, 29 (3): 349360 

4.5. Estudia de la cinética de deshidratación asmótica de bieni (Actinidia deliciosa cu Hayward) mediante la cutilización de espectros dieléctricas 



\title{
Nonlinear thermodynamic and structural approach to analyze osmotic dehydration of kiwifruit (Actinidia deliciosa cv Hayward) at short treatment times
}

\author{
M. Castro-Giráldez ${ }^{1}$, P.J. Fito ${ }^{1 *}$, U. Tylewicz ${ }^{2}$, M. Dalla Rosa ${ }^{2}$, P. Fito ${ }^{1}$ \\ 1 Instituto Universitario de Ingeniería de Alimentos para el Desarrollo, Universidad Politécnica de Valencia, Camino de Vera s/n, 46022 Valencia, Spain
} 2 Università degli Studi di Bologna, Facoltà di Agraria, Corso di Laurea in Scienze e Tecnologie Alimentari, Via Ravennate 1020, 47023 Cesena, Italy

ARTICLE INFO

Article history:

Received 10 August 2010

\section{Keywords:}

Osmotic dehydration

Thermodynamic model

Mass transfer

Nonlinear model

Kiwifruit

\begin{abstract}
A B S T R A C T
Osmotic dehydration experiments of kiwifruit (Actinidia deliciosa cv Hayward) were carried out in order to model the operation by using a nonlinear irreversible thermodynamic approach. Samples were immersed into 65\% $(\mathrm{w} / \mathrm{w})$ sucrose aqueous solution at $30^{\circ} \mathrm{C}$ during $5,10,15,20,30,45,60,90$, $120,180,250,320,400,720,1440$ minutes. Some physical-chemical parameters were measured in fresh, treated and reposed $\left(24 \mathrm{~h}\right.$ at $30^{\circ} \mathrm{C}$ ) samples. The results show that the water transport through the apoplastic ways in kiwifruit osmodehydration can be modelled by a nonlinear thermodynamic approach obtaining a phenomenological coefficient $\left(5.46 \cdot 10^{-6}\right.$ $\mathrm{mol}^{2} / \mathrm{J} \mathrm{s} \mathrm{m}^{2}$ ). The system suffers strong contractions and expansions during the treatment which are translated in macroscopic changes of volume and structure, and also cause compositional changes. The thermodynamic model applied quantifies these phenomena in order to better control the osmotic dehydration of kiwifruit.
\end{abstract}

(C) 2010 Elsevier Ltd. All rights reserved.

\section{Introduction}

Osmotic treatment is a dehydration technique usually used in fruits and vegetables, which produces a reduction in food water activity and therefore allows storing the foods for longer periods improving the stability and quality of products. The osmotic process consists in the immersion of food in hypertonic solution of salts or sugars, producing a release of water from the food with a simultaneous impregnation of the material with the solute (Ferrando and Spiess, 2001). Osmotic dehydration in a multiphase system as fruits involves complex mass transfer phenomena (diffusional and also mechanical) simultaneously producing physical and structural changes (CastroGiráldez et al., 2010e). So, structure of plant tissue can be considered one of the main factors for understanding osmotic dehydration process (Mavroudis et al., 1998).

Kiwifruit is a biological system constituted by three distinct tissue types, namely outer pericarp, inner pericarp and core. The core is composed by

*Corresponding author. Tel.: +34 963877369

E-mail address: pedfisu@tal.upv.es (P.J.Fito). spherical/ellipsoidal cells $\quad 0.1$ and $0.2 \mathrm{~mm}$ diameter), whereas the outer pericarp is composed by large cells (0.5-0.8 $\mathrm{mm}$ diameter) dispersed in a matrix of smaller cells (0.1-0.2 mm diameter) (Hallett et al., 1992). The inner pericarp consists of the locules, which are enclosed within locule walls (Hallett et al., 1992). Each locule is composed of large radially elongated thin-walled cells $(0.2-0.4$ $\mathrm{mm} x>1 \mathrm{~mm}$ ) and seeds, while the locule wall is a narrow region composed of smaller thicker walled cells (Hallett et al., 1992). Each of these tissues has different chemical composition (Ferguson, 1980; MacRae et al., 1989a), texture properties (MacRae et al., 1989b; Jackson and Harker, 1997), cell wall composition (Redgwell et al., 1991, 1992) and cell characteristics (Hallett et al., 1992).

Gerchenson et al (2001) reported that kiwifruit behaves as an elastic solid with storage moduli dominating the viscoelastic response when it is subjected to an osmotic dehydration process. In this complex scenario, very little work has been carried out to analyze the effect of osmotic dehydration on structure and composition of kiwifruit, and to understand the mechanisms that impulse the mass transfer through this operation. 


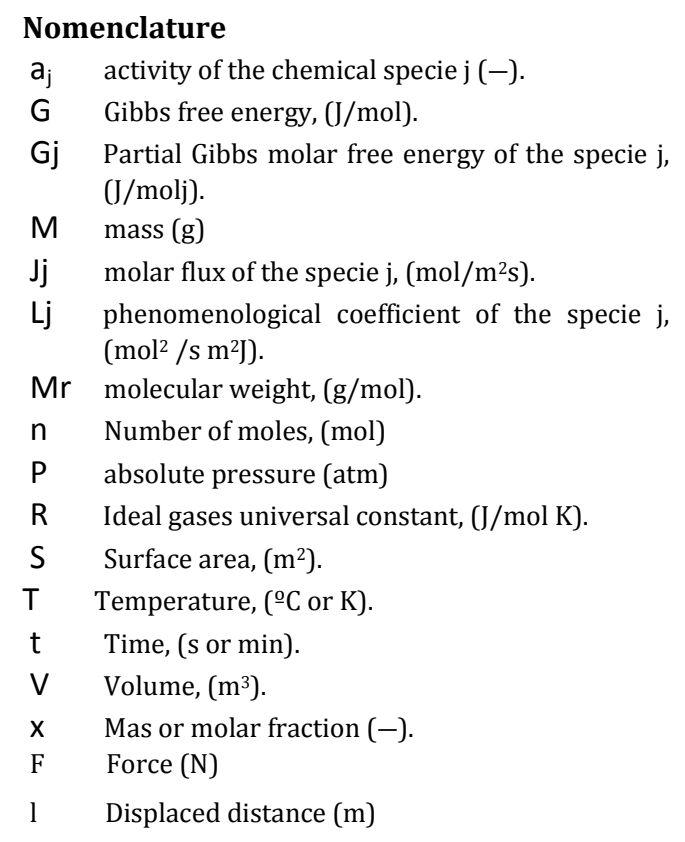

$\bar{F} \quad$ Molecular force (N/mol)

Z Mass or molar fraction of the liquid fraction $(-)$.

\section{Greek alphabet:}

$\mu \mathrm{j} \quad$ Chemical potential of the specie $\mathrm{j},(\mathrm{J} / \mathrm{mol})$

$\mu_{j}^{0} \quad$ Chemical potential of reference of the specie $j$, $(\mathrm{J} / \mathrm{mol})$

$v$ Specific volume $(\mathrm{L} / \mathrm{mol})$.

$\Delta \quad$ Variation of a variable.

\begin{tabular}{ll} 
& \multicolumn{1}{c}{ Subscript y superscript: } \\
0 & Initial time \\
24 & Time 24 hours after the treatment. \\
LP & Liquid phase. \\
max & Maximum \\
s & sucrose \\
w & water \\
t & Time, (s or min).
\end{tabular}

The objective of this work is to describe osmotic dehydration process of kiwifruit by using a nonlinear thermodynamic approach, taking into account the influence of tissue structure (ex: swelling and shrinking tissue phenomena or structural changes) in the water and sucrose transport.

\section{Materials and Methods}

Sucrose solution $\left(65 \% \mathrm{w} / \mathrm{w}, 30^{\circ} \mathrm{C}\right)$, prepared with commercial sugar and distilled water, was used as an osmotic agent. Before the experiment, kiwi fruits (Actinidia deliciosa cv Hayward) with the same size and ripeness were bought from a local supermarket and kept refrigerated until use. The kiwifruits were cut with a calimeter in half slices (1 $\mathrm{cm}$ thickness) and the core was eliminated. There were prepared 90 samples which were immersed in a vessel containing the osmotic solution with continuous stirring. The relation between the fruit and the solution was of $1: 20(\mathrm{w} / \mathrm{w})$ to avoid changes in the solution during the process. The system was maintained at $30^{\circ} \mathrm{C}$ in a constanttemperature chamber. To prevent evaporation the vessel was covered with a sheet of plastic wrap.

Preliminary kinetic studies were done at the same working conditions in order to select the osmotic dehydration times. Osmotic dehydration was conducted over several time periods: $5,10,15,20$ $30,45,60,90,120,180,250,320,400,720,1440$ minutes. Six samples were used at each dehydration time.

A flow-diagram of the experimental procedure is presented in figure 1.

Three samples per osmotic treatment time were reposed at $30^{\circ} \mathrm{C}$ for 24 hours, on Decagon containers, closed with parafilm $\AA$, in order to eliminate the concentration profiles in samples.
Mass, volume and surface water activity were analyzed for each fresh, treated and reposed sample. Representative fresh samples were used to determine the initial moisture, sugar content (oix), citric acid content, cation content and CryoSEM. Moisture and sugar content (ํㅡrix) were measured for each reposed sample. The other three samples per time were used for the cation analysis, citric acid content and Cryo-SEM.

At each osmotic time, an aliquot of sucrose solution was also taken from the vessel. Water activity and ${ }^{\circ}$ Brix of the solution were measured at each time. Mass was determined by using a Mettler Toledo Balance $( \pm 0.0001)$ (Mettler-Toledo, Inc., U.S.A.).

Volume measurements were analysed by using a photographic treatment of the samples and the software Adobe Photoshop ${ }^{\circledR}$ (Adobe Systems Inc., San Jose, CA, U.S.A.) to get the diameter and the thickness of the samples.

Surface water activity was measured in the structured samples with a dew point hygrometer Aqualab® series 3 TE (Decagon Devices, Inc., Washington, USA).

Moisture was determined by drying in a vacuum oven at $60^{\circ} \mathrm{C}$ till constant weight was reached (AOAC method 934.06 (2000)). Sugar content was determined in a refractometer (ABBE, ATAGO Model 3-T, Japan). The titrable acidity (referred to as citric acid) by using AOAC method 942.15 (2000).

Analytical determinations described above were obtained by triplicate.

Cation quantification was carried out by means of an ion chromatograph (Methrom Ion Analysis, Herisau, Switzerland), using a universal standard column (Metrosep C2-150, $4.0 \times 150 \mathrm{~mm}$ ) along with an eluent composed of tartaric acid ( $4.0 \mathrm{mmol} / \mathrm{L})$ and dipicolinic acid $(0.75 \mathrm{mmol} / \mathrm{L})$, equipped with electronic detectors. In every case, 
the fruit samples were previously homogenized at $9000 \mathrm{rpm}$ in an ULTRATURRAX T25 for $5 \mathrm{~min}$ and centrifuged (J.P. Selecta S.A., Medifriger-BL, Barcelona, Spain) at $4000 \mathrm{rpm}$ for $20 \mathrm{~min}$ Afterwards, $1 \mathrm{~mL}$ of supernatant was diluted with Milli ${ }^{\circ}-Q$ water in a $50 \mathrm{~mL}$ Erlenmeyer flask. The clarified extract was filtered through a $0.45 \mu \mathrm{m}$ Millipore filter; $15 \mathrm{~mL}$ was used to analyse the cation content. Measurements were taken in duplicate.

Low temperature scanning electron microscopy (cryo-SEM)

A Cryostage CT-1500C unit (Oxford Instruments, Witney, UK), coupled to a Jeol JSM-5410 scanning electron microscope (Jeol, Tokyo, Japan), was used. The sample was immersed in slush $\mathrm{N} 2\left(-210^{\circ} \mathrm{C}\right)$ and then quickly transferred to the Cryostage at 1 $\mathrm{kPa}$, where sample fracture took place. The sublimation (etching) was carried out at $-95^{\circ} \mathrm{C}$; the final point was determined by direct observation in the microscope, working at $5 \mathrm{kV}$. Then, once again in the Cryostage unit, the sample was coated with gold in vacuum $(0.2 \mathrm{kPa})$, applied for $3 \mathrm{~min}$, with an ionization current of $2 \mathrm{~mA}$. The observation in the scanning electron microscope was carried out at 15 $\mathrm{kV}$, at a working distance of $15 \mathrm{~mm}$ and a temperature $\leq-130^{\circ} \mathrm{C}$.

\section{Results and Discussion}

The osmotic dehydration operation with 65을 solution produces compression and relaxation phenomena (Fito and Chiralt, 1997). These mechanisms could be observed by analyzing the mass and volume variation; these variations could be estimated by the following equations:

$$
\begin{gathered}
\Delta \mathrm{M}=\frac{\mathrm{M}_{\mathrm{t}}-\mathrm{M}_{\mathrm{o}}}{\mathrm{M}_{\mathrm{o}}} \\
\Delta \mathrm{V}=\frac{\mathrm{V}_{\mathrm{t}}-\mathrm{V}_{\mathrm{o}}}{\mathrm{V}_{\mathrm{o}}}
\end{gathered}
$$

(Equation 1)

(Equation 2)

where $\mathrm{M}$ represents the mass (kg), $\mathrm{V}$ the volume $\left(\mathrm{m}^{3}\right)$, the subscripts t represent the treatment time, being 0 the initial value.

Moreover, the sucrose and water mass evolution can be observed applying equation 1 for the specific compounds as follows:

$$
\begin{array}{rr}
\Delta \mathrm{M}_{\mathrm{w}}=\frac{\mathrm{M}_{\mathrm{t}} \mathrm{x}_{\mathrm{wt}}-\mathrm{M}_{0} \mathrm{x}_{\mathrm{w} 0}}{\mathrm{M}_{0}} & \text { (Equation 3) } \\
\Delta \mathrm{M}_{\mathrm{s}}=\frac{\mathrm{M}_{\mathrm{t}} \mathrm{x}_{\mathrm{st}}-\mathrm{M}_{0} \mathrm{x}_{\mathrm{s} 0}}{\mathrm{M}_{0}} & \text { (Equation 4) }
\end{array}
$$

where $\mathrm{x}_{0}$ is the mass fraction of water $\left(\mathrm{x}_{\mathrm{w} 0}\right)$ or soluble solids $\left(\mathrm{x}_{\mathrm{s} 0}\right)$ of the sample at initial time $\left(\mathrm{kg} / \mathrm{kg}_{\mathrm{T}}\right)$ and $\mathrm{x}_{\mathrm{t}}$ is the same after dehydration process $\left(\mathrm{kg} / \mathrm{kg}_{\mathrm{T}}\right)$.

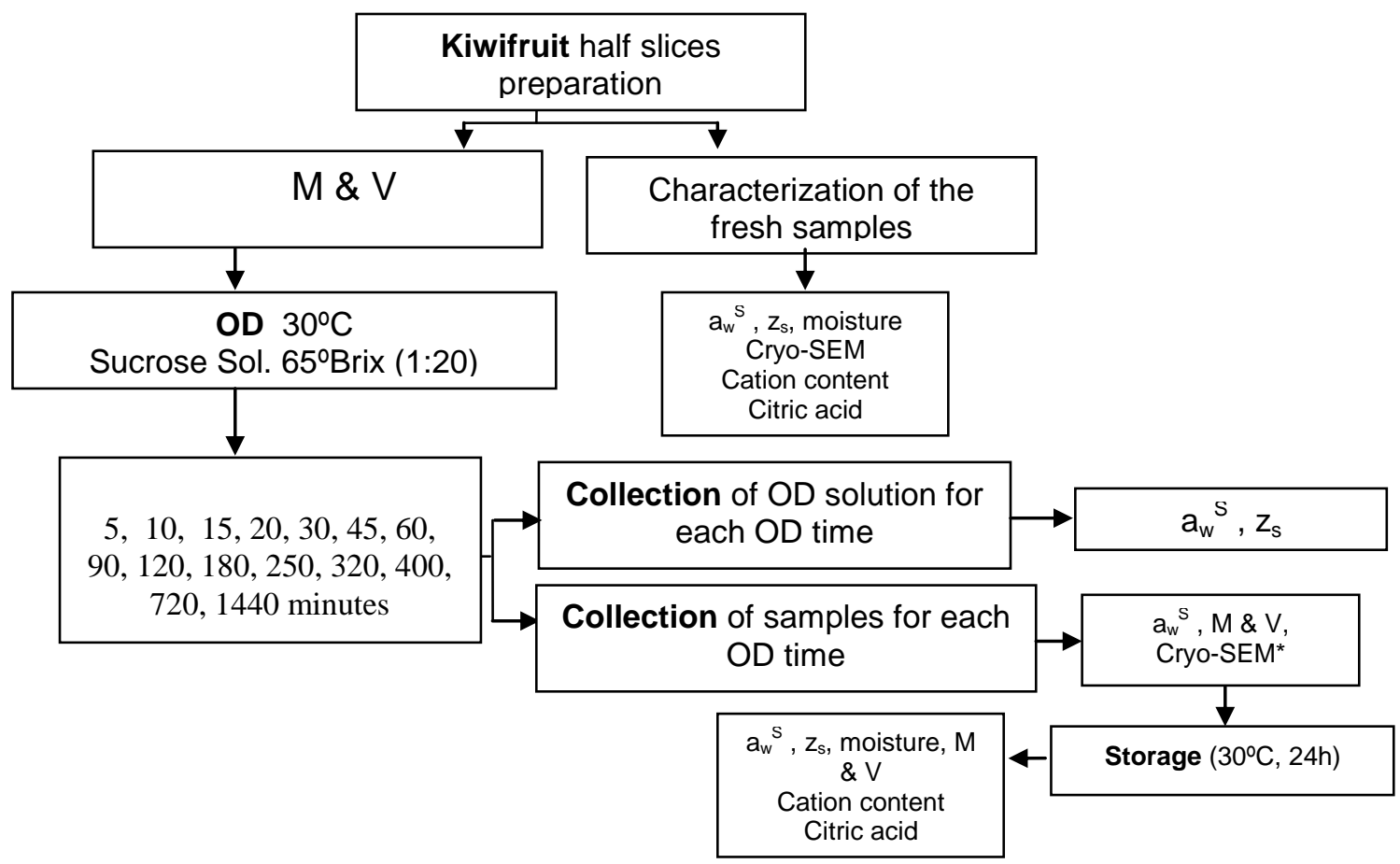

Figure 1. Diagram of the experimental procedure. * Cryo-SEM was made in fresh and treated samples until 60 minutes of treatment 
Figure 2 shows the overall mass, water and sucrose mass variation through the osmotic treatment. In the figure, the decrease in total mass is appreciated. The decrease in mass is explained by the high water losses while the sucrose mass increases during the osmotic treatment. In figure 3, the volume variation is observed; it is possible to appreciate the overall decrease in volume through the osmotic treatment. The half slice of kiwifruit can be divided in two zones (see figure 4c), zone $\mathrm{A}$ represents the external zone composed by homogeneous reservoir cells explained in the introduction; and zone B represents the internal part of the tissue, where the reservoir and vascular cells are combined in radial way. These two zones show different direction in the mechanical tension, during the contraction and expansion.

Kiwifruit behaves as a viscoelastic solid and it is possible to appreciate, at the beginning of the treatment, the important expansions and contractions of the tissue (Figure $4 \mathrm{a}$ and $4 \mathrm{~b}$ ). Figure 5a shows fresh kiwi specifying the intracellular and extracellular space, and membrane/wall system; extracellular spaces are mainly filled with air. In the first 5 minutes of treatment, the fruit suffers an important lost of turgid, and a $25 \%$ of contraction can be appreciated in the overall volume; figure $5 \mathrm{~b}$ shows the tissue with the extracellular space filled with liquid. Afterwards, until 15 minutes of treatment, the fruit suffers expansions, recovering $93 \%$ of the initial volume, recovering the zone A; Figure $5 \mathrm{c}$ shows the membrane/wall system intact, thus the expansion must be a response of the tissue to the first fast contraction. At 20 minutes of treatment, the fruit again is contracted strongly (32\% of the initial volume), disappearing again the zone $\mathrm{A}$ and contracting the zone B. After this time, the expansion/contraction phenomena are less marked and, at long osmotic times, the fruit is completely retracted (Figure $4 \mathrm{a}$ ) and zone B is absolutely contracted. It is important to highlight that although the fruit suffer important expansions at the beginning of the treatment, it is dehydrating and losing overall weight (Figure 2).

Second expansion occurs at 30 and 45 minutes, as shows figure $4 \mathrm{~b}$, recovering no more than $5 \%$ of volume; figures $6 \mathrm{a}$ and $\mathrm{b}$, show Cryo-SEM pictures of samples treated 30 minutes and figures $c$ and d show Cryo-SEM pictures of samples treated 45 minutes. All pictures show an initial plasmolysis so incipient. Therefore the second expansion must be also an elastic response to the second fast contraction.

The water and solute fluxes promoted in the osmotic treatment can be estimate with the mass variation, the process time and the variation of the samples surface.

$$
\begin{aligned}
& \mathrm{J}_{\mathrm{w}}=\frac{-\Delta \mathrm{M}_{\mathrm{w}} \cdot \mathrm{M}_{\mathrm{o}}}{\Delta \mathrm{t} \cdot \mathrm{S} \cdot \mathrm{Mr}_{\mathrm{w}}} \\
& \mathrm{J}_{\mathrm{s}}=\frac{\Delta \mathrm{M}_{\mathrm{s}} \cdot M_{o}}{\Delta \mathrm{t} \cdot \mathrm{S} \cdot \mathrm{Mr}_{\mathrm{s}}}
\end{aligned}
$$

(Equation 5)

(Equation 6)

where $\mathrm{J}_{\mathrm{w}}$ is the water flux $\left(\mathrm{mol}_{\mathrm{w}} / \mathrm{s} \mathrm{m} \mathrm{m}^{2}\right)$, $\mathrm{J}_{\mathrm{s}}$ is the sucrose flux $\left(\mathrm{mol}_{\mathrm{s}} / \mathrm{s} \mathrm{m}^{2}\right)$ during the treatment, $\mathrm{t}$ is the process time, $S$ is the measured surface area of the sample $\left(\mathrm{m}^{2}\right), \mathrm{Mr}_{\mathrm{w}}$ is the molecular weight of water $(18 \mathrm{~g} / \mathrm{mol})$ and $\mathrm{Mr}_{\mathrm{s}}$ is the molecular weight of sucrose (342 $\mathrm{g} / \mathrm{mol})$. It is possible to observe in figure 7 that both fluxes are reduced with treatment time.

Figure 8 shows a scheme of surface water activity measured in the fresh, treated and reposed samples; these measurements represent the water activity of the surface of each sample. After the

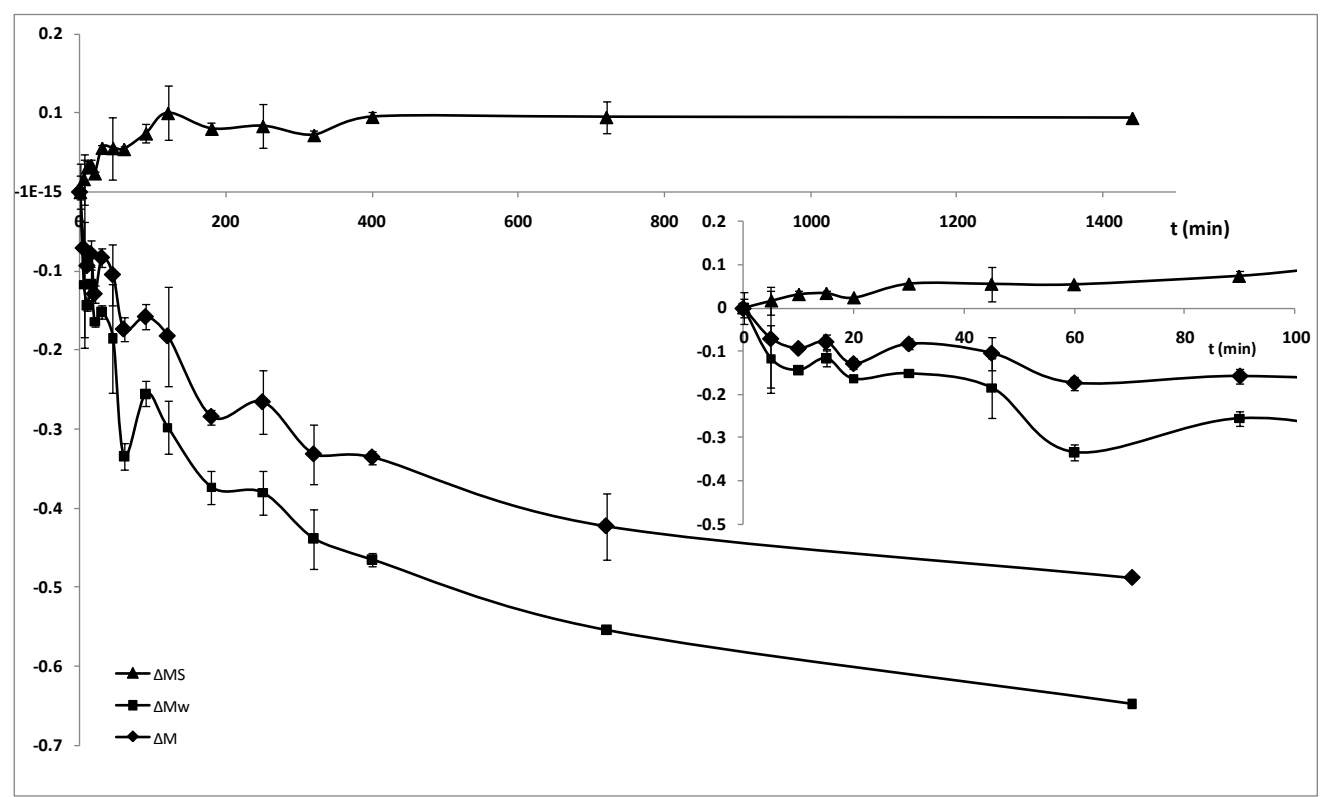

Figure 2. Evolution of overall mass $(\diamond)$, water mass $(\boldsymbol{\square})$ and sucrose mass $(\boldsymbol{\Delta})$ variation through the osmotic treatment. 


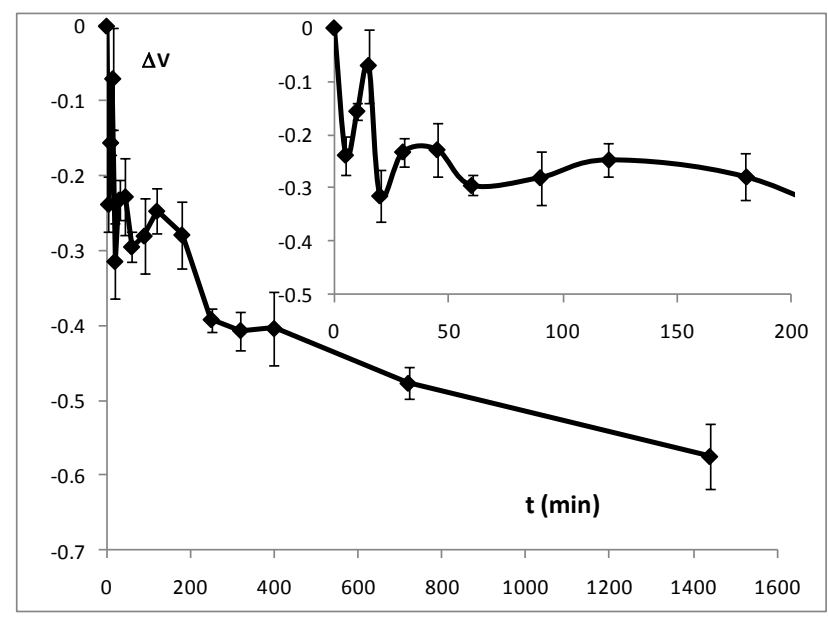

Figure 3. Evolution of the volume variation through the osmotic treatment.
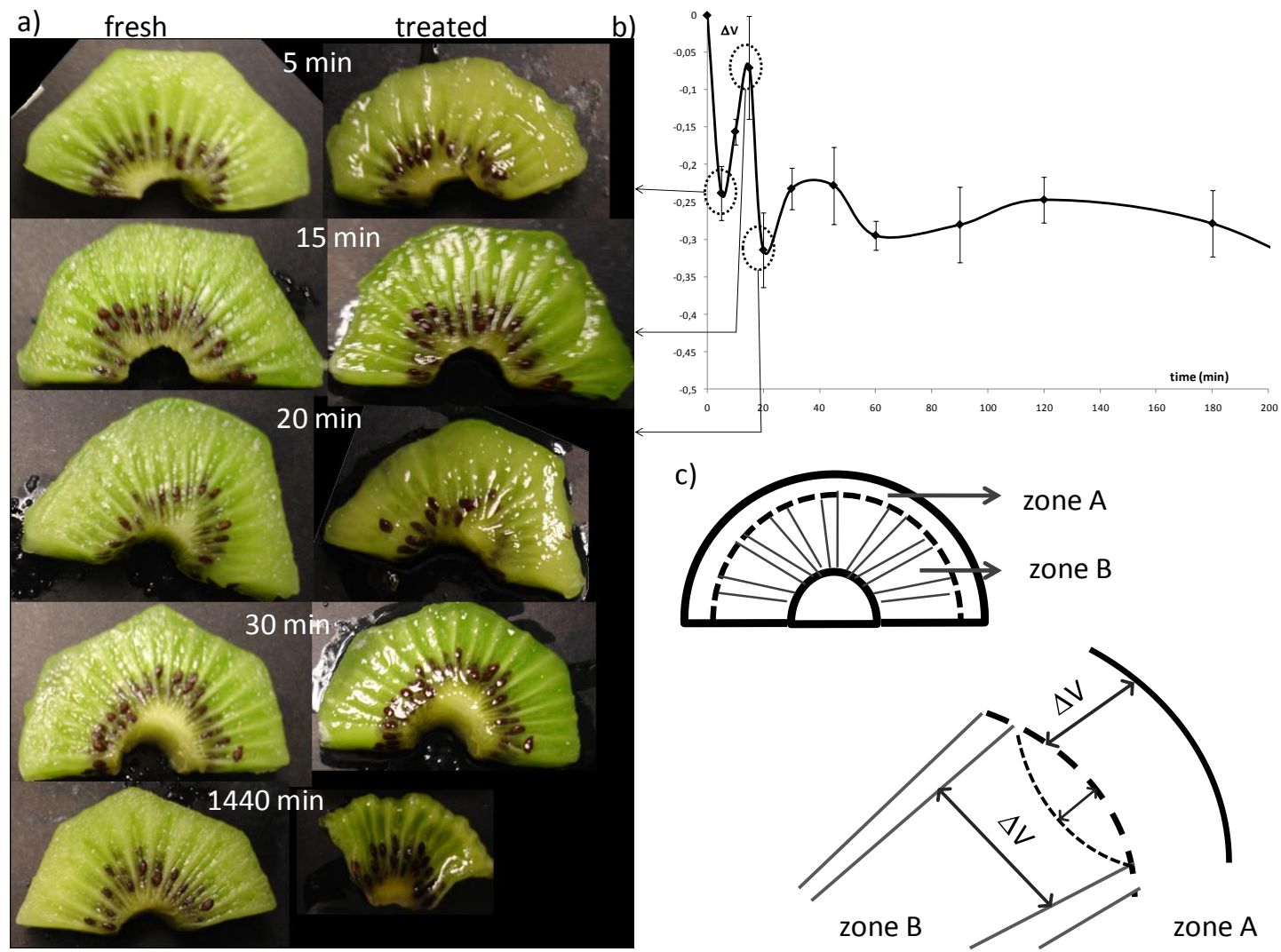

Figure 4. Kiwifruit deformation through the osmotic dehydration; a) pictures of fresh and treated kiwifruit at different treatment times; b) Volume variation curve at short treatment times; c) detail of the zones of the kiwi tissue with the sense of the deformations. 


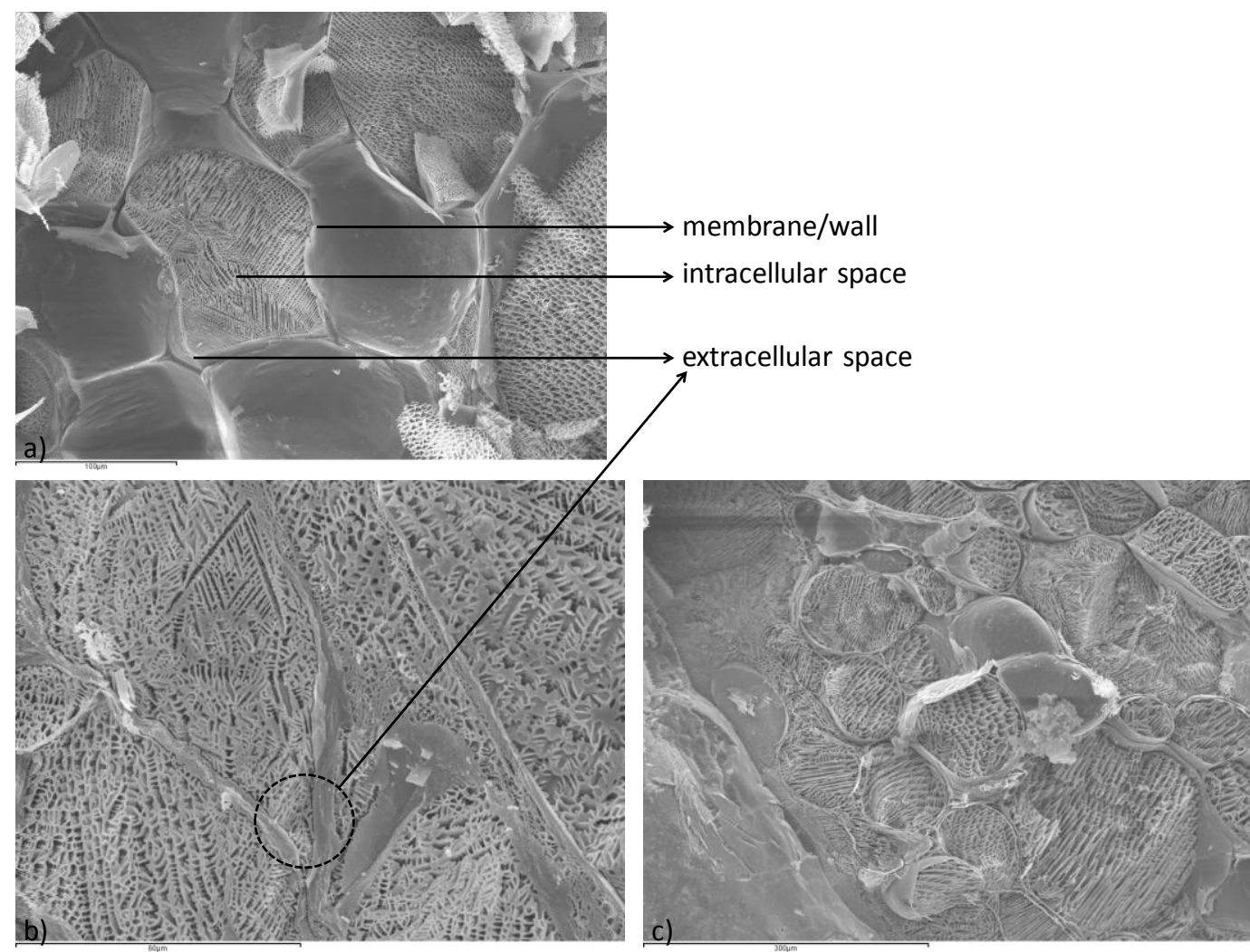

Figure 5. Cryo-SEM pictures at different treatment times; a) fresh kiwi at 350x; b) treated sample at 5 min, at $1000 \mathrm{x}$; c) treated sample at $15 \mathrm{~min}$, at $200 \mathrm{x}$.

repose time, the moisture was analyzed in whole sample. The moisture of treated samples was estimated by balances. Figure 8 shows also the relationship between the moisture in dry basis and the surface water activity of the treated, reposed samples and data from pure solutions of water and sucrose (Starzak \& Mathlouthi, 2006). In this figure it is possible to observe that the reposed samples maintain the same relationship surface water activity/moisture as the pure sucrose solution at different concentrations. Therefore, the water and sucrose concentration is homogeneous in the reposed samples, been negligible the concentration profiles through the tissue. The surface water activity of treated samples is lower than that of the reposed samples; it denotes concentration profiles in the kiwifruit tissue and an important internal transport is driven; only at the end of the treatment, the treated and the reposed values concur with the pure solution values; this fact denotes the disappearance of concentration profiles in the tissue.

Figure 9 shows the water flux and the volume variation during the 24 hours of repose time. In the figure, two steps can be observed: the first one, composed by the samples treated less than 180 minutes, shows fluctuant fluxes promoted by the shrinkage and swelling of samples during the repose time (mechanical behaviours); the second step, composed by the samples with treatment times higher than $180 \mathrm{~min}$, shows a continuous decrease of fluxes without volume variation, suggesting that the engine of the transport during the repose time must be the gravity.

\section{Non equilibrium approach to determine the water transport between the osmotic solution and the kiwifruit surface}

The thermodynamic analysis of the energy, equilibrium and fluxes in food systems is usually made in terms of the Gibbs Free Energy (Nicolis and Prigogine, 1977a,b).

In order to understand and to estimate the molecular transport through the interface (Figure 10 ), it is necessary to determine the free energy variation across the interface per mol of any chemical specie in motion. Gibbs free energy variation could be estimated in a biological tissue as equation 7 shows (Demirel, 2002, CastroGiráldez et al., 2010d, e).

$$
\mathrm{dG}=-\mathrm{SdT}+\mathrm{VdP}+\mathrm{Fdl}+\psi \mathrm{de}+\sum_{\mathrm{i}} \mu_{\mathrm{i}} \mathrm{dn}_{i}
$$

(Equation 7) 

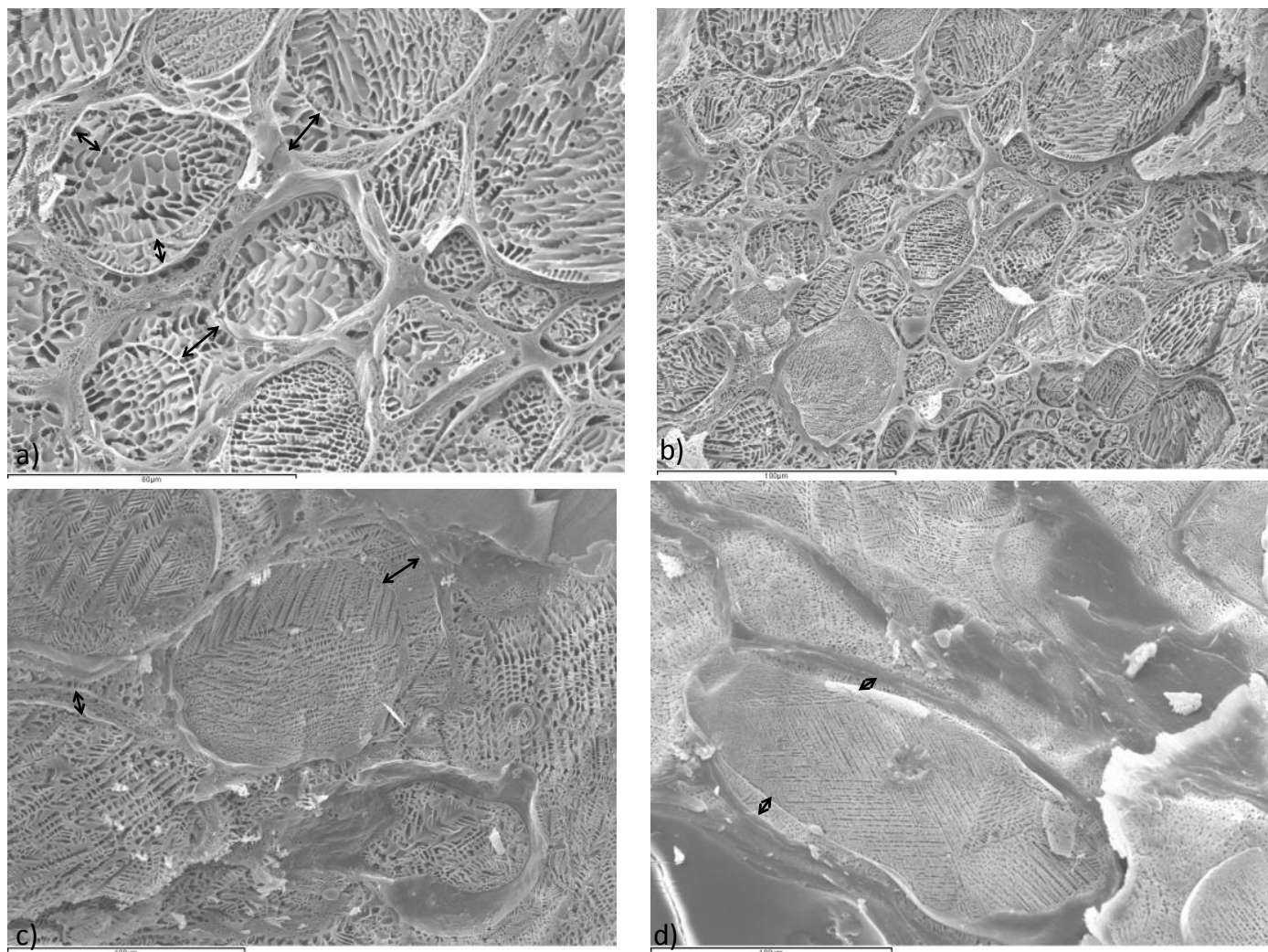

Figure 6. Cryo-SEM pictures at different treatment times; a) treated sample at $30 \mathrm{~min}$, at $1000 \mathrm{x}$; b) treated sample at $30 \mathrm{~min}$, at $500 \mathrm{x}$; c) treated sample at $45 \mathrm{~min}$, at 500x; d) treated sample at $45 \mathrm{~min}$, at 500x.

where the effect of the electric field term depends on the valence of the ions per electric charge. The effect in the free energy variations of the amount of native ions is negligible, thus the term is null. The system is isotherm, then the entropic term is negligible. So, the equation 7 is transformed in equation 8.

$$
\mathrm{dG}=\mathrm{VdP}+\mathrm{Fdl}+\sum_{\mathrm{i}} \mu_{\mathrm{i}} \mathrm{dn}_{\mathrm{i}}
$$

(Equation 8)

Therefore it is possible to develop the free energy variation per water mol (extended chemical potential of water) as follows:

$$
\Delta \mu_{w}^{e x t}=\frac{\Delta \mathrm{G}}{\Delta \mathrm{n}_{\mathrm{w}}}=\nu_{\mathrm{w}} \Delta \mathrm{P}+\overline{\mathrm{F}}_{\mathrm{w}} \Delta \mathrm{l}+\mu_{\mathrm{s}} \frac{\Delta \mathrm{n}_{\mathrm{s}}}{\Delta \mathrm{n}_{\mathrm{w}}}+\mu_{\mathrm{w}}
$$

Where the $v_{\mathrm{w}}$ represent the molar partial volume and $F_{w}$ the mechanical storage force expressed by mol. Applying equation 9 in the interface, defined in figure 10 as osmotic solution/extracellular space (apoplastic way), the water chemical potential results as follows:

$$
\Delta \mu_{w}^{e x t}=\nu_{\mathrm{w}}^{-} \Delta \mathrm{P}+\overline{\mathrm{F}}_{\mathrm{w}} \Delta \mathrm{l}+\mathrm{R} T \ln \frac{a_{s}^{O S}}{a_{s}^{e}} \frac{\Delta \mathrm{n}_{\mathrm{s}}}{\Delta \mathrm{n}_{\mathrm{w}}}+\mathrm{R} T \operatorname{Ln} \frac{a_{w}^{O S}}{a_{w}^{e}}
$$

where $\mathrm{a}_{\mathrm{s}}$ is obtained from the bibliography (Lide, 2004); superscript $e$ represents the external liquid phase (apoplastic way) close to the interface, and superscript $O S$ represents the sucrose solution.

The relation between the water and sucrose moles in motion is the same as the molar flux relation, then it is possible to use this relation in the equation 10 (Castro-Giráldez et al., 2010e) obtaining:

$$
\Delta \mu_{w}^{e x t}=\nu_{\mathrm{w}}^{-} \Delta \mathrm{P}+\overline{\mathrm{F}}_{\mathrm{w}} \Delta \mathrm{l}+\mathrm{R} T \ln \frac{a_{s}^{O S}}{a_{s}^{e}} \frac{\mathrm{J}_{\mathrm{s}}}{\mathrm{J}_{\mathrm{w}}}+\mathrm{R} T \operatorname{Ln} \frac{a_{w}^{O S}}{a_{w}^{e}}
$$

The activity terms of equation 11 were represented with regard to the water flux through the osmotic treatment time (Figure 11). At initial time, from 10 to 45 minutes (without considering the $20 \mathrm{~min}$ treatment time), the activity terms of equation 11 are predominant and are the main engine for water transport; 5 and 20 minutes were not considered in this time range because, as it was explained before in figure 4, a mechanical response of the tissue was produced at these times. Thus, in the considered time range, equation 11 can be written as:

$$
\Delta \mu_{w}^{e x t}=\mathrm{R} T \ln \frac{a_{s}^{O S}}{a_{s}^{e}} \frac{\mathrm{J}_{\mathrm{s}}}{\mathrm{J}_{\mathrm{w}}}+\mathrm{R} T \operatorname{Ln} \frac{a_{w}^{O S}}{a_{w}^{e}}
$$




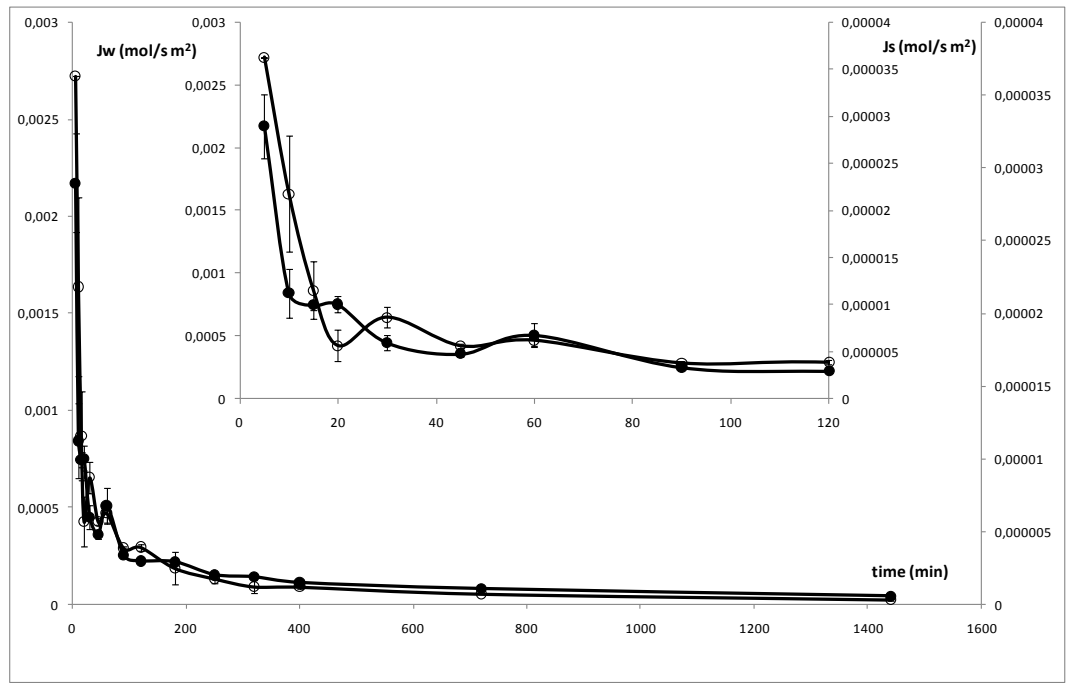

Figure 7. Variation of water $(\bullet)$ and sucrose $(\circ)$ fluxes versus time through the treatment.

Figure 8. Relationship between the moisture in dry basis and the water activity for samples dehydrated $(\bullet)$, reposed $24 \mathrm{~h}(0)$, and sucrose solutions $(-)$ obtained from Starzak \& Mathlouthi (2006).
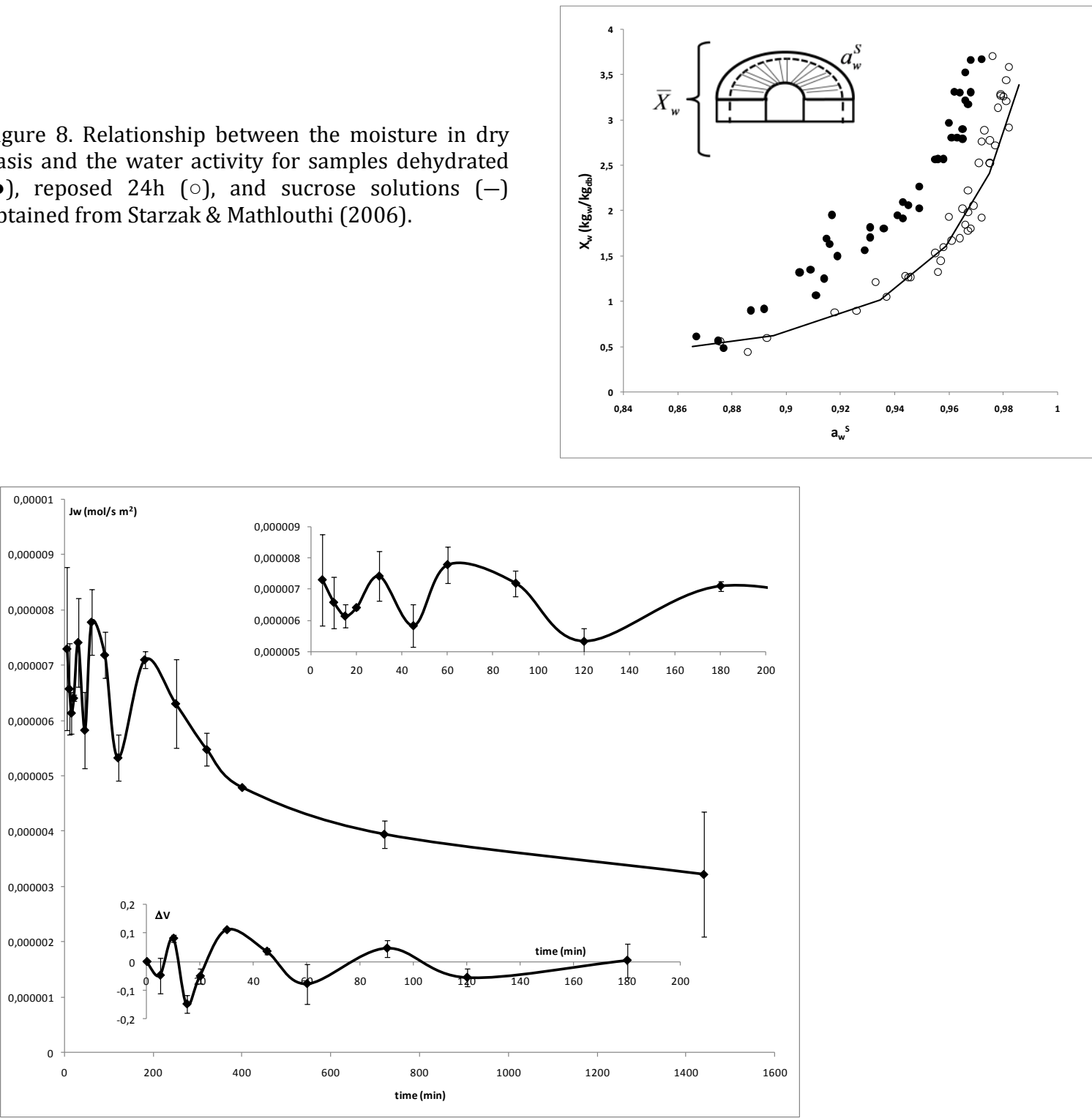

Figure 9. Water flux and volume variation during the repose time. 


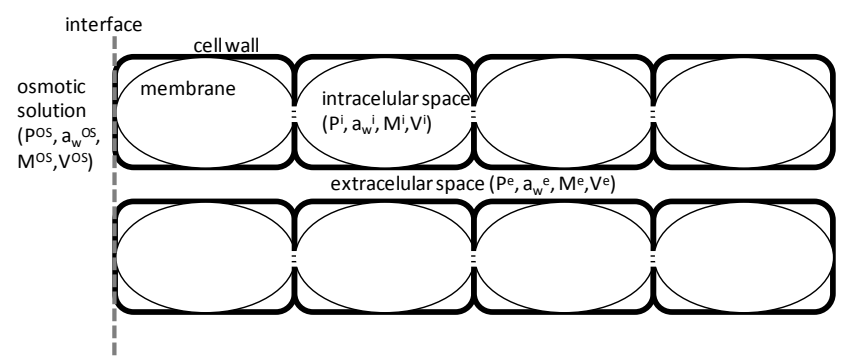

Figure 10. Kiwifruit tissue scheme with the simplified phases used in the thermodynamic model (Adapted from Castro-Giráldez et al., 2010a).

Applying the first relation of Onsager (Demirel, 2002; Gekas, 2001), water fluxes can be related with the chemical potential extended, as a driving force of the water transport, with a phenomenological coefficient showed in equation 13.

$$
J_{w}=L_{w} \cdot \Delta \mu_{w}^{e x t}
$$

(Equation 13)

Applying the equation 13 in the range from 15 to 45 minutes, the phenomenological coefficient obtained is $\mathrm{L}_{\mathrm{w}}=5.46 \cdot 10^{-6} \mathrm{~mol}^{2} / \mathrm{J} \mathrm{s} \mathrm{m}^{2}$. In fruits, different values of phenomenological coefficients of water transport through the protoplast membrane have been published; Ferrando and Spiess (2002 and 2003) showed in osmotic dehydration treatments with sucrose solution at $30^{\circ} \mathrm{C}, 1 \cdot 10^{-6}$ $\mathrm{mol}^{2} / \mathrm{J} \mathrm{s} \mathrm{m}^{2}$ for onions, $5.2 \cdot 10^{-6} \mathrm{~mol}^{2} / \mathrm{J} \mathrm{s} \mathrm{m}^{2}$ for carrots and $6.8 \cdot 10^{-6} \mathrm{~mol}^{2} / \mathrm{J} \mathrm{s} \mathrm{m}^{2}$ for potatos. Seguí et al. (2006) reported the value of $4.5 \cdot 10^{-5} \mathrm{~mol}^{2} / \mathrm{J} \mathrm{s} \mathrm{m}^{2}$ for apple (var Fuji). Phenomenological coefficient for apoplastic transport in osmotic dehydration treatment with sucrose solution at $30^{\circ} \mathrm{C}$ was published by Castro-Giráldez et al. (2010e) for apple tissue obtaining the value: $\mathrm{L}_{\mathrm{w}}=1,095 \cdot 10^{-5}$ $\mathrm{mol}^{2} / \mathrm{J} \mathrm{s} \mathrm{m}^{2}$. In animal tissue, phenomenological coefficient was calculated for pork meat salting process, $\mathrm{L}_{\mathrm{w}}=2.7 \cdot 10^{-5} \mathrm{~mol}^{2} / \mathrm{J} \mathrm{s} \mathrm{m}^{2}$ (Castro-Giráldez et al., 2010d).

With the phenomenological coefficient and the molar water flux it is possible to estimate the extended chemical potential in all the treatment range, as follows;

$$
\Delta \mu_{\mathrm{w}}^{\mathrm{ext}}=\frac{\mathrm{J}_{\mathrm{w}}}{\mathrm{L}_{\mathrm{w}}}
$$

(Equation 14)

Then, the mechanical terms of the equation 11, may be estimated as follows:

$$
\begin{array}{r}
\bar{v}_{\mathrm{w}} \Delta \mathrm{P}+\overline{\mathrm{F}}_{\mathrm{w}} \Delta \mathrm{l}=\Delta \mu_{w}^{e x t}-\left(\mathrm{R} T \ln \frac{a_{s}^{O S}}{a_{s}^{e}} \frac{\mathrm{J}_{\mathrm{s}}}{\mathrm{J}_{\mathrm{w}}}+\mathrm{R} T \operatorname{Ln} \frac{a_{w}^{o S}}{a_{w}^{e}}\right) \\
\text { (Equation 15) }
\end{array}
$$

Figure 12 shows the evolution of activity and mechanical terms involved in the water transport through the treatment time, where it is possible to observe a decrease of the mechanical and activity terms through the 15 minutes of treatment. Next 5 minutes, a strong contraction is produced with the natural increase of the mechanical term. The activity term also increases; this increase can be caused by the high internal transport of whole liquid phase, promoted by the mechanical energy. The liquid phase inside the sample is more diluted than the liquid phase in the interface; therefore this transport produces an increase in the surface water activity. In these initial treatment times, the engine of the mass transfer is the activity term, which is higher than the mechanical terms. The fact that the kiwifruit is so elastic produces that all the internal changes reflect macroscopic changes and volume changes. At longer times, more concretely from 180 minutes of treatment, the mechanical terms start to be predominant and the system suffer a gradual contraction which provokes the gradual retraction already commented (Figure 4a).

Graphing the mechanical terms by the structural deformation (Figure 13) it can be appreciated the initial contraction caused by the turgid lost which provokes a $25 \%$ of deformation during the 5 minutes of treatment. Then, the system suffers an expansion recovering almost the initial volume at 15 minutes of treatment and afterward the strong contration of $30 \%$ in volume. Then, the progressive contraction of the system which was commented above and which provokes a retraction of the $60 \%$ of volume.

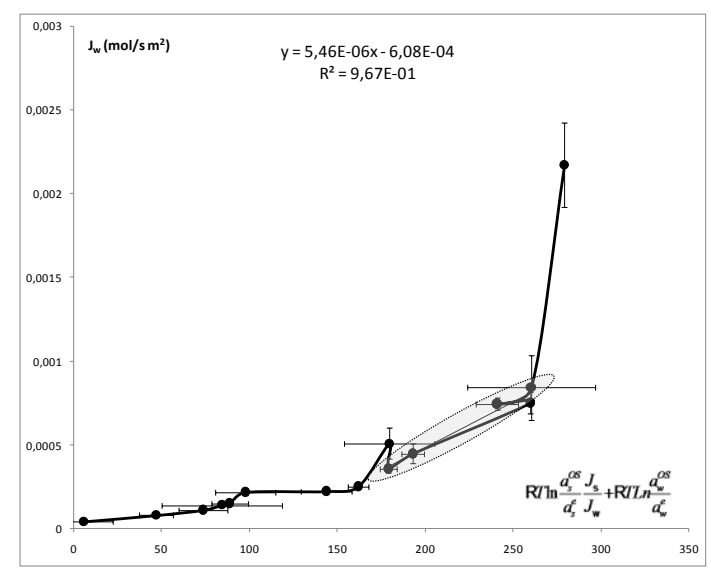

Figure 11. Activity terms obtained from equation 11 vs water flux through the osmotic treatment. 


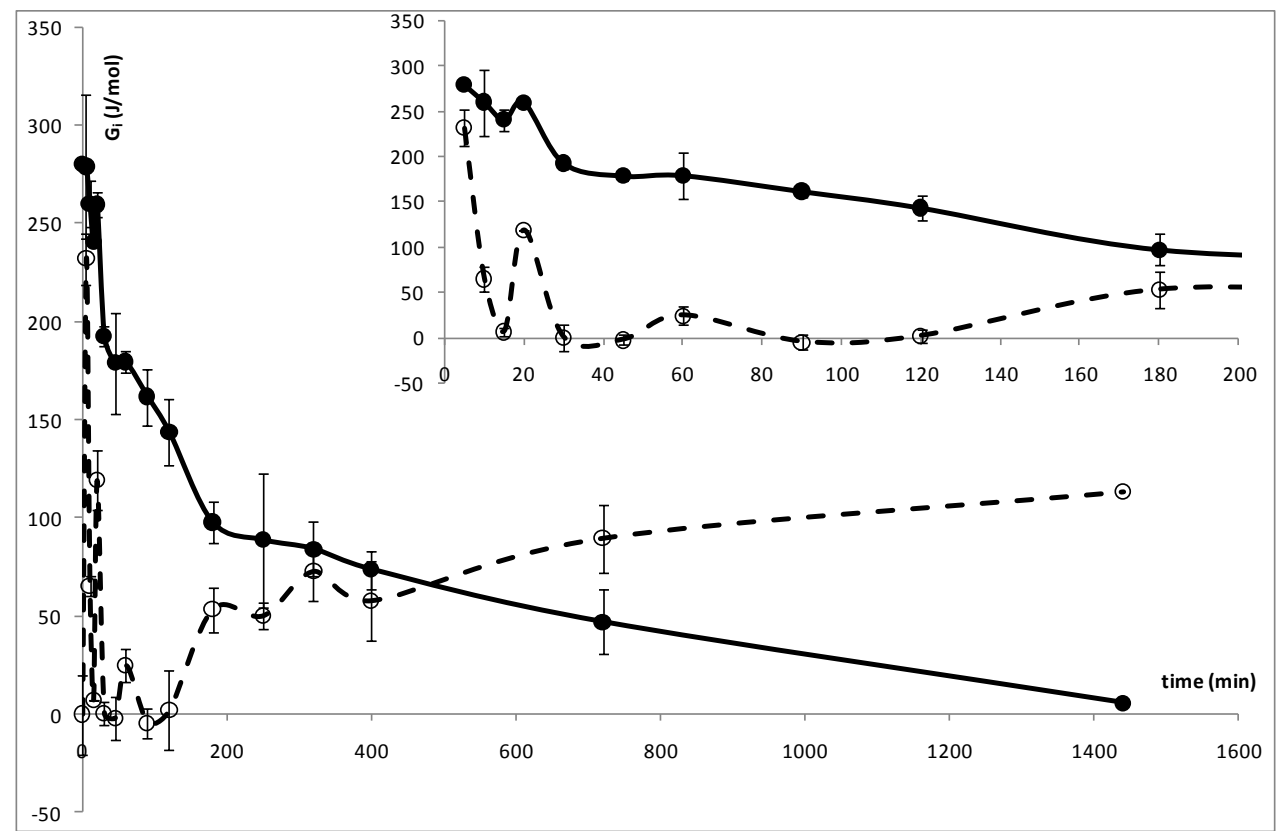

Figure 12 . Activity terms $(\bullet)$ and mechanical terms $(\circ)$ through the treatment time.

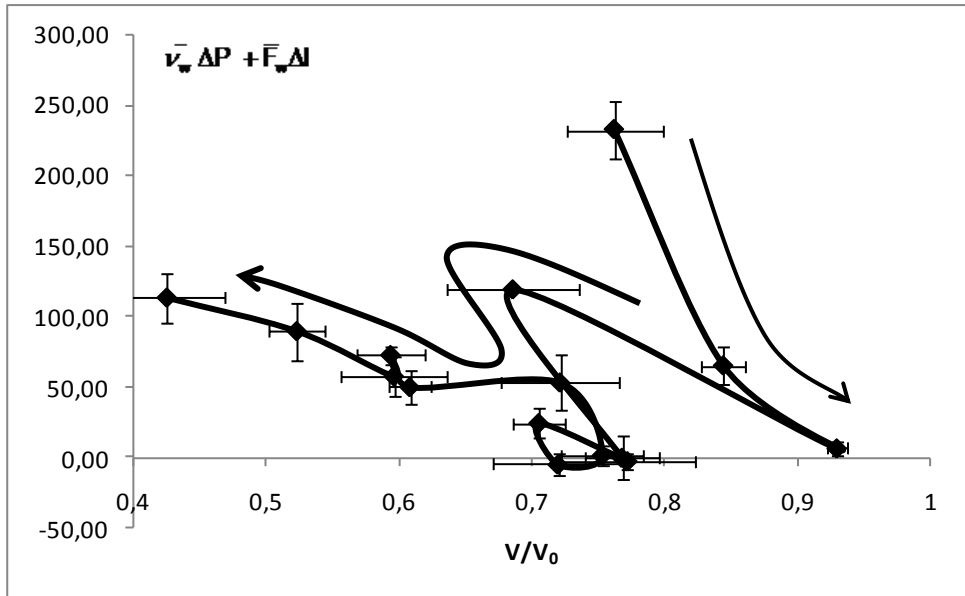

Figure 13. Relationship between the mechanical terms and the structural deformation.

Figure 13 shows the deformation by the mechanical term. This figure explains how the reduction of volume produces an increase of the mechanical terms and the enlargement of samples produces a decreasing of the mechanical terms. After 5 minutes, sample is so shrunk and the mechanical term is high, the enlargement produces the elimination of the mechanical energy given to the extracellular space in the stage before. Between 15 and 20 minutes a strong shrinkage is produced increasing the mechanical energy again, and in the next 10 minutes, the reduction of the mechanical energy is coupled with a enlargement of the product. Last reduction of sample produces a continuous increasing of the mechanical term

Osmotic solution only contains water and sucrose, then the activity gradient of other native substances present in kiwifruit is so high and promotes high losses of this native substances. These activity terms are coupled to contractions/expansions of the tissue which provokes changes in kiwifruit composition; figures 14 and 15 show the changes in citric acid and in the most important kiwifruit cations respectively during the osmodehydration treatment. It is possible to appreciate how these components are reduced during the treatment. 


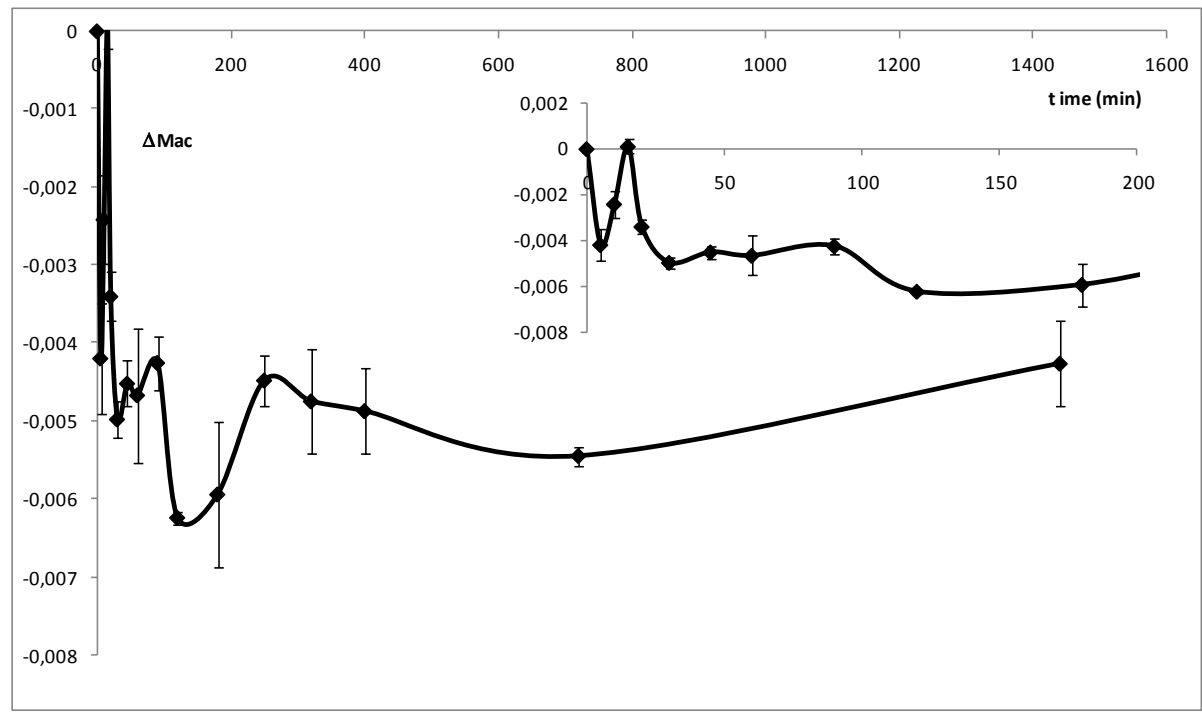

Figure 14. Variation of citric acid during the treatment.

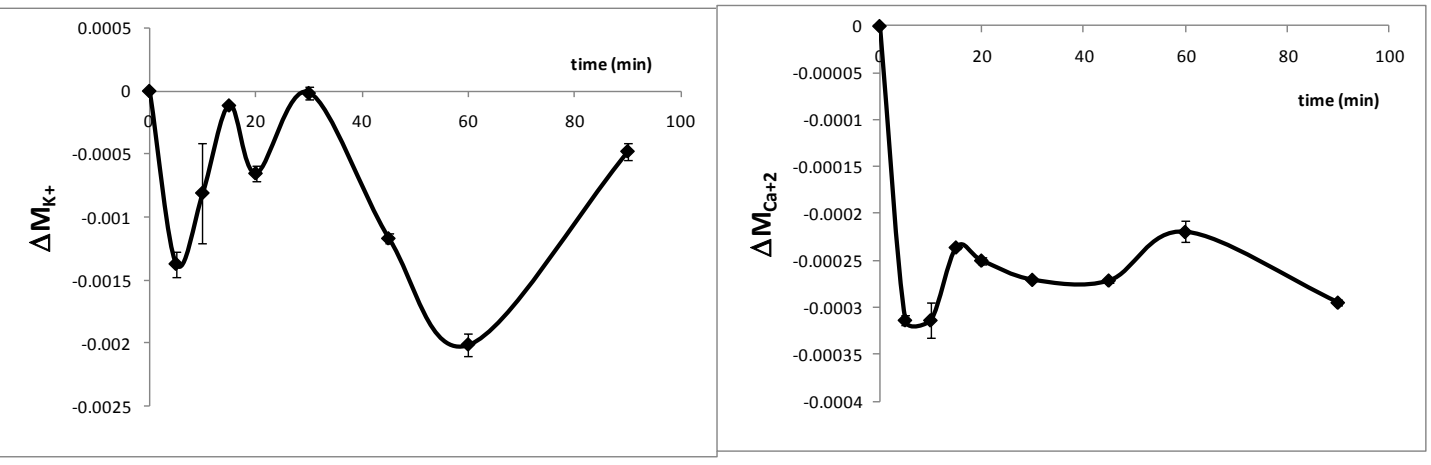

Figure 15. Variation of ions $\mathrm{K}^{+}$and $\mathrm{Ca}^{+2}$ during the treatment.

\section{Conclusions}

Is possible to develop a nonlinear thermodynamic model to determine the water transport through the apoplastic ways in kiwifruit, obtaining a phenomenological coefficient $\left(5.46 \cdot 10^{-6} \mathrm{~mol}^{2} / \mathrm{J} \mathrm{s}\right.$ $\mathrm{m}^{2}$ ). This model describes the different behaviours involved in the osmotic dehydration of kiwifruit tissue, determining the apparition of concentration profiles and the structural changes. When the tissue lost the cell turgid, the mass transport reaches a step with predominance of diffusional driving forces. In the last step of the process, the mechanical forces are predominant in the mass transport, and a retraction of the system can be observed, producing a decrease of approximately $60 \%$ of the volume.

It has been demonstrated that this fruit suffers strong contractions and expansions which are translated in macroscopic changes of volume and structure. The osmotic dehydration also produces losses in the native compounds of kiwifruit such as citric acid and Calcium and Potassium.

\section{References}

A.O.A.C, (2000). A.O.A.C, Association of official analytical chemist official methods of analysis (2000) Washington. D.C.

Castro-Giráldez, M., Fito, P.J. \& Fito, P. (2010d). Nonequilibrium thermodynamic description to analyze the pork meat (Longissimus dorsi) salting process. Journal of Food Engineering, 99(1), 24-30.

Castro-Giráldez, M. Fito, P.J. \& Fito, P. (2010e). Nonlinear thermodynamic approach to analyze long time osmotic dehydration of parenchymatic apple tissue. Journal of Food Engineering, in press.

Demirel, Y. (2002). Chapter 1: Fundamentals of Equilibrium Thermodynamics, and Chapter 11: Thermodynamics and Biological Systems. In Y. Demirel (Ed.), Nonequilibrium Thermodynamics. 
Transport and Rate Processes in Physical Chemical and Biological Systems (pp. 1-52, and pp. 541-598). Elsevier Science \& Technology Books, USA.

Ferguson, I.B., (1980). Movement of mineral nutrients into the developing fruit of the kiwifruit (Actinidia chinensis Planch.). New Zealand Journal of Agricultural Research, 23, 349-353.

Ferrando, M. \& Spiess, W.E.L. (2001). Cellular response of plant tissue during the osmotic treatment with sucrose, maltose, and trehalose solutions. Journal of Food Engineering, 49,115-127.

Ferrando, M. \& Spiess, W.E.L. (2002). Transmembrane mass transfer in carrot protoplasts during osmotic treatment. Food Engineering and Physical Properties, 67(7), 2673-2680.

Ferrando, M. \& Spiess, W.E.L. (2003). Effect of osmotic stress on microstructure and mass transfer in onion and strawberry tissue. Journal of the Science of Food and Agriculture, 83, 951-959.

Fito, P., \& Chiralt, A. (1997). Osmotic dehydration: an approach to the modelling of solid food-liquid operations. In P. Fito, E. Ortega-Rodríguez, \& G. V. Barbosa-Cánovas (Eds.), Food engineering 2000 (pp. 231-252), Chapman \& Hall, New York

Gekas, V. (2001). Mass transfer modeling. Journal of Food Engineering, 49, 97-102.

Gerschenson, L.N., Rojas, A.M., Marangoni, A.G. (2001) Effects of processing on kiwi fruit dynamic rheological behavior and tissue structure. Food Research International, 34, 1-6.

Hallett, I.C., MacRae, E.A. \& Wegrzyn, T.F., (1992). Changes in kiwifruit cell wall ultrastructure and cell packing during postharvest ripening International Journal of Plant Science, 153, 4960.

Jackson, P.J. \& Harker, F.R., (1997). Changes in firmness of the outer pericarp, inner pericarp, and core of Actinidia species during ripening. New Zealand Journal of Crop and Horticultural Science, 25, 185-189.

Lide, D.R. (2004). Thermochemistry, Electrochemistry, and Kinetics. In D.R. Lide (Ed.), CRC Handbook of chemistry and physics, 84th edition (pp.5 100). Boca Raton, FL: CRC Press, USA.
MacRae, E.A., Lallu, A., Searle, A. \& Bowen, J.H. (1989a). Changes in the softening and composition of kiwi fruit affected by maturity at harvest and postharvest treatments. Journal of the Science of Food and Agriculture, 49, 413-440.

MacRae, E.A., Bowen, J.H. \& Stec, M.G.H. (1989b). Maturation of kiwifruit (Actinidia deliciosa $\mathrm{CV}$ Hayward) from two orchards: differences in composition of the tissue zones. Journal of the Science of Food and Agriculture, 47, 401-416.

Mavroudis, N.E., Gekas, V. \& Sjöholm, I. (1998). Osmotic dehydration of apple. Shrinkage phenomena and the significance of initial structure on mass transfer rates. Journal of Food Engineering, 38, 101-123.

Nicolis, G. \& Prigogine, I. (1977a). Self organization in non equilibrium systems from dissipative structures to order through fluctuations, John Wiley and Sons, Inc.

Nicolis, G. \& Prigogine, I. (1977b). Die erforschung des komplexen. auf dem weg $\mathrm{zu}$ einem neuen verständnis der naturwissenschaften, R. Piper GmbH and Co. KG. München.

Redgwell, R.J., Melton, L.D. \& Brasch, D.J., (1991). Cell-wall polysaccharides of kiwifruit (Actinidia deliciosa): effect of ripening on the structural features of cell-wall materials. Carbohydrate Research, 209, 191-202.

Redgwell, R.J., Melton, L.D. \& Brasch, D.J., (1992). Cell wall dissolution in ripening kiwifruit (Actinidia deliciosa): solubilisation of the pectic polymers. Plant Physiology. 98, 71-81.

Seguí, L., Fito, P.J., Albors, A. \& Fito, P. (2006). Mass transfer phenomena during the osmotic dehydration of kiwi isolated protoplasts (Malus domestica vas. Fuji). Journal of Food Engineering, 77(1), 179-187.

Starzak, M. \& Mathlouthi, M. (2006). Temperature dependence of water activity in aqueous solutions of sucrose. Food Chemistry, 96(3), 346-370. 


\title{
Application of microwaves dielectric spectroscopy for controlling osmotic dehydration of kiwifruit (Actinidia deliciosa cv Hayward)
}

\author{
M. Castro-Giráldez ${ }^{1}$, P.J. Fito ${ }^{*}$, M. Dalla Rosa 2 , P. Fito ${ }^{1}$ \\ 1 Instituto Universitario de Ingeniería de Alimentos para el Desarrollo, Universidad Politécnica de Valencia, Camino de Vera s/n, 46022 Valencia, Spain
} 2 Università degli Studi di Bologna, Facoltà di Agraria, Corso di Laurea in Scienze e Tecnologie Alimentari, Via Ravennate 1020, 47023 Cesena, Italy

ARTICLE INFO

Article history:

Received 1 September 2010

\section{Keywords:}

Osmotic dehydration

Dielectric spectroscopy

Dielectric properties

Microwaves

Kiwifruit

\begin{abstract}
A B S T R A C T
Dielectric spectroscopy studies have been performed on fresh and osmotically dehydrated kiwifruits (Actinidia deliciosa cv Hayward). The osmotic treatment consisted on immerse the samples into $65 \%(\mathrm{w} / \mathrm{w})$ sucrose aqueous solution at $30^{\circ} \mathrm{C}$ during different exposure times lasted from 5 to 1440 minutes. Some physical-chemical parameters were measured in fresh, treated and reposed $\left(24 \mathrm{~h}\right.$ at $\left.30^{\circ} \mathrm{C}\right)$ samples. Dielectric spectra were measured in the frequency range from $500 \mathrm{MHz}$ to $20 \mathrm{GHz}$ by an Agilent $85070 \mathrm{E}$ Open-ended Coaxial Probe connected to an Agilent E8362B Vector Network Analyzer in the fresh, treated and reposed samples. It has been demonstrated that the dielectric technique is a good method to control the osmotic treatment in kiwifruit by determining the variation of the different terms of the water chemical potential.
\end{abstract}

(c) 2010 Elsevier Ltd. All rights reserved.

\section{Introduction}

Currently, food industry is looking for nondestructive and accurate methods to control the quality of foodstuff. In this context, sensors based on microwaves play an important role because they fulfill all these requirements. This technique has been recently used to describe the salting operation in meat products (Castro-Giráldez et al., 2010a), to analyze the apple maturity process (Castro-Giráldez et al., 2010b) and to describe osmotic dehydration of apple (Castro-Giráldez et al., 2010c); in all the cases good results were obtained.

Dielectric spectroscopy determines the dielectric properties of a medium as a function of frequency. Complex permittivity $\left(\varepsilon^{*}\right)$ (Equation 1 ) is the dielectric property that describes food behaviour when is subjected under an electromagnetic field (Metaxas and Meredith, 1993; Nelson and Datta, 2001). The real part of complex permittivity is called the dielectric constant $\left(\varepsilon^{\prime}\right)$ and the imaginary part is called loss factor $\left(\varepsilon^{\prime \prime}\right)$. The dielectric constant is related with the material ability to store energy, and the dielectric loss factor is related to

*Corresponding author. Tel.: +34 963877369 E-mail address: pedfisu@tal.upv.es (P.J.Fito). the absorption and dissipation of the electromagnetic energy in other kinds of energy such as the termic one.

$$
\varepsilon^{*}=\varepsilon^{\prime}+i \varepsilon^{\prime \prime}
$$

(Equation 1)

Foods are heterogeneous material which contains water, organic molecules, macromolecules, ions, and insoluble matrix. In some foods, these constituents are highly organized in cellular and subcellular structures forming the macroscopic structure of tissues. Dielectric properties of food tissues will reflect the contribution of some polarizations at different levels (Gabriel, 2006). It includes basically four dispersions: $\alpha, \beta, \delta, \gamma$. In microwave region, the $\gamma$ - is the main dispersion. It is called orientation polarization, is located at $\mathrm{GHz}$ region, and it is due to the polarization of dipoles, fundamentally free water molecules (Metaxas and Meredith, 1993). It is also important to analyze the energy dissipation of these relaxation phenomena in terms of loss factor spectra. Loss factor can be expressed by the equation 2 , which reflects the different contribution phenomena to the loss factor spectrum in the frequency range of the present study. The relaxation frequency can be defined as the frequency at which the loss factor is 


\section{Nomenclature}

$a_{j} \quad$ activity of the chemical specie $j(-)$.

G Gibbs free energy, (J/mol).

Gj partial Gibbs molar free energy of the specie $\mathrm{j}$, (J/molj).

m mass (g)

Jj molar flux of the specie $\mathrm{j},\left(\mathrm{mol} / \mathrm{m}^{2} \mathrm{~s}\right)$.

Lj phenomenological coefficient of the specie $\mathrm{j},\left(\mathrm{mol}^{2} / \mathrm{s}\right.$ $\left.m^{2} J\right)$.

Mr molecular weight, $(\mathrm{g} / \mathrm{mol})$.

M Mass (g)

n Number of moles, $(\mathrm{mol})$

$\mathrm{P}$ absolute pressure (atm)

$\mathrm{R} \quad$ Ideal gases universal constant, $(\mathrm{J} / \mathrm{mol} \mathrm{K})$

S Surface area $\left(\mathrm{m}^{2}\right)$.

T Temperature, $\left({ }^{\circ} \mathrm{C}\right.$ or $\left.\mathrm{K}\right)$.

$\mathrm{t}$ Time, (s or min).

$\mathrm{V}$ Volume, $\left(\mathrm{m}^{3}\right)$.

$\mathrm{X} \quad$ Mass or molar fraction (-)
Molar fraction (-).

Mass or molar fraction of the liquid fraction $(-)$.

Dielectric constant $(-)$

Loss factor $(-)$

\section{Greek alphabet:}

$\mu \mathrm{j} \quad$ Chemical potential of the specie $\mathrm{j},(\mathrm{J} / \mathrm{mol})$

$\mu_{j}^{0} \quad$ Chemical potential of reference of the specie $\mathrm{j},(\mathrm{J} / \mathrm{mol})$

Specific volume (L/mol)

Variation of a variable.

\section{Subscript y superscript:}

Initial time

Time 24 hours after the treatment.

Liquid phase.

Maximum

sucrose

water maximum in a given dispersion. In this work, it represents the relaxation frequency in the range of the dipolar effect.

$$
\varepsilon^{\prime \prime}=\varepsilon_{d}^{\prime \prime}+\frac{\sigma}{\varepsilon_{0} \omega}
$$

(Equation 2)

where:

$\varepsilon_{\mathrm{d}}$ " represents the loss factor caused by the dipolar orientation or dipolar relaxation;

$\sigma / \varepsilon_{0} \omega$ represents the loss factor due to effect of ionic conductivity, where $\sigma, \varepsilon_{0}$ and $\omega$ are the conductivity of the material, the dielectric constant in vacuum and the angular frequency, respectively.

Osmotic dehydration is a preservation technique which consists in the immersion of foodstuffs in hypertonic solutions, giving rise to an important water flow out of the food into the solution and a simultaneous transfer of solute from the solution into the food (Salvatori et al., 1999). This technique is very common nowadays in the transformation, and conservation of alimentary products (Ferrando \& Spiess, 2001). The objective of this work is to analyze the viability of controlling kiwifruit (Actinidia Deliciosa cv Hayward) osmotic dehydration process by using dielectric properties measurements at microwaves frequencies.

\section{Material and Methods}

Sucrose solution $\left(65 \% \mathrm{w} / \mathrm{w}, 30^{\circ} \mathrm{C}\right)$, prepared with commercial sugar and distilled water, was used as an osmotic agent. Before the experiment, kiwi fruits (Actinidia deliciosa cv Hayward) with the same size and ripeness were bought from a local supermarket and kept refrigerated until use. The kiwifruits were cut with a calimeter in half slices (1 $\mathrm{cm}$ thickness) and the core was eliminated. There were prepared 45 samples which were immersed in a vessel containing the osmotic solution with continuous stirring. The relation between the fruit and the solution was of $1: 20(\mathrm{w} / \mathrm{w})$ to avoid changes in the solution during the process. The system was maintained at $30^{\circ} \mathrm{C}$ in a constanttemperature chamber. To prevent evaporation the vessel was covered with a sheet of plastic wrap.

Preliminary kinetic studies were done at the same working conditions in order to select the osmotic dehydration times. Osmotic dehydration was conducted over several time periods: $5,10,15,20$, $30,45,60,90,120,180,250,320,400,720,1440$ minutes. Three samples were used at each dehydration time.

After the treatment, the samples were reposed at $30^{\circ} \mathrm{C}$ for 24 hours, on Decagon containers, closed with parafilm $\AA$, in order to eliminate the concentration profiles in samples.

Mass, volume, surface water activity and dielectric properties were analyzed for each fresh, treated and reposed sample. Representative fresh samples and reposed samples were used to determine the initial moisture and sugar content ( $\left.{ }^{\circ} \mathrm{Brix}\right)$.

At each osmotic time, an aliquot of sucrose solution was also taken from the vessel. Water activity and oBrix of the solution were measured at each time.

Mass was determined by using a Mettler Toledo Balance $( \pm 0.0001)$ (Mettler-Toledo, Inc., U.S.A.).

Volume measurements were analysed by using a photographic treatment of the samples and the software Adobe Photoshop® (Adobe Systems Inc., San Jose, CA, U.S.A.) to get the diameter and the thickness of the samples. 
Surface water activity was measured in the structured samples with a dew point hygrometer Aqualab ${ }^{\circledR}$ series 3 TE (Decagon Devices, Inc., Washington, USA).

Moisture was determined by drying in a vacuum oven at $60^{\circ} \mathrm{C}$ till constant weight was reached (AOAC method 934.06 (2000)). Sugar content was determined in a refractometer (ABBE, ATAGO Model 3-T, Japan).

Analytical determinations described above were obtained by triplicate.

\section{Dielectric properties measurement.-}

The system used to measure dielectric properties consists on an Agilent 85070E Open-ended Coaxial Probe connected to an Agilent E8362B Vector Network Analyzer. The software of the Network Analyzer calculates the dielectric constant and loss factor as a reflected signal function. For these measurements the probe was fixed to a stainless steel support, and an elevation platform brings the sample near the probe to avoid possible phase changes due to cable movements after calibration.

The system was calibrated by using three different types of loads: air, short-circuit and $30^{\circ} \mathrm{C}$ Milli $囚-Q$ water. Once the calibration was made, $30^{\circ} \mathrm{C}$ Milli ${ }^{\circledR}$ $\mathrm{Q}$ water was measured again to check calibration suitability.

The dielectric properties were measured by attaching the probe to the surface of the samples. The Mean values of three replicates of kiwifruit samples are reported in this article. All determinations were made at $30^{\circ} \mathrm{C}$ from $500 \mathrm{MHz}$ to $20 \mathrm{GHz}$

\section{Results}

The osmotic dehydration operation with 65\% Brix solution produces compression and relaxation phenomena (Fito and Chiralt, 1997). These mechanisms could be observed by analyzing the mass and volume variation; these variations could be estimated by the following equations:

$$
\begin{aligned}
\Delta \mathrm{M} & =\frac{\mathrm{M}_{\mathrm{t}}-\mathrm{M}_{\mathrm{o}}}{\mathrm{M}_{\mathrm{o}}} \quad \text { (Equation 3) } \\
\Delta \mathrm{V} & =\frac{\mathrm{V}_{\mathrm{t}}-\mathrm{V}_{\mathrm{o}}}{\mathrm{V}_{\mathrm{o}}} \quad \text { (Equation 4) }
\end{aligned}
$$

where $\mathrm{M}$ represents the mass $(\mathrm{kg}), \mathrm{V}$ the volume $\left(\mathrm{m}^{3}\right)$, the subscripts $t$ represent the treatment time, being 0 the initial value.

Figure 1 shows the overall mass and volume variation through the osmotic treatment. In the figure, the decrease in total mass and volume is appreciated.

The water and solute fluxes promoted in the osmotic treatment can be calculated with the mass variation, the process time and the variation of the samples surface (Equations 5 and 6).

$$
\mathrm{J}_{\mathrm{w}}=\frac{-\Delta \mathrm{M}_{\mathrm{w}} \cdot \mathrm{M}_{\mathrm{o}}}{\Delta \mathrm{t} \cdot \mathrm{S} \cdot \mathrm{Mr}_{\mathrm{w}}}
$$

(Equation 5)

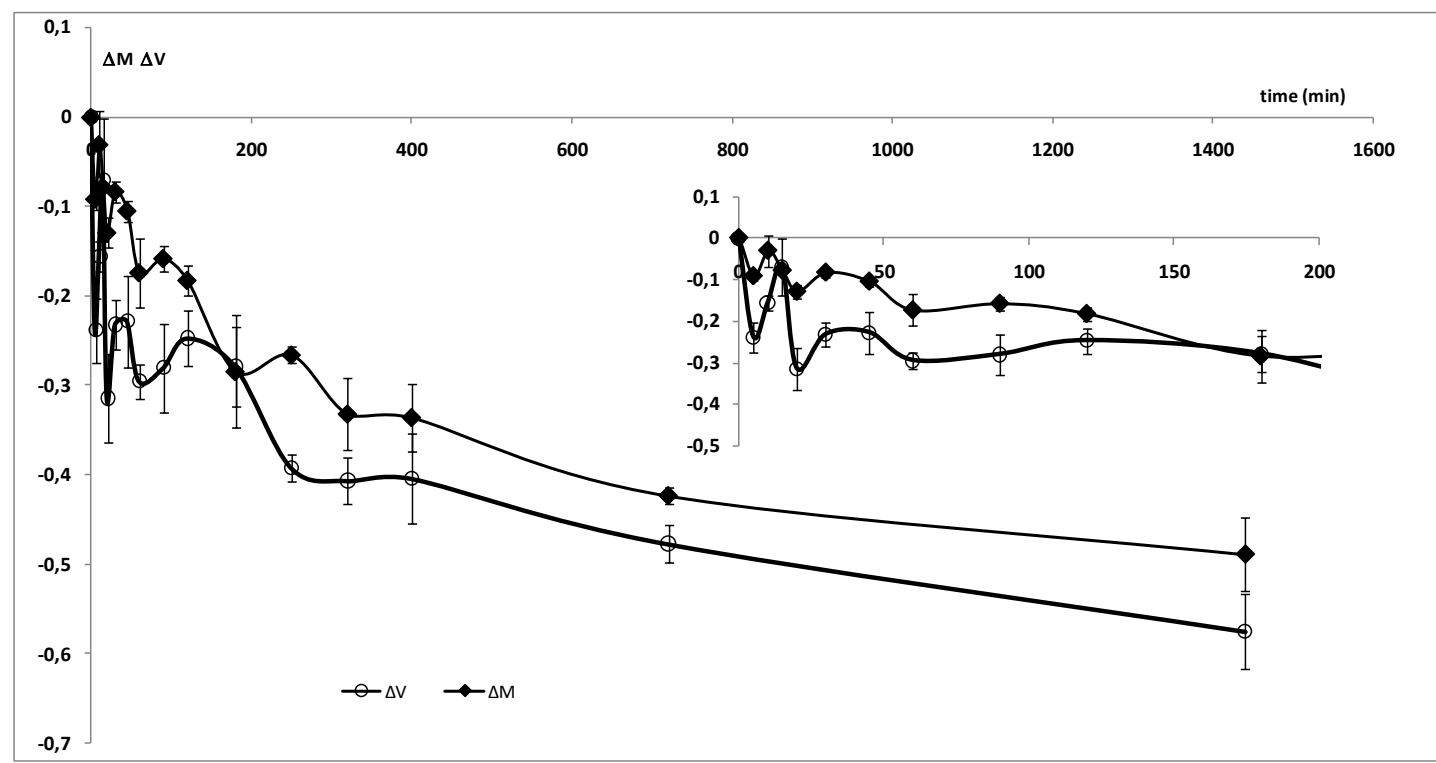

Figure 1. Evolution of overall mass

and volume (0) variation through the osmotic treatment. 


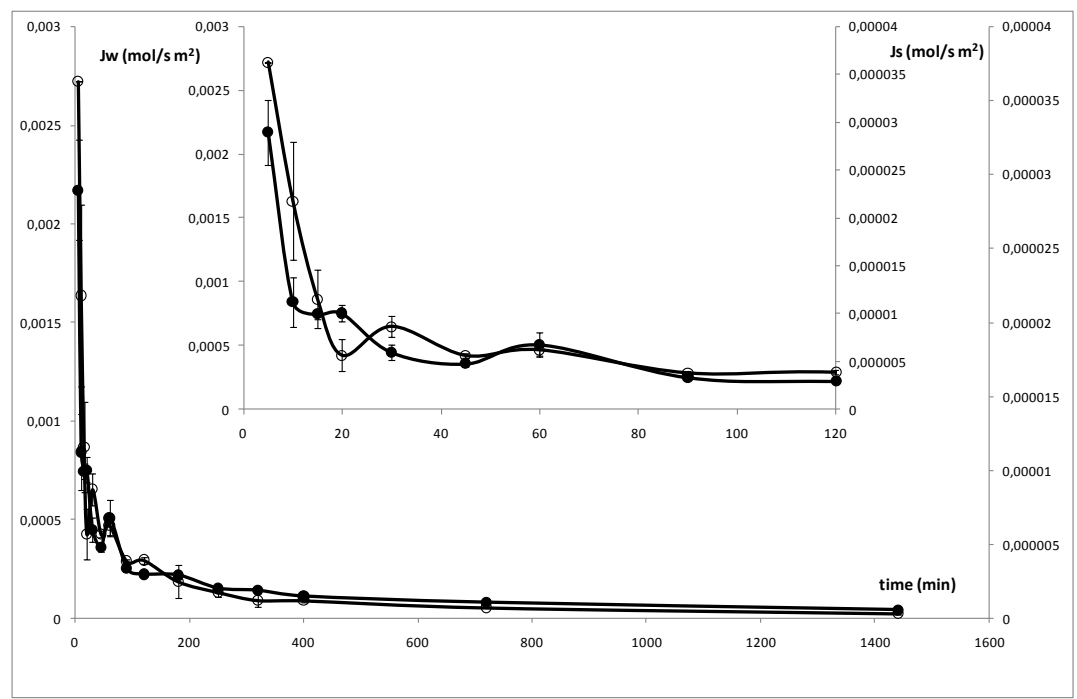

Figure 2. Variation of water $(\bullet)$ and sucrose $(\circ)$ fluxes versus time through the treatment.

$$
\mathrm{J}_{\mathrm{s}}=\frac{\Delta \mathrm{M}_{\mathrm{s}} \cdot M_{o}}{\Delta \mathrm{t} \cdot \mathrm{S} \cdot \mathrm{Mr}_{\mathrm{s}}} \quad(\text { Equation } 6)
$$

where $J_{w}$ is the water flux $\left(\mathrm{mol}_{\mathrm{w}} / \mathrm{s} \mathrm{m} \mathrm{m}^{2}\right), \mathrm{J}_{\mathrm{s}}$ is the sucrose flux $\left(\mathrm{mol}_{\mathrm{s}} / \mathrm{s} \mathrm{m}^{2}\right)$ during the treatment, $\mathrm{t}$ is the process time, $\mathrm{S}$ is the measured surface of the sample $\left(\mathrm{m}^{2}\right), \mathrm{Mr}_{\mathrm{w}}$ is the molecular weight of water (18 $\mathrm{g} / \mathrm{mol})$ and $\mathrm{Mr}_{\mathrm{s}}$ is the molecular weight of sucrose $(342 \mathrm{~g} / \mathrm{mol})$. It is possible to observe in figure 2 the flux of solutes and water through the osmotic treatment of kiwifruit.

In figure 3 , the spectra of fresh, treated samples and of the osmotic solution can be appreciated for the initial times (from 0 to 180 minutes of treatment). The osmotic treatment decreases the relaxation frequency and the spectra are decreasing in the dipolar losses zone as treatment progresses. In figure 4 , the spectra of the kiwifruit samples from 180 to 1440 minutes of treatment can be appreciated. It is possible to observe how the spectra are being flattened and getting closed to the osmotic solution. Moreover, the ionic losses of the spectra decrease drastically when increasing treatment times; this effect might be due to the fact that most of the native ionic compounds are lost during the osmotic treatment.

Figure 5 shows the dielectric loss factor spectra from fresh, treated and reposed samples at the beginning of the osmotic treatment. It is possible to observe how the loss factor in the dipolar dispersion region increases during the repose time. At longer times (Figure 6), this effect is not so marked and the spectra of treated and reposed samples are closer. This effect can be better appreciated in figure 7 . In figure 5 , it is possible to observe how the ionic losses decrease with the repose time at the beginning of the treatment; this effect can be explained because the tissue suffers relaxation phenomena during the repose, producing ionic compounds transport inside the sample. This effect will be better appreciated on figure 10. At longer treatment times, the kiwifruit native ionic compounds are lost, thus the loss factor at the lower frequencies of the spectra does not suffer important changes during the repose time.

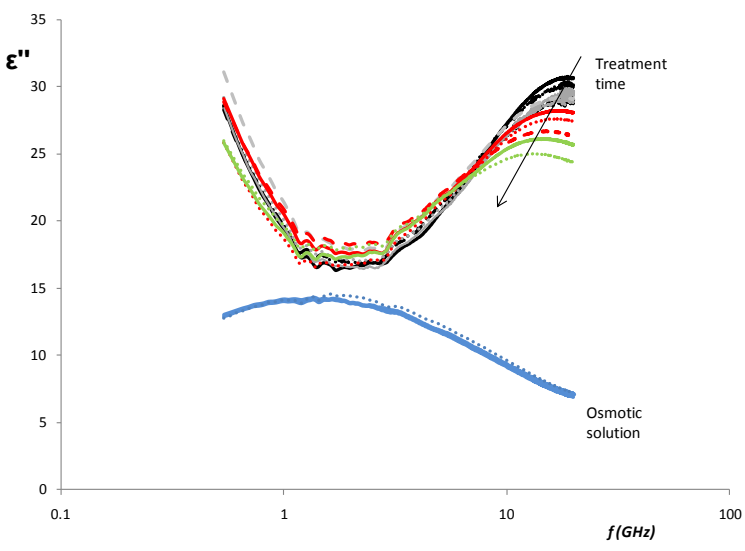

Figure 3. Dielectric loss factor spectra from fresh (-) and treated samples at different times of osmotic dehydration: $5 \min (. .),. 10 \min (---), 15 \min (-), 20$ $\min (\ldots), 30 \min (--), 45 \min (-)$, 60 min (....), 90 min (- - ), 120 min $(-), 180$ min (...), osmotic solution at $0 \mathrm{~min}(-)$, osmotic solution at $1440 \mathrm{~min}$ (....). 


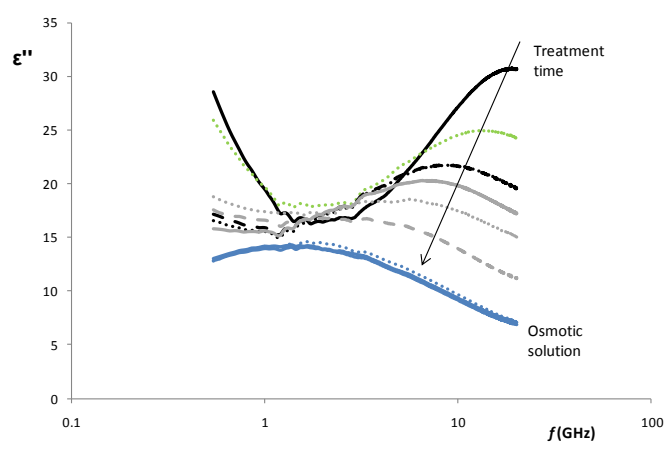

Figure 4. Dielectric loss factor spectra from fresh (-) and treated samples at different times of osmotic dehydration: a) $180 \mathrm{~min} \mathrm{( \ldots ),} 250 \mathrm{~min}(\ldots), 320 \mathrm{~min}(---), 400 \mathrm{~min}(-$ ), $720 \mathrm{~min}(\ldots .),. 1440 \mathrm{~min} \mathrm{(--)}$, osmotic solution at $0 \mathrm{~min}$ $(-)$,osmotic solution at $1440 \mathrm{~min}(\ldots .$.

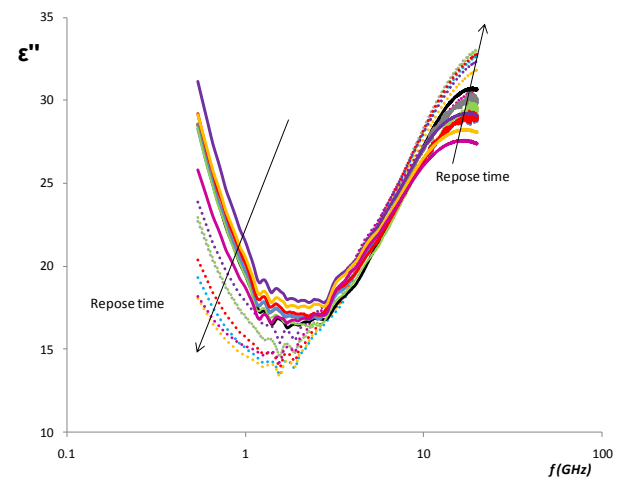

Figure 5. Dielectric loss factor spectra from fresh (black line), treated (continuous lines) and reposed (doted lines) samples at different times of osmotic dehydration: $5 \mathrm{~min}$ $(-), 10 \min (-), 15 \min (-), 20 \min (-), 30 \min (-), 45$ $\min (-), 60 \min (-)$.

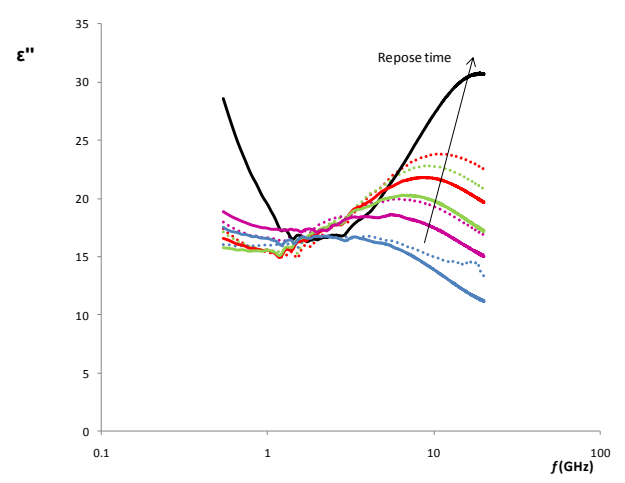

Figure 6. Dielectric loss factor spectra from fresh (black line), treated (continuous lines) and reposed (doted lines) samples at different times of osmotic dehydration: 250 $\min (-), 400 \min (-), 720 \min (-), 1440 \min (-)$.
Figure 7 shows the variation of the loss factor at relaxation frequency through the osmotic treatment for treated and reposed samples, where it is possible to observe two different ranges of variation; first one before 120 minutes, in which the loss factor increases through the repose time, thus the quantity of water molecules with induction capacity increases during the repose at the surface; at 120 minutes the loss factor remains constant during the repose time, noting that the amount of water molecules with induction capacity also remains constant. The following treatment times show minimum or neglected variations of loss factor during the repose.

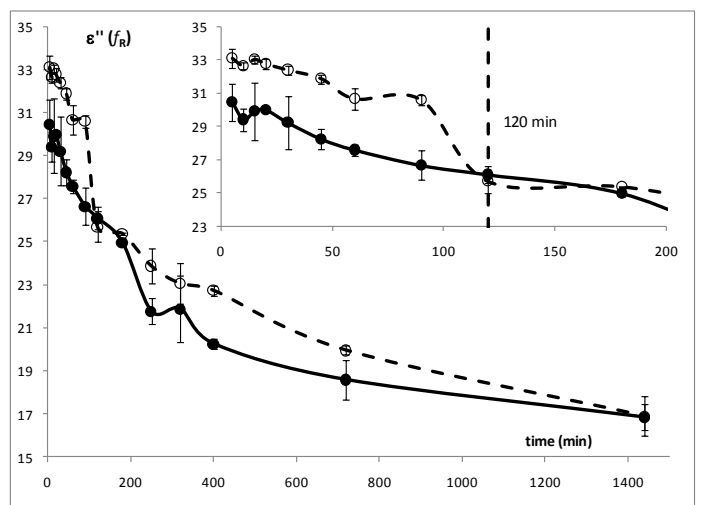

Figure 7. Loss factor variation at relaxation frequency through the process time in treated $(\bullet)$ and reposed $(O)$ samples.

In order to understand the phenomena that occur through the treatment and the repose time, it could be interesting to analyze the relationship between the moisture in dry matter and the surface water activity (Figure 8). This figure shows that the reposed samples maintain the same relationship surface water activity/moisture as the pure sucrose solution at different concentrations. Therefore, the water and sucrose concentration is homogeneous in the reposed samples, being negligible the concentration profiles through the tissue. On the other hand, the surface water activity of treated samples is lower than that of the reposed samples; it denotes concentration profiles in the kiwi tissue. Only in the last treatment time, the treated and the reposed values concur with the pure solution values; this fact denotes the disappearance of concentration profiles in the tissue due to the null diffusional transports.

Figure 9 shows the loss factor variation at relaxation frequency with regard to the surface water activity of treated and reposed samples. In this figure it is possible to appreciate a change of behaviour in the samples treated 120 minutes, 
where samples treated before this time show an increase in water activity proportional to the increase of loss factor (this variable represents the number of water molecules with mobility as was explained above). After $120 \mathrm{~min}$ of treatment, the samples suffer an increase in the surface water activity through the repose which is not related with a proportional increase in the loss factor at relaxation frequency (similar number of water molecules with capacity to rotate).

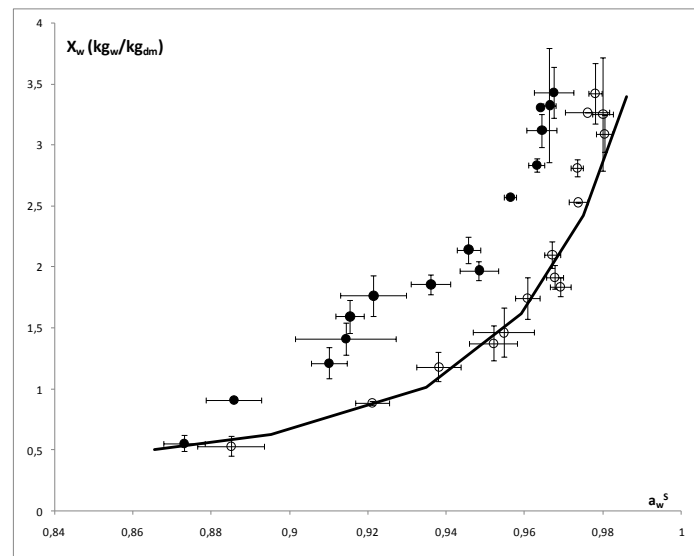

Figure 8. Moisture in dry matter versus surface water activity of treated $(\bigcirc)$ and reposed $(\bigcirc)$ samples and data from pure sucrose solutions $(-)$.

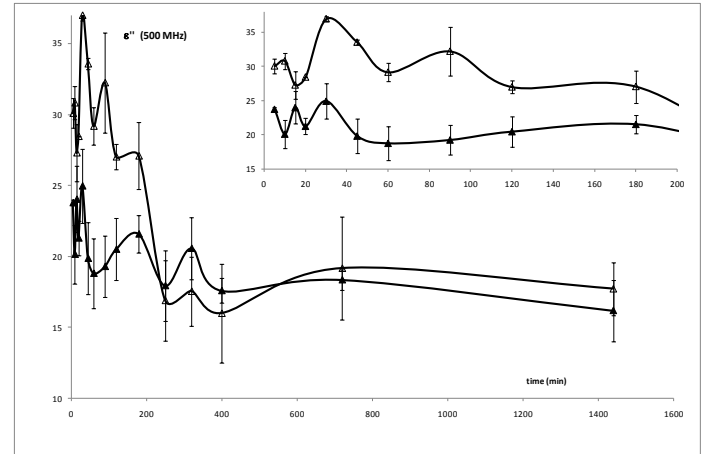

Figure 10. Loss factor ( $500 \mathrm{MHz}$ ) evolution through the treatment for treated $(\triangle)$ and reposed $(\boldsymbol{\Delta})$ samples.

Figure 10 shows the loss factor evolution for treated and reposed samples at $500 \mathrm{MHz}$, the effect of field in the matter at this frequency is the ionic conductivity, therefore high values in the loss factor are produced by ionic molecules with motion capacity, such as cations, organic acids, etc. This figure shows high values only at short times for the treated samples, and this effect disappears through the repose. In order to understand the ionic effect in the spectra, figure 11 shows the evolution of citric acid and potassium as the most important ionic compounds in kiwifruit. In shorts times, the variation of these two compounds are oscillating, this variation is induced by the volume variation (see figure 1). After 120 minutes of treatment, the signal at frequencies of ionic effect is reduced.

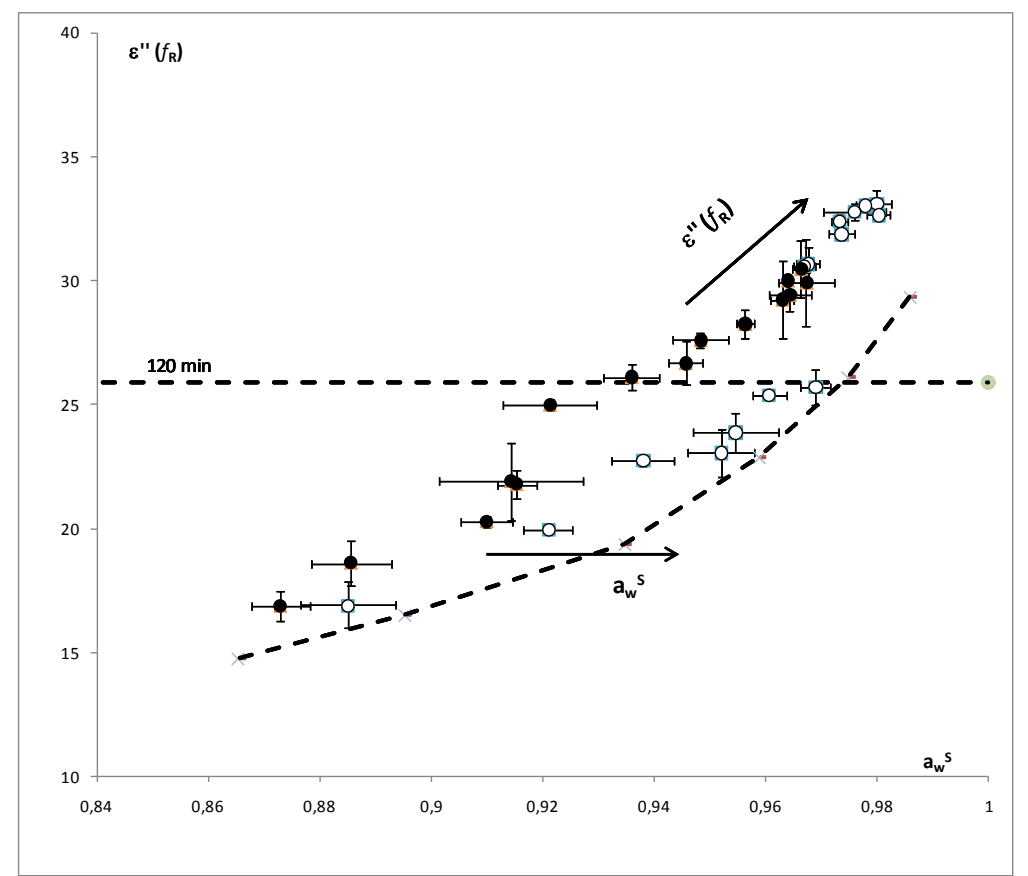

Figure 9. Loss factor variation versus surface water activity of treated $(\bullet)$ and reposed $(0)$ samples and data from sucrose solutions (- - -) obtained from Starzak \& Mathlouthi (2006). 


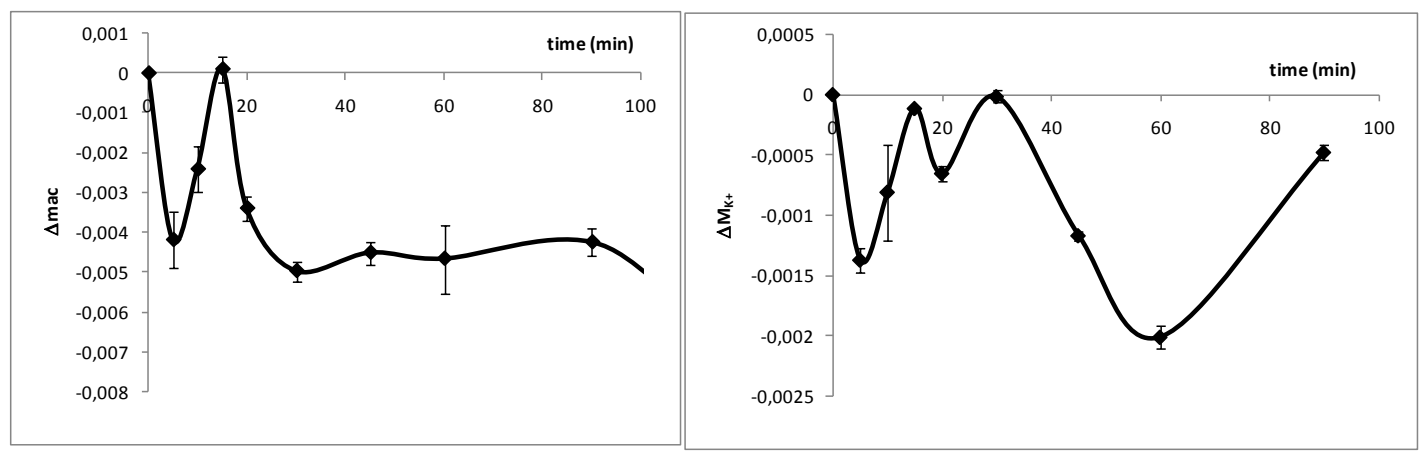

Figure 11. Mass variation of the most important ionic compounds through the treatment. Left figure represents the citric acid mass variation and right figure the potassium mass variation.

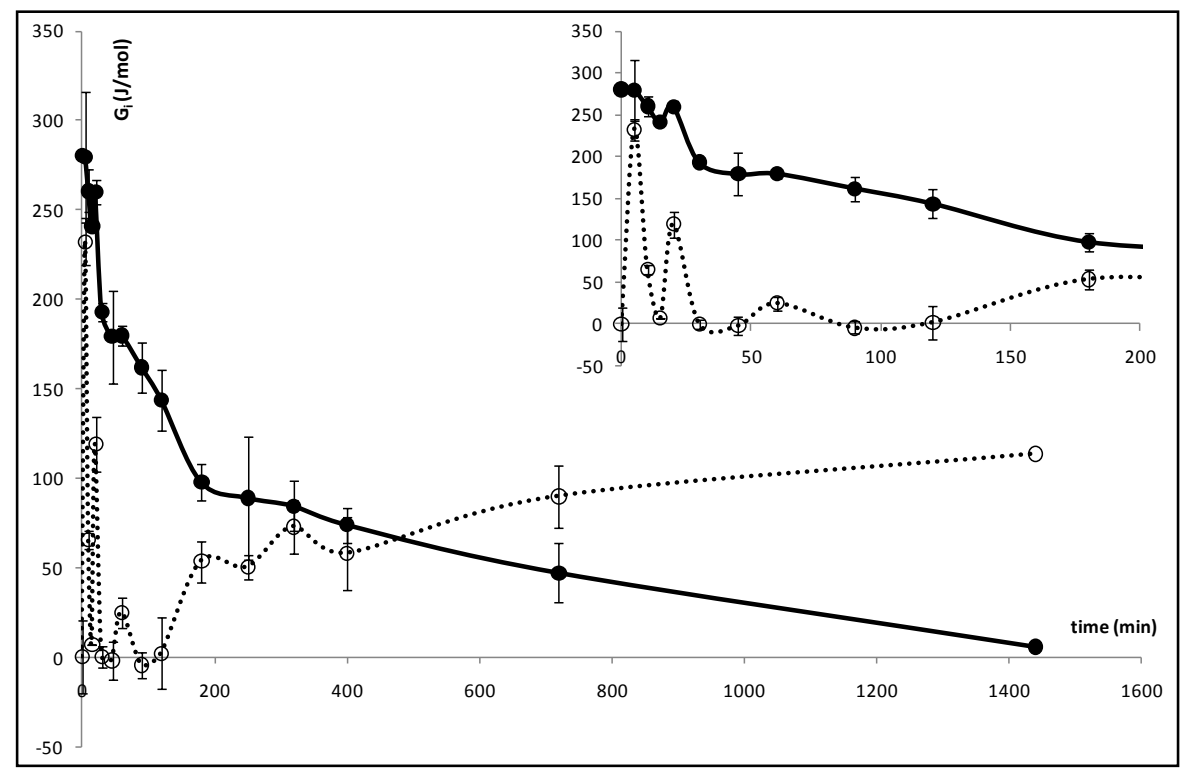

Figure 12. Activity terms $(\bullet)$ and mechanical terms $(\circ)$ from equation 7 through the treatment time.

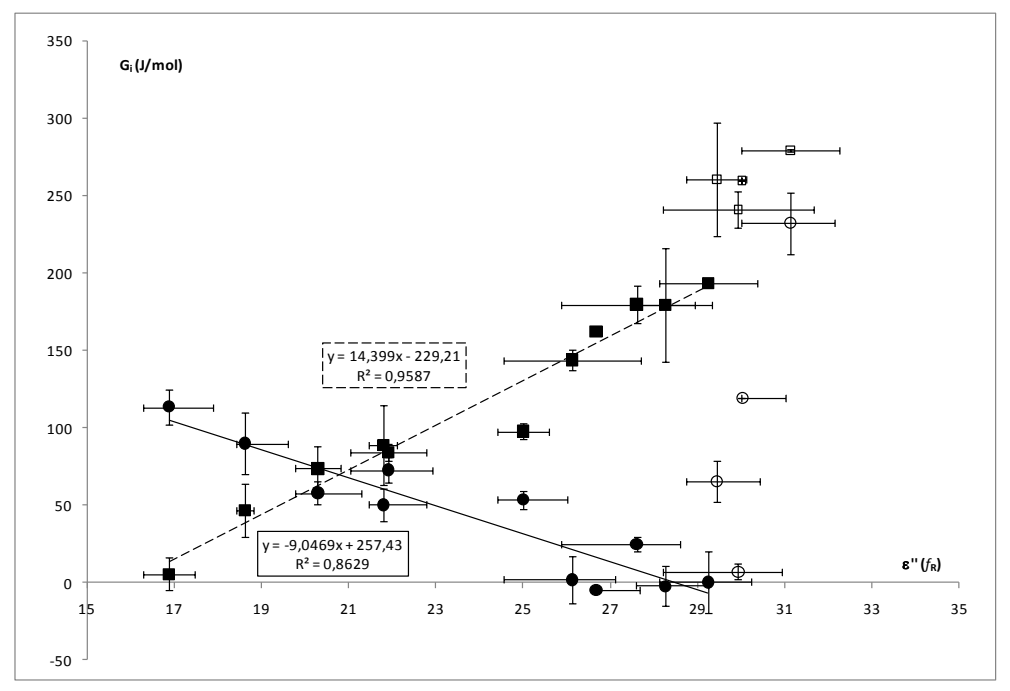

Figure 13. Variation of activity terms $(\boldsymbol{\bullet})$ and mechanical terms $(\bullet)$ from equation 7 with regard to the loss factor at relaxation frequency. 
Castro-Giráldez et al., (2010d) explained the apoplastic water transport driving forces through the kiwifruit surface in an osmotic treatment with sucrose as follows:

$$
\frac{\Delta G_{w}}{\Delta n_{w}}=\mathrm{R} T \ln \frac{a_{s}^{O S}}{a_{s}^{e}} \frac{\mathrm{J}_{\mathrm{s}}}{\mathrm{J}_{\mathrm{w}}}+\mathrm{R} T \operatorname{Ln} \frac{a_{w}^{O S}}{a_{w}^{e}}+v_{\mathrm{w}}^{-} \Delta \mathrm{P}+\overline{\mathrm{F}}_{\mathrm{w}} \Delta \mathrm{l}
$$

Where the transport driving forces were divided in two blocks, the first block is composed by compositional mechanisms (activity of the chemical species involved in mass transport) and the second block involves mechanical mechanisms. Figure 12 shows the mechanical and compositional mechanisms through the osmotic treatment. It is possible to appreciate how the activity terms are higher than the mechanical ones during the first 180 minutes of treatment; after 120 minutes, mechanical terms start being important while the activity terms decrease. In the last point, the activity terms are almost null, while the mechanical terms are the engine of the mass transport.

Figure 13 shows the variation of the different terms of the water chemical potential with regard to the loss factor at relaxation frequency, where it is possible to observe how the loss factor at relaxation frequency describes correctly the activity and mechanical terms after 20 minutes of treatment (full symbols). Therefore, after this treatment time, water molecules motion is the main factor of the variation of both terms. This means that in the activity term, the motion of water molecules affects not only to the water activity but also to the sucrose activity. On the other hand, it also shows that the water motion is the main engine for the mechanical energy liberation; this means that the expansion and contractions of the system are related with the water fluxes.

\section{Conclusions}

The variation of the loss factor at relaxation frequency through the osmotic treatment for treated and reposed samples shows two steps divided at critical time of $120 \mathrm{~min}$. Before 120 minutes, the loss factor increases through the repose time, thus the quantity of water molecules with induction capacity increases during the repose at the surface; at 120 minutes the loss factor remains constant during the repose time, noting that the amount of water molecules with induction capacity also remains constant.

Treated samples show ionic losses till $120 \mathrm{~min}$, explained by the most important ionic native compounds of kiwifruit; after that time, no ionic signal is appreciated because the native ionic compounds are lost during the osmotic treatment.

The variation of the different terms of the water chemical potential can be well described by the loss factor at relaxation frequency.
The dielectric technique is a good method to control the osmotic treatment in kiwifruit.

\section{References}

Castro-Giráldez, M., Fito, P.J. \& Fito, P. (2010a). Application of microwaves dielectric spectroscopy for controlling pork meat (Longissimus dorsi) salting process. Journal of Food Engineering, 97(4), 484-490.

Castro-Giráldez, M., Fito, P.J., Chenoll, C. \& Fito, P. (2010b). Development of a dielectric spectroscopy technique for the determination of Apple (Granny Smith) maturity. Innovative Food Science and Emerging Technologies, in press.

Castro-Giráldez, M., Fito, P.J. \& Fito, P. (2010c). Application of microwaves dielectric spectroscopy for controlling long time osmotic dehydration of parenchymatic apple tissue. Journal of Food Engineering, in press.

Castro-Giráldez, M., Fito, P.J., Tylewicz, U., Dalla Rosa, M. \& Fito, P. (2010d). Nonlinear thermodynamic and structural approach to analyze osmotic dehydration of kiwifruit (Actinidia deliciosa cV Hayward) at short treatment times. Journal of Food Engineering, artículo enviado.

Ferrando, M. \& Spiess, W.E.L. (2001). Cellular response of plant tissue during the osmotic treatment with sucrose, maltose, and trehalose solutions. Journal of Food Engineering, 49,115-127.

Fito, P., \& Chiralt, A. (1997). Osmotic dehydration: an approach to the modelling of solid food-liquid operations. In P. Fito, E. Ortega-Rodríguez, \& G. V. Barbosa-Cánovas (Eds.), Food engineering 2000 (pp. 231-252), Chapman \& Hall, New York.

Gabriel, C. (2006). Dielectric properties of biological materials. In F.S. Barnes, B. Greenebaum (Eds.), Bioengineering and biophysical aspects of electromagnetic fields, Handbook of biological effects of electromagnetic fields (pp. 51-100), CRC Press, Boca Raton, third edition, U.S.A.

Metaxas, A.C. \& Meredith, R.J. (1993). Industrial Microwave Heating. IEE Power Engineering series 4, Peter Peregrinus LTD, London, UK.

Nelson, S.O. \& Datta, A.K. (2001). Dielectric properties of Food Materials and Electric Field Interactions. In A.K. Datta, R.C. Anantheswaran (Eds), Handbook of Microwave Technology for Food Applications (pp. 69-114). Marcel Dekker, New York.

Salvatori, D., Andrés, A., Chiralt, A. \& Fito, P. (1999). Osmotic dehydration progression in apple tissue I: spatial distribution of solutes and moisture content. Journal of Food Engineering, 42(3), 125-135.

Starzak, M. \& Mathlouthi, M. (2006). Temperature dependence of water activity in aqueous solutions of sucrose. Food Chemistry, 96(3), 346-370. 
4.6. Patentes Intermacionales 



\section{PATENTE P200803559: PROCEDIMIENTO Y DISPOSITIVO PARA}

\section{LA DISCRIMINACIÓN DE ALIMENTOS}

Es objeto de esta invención un procedimiento de discriminación de alimentos que permite establecer si dichos alimentos verifican criterios de calidad preestablecidos. El procedimiento de discriminación requiere de un primer método de calibración tras el cual es posible llevar a cabo el procedimiento de discriminación sobre una pluralidad de alimentos, tales como los procedentes de una línea de producción. El método de calibrado aplica una radiación electromagnética al alimento a analizar. Esta radiación cubre un espectro muy amplio de frecuencias. Se analiza para cada frecuencia la respuesta dieléctrica y se establecen valores discretos de la frecuencia para los cuales la respuesta dieléctrica es un valor que varía con las propiedades determinantes de la calidad del alimento. Estos valores son los utilizados con una correlación adecuada para posteriormente llevar a cabo la discriminación.

Pub. No. WO/2010/066918 International Application No.: PCT/ES2009/000561 Publication Date: $\quad$ 17.06.2010 International Filing Date: $\quad$ 07.12.2009

IPC:

G01D 18/00 (2006.01)

Applicants:

\section{UNIVERSIDAD POLITECNICA DE VALENCIA}

FITO MAUPOEY, Pedro [ES/ES]; (ES) (US Only). FITO SUÑER, Pedro José [ES/ES]; (ES) (US Only). CASTRO GIRALDEZ, Marta [ES/ES]; (ES) (US Only). TOLDRA VILARDELL, Fidel [ES/ES]; (ES) (US Only).

Inventors: FITO MAUPOEY, Pedro; (ES). FITO SUÑER, Pedro José; (ES). CASTRO GIRALDEZ, Marta; (ES). TOLDRA VILARDELL, Fidel; (ES).

Priority Data: P200803559

09.12 .2008 ES

Title:

(EN) METHOD AND DEVICE FOR THE DISCRIMINATION OF FOOD PRODUCTS

(ES) PROCEDIMIENTO Y DISPOSITIVO PARA LA DISCRIMINACIÓN DE ALIMENTOS

Designated States: AE, AG, AL, AM, AO, AT, AU, AZ, BA, BB, BG, BH, $\mathrm{BR}, \mathrm{BW}, \mathrm{BY}, \mathrm{BZ}, \mathrm{CA}, \mathrm{CH}, \mathrm{CL}, \mathrm{CN}, \mathrm{CO}, \mathrm{CR}, \mathrm{CU}, \mathrm{CZ}, \mathrm{DE}$, DK, DM, DO, DZ, EC, EE, EG, ES, FI, GB, GD, GE, GH, GM, GT, HN, HR, HU, ID, IL, IN, IS, JP, KE, KG, KM, KN, KP, KR, KZ, LA, LC, LK, LR, LS, LT, LU, LY, MA, MD, ME, MG, MK, MN, MW, MX, MY, MZ, NA, NG, NI, NO, NZ, OM, PE, PG, PH, PL, PT, RO, RS, RU, SC, SD, SE, SG, SK, SL, SM, ST, SV, SY, TJ, TM, TN, TR, 
T'T, TZ, UA, UG, US, UZ, VC, VN, ZA, ZM, ZW.

African Regional Intellectual Property Org. (ARIPO) (BW, GH, GM, KE, LS, MW, MZ, NA, SD, SL, SZ, TZ, UG, ZM, ZW)

Eurasian Patent Organization (EAPO) (AM, AZ, BY, KG, $\mathrm{KZ}, \mathrm{MD}, \mathrm{RU}, \mathrm{TJ}, \mathrm{TM})$

European Patent Office (EPO) (AT, BE, BG, CH, CY, CZ, DE, DK, EE, ES, FI, FR, GB, GR, HR, HU, IE, IS, IT, LT, LU, LV, MC, MK, MT, NL, NO, PL, PT, RO, SE, SI, SK, SM, TR)

African Intellectual Property Organization (OAPI) (BF, BJ, CF, CG, CI, CM, GA, GN, GQ, GW, ML, MR, NE, SN, TD, TG). 
PATENTE P201000024: MÉTODO DE DISCRIMINACIÓN DE PIEZAS DE FRUTA SEGÚN SU GRADO DE MADUREZ, PROCEDIMIENTO DE CALIBRACIÓN DE DICHO MÉTODO Y DISPOSITIVO QUE LLEVA A CABO DICHA DISCRIMINACIÓN

La presente invención consiste en un método que permite discriminar piezas de fruta según su grado de madurez, por ejemplo para poder llevar a cabo un método de discriminación en procesos continuos de clasificación de frutos recolectados, mediante técnicas de espectroscopia dieléctrica y que no requiere la destrucción del producto. La invención consiste en realizar dos medidas del factor de pérdidas donde cada una de las medidas se lleva a cabo en un rango de frecuencias distinto para establecer en base a ambas medidas el grado de madurez de las piezas de fruta. Es también objeto de la invención el procedimiento de calibración de dicho método. 

5. Difusion y protección de los Resultados 



\section{Patentes}

Fito, P., Castro-Giráldez, M., Fito, P.J., Toldrá, F., (2009). Patente Nacional: "Procedimiento y dispositivo para la discriminación de alimentos", $\mathrm{n}^{\circ}$ Solicitud: P200803559 EN PUBLICACIÓN/PROMOCIÓN

Fito, P.J., Castro-Giráldez, M., Fito, P., Chenoll, C. (2010). Patente Nacional: "Medida no destructiva de la calidad y grado de madurez de la fruta a partir de su respuesta frecuencial", no Solicitud: P201000024 SOLICITUD DE PATENTE NACIONAL

Capítulos de libro

De los Reyes, R., Castro-Giráldez, M., Fito, P. \& De los Reyes, E. (2007). "Application of microwaves for in-line quality assessment". En Advances in Food Diagnostics (pp. 49-80). Editores: Leo ML Nollet y Fidel Toldrá. Blackwell Publishing, Iowa (EEUU). ISBN: 978-0-8138-2221-1.

$>$ Fito, P., De los Reyes, E., De los Reyes, R. \& Castro-Giráldez, M. (2007). “Aplicaciones de las microondas en alimentos". En Aplicaciones de tecnologías emergentes de procesado minimo en el sector pesquero (pp. 9-26). Editado por el Centro Tecnológico del Mar, Fundación CETMAR, España. ISBN: 978-84-611-4804-2.

> Ripoll, E., Chenoll, C., Castro-Giráldez, M. \& Fito, P.J. (2008). “Estudio de la influencia de la estructura en el análisis de las propiedades dieléctricas en manzana "Granny Smith" como método de control en línea no destructivo". I Jornada Cátedra Fomesa, España. ISBN: 978-84-691-7961-1, nº registro: 081107631.

$>$ Castro-Giráldez, M., Fito, P.J., Toldrá, F. \& Fito, P. (2009). "Physical sensors and techniques". En Handbook of Processed Meats and Poultry Analysis (pp. 7-34), Editores: Leo ML Nollet y Fidel Toldrá, Boca Raton, FL: CRC Press, E.E.U.U. ISBN: 978-1-4200-4531-4.

> Castro-Giráldez, M, Fito, P.J., Toldrá, F. \& Fito, P. (2010). "Physical sensors for quality control during processing”. En Handbook of Meat Processing (pp. 443-456), Editor: Fidel Toldrá, Wiley-Blackwell Publishing, E.E.U.U. ISBN: 978-0-81382182-5. 
Castro-Giráldez, M., Botella, P., Toldrá, F. \& Fito, P. (2010). Low-frequency dielectric spectrum to determine pork meat quality. Innovative Food Science and Emerging Technologies, 11(2), 376-386.

$>$ Castro-Giráldez, M., Fito, P.J. \& Fito, P. (2010). Application of microwaves dielectric spectroscopy for controlling pork meat (Longissimus dorsi) salting process. Journal of Food Engineering, 97(4), 484-490.

$>$ Castro-Giráldez, M., Fito, P.J. \& Fito, P. (2010). Non-equilibrium thermodynamic description to analyze the pork meat (Longissimus dorsi) salting process. Journal of Food Engineering, 99(1), 24-30.

$>$ Castro-Giráldez, M., Fito, P.J., Toldrá, F. \& Fito, P. (2010). Use of visible spectroscopy to assess color development during ageing of fresh pork from different quality classes. International Journal of Food Science and Technology, 45(8), 17101716.

$>$ Castro-Giráldez, M., Fito, P.J., Chenoll, C. \& Fito, P. (2010). Development of a dielectric spectroscopy technique for determining key chemical components of apple maturity. Journal of Agricultural and Food Chemistry, 58, 3761-3766.

> Castro-Giráldez, M., Fito, P.J., Chenoll, C. \& Fito, P. (2010). Development of a dielectric spectroscopy technique for the determination of Apple (Granny Smith) maturity. Innovative Food Science and Emerging Technologies, artículo aceptado, in press.

Castro-Giráldez, M., Fito, P.J. \& Fito, P. (2010). Nonlinear thermodynamic approach to analyze long time osmotic dehydration of parenchymatic apple tissue. Journal of Food Engineering, artículo aceptado, in press.

> Castro-Giráldez, M., Aristoy, M.C., Toldrá, F. \& Fito, P. (2010). Microwave dielectric spectroscopy for the determination of pork meat quality. Food Research International, artículo aceptado, in press.

Castro-Giráldez, M., Fito, P.J. \& Fito, P. (2010). Application of microwaves dielectric spectroscopy for controlling long time osmotic dehydration of parenchymatic apple tissue. Journal of Food Engineering, artículo aceptado, in press.

$>$ Castro-Giráldez, M., Toldrá, F. \& Fito, P. (2010). Low frequency dielectric measurements for evaluating the extent of postmortem ageing of pork meat. LWTFood Science and Technology, artículo enviado. 
Castro-Giráldez, M., Dols, L., Toldrá, F. \& Fito, P. (2010). Development of a dielectric spectroscopy technique for the determination of key biochemical markers of meat quality. Food Chemistry, artículo enviado.

> Castro-Giráldez, M., Fito, P.J., Tylewicz, U., Dalla Rosa, M., Fito, P. (2010). Nonlinear thermodynamic and structural approach to analyze osmotic dehydration of kiwifruit (Actinidia deliciosa cv Hayward) at short treatment times. Journal of Food Engineering, artículo enviado.

$>$ Castro-Giráldez, M., Fito, P.J., Dalla Rosa, M., Fito, P. (2010). Application of microwaves dielectric spectroscopy for controlling osmotic dehydration of kiwifruit (Actinidia deliciosa cv Hayward). Journal of Food Engineering, artículo enviado.

> Tylewicz, U., Fito, P.J., Castro-Giráldez, M., Fito, P., Dalla Rosa, M., (2010). Relationship among water, sucrose and cell structure of kiwifruit (Actinidia deliciosa cv Hayward) during the osmotic dehydration. Journal of Food Engineering, artículo enviado.

\section{Participación en Conferencias y Congresos}

Castro-Giráldez, M., Fito, P., De los Reyes, R. \& De los Reyes, E. (2006). "Dielectric spectroscopy studies of commercial york ham". Tipo de participación: Artículo del libro de resúmenes del $40^{\text {th }}$ Annual International Microwave Symposium, Boston, Massachussets, E.E.U.U.

Castro-Giráldez, M., De los Reyes, R., Barat, J.M., Fito, P. \& De los Reyes, E. (2006). "Dielectric spectroscopy studies of "salted porcine meat-water" systems at different salting stages". Tipo de participación: Artículo del libro de resúmenes del $40^{\text {th }}$ Annual International Microwave Symposium, Boston, Massachussets, E.E.U.U.

Castro-Giráldez, M., Fito, P., De los Reyes, R. \& De los Reyes, E. (2006). "Dielectric spectroscopy studies of Longissimus Dorsi pork samples". Tipo de participación: Póster, en el congreso Sustainability of the AGRI-FOOD Chain (EFFOST 2006), la Haya, Holanda. 
> Castro-Giráldez, M., Fito, P.J., Chenoll, C., Toldrá, F. \& Fito, P. (2007). "Dielectric spectroscopy studies to control meat salting processes". Tipo de participación: Póster, en el congreso FOOD - NEW OPTIONS FOR THE INDUSTRY (EFFOST 2007), Lisboa, Portugal.

> Castro-Giráldez, M., Fito, P.J., Chenoll, C. \& Fito, P. (2007). "Analysis of osmodehydration kinetics by dielectric spectroscopy throughout the candying process of apple". Tipo de participación: Póster, en el congreso FOOD - NEW OPTIONS FOR THE INDUSTRY (EFFOST 2007), Lisboa, Portugal.

> Castro-Giráldez, M., Chenoll, C., Fito, P.J., Toldrá, F. \& Fito, P. (2007). "Analysis of water- $\mathrm{NaCl}$-solid matrix relationships in pork meat by dielectric spectroscopy. New approach to develop salted meat isotherms". Tipo de participación: Póster, en el congreso FOOD - NEW OPTIONS FOR THE INDUSTRY (EFFOST 2007), Lisboa, Portugal.

> Castro-Giráldez, M., Fito, P., Toldrá, F. (2007). "Dielectric spectroscopy studies as a tool for quality control in meat industry". Tipo de participación: Póster, en el congreso FOOD - NEW OPTIONS FOR THE INDUSTRY (EFFOST 2007), Lisboa, Portugal.

$>$ Castro-Giráldez, M., Chenoll, C., Fito, P.J. \& Fito, P. (2007). "Use of dielectric spectroscopy to the development of candying apple "Granny Smith" Isotherms". Tipo de participación: Póster, en el congreso FOOD - NEW OPTIONS FOR THE INDUSTRY (EFFOST 2007), Lisboa, Portugal.

$>$ Ripoll, E., Chenoll, C., Castro-Giráldez, M. \& Fito, P.J. (2008). “Estudio de la influencia de la estructura en el análisis de las propiedades dieléctricas en manzana "Granny Smith" como método de control en línea no destructivo". Presentación oral, I Jornada Cátedra Fomesa, Valencia, España.

$>$ Castro-Giráldez, M., Chenoll, C., Fito, P.J \& Fito, P. (2009). "Development of a dielectric spectroscopy technique for the determination of apple (Granny Smith) maturity". Presentación Oral, en el congreso "International Microwave Power Institute's $43^{\text {rd }}$ Annual Symposium”, Washington D.C., E.E.U.U.

$>$ Castro-Giráldez, M., Fito, P.J., Chenoll,C. \& Fito, P. (2009). "Use of the dielectric spectroscopy to control the pork meat (longissimus dorsi) salting process". Presentación Oral, en el congreso “International Microwave Power Institute's $43^{\text {rd }}$ Annual Symposium”, Washington D.C., E.E.U.U. 
Fito, P.J., Castro-Giráldez, M., Chenoll,C., Visquert, M., Domenech, E., Escriche, I. \& Fito, P. (2009). "Use of the dielectric spectroscopy to control the sugars vitreous formation in azahar honey". Presentación Oral, en el congreso “International Microwave Power Institute's $43^{\text {rd }}$ Annual Symposium”, Washington D.C., E.E.U.U.

$>$ Chenoll, C., Castro-Giráldez, M., Fito, P.J \& Fito, P. (2009). "Analysis of candied "Granny Smith" apple isotherms by using dielectric spectroscopy". Presentación Oral, en el congreso "International Microwave Power Institute's $43^{\text {rd }}$ Annual Symposium”, Washington D.C., E.E.U.U.

$>$ Chenoll, C., Castro-Giráldez, M., Fito, P.J \& Fito, P. (2009). "Analysis of cured ham by dielectric spectroscopy". Presentación Oral, en el congreso “International Microwave Power Institute's 43 ${ }^{\text {rd }}$ Annual Symposium”, Washington D.C., E.E.U.U.

$>$ Castro-Giráldez M., Fito P.J., Chenoll, C. \& Fito P. (2009). "New technique to obtain salted meat isotherms by using dielectric spectroscopy". Tipo de participación: Póster, en el congreso "IDMRCS: 6th International Discussion Meeting on Relaxations in Complex Systems", Roma, Italia.

Castro-Giráldez M., Fito P.J. \& Fito P. (2009). "New dielectric and thermodynamic approach to analyze the osmotic dehydration of Apple" ". Tipo de participación: Póster, en el congreso "IDMRCS: 6th International Discussion Meeting on Relaxations in Complex Systems”, Roma, Italia.

\section{Trabajos Final de Carrera}

Marques, M. (2007). Analysis of the osmotic dehydration of Apple "Granny Smith" by dielectric spectroscopy and "SAFES" methodology, Universidad Politécnica de Valencia, Valencia (España). NOTA: 8.

Gómez, D. (2007). Análisis de la cinética de escarchado de manzana "Granny Smith" mediante la utilización de espectros dieléctricos, Universidad Politécnica de Valencia, Valencia (España). NOTA: 10 (Matrícula de Honor). Premio de la escuela de Ingenieros Agrónomos. 
Dols, L. (2008). Estudio de los espectros dieléctricos del lomo de cerdo y su relación con los parámetros de calidad de la carne, Universidad Politécnica de Valencia (España). NOTA: 10 (Matrícula de Honor).

$>$ Botella, P. (2008). Estudio de los espectros dieléctricos del lomo de cerdo (longissimus dorsi) durante el proceso de maduración. Relación con algunos parámetros de calidad, Universidad Politécnica de Valencia, Valencia (España). NOTA: 10 (Matrícula de Honor). Premio de la escuela de Ingenieros Agrónomos.

> Martínez, R. (2008). Análisis de la relación agua-sacarosa-matriz en escarchado de manzana "Granny Smith" mediante el estudio de espectros dieléctricos, Universidad Politécnica de Valencia (España). NOTA: 10 (Matrícula de Honor).

González, V. (2008). Análisis de las relaciones agua-NaCl-matriz sólida en lomo de cerdo mediante la utilización de espectros dieléctricos, Universidad Politécnica de Valencia (España). NOTA: 10 (Matrícula de Honor).

\section{Tesinas de Máster}

Ripoll, E. (2008). Estudio de la influencia de la estructura en el análisis de las propiedades dieléctricas en manzana "Granny Smith" como método de control en línea no destructivo. Tesina del máster en Ciencia e Ingeniería de los Alimentos, Especialidad en Ingeniería de Procesos y Productos, Instituto de Ingeniería de Alimentos para el Desarrollo, Universidad Politécnica de Valencia (España).

Ripoll, E. (2009). Estudio de las propiedades dieléctricas de la miel de Azahar como método de control de los tratamientos térmicos. Tesina del máster en Gestión y Seguridad Alimentaria, Instituto de Ingeniería de Alimentos para el Desarrollo, Universidad Politécnica de Valencia (España). 
6. Conclusiones generales 

1. El estudio y análisis de diferentes concentraciones de algunos componentes clave en las transformaciones bioquímicas que se producen en el músculo durante su conversión en carne, llevados a cabo mediante la preparación de disoluciones patrón, permitieron obtener buenas correlaciones entre el contenido en ácido láctico, ATP e IMP y el factor de pérdidas a las frecuencias puntuales de 0.5, 0.915 y $1 \mathrm{GHz}$. Se necesitan más estudios en este campo para poder aplicar esta metodología porque, aunque los espectros dieléctricos están directamente relacionados con algunos componentes de la bioquímica postmortem de la carne, existen algunas dificultades para obtener información clara para cada uno de ellos individualmente ya que su contribución al espectro suele coincidir en el mismo rango de frecuencias. En cualquier caso, este trabajo proporciona una buena evidencia de que los espectros dieléctricos ofrecen información relevante sobre la evolución de algunos componentes fundamentales en la bioquímica postmortem de la carne.

2. Los resultados del estudio realizado mediante espectroscopia visible (400$700 \mathrm{~nm})$ concluyeron que el espectro del visible está influenciado por el tiempo de maduración de los lomos en muestras PSE y RFN, mientras que el espectro visible de las muestras DFD no muestra variación con el tiempo postmortem. Además, se observó un mayor "blooming" en las muestras RFN a los 7 días postmortem que durante las 48 horas posteriores al sacrificio. Este fenómeno se vio reflejado mediante un contenido significativamente mayor $(\mathrm{P}<0.05)$ de oximioglobina, de las coordenadas $\mathrm{L}^{*}$, $a^{*}$ y b*, así como por un contenido significativamente menor $(\mathrm{P}<0.05)$ de desoximioglobina y del tono a los 7 días postmortem. Por lo tanto, el proceso de maduración de la carne afecta positivamente al color de las muestras RFN. Además, los resultados de este estudio mostraron que la espectroscopia visible tan sólo permite discriminar muestras PSE durante las 24 horas posteriores al sacrificio, no siendo una técnica útil para discriminar carnes DFD tal y como han concluido en estudios previos otros autores. 
3. Los espectros dieléctricos $(500 \mathrm{MHz}-20 \mathrm{GHz})$ de muestras de carne mostraron diferencias entre los tres tipos de calidades estudiadas: PSE, DFD y RFN. Estas diferencias fueron significativas a diferentes frecuencias en diferentes tiempos postmortem. Las diferencias se atribuyeron a los diferentes metabolismos de las diferentes clases de carne.

Los resultados obtenidos en este estudio permitieron confirmar la viabilidad de desarrollar un equipo industrial para evaluar la calidad de los lomos de cerdo durante las primeras horas postmortem.

4. A partir de los resultados del estudio realizado mediante espectroscopia dieléctrica a bajas frecuencias $(100 \mathrm{~Hz}$ to $0.4 \mathrm{MHz})$ se desarrollaron dos Índices ("Ageing Indexes") basados en diferentes frecuencias del espectro para determinar el grado de frescura de la carne y se demostró su eficacia y su relación con los tradicionales indicadores del envejecimiento en carne como son el valor $\mathrm{K}$, el contenido en aminoácidos libres, así como su relación con algunos parámetros de textura de la carne.

Las medidas dieléctricas $(100 \mathrm{~Hz}$ to $0.4 \mathrm{MHz})$ mostraron anisotropía en la permitividad así como en la conductividad de las muestras PSE y RFN. La dispersión $\alpha$ es mayor cuando las medidas se realizan en la dirección de las fibras, mientras que el efecto Maxwell-Wagner es mayor cuando las medidas se realizan en perpendicular a la dirección de las fibras. La anisotropía de las muestras se reduce con el tiempo postmortem en las muestras RFN y PSE. Se observó menos anisotropía en las muestras DFD.

Las diferencias más significativas $(\mathrm{p}<0.05)$ entre la constante dieléctrica y el factor de pérdidas de las diferentes clases de lomo de cerdo estudiadas se observaron a las 24 y a las 48 horas postmortem. De este modo se puede concluir que el uso de los espectros dieléctricos $(100 \mathrm{~Hz}$ to $0.4 \mathrm{MHz})$ para detectar carnes de baja calidad es más fiable tras 24 horas postmortem. Los resultados de esta investigación son prometedores y se ha demostrado que algunas frecuencias puntuales $(140 \mathrm{~Hz}, 500 \mathrm{~Hz}$ and $300 \mathrm{kHz})$ pueden resultar útiles para discriminar carnes de baja calidad. El siguiente paso en este estudio es el desarrollo de un prototipo para la realización de 
aplicaciones industriales basado en las frecuencias más interesantes obtenidas en este estudio.

5. En el estudio de salado de lomo de cerdo se concluyó que el rigor mortis afecta a las propiedades mecánicas de la carne, y por ello es determinante en el comportamiento de la muestra durante la operación de salado.

6. Es posible determinar los diferentes mecanismos envueltos en el proceso de salado utilizando una aproximación termodinámica de no equilibrio. Se determinaron tres etapas durante el tratamiento de salado de carne con disolución saturada de cloruro sódico: una primera relajación del tejido, comprimido durante el rigor mortis; una contracción del músculo promovida por la rápida relajación de las fibras elásticas; y finalmente, las muestras saladas alcanzaron el equilibrio mecánico.

7. El cloruro sódico ganado durante el tratamiento de salado se divide entre aquel de la fase líquida intra y extracelular, y aquel que se encuentra interaccionando con las proteínas de las fibras musculares (sistema actina/miosina). Sin embargo, las moléculas de agua perdidas durante el tratamiento provienen únicamente de la fase líquida de la carne. El movimiento de las moléculas de cloruro sódico está relacionado con el movimiento de las moléculas de agua, siendo posible correlacionar el flujo de agua con el factor de pérdidas a la frecuencia del fenómeno de conductividad iónica $(500 \mathrm{MHz})$. Lo mismo ocurre con las moléculas de sal, cuyo contenido en fase líquida puede ser determinado utilizando las propiedades dieléctricas. Restando dicho contenido de la cantidad total de moléculas de sal, es posible determinar las moléculas de sal que se encuentran unidas al sistema actina/miosina. Por lo tanto, se ha demostrado que las propiedades dieléctricas son una buena herramienta para analizar el reparto de moléculas de cloruro sódico en el músculo durante la operación de salado.

8. En cuanto al trabajo desarrollado en disoluciones patrón que simulaban la fase líquida de la manzana, se concluyó que este sistema permite describir correctamente las relaciones entre los componentes de la manzana y la radiación electromagnética, y permite la identificación de los fenómenos que 
se atribuyen a las especies químicas claves en el proceso de maduración de la manzana a lo largo del espectro electromagnético.

9. Se determinó una buena correlación entre el contenido en azúcar y las variaciones del factor de pérdidas a la frecuencia de relajación dipolar. Se demostró la posibilidad de determinar su contenido mediante la realización de medidas dieléctricas en disoluciones patrón así como en licuado de manzana y en tejido de manzana estructurado.

10. Se determinó una relación directa entre el factor de pérdidas a $0.5 \mathrm{GHz}$ y el contenido en malato de las disoluciones patrón y del licuado de manzana. Este efecto se ve reducido cuando la concentración de azúcares incrementa, debido a que se reduce la movilidad de las especies químicas del medio.

11. Se definió un Índice de Madurez de fruta basado en las propiedades dieléctricas restando el factor de pérdidas a la frecuencia de relajación al factor de pérdidas a $0.5 \mathrm{GHz}$. Se demostró que este nuevo índice de Madurez basado en las propiedades dieléctricas muestra una buena correlación con el Índice de Thiault en las disoluciones patrón preparadas así como en el tejido estructurado de manzana Granny Smith.

12. Se modelizó la operación de deshidratación osmótica de manzana Granny Smith mediante una aproximación termodinámica no lineal. Se determinaron tres etapas en esta operación. Al principio del tratamiento, las células están turgentes y el sistema membrana plasmática/pared celular almacena una gran cantidad de energía mecánica. En esta primera etapa se produce un rápido encogimiento de la muestra. En la segunda etapa, la fuerza impulsora del transporte era la difusional. La muestra presenta importantes perfiles de concentración y es en esta etapa cuando el tejido alcanza el máximo encogimiento, de aproximadamente el 60\%; este encogimiento provoca un gran cambio estructural en el tejido, que hace que desaparezcan los perfiles de concentración, cambiando además la fuerza impulsora del transporte. La última etapa muestra las relajaciones internas del tejido que provocan que el transporte sea gobernado por fenómenos mecánicos. 
13. Se demostró que los espectros dieléctricos permiten controlar el proceso de deshidratación de manzana utilizando el factor de pérdidas a la frecuencia de relajación.

14. Se modelizó la operación de deshidratación osmótica de kiwi (Actinidia deliciosa cv Hayward) mediante una aproximación termodinámica no lineal. Este modelo permite describir el transporte de agua a través de las vías apoplásticas, obteniendo un coeficiente fenomenológico de $5.46 \cdot 10^{-6} \mathrm{~mol}^{2} / \mathrm{J}$ $\mathrm{s}^{2}$. Cuando el tejido pierde la turgencia, el transporte de masa alcanza una etapa con predominancia de fuerzas difusionales. En la última parte del proceso, las fuerzas mecánicas son predominantes y se observa un plegamiento del sistema, produciéndose una disminución de volumen de aproximadamente un $60 \%$. Se ha demostrado que esta fruta sufre marcadas contracciones y expansiones que se traducen en grandes cambios macroscópicos de volumen y estructura. La deshidratación osmótica produce además pérdidas en los componentes nativos del kiwi, como son el ácido cítrico y los iones calcio y potasio.

15. Se demostró que los espectros dieléctricos permiten controlar el proceso de deshidratación de kiwi utilizando el factor de pérdidas a la frecuencia de relajación.

16. Los resultados de los trabajos de investigación pertenecientes a esta tesis han sido objeto de dos patentes que se encuentran ya aprobadas; la primera patente: "Procedimiento y dispositivo para la discriminación de alimentos", tiene como objeto verificar si los alimentos cumplen criterios de calidad preestablecidos. El procedimiento de discriminación requiere de un primer método de calibración tras el cual es posible llevar a cabo el procedimiento de discriminación sobre una pluralidad de alimentos, tales como los procedentes de una línea de producción. El método de calibrado aplica una radiación electromagnética al alimento a analizar. Esta radiación cubre un espectro muy amplio de frecuencias. Se analiza para cada frecuencia la respuesta dieléctrica y se establecen valores discretos de la frecuencia para los cuales la respuesta dieléctrica es un valor que varía con las propiedades 
determinantes de la calidad del alimento. Estos valores son los utilizados con una correlación adecuada para posteriormente llevar a cabo la discriminación. La segunda patente: "Método de discriminación de piezas de fruta según su grado de madurez y procedimiento de calibración de dicho método", consiste en un método que permite discriminar piezas de fruta según su grado de madurez, por ejemplo para poder llevar a cabo un método de discriminación en procesos continuos de clasificación de frutos recolectados, mediante técnicas de espectroscopia y que no requiere la destrucción del producto. La invención consiste en realizar dos medidas del factor de pérdidas donde cada una de las medidas se lleva a cabo en un rango de frecuencias distinto para establecer en base a ambas medidas el grado de madurez de las piezas de fruta. Es también objeto de la invención el procedimiento de calibración de dicho método.

17. Es importante destacar que la aplicación de la espectroscopia dieléctrica se puede considerar una potente herramienta en el control de calidad de alimentos. Como se ha demostrado a lo largo de toda esta tesis, proporciona información útil sobre la composición y estructura del producto, y se ha demostrado su utilidad para el análisis de algunos procesos comunes de la industria agroalimentaria. Obviamente, como todas las técnicas de medida desarrolladas para realizar control de productos y procesos, presenta algunas limitaciones que se deben tener presentes para poder obtener información relevante y representativa de la muestra, y de este modo poder obtener resultados certeros orientados a la transferencia real de esta tecnología a la industria agroalimentaria. La mayor limitación del sistema de medida de radiación electromagnética en el rango de microondas es la poca capacidad de penetración de la onda en la materia, obteniendo como resultado una medida relativamente superficial de la muestra. En sistemas heterogéneos o en sistemas en los que se han generado perfiles, el equipo proporcionaría una información superficial de la muestra que no resultaría representativa del conjunto. Este problema se solucionaría con un tratamiento adecuado de los datos y un estudio integrado del alimento para conocer con certeza qué 
estamos midiendo; en el futuro desarrollo de un sensor a partir de la información obtenida, sería necesario un proceso previo de calibración para ese producto y proceso concreto. Por lo tanto, como conclusión es importante destacar la relevancia de un adecuado tratamiento de los datos que deben ser estudiados y analizados de manera minuciosa, además de la importancia de realizar una correcta metodología experimental. Ese estudio de los datos debe ser complementado con la información adicional del producto y del proceso, realizando un acoplamiento de las medidas dieléctricas con dicho estudio integrado del producto. Sólo mediante este procedimiento de actuación se obtendrán resultados válidos y se podrá proceder a la transferencia de esta tecnología a la industria agroalimentaria.

18. Como resumen del presente documento, es importante destacar que los trabajos realizados en esta tesis han dado lugar a: 14 artículos internacionales en revistas SCI, 3 capítulos de libro de editorial internacional, dos patentes internacionales (en proceso de publicación/promoción), 5 presentaciones orales en congresos internacionales de reconocido prestigio con sus correspondientes publicaciones en los anales del congreso y 11 pósters en diferentes congresos internacionales.

19. Como conclusión final, es importante destacar que en este trabajo se han abordado varios temas de investigación que han aportado información y soluciones a problemas reales de diferentes sectores de la Industria Alimentaria; dichos resultados se han difundido tanto a nivel del entorno científico internacional como a nivel industrial, protegiéndose los mismos mediante las dos patentes citadas anteriormente. 

7. Bibliografia 

Aberle, E.D., Forrest, J.C., Gerrald, D.E. \& Mills, E.W. (2001). Properties of fresh meat. Principles of Meat Science. Capítulo 6: pp. 112. $4^{\mathrm{a}}$ edición, Kendall/hunt Publishing Company, Iowa, E.E.U.U.

Adous, M., Quéffélec,P. \& Laguerre, L. (2006). Coaxial/cylindrical transition line for broadband permittivity measurementof civil engineering materials. Measurement Science and Technology, 8, 2241-2246.

Afsar, M.N., Birch, J.R., Clarke, R.N. \& Chantry, G.W. (1986). The measurement of the properties of materials. Proceedings of the IEEE, 74(1), 183-199.

Agilent Technologies, (2000). Agilent 16451B dielectric test fixture operation and service manual. Agilent Technologies, E.E.U.U.

Agilent Technologies, (2004). Microwave dielectric spectroscopy workshop. Measure the difference. Agilent Technologies, E.E.U.U.

Agilent Technologies, (2005a). Free space materials measurement seminar. Agilent Technologies, E.E.U.U.

Agilent Technologies, (2005b). Agilent 85070E Dielectric Probe Kit 200MHz to 50 GHz-Technical Overview. Agilent Technologies, EEUU.

Agilent Technologies, (2006). Basics of measuring dielectric materials. Application note, Agilent literature number 5989-2589EN. Agilent Technologies, E.E.U.U.

Agilent Technologies, (2008). Agilent 85070E Dielectric Probe Kit 200MHz to 50 GHz-Technical Overview. Agilent Technologies, E.E.U.U.

Agre, P., Bonhivers, M. \& Borgnia, M.J. (1998). The aquaporins, blueprints for cellular plumbing systems. The Journal of Biological Chemistry, 273(24),1465914662.

Aguilera, J.M. \& Stanley, D.W. (1999). Microstructural principles of Food Processing and Engineering. Elsevier Science, Gaithersburg, MD.

Aguilera, J.M., Chiralt, A. \& Fito, P. (2003a). Food dehydration and product structure. Trends in Food Science and Technology, 14, 432-437.

Aguilera, J.M., Chiralt, A. \& Fito, P. (2003b). Process, structrure and functionality. Special Issue on the International Conference Iberdesh 2002, Food Science and Technology International, 9,135. 
Aimoto, A. \& Matsumoto, T. (1996). Non-invasive method for measuring the electrical properties of deep tissues using an open-ended coaxial probe. Medical Engineering and Physics, 18, 641-646.

Alabaster, C.M. (2004). The microwave properties of tissue and other lossy dielectrics. Tesis doctoral, Cranfield University College of dependence Technology, Department of aerospace, Power and Sensors, Reino Unido.

Albors, A. (2002). Estudio de Perfiles Composicionales y Estructura en Tejido Parenquimático (var. Granny Smith) Deshidratada. Tesis Doctoral. Universidad Politécnica de Valencia, España.

Altmann, M., \& Pliquett, U. (2006). Prediction of intramuscular fat by impedance spectroscopy. Meat Science, 72 (4), 666-671.

Andrade, O.M., Iskander, M.F. \& Bringhurst, S. (1992). High Temperature Broadband Dielectric Properties Measurement Techniques. Materials Research Society Symposium Proceedings, 269, 527-539.

Ansorena, D. (2003). Frutas y Frutos Secos. En I. Astiasarán, J.A. Martínez (Eds.), Alimentos. Composición y Propiedades (pp. 191-211). McGraw-Hill International, Nueva York, E.E.U.U.

AOAC (1984). Official methods of analysis (14 th $\mathrm{ed}$.). Washington, DC: Association of Official Analytical Chemists.

A.O.A.C, (2000). A.O.A.C, Association of official analytical chemist official methods of analysis (2000) Washington. D.C.

April, E. W., Brandt, P.W. \& Elliot, G.F. (1972). The myofilament lattice: studies on isolated fibers II. The effects of osmotic strength, ionic concentration, and $\mathrm{pH}$ upon the unit-cell volume. J.Cell. Biol., 53, 53.

Aristoy, M.C. \& Toldrá, F. (1995). Isolation of flavor peptides from raw pork meat and dry-cured ham. In G. Charalambous, Food flavors: generation, analysis and process influence (pp. 1323-1344). Amsterdam, The Netherlands: Elsevier Science.

Aristoy, MC. \& Toldrá, F. (2008). Nucleotides and its derived compounds. En L.M.L. Nollet y F. Toldrá (Eds.), Handbook of Muscle Foods Analysis (pp. 279-288), CRC Press, BocaRaton FL, E.E.U.U. 
Ashmed, J., Ramaswamy, H.S. \& Raghavan, V.G.S. (2007). Dielectric properties of butter in the MW frequency range as affected by salt and temperature. Journal of Food Engineering, 82(3), 351-358.

Ashmore, C.R., Parker, W. \& Doerr, L. (1972). Respiration of mitochondria isolated from dark-cutting beef: postmortem changes. Journal of Animal Science, 34, 4653.

Barat, J.M., Fito, P. \& Chiralt, A. (2001). Modelling of simultaneous mass transfer and structural changes in fruit tissues. Journal of Food Engineering, 49, 77-85.

Barthel, J.M.G., Krienke, H. \& Kunz, W. (1998). Physical Chemistry of Electrolyte Solutions: Modern Aspects. En: H. Baumgärtel, E.U. Frank, W. Grünbein (Eds.), Topics in Physical Chemistry 5. Springer Berlin and Steinkopff, Darmstadt, Nueva York, E.E.U.U.

Batlle, N., Aristoy, M.C. \& Toldrá, F. (2000). Early postmortem detection of exudative pork meat based on nucleotide content. Food Chemistry and Toxicology. 65(3),413-416.

Batlle, N., Aristoy, M.C. \& Toldrá, F. (2001). ATP metabolites during aging of exudative and nonexudative pork meats. Journal of Food Science. 66(1),68-71.

Bejerholm, C., \& Barton-Gade, P. A. (1986). Effect of intramuscular fat level on eating quality of pig meat. En el libro de resúmenes del congreso 32nd European Meeting of Meat Research Workers, Ghent, 24-29 August, Vol. II (pp.389-391).

Bendall, J.R. \& Taylor, A.A. (1972). Consumption of oxygen by the muscles of beef animals and related species. II. Consumption of oxygen by post-rigor muscle. Journal of the Science of Food and Agricultural, 23, 707-711.

Bendall, J.R., \& Swatland, H.J. (1988). A review of the relationships of $\mathrm{pH}$ with physical aspects of pork quality. Meat Science, 24(1), 85-126.

Bengtsson, N.E. \& Risman, P.O. (1971). Dielectric properties of food at $3 \mathrm{GHz}$ as determined by a cavity perturbation technique. II. Measurements on food materials. Journal of Microwave Power, 6(2), 107-123.

Berbert, P.A. \& Stenning, B.C. (1996a). On-line Moisture Content Measurement of Wheat. Journal of Agricultural Engineering Research, 65, 287-296. 
Berbert, P.A. \& Stenning, B.C. (1996b). Analysis of Density-independent Equations for Determination of Moisture Content of Wheat in the Radiofrequency Range. Journal of Agricultural Engineering Research, 65, 275-286.

Berbert, P.A., Queiroz, D.M., Sousa, E.F., Molina, M.B., Melo, E.C. \& Faroni, L.R.D. (2001). Dielectric properties of parchment coffee. Journal of Agricultural Engineering Research, 80, 65-81.

Berbert, P.A., Queiroz, D.M. \& Melo, E.C. (2002). Dielectric properties of common bean. Biosystems Engineering, 83(4), 449-462.

Berbert, P.A., Viana, A.P., Dionello, R.G. \& Carlesso, V. (2004). Three dielectric models for estimating common bean moisture content. En el libro de resúmenes del congreso Drying 2004-14th International Drying Symposium (IDS 2004) Vol.B (pp. 1502-1509), 22-25 August, São Paulo, Brazil.

Bertram, H.C., Andersen, H.J. \& Karlsson, A.H. (2001). Comparative study of lowfield NMR relaxation measurements and two traditional methods in the determination of water holding capacity of pork. Meat Science, 57(2), 125-132.

Bidlingmeyer, B.A., Cohen, S.A., Tarvin, T.L. \& Frost, B.A. (1987). A new, rapid, high sensitivity analysis of amino acids in food type samples. Journal of the Association of Official Analytical Chemists, 70, 241-247.

Bircan, C. \& Barringer, S.A. (1998). Salt-starch interactions as evidenced by viscosity and dielectric property measurements. Journal of Food Science, 63(6), 983-986.

Bircan, C. \& Barringer, S.A. (2002a). Determination of protein denaturation of muscle foods using the dielectric properties. Journal of Food Science, 67 (1), 202205.

Bircan, C. \& Barringer, S.A. (2002b). Use of dielectric properties to detect egg protein denaturation. Journal of Microwave Power and Electromagnetic Energy, 37, 89-96.

Bircan, C., Barringer, S.A. \& Mangino, M.E. (2001). Use of the dielectric properties to detect whey protein denaturation. Journal of Microwave Power and Electromagnetic Energy, 36, 179-186.

Birch, J.R., Simonis, G.J., Afsar, M.N., Clarke, R.N., Dutta, J.M., Frost, H.M., Gerbaux, X., Hadni, A., Hall, W.F., Heidinger, R.H.O.W.W., Jones, C.R., Königer, F., Moore, R.L., Matsup, H., Nakano, T., Richter, W., Sakai, K., 
Stead, M.R., Stumper, U., Vigil, R.S. \& Wells, T.B. (1994). An intercomparison of Measurement techniques for the determination of the dielectric properties of solids at near millimeter wavelengths. IEEE Transactions on Microwave Theory and Techniques, 42(6), $956-963$.

Bodakian, B. \& Hart, F.X. (1994). The dielectric properties of the meat. IEEE Transactions on Dielectrics and electrical insulation, 1, 181-187.

Bohigas, X., Amigó R. \& Tejada, J. (2008). Characterization of sugar content in yoghurt by means of microwave spectroscopy. Food Research International, 41(1),104-109.

Bonnet, M., Ouali, A. \& Kopp,J. (1992). Beef muscle osmotic pressure as assessed by differential scaning calorimetry (DSC). International Journal of Food Science and Technology. 27,399-408.

Borgaard, C., Christensen, L.B. \& Jespersen, Bo L. (2003). Reflection mode microwave spectroscopy for on-line measurement of fat in trimmings. En el libro de resúmenes del congreso 49th ICoMST, 31 agosto-5 septiembre, Campinas, Brazil.

Bowker, B.C., Grant, A.L., Forrest, J.C. \& Gerrard, D.E. (2000). Muscle metabolism and PSE pork. Journal of Animal Science. 79,1-8.

Brewer, M.S., Zhu, L.G., Bidner, B., Meisinger, D.J. \& McKeith, F.K. (2001). Measuring pork color: effects of bloom time, muscle, $\mathrm{pH}$ and relationship to instrumental parameters. Meat Science, 57, 169-176.

Brewer, M.S., Novakofski, J. \& Freise,K. (2006). Instrumental evaluation of pH effects on ability of pork chops to bloom. Meat Science, 72, 596-602.

Brunton, N.P., Lyng, J.G., Zhang, L. \& Jacquier, J.C. (2006). The use of dielectric properties and other physical analyses for assessing protein denaturation in beef biceps femoris muscle during cooking from 5 to $85^{\circ} \mathrm{C}$. Meat Science, 72(2), 236-244.

Buchner, R., Hefter, G.T. \& May, P.M. (1998). Dielectric relaxation of aqueous $\mathrm{NaCl}$ solutions. Journal of Physical Chemistry A, 103, 1-9. 
Buck, D.E. (1965). The dielectric spectra of etanol-water mixtures in the microwave región. Tesis doctoral, Massachusetts Institute of Technology, Cambridge, Massachusetts.

Buckmaster, H.A. (1990). Precision microwave complex permittivity measurements of high loss liquids. Journal of Electromagnetic Waves Applications, 4, 645-656.

Bussey, H.E. (1967). Measurement of RF properties of materials-A survey. Proceedings of the IEEE, 55(6), 1046-1053.

Byrne, C.E., Downey, G., Troy, D.J. \& Buckley, D.J. (1998). Non-destructive prediction of selected quality attributes of beef by near-infrared reflectance spectroscopy between 750-1098 nm. Meat Science, 49 (4), 399-409.

Byrne, C.E., Troy, D.J. \& Buckley, D.J. (2000). Post mortem changes in muscle electrical properties of bovine $M$. longissimus dorsi and their relationship to meat quality attributes and $\mathrm{pH}$ fall. Meat Science, 54, 23-34.

Calay, R., Newborough, M., Probert, D. \& Calay, P. (2007). Predictive equations for the dielectric properties of foods. International Journal of Food Science and Technology, 29(6), 699-713.

Callow, E.H. (1939). The structure of muscular tissue. Annual report of food investigations board (pp. 55-59), London: HMSO.

Campbell, A.M. (1990). Measurement and analysis of the microwave dielectric properties of tissues. Tesis doctoral, University of Glasgow, Reino Unido.

Campbell, A.M. \& Land, D.V. (1992). Dielectric properties of female human breast tissue measured in vitro at 3.2GHz. Physics in Medicine and Biology, 37(1), 193 210.

Campbell, N.A. \& Reece, J.B. (2005). Transparency acetates for biology. Publicado por Benjamin Cummings, Pearson Education Inc., San Francisco, E.E.U.U.

Cassens, R.G. (1994). La estructura del músculo. En J.F. Price y B.S. Schweigert (Eds.), Ciencia de la carne y de los productos cárnicos (pp. 11-55). Ed. Acribia S.A. $2^{a}$ Edición. Zaragoza. España.

Castro-Giráldez, M., Toldrá, F. \& Fito, P. (2007). Dielectric spectroscopy studies as a tool for quality control in meat industry. En el libro de resúmenes del congreso Food-New Options for the Industry (EFFOST 2007), Lisboa, Portugal. 
Castro-Giráldez, M., Fito, P J., Toldrá, F. \& Fito, P. (2009). Physical sensors and techniques. En Leo ML Nollet y Fidel Toldrá (Eds.), Handbook of Processed Meats and Poultry Analysis (pp.7-34). Boca Raton, FL: CRC Press, E.E.U.U.

Castro-Giráldez, M, Fito, P.J., Toldrá, F. \& Fito, P. (2010a). Physical sensors for quality control during processing. In Fidel Toldrá (Ed.), Handbook of Meat Processing (pp.443-456). Wiley-Blackwell Publishing, E.E.U.U.

Castro-Giráldez, Fito, P.J., Chenoll, C. \& Fito, P., (2010b). Development of a dielectric spectroscopy technique for determining key chemical components of apple maturity. Journal of Agricultural and Food Chemistry, 58, 3761-3766.

Castro-Giráldez, M., Botella, P., Toldrá, F. \& Fito, P. (2010c). Low-frequency dielectric spectrum to determine pork meat quality. Innovative Food Science and Emerging Technologies, 11(2), 376-386.

Castro-Giráldez, M., Fito, P.J. \& Fito, P. (2010d). Application of microwaves dielectric spectroscopy for controlling pork meat (Longissimus dorsi) salting process. Journal of Food Engineering, 97(4), 484-490.

Castro-Giráldez, M., Fito, P.J. \& Fito, P. (2010e). Nonlinear thermodynamic approach to analyze long time osmotic dehydration of parenchymatic apple tissue. Journal of Food Engineering, in press.

Catalá, J.M. (1999). Estudio de Estructuras Guiadas Monomodo para Aplicaciones de Caracterización Dieléctrica de Materiales y Curado de Compuestos Elastoméricos a Frecuencias de Microondas. Tesis Doctoral, Universidad Politécnica de Valencia, España.

Chin, N.L., Campbell, G.M. \& Thompson, F. (2005). Characterization of bread doughs with different densities, salt contents and water levels using microwave power transmission measurements. Journal of Food Engineering, 70, 211-217.

Chizzolini, R., Novelli, E., Badiani, A., Delbomo, G. \& Rosa, P. (1993). Objective evaluation of pork quality: results of on-line measurements. Meat Science. 34,79-93. 
Choi, J.W., Cho, J., Lee, Y., Yim, J., Kang, B., Oh, K.K., Jung, W.H., Kim, H.J., Cheon, C., Lee, H. \& Kwon, Y. (2004). Microwave detection of metastasized breast cancer cells in the lymph node; potential application for sentinel lymphadenectomy. Breast Cancer Research and Treatment, 86, 107-115.

CIE. (1978). International Commission on Illumination, recommendations on uniform colour spaces, colour, difference equations, psychometric colour terms. CIE publication No. 15 (Suppl.2), (E-1.31) 1971/(TC-1.3). Bureau Central de la CIE, París, Francia.

Civille, G.V. \& Szczesniak, A.S. (1973). Guidelines to training a texture profile panel. Journal of Texture Studies, 4, 204-223.

Clerjon, S. \& Damez, J.L. (2007). Microwave sensing for meat and fish structure evaluation. Measurement Science and Technology, 18(4), 1038-1045.

Clerjon, S., Daudin, J.D. \& Damez, J.L. (2003). Water activity and dielectric properties of gels in the frequency range $200 \mathrm{MHz}-6 \mathrm{GHz}$. Food Chemistry, $82(1), 87-97$.

Cole, K.S. \& Cole, R.H. (1941). Dispersion and Absorption in Dielectrics I. Alternating Current Characteristics. Journal of Chemical Physics, 9(4), 341-351.

Collie, C.H., Hasted, J.B. \& Ritson, D.M. (1948). The dielectric properties of water and heavy water. Proceedings of the Royal Society of London, 60, 145-160.

Colligan, A., Bohuon, P., Deumier, F. \& Poligné, I. (2001). Osmotic treatment of fish and meat products. Journal of Food Engineering, 49, 153-162.

Cook, H.F. (1952). A comparison of the dielectric behavior or pure water and human blood at microwave frequencies. British Journal of Applied Physics, 60, 140-160.

Craig, D.Q.M. (1996). Dielectric analysis of biological systems. En Dielectric analysis of pharmaceutical systems (pp. 179-208). Taylor y Francis, Ltd., Londres.

Crank, J. (1985). In Mathematics of Diffusions, Oxford University Press, New York.

D.B.K. (2007). Elaborados Cárnicos, Estudio de Sectores de DBK.

Damez, J.L., Clerjon, S. (2008). Meat quality assessment using biophysical methods related to meat structure. Meat Science, 80, 132-149.

Damez, J. L., Clerjon, S. \& Abouelkaram, S. (2005). Mesostructure assessed by alternating current spectroscopy during meat ageing. En el libro de 
resúmenes del $51^{\text {st }}$ International Congress of Meat Science and Technology, Agosto 712, Baltimore, Maryland, E.E.U.U.

Damez, J. L., Clerjon, S., Abouelkaram, S \& Lepetit, J. (2006). Polarimetric ohmic probes for the assessment of meat ageing. En el libro de resúmenes del congreso 52nd International Congress of Meat Science and Technology, Dublin, Irlanda.

Damez, J. L., Clerjon, S., Abouelkaram, S. \& Lepetit, J. (2007). Dielectric behavior of beef meat in the $1-1500 \mathrm{kHz}$ range. Simulation with the Fricke/ColeCole. Meat Science, 77(4), 512-519.

Damez, J.L., Clerjon, S., Abouelkaram, S. \& Lepetit, J. (2008a). Electrical impedance probing of the muscle food anisotropy for meat ageing control. Food Control, 19(10), 931-939.

Damez, J.L., Clerjon, S., Abouelkaram, S. \& Lepetit, J. (2008b). Beef meat electrical impedance spectroscopy and anisotropy sensing for non-invasive early assessment of meat ageing. Journal of Food Engineering, 85(1), 116-122.

Daschner, F. \& Knochel, R. (2003). Dielectric microwave sensors with multivariate calibration. Advances in Radio Science, 1, 9-13

Daschner, F., Kent, M., Knochel, R. \& Berger, U.K. (2000). Optimization of the microwave determination of water in foods using principal component analysis. En el libro de resúmenes del 17th IEEE, Instrumentation and Measurement Technology Conference, 2000 (IMTC 2000), Baltimore, E.E.U.U.

Datta, A.K., Sumnu, G. \& Raghavan, G.S.V. (2005). Dielectric properties of foods. En M.A. Rao, S.S.H. Rizvi y A.K. Datta (Eds.), Engineering properties of foods (pp.501-565). Tercera edición, Taylor\&Francis Group, Boca Raton, E.E.U.U. Davey, C.L. \& Winger, R.J. (1979). In D.A.D. Parry \& L.K. Creamer (Eds.). Fibrous proteins: Scientific, industrial and medical aspects (Vol. 1, pp. 97). Academic Press, London.

Davidson, D.W. \& Cole, R.H. (1951). Dielectric Relaxation in Glycerol, Propylene Glycol, and n-Propanol. Journal of Chemical Physics, 19(12), 1484-1490. 
De Loor, G.P. \& Meijeboom, R.V. (1966). The dielectric constants of foods and other materials with high water contents at microwave frequencies. Journal of Food Technology, 1, 313-322.

De Los Reyes, R. (2007). Medida de las propiedades dieléctricas en alimentos y su aplicación en el control de calidad de productos y procesos. Tesis Doctoral, Universidad Politécnica de Valencia, España.

De los Reyes, R., Fito, P.J., De los Reyes, E. \& Fito, P. (2005a). Dielectric properties determination in citric fruits in relation with process variables. En el libro de resúmenes del congreso Innovations in Traditional Foods, EFFOST 2005, Valencia, España.

De los Reyes, R., Haas, C. \& Andrés, A. (2005b). Changes in the Dielectric Properties of "Salted Cod - Water" System during the Desalting Process and their Relation with other Physical Properties. En el libro de resúmenes del congreso Innovations in Traditional Foods Vol. 1 (pp. 273-276) (EFFOST 2005), Valencia, España.

De los Reyes, R., Fito, P.J., De los Reyes, E. \& Fito, P. (2006a). Dielectric Spectroscopy Study of Citric Fruits. En el libro del congreso International Microwave Power Institute's 40th Annual Symposium (pp.283-285), Agosto 9-11, Boston, Massachusetts, EEUU.

De los Reyes, R., Haas, C., Andrés, A., Fito, P. \& De los Reyes, E. (2006b). Dielectric Spectroscopy Studies of "Salted Cod - Water" systems during the Desalting Process. En el libro de resúmenes del congreso International Microwave Power Institute's 40th Annual Symposium (pp.67-70), Agosto 9-11, Boston, Massachusetts, EEUU.

De los Reyes, R., Castro-Giráldez, M., Fito, P. \& De los Reyes, E. (2007a). Application of microwaves for in-line quality assessment. En Leo ML Nollet, Fidel Toldrá (Eds.), Advances in Food Diagnostics (pp. 49-80). Blackwell Publishing, Iowa, E.E.U.U.

De Los Reyes, R., Heredia, A., Fito, P., De los Reyes, E. \& Andrés, A. (2007b).

Dielectric spectroscopy of osmotic solutions and osmotically dehydrated tomato products. Journal of Food Engineering, 80(4), 1218-1225.

Debye, P. (1929). Polar molecules. The Chemical catalogue Co., Nueva York, E.E.U.U. 
Decareau, R.V. (1985). Microwaves in the Food Processing Industry. Academic Press, Series of Food Science and Technology, Nueva York, E.E.U.U.

Demirel, Y. (2002). Chapter 1: Fundamentals of Equilibrium Thermodynamics, and Chapter 11: Thermodynamics and Biological Systems. In Y. Demirel (Ed.), Nonequilibrium Thermodynamics. Transport and Rate Processes in Physical, Chemical and Biological Systems (pp. 1-52, and pp. 541-598). Elsevier Science \& Technology Books, USA.

Duck, F.A. (1990). Physical Properties of Tisssue. Academic Press, London.

Dukhin, S.S. (1971). Dielectric properties of disperse systems. Surface and Colloid Science, 3, 83-85.

Dukhin, S.S. \& Shilov, V.N. (1974). Dielectric Phenomena and the Double Layer in Disperse Systems. John Wiley \& Sons, Nueva York, E.E.U.U.

Ehira, S. \& Uchiyama, H. (1974). Freshness-Lowering rates of cod and sea bream viewed from changes in bacterial count, Total Volatile Base- and Trimethylamine Nitrogen, and ATP related compounds. Bulletin of the Japanese Society of Scientific Fisheries, 40(5), 479-487.

Einolf, C.W. \& Carstensen, E.L. (1973). Passive electrical properties of microorganisms. V. Low-frequency dielectric dispersion of bacteria. Biophysical Journal, 13(1), 8-13.

Eisele, T. A. \& Drake, S.R. (2005). The partial compositional characteristics of apple juice from 175 apple varieties. Journal of Food Composition and Analysis, 18(2-3), 213-221.

Elliot, G.F. (1968). Force-balances and stability in hexagonally-packed polyelectrolyte systems. J. Theoret. Biol., 21, 71-87.

Ellison, W.J., Lamkaouchi, K. \& Moreau, J.M. (1996). Water: a dielectric reference. Journal of Molecular Liquids, 68, 171-279.

Elvira, J., Oliver, M.A., Arnau, J., Gobantes, I., Riu, P., Grèbol, N. \& Monfort, J.M. (2001). Medida de espectroscopia de impedancia eléctrica para la estimación de calidad de carne en línea. En el libro de resúmenes del I Congreso Nacional de la Carne, 16 y 17 de febrero de 2001, Madrid, España. 
Engelder, D.S. \& Buffler C.R. (1991). Measuring dielectric properties of food products at microwave frecuencies. Microwave $W$ orld, 12, 6-15.

Everard, C.D., Fagan, C.C., O’Donnell, C.P., O’Callaghan, D.J. \& Lyng, J.G. (2006). Dielectric properties of process cheese from 0.3 to $3 \mathrm{GHz}$. Journal of Food Engineering, 75(3), 415-422.

Faostat, www.fao.org

Faure, N., Flachat, C., Jenin, P., Lenoir, J., Roullet, C. \& Thomasset, A. (1972). Contribution a l'étude de la tendreté et de la maturation des viandes par la méthode de la conductibilité électrique en basse et haute fréquence. Revue de Médecine Vétérinaire, 123, 1517-1527.

Fear, E.C., Hagness, S.C., Meaney, P.M., Okoniewski, M. \& Stuchly, M.A. (2002). Enhancing breast tumor detection with near-field imaging. IEEE Microwave magazine, 3(1), 48-56.

Fear, E.C., Meaney, P.M. \& Stuchly, M.A. (2003). Microwaves for breast cancer detection?. IEEE Potentials, 22(1), 12-18.

Feldman, Y., Ermolina, I. \& Hayashi, Y. (2003). Time domain dielectric spectroscopy study of biological systems. IEEE Transactions on Dielectrics and Electrical Insulation, 10(5),728-753.

Feng, H., Tang, J. \& Cavalieri, R.P. (2002). Dielectric properties of dehydrated apples as affected by moisture and temperature. Transactions of the ASAE, 45, $129-135$.

Ferguson, I.B., (1980). Movement of mineral nutrients into the developing fruit of the kiwifruit (Actinidia chinensis Planch.). New Zealand Journal of Agricultural Research, 23, 349-353.

Ferrando, M. \& Spiess, W.E.L. (2001). Cellular response of plant tissue during the osmotic treatment with sucrose, maltose, and trehalose solutions. Journal of Food Engineering, 49,115-127.

Ferrando, M. \& Spiess, W.E.L. (2002). Transmembrane mass transfer in carrot protoplasts during osmotic treatment. Food Engineering and Physical Properties, 67(7), 2673-2680. 
Ferrando, M. \& Spiess, W.E.L. (2003). Effect of osmotic stress on microstructure and mass transfer in onion and strawberry tissue. Journal of the Science of Food and Agriculture, 83, 951-959.

Fito, P., \& Chiralt, A. (1997). Osmotic dehydration: an approach to the modelling of solid food-liquid operations. In P. Fito, E. Ortega-Rodríguez, \& G. V. Barbosa-Cánovas (Eds.), Food engineering 2000 (pp. 231-252), Chapman \& Hall, New York.

Fito, P., LeMaguer, M., Betoret, N., Fito, P.J. (2007). Advanced food process engineering to model real foods and processes: The "SAFES" methodology. Journal of Food Engineering, 83(2), 173-185.

Fito, P., Le Maguer, M., Betoret, N. \& Fito, P.J. (2008). Advanced food products \& process engineering (SAFES) I: Concepts \& methodology. In G.F. Gutiérrez-López, G.V. Barbosa-Cánovas, J. Welti-Chanes \& E. Parada-Arias (Eds.), Food engineering integrated approaches (pp. 117-137), Food Engineering Series, Springer, U.S.A.

Fito, P., Toldrá, F., Fito, P.J. \& Castro-Giráldez, M. (2009). "Procedure and device to discriminate foods" Spanish patent Application.

Flores, M., Aristoy, M-C, Spanier, A.M \& Toldrá, F. (1997). Non-volatile components effects on quality of Serrano dry-cured ham as related to processing time. Journal of Food Science, 62, 1235-1239.

Flores, M., Armeros, E., Aristoy, M.C. \& Toldrá, F. (1999). Sensory characteristics of cooked pork loin as affected by nucleotide content and post-mortem meat quality. Meat Science, 51,53-59.

Flores, M., Moya, V.J., Aristoy, M.C. \& Toldrá, F. (2000). Nitrogen compounds as potential biochemical markers of pork meat quality. Food Chemistry, 69,371377.

Forrest, J.C., Morgan, M.T., Borggard, C., Rasmussen, A.J., Jespersen, B.L. \& Andersen, J.R. (2000). Development of technology for the early post mortem prediction of water holding capacity and drip loss in fresh pork. Meat Science, $55,115-122$. 
Fortin, A. \& Raymond, D.P. (1988). The use of the electrical characteristics of muscle for the objective detection of PSE and DFD in pork carcasses under commercial conditions. Canadian Institute of Food Science and Technology Journal, 21, 260-265.

Foster, K.R. \& Schwan, H.P. (1986). Dielectric properties of tissues-a review. En Charles Polk y Elliot Postow (Eds.), Handbook of Biological Effects of Electromagnetic Radiation (pp.27-96). Boca Raton, FL: CRC Press, E.E.U.U.

Foster, K.R., \& Schwan, H.P. (1989). Dielectric properties of tissues and biological materials: a critical review. En J.R. Bourne (Ed.), Critical Reviews in Biomedical Engineering (17(1), 25-104). Boca Raton, Fla.: CRC Press.

Foster, K.R. \& Schwan, H.P. (1996). Dielectric properties of tissues. En Charles Polk y Elliot Postow (Eds.), Handbook of Biological Effects of Electromagnetic Fields (pp.25-102). Segunda edición, Boca Raton, FL: CRC Press, E.E.U.U.

Fuchs, K. \& Kaatze, U. (2002). Dielectric spectra of mono- and disaccharide aqueous solutions Journal of Chemical Physics, 116, 7137-7144.

Fujita, T., Hori,Y., Otani, T., Kunita, Y., Sawa, S., Sakai, S., Tanaka, Y., Takagahara, I \& Nakatani, Y. (1988). Applicability of the $\mathrm{K}_{0}$ value as an Index of Freshness for porcine and Chicken muscles, Agricultural Biology and Chemistry, $52(1), 107-112$.

Funebo, T. \& Ohlsson, T. (1999). Dielectric properties of fruits and vegetables as a function of temperature and moisture content. Journal of Microwave Power and Electromagnetic Energy, 34(1), 42-54.

Gabriel, C. (1996). Compilation of the Dielectric Properties of Body Tissues at RF and Microwave Frequencies, Report N. AL/OE-TR-1996-0037, Occupational and environmental health directorate, Radiofrequency Radiation Division, Brooks Air Force Base, Texas, E.E.U.U.

Gabriel, C. (2006). Dielectric properties of biological materials. En F.S. Barnes, B. Greenebaum (Eds.), Bioengineering and biophysical aspects of electromagnetic fields, Handbook of biological effects of electromagnetic fields (pp. 51-100). Tercera edición, Boca Raton, FL: CRC Press, E.E.U.U. 
Gabriel, C. \& Gabriel, S. (1996). Compilation of the Dielectric Properties of Body Tissues at RF and Microwave Frequencies. Documento de internet. URL: http://www.emfdosimetry.org/dielectric/Report/Report.html.

Gabriel, C., Gabriel, S. \& Corthout, E. (1996a). The dielectric properties of biological tissues: I. Literature survey. Physics in Medicine and Biology, 41(11), 2231-2249.

Gabriel, S., Lau, R.W. \& Gabriel, C. (1996b). The dielectric properties of biological tissues: II. Measurements in the frequency range $10 \mathrm{~Hz}$ to $20 \mathrm{GHz}$. Physics in Medicine and Biology, 41(11), 2251-2269.

Gabriel, S., Lau, R.W. \& Gabriel, C. (1996c). The dielectric properties of biological tissues: III. Parametric models for the dielectric spectrum of tissues. Physics in Medicine and Biology, 41(11), 2271-2293.

Gabriel, C., Gabriel, S., Grant, E.H., Halstead, B.S.J. \& Mingós, D.M.P. (1998). Dielectric parameters relevant to microwave dielectric heating. Chemical Society Reviews, 27, 213-223.

Garcia, A., Torres, J.L., Prieto, E. \& De Blas, M. (2001). Dielectric properties of grape juice at 0.2 and $3 \mathrm{GHz}$. Journal of Food Engineering, 48, 203-211.

García, A., Torres, J.L., De Blas, M., De Francisco, A. \& Illanes, R. (2004). Dielectric Characteristics of Grape Juice and Wine. Biosystems Engineering, 88(3), 343-349.

Garrido, M.D. \& Honikel, K.O. (1995). Relación entre las características de la calidad de la carne de cerdo en las primeras horas pm y después del enfriamiento. Fleischwirtschaft.2,4-8.

Garrido, M.D., Pedauye, J., Banon, S. \& Laencina, J. (1994a). Objective assessment of pork quality. Meat Science, 37 (3), 411-420.

Garrido, M.D., Pedauye, J., Bañón, S. \& Laencina, J. (1994b). Objective meat quality measurements of ham-. A practical classification method on the slaughterline. Meat Science, 37,421-428.

Gekas, V. (2001). Mass transfer modeling. Journal of Food Engineering, 49, 97-102. 
Gerschenson, L.N., Rojas, A.M., Marangoni, A.G. (2001). Effects of processing on kiwi fruit dynamic rheological behavior and tissue structure. Food Research International, 34, 1-6.

Ghatass, Z.F., Soliman, M.M., \& Mohamed, M.M. (2008). Dielectric technique for quality control of beef meat in the range $10 \mathrm{kHz}-1 \mathrm{MHz}$. American-Eurasian Journal of Scientific Research, 3(1), 62-69.

Gilbert, P.A. \& Heisler, G. (2004). Salt and health. Nutrition Bulletin, 30,62-69.

Goedeken, D.L., Tong, C.H. \& Virtanen, A.J. (2006). Dielectric properties of a pregelatinized bread system at $2450 \mathrm{MHz}$ as a function of temperature, moisture, salt and specific volume. Journal of Food Science, 62(1), 145-149.

Goldman, Y.E., Matsubara, I.\& Simmons, R.M. (1979). Lateral filamentary spacing in frog skinned fibres in the relaxed and rigor states. Journal of Physiology, 295, 80$81 \mathrm{P}$.

Gómez-Sánchez, J.A., Aristizábal-Botero, W., Barragán-Arango, P.J., \& Felice, C.J. (2009). Introduction of a muscular bidirectional electrical anisotropy index to quantify the structural modifications during aging in raw meat. Measurement Science and Technology, 20, 1-9.

Gotoh, T. \& Shikama, K. (1974). Autoxidation of oxymyoglobin from bovine heart muscle. Archives Biochemistry and Biophysics, 163, 476-478.

Govindarajan, S. (1973). Fresh meat colour. CRC Critical Reviews in Food Technology, 4,117-140.

Goy, B., Martin, P. \& Leban, J.M. (1992). The measurement of wood density by microwave sensor. Holz. Als Roh-Und Werkstoff, 50, 163-166.

Grant, E.H. (1965). The structure of water neighboring proteins, peptides and amino acids as deduced from dielectric measurements. Annals of the New York Academy of Sciences, 125, 418-427.

Grant, E.H. (1966). Dielectric dispersion in bovine serum albumin. Journal of Molecular Biology, 19(1),133-139.

Grant, E. \& Shack, R. (1967). Complex permittivity measurements at $8.6 \mathrm{~mm}$ wavelength over the temperature range 1-60 degrees centigrade. British Journal of Applied Physics, 18, 1807-1814. 
Grant, E. H. \& Sheppard, R.J. (1974). Dielectric relaxation in water in the neighbourhood of $4^{\circ} \mathrm{C}$. Journal of Chemical Physics, 60, 1792-1796.

Grant, E.H. \& Gabriel, C. (1991). Biological effects of radiowaves and microwaves. En el libro de resúmenes del Microwave and High Frequency, Congress International, Nice, Vol.I, pp. 800-813, Comite Français de L’Electricite.

Grant, E., Buchanan, T. \& Cook, H. (1957). Dielectric behaviour of water at microwave frequencies. Journal of Chemical Physics, 26, 156-161.

Grant, E.H., Keefe, S.E. \& Takashima, S. (1968). The dielectric behaviour of aqueous solutions of bovine serum albumin from radio wave to microwave frequencies. Journal of Physical Chemistry, 72, 4373-4380.

Grant, E.H., South, G.P., Takashima, S. \& Ichimura, H. (1971). Dielectric Dispersion in Aqueous Solutions of Oxyhaemoglobin and Carboxyhaemoglobin. Biochemical Journal, 122, 691-699.

Grant, E.H., Sheppard, R.J. \& South, G.P. (1978). Dielectric Behaviour of Biological Molecules in Solutions (pp. 145-184). Oxford University Press, Oxford.

Grant, E.H., Szwarnowski, S. \& Sheppard, R.J. (1981). Dielectric properties of water in the microwave and infrared regions. En K.H. Illinger (Ed.), Biological effects of nonionising radiation (pp. 47-56). American Chemical Society Symposium Series, Washington, DC, E.E.U.U.

Greaser, M.L. (1986). Conversion of muscle to meat. En P.J. Bechter (Ed.), Muscle as food (pp.37-102), Academic Press, Orlando, Flo, U.S.A.

Greaser, M.L. (2008) Nucleotides and its derived compounds. En L.M.L. Nollet y F. Toldrá (Eds.), Handbook of Muscle Foods Analysis (pp. 57-73), CRC Press, BocaRaton FL, E.E.U.U.

Grimnes, S. \& Martinsen, Ø.G. (2007). Sources of error in tetrapolar impedance measurements on biomaterials and other ionic conductors. Journal of Physics D: Applied Physics, 40, 9-14.

Grimnes, S. \& Martinsen, Ø.G. (2008). Passive tissue electrical properties. En S. Grimnes, O. GrØttem-Martinsen (Eds), Bioimpedance and bioelectricity basics (pp. 93-138), Segunda edición. Great Britain: Academic Press. 
Guerrero, L., Gobantes, I., Oliver, M.A., Arnau, J., Guàrdia, M.D., Elvira, J., Riu, P., Grèbol, N., \& Monfort, J.M. (2004). Green hams electrical impedance spectroscopy (EIS) measures and pastiness prediction of dry cured hams. Meat Science, 66, 289-294.

Guil, J.L. (2001). Bioquímica y tecnología de la carne. Servicio de publicaciones Universidad de Almería, España.

Gulino, A., Bellia, P., Falciglia, F., Musumeci, F., Pappalardo, A., Scordino, A. et al. (2005). Role of water content in dielectric properties and delayed luminiscence of bovine Achiles’ tendón. Febs Letters. 579(27),6101-6104.

Guo, W., Nelson, S.O., Trabelsi, S. \& Kays, S.J. (2007a). 10-1800MHz dielectric properties of fresh apples during storage, 83(4), 562-569.

Guo, W., Trabelsi, S., Nelson, S.O. \& Jones, D.R. (2007b). Storage effects on dielectric properties of eggs from 10 to $1800 \mathrm{MHz}$. Journal of Food Science, 72(5), 335-340.

Haggis, G.H., Hasted, J.B. \& Buchanan, T.J. (1952). The dielectric properties of water in solutions. Journal of Chemical Physics, 20, 1452-1465.

Hallett, I.C., MacRae, E.A. \& Wegrzyn, T.F., (1992). Changes in kiwifruit cell wall ultrastructure and cell packing during postharvest ripening. International Journal of Plant Science, 153, 49-60.

Hamm, R. (1960). Biochemistry of meat hydration. Advanced Food Research, 10, 355-463.

Hamm, R. (1975). Water-holding capacity of meat. In D.J.A. Cole, R.A. Lawrie (Eds), Meat (pp. 321-338). Butterworth \&co., London, UK.

Hamm, R. (1981).Post-mortem changes in muscle as affecting the quality of comminuted meat products. En R.A. Lawrie (Ed.), Developments in Meat Science 2, (pp. 93-124). Pergamon press, London .

Hamm, R. (1982). Post mortem changes in muscle with regard to processing of hotboned beef. Food Technology, 36(11), 105-115.

Hanai, T. (1968). Electrical properties of emulsions. En P. Sherman (Ed.), Emulsions Science (pp.353-478). Academic Press, Nueva York, E.E.U.U.

Harker, F.R., Marsh, K.B., Young, H., Murray, S.H., Gunson, F.A. \& Walker, S.B., (2002). Sensory interpretation of instrumental measurements 2: sweet and acid taste of apple fruit. Posthasvest Biology and Technology, 24, 241-250. 
Hasted, J.B. \& El Sabeh. (1953). The dielectric properties of water in solutions. Transactions of the Faraday Society, 49, 1003-1011.

Hasted, J.B. (1961). The dielectric properties of water. En J.B. Birks, J. Hart (Eds.), Progress in Dielectrics 3 (pp. 101-149). John Wiley and Sons Inc, E.E.U.U.

Hasted, J.B., Husain, S.K., Frescura, F.A.M. \& Birch, J.R. (1985). Far-infrared absorption in liquid water. Chemical Physics Letters, 118(6), 622-625.

Henry, F., Gaudillat, M., Cadillon Costac, L. \& Lakkis, F. (2003). Free and/or bound water by dielectric measurements. Food Chemistry, 82(1),29-34.

Herrera-Mendez, C.H., Becila, S., Boudjellal, A. \& Ouali, A. (2006). Meat ageing: Reconsideration of the current concept. Trends in Food Science and Technology. 17(8),394-405.

Herve, A.G., Tang, J., Luedecke, L. \& Feng H. (1998). Dielectric properties of cottage cheese and surface treatment using microwaves. Journal of Food Engineering, 37, 389-410.

Hewlett-Packard, (1992). Basic of measuring the dielectric properties of materials. Application note 1217-1. Hewlett-Packard Company, E.E.U.U.

Holm, F. (2003). Food Quality Sensors. Flair-Flow 4 synthesis report, SMEs No4, Francia.

Honikel, K.O. (1997). Reference methods supported by OECD and their use in Mediterranean meat products. Food Chemistry, 59 (4), 573-582.

Honikel, K.O. (1998). Reference methods for the assessment of physical characteristics of meat. Meat Science, 49(4),447-457.

Honikel, K.O. \& Fischer, C. (1977). A rapid method for the detection of PSE and DFD porcine muscle. Journal of Food Science, 42(6), 1633-1636.

Hoving-Bolink, A.H., Eikelenboom, G., van Diepen, J.Th.M., Jongbloed, A.W. \& Houben, J.H. (1998). Effect of dietary vitamin E supplementation on pork quality. Meat Science, 49 (2), 205-212.

Hu, X. \& Mallikarjunan, P. (2004). Thermal and dielectric properties of shucked oysters. LWT-Food Science and Technology, 38, 489-494. 
Huff-Lonergan, E. \& Lonergan, S.M. (2005). Mechanism of water-holding capacity of meat: the role of postmortem biochemical and structural changes. Meat Science. 71,194-204.

Hullberg, A. (2004). Quality of Processed Pork. Influence of RN genotype and processing conditions. Tesis doctoral, Swedish University of Agricultural Sciences, Uppsala, Suecia.

Hulme, A.C. (1958). Some aspects of the biochemistry of apple and pear fruits. In E.M. Mrak, G.F. Stewart \& C.O. Chichester, Advances in Food Research (pp. 297-413). New York: Academic Press.

Hulme, A.C., Dones, J.D. \& Wooltorton, L.S. (1963). The respiration climacteric in apple fruits. Proceedings of the Royal Society B, 158,514-535.

Hunt, M.C., Acton, J.C., Benedict, R.C., Calkins, C.R., Cornforth, D.P., Jeremiah, L.E., et al (1991). Guidelines for meat colour evaluation. En el libro de resúmenes del 44th Annual Reciprocal Meat Conference, Junio 9-12, Kansas City University, Manhattan, KS. (pp.1-17). Chicago, IL, E.E.U.U. Publ. National Live Stock and Meat Board.

Içier, F. \& Baysal, T. (2004a). Dielectrical Properties of Food Materials-1: Factors Affecting and Industrial Uses. Critical Reviews in Food Science and Nutrition, 44, 465-471.

Içier, F. \& Baysal, T. (2004b). Dielectrical Properties of Food Materials-2: Measurement Techniques. Critical Reviews in Food Science and Nutrition, 44, 473478.

ISO 1442:1997. (1997). Methods of test for meat and meat products. Determination of moisture content. BS 4401-3:1997

Jackson, P.J. \& Harker, F.R., (1997). Changes in firmness of the outer pericarp, inner pericarp, and core of Actinidia species during ripening. New Zealand Journal of Crop and Horticultural Science, 25, 185-189.

Jain, R.C. \& Voss, W.A.G. (1994). Dielectric measurement methods for industrial scientific and medical applications in the microwave frequency range. IETE Technical Review, 11(5 \& 6), 297-311. 
Jaud, D., Weisse, K., Gehlen, K.H., \& Fischer, A. (1992). pH and conductivity Comparative measurements on pig carcasses and their relationship to drip loss. Fleischwirtschaft, 72 (10), 1416-1418.

Jaworek, D., Gruber, W. \& Bergmeyer, H.U. (1974). Adenosine 5'-triphosphate determination with 3-phosphoglycerate kinase. In H.U. Bergmeyer (Ed.), Methods of Ensymatic Analysis. Vol. 4. (pp. 2097-2101). Academic Press, New York.

Joines, W.T., Zhang, Y., Li, C.X. \& Jirtle, R.L. (1994). The measured electrical properties of normal and malignant human tissues from 50 to $900 \mathrm{MHz}$. Medical Physics, 21, 547-550.

Joo, S.T., Kauffman, R.G., Kim, B.C. \& Park, G.B. (1999). The relationship of sarcoplasmic and myofibrillar protein solubility to colour and water-holding capacity in porcine longissimus muscle. Meat Science, 52, 291-297.

Kaatze, U. (1986). The dielectric spectrum of water in the microwave and nearmillimetre wavelength region. Chemical Physics Letters, 132(3), 291-293.

Kaatze, U. (1988). Complex permittivity of water as a function of frequency and temperature. Journal of Chemical Engineering, 34, 371-374.

Kaatze, U. (1989). Complex permittivity of water as a function of frequency and temperature. Journal of Chemical and Engineering Data, 34, 371:384.

Kaatze, U. (1995). Microwave dielectric properties of liquids. Radiation Physics and Chemistry, 45, 549-566.

Kaatze, U. (1996). Microwave dielectric properties of water. En: A. Kraszewski (Ed.), Microwave Aquametry. Electromagnetic wave interactions with water-containing materials (pp. 37-53). IEEE Press, Nueva York, E.E.U.U.

Kaatze, U. (1997). The dielectric properties of water in its different states of interaction. Journal of Solution Chemistry, 26, 1049-1112.

Kaatze, U. (2000). Hidrogen network fluctuations and the microwave dielectric properties of liquid water. Surface Sensing Technology Applications, 4, 377-391.

Kaatze, U. (2005). Electromagnetic wave interactions with water and aqueous solutions. En Klaus Kupfer (Ed.), Electromagnetic aquametry (pp. 15-37). Springer, Nueva York, E.E.U.U. 
Kaatze, U., Behrends, R. \& Pottel, R. (2002). Hydrogen network fluctuations and dielectric spectrometry of liquids. Journal of Non-crystalline solids, 305, 19-28.

Kader, A.A. \& Barret, D.M. (1996). Classification, composition of fruits and postharvest maintenance of quality. In L.P. Somogyi, H.S. Ramaswamy, Y.H. Hui, Processing fruits: Science and Technology Vol I. Biology, principles and applications (pp. 1-24). Lancaster, Pennsylvania: Technomic Pub. Co. Inc.

Kao, K.C. (2004). Electric polarization and relaxation. En K.C. Kao (Ed.), Dielectric phenomena in solids (pp. 41-114). Academic Press, E.E.U.U.

Kato, H., Rhue, MR. \& Nishimura, T. (1989). Role of free amino acids and peptides in food taste. In R.Teranishi, R.G. Buttery, \& F. Shahidi, Flavor Chemistry. Trends and development (pp. 158-174). ACS Symposium Series 388. Washington DC: ACS.

Keefe, S.E. \& Grant, E.H. (1974). Dipole moment and relaxation time of ribonuclease. Physics in Medicine and Biology, 19, 701-707.

Kent, M. (1990). Hand-held instrument for fat/water determination in whole fish. Food Control, 1, 47-53.

Kent, M. (2001). Microwave measurements of product variables. En Erika KressRogers y Christopher J.B. (Eds.), Instrumentations and sensors for the food industry (pp. 233-279). Segunda edición, Boca Raton, FL: CRC Press, E.E.U.U

Kent, M. (2003). Measurement of added water in foodstuffs. En I. Tothill (Ed.), Rapid and on-line instrumentation for food quality assurance (pp.240-269). GBR: Woodhead Publishing, Cambridge.

Kent, M. (2007). Measurement of dielectric properties of herring flesh using transmission time domain spectroscopy. International Journal of Food Science and Technology, 25(1), 26-38.

Kent, M. \& Jason, A.C. (1975). Dielectric properties of foods in relation to interactions between water and the substrate. In R.B. Duckworth (Ed.), Water relations of foods (pp.211-231). Academic Press, Nueva York, E.E.U.U.

Kent, M. \& Anderson, D. (1996). Dielectric studies of added water in poultry meat and scallops. Journal of Food Engineering, 28, 239-259. 
Kent, M. \& Stroud, G. (1999). A new method for the measurement of added glaze on frozen foods. Lournal of Food Engineering, 39(3), 313-321.

Kent, M., Lees, A. \& Roger, A. (1993). Estimation of the fat content of minced meat using a portable microwave fat meter. Food Control, 4, 222-227.

Kent, M., Knökel, R., Daschner, F. \& Berger, U.K. (2000a). Composition of foods using microwave dielectric spectra. European Food Research and Technology, 210, 359-366.

Kent, M., MacKenzie, K., Berger Knöchel, R. \& Daschner, F. (2000b). Determination of prior treatment of fish and fish products using microwave dielectric spectra. European Food Research and Technology, 210(6), 427-433.

Kent, M., Knökel, R., Daschner, F. \& Berger, U.K. (2001). Composition of foods including added water using microwave dielectric spectra. Food Control, 12, 467-482.

Kent, M., Peymann, A., Gabriel, C. \& Knight, A. (2002). Determination of added water in pork products using microwave dielectric spectroscopy. Food Control, 13(3), 143-149.

Kent, M., Oehlenschlager, J., Mierke-Klemeyer, S., Manthey-Karl, M., Knöchel, R., Daschner, F. \& Schimmer, O. (2004a). A new multivariate approach to the problem of fish quality estimation. Food Chemistry, 87(4), 531-535.

Kent, M., Oehlenschlager, J., Mierke-Klemeyer, S., Knöchel, R., Daschner, F. \& Schimmer, O. (2004b). Estimation of the quality of frozen cod using a new instrumental method. European Food Research and Technology, 219(5), 540-544.

Kent, M., Knöchel, R., Daschner, F., Schimmer, O., Tejada, M., Huidobro, A., Nunes, L., Batista, I. \& Martins, A. (2005). Determination of the quality of frozen hake using its microwave dielectric properties. International Journal of Food Science and Technology, 40(1), 55-65.

Kent, M., Lees, A. \& Christie, R.H. (2007). Seasonal variation in the calibration of a microwave fat: water content meter for fish flesh. International Journal of Food Science and Technology, 27(2),137-143.

Kleibel, A., Pfüzner, H., \& Krause, E. (1983). Measurement of dielectric loss factor a routine method of recognizing PSE muscle. Fleischwirtsch, 63(7), 1183-1185. 
Kocwin-Podsiadla, M., Przybylski, W., Kuryl, J., Talmant, A. \& Monin, G. (1995). Muscle glycogen level and meat quality in pigs of different halothane genotypes. Meat Science, 40(1),121-125.

Koohmaraie, M. (1992). The role of $\mathrm{Ca}^{+2}$-dependent proteases (calpains) in postmortem proteolysis and meat tenderness. Biochimie, 74, 239-245.

Koohmaraie, M. (1994). Muscle proteinases and meat ageing. Meat Science. 36, 93104.

Koohmaraie, M. (1996). Biochemical factors regulating the toughening and tenderization processes of meat. Meat Science, 43, 193-201.

Kraszewski, A. W. (1980). Microwave aquametry-a review. Journal of Microwave Power, 15(4), 209-220.

Kraszewski, A. W. (1991). Microwave aquametry-Needs and perspectives. IEE Transactions on Microwave Theory and Techiques, 39(5), 828-835.

Kraszewski, A. W. (1996). Microwave aquametry-Electromagnetic wave interactions with water containing materials. IEE Press, Nueva York.

Kraszewski, A.W. (2000). Recent bibliography on moisture sensing: 1990-1998 (Sensors, Methods, Applications). En H. Baltes, W. Göpel, J. Hesse (Eds.), Sensors update (pp. 393-414). Wiley-VCH, Weinheim, Alemania.

Kraszewski, A.W. \& Nelson, S.O. (1990). Study on grain permittivity measurements in free space. Journal of Microwave Power and Electromagnetic Energy, 25(4), 202210.

Kraszewski, A.W. \& Nelson, S.O. (1992). Wheat moisture content and bulk density determination by microwave parameters measurement. Canadian Agricultural Engineering, 34(4), 327-335.

Kraszewski, A.W. \& Nelson, S.O. (1993a). Microwave permittivity of pecan nuts. Journal of Microwave Power and Electromagnetic Energy. 28(3), 165-173.

Kraszewski, A.W. \& Nelson, S.O. (1993b). Nondestructive microwave measurement of moisture content and mass of single peanut kernels. Transactions of the ASAE, 36(1), 127-134.

Kraszewski, A.W. \& Nelson, S.O. (1994). Determination of moisture content and bulk density of shelled corn by measurement of microwave parameters. Journal of Agricultural Engineering Research, 58, 37-46. 
Kraszewski, A.W., Trabelsi, S. \& Nelson, S.O. (1995). Microwave dielectric properties of wheat. En el libro de resúmenes del 30th Microwave Power Symposium (pp.90-93), July 9-12, Denver, CO, E.E.U.U.

Kraszewski, A.W., Trabelsi, S. \& Nelson, S.O. (1998). Simple grain moisture content determination from microwave measurements. Transactions of the ASAE, 41(1), 129-134.

Kress-Rogers, E. \& Kent, M. (1987). Microwave measurement of powder moisture and density. Journal of Food Engineering, 6(55), 345-376.

Kuang, W. (1996). Low-frequency dielectric properties of biological tissues: electrical double layer on membranes and ionic conduction through membrane pores. Tesis Doctoral, Universidad de Georgia, Athens, Ga., E.E.U.U.

Kuang, W., \& Nelson, S.O. (1997). Low-frequency dielectric dispersion from ion permeability of membranes. Journal of Colloid and Interface Science, 193, 242-249.

Kuang, W., \& Nelson, S.O. (1998). Low-frequency dielectric properties of biological tissues: a review with some new insights. American Society of Agricultural Engineers, 41(1), 173-184.

Laack, R.L.J.M., van Kauffman, R.G., Sybesma, W., Smulders, F.J.M., Eikelenboom, G. \& Pinheiro, J.C. (1994). Is color brightness (L-value) a reliable indicators of water holding capacity in porcine muscle?. Meat Science. 38,193-201.

Lal Kaushal, B.B. \& Sharma, P.C. (1995). Apple. In D.K. Salunkhe, S.S. Kadam, Handbook of fruit science and technology: production, composition, storage and processing (pp. 91-122). New York: Marcel Dekker.

Lanahan,A., Black, R. \& Ecker, J.R.(1996). Hookless1, an ethylene response gene, is required for differential cell elongation in the Arabidopsis hook. Cell, 85,183194.

Lanari, M.C. \& Cassens, R.G. (1991). Mitochondrial activity and beef muscle colour stability. Journal of Food Science, 56, 1476-1479.

Lane, J.A. \& Saxton, J.A. (1952). Dielectric dispersion in pure polar liquids at very high radio frequencies. Proceedings of the Royal Society of London, 213, 400-408. 
Lawrie, R.A. (1998). Lawrie's Meat Science. $6^{\text {th }}$ edition Technomic Publishing Co., Lancaster, PA.

Lawrie, R.A. (2006). Lawrie's Meat Science. $6^{\text {th }}$ edition Technomic Publishing Co.,Lancaster, PA.

Lazarides, H.N. \& Mavroudis, N.E. (1995). Freeze/thaw effects on mass transfer rates during osmotic dehydration. Journal of Food Science, 60(4), 826-828.

Lazebnik, M., McCartney, L., Popovic, D., Watkins, C.B., Lindstrom, M.J., Harter, J., Sewall, S., Magliocco, A., Booske, J.H., Okoniewski, M. \& Hagness, S.C. (2007). A large-scale study of the ultrawideband microwave dielectric properties of normal breast tissue obtained from reduction surgeries. Physics in Medicine and Biology, 52, 2637-2656.

Le Meste, M., Lorient, D.\& Simatos, D. (2002). L'eua dans aliments. Editions Tec \& Doc, Paris.

Ledward, D.A. (1992). Colour of raw and cooked meat. In: The chemistry of musclebased foods (edited by D.E Johnston, M.K. Knight and D.A. Ledward). Pp. 128-144. Cambridge, UK: Royal Society of Chemistry.

LeMaguer, M. (1988). Osmotic dehydration: review and future directions. In Proceedings of the International symposium on progress in food preservation processes (pp. 283-309). Brussels, CERIA.

LeMaguer, M. \& Yao, Z. (1995). Mass transfer during osmotic dehydration at the cellular level. In G. V. Barbosa-Cánovas \& J. Welti-Chánes (Ed.), Food preservation by moisture control. Fundamentals and applications (pp. 325-350). Technomic Publisher Co. Inc., Lancaster.

Lenart, A. \& Lewicki, P.P. (1988). Energy consumption during osmotic and convective drying of plant tissue. Acta Alimentaria Polonica, 14 (1), 65-72.

Lerici, C.R., Mastrocola, D., Sensidoni, A. \& Dalla Rosa, M. (1988). Osmotic concentration in food processing. In S. Bruin (Ed.), Preconcentration and Drying of Food Materials (pp. 123). ElSevier Science, Amsterdam.

Lepetit, J. \& Buffiere, C. (1995). Meat aging measurement - comparison between 2 mechanical method. Fleischwirtschaft, 75 (10), 1220-1222. 
Lepetit, J. \& Hamel, C. (1998). Correlations between successive measurements of myofibrillar resistance of raw longissimus dorsi muscle during ageing. Meat Science, 49(2), 249-254.

Lepetit, J., Salé, P., Favier, R. \& Dalle, R. (2002). Electrical impedance and tenderisation in bovine meat. Meat Science, 60(1), 51-62.

Lepetit, J., Damez, J. L., Clerjon, S., Favier, R., Abouelkaram, S. \& Dominguez, B. (2006). Multi-electrode sensor for measuring the electric anisotropy of a biological material and the use of said sensor. Patente Francesa FR2880124 WO2006070169.

Lewis, M.J. (1987). Physical properties of foods and food processing systems (pp. 61-62). Chichester, England: Ellís Horwood Ltd.

Li, A. \& Barringer, S. (1996). Effects of protein denaturation on the dielectric properties for ham, egg and milk. En el libro de resúmenes del congreso IFT Annual Meeting, 60 (2), 141-145.

Li, X., Zyuzin, S. \& Mamishev, A.V. (2003). Measuring moisture content in cookies using dielectric spectroscopy. Electrical Insulation and Dielectric Phenomena, annual report, 459-462.

Liao, X.J., Raghavan, G.S.V., Dai, J. \& Yaylayan, V.A. (2003). Dielectric properties of $\alpha$-D-glucose aqueous solutions at $2450 \mathrm{MHz}$. Food Research International, 36, 485-490.

Lide, D.R. (2004). Thermochemistry, Electrochemistry, and Kinetics. In D.R. Lide (Ed.), CRC Handbook of chemistry and physics, 84th edition (pp.5-100). Boca Raton, FL: CRC Press, USA.

Lindahl, G. (2005). Colour characteristics of fresh pork. Doctoral Thesis, Swedish University of Agricultural Sciences, Uppsala (Sweden).

Lindahl, G., Lundström, K. \& Tornberg, E. (2001). Contribution of pigment content, myoglobin forms and internal reflectance to the colour of pork loin and ham from pure breed pigs. Meat Science, 59, 141-151.

Lindahl, G., Karlsson, A.H., Lundström, K. \& Andersen, H. J. (2006a). Significance of storage time on degree of blooming and colour stability of pork loin from different crossbreeds. Meat Science, 72, 603-612. 
Lindahl, G., Enfält, A.C., Andersen, H.J. \& Lundström, K. (2006b). Impact of RN genotype and ageing time on colour characteristics of the pork muscles longissimus dorsi and semimembranosus. Meat Science, 74, 746-755.

Liu, Y.D., Yin-bin, Y., Xiaping, F. \& Huisan, L. (2007). Experiments on predicting sugar content in apples by FT-NIR Technique. Journal of Food Engineering, 80, 986-989.

Lizhi, H., Toyoda, K. \& Ihara, I. (2008). Dielectric properties of edible oils and fatty acids as a function of frequency, temperature, moisture and composition. Journal of Food Engineering, 88(2),151- 158.

Lyng, J.G., Scully, M. McKenna, B., Hunter, A. \& Molloy, G. (2002). The influence of compositional changes in beefburgers on their temperatures during microwave heating and their thermal and dielectric properties. Journal of Muscle Foods, 13 (2), 123-142.

Lyng, J.G., Zhang, L. \& Bruton, N.P. (2005). A survey of the dielectric properties of meats and ingredients used in meat product manufacture. Meat Science, 69, 589-602.

M.A.P.A. -Ministerio de Agricultura, Pesca y Alimentación. (2007a). La alimentación en España, Ministerio de Agricultura, Pesca y Alimentación.

M.A.P.A. -Ministerio de Agricultura, Pesca y Alimentación. (2007b). La carne de cerdo en la producción final de la agricultura española, Ministerio de Agricultura, Pesca y Alimentación.

M.A.R.M.-Ministerio de Medio Ambiente y Medio Rural y Marino. (2007). Previsión de los mercados agrarios europeos 2007 - 2014.

M.A.R.M.-Ministerio de Medio Ambiente y Medio Rural y Marino. (2009). El sector de la carne de cerdo en cifras. Principales indicadores económicos de 2008.

MacDougall, D.B. \& Jones, S.J. (1981). Translucency and colour defects of darkcutting meat and their detection. In: The Problem of the Dark-cutting in Beef (edited by D.E. Hood and P.V. Tarrant). Pp. 328-339. Hague, Netherlands: Martinus Nijhoff Publishers.

MacDougall, D.B. (1982). Changes in the colour and opacity of meat. Food Chemistry, 9,75-80. 
MacRae, E.A., Lallu, A., Searle, A. \& Bowen, J.H. (1989a). Changes in the softening and composition of kiwi fruit affected by maturity at harvest and postharvest treatments. Journal of the Science of Food and Agriculture, 49, 413-440.

MacRae, E.A., Bowen, J.H. \& Stec, M.G.H. (1989b). Maturation of kiwifruit (Actinidia deliciosa cv Hayward) from two orchards: differences in composition of the tissue zones. Journal of the Science of Food and Agriculture, 47, 401-416.

Madavi, D.L. \& Carpenter, C.E. (1993). Ageing and processing affect colour, metmyoglobin reductase and oxygen consumption of beef muscles. Journal of Food Science, 58, 939- 947.

Madsen, N. T., Borggaard, C., Rasmussen, A. J. \& Christensen, L. B. (1999). On-line measurement of intramuscular fat/marbling in beef carcasses using electric impedance. En el libro de resúmenes del 45th International Conference of Meat Science and Technology (pp.378-379), Yokohama, Japón.

Mancini, R.A. \& Hunt, M.C. (2005). Current research in meat colour. Meat Science, $71,100-121$.

Mancini, R. A., Hunt, M.C. \& Kropf, D.H. (2003). Reflectance at 610nm estimates oxymyoglobin content on the surface of ground beef. Meat Science, 64, 157162.

Mansour, R., Latche, A., Vaillant, V., Pech, J.C. \& Reid, M.S. (1986). Metabolism of 1-aminocyclopropane-1-carboxylic acid in ripening apple fruits. Physiology Plant, 66,495-502.

Mao, W., Watanabe, M. \& Sakai, N. (2003). Dielectric properties of surimi at 915 $\mathrm{MHz}$ and $2450 \mathrm{MHz}$ as affected by temperature, salt and starch. Fisheries Science, 69, 1042-1047.

Marchello, M.J., Slanger, W.D., \& Carlson, J.K. (1999). Bioelectrical impedance: Fat content of beef and pork from different size grinds. Journal of Animal Science, 77(9), 2464-1468.

Marcotte, M. \& Le Maguer, M. (1991). Mass transfer in cellular tissues. Part I: the mathematical model. Journal of Food Engineering, 13, 199-220.

Marieb, E.N. (2004). Human anatomy and physiology, 5thedition, Redwood City: Benjamin Cummings. 
Marsh, B.B. \& Carse, W.A. (1974). Meat tenderness and the sliding-filament hypothesis. Journal of Food Technology, 9,129-139.

Martín, P., Moroño, A. \& Hodgson, E.R. (2004). Cuarzo KU1 de alta resistencia a la radiación. Boletín de la Sociedad Española de Cerámica y Vidrio, 43(2), 452454.

Mashimo, S., Kuwabara, S., Yagihara, S. \& Higasi, K. (1987). Dielectric relaxation time and structure of bound water in biological materials. Journal of Physical Chemistry, 91(25), 6337-6338.

Matsubara, I. \& Elliott, G.F. (1972). X-ray diffraction studies on skinned single fibres of frog skeletal muscle. J.Mol.Biol, 72, 657-669.

Matsumoto, M. \& Yamanaka, H. (1990). Postmortem biochemical changes in the muscle of Kuruma Prawn during storage and evaluation of the freshness. Nippon Suisan Gakkaishi, 56(7), 1145-1149.

Matthews, K. \& Strong, M. (2005). Salt-its role in meat products and the industry's action plan to reduce it. British Nutrition Foundation Nutrition Bulletin, 30,5561.

Mavroudis, N.E., Gekas, V. \& Sjöholm, I. (1998). Osmotic dehydration of apples. Shrinkage phenomena and the significance of initial structure on mass transfer rates. Journal of Food Engineering, 38, 101-123.

McWilliams, M. (1989). Foods: experimentals perspectives. MacMillan Publishing Company, Nueva York, 161-162, 277-279.

Metaxas, A.C., \& Meredith, R.J. (1993). Industrial Microwave Heating. IEE Power Engineering series 4, Peter Peregrinus LTD, London, UK.

Millar, S., Wilson, R., Moss, B.W. \& Ledward, D.A. (1994). Oxymyoglobin formation in meat and poultry. Meat Science, 36, 397-406.

Millman, B.M. (1981). Filament lattice forces in vertebrate striated muscle: relaxed and in rigor. J. Physiol, 320,118P.

Millman, B.M. \& Nickel, B.G. (1980). Electrostatic forces in muscle and cylindrical gel systems. Biophysical Journal, 32, 49-63.

Millman, B.M., Racey, T.J., \& Matsubara,I. (1981). Effects of hyperosmotic solutions on the filament lattice of intact frog skeletal muscle. Biophysical Journal, 33, 189202. 
Miura, N., Yagihara, S. \& Mashimo, S. (2003). Microwave Dielectric Properties of Solid and Liquid Foods Investigated by Time-domain Reflectometry. Journal of Food Science, 68(4), 1396-1403.

Monin, G. (1998). Recent methods for predicting quality of whole meat. Meat Science, 49(1), 231-243.

Morgan, J.B., Smith, G.C., Cannon, J., McKeith, F.K., \& Heavner, J.L. (1994). Pork Distribution Channel Audit Report, Pork Chain Quality Audit. National Pork Producers Council, Des Moines, IA.

Mudgett, R.E. (1985). Dielectric Properties of Foods. En R.V. Decareau (Ed.), Microwaves in the Food Processing Industry (pp. 15-37), Food Science and Technology, a series of monographs, Academic Press, Inc, Florida, E.E.U.U.

Mudgett, R.E., Smith, A.C., Wang, D.I.C. \& Goldblith, S.A. (1974a). Prediction of dielectric properties in non-fat milk at frequencies and temperatures of interest in microwave processing. Journal of Food Science, 39(1), 52-54.

Mudgett, R.E., Wang, D.I.C. \& Goldblith, S.A. (1974b). Prediction of dielectric properties in oil-water and alcohol-water mixtures at $3000 \mathrm{MHz}, 25^{\circ} \mathrm{C}$ based on pure component properties. Journal of Food Science, 39(3), 632-635.

Mudgett, R.E., Goldblith, S.A., Wang, D.I.C. \& Westphal, WB. (1977). Prediction of dielectric properties in solid foods of high moisture contents at ultra-high and microwave frequencies. Journal of Food Processing and Preservation, 1, 119125.

Mudgett, R.E., Goldblith, S.A., Wang, D.I.C. \& Westphal, W.B. (1979). Dielectric properties of frozen meats. Journal of Microwave Power, 14(3), 209-216.

Mudgett, R.E., Goldblith, S.A., Wang, D.I.C. \& Westphal, W.B. (1980). Dielectric behaviour of a semisolid food at low, intermediate, and high moisture content. Journal of Microwave Power, 15, 27-36.

Muñoz-Pérez, M. (2008). Herramientas de apoyo a la Innovación Tecnológica en las Empresas del Sector Agroalimentario. Boletín Informativo no173, Fundación de Estudios Bursátiles y Financieros, Septiembre de 2008.

Nakatani, Y., Fujita, T., Sawa, S., Otani, T., Hori, Y. \& Takagahara, I. (1986). Changes in the ATP-related compounds of beef and rabbit muscles and a 
new index of freshness of muscle. Agricultural Biology and Chemistry, 50(7), 1751-1756.

Nanjundaswamy, A.M. \& Madhakrishniak, S.G. (1989). Advances in dehydration processes for fruits, vegetables and their products. In Ragavenfra Rao M.R. et al. (Eds.), Trends in Food Science and Technology (pp. 369), India.

Ndife, M.K., Sumnu, G. \& Bayindirli, A.L. (1998). Dielectric properties of six different species of starch at 2450MHz. Food Research International, 31(1), 4352.

Nelson, S.O. (1977). Use of electrical properties for grain moisture measurement. Journal of Microwave Power, 12(1), 67-72.

Nelson, S.O. (1978a). Electrical properties of grain and other food materials. Journal of Food Processing and Preservation, 2, 137-154.

Nelson, S.O. (1978b). Frequency and moisture dependence of dielectric properties of high moisture corn. Journal of Microwave Power, 13, 213-218.

Nelson, S.O. (1980). Microwave dielectric properties of fresh fruits and vegetables. Transaction of the ASABE, 23(5), 1314-1316.

Nelson, S.O. (1983). Dielectric properties of some fresh fruits and vegetables at frequencies of 2.45 to $22 \mathrm{GHz}$. Transaction of the .ASABE, 26(2), 613-616.

Nelson, S.O. (1987). Frequency, moisture, and density dependence of the dielectric properties of small grains. Transactions of the ASABE, 35(2), 625-629.

Nelson, O.S. (1991). Dielectric Properties of Agricultural Products-Measurements and applications. IEEE Transactions on Electrical Insulation, 26(5), 845-869.

Nelson, S.O. (1992). Microwave dielectric properties of fresh onions. Transactions of the ASABE, 35(3), 963-966.

Nelson, S.O. (1995). Assessment of microwave permittivity for sensing peach maturity. Transations of the ASABE, 38(2), 579-581.

Nelson, S.O. (1999). Dielectric properties measurement techniques and applications. Transations of the ASABE, 42(2), 523-529.

Nelson, S.O. (2003). Frequency and temperature dependent permittivities of fresh fruits and vegetables from 0.01 to $1.8 \mathrm{GHz}$. Transations of the ASABE, 46(2), 567-569. 
Nelson, S.O. (2005). Dielectric spectroscopy of fresh fruit and vegetable tissues from 10 to $1800 \mathrm{MHz}$. Journal of Microwave Power and Electromagnetic Energy, 40(1), 31-47.

Nelson, S.O. \& Russell, R.B. (1986). Models for estimating the dielectric constants of cereal grains and soybeans. Journal of Microwave Power, 21(2), 110-111.

Nelson, S.O. \& Kraszewski, A.W. (1990). Dielectric properties of materials and measurement techniques. Drying Technology, 8(5), 1123-1142.

Nelson, S.O. \& Bartley, P.G. (2000). Measuring frequency and temperature dependent dielectric properties of food materials. Transactions of the $A S A B E$, 43(6), 1733-1736.

Nelson, S.O. \& Datta, A.K. (2001). Dielectric properties of Food Materials and Electric Field Interactions. En A.K. Datta, R.C. Anantheswaran (Eds), Handbook of Microwave Technology for Food Applications (pp. 69-114). Marcel Dekker, Nueva York.

Nelson, S.O., Prakash, A. \& Lawrence, K. (1991). Moisture and temperature dependence of the permittivities of some hydrocolloids at $2.45 \mathrm{GHz}$. Journal of Microwave Power Electromagnetic Energy, 26, 178-185.

Nelson, S.O., Forbus, W.R. \& Lawrence, K.C. (1993). Microwave permittivities of fresh fruits and vegetables from 0.2 to $20 \mathrm{GHz}$. Transactions of the $A S A B E$, 37(1), 183-189.

Nelson, S.O., Forbus, W.R. \& Lawrence, K.C. (1994). Permittivities of fresh fruits and vegetables from 0.2 to 20GHz. Journal of Microwave Power and Electromagnetic Energy, 29(2), 81-93.

Nelson, S.O., Forbus Jr., W.R. \& Lawrence, K.C. (1995). Assessment of microwave permittivity for sensing peach maturity. Transations of the ASAE, 38(2),579585.

Nelson, S.O., Trabelsi, S. \& Kays, S.J. (2006). Dielectric spectroscopy of honeydew melons from $10 \mathrm{MHz}$ to $1.8 \mathrm{GHz}$ for quality sensing. Transactions of the $A S A E$, 49(6),1977-1982. 
Nelson, S.O., Guo, W., Trabelsi, S. \& Kays, S.J. (2007). Dielectric spectroscopy of watermelons for quality sensing. Measurement Science and Technology, 18,18871892.

Nicolis, G. \& Prigogine, I. (1977a). Self organization in non equilibrium systems from dissipative structures to order through fluctuations, John Wiley and Sins, Inc.

Nicolis, G. \& Prigogine, I. (1977b). Die erforschung des komplexen. auf dem weg $\mathrm{zu}$ einem neuen verständnis der naturwissenschaften, R. Piper $\mathrm{GmbH}$ and Co. KG. München.

Nigmatullin, R.R., Arbuzov, A., Nelson, S.O. \& Trabelsi, S. (2006). Dielectric relaxation in complex systems: quality sensing and dielectric properties of honeydew melons from $10 \mathrm{MHz}$ to $1.8 \mathrm{GHz}$. Publicado por el Institute of Physics Publishing and Sissa, pp.1-19.

Nishimura, T. (1998). Mechanism involved in the improvement of meat taste during postmortem aging. Food Science Technology International, 4(4), 241-249.

Nishimura, T. \& Kato, H. (1988). Taste of free amino acids and peptides. Food Reviews International, 4,175-194.

Nishimura, T., Rhyu, M.R., Okitani, A. \& Kato, H. (1988). Components contributing to the improvement of meat taste during storage. Agricultural Biology and Chemistry, 52, 2323-2330.

Norman, J.L., Berg, E.P., Heymann, H. \& Lorenzen, C.L. (2003). Pork loin colour relative to sensory and instrumental tenderness and consumer acceptance. Meat Science, 65(2), 927-933.

Nunes, A.C., Bohigas, X. \& Tejada, J. (2006). Dielectric study of milk for frequencies between 1 and 20 GHz. Journal of Food Engineering, 76(2), 250-255.

Offer, G. \& Trinick, J. (1983). On the mechanism of water holding in meat: the swelling and shrinking of myofibrils. Meat Science. 8,245-281.

Offer, G. \& Knight, P. (1988). The structural basis of water-holding in meat. Part 2: Drip losses. In: Development in meat science (edited by R. Lawrie). Vol. 4, pp. 172-243. London: ElSevier Applied Science. 
Offer, G. \& Cousin, T. (1992). The mechanism of drip production-formation of two compartments of extracellular-space in muscle post-mortem. Journal of the Science of Food and Agricultural, 58, 107-116.

Offer, G., Knight, P., Jeacoke, R., Almond, R., Cousins, T., Elsey, J., et al (1989). The structural basis of waterholding, appearance and toughness of meat and meat products. Food Microstructure, 8,151-170.

Ohlsson, T. (1987). Industrial uses of dielectric properties of foods. En R. Jowitt, F. Escher, M. Kent, B. McKenna, M. Roques (Eds.), Physical properties of foods: 2. COST 90 bis Final Seminar Proceedings (pp. 199-211). Elsevier Applied Science, Londres.

Oliver, M.A., Gispert, M., Tibau, J. \& Diestre, A. (1991).The measurement of light scattering and electrical conductivity for the prediction of PSE pig mea tat various times postmortem. Meat Science, 29, 141-151.

Oliver, M.A., Gobantes, I., Arnau, J., Elvira, J., Riu, P., Grebol, N. \& Monfort, J.M. (2001). Evaluation of the electrical impedance spectroscopy (EIS) equipment for ham meat quality selection. Meat Science, 58(3), 305-312.

Ouali, A. (1992). Proteolytic and physicochemical mechanism involved in meat texture development. Biochimie, 74, 251-265.

Padua, GW. (1993). Proton NMR and dielectric measurements on sucrose filled agar gels and starch pastes. Journal of Food Science, 58(3), 603-626.

Pate, E.F. \& Brokaw, C.J. (1980). Cross-bridge behaviour in rigor-muscle. Biophysics of Structure \& Mechanism, 7,51-54.

Pearson, J.A. \& Roberson, R.N. (1954). The physiology of growth in apple fruits. VI. The control of respiration rate and synthesis. Australian Journal of Biological Sciences, 7(1),1-17.

Peebles, D.M., Edwards, A.D., Wyatt, J.S., Bishop, A.P., Cope, M. \& Delpy, D.T. (1992). Changes in human fetal cerebral hemoglobin concentration and oxygenation during labor measured by near-infrared spectroscopy. American Journal of Obstetrics and Gynecology, 166, 1369-1373.

Pethig, R. (1979). Dielectric and Electrical Properties of Biological Materials. J. Wiley \& Sons, Chichester. 
Pethig, R., \& Kell, D. B. (1987). The passive electrical properties of biological systems: Their significance in physiology, biophysics and biotechnology. Physics in Medicine and Biology, 32,933-937.

Pliquett, U., Altmann, M., Pliquett, F. \& Schöberlein, L. (2003). Py-a parameter for meat quality. Meat Science, 65, 1429-1437.

Ponne, C.T. \& Bartels, P.V. (1995). Interaction of electromagnetic energy with biological material-relation to food processing. Radiation Physical Chemistry, 45(4), 591-607.

Porro, D., Datlaserra, M., Dorigatti, C. \& Zatelli, A. (2002). Fitoregolatori efitormoni: risposta produttiva ed económica di Golden Delicious. Terra Trentina, 6,28-33.

Prakash, A., Nelson, S.O., Mangino, M.E. \& Hansen, P.M.T. (1992). Variation of microwave dielectric properties of hydrocolloids with moisture content, temperature and stoichiometric charge. Foods Hydrocolloids, 6(3), 315-322.

Raatikainen, O., Reinikainen, V., Minkkinen, P., Ritvanen, T., Muje, P., Pursiainen, J., Hiltunen, T., Hyvönen, P., von Wright, A. \& Reinikainen, S. (2005). Multivariate modelling of fish freshness index based on ion mobility spectrometry measurements. Analytica Chimica Acta, 544, 128-134.

Raicu, V., Kitugawa, N. \& Irimajiri, A. (2000). A quantitative approach to the dielectric properties of skin. Physics in medicine and biology, 45(2), 1-4.

Rastogi, N.K., Angersbach, A., \& Knorr, D. (2000). Evaluation of mass transfer mechanisms during osmotic treatment of plant materials. Journal of Food Science, 65,1016-1019.

Raveendranath, U. \& Mathew, K.T. (1995). Microwave technique for water pollution study. Journal of Microwave Power and Electromagnetic Energy, 30(3), 188194.

Redgwell, R.J., Melton, L.D. \& Brasch, D.J., (1991). Cell-wall polysaccharides of kiwifruit (Actinidia deliciosa): effect of ripening on the structural features of cell-wall materials. Carbobydrate Research, 209, 191-202.

Redgwell, R.J., Melton, L.D. \& Brasch, D.J., (1992). Cell wall dissolution in ripening kiwifruit (Actinidia deliciosa): solubilisation of the pectic polymers. Plant Physiology. 98, 71-81. 
Regier, M. \& Schubert, H. (2005). Introducing microwave processing of food: principles and technologies. En H. Schubert (Ed.), Microwave processing of foods (pp.3-10). GBR: Woodhead Publishing, Cambridge.

Ribereau-Gayon, J. \& Peynaud, E. (1971). Physiologie et biochimie de la vigne. Biochimie de la vigne et du raisin. In Dunod, Sciences et Techniques de la Vigne, Vol.1 (pp. 456), Paris.

Rigaud, B., Morucci, J. P., \& Chauveau, N. (1996). Bioelectrical impedance techniques in medicine. Part I: Bioimpedance measurement. Critical Reviews in Biomedical Engineering, 24(4-6), 257-351.

Roebuck, B.D., Goldblith, S.A. \& Westphal, W.B. (1972). Dielectric properties of carbohydrate-water mixtures at microwave frequencies. Journal of Food Science, 37, 199-204.

Rome, E. (1967). Light and x-ray diffraction studies of the filament lattice of glycerolextracted rabbit muscle. Journal of Molecular Biology, 27, 591-602.

Rome, E. (1968). X-ray diffraction studies of the filament lattice of striated muscle in various bathing media. Journal of Molecular Biology, 37(2), 331-344.

Rome, E. (1972). Relaxation of glycerinated muscle:low-angle x-ray diffraction studies. Journal of Molecular Biology, 65(2), 331-345.

Rosenvold, K. \& Andersen, H.J. (2003). The significance of pre-slaughter stress and diet on colour and colour stability. Meat Science, 63, 199-209.

Ryder, J.M. (1985). Determination of adenosine triphosphate and its breakdown products in fish muscle by High-Performance Liquid Chromatography. Journal of Agricultural and Food Chemistry, 33,678-680.

Ryynanen, S. (1995). The electromagnetic properties of food materials: a review of the basic principles. Journal of Food Engineering, 26, 409-429.

Rzepecka, M.A. (1973). A cavity perturbation method for routine permittivity measurement. Journal of Microwave Power, 8, 3-11.

Saito, T., Arai, K. \& Matuyoshi, M. (1959). A new method for estimating the freshness of fish. Bulletin of the Japanese Society of Scientific Fisheries, 24, 749-750. 
Salisbury, F. \& Ross, C. (1991). Plant physiology and plant cells. En F. Salisbury y C. Ross (Eds.), Plant Physiology (pp.3-26). Wadsworth Pub Co, 4a edición, Belmont, California, E.E.U.U.

Salvatori, D., Andrés, A., Chiralt, A. \& Fito, P. (1999). Osmotic dehydration progression in apple tissue I : spatial distribution of solutes and moisture content. Journal of Food Engineering, 42(3), 125-135.

Schanne, O.F. \& P-Ceretti, E.R. (1978). Impedance measurements in Biological Cells. John Wiley \& Sons, Nueva York.

Scheffler, T.L. \& Gerrard, D.E. (2007). Mechanism controlling pork quality development: the biochemistry controlling postmortem energy metabolism. Meat Science. 77,7-16.

Schmidt, F.C. (2006). Estudo das trocas de massa durante o tratamento de cortes de peito de frango com soluções salinas.En Dissertação (mestre em Engenharia de Alimentos). Universidade Federal de Santa Catarina, Brazil.

Schmidt, F.C., Carciofi, B.A.M. \& Laurindo, J.B. (2008). Salting operational diagrams for chicken breast cuts: hydration-dehydration. Journal of Food Engineering, 88, 36-44.

Schwan, H. P. (1957). Electrical properties of tissues and cell suspensions. Advances in biological and medical physics, 5, 147-209.

Schwan, H.P. (1965). Electrical properties of bound water. Annals of the New York Academy of Sciences, 125, 344-354.

Schwan, H.P. (1981). Dielectric properties of biological tissue and physical mechanisms of electromagnetic field interaction. En Karl H. Illinger (Ed.), Biological Effects of Nonionizing Radiation, ACS Symposium Series 157, American Chemical Society, Washington, DC, E.E.U.U.

Schwan, H.P. (1988). Biological effects of non-ionizing radiations: cellular properties and interactions. Annals of Biomedical Engineering, 16,245-263.

Schwan, H.P. (1992). Linear and nonlinear electrode polarization and biological materials. Annals of Biomedical Engineering, 20, 269-288.

Schwan, H.P. \& Foster, K.R. (1980). R-F field interactions with biological systems: electrical properties and biophysical mechanisms. Proceedings IEEE, 68,104106. 
Schwan, H.P., Schwarz, G., Maczuk, J. \& Pauly, H. (1962). On the low frequency dielectric dispersion of colloidal particles in electrolyte solution. Journal of Physical Chemistry, 66, 2626-2635.

Schwan, H.P., Sheppard, R.J. \& Grant, E.H. (1976). Complex permittivity of water at $25^{\circ} \mathrm{C}$. Journal of Chemical Physics, 64, 2257-2258.

Schwarz, G. (1972). Dielectric relaxation of biopolymers in solution. Advances in Molecular Relaxation Processes, 3, 281-295.

Seaman, R. \& Seals, J. (1991). Fruit pulp and skin dielectric properties for $150 \mathrm{MHz}$ to $6400 \mathrm{MHz}$. Journal of Microwave Power and Electromagnetic Energy, 26,72-81.

Seguí, L., Fito, P.J., Albors, A. \& Fito, P. (2006). Mass transfer phenomena during the osmotic dehydration of apple isolated protoplasts (Malus domestica vas. Fuji). Journal of Food Engineering, 77(1), 179-187.

Seguí, L., Fito, P.J., Fito, P. (2010). Analysis of structure-property relationships in isolated cells during OD treatments. Effect of initial structure on the cell behavior. Journal of Food Engineering, 99 (4), 417-423.

Sharma, G.P. \& Prasad, S. (2002). Dielectric properties of garlic (Allium sativum L.) at $2450 \mathrm{MHz}$ as function of temperature and moisture content. Journal of Food Engineering, 52 (4), 343-348.

Shiinoki, Y., Motouri, Y. \& Ito, K. (1998). On-line monitoring of moisture and salt contents by the microwave transmission method in a continuous salted butter-making process. Journal of Food Engineering, 38(2),153-167.

Shukla, T.R. \& Anantheswaran, R.C. (2001). Ingredient interactions and product development for microwave heating. En A.K. Datta y R.C. Anantheswaran (Eds.), Handbook of microwave technology for food applications (pp. 355-397). Marcel Decker Inc, Nueva York.

Sinha, N.K. (2006). Apples. In Yiu H.Hui, Handbook of fruits and fruit processing (pp. 265-278). U.S.A: Blackwell Publishing.

Sipahioglu, O. (2002). Modeling dielectric properties of foods as a function of composition and temperature. Tesis doctoral, Universidad de Ohio, EEUU. 
Sipahioglu, O. \& Barringer, S.A. (2003). Dielectric Properties of Vegetables and Fruits as a Function of Temperature, Ash, and Moisture Content. Journal of Food Science, 68, 234-239.

Sipahioglu, O., Barringer, S.A., Taub, I. \& Prakash, A. (2003a). Modeling the dielectric properties of ham as a function of temperature and composition. Journal of Food Science, 68(3), 904-909.

Sipahioglu, O., Barringer, S.A., Taub, I. \& Yang, A.P.P. (2003b). Characterization and modeling of dielectric properties of turkey meat. Journal of Food Science, 68(2), 521-527.

Skrlep, M. \& Candek-Potokar, M. (2007). Pork color measurement as affected by bloom time and measurement location. Journal of Muscle Foods, 18, 78-87.

Slanger, W.D., \& Marchello, M.J. (1994). Bioelectrical impedance can predict skeletal muscle and fat-free skeletal muscle of beef cows primal cuts. Journal of Animal Science, 72(12), 3124-3130.

Smith, G., Duffy, A.P., Shen, J. \& Olliff, C.J. (1995). Dielectric relaxation spectroscopy and some applications in the pharmaceutical sciences. Journal of Pharmaceutical Sciences, 84,1029-1044.

Somers, C., Tarrant, P.V. \& Sherington, J. (1985). Evaluation of some objective methods for measuring pork quality. Meat Science. 15,63-76.

Sosnicki, A.A., Greaser, M.L., Pietrzak, M., Pospiech, E. \& Sante, V. (1998). PSElike syndrome in breast muscle of domestic turkeys: a review. Journal of muscle foods. 9,13-23.

Starzak, M. \& Mathlouthi, M. (2006). Temperature dependence of water activity in aqueous solutions of sucrose. Food Chemistry, 96(3), 346-370.

Stetzer, A.J. \& McKeith, F.K. (2003). Benchmarking value in the pork supply chain: Quantitative strategies and opportunities to improve quality. Savoy, IL: American Meat Science Association.

Stoneman, M.R., Kosempa, M., Gregory, W.D., Gregory, C.W., Marx, J.J., Mikkelson, W., Tjoe, J. \& Raicu, V. (2007). Correction of electrode polarization contributions to the dielectric properties of normal and cancerous breast tissues at audio/radiofrequencies. Physics in Medicine and Biology, 52, 6589-6604. 
Stuchly, M.A. (1979). Interaction of radiofrequency and microwave radiation with living systems. Radiation and Environmental Biophysics, 16, 1-5.

Stuchly, M.A. \& Stuchly, S.S. (1980). Dielectric properties of biological substancestabulated. Journal of Microwave Power, 15, 19-23.

Sun, E., Datta, A. \& Lobo, S. (1995). Composition-Based prediction of dielectric properties of foods. Journal of Microwave Power and Microwave and Electromagnetic Energy, 30(4), 205-212.

Swami, S. \& Mudgett, R.E. (1981). Effect of moisture and salt contents on the dielectric behaviour of liquids and semi-solid foods. Artículo presentado en el Symposium: 16 th International Microwave Power Institute, Toronto, Canadá.

Swantek, P.M., Crenshaw, J.D., Marchello, M.J. \& Lukaski, H.C. (1992). Bioelectrical impedance: A non-destructive method to determine fat-free mass of live market swine and pork carcasses. Journal of Animal Science, 70, 169-177.

Swatland, H.J. (1980). Postmortem changes in electrical capacitance and resistivity of pork. Journal of Animal Science, 51, 1108-1112.

Swatland, H.J. (1985). Optical and electronic methods of measuring $\mathrm{pH}$ and other predictors of meat quality in pork carcasses. Journal of Animal Science, 61,887895.

Swatland, H.J. (1995). Near-infrared birefringence and transmittance of pork in relation to $\mathrm{pH}$, sarcomerelength, cold-shortening, and causes of paleness. Food Research International. 28,153-159.

Szczesniak, A.S. (1963). Classification of textural characteristics. Journal of Food Science, 28, 385-389.

Tabilo, G., Flores, M., Fiszman, S.M. \& Toldrá, F. (1999). Postmortem meat quality and sex affect textural properties and protein breakdown of dry-cured ham. Meat Science, 51, 255-260.

Taiz, L. \& Zeiger, E. (2002). Ethylene: the gaseous hormone. En L. Taiz, E. Zeiger (Eds.), Plant Physiology (pp. 519-538). Sinauer Associates, Inc., Publishers, Sunderland, Massachusetts, E.E.U.U. 
Taiz, L. \& Zeiger, E. (2006). Cell walls: Structure, Biogenésis, and Expansion. En L. Taiz y E. Zeiger (Eds.), Plant Physiology (pp. 283-308), Sinauer Associates, Inc., Publishers, Sunderland, Massachusetts, E.E.U.U.

Tan, J. (2004). Meat quality evaluation by computer vision. Journal of Food Engineering, $61(1), 27-35$.

Tanaka, F., Morita, K., Mallikarjunan, P., Hung, Y.-C. \& Ezeike, G.O.I. (2005). Análisis of dielectric properties of soy sauce. Journal of Food Engineering, 71, 92-97.

Thiault, J. (1970). Etude de criteres objectifs de la qualite gustative de pommes Golden Delicious. Bulletin Technique d'Information (Ministerio de Agricultura Francés), 248, 191-201.

Thompson, D.R. \& Zachariah, G.L. (1971). Dielectric theory and bioelectrical measurements. Transations of ASAE, 14(2), 214-215.

Tikk, K., Lindahl, G., Karlsson, A.H. \& Andersen, H.J. (2008). The significance of diet, slaughter weight and ageing time on pork colour and colour stability. Meat Science, 79, 806-816.

To, EC., Mudgett, RE., Wang, D.I.C. \& Goldblith, S.A. (1974). Dielectric properties of food materials. Journal of Microwave Power, 9, 303-315.

Toldrá, F. (2006). Meat: Chemistry and biochemistry. En Y.H. Hui, J.D. Culbertson, S. Duncan, I. Guerrero-Legarreta, E.C.Y. Li-Chan, C.Y. Ma, C.H. Manley, T.A. McMeekin, W.K. Nip, L.M.L. Nollet, M.S. Rahman, F. Toldrá, Y.L. Xiong (Eds.), Handbook of Food Science, Technology and Engineering (vol. 1, pp. 281 to 28-18), CRC Press, Boca Raton, FL, E.E.U.U.

Toldrá, F. (2007) Biochemistry of muscle and fat. En F. Toldrá, YH. Hui, I. Astiasarán, WK. Nip, JG. Sebranek, ETF. Silveira, LH. Stahnke \& R. Talon (Eds.), Handbook of fermented meat and poultry (pp. 51-58), Blackwell Publishing, Ames, Iowa, E.E.U.U.

Toldrá, F. \& Flores, M. (2000). The use of muscle enzymes as predictors of pork meat quality. Food Chemistry. 69,387-395.

Toldrá, F. \& Reig, M. (2006). Biochemistry of raw meat and Poultry. En Y. H. Hui, Wai-Kit Nip, Leo M. L. Nollet, Gopinadhan Paliyath, Benjamin K. Simpson 
(Eds.), Food Biochemistry and Food Processing (pp. 293-314). Blackwell Publishing, E.E.U.U.

Trabelsi, S. \& Nelson, S.O. (2003). Free-space measurement of dielectric properties of cereal grain and oilseed at microwave frequencies. Measurement Science and Technology, 14, 589-600.

Trabelsi, S., Kraszewski, A.W. \& Nelson, S.O. (1998). Nondestructive microwave characterization for bulk density and moisture content determination in shelled corn. Measurements Science and Technology, 9, 1548-1556.

Tran, V.N., Stuchly, S.S. \& Kraszewski, A. (1984). Dielectric properties of selected vegetables and fruits 0.1-10.0 GHz. Journal of Microwave Power, 19, 251-258.

Tulasidas, T.N., Raghavan, G.S.V., van de Voort, F. \& Girard, R. (1995). Dielectric properties of grapes and sugar solutions at $2.45 \mathrm{GHz}$. Journal of Microwave Power and Electromagnetic Energy, 30(2), 117-123.

Tyerman, S.D., Bohnert, H.J., Maurel, C., Steudle, E. \& Smith, J.A.C. (1999). Plant aquaporins: their molecular biology, biophysics and significance for plant water relations. Journal of Experimental Botany, 50, special issue, 1055-1071.

Uchiyama, H. \& Kato, N. (1974). Partial freezing as a means of preserving fish freshness-1. Changes in free amino acids, TMA-N, ATP and its related compounds, and nucleic acids during storage. Bulletin of the Japanese Society of Scientific Fisheries, 40(11), 1145-1154.

Váczy, G. \& Semberg, P. (2003). Microwave milk testing. En el libro de resúmenes del congreso Milk and dairy products, European dairy congress, 15-18 de Noviembre 2003, Portaro, Eslovenia.

Van Dyke, D., Wang, DIC \& Goldblith, S.A. (1969). Dielectric loss factor of reconstituted ground beef: the effect of chemical composition. Food Technology, 23, 84-86.

Varela, P., Salvador, A. \& Fiszman, S. (2005). Shelf-life estimation of 'Fuji' apples: sensory characteristics and consumer acceptability. Postharvest Biology and Technology, 38, 18-24.

Vázquez-Ortiz, F.A., Pacheco-Aguilar, R., Lugo-Sanchez, M.E. \& Villegas-Ozuna, R.E. (1997). Application of the freshness quality index ( $\mathrm{K}$ value) for fresh 
fish to canned sardines from Northwestern Mexico. Journal of Food Composition and Analysis, 10, 158-165.

Venkatesh, M.S. \& Raghavan, G.S.V. (2005). An overview of dielectric properties measuring techniques. Canadian Biosystems Engineering, 47(7), 15-29.

VIC porc '06. (2006). La competitividad del sector porcino. Conclusiones de la mesa 1. En Retos Actuales del sector porcino español. Revisión de las estrategias acordadas en 2004. Celebrado en Vic, 29 y 30 de noviembre de 2006.

Volpato, G., Michielin, E.M.Z., Ferreira, S.R.S.\& Petrus, J.C.C. (2007). Kinetics of the diffusion of sodium chloride in chicken breast (Pectoralis major) during curing. Journal of Food Engineering, 79, 779-785.

von Hippel, A.R. (1954a). "Dielectric Materials and Applications". MIT Press, Cambridge, Massachusetts.

von Hippel, A.R. (1954b). Macroscopic approach: complex permittivity and permeability. En A.R. Von Hippel (Ed.), Dielectrics and Waves. John Wiley and Sons, Inc., Nueva York.

von Hippel, A.R. (1954c). Dielectric and waves. MIT Press, Cambridge, Massachusetts.

W.A.P.A.-The Word Apple and Pear Association. (2009). European Apple and pear crop forecast. Informe de Agosto de 2009.

Wang, D., Tang, J., Correia, L.R. \& Gill, T.A. (1998). Postmortem changes of cultivated Atlantic Salmon and their effects on salt uptake. Journal of Food Science. 63(4),634-637.

Warris, P.D. \& Brown, S.N. (1987). The relationships between initial pH, reflectance, and exudation in pig muscle. Meat Science. 20,65-74.

Warris, P.D., Brown, S.N. \& Adams, S.J.M. (1991). Use of Tecpro Pork Quality Meter for assessing meat quality on the slaughterline. Meat Science, 30, 147156.

Warris, P.D. (2003). Ciencia de la carne. .Editorial Acribia, S.A., Zaragoza (España).

Whitman, T.A., Forrest, J.C., Morgan, M.T. \& Okos, M.R. (1996). Electrical measurement for detecting early post mortem changes in Porcine Muscle. Journal of Animal Science, 74, 80-90. 
Wood, J.D., Brown, S.N., Nute, G.R., Whittington, F.M., Perry, A.M., Johnson, S.P. \& Enser, M. (1996). Effects of breed, feed level and conditioning time on the tenderness of pork. Meat Science, 44,105-112.

Wu, F.Y., \& Smith, S.B. (1987). Ionic strength and myofibrillar protein solubilization. Journal of Animal Science, 65, 597-608.

Wulf, D.M., Emnett, R.S., Leheska, J.M., Moeller, S.J. (2002). Relationships among glycolytic potential, dark cutting (dark, firm and dry) beef, and cooked beef palatability. Journal of Animal Science, 80, 1895-1903.

Yokoyama, Y., Sakaguchi, M., Kawai, F. \& Kanamori, M. (1992). Changes in concentration of ATP-related compounds in various tissues of Oyster during ice storage. Nippon Suisan Gakkaishi, 58(11),2125-2136.

Zhang, L., Lyng, J.G., Brunton, N., Morgan, D. \& McKenna, B. (2004). Dielectric and thermophysical properties of meat batters over a temperature range of 585 ${ }^{\circ}$ C. Meat Science, 68, 173-184.

Zhiming, Y. \& Le Maguer, M. (1996). Mathematical Modelling and Simulation of Mass Transfer in Osmotic Dehydration Processes. Part I: Conceptual and Mathematical Models. Journal of Food Engineering, 29 (3): 349-360.

Zhu, L.G. \& Brewer, M.S. (1998). Discoloration of fresh pork as related to muscle and display conditions. Journal of Food Science, 63, 763-767.

Zhu, L.G., Bidner, B. \& Brewer, M.S. (2001). Postmortem pH, muscle, and refrigerated storage effects on ability of vacuum-packaged pork to bloom. Journal of Food Science, 66, 1230-1235. 

8. Anexas 



\subsection{Capítulas de libra de editarial}

internacional 



\section{Chapter 25 \\ Physical sensors for quality control during processing}

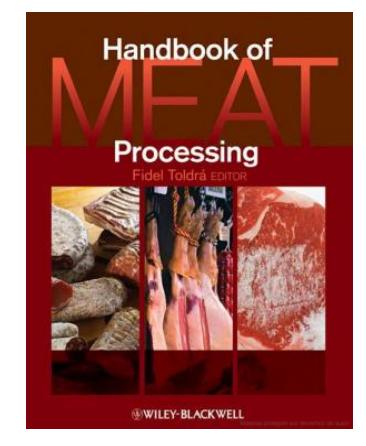

\section{Marta Castro-Giráldez, Pedro José Fito, Fidel Toldrá, and Pedro Fito}

\begin{abstract}
Introduction
Meat industry constitutes one of the main sectors in the developed countries due to its important protein contribution to human diet. Meat market has markedly changed during lasts years and its tendency leads to elaborated meat products with high quality as demanded by consumer. For this reason, the industry has the necessity of obtaining meat quality information during the production process in order to maintain quality standards. Over the last few years, some physical sensors have been developed in order to provide reliable meat quality information. These sensors can be used in process line and can obtain objective information in a fast and non-destructive way. The most important are mainly based on electromagnetic energy, ultrasounds and resonance techniques. These sensors can provide directly important information about meat composition and structure; sometimes, the information provided by the sensor does not allow discriminating low quality pieces and has to be implemented with additional information of the product.
\end{abstract}

This chapter presents an overview of the main electromagnetic physical methods for controlling meat products throughout the production process. Moreover, a brief summary of the most important marketed sensors is presented.

\section{Methods based on electromagnetic} energy

There exist different kinds of sensors based on the interaction of food with electromagnetic waves, particularly: sensors using visible radiation, ultraviolet or infrared, microwaves, radiowaves, X-rays or very high frequency waves (Nuclear Magnetic Resonance). Some applications are in the market since several years particularly for laboratory uses.

There exist also foods in-line applications: detection of foreign components throughout the application of X-rays or control of food composition by using Near Infrared (Holm 2003). Concretely, microwaves spectroscopy is currently used for the moisture content determination in some cereals and fruits (Kraszewski 1991, 1996; 



\section{Marta Castro-Giráldez, Pedro José Fito, Pedro Fito, and Fidel Toldrá}

\section{Contents}

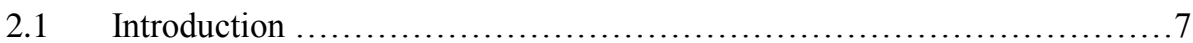

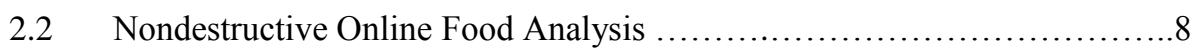

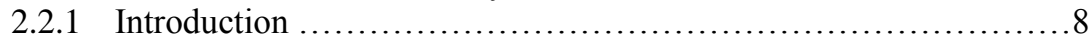

2.2.2 Basic Principles ........................................ 9

2.2.2.1 Debye Model as a Example of Relaxation Phenomenon .........13

2.2.2.2 Examples of Pork Meat Spectra...........................................14

2.2.3 Microwave Dielectric Spectroscopy...........................16

2.2.3.1 Overview of Microwave Measurement Techniques.................16

2.2.3.2 Quality Control in Meat Products by Microwave Dielectric Spectroscopy

2.2.3.3 Quality Control in Meat Products by Electrical Impedance Spectroscopy

2.2.4 Quality Control in Meat Products by Near-Infrared Spectroscopy

2.2.5 Ultrasound .25

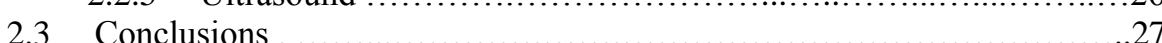

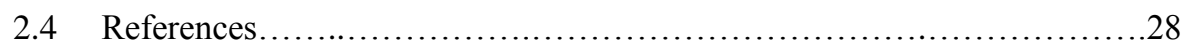

\subsection{Introduction}

Currently, the most important objective for the industry is to develop and control the processes in order to produce food products with specific properties of quality, safety 



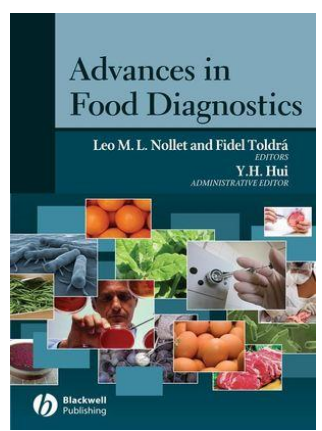

\title{
3 Application of Microwaves for On-line Quality Assessment
}

\author{
Ruth De los Reyes, Marta Castro-Giráldez, \\ Pedro Fito, and Elías De los Reyes
}

\section{Introduction}

The food industry has a growing interest in improving sensing techniques for quality control based on the behaviour of food when subjected to an electromagnetic field. Such electromagnetic parameters as complex permittivity, amplitude and phase, and scattering parameters can be related to certain quality process parameters (Nelson et al 1998; Shiinoki et al 1998; Nelson 1999; Clerjon and Damez 2005). For instance, electrical properties and moisture content, especially free water, are closely related to each other; dielectric measurements can therefore be used to analyze water activity in foodstuffs (Clerjon et al 2003). Also, instruments for measuring electromagnetic parameters are now available and, when precisely calibrated, can be used for rapid and non-destructive control measurements.

Microwaves are a common designation for electromagnetic waves at frequencies between $300 \mathrm{MHz}$ and $300 \mathrm{GHz}$ (Fig.3.1). The interest in food industry application of microwaves for dielectric heating appeared in the years following the end of the Second World War, but the development of microwaves stopped due to technological reasons and the high cost of investment (Decareau 1985). At the beginning of the 80s, the possibilities of microwave applications and their considerable advantages were recognised (Decareau and Peterson 1986) and microwave ovens become more popular. This increase in the use of domestic microwave ovens gave rise to a reduction in the cost of the relatively high power magnetron. However, the cost of these elements increases exponentially when the power is on an industrial scale (Fito et al 2004). At present, domestic microwave ovens are universally accepted by consumers, and other microwave heating applications are widely used in industry; baking, drying, blanching, thawing, tempering and packaging are the most important. Therefore wide experience has now been accumulated in this field and sensor systems based upon microwaves can be a viable nondestructive method of on-line control. The availability of components, affordable prices, speed of acquisition and processing of data make them even more attractive.

The aim of this chapter is to provide an overview of the current applications of low power microwaves for food quality control and to offer a detailed examination of the current research in this field.

\section{Microwave-material interaction aspects}

Complex permittivity $\left(\varepsilon_{\mathrm{r}}\right)$ (Equation 3.1) is the dielectric property that describes food behaviour under an electromagnetic field (Metaxas and Meredith 1993; Datta and 

8.2. Publicaciones carrespondientes a presentaciones orales en congresos internacionales 



\title{
USE OF THE DIELECTRIC SPECTROSCOPY TO CONTROL THE PORK MEAT (LONGISSIMUS DORSI) SALTING Process
}

\author{
Castro-Giráldez, M., Fito, P.J.*, Chenoll,C., Fito, P. \\ ${ }^{1}$ Instituto Universitario de Ingeniería de Alimentos para el Desarrollo, Universidad Politécnica de Valencia, Spain
}

Salting treatments is a common operation in high quality meat production, do it to conserve the product by water activity depression and transform the sensorial properties of fresh meat to the final meat products (as cured, dried or cooked meat products). Ones of its main problems are the difficulty to control the simultaneous water and salt fluxes into the product and control the protein fibbers transformation throughout processes. Dielectric properties of salted porcine meat are strongly related to its structure and composition: moisture, water activity, salt and fat content [1]. Thus, dielectric properties measurement appears as a promising method in non-destructive and on-line control of salting processes in meat industry.

Dielectric spectroscopy studies have been performed on raw and salted longissimus dorsi pork samples. Meat cylinders of $2 \mathrm{~cm}$ of diameter and $1 \mathrm{~cm}$ of thickness were salted by immersing into $25 \%$ $\mathrm{NaCl}$ brine for 5, 10, 15, 30, 45, 70, $100 \mathrm{~min}, 2,8$ and 24 hours. Dielectric spectra were measured in the frequency range $200 \mathrm{MHz}-20 \mathrm{GHz}$ by a coaxial probe (HP 85070E) connected to a Network Analyzer (HP E8362B) immediately after salting and also after 8 and 16 hours. Salt content, moisture, water activity and volume were also measured.

Salt and water fluxes has been correlated with loss factor at $10 \mathrm{GHz}$ and $500 \mathrm{MHz}$ sorting out the water and salt retained in meat matrix by adsorption or bounding protein behaviours, controlling the structural change thought the salting process.

\section{INTRODUCTION}

Currently, the most important objective for the industry is to develop and control the processes in order to produce food products with specific properties of quality, safety and nutrition as demanded by consumers. In this context, modern physical sensors play an important role for the industry and suppose an advance in controlling food properties.

Keywords: Dielectric properties, dielectric spectra, meat salting, water mass transfer 
Dielectric spectroscopy occupies an important place among the moderns measurement methods employed for chemical and physical analysis of materials. Theoretically, there could be a correlation between water and salts content and the electromagnetic characteristics of the pork meat. Measuring the dielectric properties of the product could result as an appropriate method to control the salting processes.

Complex permittivity $\left(\varepsilon_{\mathrm{r}}\right)$ is the dielectric property that describes foods behaviour under an electromagnetic field. Subscript $r$ indicates that values are related to air so the variable is dimensionless. The real part of complex permittivity is called dielectric constant ( $\left.\varepsilon^{\prime}\right)$ and reports material ability to store electromagnetic energy. The imaginary part is called effective loss factor $(\varepsilon ")$ and is related to energy absorption from wave energy; these energy absorptions are caused by different factors depending on material composition and measurement frequency. At microwave frequencies the main factors affecting $\varepsilon "$, are related to food conductivity (salts), and free and bound water which are responsible of dipolar losses.

The objective of this work is to analyze the viability of controlling salting meat processes by using dielectric properties measurements at microwaves frequencies.

\section{MATERIAL AND METHODS}

Experiments were done using pork meat (Longissimus dorsi), because of its low fat content where selected meat was 1,5 days postmortem. Experimental flowchart is shown in figure 1, where is possible to observe the salting treatment conditions using $25 \%(\mathrm{w} / \mathrm{w}) \mathrm{NaCl}$ brine at $4^{\circ} \mathrm{C}$. Samples were dipped in solution for 5, 10, 15, 25, 30, 40, 50, 60, 90, min, 2, 2.5, 3, 4, 5, 8 and 12 hours. Fresh meat isotherm was determined by drying at low thermal conditions. Samples were equilibrated in a isothermal chamber at $4^{\circ} \mathrm{C} 16$ hours. Dielectric properties were analyzed with a coaxial probe Agilent 85070E connected to a Vector Network Analyser Agilent E8362B, the surface water activity with a hygrometer (DECAGON model Aqualab CX-2, \pm 0.003 ), water content following the ISO 1442 , 1997, for meat products. Weight with a balace Mettler Toledo AB304-S ( \pm 0.001$)$, volume by Image analysis (Sony T90, Carl Zeiss optics) and ion chloride by argentometric titration of $500 \mu 1$ of the sample extract with a Sherwood model 926 Chloride Analyser.

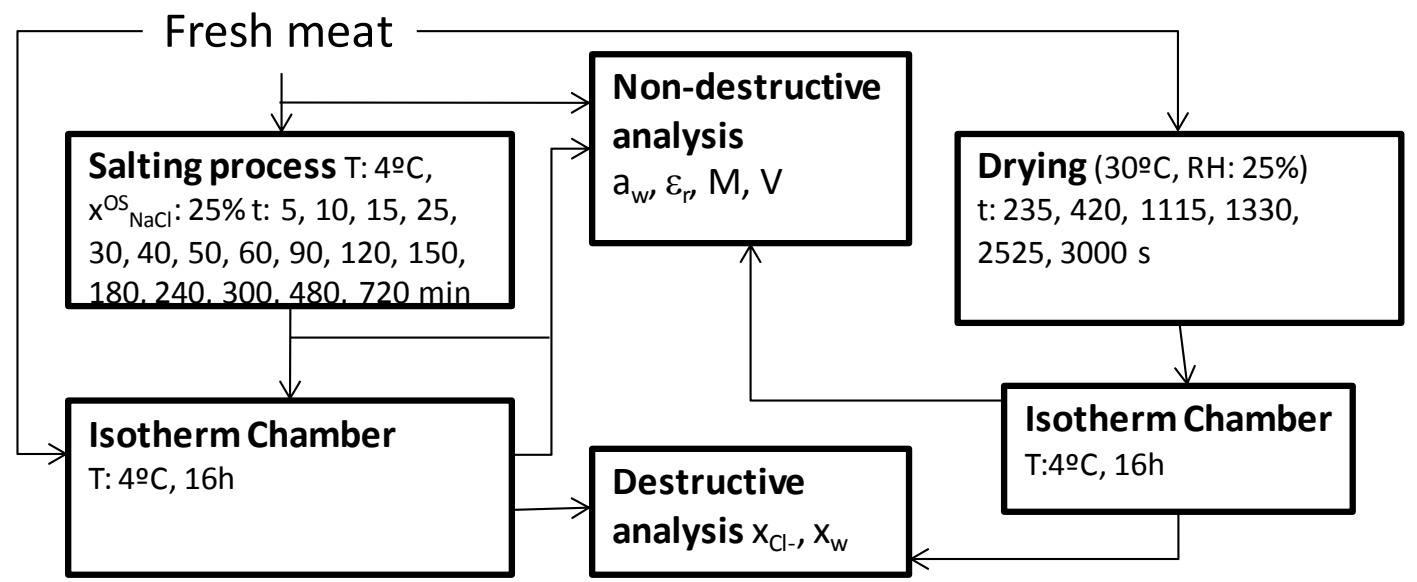

Figure 1. Experimental flowchart. 


\section{RESULTS AND DISCUSSION}

The salting operation in post-mortem muscle with chloride salt produce in muscle fibbers compression and relaxation behaviours [2]), this mechanism could be seen in the mass and volume variation, these variations could be estimated by next equations:

$$
\begin{array}{rlr}
\Delta \mathrm{M}^{\text {oh }} & =\frac{\mathrm{M}_{\mathrm{t}}^{\mathrm{oh}}-\mathrm{M}_{\mathrm{o}}}{\mathrm{M}_{\mathrm{o}}} & \text { (Equation 1) } \\
\Delta \mathrm{V}^{\mathrm{oh}}=\frac{\mathrm{V}_{\mathrm{t}}^{\mathrm{oh}}-\mathrm{V}_{\mathrm{o}}}{\mathrm{V}_{\mathrm{o}}} & \text { (Equation 2) }
\end{array}
$$

where $\mathrm{M}$ represents the mass $(\mathrm{kg}), \mathrm{V}$ the volume $(\mathrm{m} 3)$, the subscripts $\mathrm{t}$ is treatment time and 0 is initial value and superscript $\mathrm{Oh}$ is a value before treatment (not equilibrated).

Figure 2 shows the mass and volume variation though the osmotic treatment where is possible to observe and initial increment of mass and volume and a second step with losses of mass and volume. The initial increment of volume is related with the interaction between ion chloride and the myosin and the actin in the muscle fibers sites in the perimysium, the accumulation on anions produce repulsion in the actin-myosin system expanding the perimysium [3]. When the flux of chloride reach the interior of the fibbers is produced the same effect inside, producing a contraction of the fibbers with the myofibrillar proteins expansion [2].This behaviour produce weight and volume loss. First step calls "salting in" and second step calls "salting out" because in first step the relaxation produce a mechanical flux of the external fluid coming in the sample and in second step the contraction produce a mechanical flux of the internal fluid coming out the sample.

Thus, water and salt flux analysis are fundamental to understand the relaxation-compression behaviours. The water and salt fluxes promoted in the osmotic treatment can be calculated with the mass variation, the process time and the variation of the samples surface (see next equations) [4].

$$
\begin{array}{ll}
\mathrm{J}_{\mathrm{w}}^{0 \mathrm{~h}}=\frac{-\Delta \mathrm{M}_{\mathrm{w}}^{0 \mathrm{~h}} \cdot \mathrm{M}_{\mathrm{o}}}{\Delta \mathrm{t} \cdot \mathrm{S} \cdot \mathrm{Mr}_{\mathrm{w}}} & \text { (Equation 3) } \\
\mathrm{J}_{\mathrm{s}}^{\mathrm{Oh}}=\frac{\Delta \mathrm{M}_{\mathrm{s}}^{0 \mathrm{~h}} \cdot M_{o}}{\Delta \mathrm{t} \cdot \mathrm{S} \cdot \mathrm{Mr}_{\mathrm{s}}} & \text { (Equation 4) }
\end{array}
$$

Where, $\mathrm{J}$ is a flux $\left(\mathrm{mol} / \mathrm{s} \mathrm{m}^{2}\right), \Delta \mathrm{t}$ is the process time, $\mathrm{S}$ is the average measured surface of the sample during treatment $\left(\mathrm{m}^{2}\right), \mathrm{Mr}$ is the molecular weight of compound $(18 \mathrm{~g} / \mathrm{mol}$ for water and $58.4 \mathrm{~g} / \mathrm{mol}$ for sodium chloride), the subscripts w represents water and s salt.

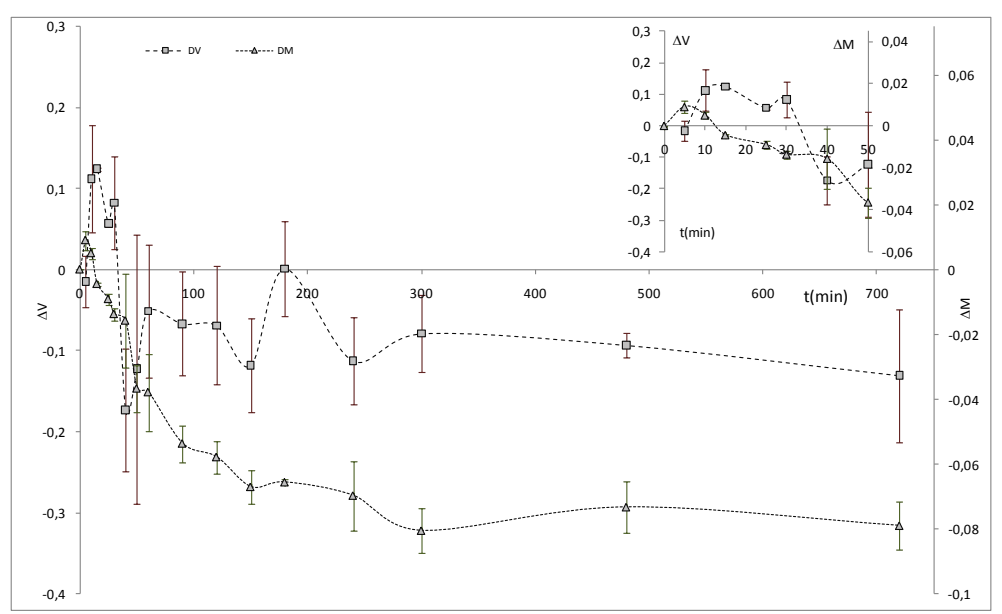

Figure 2. Weight and Volume variation by process time 
In figure 3 it is possible to observe the water and salt fluxes estimated with the equations 3 and 4 , expressed in molar quantity. Water flux is promoted by diffusional mechanisms (high gradient of water activities between salt solution and samples) and mechanical mechanisms (relaxation and compression of the samples tissue).

The molecular mobility of water and the ions $\left(\mathrm{Cl}^{-}\right.$and $\left.\mathrm{Na}^{+}\right)$must be related with the dielectric properties in range of microwaves [5]. Then water and solute interactions with the tissue and their reductions of motion could be analyzed with the dielectric properties also.

Figure 4 shows the variation of imaginary part of the permittivity (loss factor) at four frequency values covering the majority part of the microwaves range. Figure 4 mark with a discontinuous line the critical point when the salting in finish.

In the loss factor variation is possible to observe (see figure 4) a discontinuity of the tendency at the end of the salting in, higher when the frequency increase. It shows the possibility to control the effect of the tissue in the salting operation using the loss factor measures.

Figure 5 relates the molar water flux with the loss factor at $500 \mathrm{MHz}$, showing an excellent correlation; consequently it is possible to control the mass water loss and salt gained by dielectric measures, involved in a complex relation with the tissue. And therefore it is possible to control salting operation with dielectric measures.

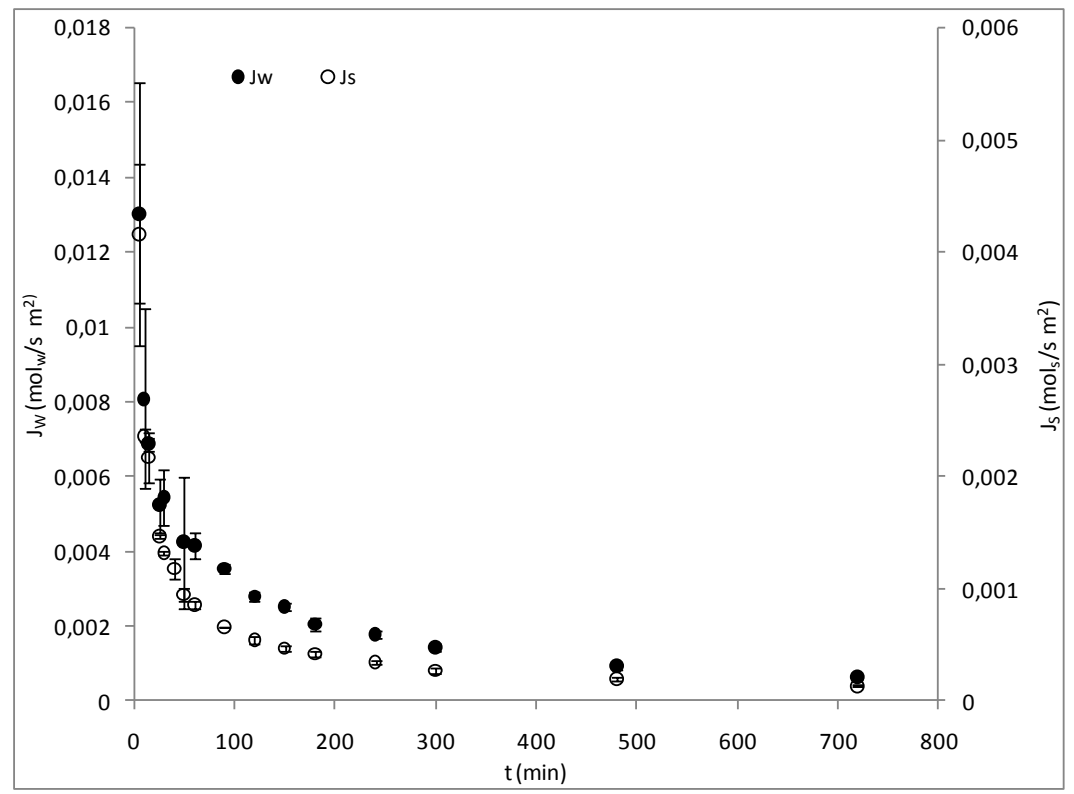

Figure 3. Salt and water distribution, left plot shows amount of water sharing out in liquid phase and adsorbed and right plot shows the among of sodium chloride sharing out in liquid phase and in interactions with the tissue. 


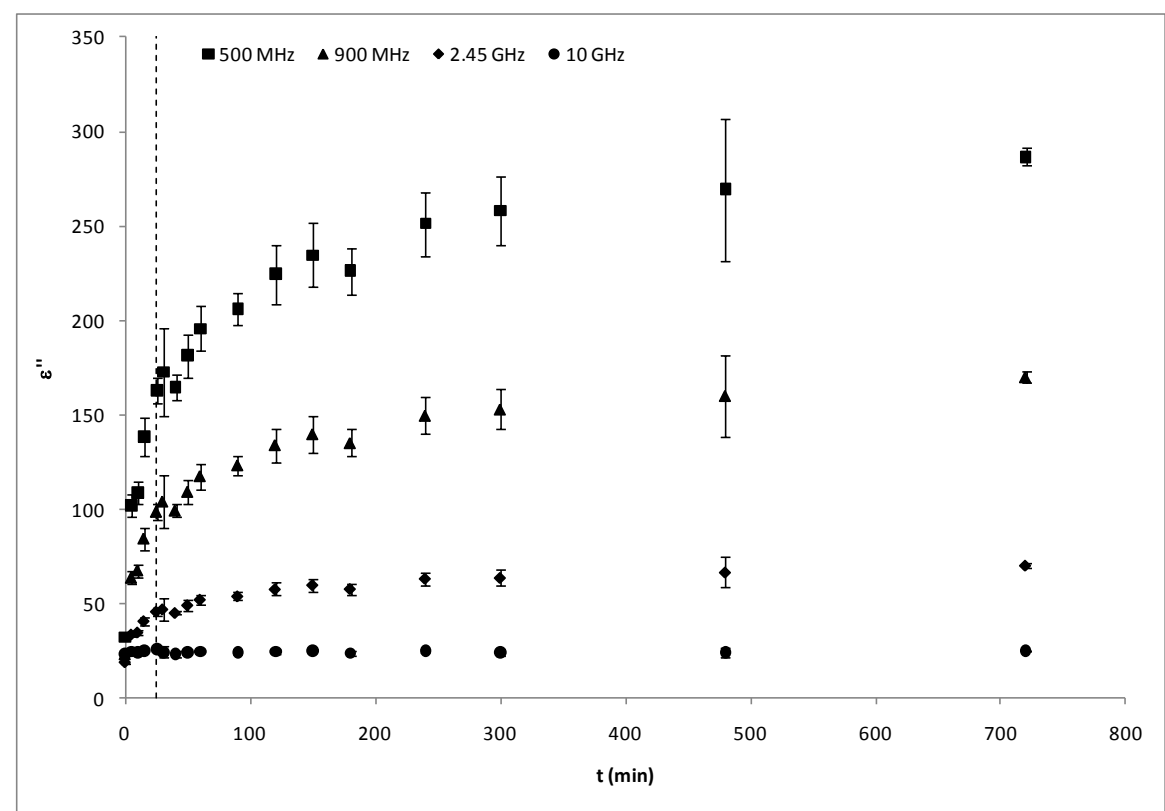

Figure 4. Loss factor variation at different frequencies through salting process.

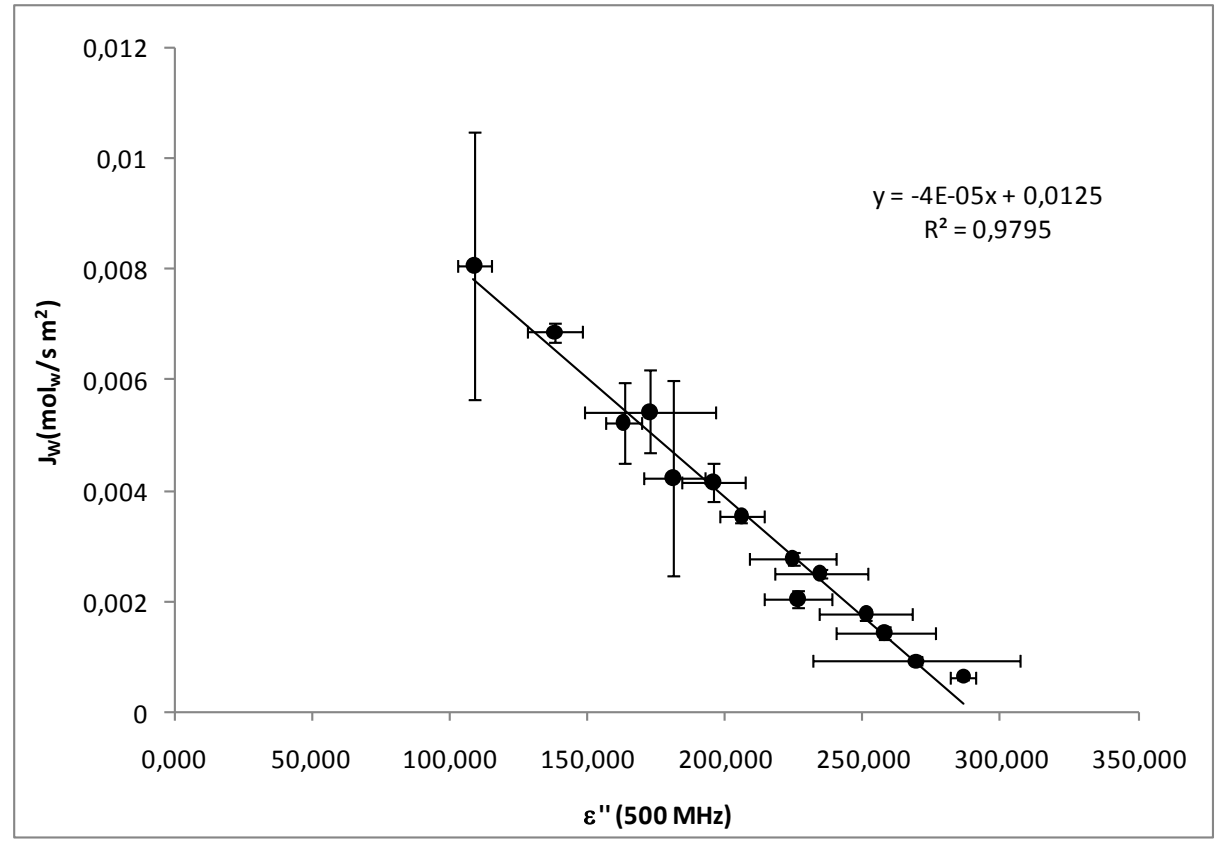

Figure 5. Relationship between water flux and loss factor at 500MHz. 


\section{CONCLUSIONS}

Dielectric properties can detect the different steps in the salting operation of meat; "salting in" and "salting out". These two steps are produced by the tissue interactions with the internal and external fluid, and the mechanism involves in mass transport are diffusional and mechanical. The overall flux of water, promoted by mechanical and diffusional behaviors, is predicted, with an excellence in the correlation, by dielectric measures at $500 \mathrm{MHz}$.

\section{REFERENCES}

[1] Castro-Giráldez, M; Fito, P J ; Toldrá, F ; Fito, P. 2008. "Physical sensors and techniques", in Handbook of Processed Meats and Poultry Analysis, Editores: Leo ML Nollet y Fidel Toldrá, CRC Press.

[2] Schmidt, F.C., Carciofi, B.A.M. and Laurindo, J. B. (2008), Salting operational diagrams for chicken breast cuts: Hydration-dehydration” Journal of food engineering vol:88 pp: 36-44

[3] Offer, G. and Cousin, T. (1999), The mechanism of drip production-formation of 2 compartments of extracellular space in muscle post-mortem, journal of science of food and agriculture vol: 58 pp 107-116

[4] Fito, P., Fito, P.J., Betoret, N., Argüelles, A., Chenoll, C. (2009), Thermodynamic Approach To Equilibrium Isotherms In Salted Structured Food, Journal of Food Process Engineering, Accepted. (on May, 2009)

[5] Metaxas A.C. and Meredith R.J. (1993), Industrial microwaves heating. IEEE Power engineering series 4. Peter Peregrinus LTD, London, UK 


\title{
THE DIELECTRIC PROPERTIES OF Biological Tissues: Parametric MODELS FOR THE DIELECTRIC SPECTRUM OF PORK MEAT
}

\author{
Castro-Giráldez, M. ${ }^{1}$, Fito, P.J. ${ }^{*}{ }^{*}$ Fidel Toldrá $^{2}$, Fito, P. $^{1}$ \\ ${ }^{1}$ Instituto Universitario de Ingeniería de Alimentos para el Desarrollo, Polytechnical University of Valencia, \\ Camino de Vera s/n, 46022 Valencia, Spain. \\ ${ }^{2}$ Instituto de Agroquímica y Tecnología de Alimentos (CSIC), PO Box 73, 46100 Burjassot (Valencia), Spain.
}

A parametric model was developed to describe the variation of dielectric properties of pork meat as a function of frequency. The experimental spectrum from $40 \mathrm{~Hz}$ to $20 \mathrm{GHz}$ was modeled with four dispersion regions. The purpose is to enable the prediction of dielectric data in biological tissue in order to use this model for controlling the meat quality in line. The analysis was carried out by using SPSS 15.012006 (SPSS Inc, Chicago, IL, U.S.A) for windows XP.

Keywords: Dielectric properties, dielectric spectra, meat quality, Cole-Cole dispersions

\section{INTRODUCTION}

The needs of developing techniques to control meat quality in Food Industry require the study of biological tissue relaxations when exposed to electromagnetic radiation and also the modeling of such relaxations by expressing its frequency dependence. This modeling provides useful information in order to obtain the dielectric properties of tissues at all frequencies of interest by measuring them only in a short range. Basing on the current state of knowledge about the dielectric properties of biological tissues, the present study describes the dielectric behavior of pork muscle after slaughter from $40 \mathrm{~Hz}$ to $20 \mathrm{GHz}$ in terms of four dispersion regions; the frequency dependence in each dispersion was expressed as a Cole-Cole term. This model can be used at all frequencies in the specified range in order to obtain the dielectric properties of the pork meat at the specified hours after slaughter for Red Firm and Non-exudative (RFN) meats. The real importance of this model is to obtain the complete spectrum of the sample leading to relevant information about the quality of the product by analyzing the relationship between dielectric and molecular parameters of the meat in a specified dispersion.

Dielectric behavior of biological material: Complex permittivity $\left(\varepsilon_{\mathrm{r}}\right)$ is the dielectric property which define the behavior of the tissue when is subjected to an electromagnetic field [1][2]. This property is defined by next equation: 


$$
\varepsilon_{\mathrm{r}}=\varepsilon^{\prime}-\mathrm{j} \cdot \varepsilon^{\prime} \quad(\text { Equation } 1)
$$

The real part of complex permittivity is called dielectric constant ( $\left.\varepsilon^{\prime}\right)$ and is related with the ability of the material to store electric energy. The imaginary part of the complex permittivity is called lost factor $\left(\varepsilon^{\prime \prime}\right)$ and is related to the dissipation of electric energy in other kinds of energy (e.g. thermal energy).

The dielectric properties of a biological tissue result from the interaction of electromagnetic radiation with its constituents at the cellular and molecular level. The dielectric constant of a tissue can reach values about up to $10^{6}$ or $10^{7}$ at frequencies below $100 \mathrm{~Hz}$ and it decreases at high frequencies in different steps known as dispersions [3]. Dispersion dependence with frequency allow to identifying different relaxation phenomena and to researching different relaxation phenomena. For this reason, the dielectric properties study has been important in biophysics and also in medicine, taking real importance in food engineering field lasts years [4].

The dielectric spectrum of a biological tissue is characterized by three main relaxation regions $\alpha, \beta$ and $\gamma$ at low, medium and high frequencies, and other minor dispersions such as the $\delta$ dispersion [5]. Each dispersion zone corresponds with a fall in polarizability at certain specific relaxation frequencies (Figure 1).

The $\gamma$-dispersion, which is located over $20 \mathrm{GHz}$, is due to the polarization of the free water molecules [5]. Foods present usually an important aqueous phase and for this reason water is the main component which contributes to the microwave food heating. The $\beta$-dispersion, which is located about hundred of $\mathrm{KHz}$, is due mainly to the cell membrane properties [3]. This phenomenon is typical of complex and heterogeneous foods, which present non-conducting regions surrounding conducting regions; so this phenomenon is due to the presence of material interfaces which are typical in biological tissues [7]. Other contributions to the $\beta$-dispersion come from the polarization of proteins and other organic macromolecules. The $\alpha$-dispersion, which is located between 0,1 and $10 \mathrm{kHz}$, is associated with ionic diffusion processes in cellular membrane [3]. Usually an additional dispersion region can be distinguished between the $\beta$ and $\gamma$ dispersion at around $0,1-1 \mathrm{GHz}$. This dispersion may be due to the partial orientation of polar side chains or to the bound water at the surface of macromolecules [8][9].

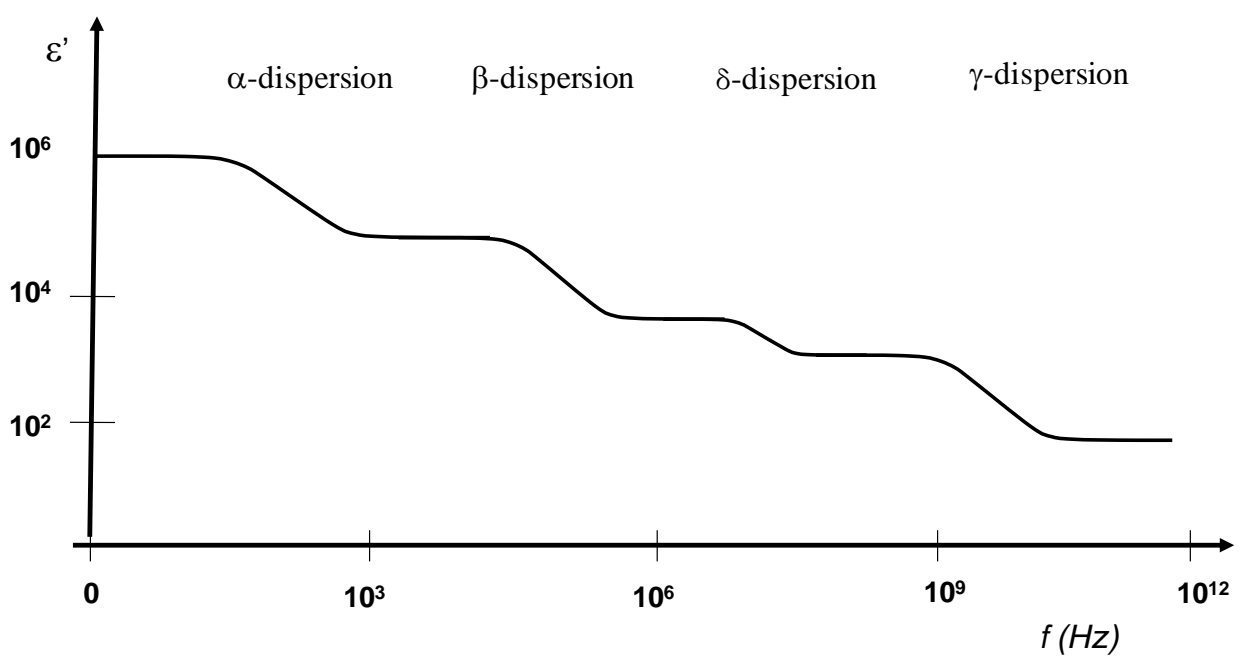

Figure 1. Dielectric spectrum of biological tissue with the four principal dispersion regions $(\alpha, \beta, \delta$ and $\gamma$ ) (Adapted from Grant, 1980) [6]. 
Model for the dielectric spectrum of biological tissue: pork meat samples: In its simplest form, each of these relaxation regions is due to a polarization mechanism characterized by a single time constant $(\tau)$ and which simplifying at maximum, can be defined by the following expression:

$$
\varepsilon_{r}=\varepsilon^{\prime}-j \varepsilon^{\prime \prime}=\varepsilon_{\infty}+\frac{\varepsilon_{s}-\varepsilon_{\infty}}{1+j \omega \tau}
$$

This equation corresponds with Debye model [10] which describes the dipole behavior in pure liquids. In the equation, $\varepsilon \infty$ is the permittivity at field frequencies where $\omega \tau>>1$, and $\varepsilon s$ is the permittivity at $\omega \tau<<1$. The magnitude of the dispersion corresponds with $\Delta \varepsilon=\varepsilon s-\varepsilon \infty$.

However, meat is a complex material due to its structure and composition and, for this reason, it is better model similar to biological tissue. It was demonstrated that dielectric spectra of biological material can be model by the summation of four Cole-Cole dispersions in addition to a conductivity term in which $\sigma$ i corresponds to the ionic conductivity and $\varepsilon 0$ is the permittivity of free space [11][12] (Equation 3).

$$
\varepsilon(w)=\varepsilon_{\infty}+\sum \frac{\Delta \varepsilon_{n}}{1+\left(j \omega \tau_{n}\right)^{\left(1-\alpha_{n}\right)}}+\frac{\sigma_{i}}{j \omega \varepsilon_{0}}
$$

(Equation 3)

This expression can be used to model pork meat spectra with a choice of parameters appropriate to this kind of tissue. This model can be used to predict the dielectric behavior of meat over the desired frequency range.

\section{MATERIAL AND METHODS}

Raw material: 20 pigs (Ladrance x Duroc, 16 males and 10 females) were slaughtered in a commercial slaughterhouse located near the Institute of Food Engineering for Development. Carcasses were rapidly chilled at $-10^{\circ} \mathrm{C}$ for $45 \mathrm{~min}$ and the L.Dorsi muscle removed. The muscle was kept at $4^{\circ} \mathrm{C}$ until sampled.

Sample preparation: $\mathrm{pH}$ was measured in pork loins at 24 hours post-mortem. At the same time, colour measurements were made in slices $(\mathrm{L}=2 \mathrm{~cm})$.

Three cubes of each loin $(\mathrm{L}=3 \mathrm{~cm})$ were used to the dielectric spectra measurement with the coaxial probe Agilent 85070E connected to a Vector Network Analyser Agilent E8362B. The fiber direction was correctly identified and meat samples were introduced in metacrilate cubes to avoid superficial dehydration and maintained in a $4^{\circ} \mathrm{C}$ chamber. Dielectric spectra were measured at $12 \mathrm{~h}$ post mortem in the direction of the fibers. Dielectric spectra were measured ten times on each direction, on different regions of the meat sample. For every time, three different cubes of the pork loin were used. During measurements, temperature was kept at a controlled $4{ }^{\circ} \mathrm{C} \pm 1{ }^{\circ} \mathrm{C}$.

Six slices $(\varnothing=4.6 \mathrm{~cm}, \mathrm{~h}=0.3 \mathrm{~cm})$ were sliced for the dielectric spectra measurements with the parallel plate Agilent 16451B connected to an Impedance Analyser Agilent 4194A. Three slices were cut in the direction of the fibers. These measurements were also made at $4{ }^{\circ} \mathrm{C} \pm 1{ }^{\circ} \mathrm{C}$ at $12,24,48 \mathrm{~h}$ and 7 days post mortem. .

Technological Quality Analysis: Samples $\mathrm{pH}$ was measured through a portable $\mathrm{pH}-\mathrm{meter}$ CRISON PH25®. Drip loss was determined by the method of Honikel (1998) [13]. The color of the samples 
was measured through the surface reflectance spectra in a spectrocolorimeter Minolta CM-1000R. The colour co-ordinates CIE L*a*b* and the reflectance spectra between 400 and $700 \mathrm{~nm}$ for D65 illuminant and $10^{\circ}$ observer were obtained.

\section{Dielectric properties measurement}

Coaxial Probe Measurements: The system used to measure dielectric properties consists of an Agilent 85070E open-ended coaxial probe connected to an Agilent E8362B network analyzer. The software of the network analyzer calculates the dielectric constant and loss factor as a reflected signal function. For these measurements the probe was fixed to a stainless steel support, and an elevation platform brings the sample near the probe to avoid possible phase changes due to cable movements after calibration.

The system was calibrated by using three different types of loads: open circuit (air), short-circuit and $25{ }^{\circ} \mathrm{C}$ distilled water. Once the calibration was made, $25^{\circ} \mathrm{C}$ distilled water was measured again to check calibration suitability.

For deformable solids (pork loin), the dielectric properties were measured by attaching the probe to the surface of the samples. Dielectric spectra of meat samples were measured following the direction of the fibers avoiding fat phase of the meat. The Mean values of ten replicates of the pork loin samples are reported in this article. All determinations were made at $4{ }^{\circ} \mathrm{C}$ from $500 \mathrm{MHz}$ to $20 \mathrm{GHz}$.

Parallel Plate Measurements: The system used to measure dielectric spectra at low frequencies consists of an Agilent 16451B parallel plate fixture connected to an Agilent 4194A impedance analyzer. It was used the electrode A of the fixture, which has a $38 \mathrm{~mm}$ guarded/guard electrode. The diameter of the samples used was $46 \mathrm{~mm}$ and the thickness was $3 \pm 1 \mathrm{~mm}$. It was used the contacting electrode method, which consist in setting the sample between the electrodes (Figure 2).

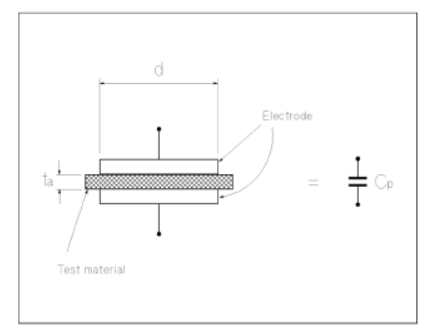

Figure 2. Scheme of the contacting electrode method (Agilent Technologies, 2000).

The dielectric properties were measured by performing an OPEN/SHORT correction.

Dielectric spectra of meat samples were measured in the direction of the fibers. The Mean values of three replicates of the pork loin samples are reported in this article. All determinations were made at $4{ }^{\circ} \mathrm{C}$ from $40 \mathrm{~Hz}$ to $10^{6} \mathrm{~Hz}$.

The software of the impedance analyzer calculates the capacitance $\left(C_{P}\right)$ and dissipation factor (D) and then the dielectric constant $\left(\varepsilon^{\prime}\right)$ and Dissipation factor $\left(D_{t}\right)$ of test material were calculated by using the following equations: 


$$
\begin{gathered}
\varepsilon^{\prime}=\frac{t_{a} \times C_{p}}{\pi \times\left(\frac{d}{2}\right)^{2} \times \varepsilon_{0}} \quad \text { (Equation 4) } \\
D_{t}=D=\tan \delta \quad \text { (Equation 5) }
\end{gathered}
$$

Where, $\varepsilon^{\prime}$ : Dielectric constant; D: Dissipation factor; $\mathrm{D}_{\mathrm{t}}$ : Dissipation factor of the test material; $\tan \delta$ : loss tangent; $\mathrm{C}_{\mathrm{p}}$ : Equivalent parallel capacitance $(\mathrm{F}) ; \mathrm{t}_{\mathrm{a}}$ : Sample thickness $(\mathrm{m})$; A: Area of Guarded electrode $\left(\mathrm{m}^{2}\right)$; d: Diameter of Guarded electrode $(\mathrm{m})\left[38 \times 10^{-3} \mathrm{~m}\right] ; \varepsilon_{0}=8.854 \times 10^{-12}(\mathrm{~F} / \mathrm{m})$

\section{RESULTS AND DISCUSSION}

The pork loins were classified as RFN (Red Firm and Non-exudative) meats based on pH at 24 hours post-mortem, $\mathrm{L}^{*}$ value, and drip loss.

Modeling the dielectric spectra from $40 \mathrm{~Hz}$ to $20 \mathrm{GHz}$ of $\mathrm{RFN}$ meats: The dielectric data were fitted by using four Cole and Cole dispersions in addition to an ionic conductivity term as was showed in equation 3 , separating into real and imaginary parts.

The figures 3 and 4 show a graphical prediction of the model applied to 20 meat samples together with the corresponding experimental measurements. In the figures the dielectric constant and loss factor spectra of tissues are presented (Figures 3 and 4, respectively). The model parameters used to generate the graphs in these figures are given in table 1.

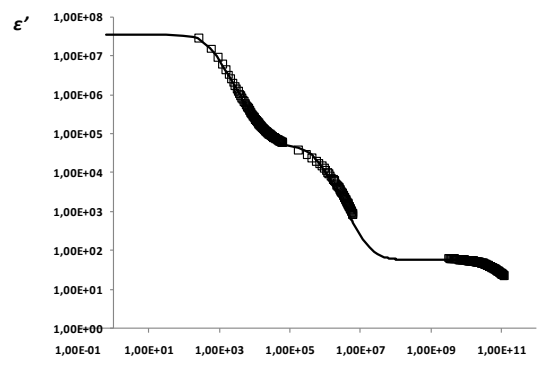

Figure 3. Dielectric constant spectrum of pork muscle (longissimus dorsi), where the experimental data are represented by $\square$. The continue line represent the fit of the model by using a summation of four Cole\&Cole dispersions. Measurements were made at $4^{\circ} \mathrm{C}$. 


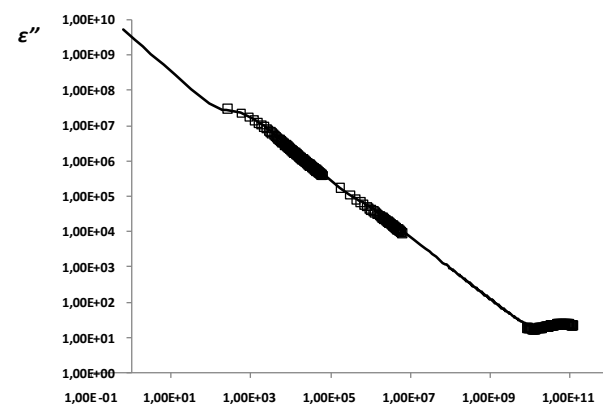

$f(\mathrm{~Hz})$

Figure 4. Loss factor spectrum of pork muscle (longissimus dorsi), where the experimental data are represented by $\square$. The continue line represent the fit of the model by using a summation of four Cole\&Cole dispersions. Measurements were made at $4^{\circ} \mathrm{C}$.

Table 1. Parameters of the model for muscle tissue (pork meat) measured in the direction of the fibers at $4^{\circ} \mathrm{C}$.

\begin{tabular}{|l|l|}
\hline $\begin{array}{l}\text { Model } \\
\text { parameters }\end{array}$ & \\
\hline $\boldsymbol{\varepsilon}_{\infty}$ & 4 \\
\hline$\Delta \boldsymbol{\varepsilon}_{\mathbf{1}}$ & 56 \\
\hline $\boldsymbol{\tau}_{\mathbf{1}}(\mathbf{p s})$ & 8,83 \\
\hline $\boldsymbol{\alpha}_{\mathbf{1}}$ & 0,05 \\
\hline$\Delta \boldsymbol{\varepsilon}_{\mathbf{2}}$ & 51000 \\
\hline $\boldsymbol{\tau}_{\mathbf{2}}(\mathbf{p s})$ & 1,94 \\
\hline $\boldsymbol{\alpha}_{\mathbf{2}}$ & 0,08 \\
\hline $\boldsymbol{\sigma}_{\mathbf{i}}$ & 0,03 \\
\hline$\Delta \boldsymbol{\varepsilon}_{\mathbf{3}}$ & 1,5 \\
\hline $\boldsymbol{\tau}_{\mathbf{3}}(\mathbf{p s})$ & 378,31 \\
\hline $\boldsymbol{\alpha}_{\mathbf{3}}$ & 0,07 \\
\hline$\Delta \boldsymbol{\varepsilon}_{\mathbf{4}}$ & $3,50 \mathrm{E}+07$ \\
\hline $\boldsymbol{\tau}_{\mathbf{4}}(\mathbf{p s})$ & 2 \\
\hline $\boldsymbol{\alpha}_{\mathbf{4}}$ & 0 \\
\hline & \\
\hline
\end{tabular}

\section{CONCLUSIONS}

A model simulating four Cole-Cole dispersions has been used to describe the frequency dependence of the dielectric properties in the frequency range from $\mathrm{Hz}$ to $\mathrm{GHz}$ as Gabriel et al did in 1996 for different tissues. Other term was added in the loss factor spectra for including the ionic conductivity losses. The predictions of the model can be used with confidence in the whole frequency range for RFN meat samples. This model can be useful in order to control meat quality on line by using dielectric properties measurements. 


\section{REFERENCES}

[1] Datta, A.K.and Anantheswaran, R.C. (2001). "Handbook of Microwave Technology for Food Applications". A.K. Datta and R.C. Anantheswaran Eds., Marcel Dekker, New York, pp.355-395.

[2] Metaxas, A.C. and Meredith, R.J. (1993). "Industrial Microwave Heating". IEE Power Engineering series 4, Peter Peregrinus LTD, London, UK.

[3] Gabriel, C., Gabriel, S. and Corthout, E. (1996a). "The dielectric properties of biological tissues: I. Literature survey". Physics in Medicine and Biology. 41(11):2231-2249.

[4] Feldman, Y., Ermolina, I. and Hayashi, Y. (2003). "Time domain dielectric spectroscopy study of biological systems". IEEE Transactions on Dielectrics and Electrical Insulation. 10(5):728-753.

[5] Gabriel, C. (2006). "Dielectric properties of biological materials". In Bioengineering and biophysical aspects of electromagnetic fields, Handbook of biological effects of electromagnetic fields, third edition. F.S. Barnes and B. Greenebaum Eds., CRC Press, Boca Raton (U.S.A.).

[6] Grant, E.H. (1980). "Biological effects of radiowaves and microwaves". Physical Technology. 11:99-104.

[7] Foster, K.R. and Schwan, H.P. (1996). "Dielectric properties of tissues“, in Handbook of Biological Effects of Electromagnetic Fields. Editors: Charles Polk and Elliot Postow, CRC Press, second edition, U.S.A., pp.25-102.

[8] Foster, K.R. and Schwan, H.P. (1986). "Dielectric properties of tissues-a review“, in Handbook of Biological Effects of Electromagnetic Radiation. Editors: Charles Polk and Elliot Postow, CRC Press, U.S.A., pp.27-96.

[9] Grant, E.H., Sheppard, R.J. and South, G.P. (1978). "Dielectric Behaviour of Biological Molecules in Solutions". Oxford University Press, Oxford.

[10] Debye, P. (1929). "Polar molecules". The Chemical catalogue Co. New York. E.E.U.U.

[11]El-Lakkani, A. (2001). "Dielectric response of some biological tissues". Bioelectromagnetics. 22:272-279.

[12] Gabriel, S., Lau, R.W. and Gabriel, C. (1996b). "The dielectric properties of biological tissues: III. Parametric models for the dielectric spectrum of tissues". Physics in Medicine and Biology. 41(11): 2271-2293.

[13] Honikel, K.O. (1998). Reference methods for the assessment of physical characteristics of meat. 49(4):447-457. 



\title{
USE OF THE DIELECTRIC SPECTROSCOPY TO CONTROL THE SUGARS VITREOUS FORMATION IN AZAHAR HONEY
}

\author{
Fito, P.J.*; Castro-Giráldez, M.; Chenoll,C.; Visquert, M.; Domenech, E.; \\ Escriche, I.; Fito, P.
}

Instituto Universitario de Ingeniería de Alimentos para el Desarrollo, Polytechnical University of Valencia, Camino de Vera s/n, 46022 Valencia, Spain.

\begin{abstract}
One of the most important quality problems in the honey industry is the sugar vitreous solids (fructose and glucose) formation, forcing industry to apply a heat operation to eliminate these vitreous but increasing the HMF (hydroxy-methyl-furfural) production. Dielectric properties of honey are strongly related to its structure and composition: aggregation state changes of sugars, moisture, water activity, amount of dissolute sugars, ion content. Thus, dielectric properties measurement appears as a promising method in non-destructive and on-line control of heat treatment in honey.

Dielectric spectra were measured in the frequency range $500 \mathrm{MHz}-20 \mathrm{GHz}$ by a coaxial probe (Agilent 85070E) connected to a Network Analyzer (Agilent E8362B) in: vitreous honey and heated at different temperatures reaching $80^{\circ} \mathrm{C}$ (liquid honey). Same samples (vitreous and treated honey) have been analyzed by DSC (differential scanning calorimetry), water activity by hygrometry (Decagon Aqualab $x-2$ ), HMF content (spectrophotometric scanning at 240-350 nm) and sugar content by refractometry (ABBE Atago).

Vitreous transitions has been determinated by DSC and by the water activity evolution, showing in the loss factor spectra variation through heat treatment two stages, below $50^{\circ} \mathrm{C}$ the vitreous degradation and over $50^{\circ} \mathrm{C}$ the $H M F$ production. Thus dielectric measures can be a good method to determine the heat treatment minimizing the HMF production.
\end{abstract}

Keywords: Dielectric properties, dielectric spectra, honey crystallization, sugars vitreous

\section{INTRODUCTION}

Honey is natural complex food product composed by sugars (mainly glucose and fructose in the same proportion), organic acids, various amino acids and many biologically active compounds. It is produced by bees from nectar of plants and also from honeydew [1]. From this definition it can be affirmed that honey is a heterogeneous product which may be studied in order to optimize its processing. On the other hand, the society is demanding high quality food

products and, for this reason, honey industry needs to be modernized for competing in market with good guarantees. This modernization includes improvements at processing level diminishing the losses that currently must assume the sector. Therefore, the economic development of apicultural sector needs innovation and technological transference.

Honey is processed by submitting to thermal treatments $\left(78-85^{\circ} \mathrm{C}, 2-8 \mathrm{~min}\right)$ in order to liquefy and delay its natural tendency to crystallization, to reduce viscosity, and also to destroy microorganism which can contaminate it [2]. This treatment affects negatively to honey quality which can be evaluated by diastase index (ID) and Hydroxymethylfurfural content (HMF). Low values of ID or high values of HMF reflect an excessive heat treatment or a prolonged storage. HMF can be formed by hexose dehydration in acid media or by the Maillard reaction [3][4][5]. Its maximum value is 
established by Codex Alimentarius (Alinorm 01/25 2000) in 80mg/kg after processing. On the other hand, The European Union (EU Directive 110/2001) fixed a HMF limit in honey of $40 \mathrm{mg} / \mathrm{kg}$.

Dielectric spectroscopy is currently used in food industry to control of products and processes. This technique is based in the interaction of electromagnetic energy with food constituents at molecular and structural level [6]. Moisture, water activity, sugar content and complex molecules are determinant factors which influence the dielectric properties of the food; for this reason, dielectric spectroscopy can be used to control industrial processes and products. Moreover, the use of dielectric spectra in a wide range of frequencies has some advantages with regard to traditional control methods. The most important is the possibility of applying the sensor on line and the fact that is nondestructive method. More concretely, the application of dielectric properties in apicultural sector present lots of applications, being necessary to extend the knowledge in this field.

\section{MATERIAL AND METHODS}

Raw material was azahar honey solidified by freezing, heated in tubes immersed in a stirred oil bath at $85^{\circ} \mathrm{C}$, and analyzed following the experimental diagram flow shown in figure 1. Dielectric spectra were measured at $25^{\circ} \mathrm{C}$ in the frequency range $500 \mathrm{MHz}-20 \mathrm{GHz}$ by a coaxial probe (Agilent $85070 \mathrm{E}$ ) connected to a Network Analyzer (Agilent E8362B) in: vitreous honey and heated at different temperatures reaching $80^{\circ} \mathrm{C}$ (liquid honey). Same samples (vitreous and treated honey) were analyzed by DSC (differential scanning calorimetry), water activity by hygrometry (Decagon Aqualab x-2), HMF content (spectrophotometric scanning at 240-350 $\mathrm{nm}$ ) and sugar content by refractometry (ABBE Atago).

Thermal diffusivity was estimated using the solution of Fick's law proposed by Crack [7] exposed in equation 1 .

$$
1-\frac{T_{e}-T_{t}}{T_{e}-T_{0}}=4\left(\frac{\alpha \cdot t}{\pi \cdot r^{2}}\right)^{1 / 2}
$$

(equation 1)

were $T_{e}$ is the bath temperature, $T_{t}$ is the temperature of sample at treatment time, $T_{0}$ is the initial temperature of sample, $\alpha$ is the thermal diffusivity and $\mathrm{r}$ is the tube radio (see figure 1 ).

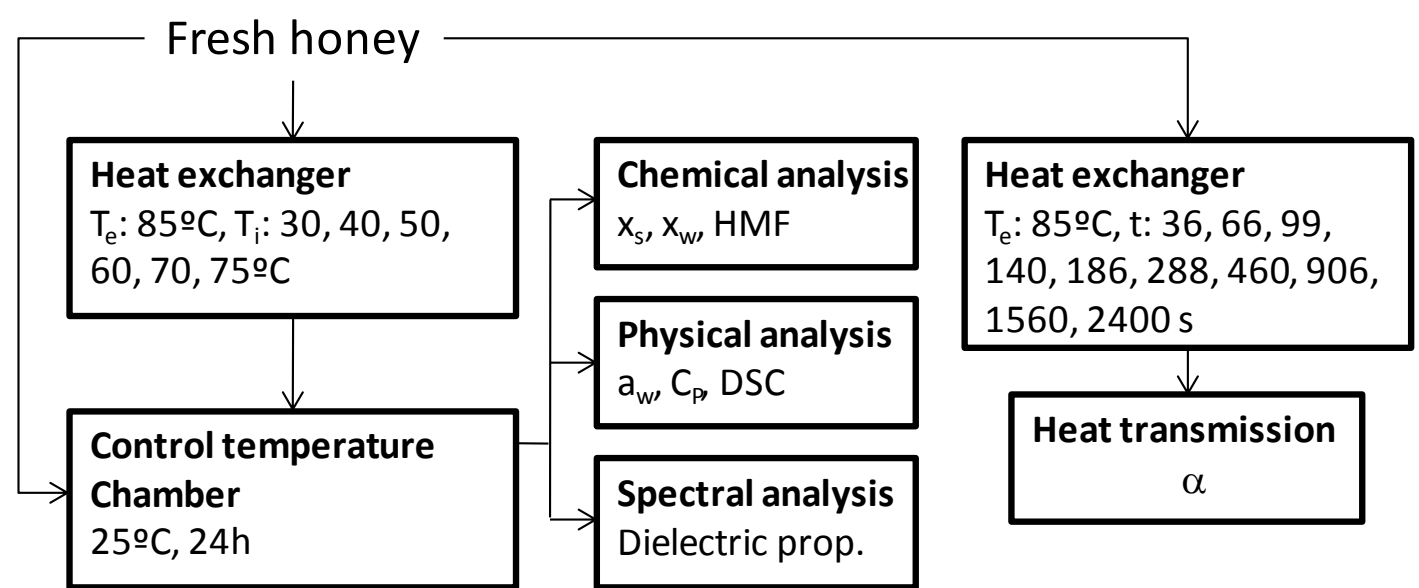

Figure 1. Experimental diagram flow. 


\section{RESULTS AND DISCUSSION}

Solid honey was heated in tubes immersed in a stirred oil bath at $85^{\circ} \mathrm{C}$ at different times as explained in Material and Methods, following the parameters used in the industrial process to liquefy the solid honey. Treated and raw samples were analyzed by differential scanning calorimetry (DSC) (see figure $2 \mathrm{~b}$ ). Figure $2 \mathrm{a}$ shows the fresh honey with a typical curve of vitreous behavior [8]. In figure $2 \mathrm{c}$ it is possible to observe how the vitreous curves were reducig, reaching the minimum curve at $50^{\circ} \mathrm{C}$ and disappearing above it (see figure $2 \mathrm{~d}$ ).

Thus, solid honey is a subfreezing liquid and in the honey liquefying operation in the industrial process the vitreous glasses are eliminated.

The subfreezing process is a thermodynamic behavior guided, in this isothermal case, by the water activity reduction. The low molecular mobility (high viscosity) promotes the heterogeneity of the media, allowing the vitreous formation and liquid solution with higher water activity than the average value. The hygrometer obtain the water activity value of the liquid phase of honey, these values are shown in figure 3.

Specific Heat was calculated with the initial slope of the DSC curves (see figure 2), in fresh and treated samples, and thermal diffusion was estimated using the equation 1, they are shown in figure 4, where it is possible to observe two tendencies; below $50^{\circ} \mathrm{C}$ an increment of thermal diffusion caused by the increment of the temperature and a reduction of the specific heat caused by the reduction of the water activity. Above $50^{\circ} \mathrm{C}$ a reduction of thermal diffusion and an increment of the specific heat, this variation could be produced by a chemical change in the honey composition. At $25^{\circ} \mathrm{C}$, fresh honey, the Hydroxymethylfurfural content was $4.8 \pm 0.5 \mathrm{mg} / \mathrm{kg}$, the treated honey at $45^{\circ} \mathrm{C}$ was $6.0 \pm 0.6 \mathrm{mg} / \mathrm{kg}$ and at $75^{\circ} \mathrm{C} 8.5 \pm 0.8 \mathrm{mg} / \mathrm{kg}$ and at $80^{\circ} \mathrm{C} 11 \pm 1 \mathrm{mg} / \mathrm{kg}$, these data shows the increment in the $\mathrm{HMF}$ production through the heat treatment and the chemical variation of the honey composition. HMF structure is shown in figure 4.
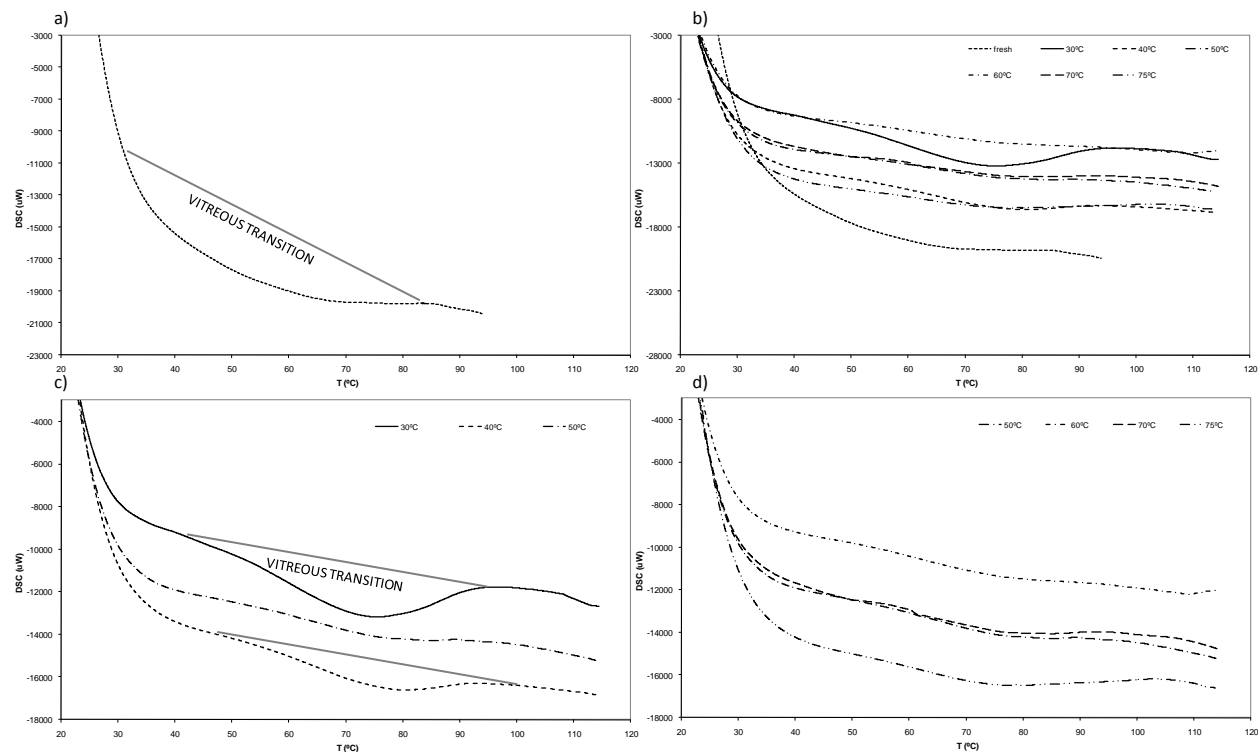

Figure 2. Structural analysis of fresh and treated samples by differential scanning calorimetry (DSC).a) fresh honey (solid); b) treated and fresh samples; c) fresh and treated samples with vitreous curve behavior; d) treated samples without vitreous behavior. 


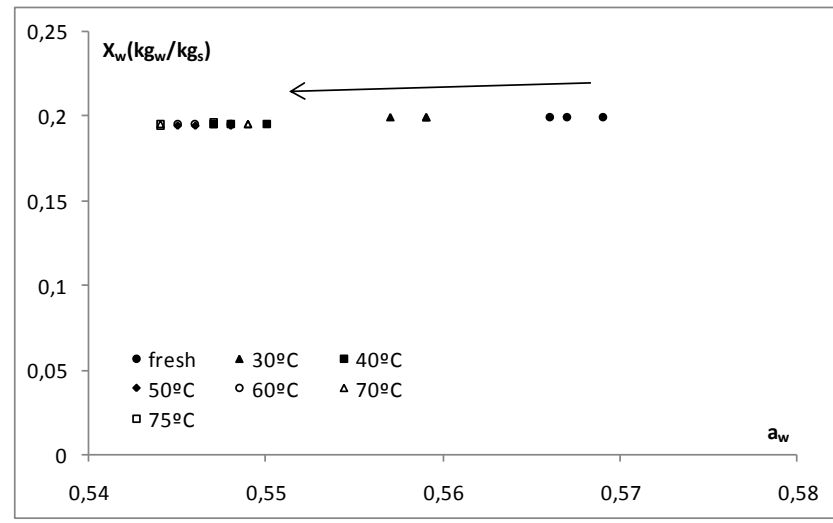

Figure 3. Relation between water content and water activity through the heat treatment.

Loss factor and dielectric constant in frequency range of $500 \mathrm{MHz}$ to $20 \mathrm{GHz}$ are shown in figure 5, where is possible to observe in left plot how decrease the signal when increase the treatment temperature. In Figure 6 it is possible to observe, in right plot, the variation of loss factor and the dielectric constant at $500 \mathrm{MHz}$, where both parameters decreases when the temperature treatment increase below $50^{\circ} \mathrm{C}$. The same thing occurs in the water activity (see fig. 5, left plot). Loss factor and dielectric constant decrease because the motion of the water molecules is reduced with the heat treatment and, as explain figure 2. It is occurred because the heterogeneous system, full of vitreous nucleus (with low water activity) involves in liquid solution (with high water activity), a system with high viscosity and low capacity to reach the thermodynamic equilibrium, change with the heat treatment, reducing the viscosity, and reaching the thermodynamic equilibrium in a homogeneous system, with lower water activity resultant.

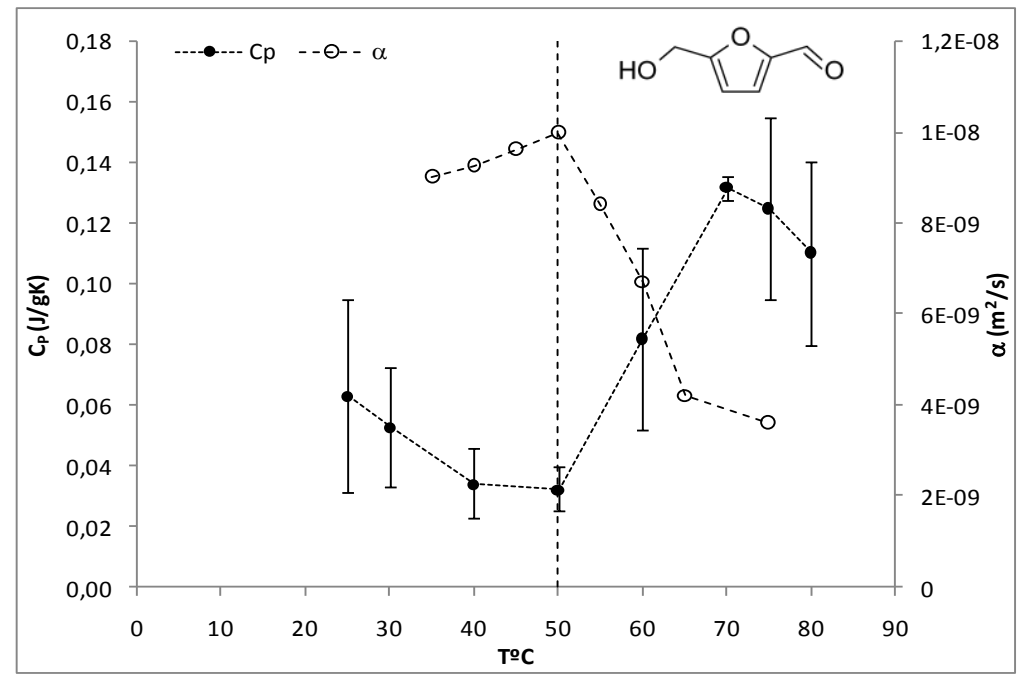

Figure 4. Specific Heat and thermal diffusion at different heat treatments. 


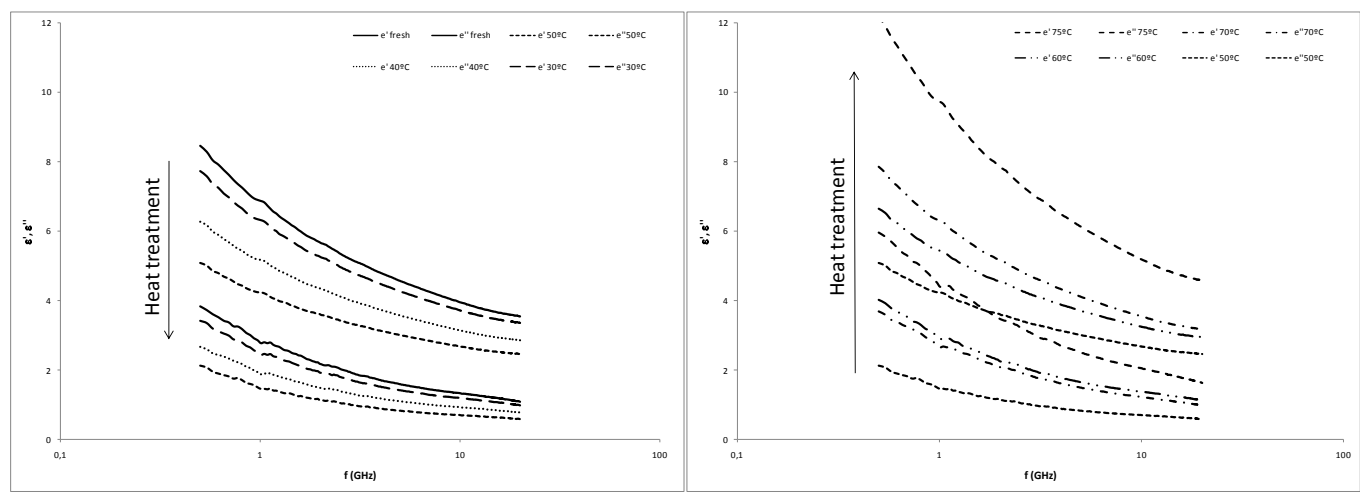

Figure 5. Dielectric spectra. Left plot shows the dielectric spectra of samples fresh and treated below 50 ㅇ $\mathrm{C}$ and Right plot shown the dielectric spectra of samples treated above 50 ㅇ.

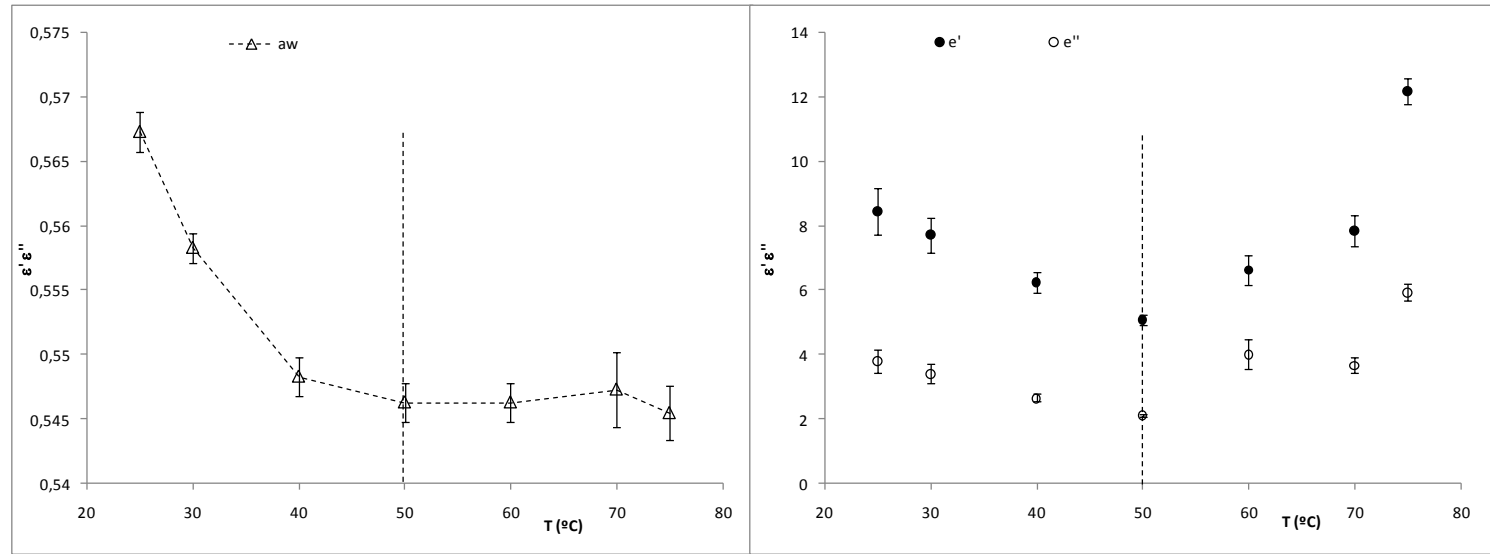

Figure 6. Left plot shows the water activity variation and right plot shows the dielectric constant and the loss factor at $500 \mathrm{MHz}$ of frequency, analyzed at $25 \% \mathrm{C}$.

Above $50^{\circ} \mathrm{C}$, the water activity is constant with the heat treatment but the dielectric properties increase, changing the tendency, it occurs because (as explained in figure 4) the chemical composition of samples change, with the fructofuranose degradation to generate HMF.

\section{CONCLUSIONS}

Solid honey is a subfreezing liquid and in the honey liquefying operation in the industrial process the vitreous glasses are eliminated. Initially the heterogeneous system full of vitreous nucleus (with low water activity) involves in liquid solution (with higher water activity) in a system with high viscosity and low capacity to reach the thermodynamic equilibrium, change with the heat treatment, reducing the viscosity, and reaching the thermodynamic equilibrium in a homogeneous system with lower water activity resultant. It occurs below $50^{\circ} \mathrm{C}$ and the dielectric properties, in this frequency range, detect this behaviour. Above $50^{\circ} \mathrm{C}$ the HMF production changes the chemical composition of honey increasing the signal of the media. 


\section{REFERENCES}

[1] Ahmed J., Prabhu S.T., Raghavana, G.S.V. and Ngadi, M. (2007). "Physico-chemical, rheological, calorimetric and dielectric behavior of selected Indian honey". Journal of Food Engineering. 79(4), pp. 1207-1213.

[2] Singh N., Singh S., Bawa A.S. and Sekhon K.S. (1988) "Honey-its food uses". Indian Food Packer. 42, pp. 15-25.

[3] Feather, M. S., Harris, D. W. and Nichols, S. B. (1982). "Routes of conversion of D-xilose, hexouronics acids and L-ascorbic acid to 2-furaldehyde". Journal of Organic Chemistry. 37, pp.1600-1606.

[4] Hoseney, R. C. (1984). "Chemical changes in carbohydrates produced by thermal processing". Journal of Chemical Education. 61, pp. 308-312.

[5] Belitz, H.D. and Grosch W. (1999). Food Chemistry. Berlin; Springer-Verlag,

[6] Castro-Giráldez M., Fito, P.J., Fito, P. and Toldrá, F. (2008) "Physical sensors and techniques". Handbook of Processed Meats and Poultry Analysis, Ed: Toldra and Nollet, CRC Press, pp. 735.

[7] Crank, J. (1975). "The mathematics of the diffusion". Ed, Clarendon Press, Oxford, U.K

[8] Mathlouthi, M. and Reiser P. (1995). "Sucrose: properties and applications". Chapman \& Hall, London UK. 


\title{
Relationship among water, sucrose and cell structure of kiwifruit (Actinidia deliciosa var. Hayward) during the osmotic dehydration
}

\author{
Tylewicz, U.1 , Fito, P.J. ${ }^{2 *}$, Castro-Giráldez, M. ${ }^{2}$, Fito P. ${ }^{2}$, Dalla Rosa, M. ${ }^{1}$ \\ ${ }^{1}$ Department of Food Science, Alma Mater Studiorum, University of Bologna, Piazza Goidanich 60, 47023 Cesena (FC), Italy. \\ ${ }^{2}$ Institute of Food Engineering for Development, Department of Food Technology, Universidad Politécnica de Valencia, España.
}

\begin{abstract}
The shelf life of kiwifruit is short and requires conservation techniques to enhance its commercial life. In this sense, modern techniques to analyze the changes of the product through the treatment, allow to develop a new product with specific characteristics required. In this work, the structural and physico-chemical changes of kiwifruit through the osmotic dehydration treatment with $61,5 \%(\mathrm{w} / \mathrm{v})$ sucrose solution at short times from 0 to 300 minutes were explained.

SAFES model (Systematic Approach in Food Engineering Systems) applied in kiwifruit allows obtaining the internal composition of each phase, controlling the fruit changes and determines the behaviours involved in transports. Moreover the evaluation of Gibbs free energy, enthalpy and the entropy of each phase was done in order to analyze the irreversibility of the process.
\end{abstract}

Keywords: kiwifruit, osmotic dehydration, SAFES 



\begin{tabular}{|c|c|c|c|}
\hline \multicolumn{4}{|c|}{ Nomenclature } \\
\hline G & Gibbs free energy, (J) & \multirow[t]{6}{*}{$M_{n, n-1}$} & \multirow{2}{*}{$\begin{array}{l}\text { Descriptive matrix of product flowing out of the } \\
\text { stage of change } n \text { referred to the strain } n-1\end{array}$} \\
\hline S & Entropy, $(\mathrm{J} / \mathrm{mol} \mathrm{K})$ & & \\
\hline $\mathrm{V}$ & Volume, $\left(\mathrm{m}^{3}\right)$ & & considering the overall mass in the system equal \\
\hline $\mathrm{P}$ & Absolute pressure, (atm) & & to $\mathrm{m}_{\mathrm{n}} / \mathrm{m}_{\mathrm{n}-1} \neq 1$ \\
\hline $\mathrm{T}$ & Temperature, (K) & & 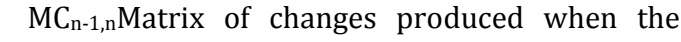 \\
\hline $\mathrm{F}$ & Force, $(\mathrm{N})$ & & strain $m_{n-1}$ pass through the stage of change $n$. \\
\hline 1 & Displaced distance, $(\mathrm{m})$ & & \\
\hline$\mu_{\mathrm{i}}$ & Chemical potential of $\mathrm{i}$-component, $(\mathrm{J} / \mathrm{mol}$ of $\mathrm{i})$ & \multicolumn{2}{|c|}{$\underline{\text { Subscripts }}$} \\
\hline \multirow[t]{2}{*}{$\mu_{\mathrm{i}}^{\mathrm{ext}}$} & Extended Chemical potential of i-component, & $\mathrm{i}$ & some property referred to i-component \\
\hline & $(\mathrm{J} / \mathrm{mol}$ of $\mathrm{i})$ & $\mathrm{w}$ & some property referred to water \\
\hline$n_{i}$ & Number of moles of i-component, $(-)$ & $\mathrm{s}$ & some property referred to solutes \\
\hline \multirow[t]{2}{*}{ Vi } & Partial Molar Volume of i-component, $\left(\mathrm{m}^{3} / \mathrm{mol}\right.$ & LP & liquid phase \\
\hline & of i) & ILP & intracellular liquid phase \\
\hline$a_{j}$ & Activity of the chemical specie $j,(-)$ & ELP & extracellular liquid phase \\
\hline $\mathrm{X}_{\mathrm{i}}$ & Mass fraction of component $\mathrm{i}$, ( $\mathrm{kg}$ of $\mathrm{i} /$ total $\mathrm{kg}$ ) & SM & solid matrix \\
\hline \multirow[t]{2}{*}{$\mathrm{z}_{\mathrm{i}}$} & Mass fraction of the liquid fraction of component & e & external \\
\hline & i, (kg of i/ kg of LP) & ads & adsorbed \\
\hline $\mathrm{R}$ & Ideal gases universal constant, $(\mathrm{J} / \mathrm{mol} \cdot \mathrm{K})$ & os & osmotic solution \\
\hline $\mathrm{U}$ & Internal energy, $(\mathrm{J})$ & ns & non soluble \\
\hline $\mathrm{S}$ & Enthalpy, (J) & $\mathrm{g}$ & gas \\
\hline ? & Porosity, (m3/m3) & $\mathrm{p}$ & parenchymatic \\
\hline$\rho_{\mathrm{r}}$ & Real density, (kg/m3) & $\mathrm{t}$ & time, (min) \\
\hline$\rho_{a}$ & Apparent density, $\left(\mathrm{kg} / \mathrm{m}^{3}\right)$ & & \\
\hline \multirow[t]{4}{*}{$\mathrm{M}_{\mathrm{n}, \mathrm{n}}$} & Descriptive matrix of product flowing out of the & \multicolumn{2}{|c|}{ Superscripts } \\
\hline & stage of change $n$ considering the overall mass in & & internal \\
\hline & the system equal to $\mathrm{m}_{\mathrm{n}} / \mathrm{m}_{\mathrm{n}}=1$. & & vascular \\
\hline & & s & surface \\
\hline
\end{tabular}

\section{Introduction}

Kiwifruit is very important fruit in the human diet because contains high amount of vitamins, antioxidants and ions, fundamentals in an equilibrated meal. However the shelf life of this fruit is short and requires conservation techniques to enhance its commercial life. One of these techniques is osmotic dehydration that consists of cellular tissue immersion in sugar or salts solution with lower $\mathrm{a}_{\mathrm{w}}$ than that of the product (Dalla Rosa \& Torreggiani, 2000). The difference in water chemical potential between the internal liquid phase and the external solution promotes water lost from the food into the osmotic medium, while osmotic solutes are transferred from the medium into the product (Chiralt \& Talens, 2005; Dalla Rosa \& Giroux, 2001; Lazarides et al., 1999). A lot of papers about osmotic dehydration of kiwifruit have been published (Bressa et al., 1997; Cao et al., 2006; Escriche et al., 2002; Gianotti et al., 2001; Rząca et al., 2009; Tocci \& Mascheroni, 2008; Tylewicz et al., 2009).

The properties of final product can be influenced by a huge number of factors such as the raw material characteristics or the process parameters applied. The role of structure in plant tissue dehydration, or any biological system, is very important to understand the transport properties of the tissue. It is important to consider that the concept of structure is very complex and includes not only the conformation of cells (wall, protoplast, vacuoles, etc..) but also the connections between them (plasmodesmata and symplastic paths), the active and passive transports through the membrane (water channels, ion channels, aquaporins, etc...) and the external space between cells bonded by the middle lamellae (porous filled with air or liquid), the biochemical reactions involved in normal biological pathways of the cells (aerobic or anaerobic respiration) and others depending on the type of tissue (parenchymatic, vascular, etc...) (Aguilera et al., 2003; Seguí et al., 2006; Moraga et al., 2009; Seguí et al., 2010). Therefore, in order to understand the behaviours involved in mass transfer, it is important to define the different phases (solid matrix, liquid or gas phase) and components (water and solids) that conform the structure of samples and how they change during the treatment.

The different chemical compounds move in the way of free energy gradients (Fito et al., 2007), for that reason, the thermodynamic analysis of the fluxes in food systems is usually made by Gibbs free energy evaluation. Demirel (2002) defined the Gibbs free energy for biological tissue as follows:

$$
d G=-S d T+V d P+F d l+\psi d e+\sum_{i} \mu_{i} d n_{i}
$$

Defining interfaces between the phases previously explained it is possible to apply gradients of Gibbs free energy by mol of the compound in transport or chemical potential in order to estimate the different behaviours involved in transport (Castro-Giráldez et al., 2010):

$$
\Delta \mu_{w}^{e x t}=\frac{\Delta G}{\Delta n_{w}}=v_{w}^{-} \Delta P+F_{w} \Delta l+\mu_{s} \frac{\Delta n_{s}}{\Delta n_{w}}+\mu_{w}
$$

The connection of structure concepts with the thermodynamic state variables produces a very complex net of a big amount of data with high difficulty for its management. SAFES methodology (Systematic Approach to Food Engineering Systems) is a technique that recognizes the complexity of food system and describes the structure of 


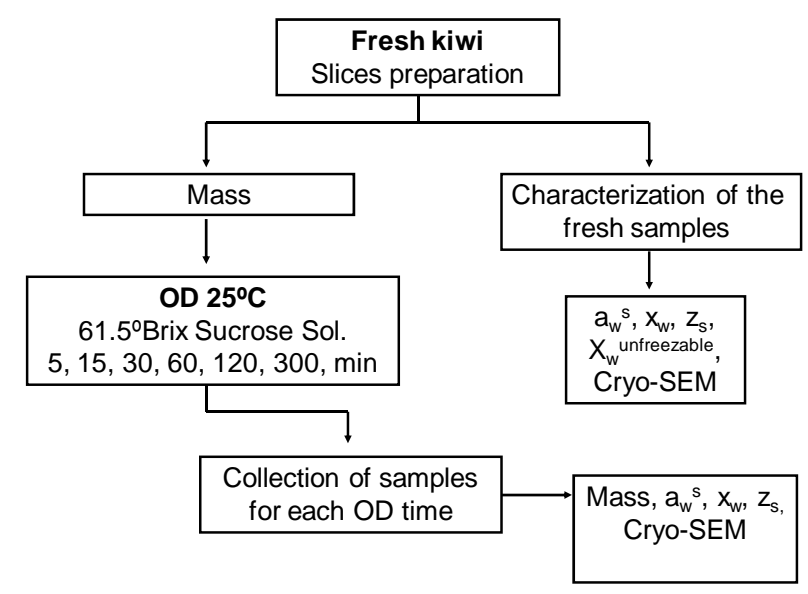

Figure 1. Flow chart of the experimental procedure

food in three dimensional spaces ( $\mathrm{i}$ - phases, $\mathrm{j}$ - components, $\mathrm{k}$ - aggregation states) through any treatment which provides the physicochemical transitions, chemical and biochemical reactions and energy and mass transports (Fito et al., 2007).

In recent years, SAFES methodology has been applied to several food manufacture processes like apple dehydration and candying (Bertoret et al., 2007; Barrera et al., 2007a), strawberry freezing process (Castelló et al., 2007), coffee (Fito et al., 2007), cheese (Argüelles et al., 2007) or french fries manufacture (Barrera et al., 2007b) and many others processes.

The objective of this work was to describe the osmotic dehydration process of kiwifruit by using SAFES approach in order to show, in a systematic way, the structural and physico-chemical changes and to analyze the thermodynamic variables during the whole process.

\section{Material and Methods}

\subsection{Raw Material}

The kiwifruits (Actinidia deliciosa var. Hayward) were bought on the local market and stored at $4-5^{\circ} \mathrm{C}$ until they were processed. Experimental flow chart is shown in figure 1.

\subsection{Osmotic dehydration treatment}

The osmotic dehydration was carried out in a closed tank containing $61,5 \%(\mathrm{w} / \mathrm{v})$ sucrose solution. Product/solution ratio was $1: 4(\mathrm{w} / \mathrm{w})$ to avoid changes in the solution during the process. The samples (10 $\mathrm{mm}$ thickness slices) were immersed in the osmotic dehydration solution at $25^{\circ} \mathrm{C}$ for different times $(0,5,15,30,60,120$ and 300 minutes). The temperature of the solution was maintained by a thermostatically controlled water bath.

\subsection{Analytical determinations}

Kiwifruit samples were weighted before and after osmotic dehydration process. The surface water activity $\left(\mathrm{a}_{\mathrm{w}} \mathrm{s}\right)$ was determined by a dew point hygrometer Acqualab ${ }^{\circledR}$ series 3TE (Decagon Devices, Inc., Washington, USA) with precision $\pm 0,003$. Moisture was determined by drying in a vacuum oven at $60^{\circ} \mathrm{C}$ till constant weight was reached (AOAC method 934.06 (2000)).. Soluble solids content were determined at $20^{\circ} \mathrm{C}$ by measuring the refractive index with a digital refractometer (PR1, Atago, Japan). Unfreezable water content was evaluated by DSC (differential scanning calorimetry) analysis carried out on a Pyris 6 DSC (PerkinElmer Corporation, Wellesley, USA). Internal areas of fresh kiwifruit were estimated by using low temperature scanning electron microscopy (cryo-SEM). A Cryostage CT-1500C unit (Oxford Instruments, Witney, UK), coupled to a Jeol JSM5410 scanning electron microscope (Jeol, Tokyo, Japan), was used. The sample was immersed in slush N2 $\left(-210^{\circ} \mathrm{C}\right)$ and then quickly transferred to the Cryostage at $1 \mathrm{kPa}$, where sample fracture took place. The sublimation (etching) was carried out at $-95{ }^{\circ} \mathrm{C}$; the final point was determined by direct observation in the microscope, working at $5 \mathrm{kV}$. Then, once again in the Cryostage unit, the sample was coated with gold in vacuum $(0.2 \mathrm{kPa})$, applied for $3 \mathrm{~min}$, with an ionization current of $2 \mathrm{~mA}$. The observation in the scanning electron microscope was carried out at $15 \mathrm{kV}$, at a working distance of $15 \mathrm{~mm}$ and a temperature $\leq-130^{\circ} \mathrm{C}$.

Image analysis was used for sharing out the core from the parenchymatic tissue in each sample.

The pictures were analyzed with adobe photoshop ${ }^{\circledR}$ (Adobe System Inc., San Jose, CA, USA).

Each determination was carried out by triplicate.

\subsection{SAFES methodology}

SAFES methodology is based on mathematic matrices designed for mass balances which includes different food phases in columns and food components in different aggregation state in rows (Fito et al., 2007). There are two kind of matrices, the descriptive one and the matrices of changes. The descriptive matrices define the product before and after each stage of changes and can be referred to the overall mass in the system equal to $m_{n} / m_{n}=1\left(M_{n, n}\right)$ or can be referred to the basis of a product at a different stage and called transformed matrix $\left(\mathrm{M}_{\mathrm{n}, \mathrm{n}-1}\right)$. The matrix of changes $\left(\mathrm{MC}_{\mathrm{n}-1, \mathrm{n}}\right)$ shows up the phase transitions, the compositional and structural changes and the transport phenomena involved in a stage of changes or in a unit operation.

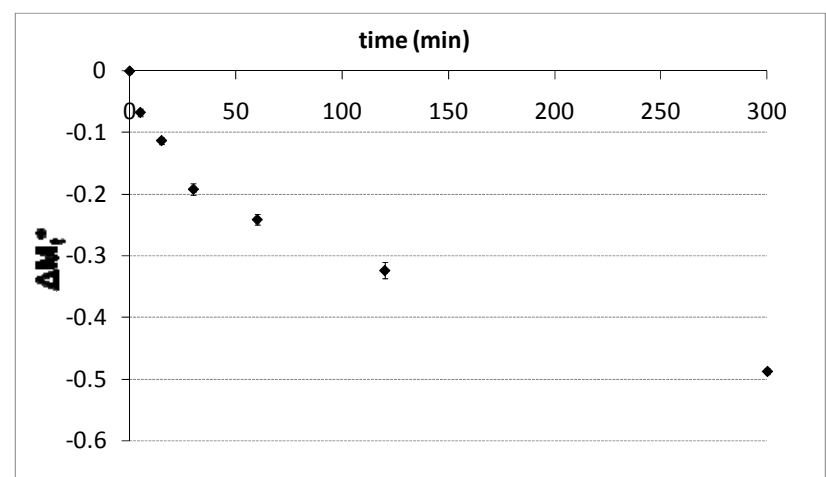

Figure 2. Evolution of weight loss during osmotic dehydration of Actinidia deliciosa kiwifruit at $25^{\circ} \mathrm{C}$.

\section{Results and discussion}

In an osmotic dehydration treatment, Kiwifruit losses water and gains sucrose by osmodiffusional mechanisms (Talens et al., 2003). A useful tool to analyze the behaviours involved in the osmotic treatment is the mass variation curve (Figure 2) where it can be appreciated that, in this short treatment, the chemical pseudoequilibrium is not reached. The curve shows the continuous weight lost during the treatment, therefore only one stage of changes is considered (Figure $4 a)$. 


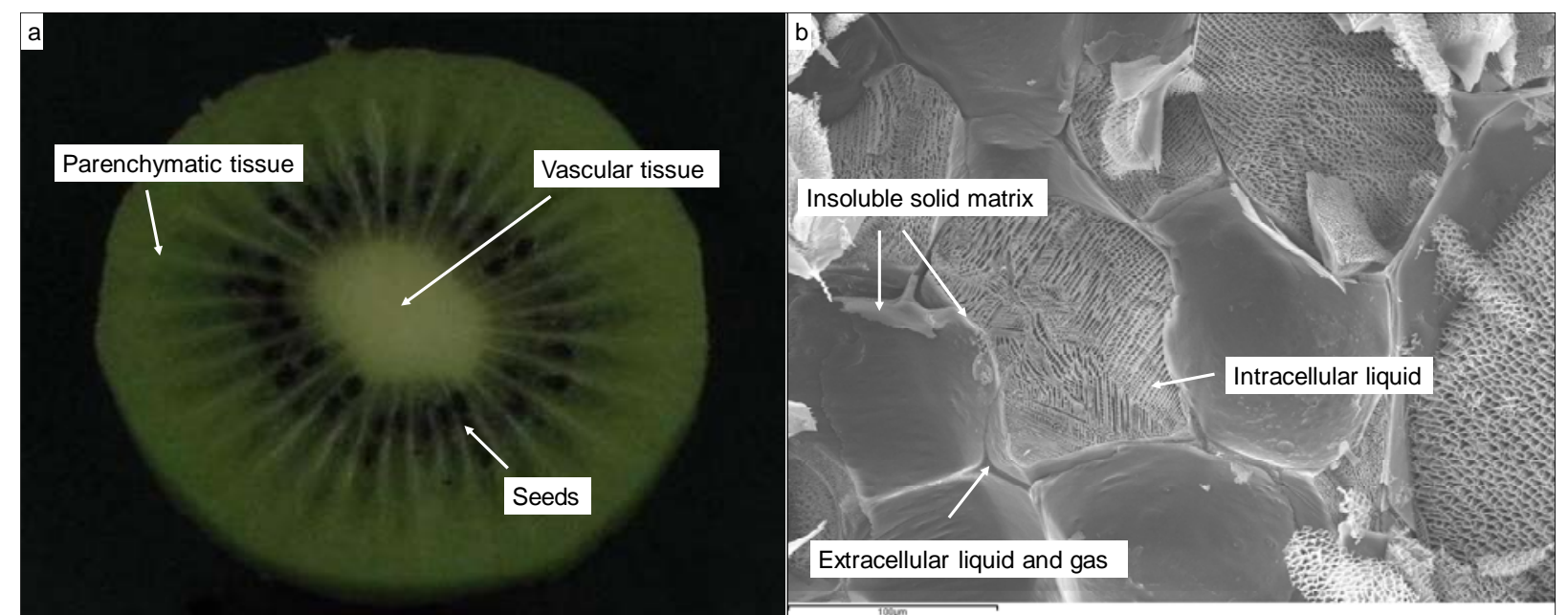

Figure 3. Structure of fresh kiwifruit tissue, analysed by Image Analyses (a), and by Cryo-SEM observation (b).

a)

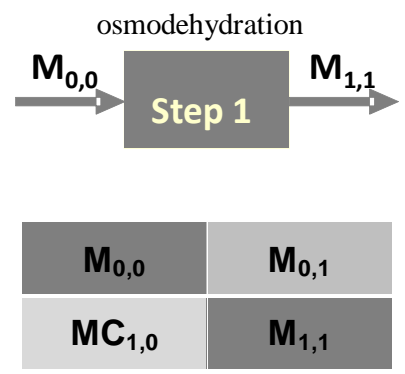

Water content: $\mathbf{x}_{\mathrm{w}}$

$X_{w}=x_{w(a d s)}^{S M}+x_{w(p)}^{I L P}+x_{w(p)}^{E L P}+{ }_{w(v)}^{E L P}$

Soluble solids: $\mathbf{x}_{\mathrm{s}}$

$x_{s}=z_{s} x_{w} / 1-x_{w}$

Non soluble solids: $x_{\mathrm{ns}}$

$x_{n s}=1-\left(x_{w}+x_{s}\right)$

Volume estimation:

Liquid Phase: $\mathrm{V}_{\mathrm{LP}}$

$V^{L P}=x^{L P} / \rho_{r}^{L P}$

$\rho_{r}^{L P}=46217 z_{s}+991,05$

(6b) (Lewis, 1987)

Gas Phase: $\mathbf{V}_{\mathrm{g}}$

$V_{g}=\varepsilon \rho_{a}$

Rest of Phases: $V_{j}$

$V_{j}=\sum x_{i}^{k} / \rho_{i}$ b) $\begin{array}{ll}X_{i j} & \mathbf{M}_{0,0} \text { raw kiwi } \\ \mathbf{M}_{1,1} \text { dehydrated kiwi }\end{array}$

\begin{tabular}{|c|c|c|c|c|c|}
\hline PHASES & $\mathbf{j}$ & COMPONENTS & $\mathbf{i}$ & STATES & $\mathbf{k}$ \\
\hline Solid matrix & 1 & Water & 1 & Gas (G) & 0 \\
\hline Liquid intracell. (p) & 2 & Non soluble solids (native) & 2 & Liquid (L) & 1 \\
\hline Liquid extracell. (p) & 3 & Soluble solids (native) & 3 & Adsorbed (A) & 2 \\
\hline Liquid phase (v) & 4 & Soluble solids (addes) & 4 & Rubber (R) & 3 \\
\hline Soluble solids (solid) & 5 & $\mathrm{CO}_{2}$ & 5 & Vitreous (V) & 4 \\
\hline Gas & 6 & Whole foods & 6 & Crystal (K) & 5 \\
\hline Whole food & 7 & & & & \\
\hline External phase & 8 & & & & \\
\hline
\end{tabular}

c)

\begin{tabular}{|c|c|l|}
\hline \multicolumn{3}{|c|}{ Initial Composition } \\
\hline $\mathrm{X}_{\mathrm{W}}$ & 0,861 & $\mathrm{~g} \mathrm{H}_{2} \mathrm{O} / \mathrm{g}$ fresh kiwi \\
\hline $\mathrm{z}_{\mathrm{s}}$ & 0,112 & $\mathrm{~g} \mathrm{ss} / \mathrm{g}$ liquid phase(LP) \\
\hline $\mathrm{X}_{\mathrm{W}}{ }^{\text {unfreezable }}$ & 0,180 & $\mathrm{~g} \mathrm{H}_{2} \mathrm{O} / \mathrm{g}$ fresh kiwi \\
\hline
\end{tabular}

Mass balance for invarient compounds:

$$
x_{i j}^{k} M_{1,1}=x_{i j}^{k} M_{0,0} /(\Delta M+1)
$$

Transformed matrix:

$$
x_{i j}^{k} M_{0,1}=x_{i j}^{k} M_{1,1}(1+\Delta M)
$$

\section{Matrix of changes:}

$x_{i j}^{k} M G_{1,0}=x_{i j}^{k} M_{0,1}-x_{i j}^{k} M_{0,0}$ 
There were defined two different kind of tissue: the vascular tissue which represents the $7.5 \% \pm 0.85$ of the total area estimated by image analysis and parenchymatic tissue that represents the $92.5 \% \pm 0.85$ of total area (Figure 3a). The microstructure studies of kiwifruit made by Cryo-SEM (Figure 3b) allow sharing out, in the parenchymatic tissue, the intra and extracellular space (Figure 4b). Extracellular space obtained $(8 \% \pm 0.97 \mathrm{v} / \mathrm{v})$ was divided in gas, using the porosity, 2.3\% v/v (Salvatori et al., 1997), and liquid phase, which was transformed in mass fraction using equation $6 \mathrm{~b}$. The components that change through a kiwi osmotic dehydration treatment are water and soluble solids (Talens et al., 2003). The chemical composition of fresh kiwifruit is shown in figure 4c, and the compounds shared out in the different phases are explained below.

In order to fill the descriptive matrix of raw kiwi (Figure 6) it is necessary to consider next aspects; the water content was segregated in adsorbed water in solid matrix $\left(X_{w(\text { ads })}^{S M}\right)$ and liquid water in three phases: parenchymatic liquid phase (intra- and extracellular) and the vascular liquid phase (see Eq. (3) in Fig. 4). In order to estimate the adsorbed water, it was necessary to consider that this water is the average between the unfreezable water content and the monomolecular moisture layer obtained from the water isotherm of kiwi (Moraga et al., 2006). Surface water activity was measured and it can be considered as the extracellular and vascular water activity (see figure 5), water and sucrose mass fraction by liquid phase $\left(\mathrm{z}^{\mathrm{e}}\right)$ were obtained from the sucrose solution isotherm (Starzak \& Mathlouthi, 2006), multiplying by the ELP mass fraction the external water and sucrose mass fractions were obtained. Applying the equation 3 , it is possible to obtain the internal water mass fraction. Using the ILP fraction and the sucrose isotherm, the internal water activity is obtained. Raw tissue needs low gradients of free energy to maintain sugars inside the vacuoles and high concentration of water outside the protoplast, therefore, it is possible to consider neglected the gradients of free energy per each compound, thus, using equation 12 , it is possible to obtain the internal pressure because external pressure can be considered the atmospheric.

Soluble solids were divided in three phases $\left(\mathrm{LP}_{\mathrm{v}}, \mathrm{ILP}_{\mathrm{p}}, \mathrm{ELP}_{\mathrm{p}}\right)$ using the sucrose solution isotherm (Starzak \& Mathlouthi, 2006) and the water activity values for vascular and parenchymatic tissue (see Eq. (4) in Fig. 4).

Non soluble solid phase was calculated by subtraction of water content and soluble solid content from the whole system (see Eq. (5) in Fig. 4).
As shows the equation $6 a$, the volume of each liquid phase was estimated with the liquid mass fraction and the density (equation 6b), and the solid matrix volume was estimated with the mass fraction and density of cellulose and pectin compounds obtained from the bibliography (Fito et al., 2007) (equation 8). The air phase volume was estimated using the porosity and apparent density of kiwi (equation 7). As the figure 2 shows, samples never reach the chemical pseudoequilibrium (Chiralt \& Fito, 2003; Castro-Giráldez et al., 2010) therefore, the plasmolysis is not finished and then the tissue can recover it initial structure. The variation of entropy, enthalpy and Gibbs free energy for the different liquid phases is:

$$
\begin{aligned}
& d S^{L P}=d U^{L P} \cdot \frac{1}{T}+\frac{v d P}{T}+d \mu_{s} \frac{1}{T}+d \mu_{w} \frac{1}{T} \\
& d H^{L P}=d U^{L P}+d(V P) \\
& d G^{L P}=d H^{L P}-T d S^{L P}
\end{aligned}
$$

Where the internal energy can be estimated with the specific heat obtained from the bibliography for sucrose solutions (Chen et al., 1993), and the chemical potentials can be estimated with the activity of the major compounds, sucrose and water. The variation of the entropy in the gas phase has not sense because the entropy is expressed by mass and the mass fraction of gas phase is neglected. Nevertheless, it could be estimated as a fluid using the equation (13) applying the activities in gas phase.

The entropy of the solid matrix, which is conformed by cell wall, membrane and middle lamellae could be defined as:

$$
d S^{S M}=d U^{S M} \cdot \frac{1}{T}+\frac{F d l}{T}
$$

Where it is possible to estimate the internal energy of solid matrix using the specific heat of its major compounds, but the internal elongation of the tissue with the mechanical tension could be difficult to obtain.

Then it is possible to apply an entropy balance in a closed system composed by kiwifruit samples surrounded by osmotic solution, where the overall entropy variation can be developed as follows:

$$
d S^{0}=d S_{i}^{L P}+d S_{S M}+d S_{e}^{L P}+d S_{V}^{L P}+d S_{G A S}+d S_{O S}^{L P}
$$

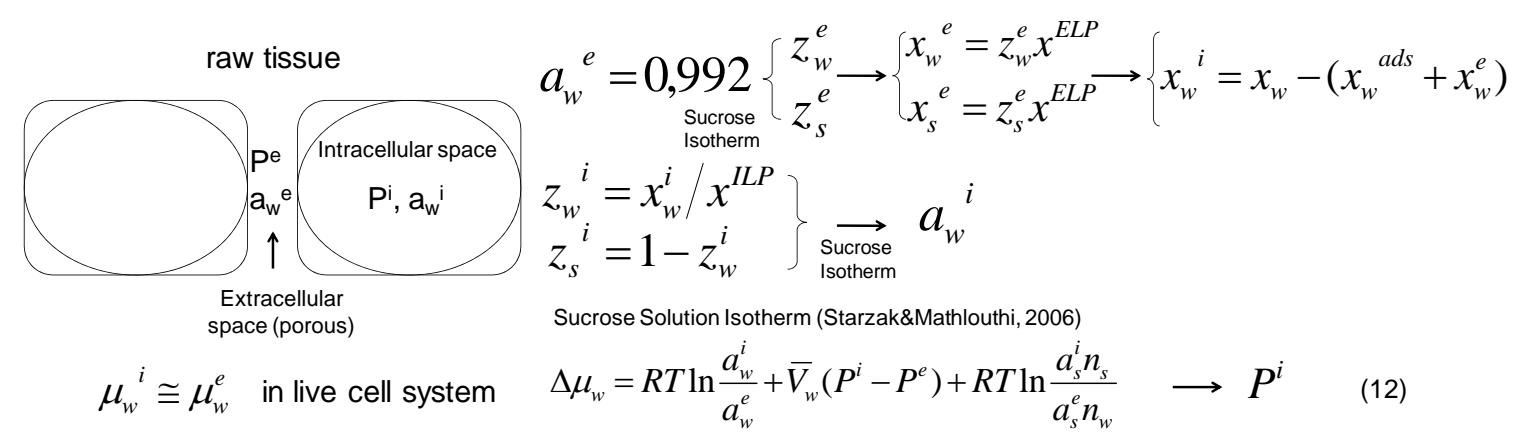

Figure 5. Flow chart of thermodynamics variables estimation in order to apply the SAFES methodology 


\begin{tabular}{|c|c|c|c|c|c|c|c|c|c|}
\hline \multicolumn{2}{|c|}{ COMPONENTS } & \multicolumn{8}{|c|}{ PHASES } \\
\hline COMPONENT & STATE & $\begin{array}{l}\text { Solid Matrix } \\
\text { (SM) }\end{array}$ & $\begin{array}{l}\text { Intracellular } \\
\text { Liquid (IL) }\end{array}$ & $\begin{array}{c}\text { Extracellular } \\
\text { Liquid (EL) }\end{array}$ & $\begin{array}{c}\text { Vascular } \\
\text { Liquid phase }\end{array}$ & $\begin{array}{c}\text { Soluble Solids } \\
\text { (solid) (SS) }\end{array}$ & Gas (G) & $\begin{array}{l}\text { Whole } \\
\text { Food } \\
\text { (WF) }\end{array}$ & $\begin{array}{c}\text { External } \\
\text { Phase (EP) }\end{array}$ \\
\hline \multirow{7}{*}{ WATER } & G (gas) & & & & & & 0 & 0 & \\
\hline & L (liquid) & & 0,6992 & 0,0481 & 0,0207 & $\pi$ & & 0,768 & 0,385 \\
\hline & A (adsorbed) & 0,09319 & & & 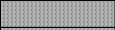 & 0 & & 0,09319 & \\
\hline & $\mathrm{R}$ (rubber) & & & & & & & & \\
\hline & $\mathrm{V}$ (vitreous) & & & & & & & & \\
\hline & K (crystal) & & & & & & & & \\
\hline & TOTAL & 0,093 & 0,699 & 0,048 & 0,0207 & 0 & 0 & 0,861 & 0,385 \\
\hline \multirow{6}{*}{$\begin{array}{l}\text { NON SOLUBLE } \\
\text { SOLIDS } \\
\text { (NATIVE) }\end{array}$} & L (liquid) & & & & & & & & \\
\hline & A (adsorbed) & & & & & & & & \\
\hline & $R$ (rubber) & 0,031 & & & & & & 0,031 & \\
\hline & $\mathrm{V}$ (vitreous) & 0 & & & & & & 0 & \\
\hline & K (crystal) & 0 & $+\frac{1}{2}$ & 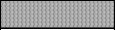 & 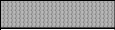 & 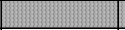 & 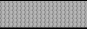 & 0 & 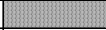 \\
\hline & TOTAL & 0,031 & 0 & 0 & 0 & 0 & 0 & 0,031 & 0 \\
\hline \multirow{6}{*}{$\begin{array}{l}\text { SOLUBLE } \\
\text { SOLIDS } \\
\text { (NATIVE) }\end{array}$} & L (liquid) & & 0,097 & 0,007 & 0,004 & 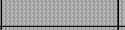 & - & 0,108 & \\
\hline & A (adsorbed) & 0 & & & 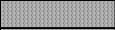 & - & & 0 & \\
\hline & $R$ (rubber) & & & & & 0 & & 0 & \\
\hline & $\mathrm{V}$ (vitreous) & & & & & 0 & & 0 & \\
\hline & K (crystal) & & & & & 0 & & 0 & \\
\hline & TOTAL & 0 & 0,097 & 0,007 & 0,004 & 0 & 0 & 0,108 & 0 \\
\hline \multirow{6}{*}{$\begin{array}{l}\text { SOLUBLE } \\
\text { SOLIDS } \\
\text { (ADDED) }\end{array}$} & L (liquid) & & 0 & 0 & 0 & $m$ & $m$ & 0 & 0,615 \\
\hline & A (adsorbed) & 0 & & & - & - & 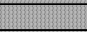 & 0 & \\
\hline & $R$ (rubber) & & & & & 0 & & 0 & \\
\hline & $\mathrm{V}$ (vitreous) & & ? & & 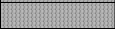 & 0 & 114 & 0 & \\
\hline & $\mathrm{K}$ (crystal) & 的 & (n) & 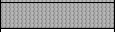 & + & 0 & 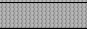 & 0 & 113 \\
\hline & TOTAL & 0 & 0 & 0 & 0 & 0 & 0 & 0 & 0,615 \\
\hline GASES & TOTAL & 0 & 0 & 0 & 0 & 0 & 0 & 0 & \\
\hline \multicolumn{2}{|c|}{ WHOLE FOOD MASS } & 0,124 & 0,796 & 0,055 & 0,025 & 0,000 & 0,000 & 1,00 & 1,00 \\
\hline \multicolumn{2}{|c|}{ WHOLE FOOD VOLUME (L/kg) } & 0,095 & 0,763 & 0,053 & 0,025 & 0,000 & 0,024 & 0,962 & 0,772 \\
\hline \multicolumn{2}{|c|}{ W.F.TEMPERATURE (K) } & 298 & 298 & 298 & 298 & 298 & 298 & 298 & 298 \\
\hline \multicolumn{2}{|c|}{ W.F.PRESSURE (MPa) } & 0,1 & 0,1 & 0,1 & 0,1 & 0,1 & 0,1 & 0,1 & 0,1 \\
\hline \multicolumn{2}{|c|}{ FREE ENERGY (kJ/kg) } & & $-113,82$ & $-9,05$ & $-5,52$ & & & $-128,40$ & $-506,54$ \\
\hline \multicolumn{2}{|c|}{ ENTHALPY (kJ/kg) } & & 78,75 & 5,48 & 2,44 & & & 86,67 & 98,93 \\
\hline \multicolumn{2}{|c|}{ ENTROPY (kJ/kgK) } & & 0,65 & 0,05 & 0,03 & & & 0,72 & 2,03 \\
\hline
\end{tabular}

Figure 6. Descriptive matrix of raw kiwifruit.

\begin{tabular}{|c|c|c|c|c|c|c|c|c|c|}
\hline \multicolumn{2}{|c|}{ COMPONENTS } & \multicolumn{8}{|c|}{ PHASES } \\
\hline COMPONENT & STATE & $\begin{array}{c}\text { Solid } \\
\text { Matrix } \\
\text { (SM) }\end{array}$ & $\begin{array}{l}\text { Intracellular } \\
\text { Liquid (IL) }\end{array}$ & $\begin{array}{l}\text { Extracellular } \\
\text { Liquid (EL) }\end{array}$ & Vascular Liquid & $\begin{array}{c}\text { Soluble Solids } \\
\text { (solid) (SS) }\end{array}$ & Gas (G) & $\begin{array}{l}\text { Whole } \\
\text { Food } \\
\text { (WF) }\end{array}$ & $\begin{array}{c}\text { External } \\
\text { Phase (EP) }\end{array}$ \\
\hline \multirow{7}{*}{ WATER } & G (gas) & & & & & & 0 & 0 & \\
\hline & L (liquid) & & 0,3232 & 0,0187 & 0,0187 & & & 0,3607 & 0,4733 \\
\hline & A (adsorbed) & 0,182 & & & & 0 & & 0,1818 & \\
\hline & R (rubber) & & & & & & & & \\
\hline & $\mathrm{V}$ (vitreous) & & & & & & & & \\
\hline & K (crystal) & & & & & & & & \\
\hline & TOTAL & 0,1818 & 0,3232 & 0,0187 & 0,0187 & 0 & 0 & 0,543 & 0,4733 \\
\hline \multirow{6}{*}{$\begin{array}{c}\text { NON SOLUBLE } \\
\text { SOLIDS } \\
\text { (NATIVE) }\end{array}$} & L (liquid) & & & & & & & & \\
\hline & A (adsorbed) & & & & & & & & \\
\hline & R (rubber) & 0,060 & & & & & & 0,0601 & \\
\hline & V (vitreous) & 0 & & & & & & 0 & \\
\hline & K (crystal) & 0 & & 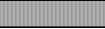 & ind & 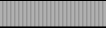 & 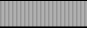 & 0 & \\
\hline & TOTAL & 0,060 & 0 & 0 & 0 & 0 & 0 & 0,0601 & 0 \\
\hline \multirow{6}{*}{$\begin{array}{l}\text { SOLUBLE } \\
\text { SOLIDS } \\
\text { (NATIVE) }\end{array}$} & L (liquid) & & 0,189 & 0,014 & 0,008 & & & 0,2107 & \\
\hline & A (adsorbed) & 0 & & & & & & 0 & \\
\hline & $\mathrm{R}$ (rubber) & & & & & 0 & & 0 & \\
\hline & V (vitreous) & & & & & 0 & & 0 & \\
\hline & K (crystal) & & & & & 0 & & 0 & \\
\hline & TOTAL & $\begin{array}{llll}0 & & & \\
\end{array}$ & 0,189 & 0,014 & 0,008 & 0 & $\begin{array}{llll}0 & & & \\
0\end{array}$ & 0,211 & 0 \\
\hline \multirow{6}{*}{$\begin{array}{l}\text { SOLUBLE } \\
\text { SOLIDS } \\
\text { (ADDED) }\end{array}$} & L (liquid) & & 0 & 0,1476 & 0,0153 & & & 0,1629 & 0,5267 \\
\hline & A (adsorbed) & 0 & & & & - & & 0 & \\
\hline & $\mathbf{R}$ (rubber) & & & & & 0 & & 0 & \\
\hline & V (vitreous) & & & & & 0 & & 0 & \\
\hline & K (crystal) & & & & & 0 & & 0 & \\
\hline & TOTAL & 0 & 0 & 0,1476 & 0,0153 & 0 & 0 & 0,1629 & 0,5267 \\
\hline GASES & TOTAL & 0 & 0 & 0 & 0 & 0 & 0 & 0 & 0 \\
\hline \multicolumn{2}{|c|}{ WHOLE FOOD MASS } & 0,242 & 0,512 & 0,181 & 0,042 & 0,000 & 0,000 & 1,0 & 1,00 \\
\hline \multicolumn{2}{|c|}{ WHOLE FOOD VOLUME (L/kg) } & 0,185 & 0,491 & 0,173 & 0,040 & 0,000 & 0,024 & 0,939 & 0,772 \\
\hline \multicolumn{2}{|c|}{ W.F.TEMPERATURE $\left({ }^{\circ} \mathrm{C}\right)$} & 298 & 298 & 298 & 298 & 298 & 298 & 298 & 298 \\
\hline \multicolumn{2}{|c|}{ W.F.PRESSURE (MPa) } & 0,1 & 0,1 & 0,1 & 0,1 & 0,1 & 0,1 & 0,1 & 0,1 \\
\hline \multicolumn{2}{|c|}{ FREE ENERGY (kJ/kg) } & & $-324,69$ & $-10,48$ & $-11,39$ & & & $-346,56$ & $-440,54$ \\
\hline \multicolumn{2}{|c|}{ ENTHALPY (kJ/kg) } & & 50,64 & 17,86 & 4,14 & & & 72,64 & 98,92 \\
\hline \multicolumn{2}{|c|}{ ENTROPY (kJ/kgK) } & & 1,26 & 0,10 & 0,05 & & & 1,41 & 1,81 \\
\hline
\end{tabular}

Figure 7. Descriptive matrix of treated kiwifruit. 


\begin{tabular}{|c|c|c|c|c|c|c|c|c|c|}
\hline \multicolumn{2}{|c|}{ COMPONENTS } & \multicolumn{8}{|c|}{ PHASES } \\
\hline COMPONENT & STATE & $\begin{array}{c}\text { Solid } \\
\text { Matrix } \\
\text { (SM) }\end{array}$ & $\begin{array}{l}\text { Intracellular } \\
\text { Liquid (IL) }\end{array}$ & $\begin{array}{l}\text { Extracellular } \\
\text { Liquid (EL) }\end{array}$ & Vascular Liquid & $\begin{array}{c}\text { Soluble Solids } \\
\text { (solid) (SS) }\end{array}$ & Gas (G) & $\begin{array}{c}\text { Whole } \\
\text { Food (WF) }\end{array}$ & $\begin{array}{c}\text { External } \\
\text { Phase (EP) }\end{array}$ \\
\hline \multirow{7}{*}{ WATER } & G (gas) & & & & & & 0 & 0 & \\
\hline & L (liquid) & & 0,1657 & 0,0096 & 0,0096 & & & 0,1849 & 0,5309 \\
\hline & \begin{tabular}{|l|} 
A (adsorbed) \\
\end{tabular} & 0,0932 & & & & 0 & & 0,0932 & \\
\hline & R (rubber) & & & & & & & 0 & \\
\hline & V (vitreous) & & & & & & & 0 & \\
\hline & $\mathrm{K}$ (crystal) & & & & & & & 0 & \\
\hline & TOTAL & 0,093 & 0,166 & 0,010 & 0,010 & 0,000 & 0,000 & 0,278 & 0,5309 \\
\hline \multirow{6}{*}{$\begin{array}{l}\text { NON SOLUBLE } \\
\text { SOLIDS } \\
\text { (NATIVE) }\end{array}$} & L (liquid) & & & & & & & & \\
\hline & A (adsorbed) & & & & & & & & \\
\hline & R (rubber) & 0,03080 & & & & & & 0,031 & \\
\hline & V (vitreous) & 0 & & & & & & 0,000 & \\
\hline & $\mathrm{K}$ (crystal) & 0 & & & & & & 0,000 & \\
\hline & TOTAL & 0,031 & 0 & 0 & 0 & 0 & 0 & 0,031 & 0 \\
\hline \multirow{6}{*}{$\begin{array}{l}\text { SOLUBLE } \\
\text { SOLIDS } \\
\text { (NATIVE) }\end{array}$} & L (liquid) & & 0,097 & 0,007 & 0,004 & & & 0,108 & \\
\hline & A (adsorbed) & 0 & & & & 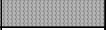 & & 0 & \\
\hline & $\mathrm{R}$ (rubber) & & & & & 0 & & 0 & \\
\hline & V (vitreous) & & & & & 0 & & 0 & \\
\hline & K (crystal) & & & & & 0 & & 0 & \\
\hline & TOTAL & 0 & 0,0967 & 0,0073 & 0,0040 & 0 & 0 & 0,108 & 0 \\
\hline \multirow{6}{*}{$\begin{array}{l}\text { SOLUBLE } \\
\text { SOLIDS } \\
\text { (ADDED) }\end{array}$} & L (liquid) & & 0 & 0,0757 & 0,0078 & & & 0,0835 & 0,5909 \\
\hline & A (adsorbed) & 0 & & & & & & 0 & \\
\hline & $\mathrm{R}$ (rubber) & & & & & 0 & & 0 & \\
\hline & V (vitreous) & & & & & 0 & & 0 & \\
\hline & $\mathrm{K}$ (crystal) & 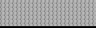 & L & 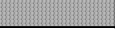 & & 0 & 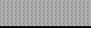 & 0 & \\
\hline & TOTAL & 0 & 0 & 0,0757 & 0,0078 & 0 & 0 & 0,0835 & 0,5909 \\
\hline GASES & TOTAL & 0 & 0 & 0 & 0 & 0 & 0 & 0,000 & 0 \\
\hline \multicolumn{2}{|c|}{ WHOLE FOOD MASS } & 0,124 & 0,262 & 0,093 & 0,021 & 0,000 & 0,000 & 0,500 & 1,1219 \\
\hline \multicolumn{2}{|c|}{ WHOLE FOOD VOLUME (L/kg) } & 0,095 & 0,252 & 0,089 & 0,021 & 0,000 & 0,012 & 0,481 & 0,8663 \\
\hline \multicolumn{2}{|c|}{ W.F.TEMPERATURE $\left({ }^{\circ} \mathrm{C}\right)$} & 298 & 298 & 298 & 298 & 298 & 298 & 298 & 298 \\
\hline \multicolumn{2}{|c|}{ W.F.PRESSURE (MPa) } & 0,1 & 0,1 & 0,1 & 0,1 & 0,1 & 0,1 & 0,1 & 0,1 \\
\hline \multicolumn{2}{|c|}{ FREE ENERGY (kJ/kg) } & & $-166,42$ & $-5,37$ & $-5,84$ & & & $-177,63$ & $-494,23$ \\
\hline \multicolumn{2}{|c|}{ ENTHALPY (kJ/kg) } & & 25,95 & 9,16 & 2,12 & & & 37,23 & 110,98 \\
\hline \multicolumn{2}{|c|}{ ENTROPY (kJ/kgK) } & & 0,65 & 0,05 & 0,03 & & & 0,72 & 2,03 \\
\hline
\end{tabular}

Figure 8. Descriptive Matrix $M_{1,1}$ referred to the weight of $M_{0,0}$

\begin{tabular}{|c|c|c|c|c|c|c|c|c|}
\hline \multicolumn{7}{|c|}{ MC 1,0} \\
\hline \\
\hline
\end{tabular}

Figure 9. Matrix of changes 
The entropy balance must explain the irreversible changes through the treatment. In this case, with short treatment times, the tissue does not reach the chemical equilibrium, and as it was explained before the plasmolysis is not finished, therefore the deformation of tissue could be considered as a reversible process, being $\mathrm{d} \mathrm{S}^{0} \cong 0$.

Considering the neglected variation of the overall entropy it is possible to estimate the variation of entropy in the solid matrix because the other terms of equation (17) are known.

Figures 6 and 7 show the matrices of raw and treated kiwifruit, where all the estimations described above are introduced in the cells of the matrices. Values are exposed by overall mass of kiwifruit, then mass fraction of each phase is needed to fill the matrix. The mass reference in descriptive matrix of treated samples $\left(\mathrm{M}_{1,1}\right)$ was changed in order to compare the evolution of the samples through the dehydration process. Transformed matrix is obtained following the equation 10 of figure 4. Finally, in order to explain the evolution of samples through the treatment, the matrix of changes was obtained using the equation 11 .

In figure 9 it can be appreciated (indicated with black rows) that water is flowing to the external phase (the most part from intracellular space) and the sucrose is flowing inside the tissue and storing in the external and vascular phase. Also, figure 9 shows the overall mass lost corresponding with the figure 2 , and the shrinkage is shown in the overall volume variation. Osmotic solution is four times bigger than the samples, then dividing by four the addition of the free energy of samples, it is obtained $12.307 \mathrm{~kJ} / \mathrm{kg}$, same value of the free energy variation of the osmotic solution, showing the driving forces of water and sucrose transport. The variation of entropy for each phase is zero; it shows the reversibility of changes through the treatment and allows determining that the entropy variation of solid matrix must to be neglected too.

\section{Conclusions}

SAFES model applied in kiwi allows obtaining the internal composition of each phase, control changing and determines the behaviours involved in transports.

It is possible to estimate the Gibbs free energy, enthalpy and the entropy of each phase in order to determine the different behaviours occurred through the osmotic treatment and to analyze the irreversibility of process.

The matrix of changes shows that the water flows from the internal phase of kiwi and the added sucrose is stored in the external and vascular phase. Moreover the shrinkage of the tissue during the treatment can be observed and the reversibility of this phenomenon can also be appreciated.

\section{References}

Aguilera, J.M., Chiralt, A., Fito, P. (2003). Food dehydration and product structure. Trend in Food Science \& Technology 14, 432-437.

Argüelles, A., Castelló, M., Sanz, J., Fito, P. (2007). Application of SAFES methodology in Manchego-type cheese manufacture. Journal of Food Engineering, 83 (2), 229237.

Barrera, C., Betoret, N., Heredia, A., Fito, P. (2007). Application of SAFES (Systematic Approach to Food Engineering Systems) methodology to apple candying. Journal of Food Engineering 83, 193-200.
Barrera, C., Chenoll, C., Andrès, A., Fito, P. (2007). Application of SAFES (Systematic Approach to Food Engineering Systems) methodology to French fries manufacture. Journal of Food Engineering 83, 201-210.

Betoret, N., Andrès, A., Seguí, L., Fito, P. (2007) Application of Safes (Systematic Approach to Food Engineering Systems) methodology to dehydration of apple by combined methods" Journal of Food Engineering 83, 186-192.

Bressa, F., Dalla Rosa, M., Mastrocola, D. (1997). Use of direct osmosis treatment to produce minimally processed kiwifruit slices in a continuous pilot plant. Acta Horticulturae, 444 (2), 649-654.

Cao, H., Zhang, M., Mujumdar, A.S., Du, W., Sun, J. (2006) Optimization of Osmotic Dehydration of kiwifruit. Drying Technology, 24, 89-94.

Castelló, M.L. ,Fito, P.J., Argüells, A., Fito, P. (2007). Application of the SAFES (systematic approach to food engineering systems) methodology to strawberry freezing process. Journal of Food Engineering, 83, 238-249.

Castro-Giráldez, M., Fito, P.J., Fito, P. (2010). Non-equilibrium thermodynamic approach to analyze the pork meat (Longissimus dorsi) salting process. Journal of Food Engineering, 99, 24-30.

Chen, J. (1993). Cane sugar handbook. John Wiley \& Son Inc., U.S.A.

Chiralt, A., Fito, P. (2003). Transport mechanism in osmotic dehydration. The role of the structure. Food Science and Technology International, 9 (3), 179-186.

Chiralt, A., Talens, P. (2005). Physical and chemical changes induced by osmotic dehydration in plant tissues. Journal of Food Engineering 67, 167-177.

Dalla Rosa, M. \& Giroux, F. (2001). Osmotic treatments (OT) and problems related to the solution management. Journal of Food Engineering, 49, 223-236.

Dalla Rosa, M. \& Torreggiani, D. (2000). Improvement of food quality by application of osmotic treatments. In Industrial application of osmotic dehydration/treatments of food. Edited by Marco Dalla Rosa and Walter E.L. Spiess. Forum.Udine.

Demirel Y. (2002). Nonquilibrium Thermodynamics. Transport and Rate Processes in Physical, Chemical and Biological Systems. Elsevier Science and Technology Books, USA.

Escriche, I., Garcia-pinchi, R., Andrès, A., Fito, P. (2000). Osmotic dehydration of kiwifruit (Actinidia chinensis): fluxes and mass transfer kinetics. Journal of food process engineering, 23, 191-205

Fito, P., LeMaguer, M., Betoret, N., Fito, P.J. (2007). Advanced food process engineering to model real foods and processes: The "SAFES" methodology. Journal of Food Engineering 83, 173-185.

Gianotti, A., Sacchetti, G., Guerzoni, M.E., Dalla Rosa, M. (2001). Microbial aspects on short time osmotic treatment of kiwifruit. Journal of Food Engineering, 49, 265-270.

Lazarides, Harris N., Fito, F., Chiralt, A., Gekas, V., Lenart, A. (1999). Advances in osmotic dehydration" In: Processing Food, Quality Optimization and Process Assessment. Edited by Jorge C. Oliveira and Fernanda A. R. Oliveira CRC Press.

Lewis, M.J. (1987). Physical properties of foods and food processing systems. Ellis Horwood Ltd., Chichester, U.K.

Moraga, G., Martínez-Navarrete, N., Chiralt, A. (2006). Water sorption isotherms and phase transitions in kiwifruit. Journal of Food Engineering 72, 147-156.

Moraga, M.J., Moraga, G., Fito, P.J., Martínez-Navarrete, N. (2009). Effect of vacuum impregnation with calcium lactate on the osmotic dehydration kinetics and quality of osmodehydrated grapefruit. Journal of Food Engineering, 90 (3), 372-379.

Rojas, A.M., Gerschenson, L.N., Marangoni, A.G. (2001). Contributions of cellular components to the rheological behaviour of kiwifruit. Food Research International 34, 189-195.

Rząca, M., Witrowa-Rajchert, D., Tylewicz, U., Dalla Rosa, M. (2009). Mass exchange in osmotic dehydration process of kiwi fruits. ŻYWNOŚĆ. Nauka. Technologia. Jakość, 6 (67), $140-$ 149. 
Salvatori, D., Andrés, A., Chiralt, A., Fito, P. (1998). The response of some properties of fruit to vacuum impregnation. Journal of Food Process Engineering 21,59-73.

Seguí, L., Fito, P.J., ALbors, A., Fito, P. (2007). Mass transfer phenomena during the osmotic dehydration of apple isolated protoplast (Malus domestica var. Fuji). Journal of Food Engineering 77, 179-187.

Seguí, L., Fito, P.J., Fito, P. (2010). Analysis of structure property relationship in isolated cells during OD treatment. Effect of initial structure on the cell behavior. Journal of Food Engineering, 99, 417-423.

Starzak, M., Mathlouthi, M. (2006). Temperature dependence of water activity in aqueous solutions of sucrose. Food Chemistry 96, 346-370.
Talens, P., Escriche, I., Martínez-Navarrete, Chiralt, A. (2003). Influence of osmotic dehydration and freezing on the volatile profile of kiwi fruit. Food Research International, 36 (6), 635-642.

Tocci, A.M., Mascheroni, R. H. (2008). Some thermal properties of fresh and osmotically dehydrated Kiwifruit above and below the initial freezing temperature. Journal of Food Engineering 88, 20-27.

Tylewicz, U., Rocculi, P., Cocci, E. and Dalla Rosa, M. (2009). Mass transfer phenomena during osmotic dehydration of yellow kiwifruit (Actinidia chinensis cv. Hort16A) Industrie Alimentari, 48, 1-5. 